UR. IGOR Ž. $\check{\text { ŽAGAR }}$

IN ANA MLEKUŽ

raziskovanje v vzgoji in izobraževanju:

mednarodni vidiki vzgoje in izobraževanja 
digitalna knjižnica - digital library

uredniški odbor - editorial board igor ž. žagar jonatan vinkler janja žmavc alenka gril 



\section{raziskovanje v vzgoji in izobraževanju}

ur. Igor Ž. Žagar in Ana Mlekuž 



\section{Vsebina}

11 Kazalo slik in tabel

Igor $\check{Z}$.̌agar

15 Uvod

Pavel Zgaga

17 Raziskovanje edukacije in edukacijske politike, ali o razmerju 'kraljev' in 'filozofov'

Paul Stubbs

33 Inequality, Poverty and Education in the Post-Yugoslav Space: from immobility to inclusion?

\section{Znanstveni prispevki}

55 Inovativni pristopi $k$ učenju in poučevanju

Lilijana Gomerčić

57 Predšolska vzgoja v državah članicah EU (Slovenija, Hrvaška) in nečlanicah (Bosna in Hercegovina, Srbija)

\section{Izobraževalne politike}

Elena Nacevska, Danica Fink Hafner, Barbara Brečko, Tanja Oblak Črnič

73 Evropska študijska mobilnost in karierni načrti mladih 
Maruša Hauptman Komotar

91 Mobilnost študentov v primerjalni perspektivi:

Slovenija in Nizozemska

Barbara Baloh, Silva Bratož

109 Spodbujanje medkulturne zmožnosti s čezmejnimi razredi

Nebojša Pavlović

125 Social factors and teacher performance evaluation in faculties

131 Profesionalni razvoj pedagoških delavcev

Maja Šebjanič Oražem

133 Zaznave učiteljev začetnikov o svojih mentorjih in sodelovanju z njimi

Irina Lešnik

147 Konsenz o znanstveni terminologiji s področja gledališke pedagogike

Nika Bedek, Maruša Loboda, Urška Žerak, Janez Vogrinc,

Mojca Juriševič

157 Mentalne reprezentacije študentov pedagoških smeri do nadarjenih in njihovega izobraževanja

Ana Stanovnik Perčič

173 Vpliv mednarodnega sodelovanja na profesionalni razvoj izobraževalcev odraslih

Lela Vuković

179 Horizontal learning: Teachers as learners in continuing professional development

\section{Socialni odnosi v vzgoji in izobraževanju}

Maja Kuronja, Majda Schmidt Krajnc

193 Zaznava samoučinkovitosti učiteljev učencev $\mathrm{z}$ učnimi

ter čustvenimi in vedenjskimi težavami

Tina Pivec, Ana Kozina

205 Dejavniki doživljanja nasilja med mladostniki iz Slovenije, Hrvaške in Švedske

Valerija Vendramin

221 Nekaj epistemoloških zapiskov o raziskovanju spola v edukaciji 
Simona Tancig

229 Raziskave digitalizacije branja in pisanja ter medijske večopravilnosti - kakšne so spremembe na kognitivnem, čustveno-socialnem in nevrološkem področju ter $\mathrm{v}$ učnih dosežkih?

Monika Mithans, Milena Ivanuš Grmek

249 Besedna interakcija med poukom: kako nanjo vpliva znanje učencev Natalija Budinski

263 Mathematical modelling in primary schools-advanced topics at elementary level

Meleka Asotić, Ajša Bahović Latifović

269 Diverse teaching methods: How to approach to different levels of anxiety

\section{Strokovni prispevki}

283 Evalvacija in zagotavljanje kakovosti

Andreja Lenc

285 Trajnost projektnih rezultatov - ključ do učinka projektov EU

\section{Inovativni pristopi $k$ učenju in poučevanju}

Aleksandra Stevanović, Snježana Djurdjević, Bojana Sokolović

295 Mini-companies as an essential part of a lifelong learning program for high school students

\section{Profesionalni razvoj pedagoških delavcev}

Silvija Komočar

309 Timsko vodenje in sistematično razvijanje strokovnih timov v vrtcu v luči profesionalnega razvoj

Zsofia Hangyal

325 Internationalisation of the curriculum: A case study from Hungary

\section{Učenje in poučevanje} Ana Gorše

335 Bralni test v 3. razredu na OŠ Loka Črnomelj 
Vesna Kostić, Jelena Mucić, Jovana Vasić

343 The opinion of the teachers and the pupils on teaching and learning at elementary school "Jovan Dučić"

351 Povzetki - Summaries

389 O avtorjih

409 Stvarno kazalo 


\section{Kazalo slik in tabel}

41 Slika 1: Percentage of tertiary Level Students in Croatia By Father's Educational evel 2001/2 - 2011/1

42 Slika 2: Levels of Education by Father and Mother's Educational Level in Croatia 1999-2010

44 Slika 3: Educational Mobility by European Region 1960-2010

45 Slika 4: Question from Life in Transition Survey 2016

47 Slika 5: Parental Views on Necessities for School-Age Children

8o Slika 6: Študentsko delo

81 Slika 7: Iskanje zaposlitvenih priložnosti - ključne razlike med domačijskim in kozmopolitskim tipom mladih

83 Slika 8: Učenje tujih jezikov

162 Slika 9: Semantične kategorije za pojem nadarjen učenec

164 Slika 10: Semantične kategorije za pojem izobraževanje nadarjenih

265 Slika 11: Mathematical modelling cycle in the educational settings

267 Slika 12: Solution of the real-world problem and its graphical representation

277 Slika 13: Distribution of anxiety during foreign language speaking

39 Tabela 1: Trends in Higher Education in Yugoslavia, 1938-1985

39 Tabela 2: Education indicators by Yugoslav Republic 1971 and 1981

48 Tabela 3: Educational Mobility by European Region 1960-2010

48 Tabela 4: Childrens' Preceptions of Ostacles to Fulfilling Plans

65 Tabela 5: Število vrtcev in vključenost predšolskih otrok v vrtce v državah 
66 Tabela 6: Normativi za število otrok $v$ skupini

79 Tabela 7: Razlogi za študijsko mobilnost

117 Tabela 8: Faze akcijske raziskave

140 Tabela 9: Začetna pričakovanja učiteljev začetnikov do mentorja

141 Tabela 10: Ocena sodelovanja $z$ mentorjem

142 Tabela 11: Ocena usposobljenosti mentorja za opravljanje nalog mentorja

143 Tabela 12: Ocena mentorjeve profesionalne kompetence

149 Tabela 13: Gledališka pedagogika obsega tri vidike vključevanja gledaliških elementov $v$ izobraževalni proces.

151 Tabela 14: Učne tehnike, metode in pristopi gledališke pedagogike

160 Tabela 15: Obtežitve asociacij

170 Tabela 16: AGA-nadarjen učenec - struktura semantičnih kategorij

171 Tabela 17: AGA-izobraževanje nadarjenih - struktura semantičnih kategorij

195 Tabela 18: Izid Mann-Whitneyevega preizkusa razlik $v$ samooceni učinkovitosti učiteljev pri učenčevem sodelovanju glede na šolo poučevanja

197 Tabela 19: Izid Mann-Whitneyevega preizkusa razlikv samooceni učinkovitosti učiteljev pri poučevanju glede na šolo poučevanja

198 Tabela 20: Izid Mann-Whitneyevega preizkusa razlik $v$ samooceni učinkovitosti učiteljev pri vodenju razreda glede na šolo poučevanja

210 Tabela 21: Deskriptivna statistika in korelacije na vzorcu učencev iz Slovenije

211 Tabela 22: Hierarhična regresijska analiza za spremenljivke, ki napovedujejo viktimizacijo na vzorcu učencev iz Slovenije

212 Tabela 23: Deskriptivna statistika in korelacije na vzorcu učencev iz Hrvaške

212 Tabela 24: Hierarhična regresijska analiza za spremenljivke, ki napovedujejo viktimizacijo na vzorcu učencev iz Hrvaške

213 Tabela 25: Deskriptivna statistika in korelacije na vzorcu učencev iz Švedske

214 Tabela 26: Hierarhična regresijska analiza za spremenljivke, ki napovedujejo viktimizacijo na vzorcu učencev iz Švedske

255 Tabela 27: Števila $(f)$ in strukturni odstotki ( $f \%$ učencev po znanju, izraženi z modalno oceno, pri opazovanem predmetu.

255 Tabela 28: Števila $(f)$ in strukturni odstotki ( $f$ \%) učencev po govorni participaciji.

256 Tabela 29: Izid-preizkusa razlik $v$ znanju glede na stopnjo govorne participacije.

274 Tabela 30: Descriptions of anxiety reactions and opposite reactions to anxiety in foreign language learners. 
276 Tabela 31: Tabular view of applied Horn parallel analysis with data permutation $(K=300)$.

276 Tabela 32: Correlation between items and factor.

287 Tabela 33: Definicija trajnosti rezultatov

290 Tabela 34: Trajnost rezultatov in tip projekta

299 Tabela 35: Gender of respondents

299 Tabela 36: Contribution to student's competencies by participating in mini-companies in relation with current occupation of students

300 Tabela 37:Degree of satisfaction with the program and attenting subject entrepreneurship in school (cross tabulation)

300 Tabela 38: Recommendation of the program and current occupation of students (cross tabulation)

302 Tabela 39: Students opinion about knowledge and skills improved during the program (the respondents were able to choose 4 answers in total)

302 Tabela 40: Teachers opinion of knowledge and skills students improved during the program (the respondents were able to choose 4 answers in total)

312 Tabela 41: Pet dimenzij učinkovitega timskega dela po Ohlandu

316 Tabela 42: Časovni in vsebinski potek akcijskega raziskovanja

317 Tabela 43: Čas zbiranja podatkov s posameznimi raziskovalnimi pripomočki

318 Tabela 44: Dejavnosti in merila $v$ šolskem letu 2017/18

319 Tabela 45: Primerjava rezultatov zaznavanja elementov timskega dela

320 Tabela 46: Primerjava rezultatov osebne pripravljenosti za timsko delo

339 Tabela 47: Število testiranih tretješolcev OŠ Loka Črnomelj (N) po posameznih letih glede na podtest (Hitrost razumevanja in Stopnja razumevanja) ter rezultati (številčno in vodstotkih) po posameznih območjih (nadpovprečen, povprečen, podpovprečen rezultat).

340 Tabela 48: Rezultati Bralnega testa posameznih učencev istega razreda

345 Tabela 49: Structure of the sample in relation to the class that respondents attend 



\section{Uvod}

Igor Ž. Žagar

\section{$\mathrm{V}$}

prostorih Znanstveno-raziskovalnega centra SAZU je 18. in 19. septembra 2019 potekala 4. nacionalna znanstvena konferenca »Raziskovanje v vzgoji in izobraževanju«. Na konferenci je bilo predstavljenih 96 prispevkov (6o znanstvenih in 37 strokovnih) v sedmih sekcijah (Izobraževalne politike, Evalvacija in zagotavljanje kakovosti, Profesionalni razvoj pedagoških delavcev, Učenje in poučevanje, Inovativni pristopi k učenju in poučevanju in Socialni odnosi v vzgoji in izobraževanju), udeležilo pa se je je 161 zainteresiranih posameznikov in posameznic. To je bila do sedaj največja in najbolje obiskana konferenca, ki jo skupaj organiziramo Pedagoški inštitut, SLODRE in CMEPIUS.

Kot plenarna predavatelja sta nastopila dr. Paul Stubbs, Ekonomski inštitut v Zagrebu, s predavanjem Inequality, Poverty and Education in the Post-Yugoslav space: from immobility to inclusion, in prof. dr. Pavel Zgaga, Pedagoška fakulteta Univerze v Ljubljani, ki je predaval na temo Raziskovanje edukacije in edukacijske politike.

$\mathrm{Na}$ konferenci smo, kakor vsako leto, podelili tudi 3 priznanja, in sicer: dr. Marini Volk (Univerza na Primorskem, Pedagoška fakulteta), ki je prejela Priznanje za najboljše doktorsko delo na področju raziskovanja vzgoje in izobraževanja za leto 2019, izr. prof. dr. Gregorju Torkarju (Univerza v Ljubljani, Pedagoška fakulteta), ki je prejel Priznanje za izjemne dosežke na področju raziskovanja vzgoje in izobraževanja za leto 2019, ter ddr. Zdenku 
Kodelji (Pedagoški inštitut), ki je prejel Priznanje za življenjsko delo na področju raziskovanja vzgoje in izobraževanja za leto 2019.

Recenzijski postopek je uspešno prestalo 23 razširjenih prispevkov s konference, in sicer $4 \mathrm{v}$ kategoriji strokovnih prispevkov in $19 \mathrm{v}$ kategoriji znanstvenih prispevkov. Glede na skupno število predstavljenih prispevkov se številka morda ne zdi velika, vsekakor pa dokaj reprezentativno naslavljajo večino tem, ki jim je konferenca posvetila svojo pozornost.

Zaželim vam lahko le še prijetno branje!

prof. dr. Igor Ž. Žagar, predsednik Programskega odbora 


\section{Raziskovanje edukacije in edukacijske politike, ali o razmerju 'kraljev' in 'filozofov'}

Pavel Zgaga

\section{$\mathrm{O}$ »akademskem« in »administrativnem« diskurzu}

Edukacijski sistemi so v minulih dveh stoletjih postali vseobsežna struktura, ki vsakogar močno in odločilno zaznamuje, praviloma večkrat $\mathrm{v}$ življenju. So ena izmed ključnih značilnosti modernih družb, vključno z njihovo postmoderno fazo. $\mathrm{V}$ dveh stoletjih so se postopoma, a temeljito spreminjali ob vključenosti tako »stroke« kot "politike« in tudi najširše javnosti: »šolske reforme« poznamo vsi, sedanje in pretekle generacije. Med nekdanjimi in sedanjimi reformami pa je kar nekaj opaznih razlik. Ena med njimi je vse večja intenzivnost reform.

$\mathrm{V}$ javnosti je že lep čas sprejeto razumevanje, da t.i. »nenehne spremembe v družbi« pač zahtevajo tudi nenehne reforme družbenih podsistemov. In ker je šolstvo nadvse kompleksen podsistem, je treba njegovo reformiranje utemeljiti na premišljenih in preverjenih strategijah, edukacijskih politikah, kar pa seveda ne bi bilo mogoče, če reformatorjem ali odločevalcem ne priskočijo na pomoč raziskovalci, ki zagotovijo, da so nove politike (policy; ne politics) res »utemeljene na dokazih«. Tu se začenja naš problem: če podrobneje opazujemo razmerje med oblikovanjem politik in zagotavljanjem njim potrebne raziskovalne podpore, lahko ugotovimo, da je to razmerje pogosto krhko in ambivalentno.

Po sodobnem razumevanju je predpogoj za reformo, tj. za učinkovito modernizacijo kateregakoli podsistema sodobnih družb, medsebojna po- 
vezanost med oblikovanjem politik in raziskavami na danem področju. ${ }^{1}$ Od sredine prejšnjega stoletja dalje se je uveljavilo prepričanje, da morajo v demokratičnih ureditvah javne politike »temeljiti na dokazih«. In kdo naj jih zagotovi, če ne raziskovalne ustanove? Na prvi pogled se zdi argument pričakovan in neproblematičen. Vendar se ta idealna slika hitro zaplete. $\mathrm{Na}$ eni strani je zahteva, da demokratične reformne politike ne temeljijo na nejasnih ali spornih predpostavkah, še manj na golih verovanjih neke družbene skupine; na drugi strani pa obstoji bojazen pred raziskovanjem, zaklenjenem v »slonokoščene stolpe " in "oddaljenem od resničnega življenja«. Skratka, reforme morajo biti "znanstveno« utemeljene, zahtevano »znanje « pa ne sme biti »akademsko«, »abstraktno« ali »nerelevantno«, kot je temu popularno reči danes. Normativnost, ki jo izražajo takšna stališča, je povezana s situacijami, $\mathrm{v}$ katerih oblikovanje področnih politik (policy) in sprejemanje odločitev zadene $\mathrm{v}$ jedro strankarske in institucionalne politike (politics). Nič manj ni povezana s situacijami, ko se raziskovalci dejansko zaprejo v svoje »stolpe«, da bi zaobšli različne slutene težave, npr. tiste, ki ogrožajo njihov akademski status, avtonomijo in dostojanstvo.

Oblikovanje politik je hiša iz kart, če ga ne podpirajo ugotovitve ter dokazi, do katerih se dokoplje raziskovanje. Toda ob tistih vprašanjih, o katerih se odloča akademsko, na podlagi raziskovalnih teorij in metodologij, razprave in polemik, očitno obstojijo še vprašanja nekega drugega reda, vprašanja, o katerih se lahko odloča le politično, npr. v parlamentu, na vo-

1 Skozi različna očala je zgodovino tega razmerja moč opazovati bodisi kot zelo dolgo bodisi kot precej kratko (Simons, Olsen \& Peters, 2009: 1-2): začnemo lahko pri izobraženih svetovalcih raznih vladarjev preteklosti (ali še širše: npr. Aristotel je bil vzgojitelj Aleksandra Velikega) ter nadaljevati preko npr. Polizeiwissenschaften 18. stoletja vse do osamosvojitve družbenih ved proti koncu 19. stoletja. Danes se vzpostavitev tega razmerja sicer najpogosteje navezuje na čas po koncu druge svetovne vojne - takrat se v ZDA pojavi odmevna trditev, da bi morala biti znanost edina prava skrb vlade (Bush, 1945) -, ko je postopoma pričela nastajati analiza politik (policy analysis) kot posebna znanstvena disciplina (Lasswell, 1951). Pri tem je smiselno razlikovati med raziskavami »o« javnih politikah in raziskavah »za« javne politike (Fink-Hafner, Lajh, 2002: 8). V našem primeru imamo v mislih predvsem slednje.

Metafora o akademskih "slonokoščenih stolpih" se v javnosti najraje razume v kontekstu tradicije »temačnega srednjega veka«, vendar je to očitno podoben mit kot zgodba o srednjeveškem sežiganju čarovnic, široko prakticiranem v novem veku. Harvardski profesor Henry Rosovsky je raziskoval to metaforo in njeno prvo navezavo na akademskim kontekst pripisuje pisatelju H.G. Wellsu, ki je v delu The New World Order (1940, str. 133) zapisal: »Želimo ministra za izobraževanje, ki bi lahko ... naelektril in pomladil stare dons /profesorje/ ali pa jih odložil v slonokoščene stolpe « (gl. Rosovsky, 2002: 14). Tudi ta mit torej priča o človeškem nagnjenju, ki se temnih podob sedanjosti reši tako, da jih pripiše preteklosti. 
litvah ali referendumu ipd. Pomembno je torej zavedati se konceptualne razlike, ki jo slovenimo kot razliko med politikami - ali strategijami, načrti urejanja danega družbenega podsistema - in politiko (Fink-Hafner, Lajh, 2002: 8-11), politično močjo.

$\mathrm{V}$ razmerju med raziskovanjem in oblikovanjem politik se vsak pol srečuje s posebnimi zahtevami in pričakovanji. Ena stran (recimo ji administrativna) se, na primer, srečuje $\mathrm{z}$ zahtevo, ki lahko prihaja iz krogov političnih elit, lahko pa tudi iz širše javnosti, da je treba sistem, za katerega je odgovorna, "upravljati učinkovito", to je, da npr. »smotrno vlaga denar davkoplačevalcev«, da so dejavnosti »družbeno relevantne«, da sistem dosega »odlične rezultate«, zlasti v mednarodni primerjalni razsežnosti, ipd. Takšne zahteve in pričakovanja pogojujejo in vzpostavljajo diskurz, ki se bistveno razlikuje od diskurza druge strani (recimo ji akademska), to je diskurza, ki ga - vsaj v idealni perspektivi - terja zahteva po objektivnem, nepristranskem iskanju resnice, odmaknjenem od parcialnih interesov, kot se izražajo v politiki in družbi sploh: na primer, da se objektivno in kritično preuči, ali in v čem je nek izobraževalni sistem resnično uspešen ali neuspešen.

Prav razlika med tema dvema diskurzoma - diskurzom »učinkovitosti« in »relevantnosti« ter diskurzom »objektivnega iskanja resnice« - je tisto, zaradi česar pri razmerju med raziskovalci in oblikovalci politik ne moremo pričakovati ravno "srečnega zakona«, čeprav obstajajo še drugi razlogi, da je temu tako. Ta potencialni antagonizem in posledična ambivalentnost teh dveh diskurzov ni odkritje našega časa. O tem več kasneje; najprej želim odpreti neko drugo vprašanje: vprašanje, ki zadeva pojem upravljanja in $\mathrm{z}$ njim povezanega vprašanja reform.

\section{O upravljanju »resničnega življenja«: »tu ni nič ustaljenega«}

Šolska reforma - in reforme kateregakoli drugega socialnega podsistema ni mogoča kot simulacija v laboratoriju. Sistema ni mogoče »izklopiti« npr. za eno leto, da bi ga $\mathrm{v}$ tem času $\mathrm{v}$ miru temeljito obnovili in prenovili, kot to delamo s šolskimi poslopji $v$ času počitnic. Izpeljati jo je treba $v$ t.i. »resničnem življenju«, ki ga zaznamuje enkratnost z vsakokrat drugačnimi posebnimi okoliščinami. In v »resnično življenje« smo vedno vpleteni osebno.

Da bi temeljiteje doumeli, v čem so problemi "resničnega življenja«, pa tudi to, da ob njihovem reševanju lahko tvegamo ustvariti nove probleme, osebne izkušnje niso dovolj. Potrebujemo »laboratorije«, v katerih se na podlagi akumuliranih in ustrezno obdelanih podatkov oblikujejo smisel- 
ni zaključki, itd. To so nujna izhodišča, da se racionalne reforme lahko lotimo. Le z naslonitvijo na raziskovalne rezultate lahko postane reformni proces predvidljiv in uspešen, čeprav morda le do evalvacijskega poročila, ki opozori na neuspeh določenih reformnih ukrepov in reformatorje sili, da se odločijo za nadaljnje popravke sistema, za reformo reforme. Delovanje vsakega družbenega podsistema je pod pritiskom tega, čemur se popularno reče »imperativ nenehnih sprememb «, to pa močno oteži življenje oblikovalcev politik. A brez »laboratorija « bi bili v še bolj brezupnem položaju.

Reforme podsistemov izvajajo pristojne oblasti, običajno vlade. Vlado povezujemo s politično močjo in $\mathrm{z}$ izvajanjem te moči. Politična moč ureja podsisteme preko nekega navidezno nevtralnega orodja, ki smo ga imenovali »administrativna stran«. Tej nasproti stoji »akademska stran«, torej tista, ki je vezana na neko drugo moč, na moč znanja in na izvajanje te specifične moči. Vsaka od teh dveh strani deluje po drugačnih pravilih, znotraj drugačnega diskurza. Nekoliko poenostavljeno rečeno: ena stran misli, druga stran pa upravlja. Videti je, kakor da je glagol upravljati tu rezerviran zgolj za izvrševanje politične moči. Najprej se bomo malo zadržali pri etimologiji.

Pojem »upravljanje« je v sodobnih jezikih pretežno administrativen, instrumentalen pojem. SSKJ kot možnosti najprej omenja »upravljanje države« ali »občine«, nato »upravljanje gozdov«, »upravljanje strojev« ipd. Snojev (1997) etimološki slovar pa povezuje slovenski pojem »uprava« s hrvaškim »upraviti«, torej »usmeriti«, prvotno »delati prav«, kar kaže na širši pomenski horizont. Ta horizont je etimološko morda bolje prisoten $v$ nekem drugem izrazu, ki pa se $\mathrm{v}$ našem jeziku ni uveljavil in danes $\mathrm{v}$ njem deluje kot relativno obrobna tujka. $\mathrm{V}$ mislih imam besede, ki koreninijo $\mathrm{v}$ latinski gubernare. Čeprav so nekateri jeziki, npr. francoščina in angleščina, obdržali tesnejši stik s tem latinskim korenom (le gouvernement; governance ipd.), pa samo zaradi tega ne moremo trditi, da tudi $v$ teh jezikih iz njega izhajajoči pojmi danes nimajo prvenstveno instrumentalnega pomena.

$\mathrm{V}$ takih primerih ob etimologiji pomaga tudi vpogled $\mathrm{v}$ zgodovino idej. Starogrški kybernaein - v njem je ozadje latinskega gubernare - sodobna ušesa lahko povežejo s kibernetiko, sodobno interdisciplinarno znanostjo o tehničnih, sociotehničnih in družbenih sistemih oz. njihovim usmerjanjem $v$ želeno smer, kot pravi ena izmed definicij. Takšna povezava ima podlago, a še vedno poudarja instrumentalno dimenzijo, tako značilno za moderno dobo. Ko so antični filozofi razpravljali o človeških dejanjih, 
je bila kybernetike tekhne - umetnost krmarjenja, navigacija, upravljanje plovila na morju - pogosto uporabljena metafora. V Aristotelovi Nikomahovi etiki najdemo odlomek, ki lahko pomaga pri rekonstrukciji druge, ne-instrumentalne dimenzije pojma u-pravljanja (kot delati prav, delati pravično):

/.../ poudarimo, da se moramo pri razpravljanju o dejanjih zadovoljiti z grobim orisom in da nima smisla o tem razpravljati $z$ vso natančnostjo. Saj smo že uvodoma poudarili, da se mora oblika razprave prilagoditi obravnavani snovi. $\mathrm{V}$ območju dejavnosti in koristnosti ni nič ustaljenega - podobno kot v vprašanjih zdravja. Kar velja za razpravo o splošnih vprašanjih, to velja še tem bolj za posameznosti: tu je natančnost povsem izključena. Zakaj teh posameznosti ni mogoče uravnavati po nekih strokovnih predpisih ali navodilih, ampak ljudje morajo v svojih dejanjih upoštevati vse okoliščine, ki spremljajo trenutno situacijo - prav tako, kot je to v zdravniški ali krmarski stroki. (Aristotel, 1964: 1104 a)

Ko gre za območje dejavnosti in koristnosti, to je, za zadeve, ki se nanašajo na človeška dejanja in za vprašanje, kaj je za nas dobro, si Aristotel pomaga $\mathrm{z}$ nečem, kar $\mathrm{v}$ sodobnosti povezujemo $\mathrm{z}$ instrumentalnim umom: zdravniška ali krmarska stroka. Kapitan ladje je lahko resnično dober člo$v e k$, a za sodobno racionalnost nam $\mathrm{v}$ strahotnem viharju to ne pomaga; pomaga lahko le njegova tehnična izurjenost. Tu pa preberemo še nekaj: $\mathrm{v}$ tem, kar opredeljuje krmarjevo ali zdravnikovo kakovost, izurjenost, ni nič ustaljenega; za prakticiranje takšnih poklicev velja, da ju ni mogoče uravnavati po nekih strokovnih predpisih ali navodilih, ampak morajo akterji v svojih dejanjih upoštevati vse okoliščine, ki spremljajo trenutno situacijo. Nekaj odstavkov pred tem mestom (1097 a) Aristotel - v očitni polemiki s Platonom - dodaja, da védenje o »dobrem samem na sebi« ne bi prav nič pripomoglo k temu, da bi nekdo postal boljši zdravnik, kajti »zdravnik ne išče /.../ ,zdravja samega po sebi', ampak išče le človekovo zdravje, še več, išče le zdravje konkretnega pacienta; saj mora vsak posamezen primer zdraviti posebej« (kurziva P. Z.). Z drugimi besedami, v polju človeških zadev ni načelnih in splošnih rešitev (»idej«), tako kot recimo v polju matematičnih in podobnih problemov; tu ni rutinskih obrazcev ali receptov, ki bi jih lahko brez poglabljanja $\mathrm{v}$ podrobnosti uporabili $\mathrm{v} v$ seh posameznih situacijah. Skratka, tu »ni nič ustaljenega«. 
Zakaj govorimo o tem? Zato, ker smo danes nenehno soočani s ponudbo receptov in obrazcev, ki z eno »formulo « obljubljajo rešiti vsak problem »resničnega življenja«. Eden med njimi je npr. ta, da privatizacija prinaša večjo »učinkovitost«, itd., pa naj gre za gospodarska podjetja ali ustanove, kot so bolnišnice in šole. Pri tem ne gre zgolj za pritisk trenutne konstelacije politične moči in njene ideologije, pač pa za podrobno izdelane koncepte in teorije, ki jih po naši prejšnji razdelitvi lažje pripišemo »akademski« kot »administrativni« strani. Ko gre za upravljanje različnih sfer javnega življenja, se (zlasti v akademskih krogih) pogosto domneva, da je »akademski« strani kar po njeni naravi lastna kritična naravnanost do (predpostavljenega) oportunizma »administrativne« strani. V takšnih primerih je priporočljiva predvsem kritična in reflektivna samo-naravnanost, ki pa je žal ni vedno moč prepoznati kot neločljive prvine akademskega diskurza.

Aristotel je opozoril na enkratnost in edinstvenost "priložnosti«, s katerimi se v »resničnem življenju« srečujemo vedno znova in ob katerih je treba temeljito premisliti, kaj je v danem primeru najbolj »primerno«: kaj naj usmerja, vodi, u-pravlja našo odločitev. Zavrnil je "recepte«, tehnično-nevtralna orodja, ki so sicer lahko »učinkovita « in prinašajo value for money, če uporabimo sodoben izraz. Techne, tehnične veščine so nujni, a ne zadostni temelj civilizacije; za delovanje $\mathrm{v}$ družbenem svetu je potrebna phronesis, praktična modrost kot kultivirana sposobnost, usposobljenost za vpogled v človeško, usposobljenost, ki pomaga, da sprejmemo prave odločitve $\mathrm{v}$ različnih človeških situacijah. Biti krmar ali zdravnik, vladar ali raziskovalec - vse to so človeške situacije, močno različne ena od druge, pa vendar še kako človeške. Odločitve, ki jih sprejemamo v teh situacijah, so odločitve, ki nas »u-pravijo«, popeljejo v »pravo smer«. Ali pa tudi ne.

Tu smo že pri edukaciji. Seveda mora biti krmar posvečen v skrivnosti »teorije svojega poklica«, to pomeni, da mora biti izobražen in usposobljen za branje pomorskih zemljevidov, za razumevanje in predvidevanje spreminjajočih se vremenskih razmer, poznati mora tehnične značilnosti plovil, itd. Ko pa se na viharnem morju sreča z grožnjo življenju, se mora opremljen $z$ znanjem in veščinami ustrezno odločiti, ne pa zgolj »držati predpisov«, naučenih na kopnem in morda določenih le po tistih ljudeh, ki ostajajo na kopnem. Zato se nihče ne more naučiti krmariti preprosto tako, da se nauči norm, "pravilnega samega po sebi«, "splošnih predpisov«, saj nikoli ne morejo biti dovolj podrobni, da bi jih lahko uporabili prav v vsakokratnih posebnih okoliščinah in prav za vsak poseben primer, s katerim 
se v »resničnem življenju« lahko srečamo. Instrumentalni um je v takšnih situacijah nezadosten.

Aristotelovega metaforičnega »krmarja«, torej »u-pravitelja plovila«, tistega, ki usmerja $v$ pravo smer oziroma deluje prav, po svoje lahko razumemo kot nekakšen spoj tega, kar v sodobnem času izražamo z dvema potencialno polarnima izrazoma: raziskovalec in odločevalec. Da bi odločili o pravi smeri, to je, da bi $u$-pravljali prav, moramo marsikaj vedeti, znati: odločitev in svoja dejanja moramo nasloniti na znanje, vendar ne le na znanje kot techne, produktivno veščino, ki prevladuje $\mathrm{v}$ naši dobi, ampak tudi na phronesis, praktično znanje $e^{3}$ oziroma modrost za odločanje in u-pravljanje bodisi z lastnim življenjem bodisi z življenji drugih ljudi. Glagola upravljati torej nikakor ne moremo rezervirati le za instrumentalne diskurze, za $i z v r$ ševanje politične moči, vključno $\mathrm{z}$ administracijo, tehnologijami itd. Prisoten je tudi pri izvrševanju moči znanja, npr. ob vprašanjih, ki se tičejo raziskovalne etike, a nikakor ne samo tu. $S$ tem se odpira nov spekter vprašanj.

\section{O (ne)razsvetljenosti vlad in (ne)razsvetljenosti znanosti}

Dva diskurza, o katerih govorimo, sta strukturno različna, do določene mere nezdružljiva, vendar soodvisna. Situacije, v katerih se lahko znajdeta $\mathrm{v}$ sporu, so pomešane $\mathrm{s}$ situacijami sodelovanja. Njuno razmerje je ambivalentno. Dodati je treba naslednje: nujen pogoj, da se ta ambivalentnost reducira na normalno, »znosno" raven, ki omogoči, da rezultati raziskav dejansko lahko prispevajo k reševanju družbenih izzivov, je obstoj »razsvetljene" vlade.

Toda to še ni zadosten pogoj; nekaj je odvisno tudi od znanosti same in njene lastne "razsvetljenosti«. Bolj ko politika izgublja razsvetljeni značaj (kot npr. v sedanji dobi populizma), bolj problematična postaja družbena relevantnost raziskovanja. $\mathrm{V}$ takšnih razmerah bi se morale $\mathrm{v}$ akademskem diskurzu krepiti kritične in celo provokativne note, sicer ta diskurz tvega, da bo povsem reduciran na instrumentalnost, na vladno tehnologijo. To tveganje nikakor ni le abstraktna možnost.

Tu je potrebna kratka opomba o tem, kaj mislim z izrazom razsvetljenost znanosti. Kot sem bežno že omenil, akademskemu diskurzu samemu po sebi ne bi smeli avtomatično pripisati kritičnosti in kar verjeti, da se brez vsake pragmatične računice vedno in takoj odloči za spopad z vsako obli-

3 Za Aristotela obstajata dve vrsti človeške dejavnosti: praxis in poiesis. Prva je etično odgovorno ravnanje, cilj sama po sebi; druga je raznovrstno ustvarjanje, sredstvo za dosego cilja. 
ko »nerazsvetljenega administriranja«. Vzporedno z dihotomijo »razsvetljenega" in "nerazsvetljenega" vladanja lahko govorimo tudi o dihotomiji »razsvetljenega in »nerazsvetljenega« raziskovanja. Slednje je tisti tip raziskovanja, ki ga bistveno opredeljuje instrumentalna naravnanost. Ne gre le za domnevno penetracijo "političnega $\mathrm{v}$ »akademsko«; ta naravnanost je tudi posledica notranjih oblastvenih hierarhij, značilnih za svet homo academicus (Bourdieu, 2012).

Za primer jemljem občutljivo temo izobraževanja za demokratično državljanstvo, pomembno tudi v raziskovanju edukacije. Eden izmed nasledkov razsvetljenske ideje o obveznem javnem šolstvu je $\mathrm{v}$ tem, da je bila med ključne cilje kurikuluma zapisana tudi edukacija (bodoče/ga) državljanke in državljana. Ne »vernika«, kot bi veljalo v tradiciji verouka, niti ne kozmopolitanskega »človeka«, kot npr. pri Kantu, pač pa »državljana«, »državljanke«. Ta ideja se je realizirala na protislovne načine, ki so temeljili tako na »razsvetljenih« kot »nerazsvetljenih« interpretacijah. Pri mislecih kot je npr. John Dewey, zavezuje ljudi k skupnemu človeškem prizadevanju, v političnih diskurzih, ki so $\mathrm{v}$ moderni dobi vzniknili z rojstvom nacionalne, pa tudi (brez)razredne države, pa kot »vzgajanje pravega rodoljuba«.

Obvezno izobraževanje so že vlade v 19. stoletju porojenih nacionalnih držav razumele kot edinstveno priložnost ne le za povečanje ekonomske učinkovitosti, pač pa tudi za normalizacijo svoje populacije. Socializacijska in normalizacijska funkcija edukacije je bila prav v ospredju nastajajočih nacionalnih edukacijskih sistemov, čeprav $\mathrm{v}$ protislovni in sprevrnjeni obliki glede na izvorne razsvetljenske ideje; če si pomagamo z Althusserjevim konceptom, se je udejanjala videoloških aparatih države. Ta funkcija je postopoma prešla tudi v ospredje družboslovnih raziskav, tako "razsvetljenih" kot »nerazsvetljenih«. Po koncu 2. svetovne vojne pa pride do pomembne spremembe, ki se je najprej in najbolje izrazila v ameriškem kontekstu.

Šok, ki je v ameriški javnosti nastopil s Sputnikom 1 ( 1957), je dobro znan. Izzvalo ga je dejstvo, da je znanje, ki ga je do takrat akumulirala domnevno civilizacijsko zaostala Sovjetska zveza, tehnološko premagalo superiorno znanje Združenih držav, ki se je dokazalo $\mathrm{v}$ številnih tehničnih izumih in inovacijah še iz časa druge svetovne vojne. Učinek šoka je med drugim pripeljal do hitrega povečanja sredstev za raziskovanje, ki so merila predvsem na to, da ZDA znova pridobijo premoč na področju znanja in inovativnosti. Pri tem so se pomembno povečala tudi sredstva za raziskovanje edukacije. 
Ameriški avtorji so analitično pokazali, da je bila v obdobju hladne vojne socializacijska funkcija edukacijskega sistema porinjena na margino, poudarek pa se je prenesel na pomen edukacijskega sistema za razvoj znanosti. Sputnikov šok je močno pospešil to spremembo. Konceptualno se je pričel že v 2. svetovni vojni ali celo pred njo, nato pa se je napajal iz hladne vojne, ki je sledila. Inženir, izumitelj in znanstveni administrator /science administrator/ Vannevar Bush, ki je med vojno vodil Ameriški urad za znanstveno raziskovanje in razvoj, je v odmevnem dokumentu Science - The Endless Frontier Beli hiši že leta 1945 sporočil, da je le znanost prava skrb vlade (Bush, 1945). Njegovi pogledi so prispevali k temeljitemu zasuku v ameriških znanstvenih in tudi edukacijskih politikah, posredno pa so prispevali k novi instrumentalni zasnovi smotrov edukacije, ki se je iz ZDA postopoma razširil praktično po vsem svetu.

$\mathrm{V}$ tem zgodovinskem in geografskem kontekstu se je oblikovala the policy science (Lasswell, Lerner, 1951) z velikim vplivom vse do današnjih dni. Pričelo se je $\mathrm{z}$ vero političnih in administrativnih elit $\mathrm{v}$ scientifično ${ }^{4}$ racionalnost kot ključ za reševanje skupnostnih problemov. V krog teh elit so vstopili scientokrati, reševanje skupnostnih problemov pa je zadobilo poudarjen tehnokratski značaj (gl. Innerarity, 2012). Dobrega pol stoletja je seveda prispevalo k mnogim premenam tega koncepta. Naraščajoča scientifikacija politike, tj. "govoriti môči resnico«, je vodila k politizaciji znanosti (Hoppe, 1999). Ampak scientifično znanje se je v nekaterih odmevnih dogodkih izkazalo za zmotljivo. Weingart (1999: 151) npr. omenja nesrečo v nuklearnem reaktorju na Otoku treh milj (ZDA) leta 1979, kjer je bila »znanstvena kredibilnost« prva žrtev. Tovrstne izkušnje, pa tudi akademska kritika "pozitivističnega uma« je tehnokratski opciji zoperstavila »rekurzivni model « (ibid.: 154-157), ki opozarja na »zainteresiranost « znanja in terja demokratizacijo znanstvenega svetovanja. Zgodi se premik od »govoriti môči resnico« k »skupnemu oblikovanju smisla" (Hoppe, 1999: 209).

Ob petdesetletnici Sputnikovega šoka je Alvin Powell v The Harvard Gazette zapisal: »Post-Sputnikove reforme so bile položene v roke znanstvenikov, na precejšnje zgražanje nekaterih pedagogov/educators/ in zainteresiranih državljanov, ki so poprej imeli veliko vlogo pri oblikovanju učnih načrtov« (Powell, 2007). Diana Reische, nekdanja raziskovalka pri nevladni American Association of School Administrators, pa je v študiji iz leta 1987 o tem obdobju zapisala: »Tudi družboslovci so menili, da ,drža-

$4 \quad$ Namenoma na uporabljam slovenskega termina znanost (in njegovih izpeljank), ker ga glede na anglosaksonsko science zaznamuje konceptualna drugačnost. 
vljanstvo' ni intelektualno vreden cilj raziskovanja«. Bruce Macfarlane, profesor na Univerzi v Bristolu, je to trditev še poglobil, ko je pojem »the retreat from citizenship« (»umik od državljanstva«) povezal s pojmom »the disengaged academic « (torej »neangažirani«, »raz-angažirani akademik«). Članek se prične s stavkom: »We live in an age of civic disengagement«. (Macfarlane, 2005: 296).

Teh nekaj navedkov bo dovolj, da lahko ilustriramo trend od obdobja hladne vojne do današnjih dni. V dobrega pol stoletja akademska okolja sicer niso bila povsem izločena iz družbenih gibanj različnih vrst in intenzitet, toda ta angažiranost večinoma ni bila deležna institucionalnih spodbud, ampak pogosteje solzivca in vodnih topov. »Duh časa«, če uporabimo ta ohlapen termin, je odrinil zavzetost za družbeni kontekst na obrobje in jo nadomestil $\mathrm{z}$ atomističnim individualizmom, ki je dobil ikonsko upodobitev v stavku Margaret Thatcher (1987) »There is no such thing as society«. Po obdobju, v katerem so akademski teoretiki najavili »konec ideologij« (npr. Bell, 1960), je vzniknila doba neoliberalne ideologije.

Kako je vse to povezano $\mathrm{z}$ razmerjem med raziskovanjem edukacije in edukacijskimi politikami? Neoliberalna ideologija, na kratko, ponuja za "vrhovno resnico« doktrino, po kateri je (tudi) edukacija sistem vložkov in dobitkov (ali izgub), sistem torej, ki je reduciran na ekonomsko funkcijo (Starr, 2019). Ta doktrina je po svetu naletela na raznovrstne odpore, zato bi

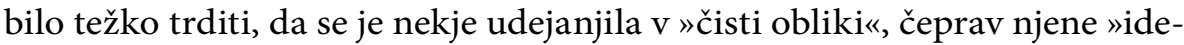
alne podobe« ni težko konstruirati. V skladu s to doktrino je legitimno raziskovanje tisto, ki prinaša "uporabne« in »koristne « industrijske inovacije, legitimna oblika izobraževanja pa je tista, ki zagotavlja »fleksibilno« delovno silo. V tej doktrini ni prostora za »državljana«, saj države praktično več ni, je le še »Trg«. Raziskovanje je servis tehnologije upravljanja, podobno kot je bila filozofija nekoč »dekla teologije«. Tu se v idealni obliki srečujemo $\mathrm{z}$ »nerazsvetljenim« vladanjem kot tudi $\mathrm{z}$ »nerazsvetljeno« znanostjo.

Pri tem pa težava sploh ni v tem, da se raziskovalci "prodajo« nekomu, ki ima denar in/ali politično moč. Težava se pojavi tudi, ko raziskovalci takšni »intelektualni prostituciji« nasprotujejo, npr. tako, da se z zgražanjem odvrnejo od »umazane politike«, meneč, da se "pravi raziskovalec ne vmešava v politiko«, ampak deluje kot nekakšen »duhovnik v templju svete čiste znanosti«. To je »raz-angažirani akademik«, o katerem govori Macfarlane. $V$ tem pa je dodaten razlog za ambivalenco med raziskovanjem in oblikovanjem politik. 


\section{$\mathrm{O} » k$ raljih» in »filozofih»}

Razpravljamo o eni izmed ključnih dilem, ki zaznamuje sodobni položaj akademskega raziskovanja. Ko je v 19. stoletju nastajala t. i. raziskovalna univerza, je položaj rednega profesorja običajno podelil vladar. Potem je profesor skrbel za svoj laboratorij, ki je včasih prinesel uporabne in včasih neuporabne rezultate, vse do smrti. Ni mu bilo treba skrbeti za levantnost«, »uporabnost«, revije z visokim »impakt faktorjem«, preglede kakovosti ali položaj svoje institucije na Šanghajski lestvici. Od tedaj se je vse spremenilo. Po svoje je presenetljivo, kako visok konsenz - tako v širši družbi kot na akademskih ustanovah - obstoji o tem, da morajo biti raziskave kolikor je le mogoče relevantne, da morajo biti njihovi rezultati kolikor je le mogoče koristni, in kako grozno da je, ker je letos Univerza v Ljubljani na Šanghajski lestvici padla za sto mest.

Zdi se, da bi bilo zelo težko - če ne že kar nemogoče - ugovarjati temu razširjenemu prepričanju. Kaj drugega pa naj bi zahtevali od ustanov, ki se financirajo $\mathrm{z}$ »denarjem davkoplačevalcev«? Drugače povedano: če zasebno podjetje naroči raziskovalno študijo, potem od nje pričakuje neko korist. Zakaj bi moralo biti drugače v primeru, ko je naročnik javna ustanova, npr. nacionalna raziskovalna agencija? S takšno argumentacijo se ni težko strinjati, obenem pa sem prepričan, da je ugovor kljub temu smiseln in celo nujen. Če namreč zahtevo po relevantnosti in koristnosti raziskovanja in znanosti postavimo pod kritično lečo, se pojavi zoprno vprašanje: kaj natančno bi bilo treba razumeti pod pojmi »relevantnost «, "uporabnost«, "učinkovitost«? Ti pojmi predpostavljajo interese, običajno poslovne, praviloma čisto materialne interese, klasična akademska poklicanost pa naj bi bila naravnana na "iskanje resnice in zahteva nepristranskost ter objektiven, »nezainteresiran " pristop. To ostaja temeljno načelo tudi v sodobnem raziskovanju; če ga spodbijemo, pade koncept znanosti, kakršen je veljal doslej. To nas vodi na nek drug horizont: da bi bilo znanje, do katerega se dokopljemo $\mathrm{z}$ raziskovanjem, veljavno, zaupanja vredno, relevantno, ga je treba ločiti od materialnih interesov. Mar se med tem načelom in post-resničnostno sedanjostjo, v kateri štejejo objave na Twitterju, ne pa priznane in preizkušene akademske založbe, ne odpira ogromna in zlovešča razpoka?

Politična ali finančna moč ni zagotovilo zaupanja vrednega znanja. Nikoli ni bila. Toda brez finančne in politične podpore raziskovanje presahne. Težava je kompleksna: če se odločim, da se pridružim strani, ki me lahko materialno podpre, a z zahtevo po določenih protiuslugah, postanem »raziskovalec prostitut«; če pa vztrajam pri stališču nepristranskosti in 
objektivnosti, postanem »the disengaged academic« in to $\mathrm{v}$ obeh pomenih, ki jih ponuja angleščina: bodisi kot »raz-angažiran« bodisi kot »izključen« akademik. Kako rešiti to protislovje? Ali obstaja tretja možnost?

Govorimo o eni izmed ključnih sodobnih dilem, ki pa vendar ni tako zelo sodobna, da o njej ne bi bili razpravljali že klasični misleci. Tu je potemtakem pravo mesto, da znova posežemo k njim. Platon je antagonizem med politično močjo in močjo znanja poskušal razrešiti z znamenito metaforo o kralju-filozofu:

Če v državah filozofi ne postanejo kralji in če se današnji tako imenovani kralji in oblastniki ne začno pošteno in temeljito ukvarjati s filozofijo, če oboje - politična moč in filozofija - ne postane eno in če ne bo množica tistih, ki se danes po svoji prirojeni nagnjenosti posvečajo samo enemu od obojega, s silo izločena, potem, dragi Glavkon, ne vidim konca nesreč ne za države in ne za ves človeški rod, in tudi naša v mislih zasnovana država ne bo mogla biti prej uresničena in ne zagledati luči sveta. To je tudi vzrok za moje dolgo obotavljanje: videl sem namreč, kako kočljive in za javnost presenetljive bodo moje besede. Težko je namreč uvideti, da ni druge poti k sreči, ne k sreči posameznika in ne k sreči za skupnost. (Platon, 1995: Knjiga V, 18)

Če poenostavimo, Platon je dilemo razrešil z združevanjem dveh antagonističnih diskurzov v enega. Žal so bili takšni kralji v zgodovini absolutna izjema, prav tako filozofi, ki bi sedeli na prestolu, kar pa ne zmanjšuje ugleda Platonove utopije. Vendar: ali je takšno zlivanje diskurzov res pravi način za rešitev problema? Je sploh možno? Razprava o tem je stoletja stara in skozi čas so se okoliščine - ki vedno odločilno vplivajo na interpretacije - večkrat in globoko spremenile. Med odzivi na rešitev, ki jo je ponudil Platon, ima posebno mesto Kantov. Na začetku moderne dobe se mu je zoperstavil s povsem drugačnim razmišljanjem:

Tega, da bi kralji filozofirali ali da bi filozofi postali kralji, ne moremo pričakovati, pa tudi ne želeti: ker posedovanje oblasti nujno kvari svobodno sodbo uma. Toda to, da kralji ali kraljevska ljudstva (ki samim sebi vladajo po zakonih enakosti) razredu filozofov ne pustijo, da izgine ali onemi, temveč mu dovolijo javno govoriti, je obojim za osvetlitev njihovega posla neizogibno potrebno, in ker je ta razred po svoji naravi nezmožen, da bi se združil v krdela in klube, mu ni mogoče očitati propagande. (Kant, 2006, 114)

Kantove misli iz daljnega leta 1795 so bile vizionarske. Očitno mu je bilo jasno, da se v tedaj pravkar rojevajoči se moderni dobi razmerje med 
»vladarji« in »misleci« lahko zaplete na nov način in da bi lahko ločnica med njimi postala ohlapna in nejasna. $\mathrm{V}$ moderni dobi imamo dejansko primere, ko so "vladarji« prevzemali vlogo »mislecev« (ali pa so si vsaj neizmerno prizadevali po taki vlogi), »misleci« pa so se lahko znašli v situacijah, ko so prevzeli vlogo »vladarjev«. Zgodovinske čitanke so polne slavnih intelektualcev moderne, ki so se "v za narod usodnih dneh « ukvarjali s politiko, pa tudi »vladarjev«, ki so za seboj pustili dvajset, trideset ali več debelih zvezkov domnevno globokih in modrih misli. Kam so izginili? Namesto dveh metrov knjig na knjižni polici se novodobni vladarji postavljajo $\mathrm{s}$ sporočili v vsega 140 twitterjevih znakih, občasno pa javnost pretresejo $\mathrm{s}$ škandalom, npr. o z goljufijo pridobljenem doktoratu znanosti. To podobo na nasprotni strani dopolnjuje figura, zaobjeta v oznaki »the disengaged academic«.

$\mathrm{S}$ vsemi temi premiki se je raziskovanje močno relativiziralo. Ko gre za moč znanja, javne akademske ustanove nimajo več monopola. Izraz »akademsko znanje « je v pogovornem jeziku dobil slabšalno konotacijo »nekoristnega znanja«. V družbi, ki jo obvladuje vsemogočni svobodni trg, ne izbiramo samo vsakodnevnih dobrin in storitev; videti je, da »deležniki« na njem lahko "svobodno izbirajo « tudi svojim potrebam in svoji »racionalni presoji« najbolj primerne »resnice« in »interpretacije«. Prispeli smo v dobo "po meri narejenih raziskovalnih študij«. Kdo je v tej dobi »vladar« in kdo »filozof«? Meja postaja zabrisana.

\section{O raziskovanju v "post-resničnostnem svetu«}

Črna slika, ki je pred nami, prikazuje tisto razsežnost našega sveta, ki jo lahko ponazorimo z besedo leta 2016 po izbiri Oxford Dictionaries: »the post-truth world", post-resničnostni svet. Slovar podaja naslednjo definicijo: »Navezava na ali označevanje okoliščin, v katerih na oblikovanje javnega mnenja manj vplivajo objektivna dejstva kot zbujanje čustev in osebnih prepričanj«. S tem se svet ni spremenil, niti ni izginila potreba po tem, da ga mislimo. Ali lahko na čustvih in osebnih prepričanjih reformirate šolski sistem, da bo izpolnil temeljna pričakovanja, o katerih vendar obstaja večinski družbeni konsenz? (Böhm and Riiheläinen, 2017) Seveda ne morete. Zato pa je mogoče s čustvi in osebnimi prepričanji okrepiti ambivalentnost, o kateri smo tu govorili, vse do stopnje, na kateri se potencialno produktiven prispevek raziskovanja »za« oblikovanje politik lahko sesuje. Pri tem ni vsa krivda na "populizmu«. Če dobo populizma med drugim zaznamuje nezaupanje in averzija do strokovnjakov in izobraženih elit, je to 
tudi zato, ker je »scientokratizem « od sredine prejšnjega stoletja sem z inflatorno uporabo svetovanja za instrumentalne namene legitimiranja političnih odločitev, kot se je utrdila $\mathrm{v}$ zahodnem svetu, postal samodestruktiven in sam sebi jemlje legitimnost (Weingart, 1999: 158). V tem je eden od temeljev populističnega nezaupanja. »Znanost lahko ponuja nasvete, ne more pa nadomestiti drugih akterjev« v načrtovanju politik (Innerarity, 2012: 9). So »filozofi«, so tudi »kralji« in, ne nazadnje, je tudi »ljudstvo«. Vsi akterji igrajo takšno ali drugačno vlogo pri »upravljanju resničnega življenja« in nobenega med njimi ne gre ignorirati.

Raziskovanje je danes razpeto v dilemi, ali naj s svojo dejavnostjo »služi participatorni demokraciji in aktivnem državljanstvu, ali pa neki domnevno razsvetljeni politični oziroma politike oblikujoči eliti« (Hoppe, 1999: 208). Hoppe predlaga, da se to dilemo preseže tako, da se diskurz, ki "môči govori resnico" nadomesti z argumentirano analizo politik /policy/, ki bi "poživila politično previdnost«/political prudence/ in vodila k »skupnemu oblikovanju smisla (ibid., 209). To pa predpostavlja dvojno pozicijo »filozofov« v odnosu do »vladarjev« (pa tudi do »tistih, ki jim vladajo«): na eni strani raziskovanje »za" potrebe oblikovanja učinkovitih politik (tehnični vidik), na drugi strani pa raziskovanje »o" politikah in politiki (kritični in interpretativni vidik). »Filozofi" ne "govorijo" samo "vladarjem« (»môči«), temveč tudi »vladanim« (skupnosti) in, ne nazadnje, morajo kritično spregovoriti tudi samim sebi. Pa tudi poslušati.

Sem lahko navežemo Kantovo misel: da namreč (razsvetljeni!) »kralji« ne pustijo, da bi »razred filozofov« izginil ali onemel, temveč mu dovolijo javno govoriti, saj je to obojim - vsakemu na svoj način - neizogibno potrebno. Razsvetljeno raziskovanje in na njem utemeljene odločitve o upravljanju »resničnega življenja« je prepoznano kot nujen pogoj za vladanje razsvetljenih »vladarjev«. Toda dialektika razsvetljenstva nas je v dveh stoletjih pripeljala do post-resničnostnega obdobja »nerazsvetljenih vladarjev«, v katerem nevarnost niso več »nori kralji«, temveč »nori predsedniki«.

$\mathrm{V}$ tem je ključni razlog za radikalen ugovor tako populističnemu zavračanju t.i. »neuporabnih akademskih teorij« kot neoliberalni redukciji raziskovanja izključno na »koristno« znanje. Za produktivno razmerje med »akademsko« in »administrativno" stranjo je kritična analiza sedanjosti in preteklosti, pa tudi prihodnosti, torej vsa ta »nekoristna šara «, kot trdijo profeti post-resničnega sveta, nujen pogoj. Povejmo to $\mathrm{z}$ besedami Ulricha Teichlerja (2003): praktični pomen družboslovja, katerega pomemben del predstavljajo tudi edukacijske vede, »temelji na oblikovanju pogojev 
za prihodnost«, zato morajo biti družbene vede »usmerjene v prihodnost« (171). To je tista točka, na kateri se raziskovanje lahko tesno poveže $z$ oblikovanjem javnih politik, pa tudi z demokratično politiko, $z$ aktivizmom ali z alternativnimi družbenimi praksami. Teichler opozarja: »Raziskovanje je lahko osveščeno glede prihodnosti, če postavlja kritična vprašanja in hipoteze, nasprotne predpostavkam akterjev« (181). »Razsvetljeni vladar« bo prepoznal vrednost, »uporabnost« te trditve. Želeti si je torej kralja, ki ga spremlja dvorni norček; hudo je imeti norega kralja, »ljubega vodjo«.

\section{Literatura}

Aristotel. Nikomahova etika. Prev. Kajetan Gantar. Ljubljana: Cankarjeva založba, 1964.

Bell, Daniel. The End of Ideology. On the Exhaustion of Political Ideas in the Fifties. Glencoe, IL: Free Press, 1960.

Bourdieu, Pierre. Homo academicus. Ljubljana: PeF UL, 2012.

Böhm, Franziska, Jari Matti Riiheläinen. Focus on: Education systems in a post-truth world. Eurydice. https:/webgate.ec.europa.eu/fpfis/mwikis/ eurydice/index.php/Publications:Focus_on:_Education_systems_in_a_ post-truth_world (31.3. 2017).

Bush, Vanndevar. Science - The Endless Frontier. A Report to the President by Vannevar Bush, Director of the Office of Scientific Research and Development, July 1945. Washington: US Government Printing Office, 1945.

Fink-Hafner, Danica. in Damijan Lajh. (ur.). Analiza politik. Ljubljana: FDV $\mathrm{UL}, 2002$.

Fran. Slovarji Inštituta za slovenski jezik Frana Ramovša ZRC SAZU. https:// fran.si/_(29. 11. 2019).

Hoppe, Robertus. "Policy analysis, sciences and politics: from 'speaking truth to power' to making sense together." Science and Public Policy, 26(3), 201210, 1999.

Innerarity, Daniel. Power and knowledge: The politics of the knowledge society. European Journal of Social Theory, 16(1), 3-16, 2012.

Kant, Immanuel. K večnemu miru. Filozofski osnutek. Prev. Samo Tomšič. V: I. Kant, Zgodovinsko-politični spisi (ur. R. Riha). Ljubljana: Filozofski inštitut ZRC SAZU, 2006.

Lasswell, Harold in Daniel Lerner. (ur.). The Policy Sciences. Stanford: Stanford University Press, 1951. 
Lexico. Definition of post-truth in English. https://en.oxforddictionaries.com/ definition/post-truth_(29. 11. 2019).

Macfarlane, Bruce. "The disengaged academic: The retreat from citizenship." Higher Education Quarterly 59(4), 296-312, 2005.

Platon. Država. Prev. Jože Košar. Ljubljana: Mihelač, 1995.

Powell, Alvin. (2007). "How Sputnik changed U.S. education." Harvard Gazette, October 11, 2007. http://news.harvard.edu/gazette/story/2007/10/ how-sputnik-changed-u-s-education/ (29. 11. 2019).

Reische, Diane L. Citizenship: Goal of Education. Arlington: American Association of School Administrators, 1987.

Rosovsky, Henry. "No Ivory Tower: University and Society in the Twenty-First Century". V: Werner Z. Hirsch, Luc E. Weber (ur.), As the Walls of Academia Are Tumbling Down, London: Economica, 13-30, 2002.

Simons, Maarten, Mark Olssen, Michael A. Peters. (ur.) Re-Reading Education Policies. Rotterdam: Sense Publ, 2009.

Snoj, Marko. Slovenski etimološki slovar. Ljubljana: Mladinska knjiga, 1997.

Starr, Karen. Education Policy, Neoliberalism, and Leadership Practice. New York and London: Routledge, 2019.

Teichler, Ulrich. "The future of higher education and the future of higher education research". Tertiary Education and Management, 9, 171-185, 2003.

Thatcher, Margaret (1987). Interview for Woman's Own. Margaret Thatcher Foundation. https://www.margaretthatcher.org/document/106689 (pridobljeno 29. november 2019).

Weingart, Peter. "Scientific expertise and political accountability: paradoxes of sciences and politics." Science and Public Policy, 26(3), 151-161, 1999. 


\section{Inequality, Poverty and Education in the Post-Yugoslav Space: from immobility to inclusion? ${ }^{\text {I }}$}

Paul Stubbs

Introduction

In this paper, I want to focus on education from a social justice perspective; a perspective that is all too often squeezed out by two other perspectives or frames. One, associated with the neoliberal phase of capitalism, addresses education in terms of preparation for the labour market, focusing on the supposed skills and competences required in the post-industrial, artificial intelligence-driven, societies of the future and, in particular, on the magic formula of STEM - science, technology, engineering and mathematics. The other, associated with what the Croatian sociologist Josip Županov (2002) referred to as desecularization (occurring alongside descientisation, retraditionalisation and repatriarchalisation), sees education as inculcating and ensuring the reproduction of national, cultural, religious, values, with schools as a place for prayer but not for sex education, apparently, and for a singular, and distorted, reading of national history. Although not the topic at hand here, I am particularly worried by the rise of a kind of authoritarian neoliberalism across the region and beyond that manages to combine the two frames perfectly well (Stubbs and Lendvai, 2019).

1 This paper is based on a keynote lecture delivered to the 4 th annual scientific conference on Research in Education and Training in Ljubljana, Slovenia on 18 September 2019. Thanks to Igor Žagar and Ana Mlekuž for their encouragement, and to Karin Doolan, Teo Matković, Saša Baucal and Slobodan Cvejić for comments on a previous draft and for guidance in searching for, and interpreting, the relevant literature. Responsibility for the text is mine alone, of course. 
The paper starts with a case study of media coverage following the President of Croatia's daughter gaining a place to study as an undergraduate at Harvard University. The next section looks historically at studies of education and mobility in socialist Yugoslavia. Section three turns to an overview of research on educational inequality in the post-Yugoslav space, surveying a literature that leaves us with more questions than answers. I then focus on my own research on child poverty and household coping strategies in Croatia before ending with some thoughts on whether another education - education otherwise - is possible, one that is not only or primarily about neoliberal skills or nationalist values, but which promotes equal opportunities, social mobility and social inclusion, borrowing, in particular, from the work of Pierre Bourdieu and Paolo Freire.

\section{The case of the president's daughter}

For three days in May 2019, the Croatian public became obsessed with the issue of education and mobility, following the acceptance of the daughter of President Kolinda Grabar-Kitarović for a fully funded place as an undergraduate at Harvard University. Once the media frenzy had died down, the debate on education and social mobility returned to normal; that is to say, it ceased to exist. Revisiting the media frenzy for the purposes of this paper, I was struck by how limited it was. What unfolded was a rather binary opposition between those who felt that Katarina Kitarović had obtained her place purely on merit, her mother proudly announcing she had scored in the top $1 \%$ of her SATs, and had been offered places by all four Ivy League colleges she had applied to; and those who felt that her acceptance was as much due to parental wealth, influence and connections/veze. A side debate occurred about whether studying abroad was a betrayal of Croatia or, as the Minister of Education Blaženka Divljak suggested, a good thing, whilst warning that »Croatia must ensure the conditions for returning and remaining for young educated people« (Trstenjak, 2019). The President's own statement noted her daughter's "wish to be free of the police officers who follow her twenty-four hours a day" and then joined in the debate, thus: "I have heard stories that she was accepted by Harvard because I am the President of Croatia, which has nothing to do with the truth because, as you know, the American education system takes no account of that." (Vojković, 2019)

The commentator Goran Vojković, on Index.hr, the very portal which carried many of the most critical articles, attacked the 'sick and pathetic' 
Croatian society for contributing to a climate where "verything can be forgiven except success «. Croatia should be proud, for Katarina's success is Croatia's success, a success that costs the rest of us nothing and stands in sharp contrast to other children of the rich and famous, who tend to have their lives more often paraded in the crna kronika section of newspapers (Vojković, 2019). Some news portals found others, from more humble backgrounds, who had also been educated in Harvard, or Princeton, or Cambridge, expounding what I like to term the Vlak $u$ snijegu meets Thatcherism maxim of "you can do anything if you put your mind to it" ("sve se može kad se hoće") (Plivelić, 2019). There were even "how to help your child get to Harvard' guides framed in terms of a sea change because, to quote one example, wit used to be thought that only the swotty kids of the rich could enroll, but now anyone can" (ibid.). We also learnt that the daughter of the former President of the Croatian Medical Chamber would be joining Katarina at Harvard (Dnevno, 2019).

Perhaps the most serious treatment of the case came from Nenad Jaric Dauenhauer (2019), also writing in Index.hr. He makes the link between the individual case and the question "how can the wealth and power of parents contribute to the academic success of their children?«. As the child of a diplomat, Katarina was educated, mainly at the expense of the Croatian taxpayer and, subsequently, NATO, in elite schools in Washington DC and Brussels. When her mother became President, she did her final year of schooling in the prestigious IB (International Baccalaureat) programme (a programme in English with a widely recognized 'modern curriculum') within the Mathematics High School in Zagreb, at a cost of some 3,000 Euro. Individual preparation for the SATs cost around 2,00o Euro and she also received individual mentoring in mathematics and in creative writing, the latter from a famous Croatian author, at an unknown cost.

Katarina was, clearly, appealing to Harvard, showing sporting prowess (she had been Croatian junior skating champion in 2016), showing compassion beyond her years (she had, apparently, written a book of short stories to help those of her classmates who were having suicidal thoughts) and had undoubtedly left a lasting impression on both faculty and students in the interview and discussion process that many have argued is the least transparent aspect of Harvard's selection process. As he also pointed out, $30 \%$ of Ivy League students have at least one parent who attended the same university (Kolinda did not) and the average annual parental income of Harvard students is some $\$ 170,000$. Looked at in terms of income quin- 
tiles, only $4.5 \%$ of students come from households with incomes in the bottom quintile and there are the same number of students from the top $1 \%$ of income earners as from the bottom $60 \%$. Of course, the issue is complicated here by transnational comparisons. Certainly, Kolinda's salary when an Assistant Secretary General of NATO was extremely high internationally. As a number of the articles point out, the stipend Katarina will receive from Harvard is twice her mother's monthly salary as President of Croatia, some net 25,000 HRK or 3,400 Euro. We should not worry too much about financial hardship in this case, however; recently, N1 reported that together with her husband Jakov, the President had savings amounting to $1.8 \mathrm{mil}$ lion kuna (240,00o Euro) and two properties with a total worth of $3.8 \mathrm{mil}$ lion kuna (o.5m. Euro) (N1 Info, 2019).

It is worth speculating on what Pierre Bourdieu would have made of the discussion, not least because his work makes a direct connection between diverse kinds of 'capital' and educational success. In Bourdieu's terms, it would be nonsense to ask if Katarina got her place on merit or through veze; or whether the material wealth of her parents made a difference or not. Bourdieu would elaborate on his concept of 'cultural capital', the intangible assets or dispositions, accumulated, or not, over time, in a relation of exchange with material wealth and correlated with attendance and success at the 'best' schools and universities (Bourdieu and Passeron, 1977). Cultural capital is the force that amplifies material inequalities, converting them, via academic success, into the reproduction of social stratification. Although there are no direct guarantees, Katarina's cultural capital was certainly high, with each and every aspect reinforcing and strengthening the others over time. What was perhaps most surprising was that, apart from comments about how bad Croatian universities were, there was little or no discussion of education and social mobility in Croatia itself.

\section{Education and social stratification in socialist Yugoslavia}

There have also been very few studies of education and social stratification in socialist Yugoslavia. Here, Kolinda Grabar-Kitarović is, also, not a great authority, in view of some of her repeated statements on the challenges of growing up near Rijeka between 1968 and 1986, going to Rijeka's gymnasium having rejected the place in a trade school offered by Šuvar's reforms and, in fourth grade of secondary school, becoming an exchange student in Los Alamos in the United States. Her recollections of the totalitarian system she lived under, "Behind the Iron Curtain" as she would have us be- 
lieve, include that one could not openly identify as 'Croat' (Tito did so frequently, however); there was only one sort of yoghurt in the shops, bread consumption was tightly controlled, hygienic products could not be obtained and one word critical of the regime and you would be sent to Goli Otok (Benačić, 2018).

The more I delve into aspects of the history of socialist Yugoslavia, the more I come to identify with the title of Darko Suvin's recent book, seeing Yugoslavia as a roller coaster of 'Splendour, Misery, and (Missed) Possibilities' (Suvin, 2016). I use the metaphor of a 'roller coaster' because it was far from a linear process of optimism leading, inexorably, to despair. Nevertheless, and here I borrow from the work of Karin Doolan and others (cf. Doolan et al, 2017), it is possible, albeit very crudely, to divide education and mobility in Yugoslavia into three conjunctures. The first, and one could argue whether this predates the break with Stalin and expulsion from the Cominform in 1948, was a period of rapid modernization and industrialization, including the fight against illiteracy and the massive expansion of higher education, both through universities and other third level institutions such as two- and four-year High Schools. Access to higher education was free and, at least theoretically, open to all; indeed, the children of peasants and the working-class were encouraged to stay on longer at school. Figures from Vojin MIlić suggest that in 1951/2 only around one third of university students were from peasant or manual worker families; only six years later, it had risen to $44 \%$ (Milić, 1966). By 1961/2, children of peasants had an Index of Representation of 0.33 (in a perfectly egalitarian society the Index would be 1); that of workers' children was 0.77; but for children of employees the figure was 3.3, albeit a reduction in over-representation from 4.72 in 1953/4. (ibid.)

Although the shrinking of the peasantry was complex, with many of the new industrial workers maintaining some contact with the land, there were two kinds of occupational mobility - peasants moving to manual and non-manual labour, albeit in a ratio of 2:1 to manual labour; and manual workers moving into non-manual jobs, albeit mainly into the lower echelons, with those already in non-manual jobs more or less keeping their positions. There was educational mobility in the period, although it was actually less than occupational mobility to meet the demands of industrialization and the expansion of administrative and managerial positions. Intergenerational mobility was also greater than intragenerational mobility, both in education and employment. 
In the second period, the era of self-management and consumer-led market socialism, there is a real divide between party ideologues, describing Yugoslav society in Marxist terms, and a growing body of sociologists using Durkheimian categories of social stratification (cf. Archer, Duda, Stubbs, 2014). There was very little work done on education in relation to social class, although surveys in 1976 (Previšić and Serdar, 1978) and 1987 (Rimac and Baranović, 1991) in the Socialist Republic of Croatia both point to parental levels of education as being the most important determinant of continuing to higher education. This was, also, of course, the period of the consolidation of what Djilas had termed the 'new class' (Djilas, 1957) or what the protesting students in 1968 in Belgrade termed the 'red bourgeoisie' (Klasić, 2012). It was also notable for the ambitious, but largely unsuccessful, educational reforms that came to be known as the Šuvar reforms after the sociologist, and reluctant politician, Stipe Šuvar (Bacevic, 2016). Influenced by both Bourdieu and a particular Marxist ideology, Šuvar influenced the thinking of the League of Communists of Yugoslavia as early as 1974, critiquing "a situation in which certain strata are reproducing themselves, their structures and their socio-economic positions, and with this, their social power." (quoted in Bacevic, 2016: 80). By 1977, he had not only analysed the problem but devised a solution, thus:

Education has been developed as a specific ritual which selects a small proportion of the population for the social elites, and places them on a pedestal which is inaccessible to the vast majority of the population. ... the class function of education, in our society, unlike in the societies of exploitation, is not, or should not be to help people escape the working class, but to enable them to fall back into it. (Suvar, 1977, quoted in Bacevic, 2016)

In retrospect, Šuvar's reforms were an attempt to respond to the first signs of problems in the Yugoslav economy, linked to the oil price hike in the early 1970s, and growing unemployment, including graduate unemployment, only partly offset through the safety valve of gastarbajter migration (le Normand, 2016). Politically, the demands of the Belgrade students in 1968 and the, rather different, demands of the Zagreb students in 1971, are responded to not through expansion of higher education for all, but through the intended abolition of dual gymnasium and vocational track secondary education, tying education to the supposed needs of the labour market (echoed by later STEM arguments) and, as Jana Bacevic (Bacevic, 2016) has pointed out, a pronounced anti-intellectualism. 
The third conjuncture, one of political and economic crisis, if not breakdown, led, if anything, to a reversal of earlier gains in terms of social mobility, IMF-induced austerity led to cutbacks in university places and the beginnings of a kind of informal marketization of higher education (Ružica; Kolarić and Svetlik, 1987). If we look at some statistics (Table 1), we can see how the seemingly inexorable expansion of higher education was reversed in the 1980s. At the same time, opportunities for women in higher education continued to grow, and reached over $50 \%$ by the end of socialism, albeit with marked discrepancies by subject.

\section{Table ı: Trends in Higher Education in Yugoslavia, 1938-1985}

\begin{tabular}{|ccccc}
\hline & $\begin{array}{c}\text { Higher ed } \\
\text { institutions }\end{array}$ & No. of students & $\begin{array}{c}\text { Students per 100,000 } \\
\text { pop }\end{array}$ & \% Female students \\
\hline 1938 & 26 & 16978 & & 22.6 \\
\hline 1955 & 81 & & & 28.9 \\
\hline 1960 & 204 & 140547 & 1282 & 39.4 \\
\hline 1965 & 246 & 261203 & 1850 & 39.8 \\
\hline 1970 & 294 & 394992 & 1848 & 45.4 \\
\hline 1975 & 356 & 411995 & 1515 & 45.8 \\
\hline 1980 & 300 & 350334 & 1491 & 47.4 \\
\hline 1985 & 322 & 348068 & & \\
\hline
\end{tabular}

Source: Šoljan, 1991 and Milić, 1966

Table 2: Education indicators by Yugoslav Republic 197I and 198I

\begin{tabular}{lcccc} 
& \multicolumn{2}{c}{$\begin{array}{c}\text { Average years of schooling } \\
\text { (adults 15+) }\end{array}$} & \multicolumn{2}{c}{ Illiteracy Rates (10+) \% } \\
\cline { 2 - 5 } & 1971 & 1981 & 1971 & 1981 \\
\hline Yugoslavia & 6.3 & 7.6 & 15.1 & 9.5 \\
\hline Slovenia & 8.2 & 8.9 & 1.2 & 0.8 \\
\hline Croatia & 6.7 & 7.8 & 9.0 & 5.6 \\
\hline Serbia (inc. APs) & 6.2 & 7.5 & 17.2 & 10.9 \\
\hline Bosnia - H & 5.4 & 6.9 & 23.2 & 14.5 \\
\hline
\end{tabular}

Source: Bevc (1993)

This table (Table 2) shows changes only between 1971 and 1981 but breaks down figures on average years of schooling and rate of illiteracy by Republics, in the context, of course, of the 1974 Constitutional reform. We can see that there were considerable differences between the richer and poorer Republics on both indicators, but that, unlike indices of social prod- 
uct for example, the gap narrowed, at least in the decade for which I was able to find figures.

Of course, as Suvin reminds us, any understanding of education and social mobility in socialist Yugoslavia has to address the extremely complex and rapidly changing class composition of the society and the fact that official statistics and survey data tend to obfuscate rather than clarify. In any case, the topic of social mobility was hardly central to Yugoslav sociology although some important work, primarily through large-scale international co-operation, was done in the 1980s (Sekulić, 1991). Ironically, many of the same problems arise when we look at education and social mobility in the post-socialist period.

\section{Education, mobility and the Post-Yugoslav space}

Moving on to education in the post-Yugoslav space, many of the same issues emerge, not least the problem of a lack, until relatively recently, of useful work on social class. Indeed, it is fair to say that, almost thirty years on from the moment of 'transition', we are still trapped within a 'transitology' paradigm that does not quite know how to conceptualise the societies that emerged from the ashes of Yugoslavia. I was struck, in particular, by Belgrade sociologist Ivana Spasić on the difficulty of capturing the 'chaotic' nature of post-Yugoslav societies marked by »a polarized collision between different dimensions of social stratification, which exist in parallel and struggle for (legitimate) domination, with a highly uncertain result" (Spasić, 2006). Mladen Lazić and Slobodan Cvejić (2007) have also charted contemporary Serbia, in particular, in similar terms, as a place where socialist, agrarian and capitalist market norms all co-exist leading to a period of 'manifest value confusion', described in one text as the co-existence of traditionalism, authoritarianism, nationalism and liberalism. Predrag Cvetičanin and his colleagues, albeit in a footnote, go further and argue:

In Western Balkan societies there are four major mechanisms which individuals and groups rely on in field struggles: mechanisms of social closure on the basis of belonging to party organizations and/or informal clan groupings; mechanisms of social closure on the basis of educational credentials; market mechanisms and, finally, crime. (Cvetičanin et al, 2015).

It is the concept of 'social closure' that is of most importance, I would suggest, and through an overview of some of the relevant literature, it is 


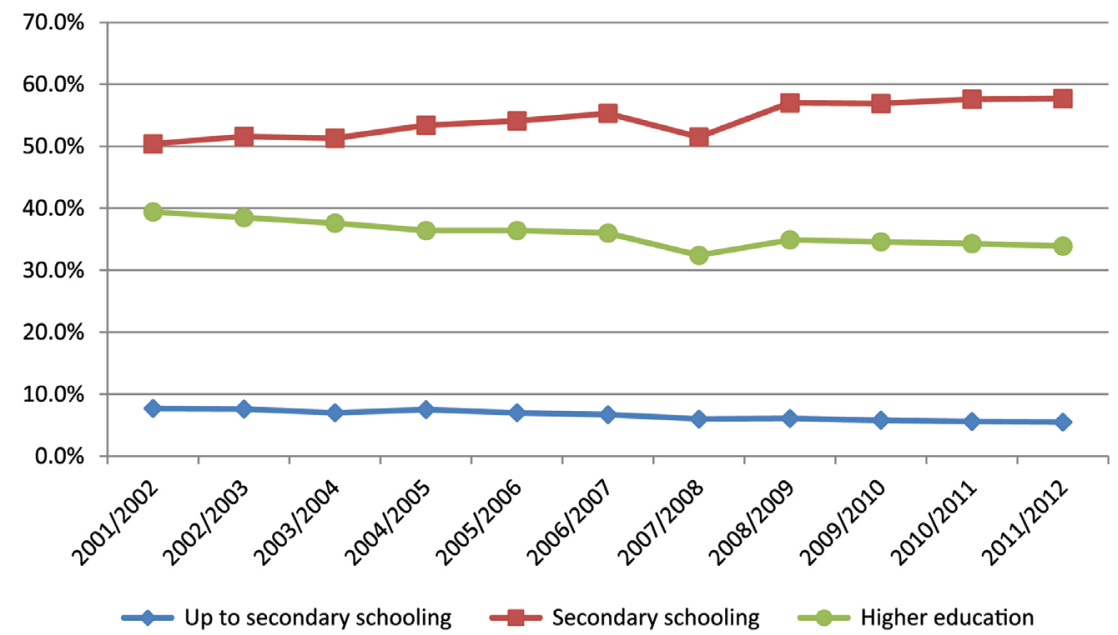

Figure i: Percentage of tertiary Level Students in Croatia By Father's Educational evel $200 \mathrm{I} / 2-20 \mathrm{II} / \mathrm{I}$

possible to trace elements of this in relation to the educational system, and particularly access to higher education. Unfortunately, there is no single text that brings together the structural and intersectional nature of educational disadvantage in our region, addressing the mutually reinforcing nature of class, gender, ethnicity, disability and region. What we have, within a normative stance that mobility is important for a kind of equal opportunity neoliberalism that leaves inequalities unchanged but allows for the exchange of elites, are crude renderings of 'educational disadvantage' by so-called 'socio-economic status' or its acronym SES (Waters and Waters, 2016). In this narrative, we are meant to prefer meritocracy to patronage, or, let us recall Katarina Kitarović here, »background, means, and connections «.

Of course, there are real problems with the deeply politicized nature of the marketization of higher education across our region: the necessity for party membership to reach positions of influence; the rise of new, and often very dubious, private universities; the number of politicians with plagiarized doctoral dissertations, and so on. However, removing all of this and leaving meritocracy intact is hardly a vision for the future. If we focus, for the moment, on Croatia, we find, even within an expansion of higher education, a reduction in the prospects of children from working-class backgrounds having access. The work of Karin Doolan and her colleagues (Doolan et al, 2017) show that student numbers rose by almost exactly $50 \%$ 

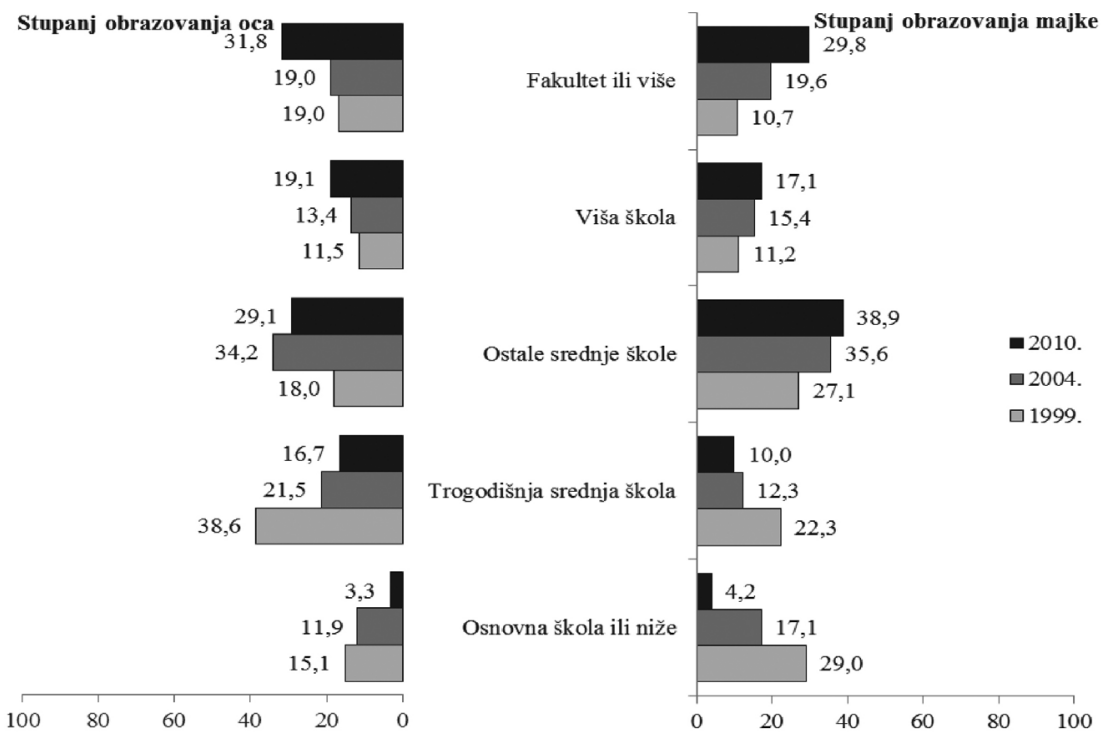

Figure 2: Levels of Education by Father and Mother's Educational Level in Croatia 19992010

Source: Ilišin (ed) (2014)

in Croatia between 2001/2 and 2013/4. As the graph shows (Figure 1), however, the share of those whose fathers did not complete secondary education, fell from an already very low base to begin with. The graph is the calculation of the authors' based on statistics they had to email the Croatian Bureau of Statistics to obtain, suggesting that information on education and mobility is still not routinely available and accessible.

Sample data from 2010 collected by Vlasta Ilšin and colleagues (Ilišin (ed), 2014) (Figure 2) show the dramatic increase in self-reproduction in university education in Croatia and its gender dimension. In 1999 only 10.7 $\%$ of university students came from families where the mother had university education, by 2010 it was $29.8 \%$. The literature also shows how the institutional structure of higher education represents a barrier to equity. The same study suggests that $80 \%$ of students received no scholarships whatsoever, and a study, again by Karin Doolan and colleagues, in 2013 (Doolan, Dolenec and Domazet, 2013), pointed out that scholarships were as much, if not more, merit-based than needs-based and that, compared to Slovenia, although living costs were approximately the same, scholarships were about half, covering less than one third of likely expenses. Crucially for me, there are no second chances: Farnell et al's study (EUROSTUDENT, 
2012) showed that only $2 \%$ of those entering higher education at university level for the first time were 21 or older. In addition, only some $5 \%$ of students reported having physical disabilities, suggesting that such students are chronically under-represented in Croatian higher education. The Doolan study hypothesizes, rather depressingly, that only when the higher education of the elite reaches saturation point, will access for working-class students improve (Doolan et al, 2013).

According to the latest EUROSTUDENT figures, $42 \%$ of students in Croatia had a least one parent who had completed tertiary education, compared to $56 \%$ for Serbia and $33 \%$ for Slovenia (EUROSTUDENT, 2018), albeit with a significant increase, of some 5 percentage points, of students in Croatia who indicated their parents did not have tertiary education compared to the previous survey. The trend in Serbia, however, is opposite, with a significant decrease of some 11 percentage points between the two surveys (ibid.).

There are very few valid and relevant cross-country comparisons including all of the post-Yugoslav states. One notable exception is a study in 2013 by Crespa Cuaresma and his colleagues (Crespo Cuaresma et al, 2013) (Figure 3). The graph below, that needs a little unpicking, shows that, between 1960 and 2010, South Eastern Europe (including all the post-Yugoslav states except Slovenia, Albania, Bulgaria, Moldova, Romania and Turkey) is the only European sub-region that shows a consistent fall in social mobility, at its greatest in the two decades from $1980-2000$. They construct an index of educational mobility which compares educational mobility, expressed as a GINI type coefficient, as the ratio of the education GINA of those aged 25-54 compared to those 55+.

Including Slovenia in the picture leads to an interesting side question about statistics. Despite its meritocratic ideology, and the unproblematic use of PISA test results, the OECD (of which Slovenia is a member, successfully blocking currently, together with Hungary, Croatia's membership) has some of the most useful and up-to-date statistics, many of which have been put together in a report from 2018 (OECD, 2018). The report suggests that some $13.5 \%$ of variation in PISA science results in Slovenia in 2015 was a result of socio-economic status, down some 4 base percentage points from 9 years earlier but above the OECD average of $12.9 \%$. The OECD defines 'disadvantaged adults' as adults with parents who did not complete lower secondary education. In 2015, only $9.5 \%$ of Slovenes from these backgrounds had completed tertiary education, although this rose to $16.5 \%$ for those aged 


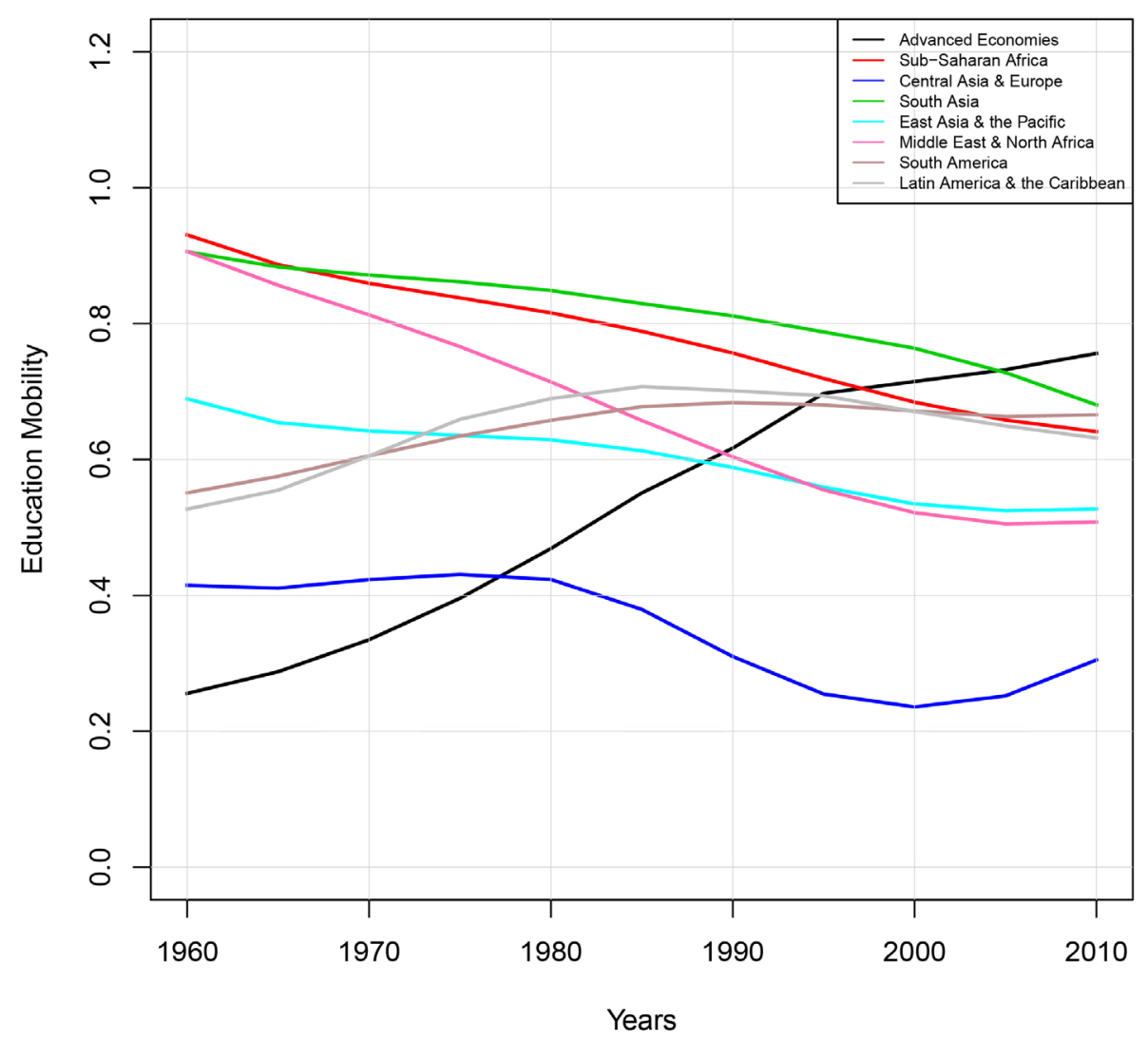

Figure 3: Educational Mobility by European Region 1960-2010

Source: Crespo Cuaresma et al (2013)

26-35. The rates are lower than most of Europe with the exception of many of the post-communist states. Interestingly, although given Slovenia's small size it is hard to know how much to read into this, it had one of the highest differences in performance depending on whether disadvantaged students went to disadvantaged schools or not.

Again, there is evidence of closure; $50 \%$ of adults aged 26 or over reported that their highest level of educational attainment was the same as that of their parents, with $38 \%$ reporting doing better than their parents and 12 $\%$ worse. Interestingly, upward educational mobility was higher for those aged 46-55, who would have been 18 in the 1980s, than those aged $26-35$. The chance of Slovenes aged 26 or over completing higher education if one of their parents had also done so was 14 times greater than those where neither 


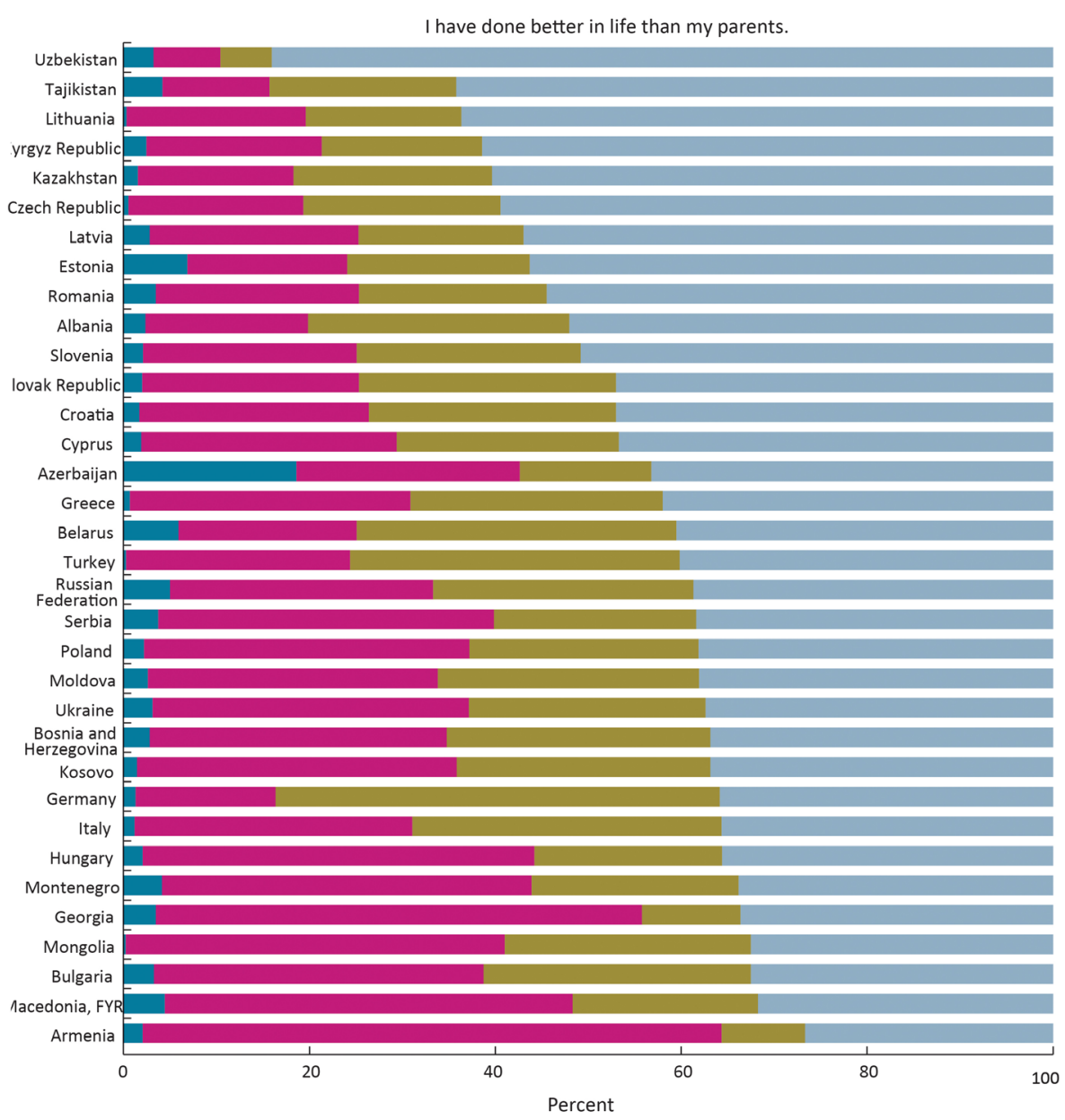

Figure 4: Question from Life in Transition Survey 2016

Source: EBRD (2016)

parent had completed upper secondary education, a ratio similar to France, and high by OECD standards, but well below figures for the Czech Republic, Slovakia or Poland, with a range between 25 and 34 times (ibid.). One similarity between Slovenia and Croatia, unsurprisingly, is that changes in class structure in the early 1990s, as Jereb and Ferjan point out for Slovenia (Jereb and Ferjan, 2008), in part at least, where as a result of the option of early retirement for manual workers whose industries had collapsed. Using 2006 survey data, they also suggest that Slovenia has higher mobility, upwards and downwards, in terms of jobs at least, than most other European countries. 
One of the most worrying aspects of access to higher education in Slovenia is a pronounced gender gap with the proportion of women aged 3034 having attained higher education exceeding that for men by some 24.1 \%. The gap amongst 25-34 years old was $23 \%$ (Eurostat, 2019). At the same time, the employment rate for tertiary educated women is below that for men, and a gender gap in earnings remains, with tertiary educated women between $25-64$ years of age earning $83 \%$ on average compared to men, although this is higher than the OECD average of $75 \%$ (ibid).

In addition, turning back to the region as a whole, a finding from the EBRD Life in Transition Survey from 2016 (EBRD, 2016) shows what might be termed subjective mobility, in terms of what percentage of adults agreed that they have done better in life that their parents. High figures for Slovenia and Croatia stand in contrast to much lower figures for Bosnia-Herzegovina, Kosovo, Montenegro and, particularly North Macedonia (Figure 4).

What the data I have shown fails to do, as well as the neglect of intersectionality, is to show the impact of quality of education, access to particular types of education, the transition from school to work, and so on. In addition, as a number of commentators stated during the "blockade" of the Faculty of Philosophy in Zagreb in 2009 when demands for free higher education were combined with a call for greater equity, educational inequality starts very early, in pre-school in fact - and is cumulative over time. By the time children reach 18 years of age, it is already too late.

\section{Poverty, coping strategies and education}

In this context, research carried out with colleagues in 2016/7 (Stubbs et al, 2017; Rubil et al, 2018), looking at the coping strategies of poor families those in receipt of social assistance, with school-age children - is highly relevant here. This was an all too rare attempt to go beyond large-scale statistical data to address the lived experiences of those living in poverty and the ways they coped with this. Hence, education was only one of many issues discussed but some observations can be made. In terms of general findings, two thirds of our interview sample reported having problems with bills and $25 \%$ had had one disconnection of a communal service, be it gas, electricity or water, in the last year. It is rare in our region, I would suggest, for social workers with clients with children who have arrears to negotiate with gas or electricity companies not to disconnect. 


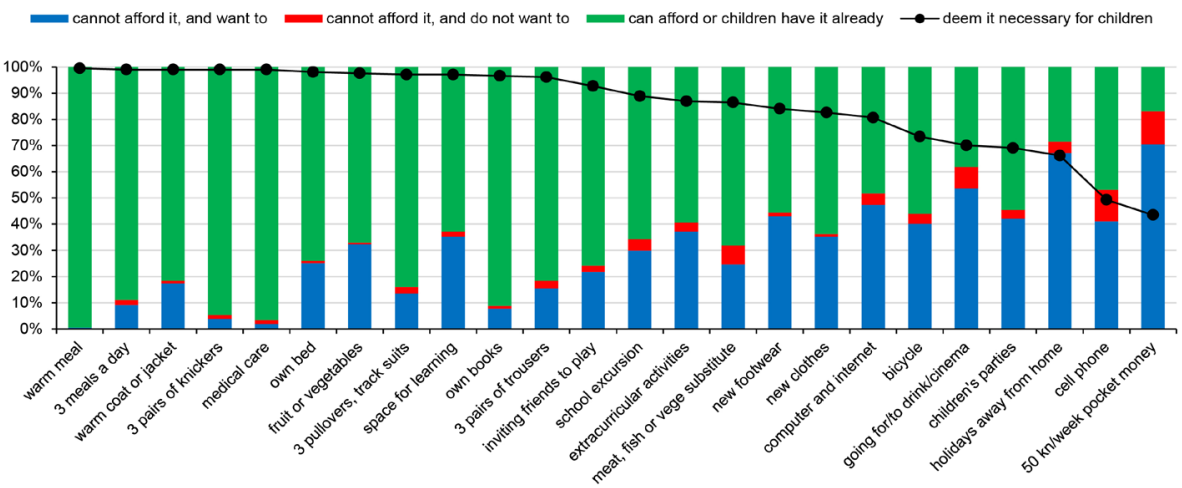

Figure 5: Parental Views on Necessities for School-Age Children

Coping strategies, all of which became less effective over time, included work in the grey economy, mostly women doing cleaning jobs or babysitting, often combined with fear of someone telling social services; selling any valuable household items; small subsistence food production, or taking food from other family members who grew their own; and borrowing on neighbours' credit cards, preferable to the high interest loan sharks who, at least in Zagreb, advertise on every street corner. After family and friends, families valued Centres for Social Work highly, with some praising the compassion of their social workers, whilst others saw them as, at best, indifferent. Interesting, given the publicity they get, NGOs, soup kitchens, church organizations and the like were much less important and those who had tried to use them found frequent changes of rules worked against them. Our work reinforced earlier studies that show how children who most need pre-school are least likely to go, with Croatia having rules that positively discriminate in favour of working parents, together with huge regional differences in rates of access (Matković and Dobrotić, 2013). One of the, perhaps, most surprising of our findings was that parents tended to have higher expectations of their children in terms of the future, levels of education, likely employment, and so on, than the children we interviewed.

The diagram shown here (Figure 5), included in the final report, points to things that parents deem necessary for children but that they cannot afford: $30 \%$ cannot afford but consider it important for children to go on a school excursion; $36 \%$ on extra-curricular activities. $80 \%$ of parents said that a computer and internet was necessary, as it certainly is, increasingly, for educational purposes, and yet almost 50\% could not afford it. Indeed, in the study, we referred to a literature on health that discusses unexpected 
significant expenditures and argued that the same concept needs to be applied to education (Ke Xu et al, 2003).

The next table (Table 3) divides the sample into those who completed only primary education and the rest. One can see that 3 in 10 children hoped to go to college or university, but that this dropped significantly if their parents had lower levels of education. For over half the children in the sample, there was a realization that lack of money might be an obstacle to fulfilling their plans (Table 4).

\section{Table 3: Educational Mobility by European Region 1960-2010}

\begin{tabular}{lccc} 
& Total sample & $\begin{array}{c}\text { Parents with Lower } \\
\text { Education }\end{array}$ & $\begin{array}{c}\text { Parents with Higher } \\
\text { Education }\end{array}$ \\
$\begin{array}{l}\text { Finish secondary } \\
\text { school and get a job }\end{array}$ & 62.6 & 67.2 & 56.8 \\
\hline $\begin{array}{l}\text { Finish a college or uni- } \\
\text { versity and get a job }\end{array}$ & 31.3 & 25.5 & 38.6 \\
\hline $\begin{array}{l}\text { Get a job as soon as } \\
\text { possible, regardless of } \\
\text { finishing school }\end{array}$ & 6.1 & 7.3 & 4.6 \\
\hline
\end{tabular}

Source: Stubbs et al (2017)

Table 4: Childrens' Preceptions of Ostacles to Fulfilling Plans

\begin{tabular}{lc} 
& TOTAL \\
\hline Lack of money & 53.5 \\
\hline Nothing & 29.3 \\
\hline Lack of real opportunities in my surroundings & 17.2 \\
\hline Lack of good information and advice & 10.1 \\
\hline Lack of correct qualifications for the job I want & 9.1 \\
\hline Family obligations & 3.0 \\
\hline Something else & 2.0 \\
\hline
\end{tabular}

Source: Stubbs et al (2017)

The focus groups with parents, all of which I conducted with a colleague, brought home the issues. This quote is from a Roma man about his daughter:

My daughter was a really good pupil and then they moved her into a different programme in the gymnasium and then she needed different books. I asked the teacher if we could exchange the books she had for the new books she needed but she didn't want to do it. And now she is failing at school because she doesn't have 
the books, she has to repeat a year and no longer has a right to a stipend. So we have enrolled her in a trade school instead.

Here are two quotes regarding the effects of peer pressure in terms of fashion and make up:

I just can't make it possible that he has the same as his friends at school. Kids are always commenting on the kinds of clothes you come to school in.

My daughter was 13 and she wanted to make herself up and she did not have trousers like the others and so they made fun of her. She came home in tears but I told her "hold your head high" and then the next month I bought her trousers. She also wants a computer but I really can't afford it. (Stubbs et al, 2017).

\section{Conclusions}

It is important to note, albeit briefly, some of the policy implications that could be derived from this paper. These are very much derived from a combination of insights from Bourdieu and the Brazilian critical educator Paulo Freire. Bourdieu, of course, has a great deal to say about educational policy, even if rarely directly (cf. Lingard et al, 2005). Taking his concept of 'field' seriously, together with 'habitus' and 'capital', points to the importance of struggles for symbolic power »in and against the state" (London-Edinburgh Weekend Return Group, 1979), and the importance of breaking down those 'logics of practice' that reproduce inequalities in education. Freire is, perhaps, more widely influential within educational policy following his landmark book Pedagogy of the Oppressed (Freire, 1970) and his subsequent work with UNESCO and others and, certainly, has a great deal to say about the nature of praxis in the 'black box' of educational policies and processes, in terms of critique of 'received' or 'banking-like' understandings of education. Even more than Bourdieu, Freire's life and work was devoted to a »liberatory pedagogy ... aimed at social transformation, at humanization, at changing the class oppression created by capitalism, and at challenging ... many other forms of oppression " (Au and Apple, 2007; 462). Combining the two re-emphasizes the importance of working at the structural and interpersonal or micro-level simultaneously to address the multifaceted reproduction of educational inequality and immobility.

In broad brush stroke terms, I outline a number of key aspects of educational policy to promote, at least, social mobility and equal opportu- 
nity whilst, of course, recognizing that these aspirations may well, themselves, fall short of the desire for a more equitable educational system for all. The first aspect is the expansion of pre-school education for all, on the grounds that this is the only possible way of ensuring a 'fair start'. At the same time, it is important that my advocacy of such a policy is not based on notions of 'parenting deficits' amongst the underprivileged that may, itself, amount to a kind of self-fulfilling prophecy, especially if the rationale for pre-school programmes is based on distorted understandings of cognitive science. Crucially, then, and secondly, the entire educational process needs to be open to greater scrutiny at grassroots level, by pupils and parents, and, at the same time, in a region where the ability to socialize in public spaces has been reduced, schools need to become genuine community resources. Thirdly, the formal and hidden curriculum needs to be more student-centred and move away from rote learning to critical consciousness ('conscientization' in Freire's terms). Fourthly, education needs to be treated as a commons, a public good open to all, and nurtured through being freely available to all. Free education is only free if there are also grants to cover living costs - and if they have to be limited, they should be based on need not so-called ability. Fifthly, meaningful participation is needed at all levels, as well as ensuring lifelong learning, second chances and, very much as the Swiss system does, multiple pathways to higher education. Children with disabilities need to be a priority, as do Roma children, not merely through scholarships for a few who can then join the middle class. More complex would be to value and support those lacking cultural capital or who do not speak in what Basil Bernstein (1971) termed 'elaborated codes' and, in this context, I would sound a warning about the current technocratic fashion for early intervention that can end up labelling the children it purports to help, instead preferring what I would term reflexive anti-oppressive practice, drawing attention to practices and structures of oppression and forming action coalitions to challenge them. In the end, perhaps, the conclusion might be that it is not possible to have a socially just educational system in a socially unjust society.

\section{Literature}

Archer, Roy, Duda, Igor and Stubbs, Paul (eds.) Social Inequalities and Discontent in Yugoslav Socialism, Abingdon: Routledge, 2016.

$\mathrm{Au}$, Wayne and M. Apple. »Reviewing Policy: Freire, Critical Education, and the Environmental Crisis«, Educational Policy, no. 21(3) (2007): 457-470. 
Bacevic, Jana. »Education, Conflict and Class Reproduction in socialist Yugoslavia." In Social Inequalities and Discontent in Yugoslav Socialism, 7794. Edited by Rory Archer, Duda, Igor and Stubbs, Paul. Abingdon: Routledge, 2016.

Bernstein, Basil. Class, Codes and Control Volume 1 Theoretical Studies Towards a Sociology of Language, London: Routledge, 1971.

Bevc, Milena. »Rates of Return to Investment in Education in Former Yugoslavia in the 1970 and 1980 o by Region«, Economics of Education Review, no. 12(4) (1993): 325-343.

Bourdieu, Pieree and Passeron, Jean-Claude. Production in Education, Society and Culture, London: Sage, 1977.

Cvjetičanin, Predrag, Misha Popovikj and Jasmina Nedeljković. »Who likes this change? Perception and evaluation of socio-economic changes in Western Balkan societies."In A Life for Tomorrow: social transformations in South-East Europe, edited by P. Cvjetičanin, I. Mangova and N. Markovikj, (S. 11-96). Skopje: Institute for Democracy, 2015.

Djilas, Milovan. The New Class: an analysis of the communist system, San Diego: Harcourt, Brace Jovanovich. 1957.

Doolan, Karin, Danijela Dolenec and Mladen Domazet, The Croatian Student Financial Support System in a European Context: a comparative study. Zagreb: Institute for the Development of Education, 2013. http://www.finhed.org/media/files/o6-ACCESS_Student_support_ENG_web.pdf

Doolan, Karin, Saša Puzić and Branislava Baranović. »Social Inequalities in Access to Higher Education in Croatia: five decades of resilient findings «, Journal of Further and Higher Education, no. 42(3) (2017): 1-15.

EBRD, Life in Transition III, Paris: EBRD, http://litsonline-ebrd.com.

Eurostudent (Cvitan, Doolan, Farnell, Matković), The Social and Economic Conditions of Student Life in Croatia. Zagreb: institute for the Development of Education, 2012. https://www.academia.edu/13099707/ Social_and_Economic_Conditions_of_Student_Life_in_Croatia_National_EUROSTUDENT_report_for_Croatia

Eurostudent (Huaschildt, Vogtle and Gwosc), Social and Economic Conditions of Student Life in Europe; EUROSTUDENT VI 2016-2018/Synopsis of indicators, Bielefled: wbv, 2018. https://www.eurostudent.eu/download_files/ documents/EUROSTUDENT_VI_Synopsis_of_Indicators.pdf

Freire, Paulo. Pedagogy of the Oppressed, New York: Continuum, 1970.

Ilišin, Vlasta. (ed.). Sociološki potret hrvayskih studenata, Zagreb: IDIZ, 2014. 
Jereb, Eva and Marko Ferjan. »Social Classes and Social Mobility in Slovenia and Europe.« Organizacija no. 41(6) (2008): 197-206.

$\mathrm{Ke} \mathrm{Xu}$ et al. »Household catarstrophic health expenditure: a multicountry analysis." The Lancet no. 9378 (2003): 111-117.

Klasić, Hrvoje. Jugoslavija i svijet 1968, Zagreb: Naklada Ljevak, 2012.

Kolarić, Zinka and Ivan Svetlik. »Jugoslovenski system blagostanja u uslovima ekonomske krize.« Sociološki pregled no. 21(1-2) (1987): 31-44.

Lazić, Mladen and Slobodan Cvejić. »Class and Values in Postsocialist Transformation in Serbia." International Journal of Sociology no. 37(3) (2007): 54-74.

Le Normand, Brigite. »The gastarbajteri as a transnational Yugoslav working class." In Social Inequalities and Discontent in Yugoslav Socialism, 38-57. Edited by R. Archer et. al. Abingdon: Routledge. 2016.

Lingard, Bob, Sandra Taylor and Shaun Rawolle. "Bourdieu and the study of educational policy: an introduction." Journal of Education Policy no. 20(6) (2005): 663-669.

London-Edinburgh Weekend Return Group, In and Against the State, London: Conference of Socialist Economists, 1979. https://ibcom.org/library/ against-state-1979

Matković, Teo and Ivana Dobrotić. »Promjene u obuhvatu programima predškolskog odgoja I obrazovanja u Hrvatskoj na nacionalnoj I županijskoj razini između 1990. I 2012. Godine."Revija za socijalnu politiku no. 20(1) (2013): 65-73.

Milić, Vojin. »General Trends in Social Mobility in Yugoslavia.« Acta Sociologica no. 9(1-2) (1966): 116-136.

OECD. Equity in Education: breaking down barriers to social mobility, Paris: OECD Publishing, 2018.

Previšić, Jozo and Vladimir Serdar. »Tko, kako I zašto na fakultet? Socijalno porijeklo I materijalni staus redovitih studenata u Hrvatskoj.« Pitanja, no. 10 (3) (1978): 4-21.

Rimac, Ivan and Branislava Baranović. »Socijalno struktura zagrebačkih studenata."In Društvenih profil zagrebačkih studenata krajem osamdesetih, 23-39. Edited by I. Magdelenić. Zagreb: Institute for Social Research, 1991.

Rubil, Ivica, Paul Stubbs and Siniša Zrinščak. »Dječje siromaštvo I strategije nošenja sa siromaštvom kućanstava u Hrvatskoj: kvantitativno-kvalitativna studija." Privredna kretanja I ekonomska politika no. 26(2) (2018): 59-116. 
Ružica, Miroslav. »Socijalna politika 8o-tih: kontinuitet ili promena strategije.« Sociološki pregled no. 21(1-2) (1987): 7-30.

Sekulić, Duško. Strukture na izmaku, klase, sukobi i socijalna mobilnost, Zagreb: Croatian Sociological Association, 1991.

Spasić, Ivana. »Distinkcija na domaći način: diskursi statusnog diferenciranja u današnjoj Srbiji.« In Nasleđe Pjera Burdijea: pouke i nedahnuća. Edited by M. Nemanjić and I. Spasić. Belgrade: Institute for Philosophy and Social Theory, 2006.

Stubbs, Paul, Marko Ledić, Ivica Rubil and Siniša Zrinščak. Child Poverty and Household Coping Strategies in Croatia, Zagreb: Institute of Economocis and Adris Foundation, 2017. https://www.eizg.hr/userdocsimages//projekti/zavrseni/Child_poverty_eng.pdf.

Stubbs, Paul. and Noemi Lendvai. »Authoritarian Neoliberalism, Radical Conservatism and Social Policy within the European Union: Croatia, Hungary and Poland." Development \& Change, no. 51(2) (2019): 540-560.

Šoljan, Nikša Nikola. »The Saga of Higher Education in Yugoslavia: beyond the myths of a self-management socialist society." Comparative Education Review no. 35(1) (1991): 131-153.

Suvin, Darko. Splendour, Misery and Possibilities: an X-Ray of socialist Yugoslavia, Leiden: Brill, 2016.

Šuvar, Stipe. Škola $i$ tvornica. Zagreb: Školska knjiga, 1977.

Waters, Tony and Dagmar Waters. Are the terms "socio-economic status" and "class status" a warped form of reasoning for Max Weber?. Palgrave Communications, 2, 2016. https://www.nature.com/articles/palcomms20162. pdf.

Županov, Josip. Od komunističkog pakla do divljeg kapitalizma, Zagreb: Hrvatska sveučilišna naklada, 2002.

\section{Webpages}

Benačić, Ana. »Grabar Kitarović o jogurtu, kruhu, zabrani izjašnjavanja »Hrvat/ic/om« I migrantima." https:/faktograf.hr/2018/og/12/grabar-kitarovic-o-jogurtu-kruhu-zabrani-izjasnjavanja-hrvat-ic-om-i-migranti$\mathrm{ma} /$ (12. 8. 2018).

Crespo Cuaresma, Jesus, K. C. Samir and Sauer, Petra. "Age-specific education inequality, education mobility and income growth." wwwforeurope Working Paper 6, web: https://epub.wu.ac.at/4716/1/WWWforEurope WPS_nooo6_MS15.pdf(1.5.2013). 
Dauenhauer, Nenad. »Bi li Kolindina kći upala na Harvard da joj majka nije bogata predsjednica?«, Index.hr, 21 May, https:/www.index.hr/vijesti/clanak/bi-li-kolindina-kci-upala-na-harvard-da-joj-majka-nije-bogata-predsjednica/2087282.aspx (1. 5. 2019).

Dnevno. »Predsjednička dinastija: nećete vjerovati kamo Kolindina kći odlazi studirati.« dnevno.hr 20 May, https://www.dnevno.hr/vijesti/predsjednicka-dinastija-necete-vjerovati-kamo-kolindina-kci-odlazi-studirati-1313157/. (1. 5. 2019).

Eurostat. „Gender Statistics«, https://ec.europa.eu/eurostat/statistics-explained/index.php/Gender_statistics\#Education (1. 5. 2019).

N1 Info. 2019. »Imovina predsjedničkih kandidata: Predsjednica štedi, Škoro najbogatiji.« http://hr.niinfo.com/Vijesti/a426609/Imovina-predsjednickih-kandidata-Predsjednica-stedi-Skoro-najbogatiji.html (20. 5. 2019).

Plivelić, Petra. »Razgovarali smo sa Zagrepčankom koja Hrvate upisuje na Harvard.« https://www.jutarnji.hr/life/zivotne-price/razgovarali-smo-sazagrepcankom-koja-hrvate-upisuje-na-harvard-nisam-se-rodila-sa-srebrnom-zlicom-ali-sve-se-moze-kad-se-hoce-ja-sam-zivi-dokaz/8891186/ (20. 5. 2019).

Trstenjak, Karla. »U Hrvatskoj se traži ogroman broj činjenica, a na Oxfordu da kažete svoje mišljenje i argumentirate ga ...«, Dnevnik.hr, https:// dnevnik.hr/vijesti/hrvatska/kci-predsjednice-kolinde-grabar-kitarovic-odlazi-studirati-na-harvard---561608.html, (21. 5. 2019).

Vojković, Goran. »Ne, frustrirani jadnici, Kolinina kći nije samo tako upisala Harvard «Index.hr, https://www.index.hr/vijesti/clanak/ne-frustrirani-jadnici-kolindina-kci-nije-samo-tako-upisala-harvard/2086998.aspx, (20. 5. 2019). 
inovativni pristopi kučenju in poučevanju 



\title{
Predšolska vzgoja v državah članicah EU (Slovenija, Hrvaška) in nečlanicah (Bosna in Hercegovina, Srbija)
}

\author{
Lilijana Gomerčić
}

\section{Predšolska vzgoja v Evropi}

Po podatkih, ki jih je objavil Eurydice (EACEA, 2014), je bilo v Evropi leta 201132 milijonov predšolskih otrok, od teh pa jih 20 milijonov ni bilo zajetih v institucionalno vzgojo in izobraževanje. Podatki iz leta 2017 kažejo nekoliko boljšo sliko, saj je od 32 milijonov predšolskih otrok na področju Evropske unije blizu 15 milijonov vključenih v institucionalno vzgojo in izobraževanje. ${ }^{I}$ Večina držav članic EU nima dovolj prostih mest v vrtcih in jih je samo nekaj vključenih v sistem spremljanja kakovosti predšolske vzgoje in izobraževanja. Prizadevanja in želje, da bi bilo $95 \%$ otrok med tretjim in šestim letom starosti vključenih v vrtce, še niso prišla do cilja. ${ }^{2}$ Svet Evropske unije je leta 2017 razglasil dokument Evropski steber socialnih pravic, ki v 3. poglavju navaja, da: a) imajo otroci pravico do cenovno dostopne in kakovostne predšlske vzgoje in varstva, b) imajo otroci pravico do varstva pred revščino. Otroci iz prikrajšanih okolij imajo pravico do posebnih ukrepov za izboljšanje njihovih možnosti. ${ }^{3}$ Ne glede na prizadevanja določenih političnih struktur je še vedno veliko, če ne preveč otrok, ki nimajo možnosti vključevanja $\mathrm{v}$ vrtce in živijo na pragu revščine ali celo $\mathrm{v}$

110 trends transforming education as we know it: https://ec.europa.eu/epsc/sites/ epsc/files/epsc_-_10_trends_transforming_education_as_we_know_it.pdf.

2 Evropski svet (2002) v Barceloni je določil kvantitativne cilje, ki naj bi se uresničili do leta 2010.

3 Medinstitucionalna razglasitev evropskega stebra socialnih pravic, Bruselj 2017 http://data.consilium.europa.eu/doc/document/ST-13129-2017-INIT/sl/pdf. 
revščini. Vse evropske države so sprejele smernice o predšolski vzgoji in varstvu, a dostopnost je dejavnik, ki se razlikuje od države do države. Priporočila Sveta Evrope, 2019: kurikulum: holistični, prilagodliiv, zahteva sodelovanje, redno izboljševati/pregledovati (revidirati). Dostop: razpoložljivo, cenovno dostopno za vse, spodbujati sodelovanje, krepiti vključevanje različnosti. Kader: strokoven in dobro usposobljen, vodstvo, ugodni delovni pogoji - podpora. Vrednotenje in spremljanje: redno in pregledno; najboljša korist za otroka; učinkovita uporaba za razvoj politike. Upravljanje in financiranje: usklajena zakonodaja in odgovornost; sodelovanje; doseganje univerzalne pravne upravičenosti. ${ }^{4}$ Nekatere mednarodne raziskave $\left(\mathrm{OECD}^{5}\right.$ in IEA $^{6}$ ) ugotavljajo, da so otroci in mladostniki, ki so obiskovali vrtce, dosegali boljše rezultate pri pismenosti in matematičnih nalogah, zato je treba ustvarjati visokokakovostne programe na zgodnji in predšolski ravni. Da bi videli, kako je za predšolsko raven poskrbljeno v naštetih državah, smo izvedli deskriptivno primerjalno analizo in jo prikazali v prispevku. Predšolska vzgoja in izobraževanje imata pomembno vlogo na nacionalni rav$\mathrm{ni}$ in sta del celotne politike vzgoje in izobraževanja. Na podlagi dostopnih virov smo pregledali in analizirali zakonodajna in programska izhodišča $\mathrm{v}$ Republiki Sloveniji, na Hrvaškem, v Srbiji in $\mathrm{BiH}$, kurikule za vrtce ter izobraževalne programe vzgojiteljev na izbranih univerzah.

\section{Namen raziskave}

V prispevku smo prikazali analizo stanja na področju zgodnje in predšolske vzgoje v državah po osamosvojitvi, ki so bile nekdaj del skupne federacije. Namen preglednega članka je bil analizirati in ugotoviti podobnosti in razlike, prednosti in primanjkljaje v vzgojno-izobraževalnih sistemih na predšolski ravni v Sloveniji in Hrvaški (EU) in tretjih državah, Bosni in Hercegovini ter Srbiji. Zanimala sta nas kakovost in zagotavljanje optimalnih pogojev za razvoj otroka v zgodnjem otroštvu v naštetih državah. $\mathrm{V}$ članku smo prikazali pregled in analizo zakonodajnih in programskih

4 Priporočilo Sveta Evrope, 2019: https://data.consilium.europa.eu/doc/document/ST7976-2019-INIT/sl/pdf.

5 OECD (Organisation for Economic Cooperation and Development) mednarodna organizacija, ki skrbi za gospodarsko sodelovanje in razvoj na svetovni ravni.

6 IEA (International Association for the Evaluation of Educational Achievement) je mednarodno združenje za vrednotenje izobraževalnih dosežkov in mednarodno združenje nacionalnih raziskovalnih institucij, vladnih raziskovalnih agencij, znanstvenikov in analitikov, ki se ukvarjajo $\mathrm{z}$ raziskavami, razumevanjem in izboljšanjem izobraževanja po vsem svetu. 
izhodišč ter programske in kurikularne usmeritve za vrtce. S primerjalno analizo raziskovalnih sklopov Zakonodajna in programska izhodišča s področja vzgoje in izobraževanja na predšolski stopnji ter Kurikuli in okvirni programi za vrtce $v$ naštetih državah smo predstavili okvire in sodobne didaktične mehanizme, ki stremijo $\mathrm{k}$ didaktično-metodični prenovi predšolskega področja. Namreč, ko gre za pravice otroka do vzgoje in izobraževanja ter ustvarjanja kvalitetnih pogojev na institucionalni ravni, pričakujemo, da se otrokom nudijo vsaj podobne možnosti. Vedno več otrok zgodnjega in predšolskega obdobja je vključenih v katero od oblik organiziranega vzgojno-izobraževalnega sistema in jim je treba nuditi visoko raven kakovosti.

\section{Metodologija}

$\mathrm{Na}$ podlagi dostopnih virov smo pregledali in analizirali zakonodajna in programska izhodišča v Republiki Sloveniji, na Hrvaškem, v Srbiji in $\mathrm{BiH}$, kurikule za vrtce ter stopnje izobrazbe vzgojiteljev. $Z$ naštetimi zakonodajnimi in programskimi izhodišči smo opravili mednarodno primerjalno analizo med Republiko Slovenijo in Republiko Hrvaško kot članicama EU, in Republiko Srbijo ter Bosno in Hercegovino, ki nista članici. Ugotavljali smo, na kakšen način je na sistemski ravni poskrbljeno za vzgojo in izobraževanje predšolskih otrok. Pri tem smo želeli ugotoviti, kako sistemi v naštetih državah delujejo, $v$ čem se razlikujejo in kaj jim je skupno na področju vzgoje in izobraževanja predšolskih otrok in ali se otrokom, ki so vključeni v institucionalno vzgojo in izobraževanje, nudijo optimalni pogoji za razvoj.

\section{Predšolska vzgoja v Sloveniji}

$\mathrm{V}$ sedemdesetih in osemdesetih letih prejšnjega stoletja so bile opazne nekatere pomembne razvojne spremembe (razvoj programov, zvišanje stopnje izobrazbe za strokovne delavke in delavce, kakovostnejša oprema igralnic in didaktičnih pripomočkov in naraščanje deleža otrok, vključenih $\mathrm{v}$ vrtec). Vsi javni vrtci in nekateri vrtci s koncesijo pri svojem delu upoštevajo načela, cilje in smernice nacionalnega Kurikuluma za vrtce (1999). Poleg tega morajo slovenski vrtci upoštevati normative o številu otrok in odraslih v oddelku (Pravilnik o normativih za opravljanje dejavnosti predšolske vzgoje, 2014) ter relativno natančne in stroge predpise o prostorski ureditvi, ki je pomembna za zdravje in varnost otrok (Pravilnik o normativih 
in minimalnih tehničnih pogojih za prostor in opremo vrtca, 2000). ${ }^{7}$ Predšolska vzgoja in izobraževanje otrok zgodnjega in predšolskega obdobja se odvijata v vzgojno- izobraževalnih zavodih. Po trenutnih podatkih Ministrstva za izobraževanje, znanost in šport je teh v Sloveniji 408 (javnih in zasebnih vrtcev), skupaj z enotami jih je 1168, pri osnovnih šolah pa delujejo 203 vrtci z vsaj eno enoto. Predšolska vzgoja v Republiki Sloveniji se izvaja na podlagi Zakona o vrtcih (1996) in Zakona o spremembah in dopolnitvah zakona o vrtcih (2010), Zakona o organizaciji in financiranju vzgoje in izobraževanja (ZOFVI, 1996), Pravilnika o normativih za opravljanje dejavnosti predšolske vzgoje (2014), Kolektivne pogodbe za vzgojo in izobraževanje v Republiki Sloveniji (2017), Kurikuluma za vrtce (1999), Bele knjige za vzgojo in izobraževanje (2011), Pravilnika o normativih in minimalnih tehničnih pogojih za prostor in opremo vrtca (2000) in ostalih zakonskih in podzakonskih predpisov na področju predšolske vzgoje. Kurikulum za vrtce (1999) je nacionalni dokument, v katerem so smernice, cilji in načela ter pripomočki vsem strokovnim delavcem v vrtcu. Okoli $95 \%$ vrtcev v Sloveniji izvaja program $\mathrm{v}$ vrtcu na podlagi kurikularnih usmeritev, ostali vrtci pa po posebnih pedagoških načelih (koncept Reggio Emilia, waldorfski pristop, pristop Montessori, katoliški program, Korak za korakom), obstaja tudi urejen sistem reguliranega varstva predšolskih otrok na domu. Slovenija ima za predšolsko vzgojo malo alternativnih programov oziroma je vanje vključenih razmeroma malo otrok. Med drugimi oblikami varstva in vzgoje predšolskih otrok poznamo predšolsko vzgojo na narodno mešanih območjih, predšolsko vzgojo, ki poteka v bolnišnicah ali na domu. Med pomembnejšimi projekti oziroma programi, ki združujejo v omrežja več vrtcev v državi, so tudi ekovrtci, »zdravi vrtci«, mreža učečih se vrtcev in šol, Korak za korakom in podobni. V oddelku vrtca delata vzgojitelj in pomočnik vzgojitelja. V vrtcu so tudi svetovalni delavci, organizator prehrane, organizator zdravstveno-higienskega režima, lahko pa tudi drugi strokovni delavci. Naloga svetovalnih delavcev je svetovalno delo z otroki (individualno in v skupini), svetovalno in posvetovalno delo s starši in strokovnimi delavci vrtca ter sodelovanje pri organizaciji in načrtovanju dela vrtca. Poslovodni organ in pedagoški vodja vrtca je ravnatelj. Zahtevane pogoje za strokovne delavce predpisujeta 40. člen Zakona o vrtcih in 92. člen Zakona o organizaciji in financiranju vzgoje in izobraževanja. Vzgojiteljice morajo imeti vsaj prvo stopnjo visoke izobrazbe, vzgojiteljice pred-

7 Eurydice 2018; https://eacea.ec.europa.eu/national-policies/eurydice/content/early-childhood-education-and-care-77_sl. 
šolskih otrok - pomočnice vzgojiteljic pa srednješolsko izobrazbo. Otroci so razdeljeni v prvo (1-3 leta) in drugo (3-6 let) starostno obdobje, na podlagi slednjega se načrtujejo vzgojno-izobraževalne dejavnosti $\mathrm{v}$ vrtcu, temelječe na ciljih in načelih slovenskega nacionalnega kurikuluma. Starši lahko otroka vpišejo $\mathrm{v}$ vrtec $\mathrm{z}$ dopolnjenimi 11 meseci in $\mathrm{v}$ njem lahko ostane do vstopa $v$ šolo oziroma do 31. avgusta tekočega leta, kadar je najmlajši od teh otrok star 5 let in osem mesecev, najstarejši pa 6 let in 8 mesecev. Po zadnjih podatkih Statističnega urada Republike Slovenije je v šolskem letu 2018/19 v vrtce v Sloveniji vključenih 87147 otrok (81,7 \%), starih od 11 mesecev do 5 let, ki so $v$ javnih vrtcih, zasebnih vrtcih, vrtcih pri osnovnih šolah in varstvenih družinah. Število vključenih otrok se povečuje, čeprav predšolska vzgoja v Sloveniji ni obvezna. Poleg Kurikuluma za vrtce se v Sloveniji izvajajo še waldorfski, montessori in katoliški program ter od šolskega leta 2018/19 krajši program za otroke, ki so leto pred vstopom v šolo in ne obiskujejo vrtca. Vsi programi morajo pridobiti pozitivno mnenje Strokovnega sveta Republike Slovenije pri Ministrstvu za znanost, izobraževanje in šport.

\section{Predšolska vzgoja na Hrvaškem}

Na Hrvaškem so se sredi 19. st. začele odpirati prve hiše, v katerih so obstajala varstva za otroke, ki pa niso imele izobraževalno vlogo, ter so bile do sredine 20. stol. zasebne ali verske. Ravno tako kot v Sloveniji se opazne spremembe začnejo dogajati $\mathrm{v}$ sedemdesetih in osemdesetih letih prejšnjega stoletja. Z osamosvojitvijo v 9o. letih so se začela spreminjati zakonodajna izhodišča, ki so zajela tudi predšolsko vzgojo in izobraževanje. Poleg Zakona o predšolski vzgoji in izobraževanju najdemo še 42 različnih zakonov, pravilnikov in podzakonskih aktov, ki so povezani s sistemom predšolske vzgoje. Na Hrvaškem se predšolska vzgoja izvaja na podlagi Zakona o predšolski vzgoji in izobraževanju (1997), Zakona o spremembah in dopolnitvah Zakona o predšolski vzgoji in izobraževanju (2007 in 2013), Državnega pedagoškega standarda predšolske vzgoje in izobraževanja (2008), Sprememb državnega pedagoškega standarda (2010), Programskih usmeritev vzgoje in izobraževanja predšolskih otrok (1991), Nacionalnega kurikuluma za zgodnjo in predšolsko vzgojo in izobraževanje (2014) ter na podlagi odlokov občin ustanoviteljic. Nacionalni kurikulum za zgodnjo in predšolsko vzgojo in izobraževanje (2014) na Hrvaškem se vsebinsko razlikuje od slovenskega. Veliko pozornosti je usmerjene $\mathrm{v}$ individualni razvoj posameznega otroka in razvoj njegovih potencialov. Osnovna načela 
temeljijo na zagotavljanju pogojev visoke ravni fleksibilnega vzgojno-izobraževalnega procesa $v$ vrtcu, sodelovanju s starši in lokalno skupnostjo, zagotavljanju kontinuitete $v$ vzgoji in izobraževanju, odprtosti za kontinuirano učenje in pripravljenosti za izboljšanje prakse (prav tam, str. 12). V ospredju vzgojno-izobraževalne dejavnosti je spodbujanje popolnega in zdravega razvoja otroka ter razvoja vseh področij otrokove osebnosti: fizične, čustvene, socialne, intelektualne, moralne in duhovne, primerno otrokovim razvojnim možnostim. Predšolska ustanova temelji na humanistično-razvojnem konceptu, ki ga sestavljajo: a) ideja humanizma (otrok je vrednota sama po sebi), b) spoznanje o posebnih značilnostih in zakonitostih otrokovega razvoja ter spoznavanje o človekovem razvoju kot celoti, c) spoznanje o značilnostih izvendružinske vzgoje predšolskih otrok. V vrtcu so zaposleni vzgojitelji predšolskih otrok (6. stopnja - prvostupnik predšolske vzgoje in 7. stopnja - magister zgodnje in predšolske vzgoje). Poklic vzgojiteljice predšolskih otrok - pomočnice vzgojiteljice ne obstaja. V vrtcu sta ravno tako zaposlena ravnatelj in svetovalna oziroma strokovno-razvojna služba, kar je odvisno od velikosti vrtca. Starši lahko vpišejo otroka po doplolnjenem letu starosti (obstajajo vrtci, ki lahko sprejmejo otroke po dopolnjenem šestem mesecu starosti, kar je predpisano $\mathrm{z}$ Zakonom $^{8}$, morajo pa izpolnjevati posebne pogoje). $\mathrm{V}$ vrtcih se ravno tako, poleg rednega programa in smernic iz kurikuluma, izvajajo še posebne oblike vzgojno-izobraževalnega dela po alternativnih programih Montessori, Waldorf, Korak za korakom, pedagogike Agazzi, verskega programa Kateheza dobrega pastirja in ostali programi, prilagojeni potrebam otrok in staršev. Po podatkih Državnega statističnega urada Republike Hrvaške je bilo v šolskem letu 2017/18 v vrtce vpisanih 139228 otrok, kar je približno 58 \% vpisanih predšolskih otrok $\mathrm{v}$ celotni državi. $\mathrm{V}$ odstotkih izstopajo glavno mesto Zagreb z vpisanimi $82 \%$ otrok predšolskega obdobja ter mesta in občine z višjo stopnjo zaposlenosti. V manjših občinah je število vpisanih otrok veliko nižje od povprečja.

\section{Predšolska vzgoja v Srbiji}

Predšolska vzgoja in izobraževanje v Srbiji se izvajata na podlagi Zakona o osnovah sistema izobraževanja in vzgoje (splošni zakon) (2017), Zakona

8 Zakon o predškolskom odgoju i obrazovanju (NN 10/97, 107/07, 94/13,) 3. člen, Predškolski odgoj organizira se i provodi za djecu od navršenih 6 mjeseci života do polaska u osnovnu školu. 
o predšolski vzgoji in izobraževanju (2010), Pravilnika o splošnih osnovah predšolskega programa (2003), Pravilnika o splošnih osnovah predšolskega programa (2006), Pravilnika o standardih kompetenc vzgojitelja in njegovega profesionalnega razvoja (2017) ter ostalih zakonskih in podzakonskih aktov. Mreža vrtcev ni enakomerna, usmerjena je v urbana področja, tako da so otroci na ruralnih področjih $\mathrm{v}$ neugodnem in depriviligiranem položaju. Čeprav je sistem pravno zelo dobro urejen, je, žal, vključevanje otrok $\mathrm{v}$ vrtce še vedno pod pričakovanim, saj je $\mathrm{v}$ tem trenutku približno $50 \%$. Ravno iz Pravilnika o splošnih osnovah predšolskih programov izhajajo osnove za načrtovanje vzgojno- izobraževalnega dela od prvega starostnega obdobja do vstopa $\mathrm{v}$ šolo. V vrtcih neposredno delajo $\mathrm{z}$ otroki strokovni delavci vzgojitelji (vaspitači) $\mathrm{z}$ visoko izobrazbo ter poklica medicinska sestra - vzgojitelj (javnoveljavni poklic v Srbiji) in defektolog - vzgojitelj. Medicinska sestra - vzgojitelj lahko dela tudi s srednješolsko izobrazbo pete stopnje, vendar samo v skupini od šestega meseca starosti do dopolnjenega 3. leta.

Vzgojitelji morajo imeti končano terciarno izobraževanje prve stopnje (osnovni strokovni študij, osnovni akademski študij ali specialistični strokovni študij) ali na drugih stopnjah (magistrski univerzitetni študij, specialistični univerzitetni študij ali magistrski strokovni študij). Na delovnih mestih za izboljšanje predšolske vzgoje je zaposlena tudi svetovalna služba naslednjih profilov: pedagog, psiholog, pedagog za likovno, glasbeno in telesno vzgojo in logoped. V Pravilniku so natančno obrazložena navodila, kako medicinske sestre - vzgojiteljice in vzgojiteljice izvajajo nego in vzgojno- izobraževalne dejavnosti po področjih. V prvem starostnem obdobju $\mathrm{z}$ otroki delajo medicinske sestre - vzgojiteljice, kar je posebnost, $\mathrm{s}$ katero se Srbija razlikuje od ostalih držav, ki jih tu omenjamo. Starši lahko vpišejo otroka v vrtec po dopolnjenem šestem mesecu starosti. Progami v vrtcih upoštevajo, poleg zakonov, tudi Pravilnik o splošnih osnovah predšolskega programa (2006), ki usmerja dejavnosti in osnovna področja razvoja predšolskega otroka. Napisan je na 72 straneh, usmeritve so razdeljene po starostnih obdobjih (6 do 18 mesecev, 18 do 24,24 do 36 ) za prvo starostno obdobje. Sledijo usmeritve oziroma skupne lastnosti modela predšolske vzgoje in izobraževanja za otroke od dopolnjenega tretjega leta starosti do vstopa v šolo, približno od 6,5 do najpozneje 7,5 let. Predvidena sta dva modela, in sicer Model A in Model B. Imata veliko skupnih lastnosti, pa tudi razlik. Model A stremi k odprtemu sistemu vzgoje ter akcijskemu razvijanju programa po željah in interesih otrok. Model B ima lastnosti kognitiv- 
no-razvojnega programa in razčlenjene vzgojno-izobraževalne cilje, naloge vzgojitelja in vrste dejavnosti, ki jih lahko vzgojitelj izbira in dopolnjuje $\mathrm{v}$ soglasju s potrebami, interesi in zmožnostmi otrok.

\section{Predšolska vzgoja v Bosni in Hercegovini}

V Bosni in Hercegovini sta predšolska vzgoja in izobraževanje zelo kompleksni, kakor tudi osnovno šolstvo in nadaljnje izobraževanje. Namreč, pristojnosti za vzgojo in izobraževanje imajo posamezne pokrajine, ki jih je deset, ter še okrožji Republika Srbska in Brčko. Za izobraževanje je pristojnih kar trinajst ministrstev, Agencija za predšolsko, osnovno- in srednješolsko izobraževanje, Oddelek za izobraževanje Vlade okrožja Brčko BiH, devet pedagoških zavodov pri Federaciji BiH, Republiki Srbski in okrožju Brčko. Okvirni zakon za predšolsko vzgojo in izobraževanje je parlament sprejel leta 2007 , vse pokrajine pa naj bi predšolsko dejavnost uskladile $s$ sprejetim Zakonom, kar pa se, žal, ne odvija najbolj uspešno. Po številu otrok, ki so zajeti v organizirano predšolsko vzgojo in izobraževanje, je Bosna in Hercegovina na zadnjem mestu na evropski celini, poročajo iz organizacije $\mathrm{v}$ Alternativnem poročilu o stanju otrokovih pravic v Bosni in Hercegovini ${ }^{10}$. Celo tisto obvezno leto pred vstopom $\mathrm{v}$ šolo je za precej otrok nedostopno (oddaljenost, socialne in ekonomske razmere $\mathrm{v}$ družini, nezaposlenost staršev). Glede na dejstvo, da zakoni za predšolsko vzgojo in izobraževanje niso sprejeti na celotnem področju $\mathrm{BiH}$, so nekateri otroci v podrejenem položaju ter nepravično in neenako obravnavani. Svet ministrov $\mathrm{BiH}$ je leta 2017 sprejel Odločbo o sprejemu Platforme za razvoj predšolske vzgoje in izobraževanja v $\mathrm{BiH}$ 2017-2022 (Sl. glasnik BiH 2/18). Predlog za sprejem Platforme je podalo Ministrstvo za civilne posle Bosne in Hercegovine. Iz dokumenta smo povzeli načela: načelo največjega interesa $z a$ otroka, načelo enakih pravic in nediskriminacije, načelo demokratičnosti in pluralizma, humanistično razvojno načelo, načelo partnerstva in sodelovanja, načelo medsektorskega sodelovanja in multidisciplinarnosti, načelo poklicne avtonomije in odgovornosti. Poleg načel so v dokumentu zapisani tudi strateški cilji za predšolsko vzgojo in izobraževanje ter "paketi dejavnosti«, s pomočjo katerih naj bi sledile izboljšave na področju vzgoje in izobraževanja predšolskih otrok v $\mathrm{BiH}$ : povečati število otrok v predšolski vzgoji in izobraževanju (pregledati trenutno stanje, analizirati človeške vire/zaposlene, urediti bazo podatkov, zagotoviti finančna sredstva, obliko-

10 Alternativno poročilo, ki sta ga izdali UNICEF BiH, Naša djeca - udruženje za ostvarivanje prava djeteta in Mreža nevladinih organizacija Snažniji glas za djecu, 2018. 
vati nove kriterije za participacijo staršev, obnoviti obstoječe objekte, graditi nove, zagotoviti kakovost predšolske vzgoje in izobraževanja (določiti izhodišča učenja in razvoja v predšolski vzgoji (PV), izboljšati prakse na podlagi izhodišč in razvoja PV, sporazumno prenoviti skupna jedra na podlagi izhodišč in razvoja $\mathrm{PV}$, napisati nove in izboljšati obstoječe programe ...); zagotoviti redno financiranje (zagotoviti zakonske predpogoje za uvedbo PV v proračune entitet, kantonov, okrožja Brčko in lokalnih skupnosti, materialno uravnotežiti strokovne kadre v vrtcu in šoli, zagotoviti zakonske pogoje za razvijanje javno-zasebnega partnerstva ...); krepiti inkluzijo (zagotoviti pristop in tehnične prilagoditve vrtcev otrokom s telesnimi primanjkljaji, izboljšati vseživljenjsko učenje za vzgojitelje in svetovalno službo, razviti koncept dodatnih kapacitet za sprejem otrok s posebnimi potrebami ...); senzibilizirati družbo (začeti pripravljati in podpisovati protokole o sodelovanju med predšolskimi, zdravstvenimi in socialnimi ustanovami na ravni lokalne skupnosti, da bi zagotovili dostopno in kakovostno PV za vse otroke, sodelovati, izvajati delavnice, javna obveščanja, publikacije .... $)^{\mathrm{II}}$.

Če bodo „paketi dejavnosti” zaživeli, pričakujemo, da bodo otroci v Bosni in Hercegovini vsaj delno pridobili, kar jim pripada.

\section{Primerjava v številkah}

Tabela s: Število vrtcev in vključenost predšolskih otrok v vrtce v državah

\begin{tabular}{|c|c|c|c|c|}
\hline & SLO & HR & SRB & $\mathrm{BIH}$ \\
\hline Število javnih vrtcev (enote) & $\begin{array}{c}1026 \\
85,95 \%\end{array}$ & $\begin{array}{c}1273 \\
74,45 \%\end{array}$ & $\begin{array}{c}2464(162) \\
86,70 \%\end{array}$ & $\begin{array}{c}187 \\
58,26 \%\end{array}$ \\
\hline Število zasebnih vrtcev (enote) & $\begin{array}{c}154 \\
13,05 \%\end{array}$ & $\begin{array}{c}437 \\
25,55 \%\end{array}$ & $\begin{array}{c}378(283) \\
13,30 \%\end{array}$ & $\begin{array}{c}134 \\
41,74 \%\end{array}$ \\
\hline Skupaj & $1180(407)$ & 1710 & 2842 & 321 \\
\hline Število otrok v vrtcih & $\begin{array}{l}87150 \\
81,7 \%\end{array}$ & $\begin{array}{c}139378 \\
71 \%\end{array}$ & $\begin{array}{c}218567 \\
50 \%\end{array}$ & $\begin{array}{c}25889 \\
14 \%\end{array}$ \\
\hline Program pred šolo (mala šola) & Ni obvezen & Obvezen & Obvezen & $\begin{array}{l}\mathrm{Da} / \text { ne (odvisno } \\
\text { od kantona) }\end{array}$ \\
\hline $\begin{array}{l}\text { Število otrok v programu pred } \\
\text { šolo }\end{array}$ & $\begin{array}{l}\text { Ni podatka } \\
\text { Začetek leta } \\
2018\end{array}$ & 10283 & 65057 & Samo $50 \%$ \\
\hline
\end{tabular}

11 Odluka o usvajanju platforme za razvoj predškolskog odgoja i obrazovanja u Bosni i Hercegovini za period 2017. - 2022. Službeni glasnik BiH, broj 2/18. 
Iz Tabele 5 lahko sklepamo, da je število otrok, zajetih v organizirano predšolsko vzgojo in izobraževanje bodisi v javnih ali zasebnih vrtcih, odstotkovno najvišje v Republiki Sloveniji, sledi na Hrvaškem. Republika Srbija ima okoli 50 \% vključenih otrok, medtem ko jev Bosni in Hercegovini porazno nizko število otrok, vključenih v organizirano predšolsko vzgojo in izobraževanje, celo v obveznem predšolskem programu.

\section{Tabela 6: Normativi za število otrok v skupini}

\begin{tabular}{|c|c|c|c|c|}
\hline Število otrok v oddelku & SLO & $\mathrm{HR}$ & SRB & $\mathrm{BIH}$ \\
\hline 6 do $12 \mathrm{~m}$ & - & 5 & 7 & - \\
\hline 1 do 2 leti & $12(2)$ & 12 & 12 & $12(10-16)$ \\
\hline 2 do 3 & $12(2)$ & 14 & 16 & $16(13-21)$ \\
\hline 3 do 4 & $17(2)$ & 18 & 20 & $19(14-25)$ \\
\hline 4 do 5 & $22(2)$ & 20 & 24 & $21(16-27)$ \\
\hline 5 do 6 & $22(2)$ & 23 & 24 & $26(20-32)$ \\
\hline 6 do vstopa v šolo & - & 25 & 26 & - \\
\hline Kombinirani 2. st. obdobja & $17(2)$ & $20-22$ & 20 & $23(18-30)$ \\
\hline
\end{tabular}

Iz Tabele 6 vidimo, da so normativi podobni v Republiki Sloveniji in na Hrvaškem, čeprav so na Hrvaškem še vedno zelo fleksibilni in v vseh vrtcih zaradi prostorske stiske ne upoštevajo normativov. Na tem področju se intenzivno dela že deset let. V Bosni in Hercegovini imajo v vrtcih še vedno zelo velike skupine, čeprav se v zadnjih letih trudijo spremeniti pogoje.

\section{Sklep}

Po pregledu zakonodajnih izhodišč, pravilnikov, izobraževanj vzgojiteljev, profilov zaposlenih v vrtcih, programskih in kurikularnih usmeritev in vse ostale dostopne literature lahko rečemo, da se sistemi v državah razlikujejo na več področjih. Pri ustanoviteljskih pravicah, programskih usmeritvah in obveznostih zavodov ni večjih odstopanj. Pri pravicah vpisa v vrtce po starostnem obdobju, strokovni usposobljenosti, profilu zaposlenih in financiranju zavodov prihaja do večjih razlik. Posebnost predšolske vzgoje lahko izpostavimo v Bosni in Hercegovini, ki nima enotnega sistema zaradi zakona, ki je okviren, in ga posamezne pokrajine prilagajajo svojim potrebam, ker so pristojne za vzgojno-izobraževalne zavode. Ko gre za Slovenijo in Hrvaško, se sistema razlikujeta v več dejavnikih, posebej pri sofinanciranju in kadrovski politiki. Republika Srbija ima veliko pravnih dokumentov, ki poudarjajo pomen poklicnega razvoja vzgojiteljev in njiho- 
vih kompetenc. V zadnjih nekaj letih so na področju predšolske vzgoje in izobraževanja naredili korak naprej ter stremijo k implementaciji evropske politike in prakse. Če povzamemo, ugotavljamo, da otroci kljub prizadevanjem določenih političnih struktur, dobrodelnih organizacij in posameznikov nimajo enakih možnosti, ne pravic in ne enake dostopnosti. Izstopajo zlasti otroci na področju Bosne in Hercegovine, zaradi neenotnosti sistema in šibkejših socialnih in ekonomskih razmer.

\section{Literatura}

EACEA. Predšolska vzgoja in varstvo $v$ Evropi: odpravljanje socialne in kulturne neenakosti. Ljubljana: Ministrstvo za šolstvo in šport, 2009.

Krek, Janez in Mira Metljak (ur.). Bela knjiga o vzgoji in izobraževanju v Republiki Sloveniji. Ljubljana: Zavod RS za šolstvo, 2011.

Alternativno izvješće o stanju prava djeteta u Bosni i Hercegovini 2011-2018. Dostopno prek: http://snaznijiglaszadjecu.org/wp-content/uploads/2019/o7/ Alternativni-izvjestaj-BH-2018.pdf, (10. 3. 2019).

Dobrotić, Ivana, Teo Matković in Vesna Menger. »Analiza pristupačnosti, kvalitete, kapaciteta i financiranja sustava ranoga i predškolskog odgoja $i$ obrazovanja u Republici Hrvatskoj.» Dostopno prek: https://www.bib.irb. $\mathrm{hr} / 945345$, (12. 3. 2019).

EACEA. Eurydiceov kratek pregled politike - Rani i predškolski odgoj i obrazovanje, 2014. Dostopno prek: http://publications.europa.eu/resource/ cellar/25c63f11-c2cb-4c4c-a3cb-85d9b1eab93b.0012.01/DOC_1, 15. 1. 2019 (2014).

EACEA. Structural Indicators for Monitoring Education and Training Systems in Europe: Eurydice Background Report. Dostopno prek: https://eacea. ec.europa.eu/national-policies/eurydice/sites/eurydice/files/structural_ indicators_2018.pdf, 21. 1. 2019 (2018).

Erčulj, Justina, Milena Ivanuš Grmek, Jurka Lepičnik Vodopivec, Kristijan Musek Lešnik, Iztok Retar, Mitja Sardoč in Tina Vršnik Perše, 2008. Evalvacija vzgoje in izobraževanja $v$ RS - projektno poročilo. Ljubljana: Pedagoški inštitut. Dostopno prek: http://www.mss.gov.si/si/delovna_podrocja/ razvoj_solstva/evalvacija_vzgojno-izobrazevalnih_programov/\#c17223, (14. 1. 2019).

Izvješće o provedbi okvirnog zakona o predškolskom odgoju i obrazovanju u BIH, Analiza stanja i preporuke. Agencija za predškolsko, osnovno i srednje obrazovanju Sarajevo, 2011. 
Kurikulum za vrtce. (1999). Ministrstvo za izobraževanje znanost in šport. Dostopno prek: http://www.mizs.gov.si/fileadmin/mizs.gov.si/pageuploads/podrocje/vrtci/pdf/vrtcikur.pdf (22. 11. 2017)

Nacionalni okvirni kurikulum za predškolski odgoj i obrazovanje te opće obvezno i srednjoškolsko obrazovanje. Ministarstvo znanosti obrazovanja i športa. Dostopno prek: https://www.azoo.hr/images/stories/dokumenti/ Nacionalni_okvirni_kurikulum.pdf, (15.12. 2018)

Okvirni zakon o predškolskom odgoju i obrazovanju u Bosni i Hercegovini; Službeni glasnik BIH 122/o7.

Platforma za razvoj predšolske vzgoje Sl. glasnik $\mathrm{BiH}$ 2/18. Dostopno prek: http://www.sluzbenilist.ba/page/akt/IgLBVvzFbEs=, 11. 1. 2019 (2018).

Pravilnik o normativih za opravljanje dejavnosti predšolske vzgoje. PIS. Dostopno prek: http://www.pisrs.si/Pis.web/pregledPredpisa?id=PRAV12026. 14. 12. 2017 (2014).

Programsko usmjerenje odgoja i obrazovanja predškolske djece. Ministarstvo znanosti i obrazovanja. Dostopno prek: https://mzo.hr/sites/default/files/ migrated/programsko_usmjerenje_odgoja_i-obrazovanja_predskolske_ djece.pdf. 22. 1. 2018 (1991).

Pravilnik o model ustanovi. Službeni glasnik Republike Srbije 88/17 in 27/18. Dostopno prek: http://www.mpn.gov.rs/wp-content/uploads/2019/o2/FINAL-Pravilnika-o-model- ustanovi.docx. 25. 3. 2019 (2017; 2018).

Pravilnik o opštim osnovama predškolskog programa. Službeni glasnik Republike Srbije; Prosvetni glasnik 14/2006. ostopno prek: http://www.pravno-informacionisistem.rs/SlGlasnikPortal/viewdoc? regactid $=408077 \&$ doctype $=$ reg\&findpdfurl=true. 25. 3. 2019 (2006).

Pravilnik o vrsti stručne spreme vaspitača, medicinskih sestara i stručnih suradnika u dečjem vrtiću. Službeni glasnik Republike Srbije; Prosvetni glasnik 1/89. Dostopno prek: http://demo.paragraf.rs/demo/combined/Old/t/t2008_03/to3_0092.htm.25.3.2019 (1989).

Pravilnik o standardima kompetencija za profesiju vaspitača i njegovog profesionalnog razvoja. Dostopno prek: http://www.mpn.gov.rs/wp-content/uploads/2018/o9/Pravilnik-o-standardima-kompetencija-za-profesiju-vaspita\%C4\%8Da-i-njegovog-profesionalnog-razvoja.docx. 25. 3. 2019 (2018).

Reforme predšolske vzgoje. Dostopno prek: 25. 3. 2019 s https://eacea.ec.europa.eu/national-policies/eurydice/content/national-reforms-early-childhood-education-and-care-68_sl. 25.3. 2019 (2019). 
Statistični urad Republike Slovenije. Dostopno prek: https:/www.stat.si/ StatWeb/Field/Index/9. 22. 5. 2019 (2019).

Zakon o vrtcih (ZVRT). Uradni list RS, št. 100/5, in Zakon o spremembah in dopolnitvah Zakona o vrtcih (ZVrt-F). Dostopno prek: http://www.pisrs.si/Pis.web/pregledPredpisa?id=ZAKO4589 in http://www.pisrs.si/Pis. web/pregledPredpisa?id=ZAKO7555\#. 28. 3. 2019 (2005).

Zakon o predškolskom odgoju i obrazovanju."Narodne novine”, broj 10/97, 107/o7 i 94/13. Dostopno prek: http://www.propisi.hr/print.php?id=5632. 10. 3. 2019 (1997).

Zakon o predškolskom vaspitanju i obrazovanju. »Sl. glasnik RS«, br. 18/2010, 101/2017, 113/2017 - dr. zakon, 95/2018 - dr. zakon i 10/2019. Dostopno prek: https://www.paragraf.rs/propisi_download/zakon-o-predskolskom-vaspitanju-i-obrazovanju.pdf. 10. 3. 2019 (2010). 



\section{izobraževalne politike}





\title{
Evropska študijska mobilnost in karierni načrti mladih
}

\author{
Elena Nacevska, Danica Fink Hafner, Barbara Brečko, Tanja Oblak Črnič
}

\begin{abstract}
Uvod
Prispevek obravnava evropsko študijsko mobilnost kot specifično obliko mobilnosti mladih, ki sooblikuje tudi njihove karierne načrte. Kadar karierni načrti vključujejo tudi mednarodno komponento, lahko predstavljajo pomembno spodbudo za mednarodno študijsko mobilnost in vplivajo na karierne poti ter poklicne preference mladih tako, da jih internacionalizirajo. Različne študije so že poudarile, da evropska študijska mobilnost prispeva k oblikovanju evropske identitete in makrodružbene formacije (gl. npr. Lesjak in Anussornnitisarn, 2017; Powell in Finger, 2013; Teichler, Ferencz in Wachter, 2011; Ifversen, 2000; Bagnoli, 2009; Genov, 2014; Golob, 2017). K tem ugotovitvam pa v tukajšnji razpravi dodajamo, da mednarodno študijsko mobilnost sooblikujejo tudi drugi dejavniki, kot so denimo odraščanje in osamosvajanje mladih (Arnett, 2004; Thomson in Taylor, 2005; Golob, 2017), imaginacijske izkušnje mladih v nacionalnem okolju, njihova izobrazba, delovne izkušnje, družbeno-ekonomske razmere in spol (Kogan in Unt, 2006; Kelly, McGuinness, O‘Connell, 2012), razredni in družbeni položaj (Lehmann, 2004), individualizacija in neugodne razmere za zaposlovanje doma (kot npr. v okoliščnah finančne krize) (Bauer in Kreuz, 2015).

Glavni cilj prispevka je tako ugotoviti, kaj vpliva na karierno načrtovanje mladih. Prispevek se podrobneje osredotoča na dve raziskovalni vprašanji: prvič, kaj mlade sploh spodbuja k temu, da se odločijo za študijsko
\end{abstract}


izmenjavo v tujini, in drugič, kaj jih od študijske mobilnosti znotraj Evrope morda odvrača. $Z$ odgovori na navedena vprašanja želimo identificirati morebitne ovire, ki nekatere skupine mladih destimulirajo na njihovi karierni poti v tujino, pa tudi ugotoviti, kakšno vlogo ima študijski program Erasmus+ pri načrtovanju zaposlitvenih karier mladih.

Osrednja teza tega prispevka je, da se karierni načrti mladih znotraj relativno homogene populacije diferencirajo in da so odvisni od mnogih dejavnikov. To pomeni, da so karierni načrti sicer lahko odraz individualnih želja in izbir, a so hkrati odvisni tudi od specifičnih družbenih, socialnih in kulturnih ozadij, v katerih se te izbire sploh lahko oblikujejo.

$\mathrm{V}$ prispevku predstavljamo ključne ugotovitve raziskave, ki je bila izvedena jeseni 2018 na populaciji študentov prve in druge stopnje Fakultete za družbene vede Univerze v Ljubljani (FDV) ter študentov, ki so prišli na mednarodno študijsko izmenjavo na FDV. Podatki so bili zbrani s spletnim anketiranjem, ki je potekalo od 7. 11. 2018 do 19. 12. 2018.

$\mathrm{V}$ prispevku najprej predstavimo podrobnejši pregled literature in javnopolitičnih dokumentov o dejavnikih študijske mobilnosti. V empiričnem delu predstavimo rezultate kvantitativne analize podatkov raziskave med študenti FDV, v zaključku pa empirične ugotovitve primerjamo $\mathrm{z}$ ugotovitvami predhodnih primerljivih raziskav.

\section{Strukturni in individualni dejavniki študijske mobilnosti}

\section{Ugotovitve znanstvene literature}

$\mathrm{Na}$ prelomu tisočletja so raziskovalci ugotavljali, da sodobni tehnološki razvoj in družbene spremembe, še posebej erozija družbenih spon, omogočajo večjemu številu mladih po vsej Evropi, da v življenjskem obdobju oblikovanja identitete in osebnega razvoja dlje časa preživijo izven svojega matičnega okolja (Arnett, 2004). A izkazalo se je, da je mobilnost mladih precej odvisna od različnih dejavnikov, predvsem od njihove izobrazbe, izkušenj, družbeno-ekonomskega oz. socialnega položaja in spola (Kondakci et al., 2018; Kelly, McGuinness, O‘Connell, 2012; Kogan in Unt, 2006).

Souto-Otero (2008) sta opozorila na to, da so študentje menili, da je bila štipendija, ki so jo prejeli, premajhna, in na to, da je stopnja izobrazbe staršev pomemben dejavnik udeležbe mladih v programu Erasmus+ (sodelovalo je namreč več študentov, katerih starši so zaključili visokošolsko izobrazbo). Van Bouwel in Veugelers (2013) sta ugotovila, da množičnost in usmeritev študentskih tokov pojasnjujeta kakovost visokošolskega siste- 
ma države prejemnice in pomanjkanje možnosti za izobraževanje v domači državi.

Zelo pomembne pri mobilnosti mladih so tudi strukturne posebnosti, kot so zahteve po delovni sili, nacionalne politike zaposlovanja, specifike političnega režima (Barry, 2010; Bynner, 2005). Po mnenju nekaterih avtorjev sta ključna dejavnika za omenjeno mobilnost razredni in socialni položaj v družbi (Lehmann, 2004), nanjo pa močno vplivajo tudi dostop do globalnih informacij (Kelly, 1999) in spodbude, ki jih ponujajo režimi/sistemi socialnega varstva (Schels, 2013). Nadalje so študijska mobilnost in bodoče poklicne kariere odvisne od posebnih institucionalnih okolij ter izobraževalnih sistemov in dostopa do trga dela (Kogan in Unt, 2006; Hannan in dr., 1997).

Poleg strukturnih okoliščin pa je obseg študijske mobilnosti lahko tudi rezultat povsem individualnih preferenc. Povezan je z osamosvajanjem in graditvijo individualne avtonomije. Študijska mobilnost namreč ne pomeni le prehoda meje $\mathrm{v}$ fizičnem smislu, temveč vsaj do neke mere pomeni tudi ločitev od skupnosti v simbolnem, fizičnem in emocionalnem smislu, vključevanje v drugačno družbeno-kulturno okolje (Golob, 2017). Pred odločitvijo za družino, zaposlitev in preostale vloge odraslega posameznika ima torej mobilnost pomembno vlogo v materialnih in simbolnih praksah, ki označujejo prehod iz adolescence v odraslost (Thomson in Taylor, 2005). Bagnoli (2009), denimo, ugotavlja, da si mladi s potovanji pridobivajo nove izkušnje in povečujejo individualni nadzor nad lastnim življenjem ter na ta način spreminjajo scenarije konstrukcije osebnosti.

Raziskave opozarjajo tudi na emocionalne in kulturne ovire, ki sooblikujejo evropsko mobilnost mladih (Golob, 2017). Pri tem ne gre le za to, da se posameznik sooča $z$ emocionalnimi izzivi, povezanimi s podporo mobilnosti doma in s slovesom od bližnjih ter pričakovanji glede življenjskih sprememb, temveč tudi z jezikovnimi ovirami in družbenimi semantičnimi razlikami.

V celoti gledano, se negativni dejavniki odločanja za študij v tujini akumulirajo pri študentih iz nižjih socialnih slojev, kar nakazuje potrebo po nacionalnih mehanizmih spodbujanja mobilnosti.

\section{Ugotovitve javnopolitičnih dokumentov}

Javnopolitični dokumenti Evropske unije govorijo o študijski mobilnosti zelo pozitivno. Študijska mobilnost je ocenjena kot pomemben sprožilec sprememb, modernizacije in višje kakovosti na vseh področjih življenja, saj 
spodbuja mreženja in izmenjave med institucijami (EK, 20o8; EK, 2019b) spodbuja učenje jezikov kot sredstva za izgradnjo evropske integracije in državljanstva ter tudi za delovanje trga (EK, 2008 in EK, 2019a). Komisija EU promovira politike mobilnosti in sodelovanja $\mathrm{v}$ izobraževanju kot sestavine enotne organizacijske strukture dodiplomskega-magistrskega-doktorskega študija in boljšega zagotavljanja kakovosti (EK, 2020a), uveljavljajo pa se tudi priporočila Sveta Evrope, naj se spodbuja avtomatično vzajemno priznavanje diplom in spričeval ter izidov iz učnih obdobij v tujini (EK, 2018 - COM(2018) 270), ideja evropske študentske izkaznice, ki omogoča boljšo izmenjavo informacij o študentih, ter ideja oblikovanja koalicij evropskih univerz za povečanje konkurenčnosti, kakovosti in odličnosti v poučevanju, raziskavah in inovacijah (EK, 2020a).

Program Erasmus+ je ocenjen kot ključni dejavnik internacionalizacije in nekoliko tudi evropeizacije visokošolskih izobraževalnih sistemov v EU (EK, 2019b). Po podatkih Evropske komisije več kot 70 \% nekdanjih študentk in študentov, ki so bili vključeni v program Erasmus+, navaja, da po vrnitvi iz tujine bolje vedo, kakšno poklicno pot si želijo, 80 \% študentk in študentov Erasmus+ pa, da jim je izkušnja v tujini pomagala najti prvo zaposlitev (EK, 2019b; EK, 2015).

Pri tem ne gre spregledati, da ima politika učne mobilnosti dva cilja: 1. okrepiti konkurenčnost Evrope in graditi družbo, ki bo temeljila na znanju; in 2. poglobiti občutek evropske identitete in državljanstva med mladimi. Zato ni naključno, da Evropska komisija v poročilu posebej poudarja, da $72 \%$ študentov študijske mobilnosti ne povezuje le s povečanjem svojih tehničnih spretnosti, s krepitvijo samozavesti in sposobnosti doseganja ciljev ter svojih zaposlitvenih možnosti, temveč tudi s povečanjem medosebnih in medkulturnih spretnosti in kompetenc ter socialne in kulturni odprtosti (EK, 2019b).

Programa Erasmus in Erasmus+, ki sta bistveno prispevala k študijski mobilnosti, sta se hitro uveljavila in dosegla široko prepoznavnost (EK, 2019b). Od leta 1987 do študijskega leta 2019 je v izmenjavi študentske mobilnosti Erasmus in Erasmus+ sodelovalo več kot 3 milijone študentov (EK, 2019c; Bauer in Kreuz, 2015). Trenutni program Erasmus +, ki je potekal od leta 2014 do 2020, je podpiral skoraj 800.000 ljudi pri študiju, usposabljanju ali delu v tujini, kar je za 10 \% več kot v letu 2016. V študijskem letu 2016/2017 (EK, 2017c) je ta program omogočil izobraževanje ali usposabljanje v tujini več kot 400.000 visokošolskim študentom, pripravnikom in vi- 
sokošolskemu osebju, oziroma okoli 34.000 študentov je prejelo nepovratna sredstva za odhod v partnerske države.

Mednarodnoprimerjalni pogled pa vendarle pokaže tudi meje evropske (študijske) mobilnosti. Glede na Poročilo o mobilnosti 2019 (EK, 2019a) je bilo leta 2018 v EU 17,6 milijona preseljencev, med katerimi je bilo 12,9 milijona delovno sposobnih oseb (20-64 let), kar pomeni, da je 4,2 \% delovno sposobnega prebivalstva EU delalo v drugi državi EU. Približno polovico mobilne delovne sile znotraj EU gostita Nemčija in Združeno kraljestvo, največji delež delovne sile glede na prebivalstvo posamezne države pa prihaja iz Litve, Romunije in Hrvaške (EK, 2019a). Poročilo tudi kaže, da polovica preseljencev ostaja $v$ gostiteljski državi za obdobje enega do štirih let. V primerjavi z ZDA, kjer tretjina državljanov (32 \%) živi zunaj države, v kateri so se rodili, je to še vedno malo.

Evropski javnopolitični dokumenti opozarjajo tudi na družbeno-ekonomske razlike kot dejavnik študijske mobilnosti (Eurostudent VI Short Report (2016-2018); Eurostudent VI Database; Eurostudent VI - Synopsis of Indicators (2016-2018). Več je namreč preseljevanja $\mathrm{v}$ države članice $\mathrm{z}$ liberalnimi ali socialdemokratskimi režimi in v države z bolj razvitim socialnim varstvom, saj imajo študenti v njih boljše zaposlitvene priložnosti. Po zadnjem poročilu Eurostudent VI - Overview and selected findings (20162018) (Gril, Bijuklič in Autor, 2018; EK, 2020c) je 51 \% študentov v času izmenjave opravljalo tudi delo za plačilo.

\section{Dejavniki študijske mobilnosti in karierne poti med študenti FDV}

\section{Cilji, metoda raziskave in zbiranje podatkov}

Anketni vprašalnik je vključeval več različnih sklopov: spraševali smo o odnosu mladih do EU in njihovih vizij Evrope v prihodnosti; o njihovi informiranosti in participaciji v EU; o karierni mobilnosti in vrednotah. V tem prispevku se osredotočamo na vprašanje, kako o svoji prihodnosti razmišljajo mladi in kako so različne vizije o njihovi prihodnosti odvisne od izkušenj s študijsko mobilnostjo in njihovo karierno potjo ali pa pogojene z nji$m i$. V tem sklopu so bila za nas ključna naslednja vprašanja: Ali so/bodo študenti opravili študij na tuji univerzi? Kateri so glavni razlogi za njihovo mobilnost? Zakaj mladi sploh odidejo $v$ tujino oz. kaj jih od študijske mobilnosti znotraj Evrope odvrača? Kakšno vlogo ima pri evropski integraciji študijski program Erasmus+ in kaj prinaša v luči zaposlitvenih karier mladih? 
$\mathrm{Z}$ anketo smo želeli zajeti čim več študentov FDV, tako domačih kot tudi študentov na izmenjavi (Erasmus+). V študijskem letu 2018/19 je bilo na prvo stopnjo študija vpisanih 1425 študentk in študentov, na drugo stopnjo pa 471 študentk in študentov, torej skupno 1896 vpisanih. V prvem semestru je bilo vpisanih 135 tujih študentov na izmenjavi (Mednarodna pisarna, FDV, 2018). Spletna anketa je bila pripravljena $\mathrm{v}$ angleškem in slovenskem jeziku, anketiranci pa so lahko izbirali, v katerem jeziku želijo odgovarjati. Anketiranje smo pričeli 7. 11. 2018, zaključili pa 19. 12. 2018. Anketo je vsaj delno izpolnilo 208 slovenskih študentov in 61 tujih, kar pomeni, da je odgovarjalo $11 \%$ vseh vpisanih slovenskih študentov in $45 \%$ vseh študentov na izmenjavi.

\section{Rezultati}

\section{Izkušnje, ovire in spodbujanje študijske mobilnosti}

Izmenjava Erasmus+ je pomemben korak k študijski mobilnosti, saj mladi tako spoznavajo študijske razmere zunaj domačega okolja. V tem kontekstu je zanimivo, da je skoraj 40 \% vprašanih del študija že opravilo v tujini $^{\mathrm{I}}$, dodatnih $35 \%$ jih to še namerava, medtem ko dobra četrtina vprašanih $(26 \%) v$ tujini še ni bila in $v$ tujino niti ne namerava oditi.

Študentom z izkušnjo študija v tujini smo zastavili vprašanje o razlogih zanj (glejte Tabelo 7) ${ }^{2}$. Študenti so odgovarjali, v kolikšni meri so navedeni razlogi vplivali na njihovo odločitev za študij v tujini (ali sploh niso vplivali, so malo vplivali, niti niso vplivali niti ne vplivali, so precej vplivali, so zelo vplivali). Podatki kažejo, da je med najpomembnejše razloge mogoče šteti spoznavanje drugih kultur $(4,5)$, vzpostavljanje medosebnih stikov in mednarodnih povezav $(4,4)$ ter izboljšanje znanja tujega jezika $(4,3)$. Zanimivo je, da tudi tisti študenti, ki se študija $v$ tujini šele nameravajo udeležiti ${ }^{3}$ za to navajajo skoraj enake ključne razloge: izboljšanje znanja tujega jezika $(4,6)$ in pridobivanje izkušenj v zvezi z drugimi kulturami $(4,4)$.

$1 \quad$ Vprašanje se je glasilo: Ali ste del svojega študija opravili na tuji univerzi? a) Da. b) $\mathrm{Ne}$ še, ampak nameravam. c) Ne, nisem in niti ne nameravam.

2 Q29 - V kolikšni meri so naslednji razlogi vplivali na vašo odločitev, da ste del študija opravili v tujini? a) Izboljšanje zaposlitvenih možnosti doma. b) Izboljšanje zaposlitvenih možnosti v tujini. c) Izboljšanje znanja tujega jezika. d) Boljše razmere za študij in raziskovalno delo. e) Spoznavanje drugih kultur. f) Pridobitev izkušenj v zvezi z drugačnimi metodami poučevanja. g) Vzpostavljanje osebnih omrežij in mednarodnih povezav. h) Izkušnja samostojnega življenja. i) Drugo: 
Tabela 7: Razlogi za študijsko mobilnost

\begin{tabular}{lccc}
\hline & $\begin{array}{c}\text { Povprečna } \\
\text { vrednost }\end{array}$ & Std. odklon & N \\
\hline Izboljšanje zaposlitvenih možnosti doma & 3,32 & 1,37 & 71 \\
\hline Boljši pogoji za študij in raziskovalno delo & 3,63 & 1,27 & 73 \\
\hline Izboljšanje zaposlitvenih možnosti v tujini & 3,66 & 1,31 & 71 \\
\hline Pridobitev izkušenj z drugimi metodami poučevanja & 4,13 & 1,07 & 71 \\
\hline Izkušnja samostojnega življenja & 4,18 & 1,10 & 72 \\
\hline Izboljšanje znanja tujega jezika & 4,26 & 0,90 & 72 \\
\hline Vzpostavljanje osebnih omrežij in mednarodnih povezav & 4,35 & 0,92 & 71 \\
\hline Spoznavanje drugih kultur
\end{tabular}

Vir: Spletna anketa, FDV, 2018

Ugotavljamo, da so med študenti glede na to, ali že imajo izkušnje s študijsko mobilnostjo ali ne, ključne razlike. Pri raziskovanju odnosa med pričakovanimi kompetencami, potrebnimi za mobilnost, in socialnim ozadjem mladih smo identificirali morebitne ovire, ki nekatere skupine mladih destimulirajo na njihovi karierni poti.

Pri študentih brez izkušenj s študijsko mobilnostjo so med naštetimi ovirami najvišje ocenjene družinske obveznosti $(2,9)$ in prenizka štipendija za študij $(2,6)$, kar vsaj posredno kaže na pretežno socialne in materialne ovire pri uresničevanju tovrstnih možnosti, vendar so povprečne vrednosti povsod relativno nizke ${ }^{4}$.

Naslednja značilnost zajetega vzorca študentov je, da jih večina poleg študija opravlja tudi delo za plačilo. To nas lahko privede do sklepa, da je razlog za neodhod v tujino ali pa ovira, zaradi katere se za odhod v tujino

b) Izboljšanje znanja tujega jezika. c) Boljše razmere za študij in raziskovalno delo.

d) Pridobitev izkušenj v zvezi z drugimi kulturami.

4 Q28 - V kolikšni meri so naslednji razlogi vplivali na to, da dela študija niste opravili v tujini? a) Prenizka štipendija, namenjena za mobilnost. b) Pomanjkljivo znanje tujega jezika. c) Študentsko delo. d) Družinske obveznosti. e) Politične in društvene aktivnosti. f) Drugi razlogi: 


\section{Ali poleg študija tudi delate za plačilo?}

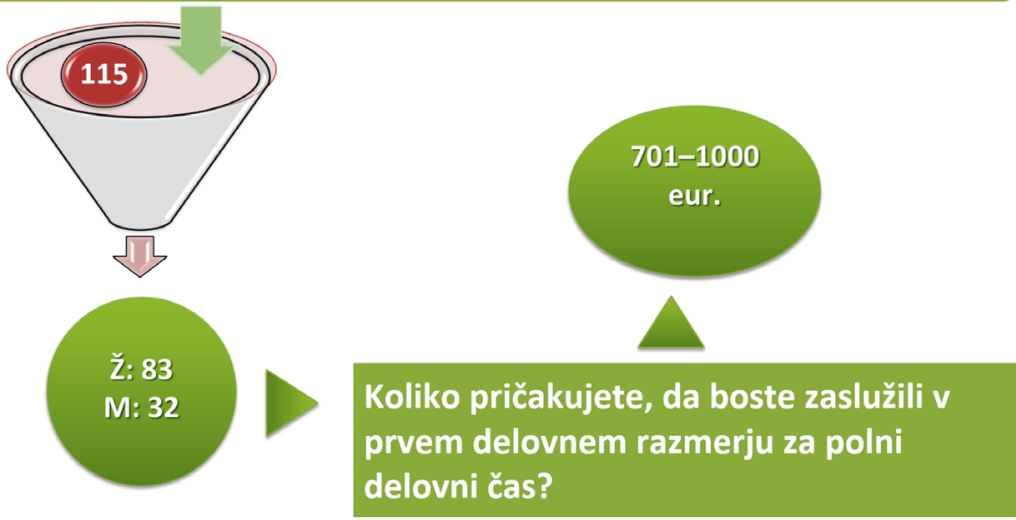

Slika 6: Študentsko delo

ne odločijo ${ }^{5}$, šibek družbeno-ekonomski status - takih respondentov je kar $65 \%$ vseh anketiranih.

\section{Karierne poti in razlike med domačijskim in kozmopolitskim tipom}

Rezultati statističnih analiz med drugim kažejo na dve podskupini znotraj vzorca študentov. Identificirali smo namreč t. i. »domačijski tip«, ki ga sestavljajo tisti, ki se za študijsko mobilnost niso odločili in se zanjo tudi v prihodnje ne nameravajo odločiti, ter »kozmopolitski tip«, ki je študijsko in tudi karierno mobilnejši. Pri raziskovalnih vprašanjih smo se osredotočili na morebiten obstoj dejavnikov (znotraj vzorca), ki kažejo na ključne razlike med tema dvema podskupinama. Domnevali smo namreč, da so karierni načrti mladih »domačijskega tipa« precej bolj odvisni od specifičnih ozadij, ki so ekonomsko in socialno determinirana. Tovrstnih ovir pri skupini mladih »kozmopolitskega tipa«, v luči njihove mobilnosti in kariernih poti, ne opažamo oziroma so te, vsaj sodeč po rezultatih, manj očitne.

Želja po študijski mobilnosti je izrazito povezana $\mathrm{z}$ iskanjem zaposlitvenih priložnosti pri kozmopolitskem tipu študentov. Ti si želijo osamosvojitve in neodvisnosti v luči iskanja zaposlitev v državah članicah EU in $\mathrm{v}$ tujini. Ugotovili smo določene razlike med študenti ( $\mathrm{v}$ skupini 


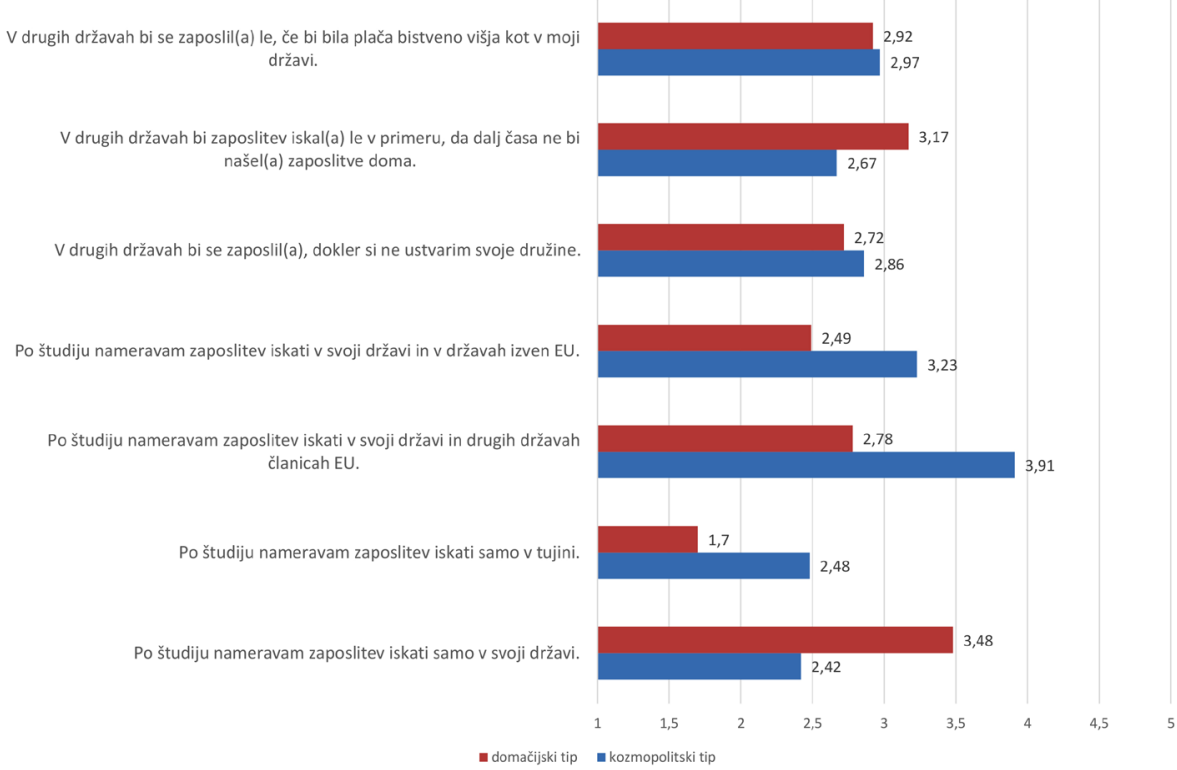

Slika 7: Iskanje zaposlitvenih priložnosti - ključne razlike med domačijskim in kozmopolitskim tipom mladih Vir: Spletna anketa, FDV, 2018

kozmopolitskega tipa), ki se bolj nagibajo $\mathrm{k}$ iskanju zaposlitve $\mathrm{v}$ EU in $\mathrm{v}$ tujini, $\mathrm{v}$ primerjavi $\mathrm{z}$ domačijskim tipom anketiranih študentov oziroma študentov, ki bi zaposlitev v tujini iskali le, če si dlje časa ne bi mogli zagotoviti zaposlitve doma. Tisti, ki so glede študijske mobilnosti že bolj izkušeni, so pokazali bistveno večjo odprtost za širše karierne priložnosti $\mathrm{v}$ tujini. Nasprotno pa se t. i. domačijski tip v veliki večini namerava zaposliti ${ }^{6}$ izključno v svoji državi, znotraj tega tipa tudi najmanj študentov načrtuje iskanje zaposlitve izključno v tujini. Podatki na Sliki 7 ravno na tej ravni kažejo najbolj očitne razlike med omenjenima skupinama. Če je torej kozmopolitski tip do zaposlitvenih možnosti zunaj doma izjemno odprt in temu naklonjen, velja za študente domačijskega tipa ravno obratno tujina je zanje možnost le v skrajnem primeru, če zaposlitve več časa ne bi uspeli dobiti doma.

6 Q35 - V kolikšni meri se strinjate oziroma se ne strinjate z naslednjimi trditvami? a) Po študiju nameravam zaposlitev iskati samo v svoji državi. b) Po študiju nameravam zaposlitev iskati samo v tujini. c) Po študiju nameravam zaposlitev iskati v svoji državi in v drugih državah članicah EU. d) Po študiju nameravam zaposlitev iskati v svoji državi in v državah izven EU. 
Pripravljenost za zaposlitev v tujini ${ }^{7}$ je pri domačijskem tipu še v največji meri odvisna od pričakovanega dohodka - največ teh študentov namreč meni, da bi se v tujini zaposlili le, če bi bila plača tam bistveno višja kot pa predvideni dohodek za delo doma, pri čemer se kažejo razlike tudi med spoloma (ženske: 34 \%; moški: 42 \%). Hkrati se jim zaposlovanje v tujini zdi bolj verjetno v obdobju, v katerem si še ne bodo ustvarili lastne družine, vendar je presenetljivo, da bi to na neodhod v tujino v večji meri vplivalo pri kozmopolitskem tipu. Golob (2017) je na podoben način pojasnila družbeni kontekst, $\mathrm{v}$ katerem se posameznik nahaja in ki deluje kot potencialni vzročni sprožilec konstitucije posameznikovega notranjega sveta in konstrukcije pomenov. Motivi za izmenjavo lahko izhajajo tudi iz nezavednih dispozicij posameznikovega habitusa, ki vplivajo na njegovo delovanje in aspiracije ter se oblikujejo v odnosu do družbenih polj (Golob, 2017).

\section{Odnos do EU in razlike v zaznavanju pomena jezikovnih kompetenc}

Pri obravnavi izmenjave je pomembno dejstvo, da shema Erasmusa, ki določa strukturne vidike obreda prehoda, ustreza potrebam tržne ekonomije, še posebej naraščajočim potrebam po specializiranih kvalifikacijah. V luči individualizirane družbe je med mladimi prisotna težnja po doseganju uspeha na podlagi individualnega truda, kar je povezano tudi z neoliberalnimi idejami atomizacije ekonomskega in političnega življenja (Genov, 2014). Študenti se, kar je pri opazovanju njihove izobraževalne poti očitno, soočajo z makrostrukturnimi učinki individualizacije. Učne načrte po bolonjskem sistemu sestavljajo številni izbirni moduli, pomembno vlogo pa igrajo strukturni dejavniki, kot so ekonomske, družbene in socialne razmere.

Mobilnost mladih se navezuje na njihov odnos do EU ter na njihov vpogled v globalne možnosti izmenjave in karierne priložnosti. Zanimivo je tudi, kakšen odnos imajo mladi do Evropske unije ter kakšne so pri tem razlike med domačijskim in kozmopolitskim tipom študentov. Raziskava med domačimi in tujimi študenti o njihovem odnosu do Evrope, o trenutnih predstavah mladih o EU in njihovih morebitnih vizijah razvoja $\mathrm{EU}^{8}$

7 Q50 - V kolikšni meri se strinjate oziroma ne strinjate z naslednjimi trditvami? a) V drugih državah bi se zaposlil(a), dokler si ne ustvarim svoje družine. b) V drugih državah bi zaposlitev iskal(a) le v primeru, da dalj časa ne bi našel(a) zaposlitve doma. c) V drugih državah bi se zaposlil(a) le, če bi bila plača bistveno višja kot v moji državi.

8 Q3 - V kolikšni meri se strinjate oziroma se ne strinjate s spodnjimi trditvami? a) Sem Evropejec/Evropejka. b) Ponosen(a) sem, da živim v Evropi. c) Čutim se kot del 


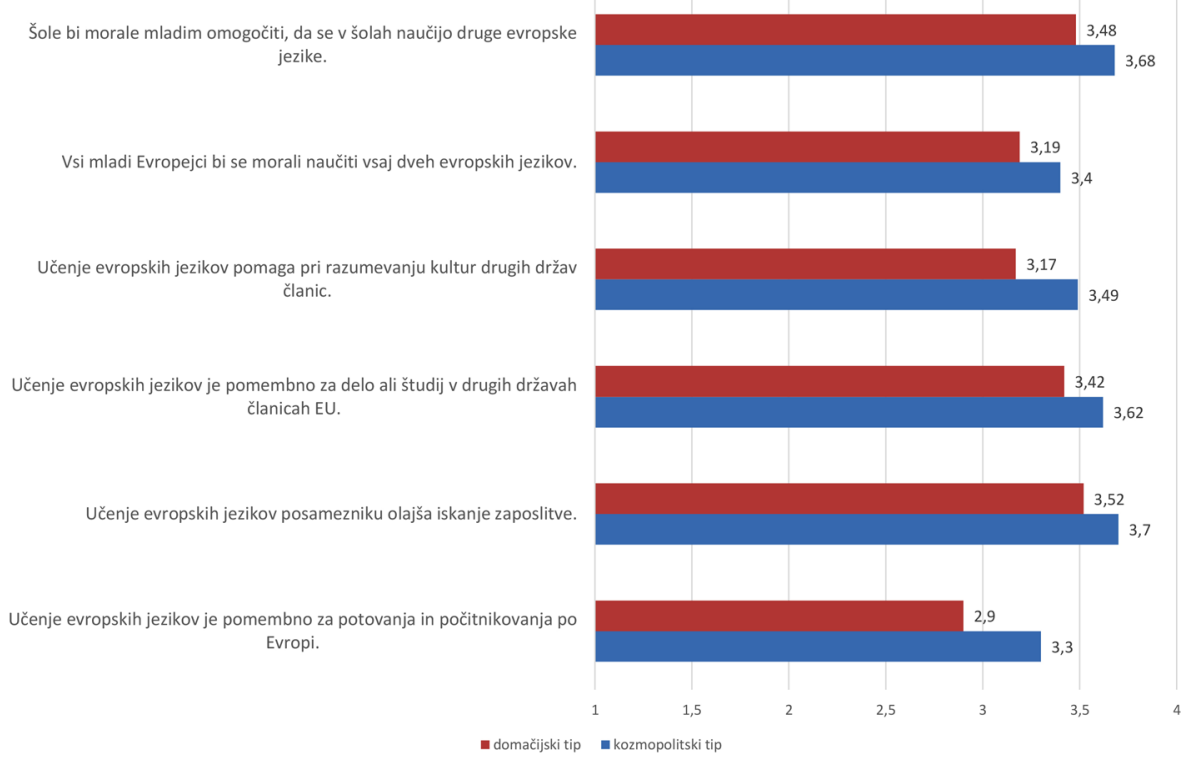

Slika 8: Učenje tujih jezikov

Vir: Spletna anketa, FDV, 2018

kaže, da je odnos večine vprašanih do EU bolj pozitiven (50 \%) oz. zelo pozitiven ( $8 \%$ ), da pa je dobra četrtina ( $27 \%)$ mladih do EU nevtralna. Trenutno predstavo, ki jo gojijo mladi o EU, smo skušali zajeti z naborom več pojmov, ki bi pokazali možen odnos mladih do EU. Izkaže se, da večina respondentov EU povezuje s pojmi, kot so »moderna $(76 \%)$, »demokratična« $(68 \%)$ in »usmerjena v prihodnost« (67 \%), kar kaže na pozitivne konotacije, ki jo ima EU za mlade.

Na drugi strani pa smo domnevali, da imata pri odločitvi za karierne poti pomembno vlogo učenje tujih jezikov in zaznava pomena jezikovnih kompetenc. Tudi v tem primeru opažamo razlike med domačijskim in kozmopolitskim tipom anketiranih študentov, vendar so te bistveno manjše.

Učenju tujih jezikov so študenti obeh skupin relativno zelo naklonje$\mathrm{ni}$, pri čemer študenti $\mathrm{z}$ izkušnjo študija $\mathrm{v}$ tujini temu prisojajo večjo pomembnost kot ostali, vendar ne moremo trditi, da študenti domačijskega tipa zanemarjajo pomen znanja tujih jezikov.

Evrope. d) Sebe vidim najprej kot državljana/državljanko Evrope in šele potem kot državljana/državljanko sveta. e) Več imam skupnega z drugimi ljudmi iz držav EU kot z ljudmi iz držav izven EU. f) Več imam skupnega z ljudmi iz moje države kot z ljudmi drugih narodov v Evropi. g) Čutim se globalnega državljana/državljanko. 


\section{Sklep}

Program Erasmus+ je postal pomemben del razvojne strategije EU do leta 2020 (Jones, 2017), ideja mobilnosti pa je postala pomembna tudi v širšem evropskem izobraževalnem prostoru (EK, 2017a, 2017b). Slovenske in mednarodne raziskave na področju študijske mobilnosti (Breznik in Đaković, 2016; Čelebič, 2008), pa tudi rezultati naše raziskave opozarjajo na mnogotere, še posebej družbeno-ekonomske razsežnosti študijske mobilnosti. Odhodna in vhodna mobilnost glede na velikost študentske populacije v vsaki državi je odvisna od ekonomskih, zgodovinskih, kulturnih in političnih dejavnikov (Breznik in Đaković, 2016; Böttcher et al., 2016). Na študijsko mobilnost vplivajo tudi višina štipendije, možnosti za namestitev in kakovost visokošolskega sistema. Pomemben dejavnik, ki vpliva na število tujih študentov, je jezik, v katerem poteka pedagoški proces (Čelebič, 2008), saj se študenti bolj odločajo za države, v katerih je učni jezik angleški (OECD, Education at a Glance 2006).

Za slovenske študente je lahko ovira za nevključitev v študijsko mobilnost predvsem financiranje študija. Čelebič (2008) opozarja, da je to ovira predvsem za posameznike in posameznice iz nižjih socialnih slojev. Dodaten finančni vir, poleg štipendije v okviru programa Erasmus, namreč pogosto predstavlja tudi finančni prispevek staršev, ki pa si ga lahko privoščijo družine $\mathrm{z}$ nadpovprečno visokim dohodkom. Zato je delež študentov iz družin z nadpovprečno visokim dohodkom precej višji kot pa delež tistih iz družin s podpovprečnim dohodkom (nadpovprečni: $36,6 \%$; podpovprečni: 14,9 \%; povprečni: 48,4\%) (Čelebič, 2008).

Rezultati v članku predstavljenih statističnih analiz naše raziskave so pokazali, da so možnosti mladih znotraj relativno homogenega vzorca diferencirane in vsaj delno odvisne od nekaterih strukturnih dejavnikov. Pomembni dejavniki, ki prispevajo k odločitvi študentov za mobilnost v okviru kariernih poti, so ekonomsko in socialno determinirani. Identificirali smo jih le delno, a vendar lahko rečemo, da so ovire za odhod v tujino tesno povezane predvsem $\mathrm{z}$ družinskimi obveznostmi študentov in s pomanjkanjem finančnih sredstev. Za poglobljeno pojasnitev tu zaznanih ekonomskih in socialnih ozadij bi bila sicer potrebna podrobnejša analiza zbranih podatkov, a omenjeno priča o pomembnih razlikah znotraj vzorca študentov. Nekateri med njimi se, strukturno gledano, že v izhodišču soočajo $\mathrm{z}$ manj spodbudnimi možnostmi za študijsko mobilnost. Skrb za družino, starše ali svojce in prenizek finančni okvir niso stvar osebnih izbir, temveč jih je treba nasloviti na ravni politik za spodbujanje študijske mobilnosti. 
Hkrati pa se zdi, da so karierni načrti vendarle vsaj do neke mere odraz individualnih želja in izbir. $V$ zvezi z raziskovalnimi vprašanji smo nadalje ugotovili, da imajo mladi o svoji prihodnosti različne vizije, ki so precej odvisne od njihovih izkušenj s študijsko mobilnostjo in z njihovo karierno potjo oziroma so pogojene $\mathrm{z}$ njimi. Rezultati statističnih analiz med drugim poudarjajo razlike med dvema podskupinama znotraj vzorca študentov, in sicer med »domačijskim tipom«, ki ga predstavljajo tisti, ki se za študijsko mobilnost niso odločili in se zanjo tudi v prihodnje ne nameravajo odločiti, in »kozmopolitskim tipom «, ki je študijsko in tudi karierno mobilnejši. Razlike med tema skupinama so še posebej razvidne v tem, kak pomen pripisujejo učenju jezikov in spoznavanju drugih kultur. Slednje govori $v$ prid tezi, da je multikulturnost pogojena tudi $z$ določenimi učnimi kompetencami in predznanji. Po drugi strani študijska mobilnost širi tudi siceršnje možnosti za karierne poti mladih, kar govori v prid tezi, da se s programom Erasmus+ bistveno povečuje tudi fizična mobilnost mladih, posledično pa mladi svojo predstavo o prihodnosti lažje umeščajo tudi onstran nacionalnih meja. Ravno z izrazito večjo odprtostjo do kariernih poti v tujini so se študenti, ki izkušnjo $s$ študijem $v$ tujini že imajo, izkazali za bistveno drugačne od študentov domačijskega tipa, ki ostajajo tudi v odnosu do lastnih vizij prihodnosti bolj navezani na dom in možnosti znotraj obstoječih nacionalnih meja. Zdi se, da je s tem delno povezana tudi njihova osebna vizija poteka lastnega družinskega življenja.

Omenjeni pozitivni učinek študijskih izmenjav (zaznaven pri eni skupini študentov) kaže jasno sporočilo, obenem pa opozarja tudi pomembno strukturno omejitev. Mladi »domačijskega tipa« so namreč manj prožni in manj mobilni predvsem zaradi specifičnih socialnih in ekonomskih ovir. To govori o pomembnih razkorakih pri karierni mobilnosti mladih, kolikor je o njej mogoče sklepati znotraj tega specifičnega namenskega vzorca. Naša raziskava ponuja še vrsto drugih dilem (vključno s spolnimi razlika$\mathrm{mi}$ ), ki bi jih veljalo nasloviti v prihodnje $\mathrm{z}$ dodatno analizo podatkov, že delni rezultati pa pričajo o potrebi po bolj poglobljenem raziskovanju razmer, v katerih živijo ravno tisti študenti, ki se za študijsko mobilnost težko ali neradi odločajo.

\section{Literatura}

Arnett, J. Jeffrey. Emerging Adulthood: The Winding Road from Late Teens through the Twenties. Oxford, New York: Oxford University Press, 2004. 
Bagnoli, Anna. „On 'An Introspective Journey’: Identities and Travel in Young People's Lives.“ European Societies, 11 (2009): 325-345.

Barry, Monika. "Youth transitions: From offending to desistance.« Journal of Youth Studies, 1 (2010): 121-136. doi.org/d4chrh.

Bauer, Thomas, in Alexandra Kreuz. »Erasmus and Ehea student mobility in times of the European Economic crisis. The situation of international teacher Training students in Austria." Journal of International Mobility, 2015/1, no. 3 (2015): 99-114. Dostop November 1, 2019. https://www.cairn. info/revue-journal-of-international-mobility-2015-1-page-99.htm.

Böttcher, Lucas in Nuno A. M. Araújo, Jan Nagler, José F. F. Mendes, Dirk Helbing, Hans J. Herrmann. »Gender gap in the Erasmus Mobility program." PLOS ONE 11/2 (2016): eo149514. https://doi.org/10.1371/ journal.pone.0149514.

Breznik, Kristijan in Goran Đaković. Erasmus student mobility flows the national-level social network analysis of Slovenia. International Journal of Innovation and Learning 20/2 (2016). DOI: 10.1504/ IJIL.2016.077843. Dostop Junij 14, 2020. https://www.inderscienceonline.com/doi/pdf/10.1504/IJIL.2016.077843, 12.6.2020.

Bynner, John. "Rethinking the youth phase of the life-course: The case for emerging adulthood? « Journal of Youth Studies, 4 (2005): 367-384. doi.org/fdp8hq.

Čelebič, Tanja. Mednarodna mobilnost študentov in pedagoškega osebja v terciarnem izobraževanju. Zbirka Delovni zvezki UMAR, 17/8 (2008). Ljubljana: Urad RS za makroekonomske analize in razvoj, 2008. Dostop Junij 29, 2020. https://www.umar.gov.si/fileadmin/ user_upload/publikacije/dz/2008/dzo8-o8-old.pdf.

Genov, Nikolai. »The Future of Individualization in Europe: Changing Configurations in Employment and Governance.« Eur J Futures Res, 2 (2014): 46. doi.org/10.1007/s40309-014-0046-5.

Golob, Tea. »Evropska študijska mobilnost kot sodobni obred prehoda.« Glasnik Slovenskega etnološkega društva, 57, št. 3/4 (2017): 75-84. http:// www.dlib.si/?URN=URN:NBN:SI:DOC-GVTCVLTY.

Gril, Alenka, Igor Bijuklič, Sabina Autor. EVROŠTUDENT VI 2016-2018, Socialni in ekonomski pogoji življenja študentov v Evropi. Nacionalno poročilo - Slovenija. Ljubljana: Pedagoški Inštitut. Dostop Junij 29, 2020. https://www.eurostudent.eu/download_files/documents/ EVROSTUDENT_VI_Porocilo_SLO.pdf. 
Hannan, Damian F., David Raffe, in Emer Smyth. „Cross-national research on school to work transitions: An analytical framework. In Youth transitons in Europe: Theories and evidence, ur. Patrick Werquin, Richard Breen in Jordi Planas, 409-442. Cereq: Marseille, 1997.

Ifversen, Jan. "Europe and European Culture - a Conceptual Analysis." European Societies, 4 (2002): 1-26. DOI: 10.1080/14616690220130973.

Jones, Hywel Cery. »Celebrating 30 years of the Erasmus programme.« European Journal of Education 52/4 (2017): 558-562. https://doi. org/10.1111/ejed.12251.

Kelly, Elish, Seamus McGuinness in Philip J. O‘Connell. »Transitions to long-term unemployment risk among young people: Evidence from Ireland." Journal of Youth Studies, 6 (2012): 780-801. doi.org/cd2b.

Kelly, Peter. »Wild and tame zones: Regulating the transitions of youth at risk." Journal of Youth Studies, 2 (1999): 193-211. doi.org/cd2c.

Kogan, Irena in Marge Unt. »Transition from school to work in transition economies.« European Societies, 2 (2006): 219-253. doi.org/d9cnx9.

Kondakci, Yasar in Svena Bedenlier, Olaf Zawacki-Richter. „Social network analysis of international student mobility: Uncovering the rise of regional hubs. " Higher Education 75/3 (2018): 517-535. https:// doi.org/10.1007/s10734-017-0154-9.

Lehmann, Wolfgang. "'For some reason, I get a little scared': Structure, agency, and risk in school-work transitions." Journal of Youth Studies, 4, (2004): 379-396. doi.org/b4w63r.

Lesjak, Dušan in Pornthep Anussornnitisarn. »InternationalisationProfessors' mobility and teaching in foreign languages in Slovenian higher education." International Journal of Innovating and Learning, 22/3 (2017): 340-352. https://doi.org/10.1504/IJIL.2017.086734.

Powell, Justin W. in Claudia Finger. »The Bologna process's model of mobility in Europe: The relationship of its spatial and social dimensions.« European Educational Research Journal, 12/2 (2013): 270-285. https://doi.org/10.2304/eerj.2013.12.2.270.

Schels, Brigitte. »Persistence or transition: Young adults and social benefits in Germany." Journal of Youth Studies, 7 (2013): 881-90o. doi.org/ cd 2 d.

Souto-Otero, Manuel. The SocioEconomic Background of Erasmus Students: A Trend Towards Wider Inclusion? International Review of Education, 54/2 (2008):135-154. DOI: 10.1007/s11159-007-9081-9. 
Teichler, Ulrich in Irina Ferencz, Bernd Wachter. Mapping mobility in European higher education. Volume I: Overview and trends (Vol. 69). Bonn, Germany: Deutscher Akademischer Austausch Dienst, 2011.

Thomson, Rachel in Rebecca Taylor. »Between Cosmopolitanism and the Locals: Mobility as a Resource in the Transition to Adulthood." Young, 13 (2005): 327-342. doi.org/10.1177/1103308805057051.

Van Bouwel, Linda in Reinhilde Veugelers. »The determinants of student mobility in Europe: The quality dimension." European Journal of Higher Education 3/2 (2013): 172-19o. https://doi.org/10.108o/21568235.2013.772345.

\section{Viri}

Evropska komisija (European Commision). (2008). »High level experts discuss future of mobility in EU."Cedefop (European Centre for the Development of Vocational Training), Januar 24, 20o8. Dostop November 9, 2019. https://ec.europa.eu/commission/presscorner/detail/en/IP_o8_85 .

Evropska komisija (2015). »Erasmus - Facts, Figures \& Trends. The European Union support for student and staff exchanges and university cooperation in 2012-13."Luxembourg: Publications Office of the European Union, 2015. Dostop Avgust 11, 2019. https://ec.europa.eu/assets/eac/education/ library/statistics/erasmus-plus-facts-figures_en.pdf.

Mednarodna pisarna, FDV. »Vpisani tuji študenti na izmenjavi.« Ljubljana, Fakulteta za družbene vede, 2018.

Eurostudent VI - Synopsis of Indicators (2016-2018). DZHW - German Center for Higher Education, Research and Science Studies.. Social and Economic Conditions of Student Life in Europe. Dostop Junij 14, 2020. https:// www.eurostudent.eu/download_files/documents/EUROSTUDENT_VI_ Synopsis_of_Indicators.pdf.

Eurostudent VI Database (Data Reporting Module). Dostop Junij 29, 2020. http://database.eurostudent.eu/.

Eurostudent VI Short Report (2016-2018). DZHW - German Center for Higher Education, Research and Science Studies. Dostop Junij 29, 2020. https:// www.eurostudent.eu/download_files/documents/EUROSTUDENT_VI_ short_report.pdf, 18.6.2020.

Evropska Komisija (2017a). Strengthening European Identity through education and culture. The European Commission's contribution to the Leaders'meeting in Gothenburg, 17 November 2017, COM (2017a) 673, 14.11.2017, Strasbourg. 
Evropska Komisija (2017b). Making mobility for all. Dostop Junij 18. 2020. https:/ec.europa.eu/commission/sites/beta-political/files/leaders-workinglunch-mobility_en.pdf

Evropska Komisija (2017c). Erasmus+: Another record year in 2017. Dostop Junij 14, 2020. https://ec.europa.eu/commission/presscorner/detail/en/ IP_19_601.

Evropska Komisija (2018). Predlog Priporočilo Sveta o spodbujanju avtomatičnega vzajemnega priznavanja visokošolskih diplom in srednješolskih spričeval ter izidov iz učnih obdobij v tujini. COM(2018) 27o final 2018/o126 (NLE). Dostop Junij 18. 2020. https://eur-lex.europa.eu/resource.html?uri=cellar:9cf2fee8-5ea7-11e8-ab9c-01aa75ed71a1.0020.02/DOC_1\&format=PDF, 18. 6. 2020 .

Evropska Komisija (2019a). Annual report on intra-EU labour mobility. Luxembourg: Publications Office of the European Union, 2019. Dostop Junij 26, 2020. https://ec.europa.eu/social/main.jsp?catId=738\&langId=sl\&pubId $=8242 \&$ furtherPubs $=$ yes.

Evropska Komisija (2019b). Erasmus+ Higher Education Impact Study. Luxembourg: Publications Office of the European Union, 2019. Publications Office of the EU. Dostop Junij 23. 2020. https:/op.europa.eu/en/publication-detail/-/publication/94d97f5c-7ae2-11e9-9fo5-01aa75ed71a1/language-en.

Evropska Komisija (2019c). Education and Training Monitor 2019. Dostop Junij 17, 2020. https://ec.europa.eu/education/sites/education/files/document-library-docs/volume-1-2019-education-and-training-monitor. pdf.

Evropska Komisija (2020a). Evropski sistem prenašanja in zbiranja kreditnih točk (ECTS). Dostop Junij 17, 2020. https:/ec.europa.eu/education/ resources-and-tools/european-credit-transfer-and-accumulation-system-ects_sl.

Evropska Komisija (2020b). Izobraževanje in usposabljanje. Mobilnost in sodelovanje. Luxembourg: Publications Office of the European Union, 2020. Dostop Junij 23, 2020. https:/ec.europa.eu/education/policies/ higher-education/mobility-and-cooperation_sl.

Evropska Komisija (2020c). Opportunities for Individuals. Dostop Junij 23, 2020. https://ec.europa.eu/programmes/erasmus-plus/opportunities/ overview_en.

Mednarodna pisarna, FDV. „Vpisani tuji študenti na izmenjavi.“ Ljubljana, Fakulteta za družbene vede, 2018.

OECD. (2006). Education st a Glance 2006. Paris. 



\section{Mobilnost študentov v primerjalni perspektivi: Slovenija in Nizozemska}

Maruša Hauptman Komotar

\section{Uvod}

Ena najvidnejših dejavnosti visokošolske internacionalizacije je zagotovo mobilnost študentov, ki se jo v Evropi že od leta 1987 precej intenzivno podpira v okviru programa izmenjav Erasmus, v katerem je do danes sodelovalo več kot tri milijone študentov. ${ }^{1}$ Evropa je tudi vodilna svetovna regija, kar zadeva delež dolgoročno mobilnih študentov, ki so vpisani na visokošolske zavode v tujini za celotno obdobje študija. Uspeh programa Erasmus, pa tudi naraščajoči interes neevropskih študentov za študij v Evropi, sta pomembno prispevala $\mathrm{k}$ razvoju politik (internacionalizacije in) mobilnosti v okviru bolonjskega procesa.

S podpisom Bolonjske deklaracije (1999) se je 29 namreč držav Evropskega visokošolskega prostora (v nadaljevanju EVP), vključno s Slovenijo in Nizozemsko, zavezalo h krepitvi mobilnosti študentov, učiteljev, raziskovalcev in administrativnega osebja. V ta namen je bil leta 2009 na leuvenski konferenci opredeljen precej ambiciozen cilj, da bo leta 2020 vsaj $20 \%$ diplomantov iz EVP del svojega študija ali usposabljanja preživelo v tujini (Leuven Communiqué, 2009). Tri leta kasneje je bila v Bukarešti sprejeta strategija Mobility for Better Learning in s tem deset ključnih ukrepov za bolj uravnoteženo mobilnost na institucionalni, nacionalni in nadnacio-

1 Prispevek govori o programu Erasmus, ki se v obdobju 2014-2020 izvaja kot Erasmus+, ki vključuje obstoječe programe EU na področju izobraževanja, usposabljanja, mladine in športa. 
nalni ravni visokega šolstva (Working Group on Mobility, 2012). Na zadnji, pariški ministrski konferenci, pa je bila izpostavljena potreba po ovrednotenju napredka pri doseganju cilja mobilnosti ,20/2020' v EVP (Paris Communiqué, 2018).

Tovrstne navedbe ustvarjajo potrebo po ocenitvi napredka pri izvajanju politik in praks $\mathrm{v}$ mobilnosti študentov $\mathrm{v}$ različnih državah EVP, npr. $\mathrm{v}$ Sloveniji in na Nizozemskem, ki sta le redko v središču primerjalnih analiz. $\mathrm{V}$ tej luči se prispevek osredinja na raziskovalno vprašanje, kakšen poudarek namenjajo mobilnosti študentov nacionalne in institucionalne politike in strategije (internacionalizacije) v slovenskem in nizozemskem visokošolskem prostoru, in na tej podlagi analizira, ali se cilji, opredeljeni v visokošolskih politikah in strategijah (internacionalizacije), tudi uresničujejo $\mathrm{v}$ praksi. V tem okviru pojasnjuje, $\mathrm{v}$ kolikšni meri sta izbrani državi izpolnili glavne bolonjske cilje na področju študentske mobilnosti, na tej osnovi pa s pomočjo primerjalne analize razpravlja tudi o podobnostih in razlikah na tem področju ter o glavnih razlogih za njihov obstoj. V zaključnem delu prispevek poglablja predhodno razpravo s teoretskimi argumenti institucionalnega izomorfizma-sociološke različice novega institucionalizma, saj je razvoj evropskega visokega šolstva $\mathrm{v}$ okviru bolonjskega procesa postavil teorijo novega institucionalizma $\mathrm{v}$ središče zanimanj raziskovalcev visokega šolstva (glej npr. Dobbins, 2008).

Namen prispevka je torej izboljšati razumevanje vloge študentske mobilnosti v internacionalizaciji slovenskega in nizozemskega visokega šolstva, in na tej osnovi prikazati, da se kljub naraščajočemu pomenu, ki ji ga pripisujejo (nad)nacionalne in institucionalne politike in strategije (internacionalizacije) visokega šolstva, tovrstna oblika internacionalizacije v tujini (glej Knight, 2008) v praksi nanaša le na majhen delež mobilnih študentov. Internacionalizacija visokega šolstva je namreč

nameren proces integracije mednarodne, medkulturne ali globalne razsežnosti v namen, funkcije in izvajanje postsekundarnega izobraževanja, da bi izboljšali kakovost izobraževanja in raziskovanja za vse študente in zaposlene in da bi pomembno prispevali k družbi. (de Wit et al., 2015: 29)

\section{Metodologija}

Prispevek izhaja iz doktorske raziskave o internacionalizaciji in zagotavljanju kakovosti v slovenskem in nizozemskem visokem šolstvu (Hauptman 
Komotar, 2018) in se metodološko opira na analizo različnih dokumentarnih virov (npr. teoretska literatura, nacionalne in mednarodne študije, zakonodaja, nacionalni programi visokega šolstva, institucionalne strategije internacionalizacije itd.). Tovrstne vire podpirajo kvantitativni podatki iz nacionalnih in mednarodnih statističnih podatkovnih baz in kvalitativne evidence iz polstrukturiranih intervjujev, ki so bili izvedeni za namene doktorske raziskave med majem in decembrom 2016. V intervjujih so sodelovali predstavniki nacionalnih agencij za internacionalizacijo in programov mobilnosti in/ali ministrstev, pristojnih za visoko šolstvo, vodstvo visokošolskih zavodov (npr. dekani, rektorji), osebje iz uradov za internacionalizacijo oziroma mednarodnih pisarn, neodvisni eksperti itn. Intervjuvanci so bili izbrani namensko, v skladu $\mathrm{z}$ njihovo vlogo in strokovnim znanjem, njihovo število pa je bilo namenoma nižje (skupaj 18, od tega 8 iz Slovenije, 7 iz Nizozemske in 3 iz širšega EVP).

\section{Primer Slovenije}

\section{Mobilnost študentov $v$ kontekstu visokošolskih politik in strategij (internacionalizacije)}

V zadnjih dveh desetletjih so na razvoj politik internacionalizacije (in predvsem (kratkoročne) mobilnosti) v slovenskem visokošolskem sistemu nedvomno vplivali nadnacionalni, zlasti evropski politični procesi (npr. vstop v EU v letu 2004) in razvoj evropskega visokega šolstva v okviru bolonjske reforme. Poleg podpisa Bolonjske deklaracije (1999) je bila npr. v Sloveniji v novembru $1999 \mathrm{~s}$ spremembami visokošolske zakonodaje uveljavljena tudi določba, da $\mathrm{z}$ vstopom države $\mathrm{v}$ EU državljani njenih držav članic pridobijo pravico do izobraževanja na slovenskih visokošolskih ustanovah pod enakimi pogoji kot veljajo za slovenske državljane (Zakon o spremembah in dopolnitvah Zakona o visokem šolstvu, 1999: 2. člen). Leta 2002 je bil sprejet (prvi) nacionalni program visokega šolstva, ki je izpostavil pomen mednarodnega institucionalnega sodelovanja v programih izmenjav EU (npr. Socrates-Erasmus), regionalnih programih (npr. CEEPUS oziroma Central European Exchange Program for University Studies) in izgradnje EVP (Ministrstvo za šolstvo, znanost in šport, 2002). Leto kasneje (2003) je bil ustanovljen tudi Center Republike Slovenije za mobilnost in evropske programe izobraževanja in usposabljanja (CMEPIUS), ki od leta 2006 deluje kot nacionalna agencija, pristojna za izvajanje programov mobilnosti in dvostranskih sporazumov. 
Tudi aktualna Resolucija o nacionalnem programu visokega šolstva za obdobje 2011-2020 je, v skladu s poudarki Evropske komisije (2013) o razvoju celovitih strategij internacionalizacije in s tem mednarodne mobilnosti, internacionalizacije kurikula in strateških partnerstev, poudarila potrebo po sprejetju nacionalne strategije internacionalizacije, ki je bila objavljena v letu 2016 (glej Ministrstvo za izobraževanje, znanost in šport, 2016a). Slednja opredeljuje mednarodno mobilnost kot ključno za razvoj visokokakovostnega visokošolskega sistema, s tem pa tudi odprtost za sodelovanje in izmenjave znotraj in zunaj EVP (ibid.). To pomeni, da naj bi študij na slovenskih visokošolskih zavodih do leta 2020 zaključilo vsaj $10 \%$ mednarodnih študentov, 20 \% slovenskih diplomantov pa naj bi sodelovalo v programih izmenjav v tujini (Ministrstvo za visoko šolstvo, znanosti in tehnologijo, 2011).

$\mathrm{Na}$ slovenskih visokošolskih zavodih je (študentska) mobilnost prav tako v ospredju institucionalnih strategij internacionalizacije, ki pa so bile sprejete predvsem na ravni univerz, na ostalih visokošolskih zavodih pa so te pogosto del širših razvojnih visokošolskih strategij. Univerza v Ljubljani npr. opredeljuje strateški cilj do leta 2020 povečanja študentskih izmenjav za tretjino in števila tujih študentov za četrtino (Univerza v Ljubljani, 2014), medtem ko Univerza na Primorskem izpostavlja, da bo do študijskega leta 2020/21 med celotno študentsko populacijo desetina tujih študentov (Univerza na Primorskem, 2014).

Ker se torej mobilnost študentov v (nad)nacionalnih in institucionalnih politikah in strategijah (internacionalizacije) dojema kot ključna dejavnost za višjo kakovost (internacionalizacije) slovenskega visokošolskega prostora, velja v nadaljevanju preučiti, v kolikšni meri se opredeljeni cilji politik in strategij na tem področju tudi dejansko uresničujejo v praksi.

\section{Mobilnost študentov $v$ praksi}

V okviru dolgoročne mobilnosti se število tujih študentov, vpisanih na slovenske visokošolske ustanove, iz leta v leto povečuje. Kot poroča Statistični urad Republike Slovenije (v nadaljevanju SURS), je bilo v študijskem letu 2018/19 na slovenske visokošolske zavode vpisanih 5,079 tujih študentov s stalnim prebivališčem v tujini (SURS, 2019), kar predstavlja 7,7 \% celotne študentske populacije. V tem študijskem letu jih je kar tri četrtine (75 \%) izviralo iz držav nekdanje Jugoslavije, in sicer iz Hrvaške (20.8 \%), Bosne in Hercegovine $(18,5 \%)$, Severne Makedonije (18,5 \%), Srbije (10,9 \%), Kosova $(3,6 \%)$ in Črne Gore (2,7 \%), izmed drugih držav pa so imele v tem letu naj- 
večji delež študentov na visokošolskem študiju v Sloveniji Italija (5,9\%), Ruska federacija $(2,9 \%)$ in Ukrajina $(1,4 \%)$ (SURS, 2019). To pomeni, da Slovenija (še vedno) ni prednostna študijska destinacija za študente iz zahodnih (evropskih) držav, saj le četrtina ( $25 \%$ ) vseh dolgoročno mobilnih študentov izvira iz držav, ki niso nekdanje jugoslovanske republike. (Nad)nacionalno strateško merilo desetine vpisanih tujih študentov na slovenskih visokošolskih ustanovah se torej v letu 2020 ni uresničilo v praksi.

Po drugi strani je bilo po podatkih Unescovega inštituta za statistiko $(\mathrm{UIS})^{2}$ na tuje visokošolske zavode v letu 2019 vpisanih tudi 3,157 slovenskih študentov; njihove prednostne ciljne države so bile v tem letu Avstrija $(24,9 \%)$, Nemčija (13,5\%) in Združeno kraljestvo (12,4 \%), ki so skupaj gostile približno polovico $(50,8 \%)$ vseh slovenskih študentov na terciarnem študiju v tujini (UIS, 2019). Vendar pa je bilo v tem letu v Sloveniji dolgoročno mobilne le 3,1\% celotne terciarne študentske populacije (UIS, 2019), glavne študijske destinacije pa, z izjemo Hrvaške in Srbije, niso bile države Zahodnega Balkana, temveč zlasti starejše članice EU-ja.

Na področju kratkoročne mobilnosti so $\mathrm{v}$ Sloveniji v študijskem letu 2014/15 prihajajoči študenti iz tujine, ki so sodelovali v programih izmenjav, predstavljali 2,9\% celotne populacije študentov, od tega jih je (kar) 2,7 \% sodelovalo v programu Erasmus (Ministrstvo za izobraževanje, znanost in šport, 2016, v Hauptman Komotar, 2018). Na slovenskih visokošolskih ustanovah so bili v tem letu najštevilčnejši španski, turški in češki Erasmus študentje (European Commission, 2017), torej so bile njihove glavne izvorne države tiste iz Srednje in Vzhodne Evrope ter starejše članice EU-ja.

V programih mobilnosti v tujini je v tem letu sodelovalo (le) 3,4 \% slovenskih študentov, kar pomeni relativno rast njihovega odstotnega deleža od leta 2009/10 dalje, ko se je za izmenjave v tujini odločilo le 1,4 \% domačih študentov (Ministrstvo za izobraževanje, znanost in šport, 2016, v Hauptman Komotar, 2018). V letu 2015 so v okviru programa Erasmus, v katerem je sodelovala velika večina prihajajočih študentov (2,5\%), del študija najpogosteje preživeli na nemških, španskih in avstrijskih visokošolskih ustanovah (European Commission, 2017), torej v državah Zahodne Evrope. Delež domačih kratkoročno mobilnih študentov je (bil) torej precej pod zadanim strateškim ciljem ,20/2020', ki je bil opredeljen tako na ravni EVP kot tudi na ravni slovenskega visokošolskega sistema (glej Leuven Communiqué, 2009; Ministrstvo za visoko šolstvo, znanosti in tehnologijo, 2011). V akcij-

2 Na voljo so podatki o terciarnem izobraževanju (srednješolsko in visokošolsko izobraževanje, ISCED 5-8). 
skem načrtu izvajanja nacionalne strategije internacionalizacije je bil v letu 2018 sicer opredeljen bolj realističen strateški cilj $5 \%$ kratkoročno mobilnih študentov do leta 2020 (Ministrstvo za izobraževanje, znanost in šport, 2019), ki pa, kot kaže, v tem letu ne bo uresničen.

V Sloveniji je tako na področju kratkoročne študentske mobilnosti sorazmerje med deležem prihajajočih in odhajajočih mobilnih študentov bolj uravnoteženo kot v okviru dolgoročne mobilnosti, medtem ko je skupni delež prihajajočih in odhajajočih, diplomsko in kreditno mobilnih študentov v slovenskem visokem šolstvu pa je še vedno relativno nizek, gibanja v mobilnosti pa nizko intenzivna. Na slednja namreč vpliva tudi (stalni) upad v številu oziroma deležu vpisanih študentov v visokošolsko izobraževanje v Sloveniji.

\section{Primer Nizozemske}

\section{Mobilnost študentov $v$ kontekstu visokošolskih politik in strategij (internacionalizacije)}

V sredini devetdesetih let preteklega stoletja so nizozemski oblikovalci visokošolskih politik pričeli poleg sodelovanja v okviru programov izmenjav na ravni EU izpostavljati tudi prihod neevropskih študentov, ki plačujejo šolnine. V zadnjem desetletju je na Nizozemskem ta "preusmeritev na visoko šolstvo kot izvozno blago« (de Wit, 2012: 437) postala bolj očitna, saj je nizozemska vlada začela intenzivneje poudarjati strateški cilj postati eno izmed petih vodilnih, na znanju temelječih ekonomij v globalnem merilu, internacionalizacijo visokega šolstva pa je opredelila kot ključno za dosego tega cilja. V letu 2014 sta tudi združenji nizozemskih univerz in univerz uporabnih znanosti predstavili svojo vizijo internacionalizacije in v skladu s tem pozvali k vnovični uvedbi nacionalnega programa štipendiranja mednarodne mobilnosti, ki je bil zaradi varčevalnih ukrepov v letu 2011 ukinjen (VSNU in VH, 2014). Kmalu zatem je tudi pristojni minister izrazil podporo vnovični vzpostavitvi programa štipendiranja, ki bi pritegnil najbolj talentirane študente iz držav zunaj Evropskega gospodarskega prostora in bi hkrati spodbudil študij domačih študentov v tujini (Ministry of Education, Culture and Science, 2014). Leta 2015 je v dolgoročnem strateškem programu o visokošolskem izobraževanju in raziskovanju (2015-2025) prav tako poudaril, da so mednarodni študenti »resnična dodana vrednost našemu izobraževanju in nizozemski ekonomiji znanja«, saj ni zanemarljivo, da 
ima »lahko vhodna mobilnost neto pozitiven učinek v višini 740 milijonov EUR letno" (Ministry of Education, Culture and Science, 2015: 12).

Tudi na institucionalni ravni je npr. Univerza Twente v svoji strategiji internacionalizacije navedla strateški cilj povečanja števila mednarodnih študentov, vključenih $\mathrm{v}$ magistrske študijske programe, iz 300 na 640 do leta 2020 (University of Twente, 2015), zadala pa si je tudi cilj, da bo $» 75$ odstotkov vseh dodiplomskih študentov v tujini pridobilo izkušnje v obsegu najmanj 15 kreditnih točk« (Intervju 2, 31. 5. 2016).

V nadaljevanju se tako prispevek osredinja na gibanja v študentski mobilnosti v nizozemskem visokošolskem prostoru, s tem pa zagotavlja ustrezno primerjalno iztočnico analize gibanj $\mathrm{v}$ mobilnosti študentov $\mathrm{v}$ obeh izbranih državah (in tudi na ravni EVP), čemur se posveča v nadaljnji razpravi.

\section{Mobilnost študentov $v$ praksi}

Kot poroča nizozemska organizacija za internacionalizacijo v izobraževanju Nuffic, je bilo v akreditirane študijske programe javnih visokošolskih zavodov v študijskem letu 2018/19 vpisanih 85,955 mednarodnih študentov, ki so predstavljali $11,5 \%$ celotne študentske populacije v nizozemskem visokošolskem izobraževanju (Nuffic, 2019a). To pomeni, da je v tem letu največ dolgoročno mobilnih študentov izviralo iz sosednje Nemčije (26,3\%), Italije $(5,6 \%)$ in Kitajske $(5,3 \%)$, in da se prav tako povečuje število mednarodnih študentov iz nekaterih južnih in vzhodnoevropskih držav (Bolgarija, Grčija, Romunija) oziroma iz držav z uradi NESO (nizozemski uradi za podporo izobraževanju), kot sta Indija in Indonezija (Nuffic, 2019a).

Po drugi strani je bilo v terciarno izobraževanje v tujini v študijskem letu 2016/17 vključenih 18,483 nizozemskih študentov oziroma 2,1 \% celotne terciarne študentske populacije (UIS, 2019). Belgija (27,4 \%), Združeno kraljestvo (19,1 \%) in ZDA (11,2 \%) so skupaj gostile nekoliko manj kot dve tretjini $(57,7 \%)$ vseh nizozemskih študentov na terciarnem študiju v tujini, med ostalimi študijskimi destinacijami pa so v tem letu prevladovale starejše članice EU-ja (UIS, 2019). Razmerje med deležem prihajajočih in odhajajočih dolgoročno mobilnih študentov je torej na Nizozemskem precej neuravnoteženo, zaradi česar gre za državo uvoznico, saj je izhodna stopnja dolgoročne mobilnosti bistveno nižja.

V okviru kratkoročne mobilnosti v programu Erasmus je na Nizozemskem v letu 2016/17 sodelovalo 12,755 študentov, izmed katerih so bili najštevilčnejši nemški, španski in francoski študenti, njihove glavne izvorne dr- 
žave pa, z izjemo Poljske in Turčije, starejše članice EU-ja (Italija, Združeno kraljestvo, Belgija) (Nuffic, 2019b). V tem letu je del študija v tujini preživelo tudi 13,107 nizozemskih Erasmus študentov, in sicer najpogosteje v Španiji, Združenem kraljestvu in Nemčiji (ibid.), kar pomeni, da so zahodnoevropske države v tem letu gostile največ nizozemskih Erasmus študentov.

$\mathrm{V}$ nasprotju s precej neuravnoteženim razmerjem med številom oziroma deležem prihajajočih in odhajajočih dolgoročno mobilnih študentov je to razmerje na področju kratkoročne mobilnosti precej bolj uravnoteženo, saj je število prihajajočih in odhajajočih Erasmus študentov skoraj enako (12,755 in 13,107 v letu 2016/17) (glej Nuffic, 2019b).

\section{Slovenija in Nizozemska $\mathrm{v}$ primerjalni perspektivi}

\section{Mobilnost študentov v primerjalnem kontekstu visokošolskih politik in strategij}

Primerjalna analiza nacionalnih in institucionalnih politik in strategij (internacionalizacije) $\mathrm{v}$ slovenskem in nizozemskem visokošolskem sistemu pokaže, da obe državi prednostno izpostavljata povečanje števila oziroma deleža dolgoročno in kratkoročno mobilnih študentov, zaradi česar se mobilnost pogosto dojema kot »oznaka za internacionalizacijo visokega šolstva« (Teichler, 2010: 267). Za razliko od Nizozemske, kjer različni strateški dokumenti vse bolj poudarjajo pomen rekrutiranja mednarodnih študentov kot ključnega za nizozemsko ekonomijo znanja (glej npr. Ministry of Education, Culture and Science, 2015), se v Sloveniji izpostavlja, da mednarodna mobilnost prispeva $k$ večji kakovosti (internacionalizacije) visokega šolstva (Ministrstvo za izobraževanje, znanost in šport, 2016). Internacionalizacija slovenskega visokega šolstva torej ni instrument za povečanje nacionalne konkurenčne prednosti v svetovnem merilu in tudi ekonomski motivi zanjo so prisotni v precej manjšem obsegu kot v nizozemskem primeru, kjer je »vlada - tako kot v številnih drugih državah - uvedla polne šolnine za ne-EU študente, [in] to je ekonomski nagib. To je razumljivo, ker zakaj bi davkoplačevalci financirali tovrstno mobilnost« (Intervju 3, 20. 6. 2016). Po drugi strani je npr. slovenski intervjuvanec v zvezi s tem poudaril naslednje:

Ko smo vstopili v OECD, so nam zelo jasno rekli: 'zakaj nimate šolnin? [...] Če boste hoteli zagotoviti takšno kakovost, kot jo imate sedaj v visokem šolstvu, je država s tem gospodarskim potencialom prešibka, da to vzdrži. Vi rabite šolnine.' /.../ In kako 
bomo imeli potem internacionalizacijo? Internacionalizacija je potem za povrh, za počitnice - takrat se greš internacionalizacijo, in to ni prav. (Intervju 5, 7. 9. 2016)

Čeprav se mobilnost $\mathrm{v}$ obeh državah dojema kot glavna dejavnost internacionalizacije visokega šolstva ( $\mathrm{v}$ tujini), je $\mathrm{v}$ nizozemskem primeru "več pozornosti namenjeno vključitvi mobilnosti $\mathrm{v}$ kurikul in internacionalizacijo doma " (Intervju 3, 20. 6. 2016). Slednje oblike internacionalizacije pa institucionalni dokumenti ne dojemajo kot alternativo mobilnosti, temveč kot dve komplementarni področji (van Gaalen et al., 2014: 3), medtem ko je v Sloveniji na večini slovenskih visokošolskih zavodov »internacionalizacija doma še zmeraj v povojih" (Klemenčič in Flander, 2013: 144). Ta ,domača razsežnost visokošolske internacionalizacije je sicer vredna nadaljnje obravnave, vendar pa se prispevek v nadaljevanju posveča primerjavi gibanj $\mathrm{v}$ dolgoročni in kratkoročni mobilnosti $\mathrm{v}$ slovenskem in nizozemskem visokošolskem prostoru, $s$ čimer primerjalno ponazori obstoječe prakse na področju dolgoročne in kratkoročne mobilnosti študentov, s tem pa tudi odzive obeh visokošolskih sistemov na prevladujoče visokošolske politike in strategije (internacionalizacije).

Mobilnost študentov $v$ slovenskem in nizozemskem visokem šolstvu $v$ praksi

V okviru dolgoročne mobilnosti je bil v letu 2018/19 delež tujih študentov s stalnim prebivališčem $\mathrm{v}$ tujini, ki so bili vpisani na slovenske visokošolske zavode 7,7-odstoten, medtem ko so na Nizozemskem v tem letu mednarodni študenti predstavljali več kot desetino $(11,5 \%)$ celotne visokošolske študentske populacije (Nuffic, 2019a). Nizozemska je namreč del elitne deseterice držav $\mathrm{z}$ najštevilčnejšo mednarodno študentsko populacijo, ki po podatkih OECD-ja zaseda šesto mesto, za Novo Zelandijo, Združenim kraljestvom, Švico, Avstrijo in Avstralijo (OECD, 2017). V obeh primerih več kot petina dolgoročno mobilnih študentov in tujine izvira iz sosednje države; v slovenskem primeru iz Hrvaške (20,8 \%), v nizozemskem pa iz Nemčije (26,3 \%).

To pomeni, da so gibanja $\mathrm{v}$ študentski mobilnosti podvržena nekaterim kontekstualno specifičnim vplivom, saj v Sloveniji kar tri četrtine vseh tujih študentov zastopajo tisti iz bivših jugoslovanskih republik (SURS, 2019). Ker želi Slovenija postati primer dobre prakse na področju regijske mobilnosti, tudi ukrepi na ravni sistema podpirajo enake pogoje šolnin za študente iz te regije kot veljajo za slovenske študente ali tiste iz EU (Mini- 
strstvo za visoko šolstvo, znanost in tehnologijo, 2011). Po drugi strani je visok delež nemških študentov na nizozemskih visokošolskih ustanovah odraz izvajanja pravila numerus clausus, ki omejuje pravico do vpisa na nekatere študijske programe (npr. medicina, veterina) na nemških visokošolskih zavodih.

Primerjalno gledano je torej delež domačih študentov na študiju v tujini v obeh državah nižji, kar je še posebej očitno v nizozemskem primeru, saj se vseskozi giblje okrog $2 \%$ celotne terciarne študentske populacije, to pa je nižje kot v slovenskem primeru (3,2 \%) (UIS, 2019). Tako v Sloveniji kot na Nizozemskem sta glavni študijski destinaciji domačih dolgoročno mobilnih študentov sosednji (zahodnoevropski) državi, in sicer Avstrija (v slovenskem primeru) in Belgija (v nizozemskem primeru). Prav tako je v obeh primerih Združeno kraljestvo ena izmed treh osrednjih ciljnih držav, ki skupaj z Nemčijo in Francijo privabi več kot polovico (55\%) vseh dolgoročno mobilnih študentov v Evropi (European Commission et al., 2018). V državah EVP so torej splošna povprečja v študentski mobilnosti močno pogojena $\mathrm{z}$ gibanji $\mathrm{v}$ teh treh študijskih destinacijah (de Wit, 2012). To tudi pomeni, da je razmerje med deležem prihajajočih in odhajajočih dolgoročno mobilnih študentov v nizozemskem primeru (precej) bolj neuravnoteženo kot v primeru Slovenije (približno 6:1, v Sloveniji približno 1: 0,7), zaradi česar je Nizozemska pogosto označena za državo ,neto uvoznico mednarodnih študentov $\mathrm{z}$ višjim deležem prihajajočih študentov, Slovenija pa za državo $\mathrm{z}$ relativno uravnoteženimi gibanji $\mathrm{v}$ dolgoročni mobilnosti študentov, ki pa so nizko intenzivna (European Commission et al., 2018).

Nadalje, kratkoročno mobilnost se $\mathrm{v}$ obeh državah najpogosteje izvaja v okviru programa Erasmus; v okviru programa so bili npr. na slovenskih visokošolskih zavodih v letu 2014/15 najštevilčnejši španski študentje, medtem ko so bili na Nizozemskem v letu 2016/17 najštevilčnejši nemški študentje. Nemčija je tudi gostila največje število slovenskih Erasmus študentov, med nizozemskimi pa je bilo najbolj priljubljeno Združeno kraljestvo. V tem letu je del svojega študija na Nizozemskem prav tako preživelo 96 Erasmus študentov iz Slovenije, 49 nizozemskih študentov pa je sodelovalo $\mathrm{v}$ tem programu na slovenskih visokošolskih ustanovah.

Gibanja v mobilnosti študentov torej ne odražajo retorike (nad)nacionalnih in institucionalnih strateških dokumentov, saj je »(v) večini slovenskih visokošolskih zavodov /.../ program Erasmus le ,dodatna oblika' mednarodnega sodelovanja (Klemenčič in Flander, 2013: 144). Po drugi strani obstajajo na Nizozemskem »številne institucije, ki se osredotočajo na mo- 
bilnost, in obstajajo tudi številne institucije, ki se osredotočajo na samo internacionalizacijo, tako da so [njihove strategije] celovitejše« (Intervju 1, 30. 5. 2016).

\section{Zaključki}

Dosedanja primerjalna razprava zagotavlja tudi ustrezno izhodišče za obravnavo podobnosti in razlik $\mathrm{v}$ izvajanju politik in praks na področju mobilnosti študentov med različnimi članicami bolonjskega procesa. Kot poroča raziskava Trends 2015, 66 \% sodelujočih visokošolskih ustanov iz EVP dojema študentsko mobilnost kot glavno dejavnost, ki prispeva $\mathrm{k}$ izboljšanju poučevanja in učenja (Sursock, 2015), saj »se institucije odločajo za veliko enostavnih oblik internacionalizacije, ker so te vidne (Intervju 1, 30. 5. 2016). Toda »[z]aradi pomena, ki ga večina nacionalnih vlad $v$ javnih izjavah pripisuje mobilnosti študentov in osebja, je presenetljivo, kako zelo malo jih je razvilo celovite in sistematične politike mobilnosti« (Teichler et al., 2011: 8). Države podpisanice bolonjskega procesa namreč ambiciozno izpostavljajo potrebo po preseganju leuvenskega cilja ,20/2020, vendar pa predstavlja njegova uresničitev (še vedno) znaten izziv tako za Slovenijo kot za mnoge druge, zlasti srednje-, vzhodno- in južnoevropske države (European Commission et al., 2018). Na ravni EVP je namreč izmed 32 držav 21 držav bodisi ,neto izvoznic' (predvsem tiste iz Vzhodne Evrope) ali ,neto uvoznic' (predvsem tiste iz Zahodne in Severne Evrope) (Teichler et al., 2011).

Države bolonjskega procesa, vključno s Slovenijo in Nizozemsko, si torej še vedno (pre)pogosto prizadevajo za kvantiteto na račun kvalitete, saj "nejasno podpirajo mobilnost kot zaželeno dejavnost in sprejemajo pristop ,the more the merrier " ${ }^{3}$ (Teichler et al., 2011: 8). Ker se v Sloveniji internacionalizacijo in s tem mobilnost (študentov) razume tudi kot prenos nadnacionalnih politik (na ravni EU in EVP) v visokošolskih sistem, je eden izmed slovenskih intervjuvancev $\mathrm{v}$ zvezi s tem izpostavil:

Ko je neka strategija ali neki delovni program sprejet na ravni EU, potem se nanj odzovemo /.../. Ko so na voljo sredstva $\mathrm{v}$ EU programih, kot je zdaj recimo Erasmus+, se bo našlo toliko in toliko institucij, ki se bodo na to odzvale /.../, zato smo počasni. (Intervju 4, 29. 6. 2016) 
Tovrstne navedbe je moč teoretsko podkrepiti s predpostavkami institucionalnega izomorfizma, sociološke različice novega institucionalizma (glej DiMaggio in Powell, 1983; Hall in Taylor, 1996), ki se v (primerjalnih) študijah visokega šolstva pogosto uporablja za pojasnjevanje zbliževanja med visokošolskimi pojavi (npr. Dobbins, 20o8). Institucionalni izomorfizem namreč trdi, da so »nacionalne države [...] bolj izomorfne, kot bi napovedala večina teorij, in se spreminjajo bolj uniformno, kot je splošno priznano « (Meyer et al. 1997: 173). V tem kontekstu naj bi tudi vključitev držav v bolonjski proces spodbudila »razvoj visoke ravni primerljivosti, združljivosti in izmenjave med visokošolskimi institucijami ter sistemi evropskega visokošolskega prostora « (Evropska komisija, 2013: 2), še posebej v okviru programov mobilnosti (študentov), saj so se članice bolonjskega procesa zavezale k uresničitvi cilja petine domačih študentov do leta 2020 (Leuven Communiqué, 2009).

Zaradi sklicevanja na homogenost pa je ena vidnejših omejitev institucionalnega izomorfizma neosredotočenost na specifična lokalna okolja (DiMaggio in Powell, 1991), s čimer spregleda možen obstoj raznolikosti $\mathrm{v}$ nacionalnih in institucionalnih (lokalnih) odzivih organizacij in akterjev na visokošolski razvoj na mednarodni (tj., globalni in regionalni) ravni (Vaira, 2004). Mednarodna mobilnost (študentov) je namreč visokošolski pojav s soodvisnimi odnosi, ki presegajo usmeritev na izključno nacionalno razsežnost visokega šolstva, npr. nacionalno državo oziroma visokošolski sistem. Naslednja, sicer bolj splošna pomanjkljivost teorije novega institucionalizma je nepriznavanje institucij kot "produkta človeških dejanj « (DiMaggio in Powell, 1991: 28) in s tem obstoja različnih prepričanj in navzkrižja interesov med različnimi visokošolskimi akterji. Različne interesne skupine namreč različno odgovarjajo na vprašanje, zakaj internacionalizirati visokošolsko dejavnost (de Wit, 2002; de Wit, 2011), s tem pa pogojujejo tako dojemanje, kaj pomeni internacionalizacija visokega šolstva, kot tudi način oblikovanja njenih politik in strategij ter njihovo skladnost z glavnimi nameni visokošolskega izobraževanja.

Motivi za internacionalizacijo visokega šolstva so namreč v Sloveniji bolj politično kot gospodarsko naravnani, medtem ko se na Nizozemskem mednarodne študente, ki plačujejo šolnine, dojema kot ključne za ustvarjanje konkurenčne prednosti nizozemske ekonomije znanja na globalni ravni. Ker je tudi v mnogih drugih državah (EVP) ustvarjanje prihodkov pomemben argument za rekrutiranje mednarodnih študentov (de Wit, 2012; de Wit et al., 2015), to razodeva "[p]aradoksalno kombinacijo med sodelo- 
vanjem in konkurenco kot prevladujočima motivoma internacionalizacije /.../ v okviru bolonjskega procesa « (Bologna Process Researchers' Conference, 2017: 5).

Vplivi raznolikih geopolitičnih, ekonomskih, zgodovinskih in družbeno-kulturnih okoliščin torej ustvarjajo tako priložnosti kot izzive za dohodno in odhodno, dolgoročno in kratkoročno mobilnost med in znotraj posameznih oddelkov, institucij, držav in svetovnih regij. Zato

[b]i bilo preveč preprosto trditi, da se v evropskem visokem šolstvu spreminjajoča se pokrajina internacionalizacije $\mathrm{v}$ smeri večje konkurenčnosti in aktivnega rekrutiranja mednarodnih študentov iz Evrope in zunaj nje razvija na podoben način. Obstajajo različni poudarki in pristopi. Strategije internacionalizacije so /.../ kontekstualizirane s specifičnim notranjim kontekstom univerze in njeno nacionalno vpetostjo. (de Wit, 2012: 436)

V Sloveniji, na Nizozemskem in tudi v širšem območju EVP-ja so namreč prisotne precejšnje razlike med visokošolskimi zavodi, kar zadeva delež mobilnih študentov, saj nekateri poročajo, da mednarodni študenti predstavljajo več kot desetino celotne študentske populacije, na veliki večini visokošolskih ustanov pa je njihov odstotek (znatno) nižji (European University Association (EUA), 2013). V svojem vključevanju v mednarodno okolje se namreč srečujejo $\mathrm{z}$ različnimi omejitvami kot tudi s številnimi možnostmi in priložnostmi za njihovo delovanje. Na ta način se prilagajajo svetu, v katerem obstajajo raznolike možnosti odnosa med njihovim mednarodnim, nacionalnim, institucionalnim in disciplinarnim razvojem visokega šolstva, $s$ tem pa tudi študentske mobilnosti.

\section{Literatura}

Bolonjska deklaracija (1999). http://archive-2010-2015.e.eaa.info/article-details.aspx?ArticleId $=80$ (2. 12. 2019).

Bologna Process Researchers' Conference (2017). Future of higher education Bologna Process researchers' conference: Conference report. http://www. ehea.info/cid1180o6/bologna-process-researchers-conference.html (29. 11. 2019).

De Wit, Hans. "Student mobility between Europe and the rest of the world: Trends, issues and challenges«. V European Higher Education at the crossroads: Between the Bologna Process and national reforms, ur. Adrian 
Curaj, Peter Scott, Lazăr Vlasceanu in Lesley Wilson, 431-439. Dordrecht: Springer, 2012.

De Wit, Hans, Fiona Hunter, Laura Howard in Eva Egron-Polak. Internationalisation of higher education. Brussels: European Parliament, Directorate-General for Internal Policies, 2015.

DiMaggio, Paul J. in Powell, Walter. »The Iron Cage Revisited: Institutional Isomorphism and collective Rationality in Organizational Fields«. American Sociological Review, 48, št. 2 (1983): 147-160.

DiMaggio, Paul J. in Powell, Walter. »Introduction«. V The New Institutionalism in Organizational Analysis, ur. Walter Powell in Paul J. DiMaggio, 1-38. Chicago: University of Chicago Press, 1991.

Dobbins, Michael. Comparing Higher Education Policies in Central and Eastern Europe: To converge or not to converge? (Doktorska disertacija). Konstanz: Universität Konstanz, 2018.

European Commission (2013). European higher education in the world. https:// ec.europa.eu/education/policy/international-cooperation/world-education_en (25.11. 2019).

European Commission. Erasmus+ annual report 2016: Statistical annex. Brussels: European Commission, 2017.

European Commission, EACEA in Eurydice. The European Higher Education Area in 2018: Bologna Process implementation report. Luxembourg: Publications Office of the European Union, 2018.

European University Association (EUA). Internationalisation in European higher education: European policies, institutional strategies and EUA support. Brussels: EUA, 2013.

Evropska komisija. Sporočilo Komisije Evropskemu parlamentu, Svetu, Evropskemu ekonomsko-socialnemu odboru in Odboru regij: Evropsko visokošolsko izobraževanje v svetu. Bruselj: Evropska komisija, 2013.

Hall, Peter A. in Taylor Rosemary C. R. »Political Science and the Three New Institutionalisms«. Political Studies, 44, št. 5 (2011): 936-957.

Hauptman Komotar, Maruša. Internacionalizacija in zagotavljanje kakovosti $v$ visokem šolstvu $v$ Sloveniji in na Nizozemskem (Doktorska disertacija). Ljubljana: Pedagoška fakulteta Univerze v Ljubljani, 2018.

Klemenčič, Manja in Alenka Flander. Evalvacija učinkov programa Erasmus na visoko šolstvo v Sloveniji. Ljubljana: CMEPIUS, 2013.

Knight, Jane. Higher education in turmoil: The changing world of internationalisation. Rotterdam: Sense Publishers, 2008. 
Leuven Communiqué (2009). http://archive-2010-2015.ehea.info/article-details.aspx?ArticleId=80 (7. 1. 2020).

Meyer, John W., Boli, John, Thomas, George M. in Ramirez, Francisco O. »World Society and the Nation State«. American Journal of Sociology, 103, št. 1 (1997): 144-181.

Ministry of Education, Culture and Science (2014). Into the world: Letter on the government's vision on the international dimension of higher education and VET. https://www.government.nl/government/members-of-cabinet/ jet-bussemaker/documents/letters/2014/o7/21/government-s-vision-on-the-international-dimension-of-higher-education-and-vet (10. 11. 2019).

Ministry of Education, Culture and Science. The value of knowledge: Strategic agenda for higher education and research 2015-2025. The Hague: Ministry of Education, Culture and Science, 2015.

Ministrstvo za izobraževanje, znanost in šport (2016). Strategija internacionalizacije slovenskega visokega šolstva 2016-2020. https://www.cmepius.si/ wp-content/uploads/2014/o2/Strategija-internacionalizacije-slovenskega-visokega-solstva-SLO-2016\%E2\%80\%932020_WEB.pdf (3. 12. 2019).

Ministrstvo za izobraževanje, znanost in šport (2019). Akcijski načrt Strategije internacionalizacije slovenskega visokega šolstva (2018-2020). https:// www.gov.si/teme/internacionalizacija-visokega-solstva/ (3. 12. 2019).

Ministrstvo za šolstvo, znanost in šport (2002). Nacionalni program visokega šolstva. http://www.pisrs.si/Pis.web/pregledPredpisa?id=NACP 33 (4. 12. 2019).

Ministrstvo za visoko šolstvo, znanost in tehnologijo (2011). Resolucija o nacionalnem programu visokega šolstva 2011-2020. http://www.drznaslovenija.mvzt.gov.si/cho1.html (5.12. 2019).

Nuffic (2019a). Incoming degree student mobility in Dutch higher education 2018-2019. https://www.nuffic.nl/en/publications/incoming-degree-student-mobility-dutch-higher-education-2018-2019/ (6. 1. 2020).

Nuffic (2019b). Facts and figures. https://www.nuffic.nl/en/subjects/facts-and-figures/ (6. 1. 2020).

OECD. Education at a glance: OECD indicators. Paris: OECD, 2017.

Paris Communiqué (2018). http://www.ehea2018.paris/Data/ElFinder/s2/ Communique/EHEAParis2018-Communique-final.pdf (23. 12. 2019).

SURS (2019). Tuji študenti visokošolskega študija po državi državljanstva, Slovenija, 2018/19 (interno gradivo). Ljubljana: SURS. 
Sursock, Andrée. Trends 2015: Learning and teaching in European universities. Brussels: EUA, 2015.

Teichler, Ulrich. »Internationalising higher education: Debates and changes in Europe«. V Changing educational landscapes, ur. Dimitris Mattheou, 263-283. Dordrecht: Springer, 2010.

Teichler, Ulrich, Irina Ferencz in Berndt Wächter (ur.). Mapping mobility in European higher education (Vol. I). Brussels: European Commission, 2011.

UNESCO Institute for Statistics. (2019). Global flow of tertiary-level students. http://uis.unesco.org/en/uis-student-flow

Univerza v Ljubljani (2014). Strategija internacionalizacije Univerze $v$ Ljubljani 2014-2017 (2020). https://www.uni-lj.si/o_univerzi_v_ljubljani/strategija_ul/ (12.12. 2019).

Univerza na Primorskem (2014). Srednjeročna razvojna strategija UP 2014 2020. https://www.famnit.upr.si/sl/resources/files/o-fakulteti/poslanstvo-in-vizija/upsrednjrazvojnastrat2014-2020.pdf (12 (12. 12. 2019).

University of Twente (2015). 2020: Educating the global citizen. https://www. utwente.nl/en/vision2020/achievements/internationalization/archive-internationalization/update-internationalization/ (15. 12. 2019).

Vaira, Massimiliano (2004). »Globalization and higher education organizational change: A framework for analysis«. Higher Education, 48, št. 4 (2004): 483-510.

Van Gaalen, Adinda, Hendrik Jan Hobbes, Sjoerd Roodenburg in Renate Gielesen. Management summary: Internationalising students in the home country. The Hague: Nuffic, 2014.

VSNU in VH (2014). Internationalization vision. https://www.vsnu.nl/files/documents/Publications/Internationalization_vision.pdf (15. 12. 2019).

Working Group on Mobility (2012). Mobility for better learning: Mobility strategy 2020 for the European Higher Education Area (EHEA). https://www. ehea.info/cid101043/ministerial-conference-bucharest-2012.html (10. 12. 2019).

Zakon o spremembah in dopolnitvah zakona o visokem šolstvu (1999). Uradni list RS, št. 99/1999.

\section{Seznam intervjujev}

Intervju s predstavnikom Nizozemske organizacije za mednarodno sodelovanje (Nuffic) - Intervju 1 (30. maj 2016). Intervju opravil M. Hauptman 
Komotar [zvočni posnetek]. Internacionalizacija v nizozemskem visokem šolstvu. [Doktorska disertacija] (I4-NIZ). Osebni arhiv, Litija.

Intervju s fakultetnim koordinatorjem za internacionalizacijo v visokem šolstvu - Intervju 2 (31. maj 2016). Intervju opravil M. Hauptman Komotar [zvočni posnetek]. Internacionalizacija v nizozemskem visokem šolstvu. [Doktorska disertacija] (I5-NIZ). Osebni arhiv, Litija.

Intervju z ekspertom za področje internacionalizacije visokega šolstva - Intervju 3 (20. junij 2016). Intervju opravil M. Hauptman Komotar [zvočni posnetek]. Internacionalizacija v nizozemskem visokem šolstvu. [Doktorska disertacija] (I7-NIZ). Osebni arhiv, Litija.

Intervju $\mathrm{z}$ ekspertom za področje internacionalizacije in zagotavljanja kakovosti v slovenskem visokem šolstvu - Intervju 4 (29. junij 2016). Intervju opravil M. Hauptman Komotar [zvočni posnetek]. Internacionalizacija in zagotavljanje kakovosti v slovenskem visokem šolstvu. [Doktorska disertacija] (I9-SLO). Osebni arhiv, Litija.

Intervju s predstavnikom Ministrstva za izobraževanje, znanost in šport Intervju 5 (7. september 2016). Intervju opravil M. Hauptman Komotar [zvočni posnetek]. Internacionalizacija in zagotavljanje kakovosti v slovenskem visokem šolstvu. [Doktorska disertacija] (I14-SLO). Osebni arhiv, Litija. 



\title{
Spodbujanje medkulturne zmožnosti s čezmejnimi razredi
}

\author{
Barbara Baloh, Silva Bratož
}

\section{Uvod}

Za sodobno evropsko družbo pomenita kulturna in jezikovna raznolikost tako obogatitev kakor tudi izziv. Kultura je neločljivo povezana $\mathrm{z}$ jezikom, saj ko se učimo jezika, obenem spoznavamo tudi kulturo, iz katere ta izhaja. To se odraža tudi v jezikovnem okviru, ki so ga sprejele članice Evropske unije (Svet Evrope 2011), saj poleg jezikovnih in pragmatičnih zmožnosti predlagani model sporazumevalne zmožnosti obsega tudi sociolingvistične zmožnosti, ki se nanašajo na sociokulturne pogoje rabe jezika in predpostavljajo, da je za uspešno sporazumevanje nujno usvojiti tudi medkulturno zmožnost. Pri opredelitvi medkulturne zmožnosti različni avtorji (Byram, Gribkova in Starkey 2002; Boecker 2008; Deardoff 2006) poleg znanja in razumevanja drugih kultur ter spretnosti, povezanih $\mathrm{z}$ interpretacijo drugih kultur, poudarjajo predvsem odnos in stališča do drugih in drugačnih. Ta se izražajo skozi radovednost in odprtost posameznika do drugih kultur ter vključujejo njegovo pripravljenost, da lastne vrednote, stališča in vedenja postavi pod vprašaj in s tem razvije zmožnost svojo kulturo pogledati s perspektive nekoga, ki prihaja iz druge kulture, z drugimi vrednotami, prepričanji in vedenjem. Omenjeni vidiki so še posebej poudarjeni $\mathrm{v}$ obmejnih prostorih, $\mathrm{v}$ katerih so učenci nenehno izpostavljeni jezikovni in kulturni raznolikosti.

Okoliščine medkulturnega sporazumevanja vključujejo dve ali več kultur, različne jezike in vedenjske vzorce, ki se jih večinoma niti ne za- 
vedamo, pač pa neupravičeno pričakujemo od pripadnikov drugih kultur, da se naših vedenjskih vzorcev zavedajo in da jih prakticirajo. Grosman (2004) meni, da je za uresničevanje razumevanja medkulturnih okoliščin in uspešno sporazumevanje potrebno razviti medkulturno zavest. $Z$ razvijanjem medkulturnega zavedanja, spoštovanja in sprejemanja različnih kultur in jezikov je smiselno začeti že v zgodnjem otroštvu, zlasti zato, ker je pri zgodnjem učenju/poučevanju jezika/jezikov učenčeva pozitivna izkušnja $\mathrm{z}$ jezikom največja motivacija za nadaljnje delo in spodbuda za doseganje višje ravni znanja. Učenec za razvoj jezika in medkulturne zmožnosti potrebuje predvsem spodbudno okolje, imeti mora priložnost slišati in uporabiti jezik $\mathrm{v}$ različnih okoliščinah, pri tem pa potrebuje tudi spodbudo odraslih in vrstnikov.

Namen pričujočega prispevka je predstaviti rezultate akcijske raziskave, ki smo jo izvedli v okviru projekta EDUKA 2 - Čezmejno upravljanje izobraževanja (projekt Interreg med Slovenijo in Italijo) in ki temelji na čezmejnem sodelovanju med šolami $\mathrm{z}$ istim in različnim učnim jezikom na meji med Italijo in Slovenijo. Osnovni cilj projekta je bil oblikovati in v praksi preizkusiti skupne učne vsebine in orodja, in sicer v obliki t. i. čezmejnih razredov, $v$ okviru katerih so se učenci sorodnih šol iz obeh strani meje srečevali ter vključevali v različne učne dejavnosti. Ta oblika sodelovanja je omogočila medsebojno spoznavanje, vzpostavljanje prijateljskih vezi ter izmenjavo šolskih izkušenj tako med učenci kot med učitelji. Koncept čezmejnih razredov temelji na izbranih didaktičnih izhodiščih, ki upoštevajo sodobne učne pristope in strategije, podprte s spodbudnim, aktivnim, odprtim in avtentičnim učnim okoljem.

\section{Teoretični okvir}

\section{Razvijanje sporazumevalne zmožnosti}

Model sporazumevalnih zmožnosti, kot ga opredeljuje Skupni evropski jezikovni okvir (SEJO), opisuje sporazumevalne jezikovne zmožnosti kot tiste, "ki osebi omogočajo delovanje z uporabo specifičnih jezikovnih sredstev" (Svet Evrope 2011: 31). Razdelimo jih lahko na več sestavin (jezikovno, sociolingvistično in pragmatično), ki obsegajo določeno znanje, spretnosti in t.i. know-how ali operativno znanje. Jezikovne zmožnosti, ki vključujejo fonološko, skladenjsko znanje in spretnosti ter druge razsežnosti jezika kot sistema, ne zajemajo le obsega in kakovosti znanja, temveč tudi načine, kako je to znanje organizirano, shranjeno in kako se do nje- 
ga dostopa (npr. $\mathrm{z}$ aktiviranjem ali priklicem), kar pa se razlikuje od posameznika do posameznika in je lahko odvisno od drugih dejavnikov, kot so, denimo, znanje drugih jezikov ali kulturno okolje, iz katerega oseba prihaja. Sociolingvistične zmožnosti zadevajo sociokulturne pogoje rabe jezika, ki so povezane z družbenimi konvencijami, kot so na primer pravila vljudnosti, norme vedęnja in druge družbene konvencije. V tej sestavini se sporazumevalne jezikovne zmožnosti najbolj približajo medkulturnim razlikam, ki se odražajo v jeziku. Pragmatične zmožnosti pa se nanašajo na rabo različnih interakcijskih izmenjav (funkcionalno rabo razpoložljivih jezikovnih virov) in od učencev zahtevajo sposobnost obvladovanja diskurza (t.j. sposobnost urejanja stavkov v koherentne jezikovne celote), vključujejo pa še funkcijsko zmožnost (t.j. rabo govorjenega diskurza in pisnih besedil $v$ sporazumevanju z določenim funkcionalnim ciljem) in zmožnost oblikovanja (t.j. poznavanje konvencij oblikovanja besedil v določeni skupnosti).

Poleg omenjenih sestavin pa SEJO uvaja še dodatno dimenzijo, in sicer razvijanje t.i. raznojezične in $\mathrm{z}$ njo povezane raznokulturne zmožnosti. Ta se nanaša na sposobnost osebe, da se sporazumeva $z$ uporabo celotnega jezikovnega repertoarja, ki mu je na voljo, vključno z maternim jezikom. Tak pogled temelji na predpostavki, da $v$ procesu usvajanja drugega jezika učenec ne izključi svojega maternega jezika in s tem povezane kulture. Ravno tako se s pridobivanjem znanja $\mathrm{v}$ drugem jeziku ne razvije popolnoma novega načina sporazumevanja in delovanja, ki je neskladen $s$ tistim, ki ga je učenec že usvojil. Ravno nasprotno, »jezikovno in kulturno zmožnost za vsak jezik delno preoblikuje znanje drugega in vsak prispeva k medkulturnemu zavedanju, spretnostim in operativnemu znanju « (Svet Evrope 2011: 67).

Kot poudarja Baloh (2019), je v dvojezičnih in večjezičnih okoljih še posebej pomembno razvijati zavedanje, da poleg maternega $v$ okolju obstaja še nek drugi jezik oziroma jeziki. Seznanjanje z jezikom/senzibilizacija je proces, $v$ katerem posameznik uzavesti, da poleg prvega jezika ob njem obstaja še drug jezik ali jeziki. Seznanjanje poteka predvsem na receptivni ravni, pri tem pa učitelj/vzgojitelj premišljeno in strokovno utemeljeno izbira vsebine in oblike dela ter načrtuje dejavnosti, ki učečemu se omogočajo seznanjanje $\mathrm{z}$ drugim jezikom. To lahko poteka $\mathrm{v}$ okviru socialnih stikov, ko je učenec v stiku z rojenimi govorci drugega jezika (jezika okolja), med obiski institucij pripadnikov drugega jezika (vrtec, šola, radio, TV ...) v urbanem okolju in neposredno v pridobivanju jezikovne zmožnosti v dru- 
gem jeziku, kjer gre predvsem za igralne ter raziskovalne dejavnosti, metode in tehnike dela, ki spodbujajo interes za spoznavanje jezika in razvijanje sporazumevalne zmožnosti. $V$ času seznanjanja $z$ jezikom je učečemu se jezika potrebno ponuditi dovolj časa, da usvoji melodijo novega jezika, razume preproste besede in sporočila, da igraje zbira besede in jih postavlja $\mathrm{v}$ svoj vrednostni sistem s ciljem razumeti in vzljubiti drugi jezik. Zato da bi znal spoštovati drugo kulturo, stališča, vrednote, navade ipd., pa mora učeči se jezika najprej spoznati sebe kot posameznika in se doživeti v okviru lastne kulture.

\section{Spodbudno učno okolje}

Raziskave kažejo (Cenčič in Perger Kuščar 2012; Baloh in Cenčič 2018; Istance in Dumond 2013; Komljanc 2010), da spodbudno in odprto učno okolje bistveno prispeva k oblikovanju popolnejše sporazumevalne zmožnosti otrok tudi v večjezičnem in večkulturnem okolju. Kot menita Cenčič in Perger Kuščar (2012), se danes poudarja pomen interaktivnih učnih okolij, ki naj bi bila hkrati izobraževalna, ustvarjalna in zabavna okolja učenja. Poleg tega naj bi spodbujala izražanje različnih inteligentnosti otrok, kar se navezuje na Gardnerja (2010), ki zagovarja stališče, da so za različne ljudi značilne različne inteligentnosti in da se posamezniki razlikujejo po kombinaciji in jakosti različnih inteligentnosti (jezikovne, logično-matematične, glasbene, prostorske, telesno-gibalne ter medosebne in osebne). $Z$ vidika poučevanja gre za na učenca osredinjen pristop, ki poudarja razlike med učenci in različne učne stile, kar se odraža tudi v metodah in tehnikah poučevanja tujega jezika. Če je učni prostor raznovrsten in razgiban, omogoča različne dejavnosti in medpredmetno povezovanje, spodbudno okolje pa deluje kot tretji učitelj/vzgojitelj ali tudi kot tridimenzionalni učbenik kot menita avtorici (Cenčič in Perger Kuščar 2012).

Sodobno in spodbudno učno okolje razumemo kot okolje, ki spodbuja otrokovo raziskovanje, dinamično interakcijo in celostno podoživljanje otrokove subjektivne izkušnje ter možnost za aktivno vključevanje vseh otrok. Sodobno spodbudno učno okolje razvija aktivno (raziskovalno) pridobivanje znanja in veščin, kar vključuje otrokovo udeležbo, saj otroci v domišljenih/izbranih situacijah (življenjskih okoliščinah) z lastno aktivnostjo pridejo do novega znanja. Učenje $\mathrm{v}$ učinkovitem in spodbudnem učnem okolju je, kot menita David Istance in Hanna Dumond (2013: 285), postavlja učenje $\mathrm{v}$ središče, spodbuja zavzetost za učenje in omogoča učencem, da se dojemajo kot učenci, je socialno in pogosto sodelovalno, v največji meri je 
usklajeno $\mathrm{z}$ motivacijo učencev in pomembnostjo čustev, je zelo občutljivo za individualne razlike, vključno s predhodnim znanjem, je zahtevno za vsakega učenca, vendar brez čezmernega preobremenjevanja, uporablja vrednotenje, ki je usklajeno s cilji in $\mathrm{z}$ močnim poudarkom na formativni povratni informaciji ter spodbuja horizontalno povezanost med dejavnostmi in predmeti $\mathrm{v}$ šoli in zunaj nje. Na takšen način $\mathrm{v}$ otroku spodbuja in razvija znanstvene navade razmišljanja, ki mu v življenju pomagajo pri soočanju z novimi situacijami in problemi in uspešnejšem iskanju rešitev zanje.

\section{Aktivno učenje}

Ena izmed uspešnejših učnih strategij, ki omogoča samostojno iskanje in razmišljanje $\mathrm{z}$ lastno aktivnostjo ter $\mathrm{s}$ tem pridobivanje lastnih izkušenj in trajno spreminjanje posameznika je izkustveno učenje (Hus in Ivanuš Grmek 2006). Marentič Požarnik (1998) izpostavlja, naj tako poučevanje temelji na trajnem spreminjanju posameznika in ne le na pridobivanju znanja, spretnosti in stališč. Plut Pregelj (2005) meni, da je najboljši način pridobivanja znanja preko lastnih izkušenj. Primeri dobre prakse (Agnič, Babšek in Udovič 2014) kažejo, da se z medpodročnim povezovanjem, ki poudarja izkustveno učenje na prostem, učenec na fizičnem, čustvenem in osebnem področju razvija celostno, razvija pa se tudi socialno in na kognitivnem področju. Pri tem morajo biti povezave jasno povezane z življenjskimi situacijami, oz. nakazana mora biti njihova uporaba v vsakdanjem življenju.

Kot meni Kužnik (2009), je ključna vloga odraslega, da s svojim zgledom in spodbudo učencu ponudi različne situacije raziskovanja in spoznavanja. Izkoristiti mora to razvojno fazo in uporabiti učenčevo notranjo motivacijo za spodbujanje k učenju in spoznavanju sveta. Pomembna pa je tudi interakcija $\mathrm{z}$ vrstniki, saj otroci zaradi podobnega načina razmišljanja večje in hitrejše možnosti iskanja izvirnih rešitev pri razmišljanju kot v interakciji z odraslo osebo.

\section{Vsebinsko in jezikovno integrirano učenje}

Vsebinsko in jezikovno integrirano učenje, za katerega tudi v slovenščini uporabljamo akronim CLIL, pogosto opisujejo kot inovativen, sodoben in odprt pristop k poučevanju tujega jezika (Lipavic Oštir, Lipovec in Rajšp 2015; Brumen, Kolbl Ivanjšič in Pšunder 2015). Nekateri ga opisujejo kot eno največjih inovacij v izobraževanju v preteklih dvajsetih letih. Gre za 
»izobraževalni pristop, pri katerem predmete, kot so geografija ali biologija, poučujemo skozi tuji jezik, in sicer udeležence, ki so vključeni v določeno obliko formalnega izobraževanja na primarni, sekundarni ali terciarni ravni«. (Dalton-Puffer, Nikula in Smit 2010, 1). Koncept predpostavlja zlitje ciljev poučevanja tujega jezika in drugih predmetnih področij.

Za razumevanje CLIL-a je pomemben štiridimenzionalni okvir, ki vključuje vsebino, kognicijo, komunikacijo in kulturo (4C - content, cognition, communication and culture), ki ga je razvila Do Coyle (2005). Pri CLIL-u je osnovni cilj poučevanja integracija vsebine (vsebina in kognicija) in jezika (komunikacija in kultura). Ob tem avtorica poudarja, da je vsebina tista, ki določa, kaj bomo poučevali, ne jezik. Z drugimi besedami, pri CLIL-u ne gre za učenje različnih vidikov jezika, temveč za rabo jezika za razpravljanje o določeni vsebini. Ključnega pomena pa je, da je jezik, ki ga pri tem uporabljamo, učencem razumljiv in dostopen. Coyle (2005) pri tem poudarja, da glavni namen CLIL-a ni ure jezika zamenjati z drugimi predmeti, temveč omogočiti učenje jezika $\mathrm{v}$ kontekstu in $\mathrm{z}$ določenim namenom.

\section{Odprto učno okolje}

Komljanc (2010) poudarja pomen odprtega učnega okolja kot prostora za čas in izmenjavo izkušenj in interesov, saj odprt učni prostor sledi potrebam človeka (učenca in učitelja), ki skupaj z drugimi razvija kulturo bivanja in odnosov za vseživljenjsko učenje. Ključni dejavnik v odprtem učnem okolju (prav tam) je svoboda za skupno prilagajanje s pozitivno učno klimo, ki spodbuja ustvarjalnost. Učimo se drug od drugega, da bi vedeli, znali in živeli ter puščali napredne sledove za kulturni razvoj družbe. Lastnosti odprtega učenja v odprtem učnem okolju so varno raziskovanje za prilagajanje, fleksibilna organizacija pouka, bogato učno okolje, skupno načrtovanje in refleksija dela, podporne oblike sodelovanja in aktivno vključevanje $\mathrm{v}$ bivalni prostor. Vse navedene lastnosti ponujajo izkušnje za samorazvoj tako učenca kakor tudi učitelja.

Odprto učenje povezuje formalno in neformalno ter priložnostno učenje (Komljanc 2010). Tako učenje ni odvisno samo od posameznika, temveč tudi od ponudb/možnosti v danem okolju. Kot prednosti učenja v odprtem učnem okolju navaja, da učenci postanejo bolj pogumni in samozavestni pri učenju in prilagajanju v življenju. Sposobni so komunicirati z različnimi ljudmi, naučijo se samouravnavanja, timskega in individualnega dela, razvijajo raziskovalni pristop k učenju, opredeljujejo osebne (učne) cilje in 
jim znajo slediti, znajo samostojno poiskati učne vire in učno skupino za interakcijo. Vse to podpira tudi Strateški okvir za evropsko sodelovanje v izobraževanju in usposabljanju (ET 2020), ki si prizadeva za uresničitev naslednjih štirih skupnih ciljev EU: uresničevanje načela vseživljenjskega učenja in mobilnosti, izboljšanje kakovosti in učinkovitosti izobraževanja in usposabljanja, spodbujanje pravičnosti, socialne kohezije in aktivnega državljanstva, spodbujanje ustvarjalnosti in inovativnosti, vključno s podjetništvom, na vseh ravneh izobraževanja in usposabljanja.

Čezmejni prostor, ki je tudi predmet naše raziskave, je priložnost za razmišljanje o izobraževanju odprtem učnem okolju v večkulturnem in večjezičnem prostoru, ki mora biti zasnovano na poznavanju realnosti tako jezikovnega kakor tudi kulturnega okvira, $\mathrm{v}$ kateri tovrsten proces poteka, temu ustrezno pa ga je potrebno spremljati in prilagajati novejšim družbenim in zgodovinskim dogajanjem. V večjezičnem in večkulturnem čezmejnem prostoru med Slovenijo in Italijo je neizbežno po eni strani upoštevati pravico učencev izobraževati se $v$ maternem jeziku, $s$ katerim ohranjamo svoj jezik in kulturo, po drugi strani pa je potrebno tenkočutno prisluhniti drugim, sosedskim kulturam. Ker je čezmejno sodelovanje med šolami z istim in različnim učnim jezikom na meji med Italijo in Slovenijo še premalo razširjeno, smo poskušali dobro in učinkovito oblikovati skupne učne vsebine in orodja, ki bi šolske dejavnosti zbliževale in povezale $\mathrm{v}$ neko čezmejno učno enoto. Zato smo V okviru projekta EDUKA2 ${ }^{1} \check{C C e z-}^{-}$ mejno upravljanje izobraževanja oblikovali čezmejne razrede, v okviru katerih smo iskali skupne didaktične poti za šole čezmejnega območja. Želeli smo oblikovati dvojezične interdisciplinarne učne enote za spoznavanje čezmejnega prostora ter tako okrepiti čezmejno sodelovanje na področju izobraževanja.

\section{Raziskava}

$\mathrm{V}$ nadaljevanju predstavljamo rezultate akcijske raziskave, ki temelji na čezmejnem sodelovanju med šolami $z$ istim in različnim učnim jezikom na meji med Italijo in Slovenijo.

Projekt EDUKA2 je bil sofinanciran v sklopu Programa Interreg V-A Italija-Slovenija 20142020 in iz sredstev Evropskega sklada za regionalni razvoj. Vodilni partner projekta je bil Slovenski raziskovalni inštitut (SLORI), partnerji pa Inštitut za narodnostna vprašanja (INV), Societât Filologjiche Furlane, Univerza v Novi Gorici, Univerza Ca'Foscari v Benetkah in Univerza na Primorskem (Pedagoška Fakulteta). 
Izhajamo iz delovnega sklopa projekta EDUKA 2 »Čezmejni razredi«, katerega osnovno izhodišče je bilo spoznavanje čezmejnega prostora, kar je prvi korak $\mathrm{k}$ razvijanju tudi drugih dejavnosti in pobud, ki pripomorejo $\mathrm{k}$ ohranjanju in ovrednotenju čezmejnega sodelovanja. Ta oblika sodelovanja je omogočila medsebojno spoznavanje, vzpostavljanje prijateljskih vezi ter izmenjavo šolskih izkušenj tako med učenci kot med učitelji. Pri oblikovanju koncepta čezmejnih razredov smo upoštevali naslednja didaktična izhodišča in metode dela: didaktična igra, spodbudno učno okolje, izkustveno/aktivno učenje, vsebinsko in jezikovno integrirano učenje ter učenje $\mathrm{v}$ avtentičnem, odprtem učnem okolju.

\section{Vzorec}

V delovnem sklopu čezmejni razredi ${ }^{2}$, ki je bil namenjen učencem 4. in 5 . razreda osnovne šole, so sodelovale štiri šole, dve iz Slovenije in dve iz Italije, dve s slovenskim učnim jezikom in dve $\mathrm{z}$ italijanskim učnim jezikom: Osnovna šola Elvire Vatovec Prade in podružnica Sv. Anton, Osnovna šola Frana Milčinskega s Katinare (Večstopenjska šola Vladimirja Bartola Trst), Osnovna šola Pier Paolo Vergerio il Vecchio iz Kopra in Osnovna šola Edmondo de Amicis (Večstopenjska šola Giovanni Lucio) iz Milj. Čezmejni razred je štel 99 učencev, ki so se pod mentorskim vodstvom $7^{3}$ učiteljev in koordinatorice udeležili treh delavnic, in sicer v Kopru, Miljah in Strunjanu. Dejavnosti so ves čas potekale v dveh jezikih.

\section{Izvedba}

Prvi del raziskave je bil namenjen analizi stanja in ugotavljanju ustreznih didaktičnih pristopov za razvijanje medkulturnega in medjezikovnega zavedanja v čezmejnem območju v Slovenski Istri in na Tržaškem. Eden osnovnih namenov je bil vzpostaviti trajne povezave med vzgojno-izobraževalnimi zavodi s slovenskim in italijanskim učnim jezikom v Sloveniji in Italiji ter tudi s širšim urbanim okoljem in lokalnimi skupnostmi. učencem 4. in 5. razreda osnovne šole v Sloveniji in v Italiji in ga je koordinirala doc. dr. Barbara Baloh s UP Pedagoške fakultete. Drugi je bil namenjen učencem tretjega VIO v Sloveniji in učencem prvostopenjske srednje šole v Italiji. Ta sklop je vodila dr. Norina Bogatec, raziskovalka s Slovenskega raziskovalnega inštituta v Trstu. 
Tabela 8: Faze akcijske raziskave

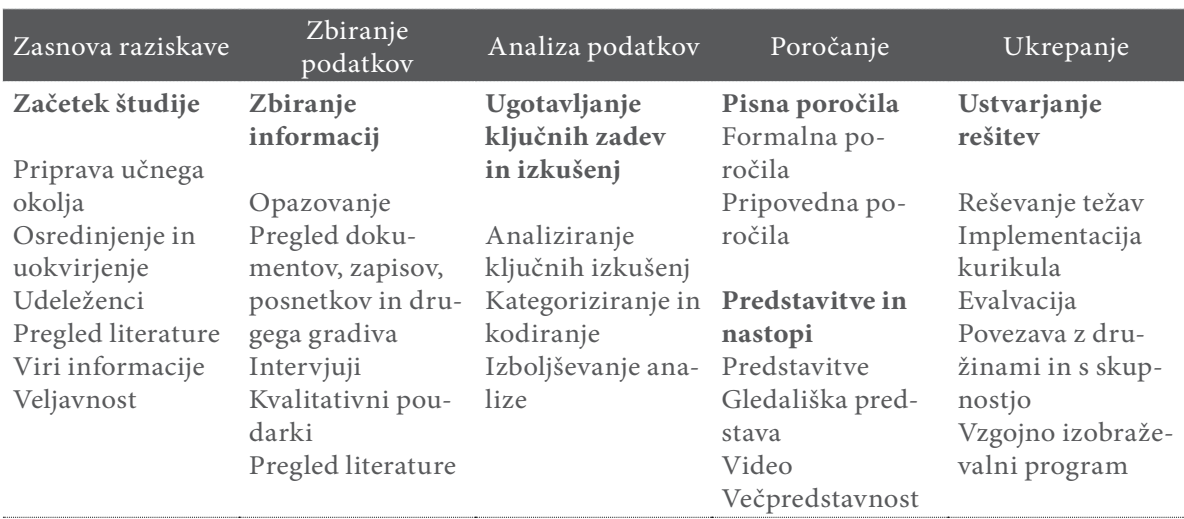

Okvirni načrt akcijske raziskave, ki smo ga oblikovali na začetku raziskovalnega procesa, smo izpopolnjevali skozi celotno raziskavo. Kot je razvidno iz Tabele 8 , smo celotno akcijsko raziskavo razgradili na posamezne uresničljive akcijske korake, pri čemer je bil vsak korak usmerjen $\mathrm{v}$ dejavnost s konkretnimi cilji. Sledili smo fazam akcijskega raziskovanja po Stringerju (2008). Število akcijskih korakov in njihovo trajanje je bilo odvisno od konkretnega raziskovalnega problema. Pri vsakem koraku smo vnaprej predvideli način, kako bomo spremljali in beležili učinke v posamezni fazi raziskave. Uporabili smo naslednje tehnike zbiranja podatkov:

- opazovanje z udeležbo,

- polstrukturirani intervjuji,

- opazovalni listi (vprašalniki z odprtimi vprašanji),

- fotografije, avdio in video posnetki,

- izdelki učiteljev (delovni listi) in otrok (likovni izdelki, fotografije, izpolnjeni delovni listi...),

- $\quad$ izjave in zgodbe/pripovedi otrok (ustne in pisne).

Dejavnosti v čezmejnem razredu so nastajale tako na delovnih srečanjih učiteljev mentorjev in vodje delovne skupine kot tudi med učenci samimi. Ugotovili so, da je tisto, kar jih druži, torej nekakšen skupni imenovalec morje, zato smo tematiko morja in obmejnega prostora skušali zajeti $\mathrm{v}$ širok obseg vsebin, od naravoslovja, družboslovja (zgodovine, geografije) do jezika. Poleg tega so učenci ugotovili, da se morajo najprej med seboj spoznati, zato se posneli kratke video predstavitve, ki so jih poslali učen- 
cem na drugi strani meje. Nato se je začelo pravo druženje v obliki skupnih delavnic. Gradivo, ki je nastalo v okviru delavnic (opis poti, didaktični scenarij in učni listi), je na voljo na spletni strani projekta www.eduka2. eu, vključno $\mathrm{z}$ interaktivno didaktično igro $\mathrm{z}$ naslovom Čezmejni valovi/Le onde transfrontaliere, kjer se učenci lahko virtualno sprehodijo po itinerarju posameznih delavnic in rešujejo didaktične naloge, povezane $z$ vsebinami projekta.

Prva delavnica v okviru čezmejnih razredov je potekala v Kopru. Začeli smo s spoznavnimi dejavnostmi in igro Burja/La bora, ki jo je čezmejna skupina učiteljev izdelala v okviru projekta EDUKA 1 - Vzgajati k različnosti. Sledil je ogled mesta Koper. Njegove kulturne in zgodovinske zanimivosti so učenci dveh šol iz Slovenije prikazali sovrstnikom iz Italije. Med ogledom so zbirali fotografije, video posnetke, podatke, zapiske, ki so jih nato oblikovali in dopolnili v okviru rednega pouka na svoji šoli. Na osnovi gradiva, ki so ga učenci ustvarili v okviru teh in nadaljnjih delavnic, je čezmejna skupina učiteljev oblikovala dvojezični učni enoti v obliki interdisciplinarne didaktične poti za spoznavanje čezmejnega prostora kot celovite in enovite geografske enote.

Druga delavnica je potekala v Miljah. Učenci iz Italije so sovrstnikom iz Slovenije prikazali kulturne in zgodovinske zanimivosti tega obmorskega mesta. Pripravili so sprejem na županstvu, ki je potekal v obeh jezikih, v slovenščini in italijanščini.

Tretja delavnica je potekala v naravnem parku Strunjanske soline. Zaradi slabega vremena smo morali delavnico nekoliko prilagoditi. Izvedli smo jo na eni izmed šol in ne v celoti v naravnem okolju, kot je bilo sprva načrtovano. Načrtovali smo sprehod po solinah in dve delavnici, proučevanje flore in favne naravnega parka s pomočjo tabličnega računalnika in dihotomnega ključa za določanje organizmov morske obale Tržaškega zaliva in likovni extempore na temo morja. Obe dejavnosti smo izvedli, vendar v računalniški učilnici in $\mathrm{v}$ večnamenskem prostoru.

\section{Rezultati in razprava}

$\mathrm{Na}$ osnovi sistematičnega opazovanja, analize opazovalnih listov in izdelkov, izjav in pripovedi otrok ter intervjujev in razgovorov $\mathrm{z}$ učitelji lahko sklenemo, da so udeleženci čezmejnih razredov prepoznali prednosti tovrstnega učenja in poučevanja. Tako učitelji kot učenci so po končanih delavnicah navajali predvsem pozitivne učinke didaktičnih dejavnosti, ki so potekale v čezmejnih razredih, saj bile primerno zahtevne za vsakega učen- 
$\mathrm{ca}, \mathrm{v}$ središče dejavnosti je bilo postavljeno učenje, ki je bilo usklajeno s cilji projekta in je temeljilo na integraciji vsebin in jezika.

Neposredni stik z okoljem je omogočil učencem, da so ga čim bolje razumeli, sprejeli in se v njem dobro počutili. Prek različnih dejavnosti (vodenega ogleda urbanih in naravnih krajev s strani učencev gostiteljev, izpolnjevanja učnih listov in tekmovanja $\mathrm{v}$ poznavanju različnih učnih vsebin med čezmejnimi skupinami) so si učenci postopoma ustvarili predstavo čezmejne regije kot celovite in enovite geografske enote, $v$ kateri se razlike in podobnosti kulturnega, jezikovnega, naravnega in arhitektonskega okolja edinstveno prepletajo, periferna območja v posamezni državi pa se postopno preoblikujejo $\mathrm{v}$ čezmejni večjezični in večkulturni prostor.

Učenci so ob koncu projekta ugotavljali, da je geografska regija, ki so jo spoznali, enovita, da so vsi kraji, ki so jih obiskali, ob morju, da imata obe mesti, tako Koper kot Milje podobno arhitekturno obliko, obe imata mandrač, ulice so enako tlakovane, stavbe so si podobne, prebivalci so prijazni, se ukvarjajo s turizmom, povezani so z ribištvom, v obeh mestih govorijo tako slovensko kot tudi italijansko. Navajali so, da so, ker so se pripravljali na vodenje sovrstnikov, tudi sami spoznali veliko novega o lastnem kraju in kulturi, bili so ponosni, da so lahko sovrstnike vodili po svojem mestu in jim hkrati pokazali tudi kaj, česar ni bilo v načrtu, recimo, kam hodijo na sladoled, na dejavnosti, v kino, kje se družijo... Nekateri so povedali, da jim je bilo težko sporazumevati se v tujem/drugem jeziku, vendar pa so te prepreke hitro in brez predsodkov premostili. Pri zgodnjem učenju/poučevanju jezika/jezikov je namreč učenčeva pozitivna izkušnja $z$ jezikom največja motivacija za nadaljnje delo in spodbuda za doseganje višje ravni znanja.

Predvsem so učenci poudarili to, da so se učili, kljub temu, da niso sedeli v učilnici, hkrati pa so izrazili ponos, da so premagali lastne strahove in nastopili pred veliko skupino sovrstnikov. Govorimo lahko torej o učnem okolju, ki prepoznava učence kot ključne udeležence in zato spodbuja njihovo aktivnost $s$ tem pa tudi razumevanje njihove lastne dejavnosti. Učinkovito učenje, ki smo ga razvili v čezmejnem razredu, ni le individualna dejavnost, temveč se dogaja $\mathrm{v}$ procesu sodelovanja, skupnega načrtovanja, skupinskega dela. Navdušenje nad tako obliko dela so pokazali tudi učitelji, ki so ugotavljali predvsem, da je pri tovrstnem učenju potrebno ponovno premisliti o lastni pedagoški praksi, pa tudi o lastnih vrednotah in oblikovati dejavnosti tako, da so otroci akterji učnega procesa, kar je bistvo sodobnega pouka. 
Na osnovi podatkov, ki smo jih zbrali v prvem delu akcijske raziskave, smo ugotovili, da so didaktični pristopi, ki smo jih načrtovali za spodbujanje medkulturnega in medjezikovnega zavedanja za udeležene v raziskavi novost in da nismo spodbujali že ustaljenih znanj ter prepričanj, zato je dejavnostim v okviru čezmejnih razredov sledilo usposabljanje drugih učiteljev, ki niso sodelovali v projektu. Izvedli smo pet delavnic na različnih lokacijah v Sloveniji in Italiji, ki so bile namenjene evalvaciji projekta in predstavitvi v projektu nastalega gradiva. Evalvacija dejavnosti, izvedenih v okviru delovnega sklopa Čezmejni razredi, je potekala v različnih oblikah. Najprej je bila izvedena evalvacija izdelanega in uporabljenega gradi$\mathrm{va}$, vključno $\mathrm{z}$ didaktično analizo po končani dejavnosti $\mathrm{z}$ didaktično igro, ki so jo na osnovi refleksije izvedli učitelji, ki so se udeležili usposabljanja v okviru projekta. Drugi del evalvacije je predstavljala refleksija učiteljev, ki so sodelovali v projektu, o izvedenih dejavnostih, in sicer v obliki predstavitev dejavnosti in didaktičnega materiala, ki je vključevala tudi povratno informacijo udeležencev (učencev in učiteljev).

Poleg omenjenih oblik evalvacije smo oblikovali tudi vprašalnik in izvedli anketo med udeleženci usposabljanja v okviru projekta (Baloh in Bratož 2019), ki je bilo namenjeno predstavitvi učnih enot za različna predmetna področja, ki omogočajo učencem, da spoznajo celovitost čezmejnega območja med Slovenijo in Italijo ter se soočijo s potrebo po zaščiti njegovega naravovarstvenega, zgodovinsko-kulturnega, umetnostnega in jezikovnega bogastva in širše predstavitvi didaktičnih izhodišč za spodbujanje učenja jezikov okolja. Osnovni namen vprašalnika je bil kritično ovrednotiti uporabnost predstavljenih vsebin in pridobiti povratno informacijo udeležencev o možnih spremembah $\mathrm{v}$ pedagoški praksi na podlagi izvedenega usposabljanja.

$\mathrm{Na}$ osnovi kritične analize oblikovanih gradiv in izvedenih dejavnosti lahko zaključimo, da didaktični koncept čezmejnih razredov sledi sodobnim didaktičnim izhodiščem in pristopom, podani pa so tudi predlogi za izboljšave, in sicer zlasti v obliki bolj sistematičnega načrtovanja razvijanja jezikovnih zmožnosti prvega jezika $v$ manjšinskih šolah in drugega jezika na dvojezičnem območju. Rezultati evalvacije usposabljanja za učitelje kažejo, da udeleženci uporabnost koncepta čezmejnih razredov vidijo zlasti v interdisciplinarnosti in medpredmetnem povezovanju in spoznavanju kulturne dediščine okolja ter podobnosti in razlik med stvarnostmi v obeh okoljih ter v učenju izven vsakdanjega šolskega konteksta. Na temelju usposabljanja, ki so se ga udeležili v okviru projekta, pa vidijo številne možnos- 
ti sprememb v svoji pedagoški praksi, kot so spodbujanje učenja v avtentičnem okolju, praktičnega, aktivnega dela $\mathrm{z}$ učenci izven šolskih prostorov, več poudarka na čezmejnih vsebinah in povezanosti med Slovenijo in Italijo, spodbujanje rabe IKT, vključno s stiki učencev na spletnih platformah in participacijo učencev, predvsem pa potrebo po izkoriščanju značilnosti okolja in ustvariti ter izvesti več medkulturnih in večjezičnih dejavnosti.

\section{Zaključek}

V prispevku smo predstavili koncept t. i. čezmejnih razredov, v okviru katerih so se učenci sorodnih šol iz obeh strani meje srečevali ter vključevali v različne učne dejavnosti. Koncept čezmejnih razredov je sodelujočim učencem omogočil boljše poznavanje in razumevanje čezmejnega okolja, v katerem živijo. Še pomembneje pa je da so učenci skozi sodelovanje z vrstniki in vključevanje $\mathrm{v}$ dejavnosti $\mathrm{v}$ okviru projekta razvili pozitivna stališča in odnose do sosedskega okolja in kulture.

Za izobraževanje $\mathrm{v}$ prihodnosti morajo raznolike potrebe učencev predstavljati učitelju, ki načrtuje in izvaja jezikovne dejavnosti, izziv, kako oblikovati učni proces, da bo vsak učenec dosegel optimalne rezultate pri razvijanju sporazumevalne zmožnosti. Pri tem je pomembno, da učenec uzavesti svojo vlogo $\mathrm{v}$ procesu učenja, $\mathrm{v}$ našem primeru medkulturnega in medjezikovnega zavedanja, učitelj pa svojo vlogo pedagoškega kulturnega posrednika, saj s svojim kulturnim kapitalom neposredno vpliva na razvoj učenčevega medkulturnega in medjezikovnega kapitala. Bešter in Medvešek (2016) poudarjata, da so izobraževalne možnosti lahko omejene, če učitelj ne upošteva etničnega, jezikovnega in kulturnega izvora sogovorca (otroka ali odrasle osebe). Nujno, je torej, da je medkulturni učitelj tudi „raziskovalno radoveden“ in proučuje lastno medkulturnost ter medkulturnost drugega, je pripravljen za pridobivanje tudi tovrstnega znanja in izkušenj.

\section{Literatura}

Agnič, Aariadna, Babšek, Renata in Udovič, Radojka. 2014. „Vrtec v gozdu in njegove skrivnosti." Zbornik zbranih povzetkov vsebin projekta Zgodnje naravoslovje temelj za trajnostni razvoj (2014): 19-23. Dostopno prek: http://www.ekosola.si/uploads/2010-o8/Zbornik2014.pdf\#page=19 (12. 12. 2019)

Baloh, Barbara. "Zgodnje učenje in poučevanje slovenščine kot J2/JT« V Doslidžennja navčannja, uredila Omelčenko, Svitlana. Slovjansk: Don- 
baskij deržavnij pedagogičnij univerzitet: Gorlivskij institut inozemniž mov, (2019): 47-64.

Baloh, Barbara in Cencič, Majda. „Učni prostor kot spodbuda inovativnega učenja sporazumevalne zmožnosti otrok v vrtcu.«V Oblikovanje inovativnih učnih, uredile Štemberger, Tina, Čotar Konrad, Sonja, Rutar, Sonja in Žakelj, Amalija. Koper: Založba Univerze na Primorskem. (2018): 267-281.

Baloh, Barbara in Bratož, Silva. »Refleksija vloge učitelja v čezmejnem prostoru." Razprave in gradivo. Revija za narodnostna vprašanja. št. 83 (2019): 5-19.

Bešter, Romana in Medvešek, Mojca. »Medkulturne kompetence učiteljev: primer poučevanja romskih učencev.» Sodobna pedagogika, št. 2 (2016): 2644 .

Boecker, M. C. »Intercultural competence - The Key Competence in the 21st Century. Bertelsmann Stiftung in fondazione Cariplo.« (2008). Dostopno prek https://www.ngobg.info/bg/documents/49/726bertelsmanninterculturalcompetences.pdf (16. 12. 2019).

Brumen, Mihaela, Kolbl Ivanjšič, Polonca in Pšunder, Mateja. »Pedagoški vidiki poučevanja nejezikovnih predmetov v tujem jeziku."Revija za elementarno izobraževanje. št. 8 (1/2) (2015): 27-42.

Byram, Michael, Gribkova, Bella in Starkey, Hugh. »Developing the Intercultural Dimension in Language Teachning. A Practical Introduction for Teachers.« Strasbourg: Council of Europe, (2002). Dostopno prek https:// rm.coe.int/168o2fc1c3 (16. 12. 2019)

Cencič, Majda, in Kuščer Perger, Marjanca. »Dejavniki učenja in sporočilnost šolskega prostora.« Sodobna pedagogika, št. 63(1) (2012: 112-124.

Coyle, Do, Hood, Philip in Marsh, David. »Content and Language Integrated Learning." Cambridge: Cambridge University Press, 2010.

Dalton-Puffer, Christiane, Nikula, Tarja in Smit, Ute. (Urednice). »Language use and language learning in CLIL classrooms (Vol. 7).« John Benjamins Publishing, 2010.

Deardorff, Darla K. »Identification and Assessment in Intercultural Competence as a Student Outcome of Internationalization. "Journal of Studies in International Education, št. 10, 3, (2006): 241-266.

Dumont, Hanna in Istance, David. »Analiziranje in oblikovanje učnih okolij za 21. Stoletje."V O naravi učenja: uporaba raziskav za navdih prakse, uredniki Dumont, Hanna, Istance, David in Benavides, Francisco. Ljubljana: Zavod Republike Slovenije za šolstvo, (2013): 23-36. 
»Evropsko sodelovanje v politiki (okvir ET 2020).«Dostopno prek https://ec.europa.eu/education/policies/european-policy-cooperation/et2020-framework_sl (22.12.2019).

Gardner, Howard. »Razsežnosti uma. Teorija o več inteligencah.« Ljubljana: Tangram, 2010.

Hus, Vlasta in Ivanuš Grmek, Milena. »Odprti pouk pri predmetu spoznavanje okolja.« Sodobna pedagogika, št. 57(2), (2006): 68-83.

Jager, Justin. »The Analysis of the Conditions Enabling a Successful Inclusion of Romani

Pupils.« V: Conference Proceedings: Hawaii International Conference on Education. Honolulu: University of Louisville, (2013): 3578-3585.

Jazbec, Saša in Lovrin, Metka. »Koncept CLIL-novost ali stalnica pri učiteljih na OŠ v Sloveniji: študija primera."Revija za elementarno izobraževanje. št. $8(1 / 2)$, (2015): 65-80.

Komljanc, Natalija. "Koncept odprtega učenja v odprtem učnem okolju.» (2010). Dostopno prek https://www.google.com/search?safe=active\&sxsr$\mathrm{f}=\mathrm{ACYBGNSb6uOpy}-9 \mathrm{tNjKxVhY31mR3kjPBwQ \% 3A1579023815298 \& -}$ source $=$ hp\&ei=x_odXoHUD8r5sAe4p 5 LAAg\&q=koncept + odprtega + u\% $4 \% 8$ Denja+v+odprtem + u\% $4 \% 8$ Dnem+okolju\&oq=Koncept+\&gs_l=psy-ab.1.o.35i39joi20319.1301.3844..5955 ..1.o..o.557.2339. oj5j4-1j2.............gws-wiz.........D12vNqG8H3Q (12. 1. 2020)

Krek, Janez in Vogrinc, Janez. „Izbrani predlogi sistemskih rešitev v šolskem sistemu z vidika socialne kohezivnosti.« V Social Cohesion in Education. Uredili Borota, Bogdana, Cotič, Mara, Hozjan, Dejan in Ljubov, Zenja Horlivka. Horlivka State Pedagogical Institute for Foreign Languages, (2011): 79-93.

Kužnik, Lea. »Interaktivno učno okolje in muzeji za otroke. Teoretski model in zasnova.« UL FF. Oddelek za etnologijo in kulturno antropologijo. Zbirka Kulturna dediščina. Zvezek 3. Ljubljana, (2009).

Marentič Požarnik, Barica. »Kako pomembna so pojmovanja znanja, učenja in poučevanja za uspeh kurikularne prenove. «Sodobna pedagogika, št. 49 (3), (1998): 244-261.

Mehisto, Peeter, Marsh, David in Frigols, Maria Jesus. „Uncovering CLIL: Content and language integrated learning in bilingual and multilingual education.« Macmillan, (2008).

Mello, Robin. »The Power of Storytelling: How Oral Narrative influences Children's Relationships in Classrooms."International Journal of education 
\& Arts, n. 2 (1), (2001). Dostopno prek http://www.ijea.org/v2n1/ (12. 12. 2019).

Oštir, Lipavic Alja, Lipovec, Alenka in Rajšp, Martina. »CLIL-orodje za izbiro nejezikovnih vsebin.«Pedagoški vidiki poučevanja nejezikovnih predmetov v tujem jeziku. Revija za elementarno izobraževanje. št. 8 (1/2), (2015): 11-27.

Plut Pregelj, Leopoldina. »Sodobna šola ostaja šola: Kaj se je spremenilo? « Sodobna pedagogika, št. 56 (1), (2005): 16-32.

Rutar, Sonja. »Večjezično učenje in poučevanje kot načelo inkluzivne prakse.» Sodobna pedagogika, št. 1, (2014): 22-37.

Stringer, Ernie. »Akcijsko raziskovanje v izobraževanju.« Ljubljana: Šola za ravnatelje. (2008)

Svet Evrope »Skupni evropski jezikovni okvir: učenje, poučevanje, ocenjevanje.« Ljubljana: Ministrstvo RS za šolstvo in šport, 2011.

Vonta, Tatjana. »Za uspešno integracijo romskih otrok v šolo je odlično komaj dovolj dobro.« Šolsko polje, 17, št. 5/6, (2006): 3-28.

Zipes, Jack. »Creative Storytelling: Building Comunity. Changing Lives.« New York/London: Routledge, 1995. 


\title{
Social factors and teacher performance evaluation in faculties
}

Nebojša Pavlović

\begin{abstract}
Introduction
The Bologna declaration has created numerous issues, but teacher performance evaluation is the most significant one. Namely, the need for job standardization in teaching required evaluating or, simply put, measuring a teacher's performance. This is because the lack of evaluation exerts a significant impact on a teacher's performance (Maksić, 2006). So, we define evaluation as a process in which teachers are analyzed, assessed, and graded according to the set criteria and standards (Robbins I Coutler, 2008; Pavlović, 2015). The Bologna Process requires an accurate assessment of a teacher's performance so as to define clear norms, standards, and procedures in teaching. This part is clear. However, the evaluation led to certain questions. How should it be carried out? Who is competent to assess teachers? How should grades be formed? How are they beneficial for teachers?
\end{abstract}

\section{Methodology}

In this qualitative research, the author collected data through interviews conducted on Google Forms. Teachers working at the five Serbian universities were asked to take part. They described the evaluation model in their faculties, and they provided suggestions on how it should look. A total of 118 participated from all five Serbian universities (from Belgrade, Novi Sad, Niš, Kragujevac, and Novi Pazar). Women accounted for $43.6 \%$ of respondents while men did for $56.4 \%$. Also, there were $24.8 \%$ of professors, $17.5 \%$ of 
associate professors, and $25.4 \%$ of lecturers. In total, $40.3 \%$ work at faculties of social sciences and humanities, $13.3 \%$ at faculties of sciences and mathematics, and $46.4 \%$ at faculties of technology. All of them had the same conditions during the interviews.

\section{Literature Overview}

There aren't many academic papers which deal with the evaluation in the higher educational institutions in Serbia. Only a few papers warn us that this issue isn't taken seriously (Mandić i Vilotijević, 1980; Vilotijević, 1992). Rarely is any information revealed by the faculties. Teachers aren't quick to talk about the evaluation, and usually it all comes down to them saying that the process isn't suitable (Janković \& Jarić, 2009: 5).

\section{Research Results}

In this part of the paper, we have singled out a number of distinctive comments from the teachers. They can serve as the basis for the further research on teacher performance evaluation. In general, comments are similar in how they judge teacher performance evaluation. We didn't change the comments as we wanted to show them as they were submitted.

All teachers mentioned that they needed the evaluation in order to better organize their lectures and adjust them to their students' needs. On the other hand, they said that the evaluation system should be better organized. Here's one belief from an associate professor:

The topic is extremely interesting. It's helpful to see that the evaluation process is taken far more seriously in elementary and high schools than in higher educational institutions. There is a more strict assessment going on in lower educational institutions. (University of $\mathrm{Niš}$ )

This is my comment: I would love clearer criteria for grading and assessing the qualities of teachers - those teaching to undergraduate, masters and $\mathrm{PhD}$ students. Also, I believe that the student evaluations of teachers should have more bearing, and they should be relevant when someone is about to get tenure. (Professor, University of Belgrade)

All teachers exhibited the desire to help improve and change the evaluation process, but it's obvious they're encountering obstacles. Some sugges- 
tions say that students should evaluate their teachers at the end of semesters, and that every grade should be public. Let's take a look at the following comment:

The evaluation should disregard the question of how appealing a subject is. In particular, this is important for those "boring" and "complicated" subjects which students have to attend, although they aren't interested in them. The way a teacher presents their subject can interest students in that topic. Furthermore, the teacher evaluation should be carried out on the final lecture. That's when fewer students are present. Besides, in their first year, students meet a small number of teachers and they evaluate only them. So, they don't have a broader picture that could help them grade a teacher as they should. Additionally, they assess how fair a teacher is without even taking the oral exam. This is why it is perhaps better for students to evaluate their teachers once they graduate. They would be more realistic in their assessments of a teacher's behavior during the exams, and it would dispel any fear they might have of giving bad grades to teachers before exams, regardless of whether the evaluation is anonymous. (Professor, University of Belgrade)

Teachers recognize different types of evaluation and they want to point out the bad sides of the process.

There are different types of the teacher evaluation. The first one was used until last year. According to it, students who attend the lecture and know the teacher are to answer questions on the sheet at the end of the semester. However, the survey is now posted online, and everyone has to respond to it. Students who only take the exam without having any contact with the teacher participate in it. This is used in lectures where there's a larger group of students and itss impossible to take note of who is present and who isn't. Therefore, this model is not good and no one takes it seriously. In contrast, the first one was much better and teachers used to take the grades and answers they received in the survey seriously. For an in-depth research, we should take into consideration the evaluation method itself. (University of Kragujevac)

An assistant professor from the University of Belgrade had a similar comment: 
The biggest issue of the evaluation is the rule that students need to fill in the form when they enroll in a new semester. They do this without giving much thought, and regardless of whether they attended the lecture or not. (University of Belgrade)

One of the most frequent complaints was aimed at the bureaucratic way of carrying out the evaluation. People often wonder whether it's possible for a teacher not to have any evaluation of their pedagogical skills. This is because most teachers haven't taught any pedagogical subject. A teacher organizes a lecture so that it resembles those they had during their time in an elementary or high school.

Since becoming a freshman (in 1972) and up until now (44 years later) no one has come to check whether my teacher or, in this case, myself is delivering a lecture. Never! Because sometimes someone doesn't do it... It seems to me that no one cares about the quality of a lecture! Not even my country that gives me a salary with which I make ends meet nor the staff that hides the real truth. The curriculum ISN'T CONNECTED WITH THE NEEDS OF THE PRACTICE. For years, people have been teaching what they want and think they should. Everyone establishes their own criteria for grading, and sometimes a person "goes crazy" after they fail an exam for the 18th time. And still nothing happens... I tried to do something with my department... they didn't even understand me, so I'm not happy with the results. (Professor, University of Belgrade)

A professor at the University of Niš shares a similar opinion. Apart from bureaucracy, she wonders whether the students are competent to evaluate their teacher. Will the grade help the teacher develop and change their approach?

The evaluation is not properly organized and doesn't make any sense. It is carried out only so that the administration can calculate the score and fill in the report about a teacher before they get an academic title (please note, there is a tendency to write the highest grade no matter what the real one is; no one comments this or checks what someone wrote in their report. No one was ever praised. No one was ever punished for getting a 1 or 2). First of all, I've witnessed students filling in the evaluation recklessly and superficially. They don't even know the teacher. They are giv- 
en the survey so that this part could be done, and, at times, they assess those who aren't their lecturers. Can students really evaluate a teacher like this?! (Professor, University of Niš)

An associate professor from Novi Sad was harsher when it comes to teacher performance evaluation done by students:

My comment is the following: teacher performance evaluation is a nonsense. The sudents are both the judges and the jury. The more lenient you are, the better you appear in their eyes. And the evaluation through the use of SCI form is reckless because a scientist doesn't need to be a good teacher. But this is complicated and should be examined in several dissertations until one finds adequate indicators. (Associate professor, University of Novi Sad)

A higher number of teachers (54.6\%) concluded that an anonymous survey of students was good and necessary. However, they said that certain rules should be introduced:

I think it's good for students to evaluate the work of a teacher, regardless of whether they are competent for that or not. With this in mind, we should select the right questions in the survey. We use a unique survey as ordered by the University of Belgrade, and I wonder whether we should change the questions which are aimed at certain faculties. And one more thing, we should compare the different surveys at the universities and the grades of teachers there. One question that we tend to ask ourselves is how many students should respond to the survey so that it could be valid. Undergraduate studies have larger groups, but masterss programs and vocational subjects (especially elective courses which are taught if at least 5 students enroll) make us wonder whether the survey is valid. (Professor, University of Belgrade)

A certain number of teachers (10.8\%) didn't want anonymous surveys:

Teacher performance evaluation is a good thing. It should and has to exist. In my faculty, students evaluate teachers and the survey is anonymous. I think that it shouldn't be anonymous because why would it be if everything is fair and square? I'm saying this because many teachers are scared to ask a student to leave their exam or sanction them because they use certain resources to pass the exam. They also fear to do anything when a student obstructs 
the lecture, as well as when they come drunk or are rude. Teachers and assistants are scared of the grade because a lower one could mean that they won't get their contracts extended." (University of Belgrade)

\section{Conclusion}

Evaluation is a popular idea. Thinking that only teacher performance evaluation would solve the issue is wrong. We can conclude that this evaluation is one of the weakest parts of the Bologna declaration. Almost all teachers commented on the evaluation process in a negative manner. More than half of the teachers said that the present evaluation model has no significance and that it isn't useful for them. But no one has a concrete suggestion on how that model should look.

\section{Literature}

Janković, Ana and Isidora Jarić. Uslovi rada nastavnog osoblja na univerzitetu u Beogradu: evaluacija rada nastavnika, Filozofija I društvo, 2009.

Maksić, Slavica. Podsticanje kreativnosti u školi, IPI Beograd, 2006.

Mandić, Petar and Mladen Vilotijevič. Vrednovanje rada u školi, Sarajevo: Svjetlost, 1980.

Pavlović, N. Nove uloge menadžmenta ljudskih resursa, Djura Jakšić, Rača, 2015.

Robbins, Stephen and Mary Coutler. Management, Datastatus, Beograd, 2008. Vilotijević, M. Vrednovanje pedagoškog rada u školi, Beograd: Naučna knjiga, 1992. 


\section{profesionalni razvoj pedagoških delavcev}





\section{Zaznave učiteljev začetnikov o svojih mentorjih in sodelovanju $\mathrm{z}$ njimi}

Maja Šebjanič Oražem

\section{Uvod}

\section{Poklicna identiteta}

Poklicna identiteta je sestavina celotne posameznikove identitete, ki nastaja in se oblikuje ob vključitvi v delo in procese dela. Ob tem je posameznik soočen $\mathrm{z}$ dvema procesoma:

- posameznik mora doseči prepoznanje institucije in posameznikov, s katerimi vstopa v interakcijo;

- identiteto mora ponotranjiti (Muršak idr., 2011).

»Poklicna identiteta torej izvira iz posameznikovih dejavnosti in socialnih odnosov med različnimi akterji.« (Muršak idr., 2011: 21, po Autret, 2009) Pri oblikovanju poklicne identitete posameznik prilagaja in ustrezno zunanjim pogojem (tj. razumevanju skupine in doseganju rezultatov) oblikuje lastno predstavo o sebi, samointerpretacijo. Gre za proces t. i. konverzije, v okviru katerega mora posameznik ustrezno izoblikovati takšno vizijo sebe in sveta, ki mu omogoča sprejem vloge in opravljanje dela, dejavnosti ali poklica. Posameznik spremeni sebe in ponotranji ideje »na štirih področjih:

- $\quad$ kaj in kako posameznik razume svoje delo;

- $\quad$ kaj bi morala biti njegova vloga;

- kakšna je ustrezna in zaželena kariera glede na prvi dve točki; in 
- $\quad$ kakšen naj bi v resnici bil sam kot nosilec poklica« (Muršak idr., 2011: 21).

$\mathrm{V}$ procesu identifikacije se posameznik uskladi s pričakovanji svoje socialno-poklicne referenčne skupine, kar pripelje do občutka pripadnosti s ponotranjanjem norm in legitimnih modelov te referenčne skupine. Referenčna skupina je v učiteljskem poklicu videna kot skupnost, »ki je socialno homogena in integrirana, $\mathrm{z}$ močno stopnjo identifikacije med člani, kar omogoča tudi stabilne socialne odnose. Posameznik doživlja sebe kot del celote, socialnega korpusa, ki mu pripada in od katerega tudi pričakuje ustrezno socialno podporo in zaščito« (ibid.: 22).

Ob vsem tem se dogaja še proces simbolne vključitve posameznika v skupino oz. t. i. iniciacije, saj ni dovolj le, da posameznik spozna in se nauči opravljati določeno delo in se z njim tako ali drugače poistoveti, ponotranji norme in načine vedenja. Posameznik mora biti tudi ustrezno iniciiran, bolj ali manj formalno vpeljan v družbeno vlogo, priznan kot predstavnik te vloge/poklica v očeh sodelavcev pa tudi v očeh drugih članov skupnosti. Ključno vlogo pri tem ima obdobje prehoda iz šolanja v zaposlitev (ibid.) oz. v učiteljskem poklicu obdobje uvajanja v pedagoški poklic.

\section{Oblikovanje poklicne identitete učitelja}

Poklicna identiteta učitelja »vsebuje učiteljevo znanje o sebi v različnih pedagoških situacijah in z njimi povezanimi socialnih odnosih" (Razdevšek Pučko in Juriševič, 2010: 13), oblikuje se »v različnih fazah in je nepretrgan proces, ki se začne že pred neposrednim vstopom ali začetkom dela na določenem poklicnem področju « (Muršak idr., 2011: 24). Gre za prvo obdobje oblikovanja poklicne identitete oz. t. i. vnaprejšnjo ali anticipatorno poklicno socializacijo. Proces vnaprejšnje identifikacije s poklicno vlogo je pomemben, saj že ob vstopu v poklic vnaprej zaznamuje posameznikov poklicni razvoj. V učiteljskem poklicu je vnaprejšnja socializacija v veliki meri vodena v okviru dodiplomskega izobraževanja, ki v okviru pedagoške pra$\mathrm{kse}^{\mathrm{I}}$ omogoča bodočim učiteljem (bolj kot pripravo na delo) pridobivanje izkušenj in srečevanje s člani poklicne skupine, ki ji bodo bodoči učitelji pripadali. »Kolikor bolj so te izkušnje in socialni stiki reflektirani in kolikor več je priložnosti, da si prihodnji učitelji take izkušnje pridobijo, toliko manjši bo vstopni šok oz. toliko manjša bo stopnja vstopne frustracije, ki nastane, ko posameznik vstopi v referenčno skupino in proces konverzije, 
ki je pogoj oblikovanja njegove identitete. Napetost, ki nastane med (vnaprejšnjo) podobo, predstavo o učitelju in dejansko (prvo) izkušnjo, bo tem manjša, kolikor bolj bomo prihodnjega učitelja že pred samostojnim vstopom $\mathrm{v}$ razred opremili $\mathrm{z}$ ustreznimi izkušnjami in vplivali na njegovo samorazumevanje.« (ibid.: 25)

Drugo obdobje pri oblikovanju poklicne identitete učitelja predstavlja začetek pedagoškega dela posameznika oz. obdobje uvajanja $\mathrm{v}$ pedagoški poklic. »To je obdobje, ko lahko s sistemom stalnega strokovnega izpopolnjevanja podpiramo in nadgrajujemo učiteljev strokovni razvoj« (prav tam: 130) na področju (temeljnih) strokovnih kompetenc in splošnih pedagoških kompetenc. V tem obdobju stroka loči tri faze (Muršak idr., 2011: 131):

- $\quad$ vstop v poklicno kulturo - začne se lahko že v času šolanja in vodenega uvajanja $\mathrm{v}$ pedagoški poklic (prvega srečanja s poklicnim delom, $\mathrm{z}$ realno referenčno skupino, pogoji, vrednotami in normami), ki ga spremlja vse večja identifikacija s poklicno vlogo;

- umestitev in soočenje $-\mathrm{z}$ razhajanjem med idealnim, zamišljenim modelom in stvarnim, dejanskim modelom, poleg referenčne skupine dobi posameznik tudi povratno informacijo o sebi in svoji vlogi;

- končna konverzija ali ponotranjenje poklicne vloge - pomeni interiorizacijo pravil, norm, vzorcev vedenja, načinov delovanja in pedagoške komunikacije, ustalitev modelov ravnanja, samorazumevanja in samoreprezentacije.

Gre torej za kontinuiran in progresiven proces $\mathrm{v}$ razvoju poklicnega življenja učitelja. Poklicna identiteta kot taka pomeni postopno oblikovanje oziroma konstrukcija znanja, ki ga učitelj ustvarja o sebi (Razdevšek Pučko in Juriševič, 2010) med uvajanjem v pedagoški poklic.

\section{Dejavniki, ki vplivajo na poklicno identiteto učitelja}

C. Razdevšek Pučko in M. Juriševič (2010: 14) po Stoutu (2001) povzemata tri skupine dejavnikov, ki vplivajo na poklicno identiteto učitelja:

- $\quad$ »učiteljevi dinamični odnosi z drugimi, še posebej znotraj referenčne skupine;

- spremembe in kulturna raznovrstnost šol in 
- $\quad$ inovacije in različni reformni posegi v šolo, ki vplivajo na naravo izobraževalnega okolja (na primer uporaba novih tehnologij, novi učni načrti)«.

Kot izjemno pomemben oziroma najmočnejši dejavnik, ki vpliva na razvoj poklicne identitete učitelja, avtorici (Ko Smith v Razdevšek Pučko in Juričevič, 2010) navajata opazovanje šolske prakse ter prvo leto poučevanja in intenzivnost teh izkušenj. Zaradi tega je izjemno pomembno ozavestiti in utrditi poklicno naravnanost $\mathrm{v}$ prvih letih študija, ko so bodoči učitelji najbolj občutljivi in dovzetni za pragmatične nasvete izkušenih učiteljev.

\section{Profesionalni razvoj učitelja začetnika}

Profesionalni razvoj učitelja je proces pomembnega vseživljenjskega učenja, ki vključuje učiteljevo osebno, poklicno in socialno dimenzijo. Pomeni učiteljevo napredovanje $\mathrm{v}$ smeri kritičnega, neodvisnega in odgovornega odločanja in ravnanja (Javornik Krečič, 2008: 16; Valenčič Zuljan, 2001: 127). Kontinuiran profesionalni razvoj učitelja se začne že z izobraževanjem na fakulteti, najintenzivnejši pa postane $\mathrm{z}$ vstopom $\mathrm{v}$ poklic oz. $\mathrm{z}$ uvajanjem v delo. Če učitelj prepozna pomembnost profesionalnega razvoja že v obdobju uvajanja v pedagoški poklic, nadaljuje s stalnim strokovnim izpopolnjevanjem in nadaljnjim izobraževanjem (Zelena knjiga ..., 2001: 15).

Uvajanje v pedagoški poklic (pripravništvo) je torej prvo obdobje v profesionalnem oz. strokovnem razvoju učitelja in je najbolj občutljivo in odločilno v učiteljevi (poklicni) socializaciji (Javornik Krečič 20o8: 38) ter hkrati pomemben dejavnik profesionalnega razvoja učitelja začetnika, saj kontekst uvajanja $\mathrm{v}$ poklic in kakovost mentorja vplivata na napredovanje in profesionalni razvoj učitelja začetnika (Valenčič Zuljan idr., 2007a: 8-9).

\section{Mentor}

Mentor kot eden najpomembnejših dejavnikov uvajanja začetnika $\mathrm{v}$ pedagoški poklic je zaupanja vreden vodja ali prijatelj ter pozitiven vzornik (Mass Mentoring Partnership, 2013). Je oseba, ki začetnika vodi, usmerja, spodbuja, mu daje naloge, ga postavlja pred nove izzive in mu organizira možnost za pridobivanje izkušenj ter svetuje v delovnih situacijah (Koki, 1997). Po drugi strani mu tudi pomaga, olajša delo in učenje ter ga varuje pred napakami in drugimi posledicami neizkušenosti (Valenčič Zuljan idr., 2007a: 11; Valenčič Zuljan idr., 2007b: 125) ter je model poučevanja (Puklek Levpušček, 2007: 50). 
Mentor s svojo vlogo najbolj neposredno vpliva na razvoj bodočega učitelja in mora služiti kot (zgleden) model učiteljeve vloge v izobraževanju (Javornik Krečič, 2008; Koki, 1997; Rebolj 2006). Za svoje delo oz. uspešno opravljanje te pomembne vloge potrebuje ustrezno znanje in usposobljenost za svoje delo (poučevanje) ter ustrezne sposobnosti oz. kompetence za opravljanje vloge mentorja (Muršak idr., 2011: 49; Rebolj, 2006: 166; Valenčič Zuljan idr., 2011: 44).

\section{Značilnosti mentorja}

Mentor naj bi svojega varovanca (učitelja začetnika/pripravnika) spodbujal, se $z$ njim pogovarjal, ga usmerjal, sistematično opazoval in analiziral njegovo delo ter mu posredoval konstruktivno povratno informacijo o svojih opažanjih ipd. (Muršak idr., 2011: 51; Rebolj, 2006: 165; Valenčič Zuljan idr., 2007a: 11-12). Odgovoren je tudi za socializacijo mentoriranca v delovno okolje, organizacijo oz. šolo in poklic (Mullen, 2012: 7) in je viden kot udeleženec, čigar izkušnje, opazovanja in interpretacije so visoko cenjene ter pomagajo drugim razumeti razmerje med poučevanjem in učenjem (Parker-Katz in Bay, 2008: 1260).

\section{Naloge mentorja}

Mentor (v Sloveniji) po Pravilniku o pripravništvu strokovnih delavcev na področju vzgoje in izobraževanja (19. člen) opravlja naslednje naloge:

- $\quad$ "pripravi program pripravništva;

- $\quad$ svetuje pripravniku pri izvajanju nalog, ki jih mora izvesti v skladu s programom;

- $\quad$ sodeluje z ravnateljem vrtca oziroma šole, šolsko svetovalno službo, ustreznimi strokovnimi aktivi in drugimi strokovnimi organi vrtca oziroma šole, pri organizaciji in izvedbi nalog programa pripravništva;

- $\quad$ svetuje pripravniku pri načrtovanju, organizaciji in izvedbi praktičnih nastopov oziroma drugih oblik neposrednega vzgojno-izobraževalnega dela, ki ga spremlja in analizira ter pripravniku sproti posreduje povratne informacije;

- $\quad$ spremlja pripravnikove priprave in njegov dnevnik glede na potek izvedbe ostalih delov programa pripravništva; 
- izdela poročilo o pripravnikovi usposobljenosti za samostojno opravljanje dela in pripravi oceno praktičnih nastopov, ki jih pripravnik uveljavlja za pristop k strokovnemu izpitu v skladu s pravilnikom, ki ureja strokovni izpit na področju vzgoje in izobraževanja;

- ob zaključku pripravništva $\mathrm{v}$ sodelovanju $\mathrm{z}$ ravnateljem poroča o spremljavi pripravništva;

- $\quad$ opravlja druge naloge, povezane s programom pripravništva.«

\section{Vloge mentorja v obdobju uvajanja v pedagoški poklic}

Iz nalog, ki jih ima mentor, njegovih (osebnostnih) značilnosti in kompetenc izhaja naslednjih šest vlog mentorja: model, informator, svetovalec, ocenjevalec, organizator in povezovalec (Muršak idr., 2011: 52; Rebolj, 2006: 167).

Mentorjeva vloga modela se nanaša na kakovosten prikaz načina poučevanja, ki naj bi bilo čim bolj raznoliko in inovativno.

Kot informator bi moral mentor pripravnika informirati o učencih, razredih, šoli, kolektivu, izboru učnih metod in pripomočkov, o formalnih in neformalnih normah ter pričakovanjih.

Svojo vlogo svetovalca naj bi mentor izpolnjeval med pripravo učnih ur, zlasti pa po opravljenih nastopih s kakovostno povratno informacijo preko natančne analize.

Vloga mentorja kot ocenjevalca se nanaša tako na opravljene nastope kot tudi na uvajanje pripravnika v kriterije samoocenjevanja.

Kot organizator mentor svojemu mentorirancu pripravi program pripravništva in mu časovno ter organizacijsko razporeja njegove dejavnosti in obveznosti.

Mentor bi moral biti tudi povezovalec po eni strani praktičnih izkušenj s teoretičnim znanjem, po drugi strani pa povezovalec med pripravnikom in šolskim kolektivom, da bi se njegov mentoriranec čim bolje vključil v šolsko okolje (Rebolj, 20o6: 167, po Marentič Požarnik, 1989). 


\section{Metoda}

$\mathrm{V}$ proučevanje uresničevanja ciljev uvajanja učitelja začetnika ${ }^{2} \mathrm{v}$ pedagoški poklic z vidika oblikovanja poklicne identitete učitelja slovenščine je bil usmerjen del raziskave na temo Vloga obdobja pripravništva pri pridobivanju kompetenc za poučevanje slovenščine. Raziskava je potekala v okviru doktorskega študija (na FF UL, pod mentorstvom red. prof. dr. Bože Krakar Vogel). V raziskavi je sodelovalo 72 učiteljev začetnikov in 60 mentorjev učiteljem začetnikom.

Od 72 anketiranih pripravnikov jih je 51 (70,8 \%) opravljalo volontersko pripravništvo, $21(29,2 \%)$ pa so ga imeli plačanega. Dobra polovica anketiranih (44 oziroma 61,1 \%) je pripravništvo opravljala v osnovni šoli, dobra četrtina (20 oziroma 27,8 \%) pa v gimnaziji. Po štirje anketirani $(5,6 \%)$ so pripravništvo opravljali v poklicni ali strokovni šoli oziroma srednji tehniški šoli.

Kot inštrument za raziskovanje smo uporabili anketni vprašalnik, ki smo ga za namene raziskave na podlagi strokovne in znanstvene literature o kompetencah učitelja slovenščine sestavili s pomočjo mentorice. Sestavili smo dva različna anketna vprašalnika - enega za učitelje začetnike/pripravnike in enega za njihove mentorje. Raziskava pa je zajemala tudi analizo sistemskih aktov in ostalih predpisov s področja uvajanja $v$ pedagoški poklic, tj. pripravništva.

Ob raziskovanju omenjene teme smo se osredotočili zlasti na proces mentoriranja, ki je ključen pri oblikovanju poklicne identitete učitelja začetnika, in si v ta namen zastavili naslednja raziskovalna vprašanja:

- Kakšna so bila njihova začetna pričakovanja do mentorja?

- Kako pripravniki ocenjujejo njihovo sodelovanje z mentorjem?

- Kako pripravniki ocenjujejo usposobljenost svojega mentorja za opravljanje ključnih nalog, ki jih imajo mentorji v času uvajanja učitelja začetnika $v$ pedagoški poklic (mentor kot model, vključevalec $\mathrm{v}$ šolsko kulturo, sponzor, podpornik in izobraževalec)?

- Kako ocenjujejo mentorjeve profesionalne kompetence?

2 V naši raziskavi smo jih imenovali pripravniki, saj je takrat veljavna slovenska zakonodaja učitelja začetnika, ki po zaključenem univerzitetnem izobraževanju vstopa v pedagoški poklic pod vodstvom usposobljenega učitelja praktika (pripravniškega mentorja), imenovala $\mathrm{z}$ izrazom pripravnik. V prispevku smo terminologijo poenotili s strokovno literaturo in pripravnika imenujemo učitelj začetnik. 
Ob tem smo na podlagi analize strokovne literature in predhodne raziskave (glej Šebjanič 2014) predpostavljali naslednje:

- Učitelji začetniki so od mentorja pričakovali, da jim bo mentor pomagal pri spoznavanju dela učitelja slovenščine in jih opozoril na "pasti« oziroma težave pri poučevanju.

- Učitelji začetniki sodelovanje z mentorjem ocenjujejo kot dobro.

- Mentorjevo usposobljenost za opravljanje nalog mentorja učitelji začetniki ocenjujejo kot dobro.

- Učitelji začetniki mentorjeve profesionalne kompetence ocenjujejo kot odlične.

\section{Rezultati}

\section{Učitelji začetniki o pričakovanjih in sodelovanju z mentorjem}

K oblikovanju poklicne identitete učitelja začetnika pomembno prispevajo pričakovanja učiteljev začetnikov do mentorjev in ocena njihovega sodelovanja $\mathrm{z}$ mentorjem. V Tabeli 9 so prikazana njihova pričakovanja, pri čemer so anketiranci imeli pri odgovarjanju na vprašanja na voljo več izbir.

Tabela 9: Začetna pričakovanja učiteljev začetnikov do mentorja

Pričakoval sem, da mi bo mentor pomagal pri spoznavanju šole, učencev in kolektiva.

Pričakoval sem, da mi bo mentor pomagal pri spoznavanju dela učitelja slovenščine.

Pričakoval sem, da mi bo mentor pomagal pri načrtovanju pouka oziroma nastopov.

$17 \quad 14,4$

Pričakoval sem, da bo mentor $\mathrm{z}$ mano delil svoje izkušnje.

Pričakoval sem, da me bo mentor opozoril na "pasti« oziroma težave pri poučevanju.

Pričakoval sem, da mi bo mentor svetoval pri izbiri strokovne literature.

1311,0

Drugo:

Šolo sem poznal, ker sem jo obiskoval in je v mojem domačem kraju. Mentor je bil tudi moj učitelj.

Pričakoval sem, da bo mentor bolj prijatelj.

*Zaradi zaokroževanja vsota strukturnih odstotkov ni ıoo,o, ampak 99,9. 
24 učiteljev začetnikov (20,3 \%) je od svojega mentorja pričakovalo, da jim bo pomagal pri spoznavanju dela učitelja slovenščine, nekoliko manj (22 oziroma 18,6 \%) pa jih je pričakovalo, da bo mentor z njimi delil svoje izkušnje oziroma da jih bo opozoril na težave pri poučevanju, torej jim na nek način prihranil negativne izkušnje. Da jim bo mentor pomagal pri spoznavanju šole, učencev in kolektiva, je pričakovalo 18 anketiranih učiteljev začetnikov (15,3\%). S 17 (14,4 \%) odgovori sledi pričakovanje anketirancev, da jim bo mentor pomagal pri načrtovanju pouka oziroma nastopov, $s$ $13(11,0 \%)$ pa, da jim bo mentor svetoval pri izbiri strokovne literature. Pod drugo sta $2(1,7 \%)$ anketiranca odgovorila, da sta pričakovala, da jima bo mentor bolj prijatelj oziroma da je šolo poznal, saj jo je obiskoval in je v njegovem domačem kraju, mentor pa je bil njegov učitelj.

$\mathrm{Na}$ podlagi prikazanih rezultatov lahko domnevo, da so učitelji začetniki od mentorja pričakovali, da jim bo pomagal pri spoznavanju dela učitelja slovenščine in da jih bo opozoril na "pasti« oziroma težave pri poučevanju, potrdimo, saj sta ta dva odgovora najpogostejša, poleg njiju pa je drugi najpogostejši še odgovor »Pričakoval sem, da bo mentor z mano delil svoje izkušnje«. Podobna pričakovanja do mentorja so navedli tudi učitelji začetniki v prej omenjeni raziskavi M. Valenčič Zuljan idr., in sicer so izpostavili pomen mentorjeve pomoči (zlasti strokovne pri opravljanju pripravništva, svetovanje, uvedbo v poklic in seznanitev z delom), kot na primer skupno načrtovanje in analiza nastopov, opozarjanje na napake, posredovanje praktičnih nasvetov in izkušenj, pomoč pri iskanju literature in podobno (2006: 142).

\section{Tabela ı: Ocena sodelovanja z mentorjem}

\begin{tabular}{lcc}
\multicolumn{1}{l}{ Ocena sodelovanja } & $\mathrm{f}$ & $\mathrm{f} \%$ \\
\hline Odlično. & 14 & 19,4 \\
\hline Dobro. & 13 & 18,1 \\
\hline Slabo. & 3 & 4,2 \\
\hline Brez odgovora & 42 & 58,3 \\
\hline Skupaj & 72 & 100,0 \\
\hline
\end{tabular}

Anketirani učitelji začetniki so svoje sodelovanje $\mathrm{z}$ mentorjem ocenili kot odlično (14 oziroma 19,4\%) oziroma dobro (13 oziroma 18,1 \%). Le 3 pri- 
pravniki (4,2 \%) so sodelovanje $\mathrm{z}$ mentorjem ocenili kot slabo. Na to vprašanje več kot polovica anketiranih (42 oziroma 58,3 \%) ni odgovorila, tako da je ocena sodelovanja $\mathrm{z}$ mentorjem nekoliko pomanjkljiva. Zaradi tega standardnega odklona nismo računali.

Našo domnevo, da učitelji začetniki njihovo sodelovanje $\mathrm{z}$ mentorjem ocenjujejo kot dobro, lahko torej z manjšim zadržkom potrdimo, saj so pripravniki v povprečju ocenili njihovo sodelovanje $\mathrm{z}$ mentorjem odlično/dobro. Takšen rezultat je spodbuden, saj tudi stroka (na primer Mullen, 2012, Valenčič Zuljan idr., 2007a) izpostavlja pomen kakovostnega medosebnega odnosa med mentorjem in mentorirancem, ki naj vključuje zaupanje in spoštovanje (primer Mass Mentoring Partnership, 2013).

\section{Učitelji začetniki o usposobljenosti mentorja za opravljanje nalog mentorja}

Učitelje začetnike smo povprašali tudi, kako ocenjujejo usposobljenost mentorja za opravljanje nalog mentorja, torej mentorja kot modela, vključevalca v šolsko kulturo, sponzorja, podpornika in izobraževalca. Njihove ocene so prikazane v Tabeli 11.

\section{Tabela II: Ocena usposobljenosti mentorja za opravljanje nalog mentorja}

\begin{tabular}{lcc}
\hline \multicolumn{1}{l}{ Ocena usposobljenosti mentorja } & $\mathrm{f}$ & $\mathrm{f} \%$ \\
\hline Odlično. & 16 & 22,2 \\
\hline Dobro. & 9 & 12,5 \\
\hline Slabo. & 4 & 5,6 \\
\hline Brez odgovora & 43 & 59,7 \\
\hline Skupaj & 72 & 100,0
\end{tabular}

Med ocenami anketiranih učiteljev začetnikov glede usposobljenosti mentorja za opravljanje ključnih nalog in vlog mentorja učitelju začetniku prevladuje odlična (16 oziroma $22,2 \%$ ) oziroma dobra ( 9 oziroma $12,5 \%$ ) ocena, 4 učitelji začetniki $(5,6 \%)$ pa so jo ocenili kot slabo. Tudi na to vprašanje večina učiteljev začetnikov (43 oziroma 59,7 \%) ni odgovorila, zato je tudi ta ocena pomanjkljiva in zaradi tega tudi standardnega odklona nismo računali. 
Našo predpostavko, da učitelji začetniki usposobljenost svojega mentorja za opravljanje ključnih nalog, ki jih imajo mentorji v času pripravništva, ocenjujejo z oceno dobro, lahko potrdimo z zadržkom, saj na vprašanje dobra polovica anketiranih v vzorcu ni odgovorila. Naši rezultati so podobni rezultatom raziskave $M$. Valenčič Zuljan idr., ki je ugotovila, da »so po mnenju pripravnikov mentorji v povprečju dobro usposobljeni za posamezne naloge, ki jih imajo v času mentorstva pripravniku« (2007b: 55 ). Podobno pa je ugotovila še ena slovenska raziskava (Javrh, 2007), in sicer so učitelji novinci navedli, da so imeli dobrega mentorja, ki jih je uvajal v poklic in spretnosti, ki jih med formalnim izobraževanjem niso mogli pridobiti.

\section{Učitelji začetniki o mentorjevi profesionalni kompetenci za poučevanje slovenščine}

Mentor je učitelju začetniku model poučevanja, zato mora imeti poleg sposobnosti za opravljanje vloge mentorja, razvite tudi ustrezne strokovne kompetence. Učitelji začetniki so ocenili tudi mentorjeve profesionalne kompetence. Njihove ocene posameznih vrst kompetenc so prikazane v Tabeli 12.

Tabela ı2: Ocena mentorjeve profesionalne kompetence

\begin{tabular}{|c|c|c|c|c|c|c|c|c|}
\hline \multirow{3}{*}{ Vrsta kompetence } & \multicolumn{6}{|c|}{ Ocena kompetence } & \multicolumn{2}{|c|}{ Skupaj } \\
\hline & \multicolumn{2}{|c|}{ Odlično } & \multicolumn{2}{|c|}{ Dobro } & \multicolumn{2}{|c|}{ Slabo } & \multirow{2}{*}{$\mathrm{f}$} & \multirow{2}{*}{$\mathrm{f} \%$} \\
\hline & f & $\mathrm{f} \%$ & $\mathrm{f}$ & $\mathrm{f} \%$ & $\mathrm{f}$ & $\mathrm{f} \%$ & & \\
\hline Literarnostrokovna kompetenca. & 22 & 73,3 & 7 & 23,3 & 1 & 3,3 & 30 & $100,0^{*}$ \\
\hline Jezikoslovna kompetenca. & 19 & 63,3 & 10 & 33,3 & 1 & 3,3 & 30 & $100,0^{*}$ \\
\hline $\begin{array}{l}\text { Splošna pedagoška kompetenca } \\
\text { za organizacijo in vodenje pouka. }\end{array}$ & 21 & 70,0 & 7 & 23,3 & 2 & 6,7 & 30 & 100,0 \\
\hline $\begin{array}{l}\text { Jezikovnodidaktična kompeten- } \\
\text { ca za poučevanje jezika. }\end{array}$ & 18 & 60,0 & 11 & 36,7 & 1 & 3,3 & 30 & 100,0 \\
\hline $\begin{array}{l}\text { Književnodidaktična kompeten- } \\
\text { ca za poučevanje književnosti. }\end{array}$ & 21 & 70,0 & 8 & 26,7 & 1 & 3,3 & 30 & 100,0 \\
\hline $\begin{array}{l}\text { Kompetenca za razvijanje ključ- } \\
\text { nih zmožnosti. }\end{array}$ & 19 & 63,3 & 8 & 26,7 & 3 & 10,0 & 30 & 100,0 \\
\hline
\end{tabular}

*Zaradi zaokroževanja vsota strukturnih odstotkov ni ıoo,o, ampak 99,9.

Od 72 anketiranih učiteljev začetnikov je mentorjeve profesionalne kompetence ocenilo le $30(41,7 \%)$ anketirancev. Od teh je mentorjevo literarnostrokovno kompetenco slabe tri četrtine učiteljev začetnikov (22 ozi- 
roma $73,3 \%)$ ocenilo kot odlično, $7(23,3 \%)$ dobro in $1(3,3 \%)$ kot slabo. Jezikoslovno kompetenco jih je 19 (63,3\%) ocenilo odlično, 10 (33,3 \%) dobro in $1(3,1 \%)$ slabo. 21 anketirancev (70,0 \%) je splošno pedagoško kompetenco mentorjev za organizacijo in vodenje pouka ocenilo kot odlično, 7 (23,3 $\%)$ dobro in $2(6,7 \%)$ slabo. Kot odlično je jezikovnodidaktično kompetenco mentorjev za poučevanje jezika ocenilo 18 učiteljev začetnikov (6o,o \%), kot dobro $11(36,7 \%)$ in kot slabo 1 (3,3 \%). Tudi književnodidaktično kompetenco mentorjev za poučevanje književnosti je kar 21 anketiranih učiteljev začetnikov (7o,o \%) ocenilo odlično, 8 (26,7 \%) dobro in 1 (3,3\%) slabo. Mentorjevo kompetenco za razvijanje ključnih zmožnosti jo je $\mathrm{z}$ odlično oceno ocenilo 19 (63,3\%), z dobro $8(16,7 \%)$ in slabo 3 učitelji začetniki (10,o $\%)$.

$S$ pomočjo prikazanih rezultatov lahko našo domnevo, da učitelji začetniki mentorjeve profesionalne kompetence ocenjujejo kot odlične, zaradi nizkega odstotka odgovorov potrdimo $\mathrm{z}$ manjšim zadržkom. V povprečju so učitelji začetniki vse profesionalne kompetence mentorjev ocenili $\mathrm{z}$ odlično oceno, $\mathrm{z}$ najvišjim odstotkom odličnih ocen literarnostrokovno kompetenco, ki ji sledita splošna pedagoška kompetenca za organizacijo in vodenje pouka ter književnodidaktična kompetenca za poučevanje književnosti.

\section{Sklep}

V procesu oblikovanja poklicne identitete učitelja začetnika je bistvenega pomena ustrezna socialna podpora, ki so je deležni zlasti od svojih mentorjev, in njihov dinamičen odnos znotraj referenčne skupine, ki jo prav tako predstavlja mentor. Stroka velik vpliv pripisuje še opazovanju šolske prakse, torej poučevanju mentorja, in izkušnje v prvem letu poučevanja, ki ga predstavlja ravno obdobje uvajanja $\mathrm{v}$ pedagoški poklic (pripravništva).

Učitelji začetniki so $\mathrm{v}$ raziskavi njihov odnos $\mathrm{z}$ mentorjem ocenili kot dober in prav tako mentorje ocenjujejo kot kompetentne za opravljanje nalog mentorja. Njihova začetna pričakovanja do mentorja so se nanašala zlasti na delo učitelja slovenščine, torej didaktično izvedbo pouka, težave pri poučevanju in deljenje (poučevalnih) izkušenj nasploh. So pa učitelji začetniki na splošno videli mentorja bolj kot človeško, kolegialno kakor didaktično oporo, saj so navajali, da so bili na večino vidikov pri pripravi na pouk pozorni na lastno pobudo (več o tem v Šebjanič Oražem, 2016). 


\section{Literatura}

Bela knjiga o vzgoji in izobraževanju v Republiki Sloveniji. Ljubljana: Zavod Republike Slovenije za šolstvo, 2011.

Javornik Krečič, Marija. Pomen učiteljevega profesionalnega razvoja za pouk. Ljubljana: i2 založba, 2008.

Javrh, Petra. »Fazni model razvoja kariere slovenskih učiteljev«. Sodobna pedagogika 58, št. 5 (2007): 68-87.

Koki, Stan. »The Role of Teacher Mentoring in Educational Reform«. V PREL Briefing Paper. Pacific Resources for Education and Learning (ZDA: Office of Educational Research and Improvement, 1997), 1-6.

Mass Mentoring Partnership. Mentoring 101 Train the Trainer Curriculum, Roles and Tasks of a Mentor, 2013. Https://www.uwb.edu/getattachment/ premajor/atp/faculty-and-staff-mentors/mentor-resources/ATP-Mentorship-Program-Roles-and-Tasks.pdf (2. 12. 2019).

Mullen, Carol A. Mentoring: An Overview. V SAGE Handbook of Mentoring and Coaching in Education (London: SAGE Publications Ltd, 2012), 7-23.

Muršak, Janko idr. Poklicni razvoj učiteljev. Ljubljana: Znanstvena založba Filozofske fakultete, 2011.

Parker-Katz, Michelle, in Bay, Mary. »Conceptualizing mentor knowledge: Learning from the insiders«. Teaching and Teacher Education 24 (2008): 1259-1269.

Peklaj, Cirila, idr. Učiteljske kompetence in doseganje vzgojno-izobraževalnih ciljev $v$ šoli. Ljubljana: Znanstvena založba Filozofske fakultete, 2009.

Puklek Levpušček, Melita (2007). Kompetence učiteljev - mentorjev študentov. V Mentorstvo in profesionalna rast učiteljev (Ljubljana: Center za pedagoško izobraževanje Filozofske fakultete, 2007), 49-57.

Razdevšek Pučko, Cveta, in Juriševič, Mojca. »Razvoj poklicne identitete učiteljev«. Vzgoja in izobraževanje 41, št. 6 (2010): 13-19.

Rebolj, Barbara. Vloga učitelja praktika kot mentorja pri pedagoški praksi. V Teorija in praksa v izobraževanju učiteljev (Ljubljana: Center za pedagoško izobraževanje Filozofske fakultete, 2006), 165-172.

Supporting teacher competence development for better learning outcomes. Bruselj: European Commission, Education and Training (Thematic Working Group »Teacher Professional Development«), 2013. Http://ec.europa. eu/assets/eac/education/experts-groups/2011-2013/teacher/teachercomp_ en.pdf (2.12. 2019). 
Šebjanič, Maja. »Pripravništvo profesorjev slovenščine v Sloveniji in Avstriji«. Jezik in slovstvo 59, št. 1 (2014): 83-95.

Šebjanič Oražem, Maja. Vloga obdobja pripravništva pri pridobivanju kompetenc za poučevanje slovenščine: doktorska disertacija. Mentorica Boža Krakar Vogel. Ljubljana: Filozofska fakulteta, 2016.

Valenčič Zuljan, Milena. »Modeli in načela učiteljevega profesionalnega razvoja«. Sodobna pedagogika 52, št. 2 (2001): 122-141.

Valenčič Zuljan, Milena, idr. Učitelj mentor v sistemu pripravništva. Ljubljana: Pedagoška fakulteta, 2006.

Valenčič Zuljan, Milena, idr. Izzivi mentorstva. Ljubljana: Pedagoška fakulteta, $2007 a$.

Valenčič Zuljan, Milena, idr. Spodbujanje profesionalnega razvoja učiteljev pripravnikov: priročnik. Ljubljana: Pedagoška fakulteta in Ministrstvo za šolstvo in šport, $2007 \mathrm{~b}$.

Valenčič Zuljan, Milena, idr. Sistemski vidiki izobraževanja pedagoških delavcev. Ljubljana: Pedagoški inštitut, 2011.

Zelena knjiga o izobraževanju učiteljev $v$ Evropi: kakovostno izobraževanje učiteljev za kakovost $v$ vzgoji, izobraževanju in usposabljanju: tematsko omrežje za izobraževanje učiteljev. Ljubljana: Ministrstvo za šolstvo, znanost in šport, 2001.

Viri

Pravilnik o pripravništvu strokovnih delavcev na področju vzgoje in izobraževanja. Uradni list RS, št. 23/2006. Http://www.uradni-list.si/1/objava.jsp?urlid=200623\&stevilka=901 (2.12. 2019). 


\section{Konsenz o znanstveni terminologiji $s$ področja gledališke pedagogike Irina Lešnik}

\section{Uvod}

Gledališka pedagogika je za marsikoga v slovenskem izobraževalnem prostoru nejasen termin, saj označuje mejno področje na preseku gledališke umetnosti in pedagoške znanosti. V zadnjih letih se predvsem po zaslugi mnogih slovenskih kulturnih in izobraževalnih institucij, ki povezujejo gledališče s pedagoškim procesom, ${ }^{1}$ poraja potreba, da bi področje gledališke pedagogike bolj jasno opredelili, definirali ključna izhodišča in se posluževali enotne terminologije. Pogosto se namreč izvorno angleške termine s področja gledališke pedagogike zelo različno prevaja, kar ustvarja zmedo tako med znanstveno srenjo kot učitelji praktiki. Gledališka pedagogika zaobjema tri vidike vključevanja gledaliških elementov v izobraževalni proces: gledališko opismenjevanje, gledališko ustvarjanje ter gledališče kot sredstvo za doseganje vzgojno-izobraževalnih ciljev. Tretji vidik, ki je v okviru našega izobraževalnega sistema najmanj uveljavljen, naprej delimo na učne pristope, metode in tehnike gledališke pedagogike. V pričujočem prispevku bomo na kratko opredelili gledališko pedagogiko, nato pa se bomo posvetili tretjemu stebru, gledališču kot sredstvu za doseganje vzgojno-izobraževalnih ciljev, ki je tudi terminološko najmanj dorečen.

1 Pionirski dom, SLOGI - Slovenski gledališki inštitut, Društvo ustvarjalcev Taka tuka, JSKD - Javni sklad za kulturne dejavnosti, Bunker - zavod za organizacijo in izvedbo kulturnih prireditev, Društvo za razvoj gledališča v izobraževanju, KUD Transformator ... 
Javni sklad za kulturne dejavnosti JSKD je 18. 9. 2019 imenoval delovno skupino za uskladitev terminologije na področju gledališke dejavnosti $^{2}$ v sestavi predstavnikov Pedagoške fakultete Univerze v Ljubljani, Pedagoške fakultete Univerze na Primorskem, Zavoda za šolstvo RS, Društva za razvoj gledališča v izobraževanju, Slovenskega gledališkega inštituta ter Društva ustvarjalcev Taka tuka. Opredelitve pojmov, ki jih predstavljam v nadaljevanju prispevka, so rezultat zasedanja omenjene delovne skupine.

\section{Opredelitev gledališke pedagogike}

Termin gledališka pedagogika (nem. theaterpädagogik) se je v našem prostoru v zadnjih letih uveljavil med pedagoškimi delavci in gledališkimi ustvarjalci, zato kaže poimenovanje ohraniti. Čeprav bi se lahko odločili tudi za prevod dramska pedagogika (hr. dramska pedagogija, ang. Drama Education), se ta kaže kot manj primeren, saj v slovenskem šolskem prostoru dramo primarno povezujemo z literarno umetnostjo in ne $\mathrm{z}$ gledališko.

Gledališka pedagogika zaobjema tri vidike vključevanja gledaliških elementov v izobraževalni proces: gledališko opismenjevanje, gledališko ustvarjanje ter gledališče kot sredstvo za doseganje vzgojno-izobraževalnih ciljev. Na kratko bomo opredelili prva dva vidika, ki sta znotraj naših vrtcev in šol že prisotna v večji meri, podrobneje pa bomo v naslednjih poglavjih razdelali tretji vidik, ki se pri nas bolj uveljavlja šele v zadnjem času.

\section{Gledališko opismenjevanje}

Gledališko opismenjevanje je del širše kulturno-umetnostne vzgoje, h kateri lahko šolsko okolje pomembno prispeva. Na gledališkem področju se to kaže v organizaciji ogleda kakovostnih gledaliških predstav, ki pa mora

JSKD - Javni sklad za kulturne dejavnosti je imenoval Delovno skupino za uskladitev terminologije s področja gledališke pedagogike v naslednji sestavi:

dr. Helena Korošec, višja predavateljica za področje lutkovnega, gledališkega in filmskega izražanja na Pedagoški fakulteti Univerze v Ljubljani;

Jelena Sitar Cvetko, izredna profesorica za področje filmskega, gledališkega in lutkovnega izobraževanja na Pedagoški fakulteti Univerze na Primorskem;

Irina Lešnik, asistentka za področje filmskega, gledališkega in lutkovnega izobraževanja na Pedagoški fakulteti Univerze na Primorskem;

mag. Tomaž Lapajne Dekleva, vodja Društva za razvoj gledališča v izobraževanju; mag. Sandra Jenko, teatrologinja in kustosinja pedagoginja na Slovenskem gledališkem inštitutu;

Veronika Gaber Korbar, vodja Društva ustvarjalcev Taka tuka;

Matjaž Šmalc, producent za gledališko in lutkovno dejavnost, JSKD;

Jan Pirnat, strokovni delavec za pripravo kulturnih projektov JSKD. 
potekati karseda celostno. To pomeni, da se priprava na ogled začne že v učilnici, z načrtovanimi dejavnostmi, ki otrokom približajo dramske like, motive, teme ... Tako bodo otroci med samo predstavo lažje razbirali posamične gledališke znake na odru in njihovo doživljanje dramskega dogajanja bo bolj kompleksno. Po ogledu predstave naj bi učitelj otrokom dal možnost izražanja lastnih doživetij na mnoge ustvarjalne načine ter tako še poglobil njihovo umetniško doživetje. Cilj gledališkega opismenjevanja je izobraziti avtonomne gledalce, ki bodo tudi po zaključenem obveznem šolanju radi zahajali v gledališče, saj bodo brez težav razumeli »jezik gledališča«; bili bodo torej gledališko opismenjeni.

\section{Gledališko ustvarjanje}

Gledališko ustvarjanje z otroki v šolskem okolju je tudi pri nas že kar stalnica, četudi gledališka umetnost v nasprotju z likovno ali glasbeno ne zaseda mesta v obveznem predmetniku osnovne šole. Poteka večinoma v okviru gledaliških krožkov in izbirnega predmeta gledališki klub. Navadno ima gledališko ustvarjanje $\mathrm{v}$ šoli za izhodišče vnaprej izbrano besedilo, ki ga učitelj skupaj z učenci postavi na (šolski) oder v sklopu raznih prireditev. Za otroke predstavlja edinstveno izkušnjo javnega nastopanja.

\section{Gledališče kot sredstvo za doseganje vzgojno-izobraževalnih ciljev}

Tabela ız: Gledališka pedagogika obsega tri vidike vključevanja gledaliških elementov v izobraževalni proces.

\begin{tabular}{lll} 
Gledališko opismenjevanje & Gledališko ustvarjanje & $\begin{array}{l}\text { Gledališče kot sredstvo za do- } \\
\text { seganje vzgojno-izobraževal- } \\
\text { nih ciljev }\end{array}$ \\
\hline Kulturno-umetnostna vzgoja & $\begin{array}{l}\text { Oblikovanje gledališkega do- } \\
\text { godka }\end{array}$ & $\begin{array}{l}\text { Učni pristopi, metode in teh- } \\
\text { nike }\end{array}$ \\
Vzgoja gledalca & Javno nastopanje & $\begin{array}{l}\text { Drama vizobraževanju, Gleda- } \\
\text { lišče v izobraževanju }\end{array}$
\end{tabular}

Če je v prejšnjih dveh točkah gledališka umetnost predstavljala tako izhodišče kot cilj pedagoškega udejstvovanja, so tokrat cilji zastavljeni širše. Gledališče je lahko namreč tudi odlično sredstvo za doseganje vzgojno-izobraževalnih ciljev z različnih predmetnih področij. Učni pristopi, ki vključujejo metode in tehnike gledališke pedagogike, lahko olajšajo obravnavo, poglabljanje in utrjevanje snovi pri vseh predmetih, od umetniških, 
družboslovnih pa vse do naravoslovnih. Ker so tovrstni pristopi pri nas manj poznani, jih bomo podrobneje razdelali v nadaljevanju.

\section{Gledališče kot sredstvo za doseganje vzgojno-izobraževalnih ciljev}

Četudi ne moremo trditi, da so metode in tehnike gledališke pedagogike popolna novost $\mathrm{v}$ slovenskem izobraževalnem prostoru, so te največkrat omejene na uvodno fazo šolske ure, namenjeno ogrevanju in motiviranju, redko jim pripade osrednje mesto pri obravnavi nove učne snovi. Pogosto se uporabljajo pri pouku tujih jezikov, kjer v skladu s sodobnimi načeli poučevanja tujega jezika učitelji poskušajo ustvariti fiktivne dialoške situacije s pomočjo ene osrednjih metod gledališke pedagogike - metodo igre vlog. Pri slovenščini, ki je znotraj našega šolskega sistema še vedno predmet, najtesneje povezan $\mathrm{z}$ gledališčem, je $\mathrm{v}$ učnem načrtu (Slovenščina, 2018) za vsako vzgojno-izobraževalno obdobje ( $v$ nadaljevanju VIO) posebej predviden razdelek Gledališče, radijska igra in film (v prvem VIO je dodana še risanka), $v$ katerem so med drugimi izpostavljeni izobraževalni cilji s področja gledaliških dejavnosti. Samo v prvem VIO najdemo omembo metode igre vlog, ki je obvezen del katerekoli gledališke dejavnosti, tudi bolj procesno usmerjene, sicer pa učni načrt usmerja h gledališki produkciji in recepciji (prvi in drugi vidik pri opredelitvi gledališke pedagogike).

Tako stanje je odraz zelo postopnega priznavanja tretjega vidika gledališke pedagogike $\mathrm{v}$ pedagoški znanstveni srenji, kar se med drugim kaže že v študijskih programih pedagoških fakultet. Z gledališčem nasploh se študentje razrednega pouka povečini seznanijo preko izbirnih predmetov, samo predmetnik Pedagoške fakultete Univerze v Ljubljani predvideva obvezni predmet Ustvarjalni gib in lutka pri pouku, vendar je v primerjavi z likovno in glasbeno umetnostjo gledališče tudi tam precej zapostavljeno. Tako se zainteresirani študentje, učitelji in pedagoški delavci z gledališčem kot sredstvom za poučevanje in učenje lahko seznanijo predvsem skozi neformalna izobraževanja.

Kako je torej strukturiran tretji vidik gledališke pedagogike, ki se poslužuje gledališča kot sredstva za doseganje vzgojno-izobraževalnih ciljev? V skladu z obstoječo pedagoško terminologijo smo najbolj konkretno zastavljene dejavnosti, ki jih lahko prenesemo neposredno v učilnico, poimenovali tehnike gledališke pedagogike. V Tabeli 14 navajamo nekaj najbolj uveljavljenih tehnik $\mathrm{v}$ svetovnem merilu, ki si postopno utirajo pot $\mathrm{v}$ slovenski prostor, vendar seznam še zdaleč ni dokončen. $\mathrm{Ob}$ njih so pred- 
Tabela I4: Učne tehnike, metode in pristopi gledališke pedagogike

Učne tehnike gledališke pedagogike
(konkretno zastavljene dejavnosti)
• Vroči stol
(Na stol, navadno v sredini polkroga, se posede
učenec/učitelj v izbrani vlogi. Ostali imajo mož-
nost zastavljati vprašanja fiktivnemu liku, ki ga
upodablja.)
- Plašč strokovnjaka
(Učenci si nadenejo fiktivni "plašč strokovnjaka«,
tako da pridobijo določeno specialistično znanje,
ki je navadno rezultat predhodne raziskave. Nato
se lahko brez težav prelevijo v arheologe, socialne
delavce, inšpektorje za varnost pri delu itn.)
- Žive slike

(Učenci v skupini z lastnimi telesi oblikujejo položaj, ki predstavlja specifično idejo ali temo in okamnijo v izbranem položaju.)

- Počasni posnetek

(Učenci izbran prizor zaigrajo v počasnem posnet$\mathrm{ku}$, navadno brez besed, samo s pomočjo giba.)

- $O(b)$ ris osebe

(Ključen fiktivni lik je zastavljen v obliki slikovnega obrisa na večji površini. Učenci s pomočjo učitelja skupaj določijo zunanje in notranje značilnosti lika ter jih zapišejo v obris.)

- Namišljeni prostor

(Obstoječi prostor je uporabljen tako, da karseda ustrezno predstavlja fiktivni dramski prostor lahko gre za dejanske predmete, kose pohištva, ki v novi funkciji postanejo del fiktivnega sveta, ali pa si novo predmetnost zgolj zamislimo.)

- Skupinska skica

(Učenci pod učiteljevim vodstvom skupaj narišejo skico, ki predstavlja fiktivni prostor ali like v drami. Skica nato postane izhodišče za nadaljnje dramske/gledališke dejavnosti.)

\section{- Manjkajoči del}

(Posamičen predmet, besedilo ali del besedila je predstavljen v uvodu v dramsko/gledališko dogajanje. Učenci morajo smiselno strukturirati manjkajoči kontekst, ki navadno vodi v celovito dramo.)

- Usodno sporočilo

(Pisni vir, navadno v obliki pisma ali kratkega sporočila, ki ga uvede učitelj, povsem spremeni potek drame.)

Itd.

\section{Učni pristopi}

(celostno zastavljeni okviri poučevanja; specifične kombinacije metod in tehnik gledališke pedagogike v obliki dramske strukture)

- Drama vizobraževanju

- Gledališče vizobraževanju
Učne metode gledališke pedagogike

(splošni načini dela v razredu)

- Igra vlog

(Učenci prevzemajo vloge in s tem razmišljanje, čustvovanje in vedenje nekoga drugega.)

- Učitelj $v$ vlogi

(Velja isto kot zgoraj, samo za učitelja.)

- Simulacija

(Učenci ohranijo lastno identiteto in namiš-

ljeno situacijo odigrajo na način, kot če bi

bila realna.)

- Vizualizacija

(Razvijanje namišljenih realnosti.)

- Improvizacija

(Sprotno, nepripravljeno delovanje; spontano odzivanje na zunanje in notranje impulze.)

- Prezentacija

(Fizična predstavitev predhodno zamišljenih realnosti; vključuje občinstvo.)

- Delo z besedilom (Dramske/gledališke dejavnosti, ki imajo za izhodišče besedilo.)

- Delo s slikovnim gradivom (Dramske/gledališke dejavnosti, ki imajo za izhodišče sliko.)

- Raba predmeta v dramskem kontekstu (Dramske/gledališke dejavnosti, pri katerih se poslužujemo izbrane predmetnosti.) 
stavljene tudi metode gledališke pedagogike, ki smo jih opredelili širše - kot splošne načine dela $\mathrm{v}$ razredu. Večina jih je vsaj terminološko že dodobra uveljavljenih tudi pri nas, saj so v veliki meri identične metodam izkušenjskega učenja, tako npr. metoda igre vlog, simulacije, improvizacije itn. (Kolb, 2015). Najbolj celostni pristopi gledališke pedagogike, ki so v slovenskem prostoru precejšnja novost, pa predstavljajo specifično kombinacijo različnih metod in tehnik gledališke pedagogike, zajeto $\mathrm{v}$ dramsko strukturo. V skladu $\mathrm{z}$ angleško terminologijo ločimo dva pristopa gledališke pedagogike: gledališče v izobraževanju (Theatre in Education, tudi TiE) in dramo v izobraževanju (Drama in Education, tudi DiE) (Bolton, 1986; Heathcote, 1967). Pri obeh je v ospredju zvrst procesne drame, ki ne nastaja zaradi občinstva, ampak v njej aktivno sodelujejo vsi prisotni. Glavna razlika med pristopoma je navadno v samih izvajalcih - gledališče v izobraževanju izvajajo za to posebej usposobljeni gledališki ansambli, dramo v izobraževanju pa načrtuje in izvede učitelj.

\section{Drama v izobraževanju kot celostni učni pristop}

Drama v izobraževanju (Drama in Education, DiE) sodi med uveljavljene učne pristope v anglosaškem svetu (Bolton, 1986; Bowell in Heap, 2013; Heathcote, 1967; McGuinn, 2014; O`Neill, 2015; O`Toole, 1992), pri nas pa se v redni pouk vključuje zgolj $\mathrm{v}$ fragmentih (igra vlog, simulacija, improvizacija ipd.). V skladu s sodobnimi sociokonstruktivističnimi načeli, ki učenje razlagajo kot aktivni miselni proces in spodbujajo dinamičnost učenja (Kroflič, 1999), ter simbolno dimenzijo dramskega medija (Bolton, 1986), se učni pristop drame v izobraževanju kaže kot primeren pri obravnavi različnih predmetnih vsebin.

O’Toole (1992: 2) dramo v izobraževanju zelo v splošnem definira kot "prevpraševanje elementov dramske forme v skladu s širšim kontekstom in namenom sodelujočih." Bowell in Heap (2013: 1) se strinjata, da gre za »Širši učni model, ki vključuje različne dramske oblike, katerih bistvo je performativnost.« Najbolj priznano in razširjeno opredelitev, ki vključuje tako gledališki kot pedagoški vidik, pa še vedno pripisujemo pionirki sodobne drame v izobraževanju, Dorothy Heathcote (v O'Neill, 2015: 3), ki pravi: »Dramo v izobraževanju definiram kot karkoli, kar vključuje učence $\mathrm{v}$ aktivni igri vlog, kjer njihovi odnosi, in ne liki sami po sebi, predstavljajo bistveni element; dogajanje izvira iz sedanjega trenutka in ni vnaprej pripravljeno /... / ter se prilagaja zakonom dramskega medija.« Dramo v izobraževanju torej sproti in v veliki meri spontano ustvarjajo vsi sodelujo- 
či, brez namena ustvariti zaključen produkt oz. predstavo za zunanje občinstvo.

Ker predstavitev pred zunanjim občinstvom umanjka, je toliko večji poudarek na notranjem občinstvu; še vedno (se) igramo, vendar izključno zase oz. za vse sodelujoče (Bowell in Heap, 2013). V skladu z navedenim v ospredje stopajo vzgojno-izobraževalni cilji in govorimo ne več samo o posebni dramski obliki, pač pa o celostnem učnem pristopu, s pomočjo katerega lahko na karseda interaktiven način obravnavamo poljubne teme iz učnega načrta. Če za učence dramsko dogajanje poteka na videz spontano, pa učitelj vnaprej jasno načrtuje cilje, ki jih želi s tovrstnim pristopom doseči. Načrtuje pa tudi specifične dejavnosti, pri katerih se poslužuje tehnik in metod gledališke pedagogike. Lahko na primer v uvodu uporabi tehniko imenovano manjkajoči del ter vzpostavi širši dramski kontekst, nato se posluži $o(b)$ risa osebe, da opredeli ključne dramske like, nakar prevzame vlogo izbranega lika in sede na vroči stol, kjer ga učenci sprašujejo po dodatnih informacijah. Ni strogih pravil, kako naj bi drama v izobraževanju potekala, pomembno pa je smiselno stopnjevanje dramske napetosti, ki ga omogoča učinkovito zastavljena dramska struktura. Tega znanja mnogi učitelji $\mathrm{v}$ času svojega študija ne dobijo, kar se trudijo spremeniti v uvodu omenjene institucije $z$ organizacijo dodatnih izobraževanj.

Ob aktivnem izražanju vsakega posameznika in čustveni vpletenosti $\mathrm{v}$ dramsko dogajanje je za dramo v izobraževanju ključna predvsem njena simbolna dimenzija, ki izhaja iz dualnosti fiktivnega in realnega konteksta drame. V gledališki pedagogiki za tovrstno distanciranje uporabljamo tudi izraz »drama kot metafora (Bolton, 1986: 42). Janko Kos (2001) v Literarni teoriji metaforo opredeli kot »rabo besed v prenesenem pomenu" (prav tam:130), pri čemer do prenosa besednih pomenov prihaja zaradi nekakšne "logične vzporednosti, podobnosti in analogije med pojavi, ki so sicer različni in med sabo brez vzročne zveze« (prav tam: 130). Podobno tudi v drami v izobraževanju med svetom dramske fikcije in lastno realnostjo obstaja nekakšna analogija, ki jo postopno odkrivamo skozi dramski proces. Tako ustvarimo izkušnjo, s katero »učenci laže razumejo medčloveške odnose, se vživijo v življenje drugih ljudi in uvidijo alternativne možnosti za odzive in dogodke.« (Korošec, 2007: 113). Ob ustvarjanju fiktivnih vlog, sovplivanju fiktivnih in realnih odnosov med sodelujočimi in raziskovanju fiktivnih kontekstov nastane idealen prostor za aktivno oblikovanje stališč, vrednot, perspektiv in mnenj o svetu, ki nas obdaja (Edmiston, 2014). Tako se 
drama v izobraževanju kaže kot učinkovit pristop pri obravnavi tudi bolj kompleksnih tem, kot so medkulturnost, ekologija ipd.

\section{Sklepne ugotovitve}

Sodobni učenec naj bi bil v pouk vključen kot »dinamična celota med seboj prepletenih elementov, pri čemer sprememba v enem pomeni možnost za spremembe v drugih « (Marentič Požarnik, Šarić in Šteh, 2019: 142). Učinkovito zastavljene učne dejavnosti bi torej težko razdelili na tiste, ki vključujejo "glavo, srce ali roke« oz. "razum ali čustva« (Andresen, 2001). Večina šolskih izzivov je sekundarne narave, saj jih učitelj prilagodi, cenzurira ipd. ter jim s tem odvzame del »življenjske uporabnosti«. Vsebine se obravnava karseda racionalno, brez čustvene vpletenosti, četudi so mnoge raziskave dokazale jasno povezavo med čustvi in pomnjenjem. »Da bi znali osmisliti znanje, moramo najprej čutiti.«, trdita avtorja monografije Planning Process Drama (Načrtovanje procesne drame) Bowell in Heap (2013: 2).

Učni pristopi, metode in tehnike gledališke pedagogike so celostno zasnovani, tako da učenci o različnih pojmih, pojavih in zakonitostih ne zgolj poslušajo in govorijo, ampak jih dobesedno utelesijo, izrazijo z mnogimi različnimi gledališkimi izraznimi sredstvi, ki so lahko verbalna ali neverbalna. Na tak način usvojeno snov lažje ponotranjijo, vzpostavijo do nje določen čustveni odnos ter pridobljena spoznanja shranijo v dolgoročni spomin.

Poenotena terminologija na področju gledališke pedagogike, predvsem tretjega vidika, ki obsega vključevanje gledališča v pouk $\mathrm{z}$ namenom doseganja vzgojno-izobraževalnih ciljev, je zgolj izhodišče za nadaljnje raziskave primerov dobre prakse pri nas, lažje primerjave s tujino, predvsem pa možnost, da se učni pristopi, metode in tehnike gledališke pedagogike širše uveljavijo v okviru slovenskega izobraževalnega sistema.

\section{Literatura}

Anderson, Michael in Julie Dunn. 2015. How Drama Activates Learning. Contemporary Research and Practice. London, New York: Bloomsbury Academic.

Andresen, Lee. 2001. "In Search of Experiental Education.« V Te Rito o te Mataraunga: Experiental Learning for the Third Millenium, Vol 2, uredila Nena in Richard Benton, 189-201. Auckland: James Henare Maori Research Centre, University of Auckland. 
Bolton, Gavin. 1986. Selected writings on Drama and Education. New York: Longman Group Limited.

Bolton, Gavin. 1999. Acting in Clasroom drama. A critical Analysis. Maine: Calendar Islands Publishers.

Bolton, Gavin. 2015. »Foreword.« V Dorothy Heathcote on Education and Drama, uredila Cecily O'Neill, 1-9. New York: Routledge.

Bowell, Pamela in Brian S. Heap. 2013. Planning Process Drama: Enriching Teaching and Learning. London, New York: Routledge.

Edmiston, Brian. 2014. Transforming Teaching and Learning with Active and Dramatic Approaches. London, New York: Routledge.

Heathcote, Dorothy. 1967. »Improvisation.« V Dorothy Heathcote: Collected writings on education and drama, uredili Liz Johnson in Cecily O'Neill, 44-48. London: Hutchinson.

Kolb, David. 2015. Experiential learning: experience as the source of learning and development. New Jersey: Pearson Education.

Korošec, Helena. 2007. »Gledališče - medij za učenje in poučevanje ter otrokov celostni razvoj.«Sodobna pedagogika, 58(3): 11-127.

Kos, Janko. 2001. Literarna teorija. Ljubljana: DZS.

Kroflič, Breda. 1999. Ustvarjalni gib - tretja razsežnost pouka. Ljubljana: Znanstveno in publicistično središče.

Lešnik, Irina. 2017. »Odnos bodočih učiteljev razrednega pouka do gledališke pedagogike." V Vidiki internacionalizacije in kakovosti v visokem šolstvu, uredila Sonja Rutar, Sonja Čotar Konrad, Tina Štemberger in Silva Bratož, 313-325. Koper: Založba Univerze na Primorskem.

Lukan, Blaž. 1996. Gledališki pojmovnik. Šentilj: Založba Aristej d. o. o.

Marentič Požarnik, Barica, Marjeta Šarić in Barbara Šteh. 2019. Izkustveno učenje. Ljubljana: Znanstvena založba Filozofske fakultete Univerze v Ljubljani.

McGuinn, Nicholas. 2014. The English Teacher's Drama Handbook. New York: Routledge.

O'Neill, Cecily. 2015. Dorothy Heathcote on Education and Drama. New York: Routledge.

O’Toole, John. 1992. The Process of Drama: Negotiating Art and Meaning. London: Routledge.

Özbek, Gökçen. 2014. »Drama v izobraževanju: ključne konceptualne poteze.« Sodobna pedagogika, 65(1): 72-89. 
Pavis, Patrice. 1997. Gledališki slovar. Ljubljana: Mestno gledališče ljubljansko (Knjižnica Mestnega gledališča ljubljanskega, 124).

Učni načrt. Program osnovna šola. Slovenščina. 2018. Ljubljana: Ministrstvo za izobraževanje, znanost in šport, Zavod RS za šolstvo.

Wagner, Betty Jane. 1999. Dorothy Heathcote. Drama as a Learning Medium. Maine: Calendar Islands Publishers LLC. 


\title{
Mentalne reprezentacije študentov pedagoških smeri do nadarjenih in njihovega izobraževanja ${ }^{\mathrm{I}}$
}

Nika Bedek, Maruša Loboda, Urška Žerak, Janez Vogrinc, Mojca Juriševič

\begin{abstract}
Uvod
Mentalne reprezentacije lahko opredelimo kot strukture, ki se oblikujejo v procesu ustvarjanja pomena pojmov v naših mislih s pomočjo jezika. Omogočajo nam organizacijo in klasifikacijo pojmov glede na kompleksne odnose med njimi ter predstavljajo povezovalni člen med pojmi in jezikom v določeni kulturi (Hall, 1997). Reprezentacije konstruiramo skozi učenje; izgrajujemo svoj mentalni svet v smislu pojmovnih zemljevidov in hkrati tudi jezik, s katerim se sporazumevamo na ravni osebnih pomenov med pripadniki iste skupine ali kulture, na splošno v življenju in v stroki. Različni kognitivni in afektivni dejavniki (npr. zaznave, pojmovne reorganizacije, stališča) vplivajo na mentalne reprezentacije v smislu njihovega mogočega spreminjanja, pa tudi različnih izkrivljanj (Carbon in Hesslinger, 2013). Mentalne reprezentacije učiteljev, ki opisujejo strokovne pojme, s katerimi učitelji dnevno operirajo besedno ali nebesedno, izhajajo iz njihovih izkušenj in rezultatov njihovih interakcij z okoljem (Sternberg, 2008).

Učitelji ključno prispevajo k izobraževalni izkušnji učencev (Swanson in Lord, 2013) in imajo na njihove dosežke pomembnejši vpliv kot kateri koli drugi dejavnik (Flynt in Brozo, 2009). Njihova stališča obsegajo osebne oz. subjektivne teorije poučevanja in učenja ter subjektivne teorije


o značilnostih učencev, ki preko učiteljevih ravnanj pomembno vplivajo na motivacijo in zadovoljstvo učencev pri določenem predmetu (Pajares, 1992). Szymanski et al. (2018) podarjajo, da imajo učitelji s svojimi stališči in vedenji med vsemi učenci največji vpliv na nadarjene, saj so oni najpogosteje tisti, ki jih prepoznajo za nadarjene in zanje predlagajo določene prilagoditve.

Pozitivna stališča učiteljev ne vplivajo le na poučevalno prakso, ampak posredno tudi na stališča in vedenja sošolcev (vrstnikov) nadarjenih ter spodbudno razredno klimo, ki zagotavlja optimalen razvoj nadarjenih učencev (Al Makhalid, 2012). Ozcan (2016) stališča prihodnjih učiteljev opisuje kot ključna za njihov nadaljnji razvoj in uspešnost poučevanja nadarjenih učencev. Avtor poudarja pomen učiteljevega dobrega poznavanja učnih značilnosti in potreb učencev ter razumevanje pomena diferenciranega in individualiziranega poučevanja za zadovoljevanje učnih potreb in spodbujanje učnih potencialov različnih učencev, med njimi tudi nadarjenih.

Raziskovalni izsledki kažejo, da imajo učitelji tako pozitivne kot tudi negativne mentalne reprezentacije o nadarjenih učencih (McCoach in Siegle, 2007). Poleg tega raziskovalci ugotavljajo, da so pri učiteljih prisotna stereotipna prepričanja o nadarjenih učencih, in sicer predvsem o tem, da imajo nadarjeni učenci visoke intelektualne sposobnosti in socialne, čustvene ali vedenjske težave (Matrić in Duh, 2019; Preckel et al., 2015). Schroth in Helfer (2009) navajata, da pri učiteljih prevladujejo tradicionalna pojmovanja nadarjenosti predvsem $\mathrm{v}$ smislu splošnih intelektualnih sposobnosti in visokih učnih dosežkov, pri tem pa so zanemarjeni nekateri specifični talenti nadarjenih učencev (npr. na področju umetnosti) in nadarjeni učenci, ki izkazujejo podpovprečne dosežke v šoli. Olthouse (2014) je $\mathrm{z}$ uporabo analize metafor ugotovila, da mentalne reprezentacije prihodnjih učiteljev o nadarjenih učencih odražajo zaznavo nadarjenosti v smislu hitrega pomnjenja dejstev in izkazanih dosežkov. Prihodnji učitelji nadarjenost dojemajo predvsem $\mathrm{v}$ splošnem smislu nadpovprečnosti na vseh področjih in izražajo pozitivno naravnane mentalne reprezentacije o nadarjenih učencih, iz česar bi bilo mogoče sklepati, da bodo ustrezno razumeli njihove izobraževalne potrebe in bodo naklonjeni specifičnim prilagoditvam (npr. akceleraciji in obogatitvenim dejavnostim). Na drugi strani ugotovitve kvantitativne študije mentalnih reprezentacij prihodnjih učiteljev kažejo (Bain et al., 2007), da študenti razumejo pojem nadarjenosti zelo 
široko ter izkazujejo egalitarne mentalne reprezentacije in pomanjkljivo razumevanje izobraževalnih potreb nadarjenih učencev.

Mentalne reprezentacije učiteljev o nadarjenosti učencev vplivajo na njihove odločitve o nominaciji potencialno nadarjenih učencev (Olthouse, 2014). Sternberg in Kaufman (2018) poudarjata, da je pri prepoznavanju nadarjenih učencev iz omenjenega razloga ne glede na teoretična izhodišča treba biti pozoren na naslednje: uporabo več raznolikih meritev, upoštevanje osebnostnih značilnosti, kot so angažiranost, ciljna usmerjenost in predanost, ter upoštevanje kontekstualnih dejavnikov, kot sta kultivacija nadarjenosti in socializacija nadarjenih.

Na osnovi povedanega je mogoče skleniti, da je mentalne reprezentacije učiteljev, kot izjemno vplivne kognicije za poučevanje in učenje učencev, mogoče raziskovati na različne načine, med drugim tudi s tehniko skupinskih asociacij AGA (angl. Associative Group Analysis; Szalay in Brent, 1967). Ta tehnika posredno meri zaznave, stališča in prepričanja posameznika s pomočjo prostih besednih asociacij; običajno uporablja za inferenčno raziskovanje medkulturnih razlik, pri čemer je v ospredju jezik kot komunikacijsko orodje preučevane skupine ljudi, s katerim ti izražajo svoje razmišljanje, doživljanje in vedenjske namere (Ross et al., 2005).

\section{Problem in cilj raziskave}

Stališča učiteljev do nadarjenih in njihovega izobraževanja so eden ključnih dejavnikov kakovostnega pedagoškega dela učiteljev z nadarjenimi učenci v šoli (Szymanski et al., 2018). Univerzitetno okolje, v katerem se izobražujejo prihodnji učitelji, zato predstavlja temeljni kontekst, v katerem lahko učitelji usvojijo znanje in izkušnje, ki prispevajo k razvoju strokovnega, na empiričnih dokazih temelječega pedagoškega pristopa. Da bi visokošolske ustanove, ki izobražujejo učitelje, to nalogo lahko kakovostno izvajale (npr. študente strokovno spodbujale, usmerjale in podpirale), je potrebno razumevanje o predznanju študentov; znanje o tem, kako študenti razmišljajo o obravnavani problematiki, kakšne so njihove osebne izkušnje, pojmovanja in stališča in kako jih je mogoče kultivirati v okviru vzgojno-izobraževalnega konteksta. Ob pregledu referenčne literature je mogoče ugotoviti, da je kljub svoji pomembnosti to področje še premalo raziskano. Cilj raziskave je bil zato ugotoviti, kako študenti - prihodnji učitelji - pred vstopom v pedagoško prakso razmišljajo o nadarjenih učencih in njihovem izobraževanju. Natančneje, zanimale so nas njihove mentalne reprezentacije o dveh teme- 
ljih pojmih s področja obravnave nadarjenih učencev v šoli, in sicer nadarjen učenec in izobraževanje nadarjenih.

\section{Raziskovalna metoda}

$\mathrm{V}$ raziskavi smo uporabili načela pedagoškega raziskovanja ter kombinacijo kvalitativnega in kvantitativnega pristopa. Udeleženci so bili študenti Pedagoške fakultete Univerze v Ljubljani v študijskem letu 2017/18, ki so bili namensko vzorčeni. To so bili redno vpisani študenti začetnega in zaključnega letnika na prvostopenjskih študijskih programih (Predšolska vzgoja, Razredni pouk, Dvopredmetni učitelj, Likovna pedagogika, Specialna in rehabilitacijska pedagogika Logopedija in Surdopedagogika in Socialna pedagogika). Sodelovalo je 480 študentov (65,7 \% osnovne populacije), od tega 284 študentov začetnega letnika (67,6 \% osnovne populacije) in 196 študentov zaključnega letnika (63,0 \% osnovne populacije). Večina študentov je bila ženskega spola $(92,5 \%)$.

Za namen raziskave smo uporabili tehniko AGA (Pergar Kuščer, 1998; Szalay in Brent, 1967), s katero smo kvalitativno preučili mentalne reprezentacije študentov oz. ugotavljali strukturo pomenov njihovih stališč o nadarjenih učencih in njihovem izobraževanju ter razlike med njimi glede letnik študija v ugotovljenih pomenskih strukturah.

Zbiranje podatkov je potekalo marca 2018. Študenti so tehniko AGA izvajali prostovoljno med predavanji po standardnih navodilih. Sledil je prepis podatkov. Asociacije smo analizirali po metodi AGA (več v Pergar Kuščer, 1998). Po ključu vsakega petega vprašalnika smo izbrali 50 preizkušancev iz vsake izmed dveh skupin. Iz nadaljnje obdelave smo izločili netipične asociacije, preostale smo točkovali z obteženimi frekvencami od 1 do 6.

\section{Tabela 15: Obtežitve asociacij}

\begin{tabular}{llllllllllll}
\hline Rang odgovora & 1 & 2 & 3 & 4 & 5 & 6 & 7 & 8 & 9 & 10 & Itn. \\
\hline Obtežitev & 6 & 5 & 4 & 3 & 3 & 3 & 3 & 2 & 2 & 1 & Itn.
\end{tabular}

Sledili so naslednji koraki: prepis asociacij posamezne skupine, združevanje glede na vsebinski pomen (sinonimi, metafore, besede v različnem številu, v različnih besednih vrstah itn.), poenotenje izrazov v obeh skupinah in seštevanje obteženih vrednosti. Nabor približno 50 asociacij smo po 
metodi odprtega kodiranja za vsak preučevanji pojem posebej razvrstili v 6 oz. 7 semantičnih kategorij.

\section{Rezultati z razlago}

Študenti začetnega in zaključnega letnika so več asociacij izrazili na pojem nadarjen učenec kot na pojem izobraževanje nadarjenih $\left(M_{z a c ̌ e t n i}=6,4\right.$ asociacij in $M_{z a k l j u c ̌ n i}=6,9$ asociacij oz. $M_{z a c ̌ e t n i}=5,4$ asociacij in $M_{z a k l j u c ̌ n i}=5,9$ asociacij). Pri obeh pojmih so bili po količini asociacij v prednosti študenti začetnega letnika (52 \% vseh asociacij pri prvem in 52,5\% vseh asociacij pri drugem pojmu). Povprečno število asociacij na posameznega študenta je bilo 6,15 asociacij, kar je nekoliko manj kot predvideva Pečjak (1994, v Pergar Kuščer, 1996), po katerem naj bi respondent v povprečju v eni minuti napisal sedem asociacij.

\section{Analiza semantičnih kategorij na osnovi asociacij študentov na pojem nadarjen učenec}

V obeh skupinah (Slika 9) največji delež pomenskega prostora zajema $k a$ tegorija A: konceptualizacija nadarjenosti $\left(f \%_{\text {začetni }}=34, f \%_{\text {zaključni }}=34\right)$, npr. pameten in nadpovprečen, $\mathrm{v}$ kateri sta profila primerjanih skupin podobna. Sledita kategorija B: področja nadarjenosti $\left(f \%_{z a c ̌ t n i}=17, f \%_{\text {zaključni }}=29\right)$, npr. učna uspešnost in umetnost, $v$ katero so večji delež asociacij prispevali študenti zaključnega letnika in kategorija C: učnomotivacijske lastnos$t i\left(f \%_{z a \check{c} t \text { tni }}=23, f \%_{\text {zaključni }}=16\right)$, npr. vedoželjen in marljiv, kjer so v prednosti študenti začetnega letnika Manjše, relativno enakomerno porazdeljene deleže v pomenskem prostoru zavzemajo naslednje kategorije: kategorija $D$ : kognitivne lastnosti $\left(f \%_{\text {začetni }}=15, f \%_{\text {zaključni }}=14\right)$., npr. divergentno razmišlja, ustvarjalen, kategorija E: socialno-emocionalne lastnosti $\left(f \%_{\text {začetni }}=7, f \%_{\text {zak- }}\right.$ liučni $=4$ )., npr. socialno spreten, asocialen in kategorija F: vidik družbe (f\%$z_{\text {začetni }}=4, f \%_{\text {zaključni }}=3$ )., npr. kritika identifikacije, izkoriščanje ugodnosti, ki jih prinaša status nadarjenega učenca. Višjo vsoto obteženih frekvenc predstavljajo asociacije študentov začetnega letnika $\left(\sum_{z a c ̌ e t n i}=1053\right.$ asociacij, $\Sigma_{z a k l j u c ̌ n i}=880$ asociacij).

Pomen pojma nadarjen učenec znotraj semantičnih skupin (A) konceptualizacija nadarjenosti in (B) področja nadarjenosti delno potrdi strokovno podprto razumevanje pojma nadarjenosti oz. nadarjenega učenca med študenti, kot je opredeljen v Beli knjigi o vzgoji in izobraževanju 2011 (Juriševič, 2011) in v prvem delu opredelitve nadarjenih učencev iz Zako- 


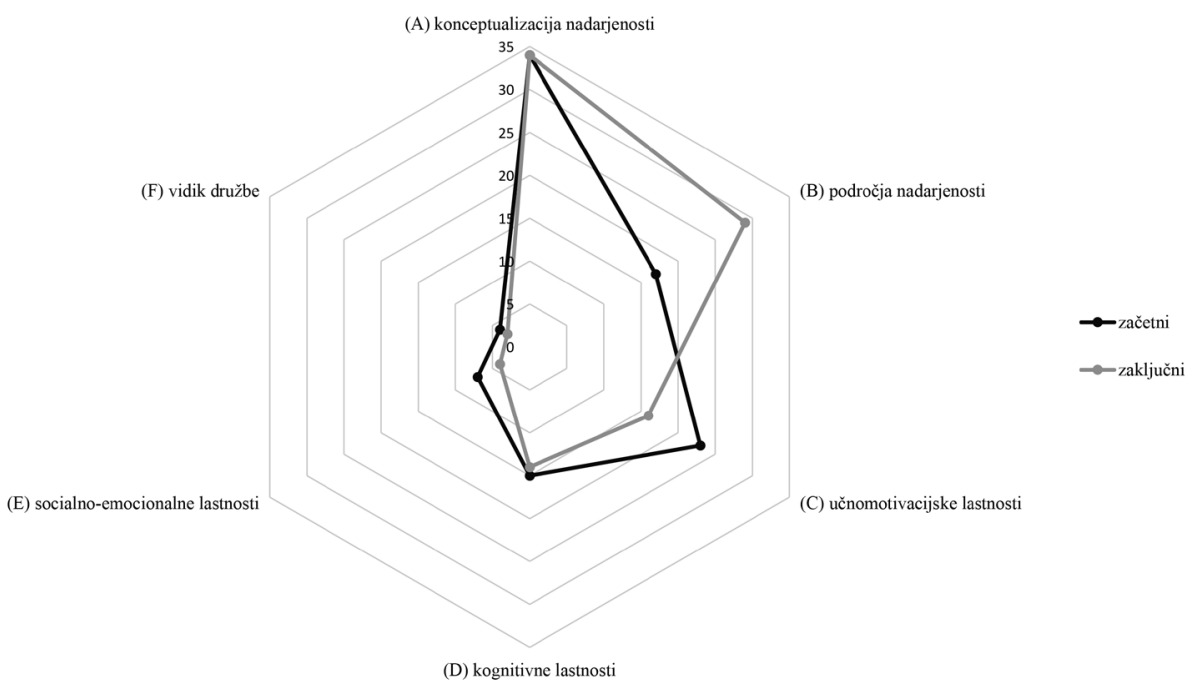

\section{Slika 9: Semantične kategorije za pojem nadarjen učenec}

na o osnovni šoli. Ta pravi, da so nadarjeni učenci »/.../ učenci, ki izkazujejo visoko nadpovprečne sposobnosti mišljenja ali izjemne dosežke na posameznih učnih področjih, v umetnosti ali športu./.../« (ZOsn, 11. člen). Mentalne reprezentacije študentov, skladno s šolsko kulturo, ki sprejema nadarjenost le na določenih področjih, in prevladujočimi stereotipi o akademsko nadarjenih učencih (IEA, 2018), postavljajo tudi v našem vzorcu nadarjenega učenca predvsem $\mathrm{v}$ šolsko okolje oz. izpostavljajo učno področje (izstopa matematika), ki mu sledi umetnost, medtem ko so denimo področje športa, $v$ smislu izjemnih psihomotoričnih sposobnosti, študenti le redko navedli kot asociacijo na dani pojem. O podobnih ugotovitvah poročajo tudi tuji raziskovalci (Olthouse, 2014; Schroth in Helfer, 2009), ki opozarjajo na pomen ustreznega razumevanja in pojmovanja nadarjenosti pri (prihodnjih) učiteljih, saj le-to ključno vpliva na njihovo poučevalno prakso. V zvezi s tem Sternberg in Kaufman (2018) poudarjata, da na konceptualizacijo nadarjenosti vplivajo tako eksplicitne kot implicitne teorije nadarjenosti, kar pomeni, da je pri izobraževanju učiteljev treba upoštevati doseženo strokovno znanje učiteljev in njihova bolj osebna oz. subjektivna pojmovanja o nadarjenosti in značilnostih nadarjenih učencev.

Kljub ugotovitvi, da so študenti kritični do množičnega prepoznavanja nadarjenih, ki je dejansko problem identifikacije v slovenski šoli (Juriševič, 2012a), njihove mentalne reprezentacije vključujejo tudi sorodne pojme, kot so talent in močna področja, kar kaže na precej nejasno poj- 
movanje nadarjenosti. Pri tem obstaja nevarnost, da to vodi v posplošeno prepričanje tipa »Vsak učenec je nadarjen.«. Zato je pomembno, da učitelji dosežejo natančnejše razumevanje pojma ter znajo razločiti med močnimi področji, ki jih imajo vsi učenci in nadarjenostjo, ki je opredeljena na osnovi kriterijev stroke in običajno pomeni izjemnost na določenem področju glede na večino vrstnikov (Juriševič, 2012a, 2018).

Iz vsebinske analize asociacij je mogoče opaziti tudi, da se semantične kategorije, vezane na lastnosti nadarjenega učenca, neposredno povezujejo s področji značilnosti nadarjenih učencev, ki jih prepoznava tudi širša stroka (Žagar et al., 1999) in sicer: miselno-spoznavno, učno-storilnostno, motivacijsko in socialno-čustveno področje; upoštevanje omenjenih psihosocialnih lastnosti pri identifikaciji nadarjenosti pomeni namreč večjo verjetnost, da je učenec nadarjen. Mentalne reprezentacije študentov v omenjenih kategorijah sovpadajo tudi z lastnostmi, ki jih med različnimi značilnostmi in vedenji učencev v razredu, slovenski učitelji najpogosteje prepoznavajo pri nadarjenih, in sicer samostojnost, zainteresiranost za šolsko delo, hitrost pri delu, vedoželjnost, zahtevnost, pozitivna predstava o sebi, prijaznost, motiviranost, pomoč drugim, uspešnost na akademskem področju itd. (Matrić in Duh, 2019).

Zanemarljiv delež v strukturi pomena pojma nadarjen učenec predstavljajo netipične značilnosti, ki jih pogosto najdemo pri učno neuspešnih nadarjenih učencih ali dvojno izjemnih učencih (Žagar et al., 1999). Kot ugotavljajo različni avtorji (Bianco in Leech, 2010; Neihart, 2018) je treba (prihodnje) učitelje senzibilizirati tudi za potrebe dvojno izjemnih učencev, kar predstavlja še poseben pedagoškopsihološki izziv na obravnavanem področju izobraževanja nadarjenih.

Skladno z empiričnimi ugotovitvami drugih raziskav (Martin et al., 2010; Neihart, 2002) so tudi izsledki te raziskave pokazali, da mentalne reprezentacije študentov nasprotujejo hipotezi disharmoničnega razvoja nadarjenih, ki predpostavlja izjemne sposobnosti in dosežke na šolskem oz. akademskem področju ter primanjkljaje in težave na psihosocialnem in emocionalnem področju (Baudson, 2016; Becker, 1978, v Matheis et al., 2019). To pomeni, da anketirani študenti nadarjene učence razumejo kot nadpovprečne oz. izjemne $\mathrm{v}$ primerjavi $\mathrm{z}$ večino vrstnikov na različnih področjih njihovega delovanja, ne le šolskem področju, kar bi bilo lahko prav tako odraz površinskega razumevanja pojma "nadarjen učenec«, saj poudarja drugi skrajni pol na kontinuumu harmoničnosti, ali pa dejansko poznavanje sodobnih raziskovalnih izsledkov, ki kažejo, da nadar- 


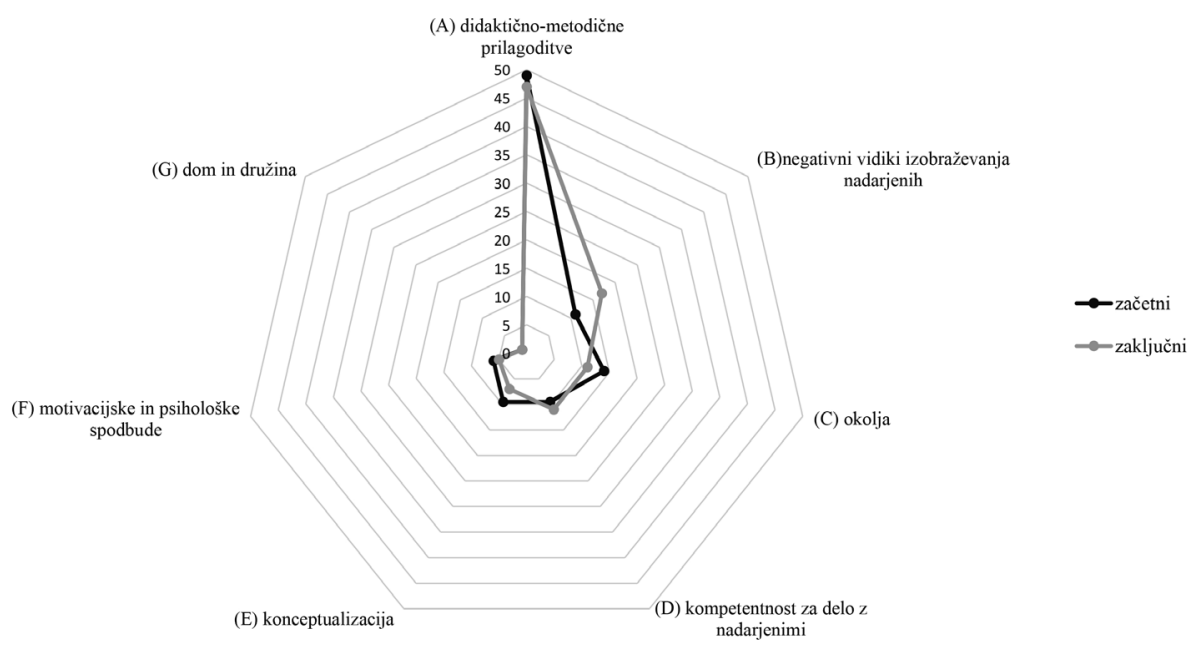

Slika ıo: Semantične kategorije za pojem izobraževanje nadarjenih

jeni učenci niso slabše osebnostno opremljeni kot njihovi vrstniki (Bergold et al., 2015; Freeman, 2010).

\section{Analiza semantičnih kategorij na osnovi asociacij študentov na pojem izobraževanje nadarjenih}

Obe primerjani skupini (Slika 10) zavzemata največji delež v semantični $k a-$ tegoriji A: didaktično-metodične prilagoditve $\left(f \%_{\text {začetni }}=49, f \%_{\text {zakljǔ̌ni }}=47\right)$, npr. dodatne naloge, dodatni pouk, zahtevnejše naloge. Sledi semantična kategorija B: negativni vidiki izobraževanja nadarjenih $\left(f \%_{\text {začetni }}=11, f \%_{\text {zak- }}\right.$ ljučni $=17)$, npr. kritika izvajanja v praksi, kritika identifikacije. Slednje nakazuje večjo kritičnost in zavedanje negativnih vidikov izobraževanja nadarjenih z višjim letnikom študija. Preostale semantične kategorije k strukturi pomena pojma prispevajo manjše, med študenti začetnega in zaključenega letnika relativno enakomerno porazdeljene deleže, in sicer kategorija C: okolja $\left(f \%_{\text {začetni }}=14, f \%_{\text {zaključni }}=11\right)$, npr. osnovna šola, obšolske dejavnosti, kategorija D: kompetentnost za delo $z$ nadarjenimi $\left(f \%_{\text {začetni }}=9,5, f \%_{\text {zaključni }}=\right.$ 12), npr. zahtevnejše delo učitelja, učiteljeva priprava, kategorija E: konceptualizacija nadarjenosti $\left(f \%_{\text {začetni }}=9,5, f \%_{\text {zaključni }}=7\right)$, npr. kultura in umetnost, testiranje, ter kategoriji F: motivacijske in psihološke spodbude ( $f \%_{\text {zǎetni }}$ $\left.=6, f \%_{\text {zakljǔ̌ni }}=5\right)$ in G: dom in družina $\left(f \%_{\text {začetni }}=1, f \%_{\text {zaključni }}=1\right)$, ki predstavljata najmanjši delež asociacij. Vsota vseh obteženih frekvenc je ponovno nekoliko višja pri študentih začetnega letnika $\left(\Sigma_{z a c ̌ e t n i}=1134, \Sigma_{z a k j j u c ̌ n i}=965\right)$. 
Asociacije na stimulativno besedno zvezo izobraževanje nadarjenih znotraj najbolj zastopane semantične kategorije didaktično-metodične prilagoditve potrdijo ponotranjeno zavedanje in če predpostavljamo, da asociacije sprožijo predhodne izkušnje (Sternberg, 20o8), do določene mere tudi implementacijo v praksi, drugega dela opredelitve nadarjenih učencev, in sicer »/.../Šola tem učencem zagotavlja ustrezne pogoje za vzgojo in izobraževanje, tako da jim prilagodi vsebine, metode in oblike dela ter jim omogoči vključitev v dodatni pouk, druge oblike individualne in skupinske pomoči ter druge oblike dela« (ZOsn, 11. člen). Prva kategorija semantično sovpada s karierno orientacijo študentov in s potrebami nadarjenih učencev (t. j. razvijanje močnih področij, individualiziran program, prilagoditve v kurikulumu, svetovanje itd.), ki jih kot pomembne pri nadarjenih učenih prepoznavajo slovenski učitelji tudi v že omenjeni raziskavi Matrić in Duh (2019). Čeprav študenti pedagoških smeri deklarativno izražajo naklonjenost do izobraževanja nadarjenih, opozarjajo na številne pomanjkljivosti implementacije v praksi. Kritičnost do sistemske ureditve in realnosti izvajanja specifičnih prilagoditev za nadarjene učence je se je pokazala tudi v raziskavi Loboda et. al. (2020), v kateri študenti poročajo o neizvajanju prilagoditev in dejavnosti za nadarjene učence $\mathrm{v}$ praksi ter so $\mathrm{z}$ vidika množičnega prepoznavanja kritični do procesa prepoznave nadarjenih, kar se sklada tudi $\mathrm{z}$ ugotovitvami ostalih slovenskih raziskovalcev (Boben, 2012; Juriševič, 2012a; Žagar, 2012).

\section{Zaključek}

Stališča prihodnjih učiteljev do izobraževanja nadarjenih so ključnega pomena za razvoj poučevanja nadarjenih učencev v prihodnosti, njihove mentalne reprezentacije pa nam omogočajo edinstven vpogled $\mathrm{v}$ njihovo razmišljanje o nadarjenih učencih. To ne predstavlja le zanimivih raziskovalnih izsledkov, temveč ima tudi aplikativno vrednost za izobraževalce učiteljev, da bi optimalno naravnali študijski proces v kultivacijo kognicij učiteljev (Huang, 2015).

Mentalne reprezentacije študentov v predstavljeni raziskavi odražajo splošno oz. površinsko razumevanje pojma nadarjen učenec, ter ga postavljajo predvsem v šolsko okolje oz. na akademsko področje, pri asociacijah pojma izobraževanje nadarjenih pa izstopata semantični kategoriji didaktično-metodičnih prilagoditev in kritika obstoječih praks dela $z$ nadarjenimi v vzgoji in izobraževanju. Zdi se, da gre za asociacije, ki izhajajo iz izkušenj študentov, predvsem na osnovi njihovega dosedanjega šolanja. $\mathrm{V}$ 
asociacijah je moč razbrati tudi naklonjenost do dodatnih izobraževanj na tem področju in zavedanje pomena strokovne kompetentnosti učitelja za poučevanje nadarjenih učencev.

Pridobljeni kvalitativni rezultati kažejo smernice za oblikovanje bolj specifičnih vsebin v študijskem procesu in razvoj strokovnih, na empiričnih dokazih temelječih pedagoških pristopov poučevanja nadarjenih, $\mathrm{v}$ smislu prožnih oblik učenja. Z razvojem ustreznih mentalnih reprezentacij o nadarjenosti pri prihodnjih učiteljih je namreč mogoče vplivati na oblikovanje njihovih pozitivno naravnanih stališč do izobraževanja nadarjenih in na povečanje njihove občutljivosti za razumevanje izobraževalnih potreb nadarjenih učencev znotraj širšega konteksta inkluzivnosti (Juriševič, 2012b).

Omejitve te raziskave oz. uporabe tehnike AGA avtorji prepoznavamo predvsem na jezikovnem področju oziroma pri izboru stimulativnih pojmov, saj avtorja tehnike Szalay in Brent (1967) priporočata uporabo ene besede, ne besedne zveze, kar verjetno vpliva na kvaliteto in kvantiteto besednih asociacij. Poleg tega je treba upoštevati tudi dejstvo, da na asociacije izbranih pojmov vpliva jezik ter širši sociokulturni kontekst. Zato bi bilo v prihodnje tehniko AGA smiselno uporabiti ob upoštevanju navedenih zaznanih izzivov in temeljiteje raziskati kognicije prihodnjih učiteljev.

\section{Literatura}

Al Makhalid, Khalid Abdu. »Primary teachers' attitudes and knowledge regarding gifted pupils and their education in the Kingdom of Saudi Arabia.« Doktorska disertacija, University of Manchester, School of Education, Manchester, 2012.

Bain, Sherry K., Stacy L. Bliss, Stephani M. Choate, and Katherine Sager Brown. »Serving children who are gifted: Perceptions of undergraduates planning to become teachers. "Journal for the Education of the Gifted 30, no. 4 (2007): 450-478.

Baudson, Tanja G. »The mad genius stereotype: Still alive and well.« Frontiers in Psychology 7 (2016): 1-9. doi: 10.3389/fpsyg.2016.00368.

Bergold, Sebastian, Linda Wirthwein, Detlef H. Rost, and Ricarda Steinmayr. "Are gifted adolescents more satisfied with their lives than their non-gifted peers? « Frontiers in Psychology 6 (2015): 1623. doi: 10.3389/fpsyg.2015.01623.

Bianco, Margarita in Nancy L. Leech »Twice-exceptional learners: Effects of teacher preparation and disability labels on gifted refferals." Teacher Education and Special Education 33 no. 4 (2010): 319-334. 
Boben, Dušica. »Smo psihologi (edini) kompetentni za identifikacijo nadarjenih?« V Posvetovanje Vloga psihologa v vzgoji in izobraževanju nadarjenih, urednici Mojca Juriševič in Božena Stritih, 57-76. Ljubljana: Pedagoška fakulteta Univerze v Ljubljani, 2012.

Carbon, Claus-Christian, and Vera Hesslinger. «Attitudes and cognitive distances: On the non-unitary and flexible nature of cognitive maps." $A d$ vances in Cognitive Psychology 9, no. 3 (2013): 121-129. doi: 10.2478/v10053oo8-0140-y.

Flynt, E. Sutton, in William G. Brozo. »It's all about the teacher." The Reading Teacher, 62 (2009): 536-538.

Freeman, Joan. Gifted lives: What happens when gifted children grow up. New York, NY: Routledge, 2010.

Hall, Stuart, ur. Representation: Cultural representations and signifying practices. Vol. 2. London, UK: Sage, 1997.

Huang, Jia-Li. »Cultivating teacher thinking: Ideas and practice. "Educational Research for Policy and Practice 14 (2015): 247-257. doi: https://doi. org/10.1007/s10671-015-9184-1.

IEA. Public attitudes towards gifted education. Pasadena, CA: Institute for Educational Advancement, 2018.

Juriševič, Mojca. »Inkluzivna edukacija nadarjenih učencev v kontekstu izobraževanja učiteljev.« V Inkluzija v sodobni šoli, urednika Dean Hozjan in Marko Strle, str. 253-268. Koper: Univerza na Primorskem, Znanstveno-raziskovalno središče, Univerzitetna založba Annales, 2012b.

Juriševič, Mojca. »Vzgoja in izobraževanje nadarjenih.« V Bela knjiga o vzgoji in izobraževanju v Republiki Sloveniji 2011, urednika Janez Krek in Mira Metljak, str. 329-345. Ljubljana: Zavod Republike Slovenije za šolstvo, 2011.

Juriševič, Mojca. »Zmorem in hočem več: nadarjen učenec pri pouku.« Fizika $v$ šoli, 23, no. 1 (2018): 2-8.

Juriševič, Mojca. Nadarjeni učenci v slovenski šoli. Ljubljana: Univerza v Ljubljani, Pedagoška fakulteta, 2012a.

Loboda, Maruša, Nika Bedek, Urška Žerak, Mojca Juriševič in Janez Vogrinc. »Stališča študentov pedagoških smeri do nadarjenih in njihovega izobraževanja." Didactica Slovenica Pedagoška obzorja 35, no. 1 (2020): 3-20.

Martin, Laurie, Rachel Burns in Matthias Schonlau. »Mental disorders among gifted and nongifted youth: A selected review of the epidemiologic literature.« Gifted Child Quarterly 54 (2010): 31-41. 
Matheis, Svenja, Lena Kristina Keller, Leonie Kronborg, Manfred Schmitt, and Franzis Preckel. "Do Stereotypes Strike Twice? Giftedness and Gender Stereotypes in Pre-Service Teachers' Beliefs about Student Characteristics in Australia." Asia-Pacific Journal of Teacher Education, 2019, 1-20.

Matrić, Maja in Matjaž Duh. »Teachers‘ perceptions of gifted, talented and EBD students.« Didactica Slovenica Pedagoška obzorja 34, no. 2 (2019): $67-81$.

McCoach, D. Betsy in Del Siegle. "What predicts teachers' attitudes toward the gifted." Gifted Child Quarterly 5, no. 3 (2007): 246-255. doi:10.1177/0016986207302719.

Neihart, Maureen. »Identifying and providing services to twice exceptional children."V Handbook of giftedness in children: Psychoeducational theory, research, and best practices, urednik Steven I. Pfeiffer, 115-137. New York, NY: Springer, 2008.

Neihart, Maureen, Sally M. Reis, Nancy M. Robinson in Sidney M. Moon. The social and emotional development of gifted children: What do we know? Waco, TX: The National Association for Gifted Children, 2002.

Ozcan, Deniz. »Predictions and attitudes towards giftedness and gifted education." International Journal of Educational Sciences 15, no. 1-2 (2016): 126133 .

Pajares, Frank. »Teachers' beliefs and educational research: Cleaning up a messy construct." Review of Educational Research 62, no. 3 (1992): 307332.

Pergar Kuščer, Marjanca. "Medkulturne razlike $v$ vrednotah in vrednotnih usmeritvah študentov. "Doktorska dizertacija, Univerza v Ljubljani, Filozofska fakulteta, Ljubljana, 1998.

Preckel, Franzis, Tanja Gabriele Baudson, Sabine Krolak-Schwerdt, and Sabine Glock. »Gifted and maladjusted? Implicit attitudes and automatic associations related to gifted children." American Educational Research Journal 52 (2015): 1160-1184. doi:10.3102/ooo2831215596413.

Ross, Alistair, Barbara Read, Marjanca Pergar Kuščer, Márta Fülöp, Cveta Pučko, Mihály Berkics, Mónika Sándor in Merryn Hutchings. »Teachers' constructions of citizenship and enterprise: Using associative group analysis with teachers in Hungary, Slovenia and England." The New Educational Review 7, 3-4 (2005): 111-139.

Sternberg, Robert J. Cognitive psychology. 5th ed. Belmont, CA: Wadsworth, 2008. 
Sternberg, Robert J. In Scott Barry Kaufman. »Theories and Conceptions of Giftedness." V Handbook of giftedness in children: Psychoeducational theory, research, and best practices, urednik Steven I. Pfeiffer, 29-47. New York, NY: Springer., 2018.

Swanson, Julie Dingle in E. Wayne Lord. »Harnessing and guiding the power of policy: Examples from one state's experiences. "Journal for the Education of the Gifted 36 (2013): 198-219.

Szalay, Lorand B. in Jack E. Brent. »The analysis of cultural meanings through free verbal associations. Journal of Social Psychology 72 (1967): 161-187.

Szymanski, Antonia, Laurie Croft in Brian Godor. »Determining attitudes toward ability: A new tool for new understanding." Journal of Advanced Academics 29, no. 1 (2018): 29-55.

Wilson, Janie H. »Predicting student attitudes and grades from perceptions of instructors' attitudes." Teaching of Psychology 33 (2006): 91-95.

ZOsn - Zakon o osnovni šoli. http://pisrs.si/Pis.web/pregledPredpisa?id=ZA$\mathrm{KO}_{448 .}$

Žagar, Drago, Jana Artač, Tanja Bezič, Mirt Nagy in Sonja Purgaj. Koncept. Odkrivanje in delo z nadarjenimi učenci v devetletni osnovni šoli. Ljubljana: Zavod Republike Slovenije za šolstvo, 1999.

Žagar, Drago. »Metodologija odkrivanja nadarjenih učencev v Sloveniji: zakaj tako in kaj spremeniti."V Posvetovanje Vloga psihologa v vzgoji in izobraževanju nadarjenih, urednici Mojca Juriševič in Božena Stritih, 19-26. Ljubljana: Pedagoška fakulteta Univerze v Ljubljani, 2012.

\section{Priloge}

Spodnji tabeli prikazujeta podrobnejšo primerjavo strukture pojmov nadarjen učenec (Tabela 16) in izobraževanje nadarjenih (Tabela 17) 
Tabela i6: AGA-nadarjen učenec - struktura semantičnih kategorij

\begin{tabular}{|c|c|c|c|c|}
\hline & \multicolumn{2}{|c|}{ Začetni letnik } & \multicolumn{2}{|c|}{ Zaključni letnik } \\
\hline & $f$ & $f \%$ & $f$ & $f \%$ \\
\hline Konceptualizacija nadarjenosti & 359 & $34 \%$ & 296 & $34 \%$ \\
\hline Pameten & 211 & & 119 & \\
\hline Nadpovprečen & 72 & & 78 & \\
\hline Sposoben & 43 & & 16 & \\
\hline Talent & 28 & & 9 & \\
\hline Močna področja & 3 & & 22 & \\
\hline Nadarjen & o & & 21 & \\
\hline Učenec s PP & 2 & & 11 & \\
\hline Dvojna izjemnost & o & & 12 & \\
\hline Gardner & o & & 8 & \\
\hline Področja nadarjenosti & 177 & $17 \%$ & 259 & $29 \%$ \\
\hline Učna uspešnost & 40 & & 84 & \\
\hline Umetnost & 76 & & 44 & \\
\hline Nadarjen na več področjih & 16 & & 57 & \\
\hline Matematika & 17 & & 24 & \\
\hline Nadarjen na enem področju & 14 & & 25 & \\
\hline Šport & 14 & & 15 & \\
\hline Nadarjen na enem ali več področjih & o & & 10 & \\
\hline Učnomotivacijske lastnosti & 238 & $23 \%$ & 143 & $16 \%$ \\
\hline Vedoželjen & 45 & & 41 & \\
\hline Marljiv & 48 & & 25 & \\
\hline Uspešen & 20 & & 26 & \\
\hline Sodeluje pri pouku & 44 & & o & \\
\hline Razgledan & 27 & & 6 & \\
\hline Aktiven & o & & 23 & \\
\hline Spreten & 19 & & o & \\
\hline Zdolgočasen & 8 & & 11 & \\
\hline Organiziran & 4 & & 11 & \\
\hline Nestereotipne lastnosti & 10 & & o & \\
\hline Samostojen & 10 & & o & \\
\hline Nemiren med poukom & 3 & & o & \\
\hline Kognitivne lastnosti & 157 & $15 \%$ & 125 & $14 \%$ \\
\hline Divergentno razmišlja & 53 & & 31 & \\
\hline Ustvarjalen & 35 & & 44 & \\
\hline Hitro dojema & 51 & & 16 & \\
\hline Logično sklepa & 11 & & 26 & \\
\hline Kritičen & 2 & & 8 & \\
\hline Igriv & 5 & & o & \\
\hline Socialno-emocionalne lastnosti & 77 & $7 \%$ & 34 & $4 \%$ \\
\hline Socialno spreten & 48 & & 19 & \\
\hline Asocialen & 10 & & 8 & \\
\hline
\end{tabular}




\begin{tabular}{lcccc} 
& \multicolumn{2}{c}{ Začetni letnik } & \multicolumn{2}{l}{ Zaključni letnik } \\
\hline & $f$ & $f \%$ & $f$ & $f \%$ \\
\hline Vodstven & 13 & & 0 & \\
\hline Perfekcionist & 0 & & 7 & \\
\hline Zadovoljen & 6 & $4 \%$ & 23 & $3 \%$ \\
\hline \multicolumn{1}{c}{ Vidik družbe } & 45 & & 0 & \\
\hline Kritika identifikacije & 22 & & \\
\hline Izkoriščanje ugodnosti & 11 & 11 & \\
\hline Piflar & 0 & 5 & 7 \\
\hline Spregledana nadarjenost & 6 & & 0 \\
\hline Stigmatizacija & 0 & & \\
\hline Pritisk družbe & 6 & & \\
\hline
\end{tabular}

Tabela 17: AGA-izobraževanje nadarjenih - struktura semantičnih kategorij

\begin{tabular}{|c|c|c|c|c|}
\hline & \multicolumn{2}{|c|}{ Začetni letnik } & \multicolumn{2}{|c|}{ Zaključni letnik } \\
\hline & $f$ & $f \%$ & $f$ & $f \%$ \\
\hline Didaktično-metodične prilagoditve & 554 & $49 \%$ & 458 & $47 \%$ \\
\hline Dodatne naloge & 167 & & 50 & \\
\hline Dodatni pouk & 92 & & 106 & \\
\hline Zahtevnejše naloge & 103 & & 48 & \\
\hline Prilagojeno delo & 35 & & 42 & \\
\hline Strategije dela & 17 & & 51 & \\
\hline Tekmovanja & 41 & & 19 & \\
\hline Diferenciacija in individualizacija & o & & 52 & \\
\hline Projektno delo & 23 & & 6 & \\
\hline Skupinsko delo & 23 & & 6 & \\
\hline Individualno delo & 21 & & 7 & \\
\hline Raznolikost dela & 21 & & 7 & \\
\hline IP & 11 & & 16 & \\
\hline Medpredmetno sodelovanje & o & & 18 & \\
\hline Problemske naloge & 14 & & 4 & \\
\hline Kreativne delavnice & 7 & & 10 & \\
\hline Akceleracija & o & & 16 & \\
\hline Negativni vidiki izobraževanja nadarjenih & 125 & $11 \%$ & 161 & $17 \%$ \\
\hline Kritika izvajanja v praksi & 66 & & 113 & \\
\hline Kritika identifikacije & 25 & & 21 & \\
\hline Kritika neenake obravnave & 21 & & o & \\
\hline Preobremenjenost nadarjenih & 8 & & 7 & \\
\hline Neusposobljenost učiteljev & 5 & & 9 & \\
\hline Pretirano poudarjanje & o & & 11 & \\
\hline Okolja & 161 & $14 \%$ & 104 & $11 \%$ \\
\hline Osnovna šola & 39 & & 51 & \\
\hline Obšolske dejavnosti & 51 & & 37 & \\
\hline
\end{tabular}




\begin{tabular}{|c|c|c|c|c|}
\hline & \multicolumn{2}{|c|}{ Začetni letnik } & \multicolumn{2}{|c|}{ Zaključni letnik } \\
\hline & $f$ & $f \%$ & $f$ & $f \%$ \\
\hline Tabori za nadarjene & 24 & & 11 & \\
\hline Študij & 24 & & 5 & \\
\hline Dodatna izobraževanja & 15 & & 0 & \\
\hline Srednja šola, gimnazija & 8 & & o & \\
\hline Kompetentnost za delo $\mathrm{z}$ nadarjenimi & 108 & $9,5 \%$ & 112 & $12 \%$ \\
\hline Zahtevnejše delo učitelja & 45 & & 21 & \\
\hline Učiteljeva priprava & 42 & & 15 & \\
\hline Izziv & o & & 30 & \\
\hline Usposabljanje učiteljev & o & & 26 & \\
\hline Lažje delo učitelja & 12 & & 4 & \\
\hline Šolska svetovalna služba & 9 & & 5 & \\
\hline Pedagoška fakulteta & o & & 11 & \\
\hline Konceptualizacija & 108 & $9,5 \%$ & 72 & $7 \%$ \\
\hline Kultura in umetnost & 45 & & o & \\
\hline Testiranje & 10 & & 28 & \\
\hline Socialno spreten & 13 & & 6 & \\
\hline Močna področja & o & & 18 & \\
\hline Pameten & 16 & & 0 & \\
\hline Samostojnost učenca & 5 & & 8 & \\
\hline Pomembnost & 10 & & 0 & \\
\hline Šolski predmeti & 1 & & 9 & \\
\hline Potencial & 3 & & 3 & \\
\hline Nadarjenost na enem področju & 5 & & 0 & \\
\hline Motivacijske in psihološke spodbude & 69 & $6 \%$ & 50 & $5 \%$ \\
\hline Spodbujanje in podpora & 37 & & 30 & \\
\hline Želje nadarjenih & 25 & & 3 & \\
\hline Višja pričakovanja & 7 & & 17 & \\
\hline Dom in družina & 9 & $1 \%$ & 8 & $1 \%$ \\
\hline Dom in družina & 9 & & o & \\
\hline Vloga staršev & o & & 8 & \\
\hline
\end{tabular}




\section{Vpliv mednarodnega sodelovanja na profesionalni razvoj izobraževalcev odraslih}

\section{Ana Stanovnik Perčič}

\section{Uvod}

Izobraževanje odraslih je področje, ki je na prvi pogled jasno opredeljeno, podrobnejši vpogled pa pokaže široko področje, ki pokriva veliko število skupin odraslih, ki potrebujejo različna znanja in pristope. Izobraževalci odraslih se soočajo z zelo raznolikimi skupinami odraslih, ki jih morajo do/izobraziti, ti odrasli pa imajo zelo različne potrebe in predznanja. Osebje v organizacijah, ki pokriva to področje, v mnogih primerih poleg samega andragoškega dela izvaja še druga dela (npr. organizacijsko, projektno delo). Zato do določene mere obstaja dilema, kdo sploh je izobraževalec odraslih in kakšna znanja naj bi posedoval in posledično nadgrajeval (Čelebič in dr. 2011, Krek, Janez in Metljak, 2011; Mikulec in Stanovnik Perčič, 2019).

Le manjši delež izobraževalcev odraslih se v času dodiplomskega ali podiplomskega študija izobražuje za ta poklic, v večini pa izobraževalci odraslih prihajajo $\mathrm{z}$ različnih strokovnih področij, andragoška znanja pa šele kasneje pridobivajo skozi andragoška izobraževanja, usposabljanja in spopolnjevanja ali na primer z vključitvijo v program za pridobitev pedagoško-andragoške izobrazbe (Možina, 2011).

V Sloveniji za usposabljanje in spopolnjevanje za andragoško delo (tako temeljno, kot specialistično usposabljanje za posebne vloge v andragoškem delu) skrbi Andragoški center Slovenije, v okviru EU pa je nadgrajevanju znanja izobraževalcev in sistema izobraževanja odraslih že od leta 2000 dalje namenjena veja EU programa, ki spodbuja sodelovanje na pod- 
ročju izobraževanja in usposabljanja (trenutno je to program Erasmus+, predhodnik tega programa pa je bil program Vseživljenjsko učenje) (Mikulec in Stanovnik Perčič, 2019).

Erasmus+ je evropski program, ki organizacijam, ki so aktivne na kateremkoli področju izobraževanja in usposabljanja, mladine in športa omogoča pridobitev sofinanciranja za izvajanje projektov, $s$ katerimi se krepi kapaciteta organizacije in prispeva $\mathrm{h}$ kakovosti sistema na nacionalni ravni. Svoje mesto v programu ima tako tudi področje izobraževanja odraslih.

$\mathrm{Ne}$ glede na to, $\mathrm{v}$ katerem tipu projekta organizacija sodeluje, je neobhodno, da se s sodelovanjem $v$ projektu zagotavlja tudi profesionalni razvoj osebja, ki v projektih sodeluje in tako v okviru mednarodnega sodelovanja pridobiva številna znanja in izkušnje. To so lahko povsem konkretna znanja, ki jih izobraževalec potrebuje pri svojem delu, izboljšano znanje tujih jezikov, spoznavanje novih metod dela, lahko pa tudi na primer globje razumevanje družbene, jezikovne in kulturne raznolikosti, sposobnost drugačnega odzivanja na te raznolikosti, spoznavanje drugih izobraževalnih sistemov ...(Evropska komisija, Vodnik za prijavitelje 2019).

CMEPIUS, nacionalna agencija programa Erasmus+ v Sloveniji je izvedla ali sodelovala pri več analizah in študijah, ki so proučevale vpliv sodelovanja osebja organizacij v različnih projektih na področjih izobraževanja in usposabljanja, kot na primer Vmesno nacionalno

poročilo o implementaciji in učinkih programa Erasmus+ (Klemenčič, 2017), Študija učinkov programa Vseživljenjsko učenje na osnovno in srednješolsko izobraževanje $\mathrm{z}$ vidika nacionalnih prioritet (Sentočnik, 2013), Vodenje in učinki mednarodnega sodelovanja kot aktivnosti profesionalnega razvoja strokovnih delavcev v vzgoji in izobraževanju (Zavašnik, Lenc, Slapšak in Šraj, 2019) in druge.

Za področje izobraževanja odraslih smo se odločili analizirati vpliv sodelovanja v EU programu ${ }^{\mathrm{I}}$ na profesionalni razvoj izobraževalcev, pri čemer smo izhajali iz predpostavke, da ima sodelovanje velik učinek na različna področja profesionalnega razvoja tako osebja, kot tudi same organizacije. Kvaliteta organizacij za izobraževanje odraslih je namreč neposredno povezana z usposobljenostjo izobraževalcev (Čelebič in dr. 2011; Krek, Janez in Metljak, 2011).

\section{Metodologija}

$S$ pomočjo kvalitativne in kvantitativne metode smo analizirali smo tri vire.

1 Gre za program Vseživljenjsko učenje (VŽU) in/ali Erasmus+. 
Prvi vir je Vmesno nacionalno poročilo o implementaciji in učinkih programa Erasmus+, ki jo je v vmesni fazi izvajanja programa Erasmus+ pripravilo Ministrstvo za izobraževanje, znanost in šport v sodelovanju z zunanjo ekspertko in CMEPIUS-om. Avtorji so preverjali učinke s pomočjo vprašalnika in polstrukturiranih intervjujev tako na ravni organizacij kot tudi na ravni sistema vzgoje in izobraževanja v Sloveniji. Analiza je med drugim preučevala tudi profesionalni razvoj na področju izobraževanja odraslih. Evalvacija je zajela 301 institucijo s področja izobraževanja odraslih (ljudske univerze, enote izobraževanja odraslih na srednjih šolah, zasebne institucije in druge zavode) in 152 respondentov; od teh so bili za analizo primerni odgovori 89 respondentov, za namen naše analize pa smo upoštevali le odgovore, ki so jih podale ljudske univerze Študija je preučevala učinke programa Erasmus+ na individualni, institucionalni in sistemski ravni. Anketiranci so v odgovoru izbrali eno od treh možnosti: ali je bil učinek na določenem področju negativen, pozitiven ali ga sploh ni bilo (Klemenčič, 2017; Mikulec in Stanovnik Perčič, 2019).

Drugi vir predstavljajo individualna poročila o izvedeni mobilnosti, ki jih izpolni vsak udeleženec projekta Individualna mobilnost posameznikov. Organizacija, prijaviteljica Erasmus+ projekta, mora o vsaki mobilnosti poročati v sistem za poročanje Mobility Tool+, preko katerega se udeležencu mobilnosti avtomatično pošlje vprašalnik, s pomočjo katerega izdela poročilo o svoji mobilnosti. Udeleženec na petstopenjski lestvici (1 - močno se ne strinjam, 5 - močno se strinjam) samooceni pomen mobilnosti na njegov osebni in profesionalni razvoj. Upoštevali smo rezultate vprašalnikov razpisnih let 2014, 2015 in 2016, odgovorilo je 207 posameznikov. Rezultate smo kvantitativno obdelali s programskim paketom SPSS (Mikulec in Stanovnik Perčič, 2019).

Tretji vir pa so ugotovitve polstrukturiranih intervjujev s koordinatoricama projektov na dveh izbranih ljudskih univerzah iz vzhodne slovenske regije o učinkih programa EU (individualna mobilnost, strateška partnerstva) na profesionalni razvoj zaposlenih v organizaciji. Ljudske univerze smo prepoznali kot ključne izvajalke izobraževanja odraslih, saj izvajajo tako formalno kot neformalno izobraževanje za poklicne, osebne ter splošne potrebe. Da bi pridobili zaupanje obeh ljudskih univerz in koordinatoric, smo jima zagotovili anonimnost. Z dovoljenjem obeh ljudskih univerz smo intervjuja posneli z napravo za snemanje zvoka. Posnetke intervjujev smo prepisali in uredili za nadaljnjo obdelavo (Mikulec in Stanovnik Perčič, 2019). 
Vse vire podatkov smo analizirali s treh vidikov. Proučevali smo mnenja respondentov o vplivu sodelovanja izobraževalca ali organizacije v EU projektu na profesionalni razvoj izobraževalca, na razvoj organizacije in na razvoj sistema izobraževanja. Proučevali smo torej tri ravni.

Prva je bila raven izobraževalca, kjer smo proučevali individualno mnenje izobraževalca o vplivu mobilnosti na njegov profesionalni razvoj po izvedeni mobilnosti.

Na drugi ravni, ki smo jo proučevali, to je raven institucije, smo proučevali vpliv sodelovanja v EU projektu na razvoj organizacije. Analizirali smo mnenja anketirancev o pozitivnem vplivu sodelovanja na več področij dela organizacij, na primer na spodbujanje medpredmetnega povezovanja, novih oblik in metod poučevanja, uporabe novih študijskih pripomočkov in gradiv idr.

Tretja raven pa je bila raven sistema izobraževanja v Sloveniji, in sicer smo analizirali mnenja anketirancev o pozitivnem vplivu na kakovost sistema izobraževanja odraslih v Sloveniji (Mikulec in Stanovnik Perčič, 2019).

\section{Rezultati}

Glede na to, da so bili viri analizirani s treh vidikov, smo rezultate strnili v tri sklope in sicer vpliv sodelovanja v EU programu na ravni posameznika, na ravni organizacije in na ravni sistema.

\section{Raven posameznika}

Za raven posameznika smo podatke črpali iz drugega vira. Najmočnejši vpliv je bil identificiran na področju pridobivanja novega znanja o dobrih praksah v tujini (povprečna ocena respondentov 4,6), na področju socialnih, jezikovnih in kulturnih kompetenc izobraževalcev odraslih (povprečna ocena respondentov ocena 4,48), na njihovem profesionalnem področju delovanja (oz. poučevanju) (povprečna ocena respondentov ocena 4,45) in na praktičnih spretnostih, pomembnih za njihov profesionalni razvoj (povprečna ocena respondentov 4,41) (Mikulec in Stanovnik Perčič, 2019).

\section{Raven institucije}

Za raven institucije smo podatke črpali iz prvega vira. $91 \%$ respondentov Vmesnega nacionalnega poročila o implementaciji in učinkih programa Erasmus+, katerih odgovore smo analizirali za potrebe te analize, meni, da 
ima sodelovanje $\mathrm{v}$ programu EU pozitiven vpliv na uporabo novih učnih pripomočkov in gradiv, seznanjenost $\mathrm{z}$ novimi oblikami in metodami poučevanja, uporabo raznolikih oblik in metod poučevanja, usposabljanje izobraževalcev $\mathrm{v}$ znanju tujih jezikov, poznavanje in razumevanje sistemov izobraževanja odraslih $\mathrm{v}$ državah partnericah, poznavanje tujih didaktičnih okolij, motiviranost izobraževalcev za uvajanje sprememb in novosti v poučevanje. (Klemenčič 2017).

\section{Raven sistema}

Za raven sistema smo podatke črpali iz prvega in tretjega vira. $96 \%$ respondentov Vmesnega nacionalnega poročila o implementaciji in učinkih programa Erasmus+, katerih odgovore smo analizirali za potrebe te analize, meni, da sodelovanje $\mathrm{v}$ programu EU pozitivno vpliva na inovacije in razširjanje dobrih praks znotraj Slovenije. 91 \% jih meni, da sodelovanje v programu EU pozitivno vpliva na pospeševanje kakovostnih izboljšav in splošen dvig kakovosti učenja/poučevanja. Med $80 \%$ in $90 \%$ respondentov pa je mnenja, da sodelovanje pozitivno vpliva na internacionalizacijo sistema izobraževanja odraslih, sodelovanje različnih deležnikov (izobraževalcev, odločevalcev, lokalne skupnosti ...), promocijo zavedanja o pomenu vseživljenjskega učenja $\mathrm{v}$ Evropi, podporo nacionalnim politikam izobraževanja odraslih (IO), razširjanje dobrih praks v Evropi in boljšo uporabo orodij EU za preglednost in priznavanje (Klemenčič, 2017). Kvalitativna analiza tretjega vira podatkov je potrdila vse zgoraj navedene ugotovitve, izpostavila pa tudi dve dejstvi, in sicer da so pozitivnih učinkov sodelovanja $\mathrm{v}$ projektu EU deležni predvsem redno zaposleni na organizaciji in ne tudi vsi ostali izobraževalci, ki svoje delo na organizacijo opravljajo v drugih oblikah zaposlitev, in da je ključnega pomena pri prenosu novopridobljenih znanj in izkušenj v redno delo organizacije v veliki mero odvisno od vodstva organizacije. Prenos se namreč ne zgodi, če organizacija mednarodnega udejstvovanja ne dojema kot način dela, ampak kot dodatno dejavnost, kar pa je odvisno od usmeritve vodstva organizacije (Mikulec in Stanovnik Perčič, 2019).

\section{Zaključne ugotovitve}

Povzetek glavnih ugotovitev analize vseh treh virov pove, da sodelovanje $\mathrm{v}$ program EU krepi profesionalni razvoj strokovnih delavcev, prispeva $\mathrm{h}$ krepitvi in posodabljanju didaktičnega znanja, k uporabi tujega jezika in delovanju v mednarodnem (interkulturnem) okolju ter krepi organizacij- 
ske in vodstvene spretnosti in prispeva h kakovosti sistema izobraževanja odraslih na sistemski ravni (ibid.).

Kljub vsem pozitivnim rezultatom pa se izkazuje tudi, da učinek ne dosega vsega osebja v organizaciji v enaki meri. To je skladno z ugotovitvijo, da izobraževalci odraslih večinoma niso redno zaposleni na organizacijah, kjer poučujejo odrasle, ampak na organizacijah, kjer poučujejo mladino ali na drugih organizacijah, delo izobraževalca odraslih pa opravljajo kot dodatno (Čelebič in dr., 2011).

Kljub temu je temeljno sporočilo rezultatov mnenje strokovnih delavcev, da sodelovanje v mednarodnem projektu prispeva tako h kakovosti sistema izobraževanja odraslih kot tudi k njihovemu profesionalnemu razvoju na sistemski ravni (Mikulec in Stanovnik Perčič, 2019).

Tako lahko zaključimo, da sodelovanje $\mathrm{v}$ mednarodnih projektih na področju izobraževanja odraslih predstavlja dodano vrednost za profesionalni razvoj posameznika, kar pa lahko ob podpori vodstva prispeva tudi kakovosti delovanja organizacije.

\section{Literatura}

Možina, Tanja. »Andragoško spopolnjevanje in strokovni razvoj izobraževalcev odraslih«. Andragoška spoznanja, 2011, 17 (4): 23-43.

Krek, Janez in Metljak, Mira. »Bela knjiga o vzgoji in izobraževanju v Republiki Sloveniji«. Ljubljana: Ministrstvo za šolstvo in šport, 2011, str. 369-418. Čelebič, Tanja., Drofenik, Olga., Ivančič, Angelca., Jelenc Krašovec, Sabina., Mohorčič Špolar, Vida. A. in Zver, Eva. »Izobraževanje odraslih v Sloveniji: stanje in izzivi«. Ljubljana: Pedagoški inštitut, 2011.

Mikulec, Borut in Stanovnik Perčič, Ana. »Profesionalni razvoj izobraževalcev odraslih in vloga programa EU«. Ljubljana: CMEPIUS, 2019.

»Strategija vseživljenjskosti učenja v Sloveniji«. Ljubljana: Ministrstvo za šolstvo in šport Republike Slovenije, 2007

Klemenčič, Eva. „Vmesno nacionalno poročilo o implementaciji in učinkih programa Erasmus+«. Ljubljana: CMEPIUS, 2017.

Jelenc Krašovec, Sabina in Mikulec, Borut. »Vpliv evropeizacije izobraževanja na potrženje in poblagovljenje politike in prakse izobraževanja odraslih v Sloveniji«. Andragoška spoznanja 2017, 23 (7): 67-85

»Zakon o izobraževanju odraslih«. Uradni list RS, št. 12/1996. Zakon o izobraževanju odraslih. (2018). Uradni list RS, št. 6/2018. 


\title{
Horizontal learning: Teachers as learners in continuing professional development
} Lela Vuković

\begin{abstract}
Introduction
In modern society, it is more than ever obvious that an era of change has imposed on teachers a necessity to nurture their continuing professional development. A knowledge society demands various new training approaches and new teacher profiles. It seems crucial that teachers should be trained and up to date regarding the latest developments in their professional fields, both through formal and non-formal ways of delivering education programmes. Hence, the traditional conception of a teacher's role is becoming a bit obsolete, and teachers seem to take on a learner's role in teachers' continuing competence development, or as it is often called today - continuing professional development (CPD). In this paper, a special focus will be given to horizontal learning as a useful concept for teachers' CPD and specifically to teachers' forums as an example of CPD. Different topics and ideas that are shared at teachers' forums and which at the same time represent various instructional strategies, methods and techniques as examples of good practice, will be discussed in the methodological part of this paper, through a case study analysis.
\end{abstract}

\section{Teachers' CPD within the educational paradigm shift}

For many years teachers have been considered professionals in the sense that they have a solid theoretical grounding, several years of practical experience within their professional area, and that they are the decisive au- 
thority to choose when and where and how to prepare their work, and teach their students (Knudsen et al., 2011). However, in recent decades a new educational paradigm shift has brought many changes to a teachers' role in the learning community. The authors in this field argue that the emphasis is on new forms of relationships within the learning community, e.g., relationships amongst teachers, colleagues, students and society (Giddens, 1994; Hargreaves, 1994). The authors claim that problems must be solved by creating new professionalism, in which cooperation rather than competition defines the modern teacher's role. Furthermore, it has been suggested that what is needed now, in the new educational paradigm, are the following principles for ,active teacher professionalism' which redefine previous practice - inclusive membership, public ethical code of practice, collaborative and collegial, activist orientation, flexible and progressive, responsive to change, self - regulating, policy active, inquiry-oriented and knowledge building (Sachs, 2003:16). According to the author, these principles refer to the necessity of teaching practice changing towards a more comprehensive and competency-based society. These principles of , active teacher professionalism' imply that new teacher profiles and training approaches within CPD are needed in new learning environments.

\section{Teachers as Learners: how teachers learn}

According to author Dave Meier (2000), and his The Accelerated Learning Handbook, there is a four-phase learning cycle which encompasses:

- preparation: arousing interest

- presentation: encountering the new knowledge or skills

- $\quad$ practice: integrating the new knowledge or skills

- performance: applying the new knowledge and skills

The author claims that unless all four phases of learning are present in one form or another, no real learning occurs. Learning actually deteriorates or stops completely when one of the four stages is not present (Meier, 2000).

Another example of the learning cycle is the well-known Kolb's Learning Cycle (1984), which shows that we learn from our experience of life, even on an everyday basis. According to the author, the process of learning follows a pattern or cycle consisting of four stages: 
- concrete experience: do something

- reflective observation: think about what you did

- abstract conceptualization: make generalizations

- active experimentation: bearing in mind your conclusions

Kumaravadivelu's KARDS model stands for a modular model for knowing, analyzing, recognizing, doing and seeing and refers to a language teacher's education as well as to the way of sharing knowledge and experience through teacher-to-teacher collaboration (Hashamdar \& Etela, 2017). For Kumaravadivelu 'knowing ' is a dynamic concept referring to the process of knowledge building through professional knowledge, procedural knowledge and personal knowledge. 'Analyzing 'is focused on the learner's needs, motivation and autonomy, while 'recognizing 'is based on the importance of recognizing a teacher's identity, beliefs and values which form a teaching self that a teacher brings to the classroom. 'Doing ' in KARDS model refers to the process of transition from a traditional teacher's language to a critical teacher's language and finally 'seeing ' refers to a teachers' ability to make the connection between conceptual knowledge and perceptual knowledge in a classroom (Hashamdar \& Etela, 2017).

With these three aforementioned models of learning, we wanted to emphasize the fact that although learning is about perceiving inputs from the outside, whether it be by reading, listening, observing, and gaining experience from one source or another in the outside world, it is at the same time a complex process that can be achieved by constant reflection and experimentation.

During the learning process, external input is transferred by a teacher, a book or experience through one of two different processes: a) a vertical approach, which represents the traditional situation of an individual (a teacher) who has more knowledge and passes it onto several individuals (students) who have less knowledge; or b) a horizontal approach, in which participants learn together and from one another, and where they can be viewed as experts themselves (Knudsen et al., 2011).

In essence, the horizontal approach seems to be the starting point for horizontal learning, as a useful concept for an effective and efficient framework for teachers' joint learning. Authors from this field claim that in order to be useful and successful, a horizontal learning approach must be based on an appropriate learning environment. In other words, there are pertinent phenomena which characterize a well-functioning learning envi- 
ronment, which in turn ensure horizontal learning while at the same time securing an excellent basis for changing and improving practice. These phenomena are: a) teacher collaboration - providing teachers with opportunities to work and learn together; b) shared power and authority - between teachers and administrators; c) egalitarianism among teachers - status, power and authority; d) variation, challenge, autonomy and choice for teachers in their work; e) organizational goals and feedback mechanisms; f) integration of work and learning; and g) accessibility of external sources of learning (Smylie, 1995:106).

To conclude, there are many reasons for choosing the horizontal approach, one of them being that it involves more experts in the learning process than the vertical approach. Furthermore, in the majority of cases, the learning process is so similar to the practice that it can be used directly. The various benefits of the horizontal approach are easily noticeable in students' educational achievements within their school learning environment as learning is closely linked to teachers' daily practice. Finally, within the horizontal approach, there are many opportunities for teachers to exchange good practice that is of direct relevance for classroom teaching and has lower costs (input) since it can be provided locally, regionally, using internal resources.

\section{Why horizontal learning?}

The concept of horizontal learning is a competence-based connection between theory and practice in the workplace, that is the school learning community. The types of horizontal learning must be carefully selected to be suitable for the learning purpose and must cover activities that will be strategically relevant for the school to spend its resources on. In this way, horizontal learning as an integral part of CPD makes a difference in teachers' competence development while simultaneously enhancing school practice. Furthermore, it is much more cost-effective compared to traditional courses and seminars organized by experts. In short, this type of teachers' competence development could rely on a school's capacities-through lectures, examples of good practice, demonstration lessons or the dissemination of new information using a school's resources and organizing activities such as horizontal learning, i.e., learning from each other (Knudsen et al., 2011).

In addition to well-known teachers' techniques of practice exchanging such as conferences, seminars or mentorships, in modern school prac- 
tice, teacher forums are becoming an effective and efficient instructional technique within the concept of horizontal learning. Teacher forums are a specific technique that allows teachers to share various examples of good practice, clarifies the incoherent points of a subject, arouses the interest of audience/colleague teachers and provides them with active engagement. Various types of continuing professional development could be covered at teacher forums such as a) themes, methods and contents teachers are interested in; b) examples of innovative practice that teachers can offer from their own work; and c) presentation of different theoretical and empirical research data on a relevant school learning community (Gunduz, 2016). As illustrated by the following output, there are many benefits to teacher forums: mutual learning and exchange of good practice is closely linked to teachers' daily practice; forums are hosted locally and based on internal resources; there are a lot of opportunities to exchange good practice and lessons learned, directly relevant for classroom teaching; and finally, teacher forums ensure various improvements in the work of schools, teaching quality, teaching resources and tools.

\section{Methodological framework}

In the methodological part of this paper, we will present relevant qualitative pedagogical research data to exemplify a variety of possible horizontal learning outcomes after teacher forums held at Pavle Savić Technical School in Novi Sad, Serbia during the last school year. The topics discussed at the teacher forums in the first semester were related to project method and project-based learning. Teacher trainers demonstrated the basic principles of project-based learning to their teacher colleagues.

According to the Buck Institute for Education, project-based learning is, ,a systematic teaching method that engages students in learning knowledge and skills through an extended inquiry process structured around complex, authentic questions and carefully designed products and tasks", (BIE, 2012). These postulates have been demonstrated at the teacher forums through project-based teaching lessons in different subjects. Qualitative pedagogical research was conducted at the end of the school year in the form of an open question/semi-structured interview while the research question was defined as follows: Are there any differences in the attitudes of students who apply project-based learning, in the perception of basic teaching variables and learning objectives, in comparison to the practice of them being taught through traditional teaching methods? In that respect, the research 
aim was defined through an analysis of outcomes, from the students' perspective, that teacher forums have on changing school climate especially in the teaching and learning domain. Secondary school students $(\mathrm{N}=60,35=\mathrm{fe}$ male, $25=$ male) were interviewed in order to check the outcomes and possible influences on teaching processes after their teachers implemented and shared new ideas, knowledge and methods acquired at teacher forums. In this case study, several examples of students' narratives will be presented and analyzed, which refer to project-based teaching and learning, as applied during lessons from different subjects, some of which were general level subjects (English, geography, history, chemistry, physics) while others were vocational subjects (chemical technology, environmental protection, food production technology). Some of the interview questions posed to the interviewees were as follows: Describe your role in the teaching process while learning through the project method of teaching; Describe your teacher's style while teaching according to the project-based method; Can you implement the knowledge, beliefs and values gained through the project method of teaching to your everyday life; and, How would you describe the main difference between project-based teaching and traditional teaching methods?

Content analysis usually refers to analyzing text, therefore, in this paper, we applied thematic deductive analysis when analyzing students' narratives. The deductive analysis was applied and the data were examined according to a previously formed framework, developing possible categories, patterns and themes. This is often called ,open coding' (Strauss and Corbin 1998:223) and for this research, we established five categories according to the teaching variables and learning objectives examined through the form of an open question/semi-structured interview. These five categories have been defined as follows: 1. Learner's role; 2 . Teacher's role \& teacher's style; 3. Interdisciplinary learning in the project-based approach; 4. Competency-based learning stimulated in the project-based approach; and 5. Key differences between traditional teaching approaches and the project-based method. The categories have been perceived as a possible learning and teaching field where a change to the previous teaching and learning practice can be observed and analyzed as it refers to and is reflected on the three aforementioned models of learning, Meier's, Kolb's and Kumaravadivelu's.

\section{Results}

Quality analysis of data/students' narratives has shown that students highly value and assess teaching and learning in project-based method, as per- 
tains to attendance, motivation and empowerment for learning and being taught according to that teaching strategy, compared to traditional teaching methods. A thematic deductive analysis illustrated numerous differences in the attitudes of students who apply project-based learning, in their perception of basic teaching variables and learning objectives, as opposed to students taught using traditional teaching methods. For illustration purposes, some of the students' answers will be presented according to the examined teaching variables and learning objectives.

\section{Learner's role}

Student 8: I am always highly motivated to take part in a project-based task because I know exactly what I am supposed to do. I like to be part of a team while doing a project, and it's not unusual for me to choose to be the „leader". In projects, you simply cannot choose to do any other thing because if you miss the chance to finish your task, or don't respect the deadlines, your group will lose.

\section{Teacher's role \& teacher's style}

Student 12: Teachers seem to be our „friends on the same task “ while we are doing project assignments in some subjects (e.g. English). I like working and learning this way because I am sure that I have the support of both the teacher and my classmates. I respect and, to be honest, enjoy sending and receiving emails from my teacher referring to my responsibilities, terms, and everything else related to the project we are working on at the time. Teachers are not as strict while we are preparing our projects.

Student 4: I really like learning and preparing projects, primarily because we are able to use extra materials from different sources such as the Internet, libraries, etc., (not only our student's book) while getting ready for our final PowerPoint presentation, or panel discussion on the project topic/ subject. I like to make a personal contribution to the starting idea in a project and I know that my teacher and my classmates will accept it. For some reason, when it comes to projects, all ideas and different creative approaches are welcome and students know that their work and diligence will be respected. 


\section{Interdisciplinary learning in a project-based approach}

Student 7: It seems that everything depends on the project topic that we are working on, but I am sure that we can always apply the various knowledge we have acquired from all the different subjects. For example, we have been preparing an English project on coming of age in Japan. In order to do our best, we connected various content, and our knowledge from different subjects such as geography, history and sociology, especially in the part which talked about Japanese cultural elements, heritage, habits and mythology.

\section{Competency-based learning stimulated in the project-based approach}

Student 25: We did a project assignment for technology production of raw materials for pharmaceutical products. What I found so interesting and important was that some of the plants we were studying were poisonous and my family used to have them at home. I was able to apply this new knowledge to my daily life and my actual surroundings.

Student 6: The project we did for physics, called Oscillation, actually illustrated how my guitar strings produce vibrations and showed how an old pendulum clock at my grandfather's cottage worked... It was very significant for me because it allowed me to explain these phenomena through the formulae we learned while doing the project. The only example I was able to give before we started the project was that of my childhood swing.

\section{Key differences between traditional teaching approaches and the project-based method}

Student 31: Whenever we do a project, it seems to me that teaching and learning become more interesting while at the same time helping us express our creativity without being pressured to fit into a 45-minute lesson, as is the case in traditional classes.

Student 28: It seems that all of us are equally involved in teaching and learning while doing projects because if we want to finish our project we have to work together. It fosters teamwork and somehow you feel more comfortable and sure that the job will be done properly.

\section{Reflection on student answers}

As far as the first category, a learner's role, is concerned, a dominant pattern appeared in the students' narratives of them being aware of the importance of constructing knowledge out of a new learning strategy, as well as 
the importance of being a member of a team and completing the assignments on time. The students' perspective, on doing project work, is in line with the three learning cycle models and our hypothesis regarding the altered teacher's and learner's role in a new paradigm shift. The same is true for the second examined category of teacher's role and teacher's style with a dominant pattern emerging regarding positive classroom management, and an atmosphere which is conducive to stimulating students' personal contribution in the joint assignment and a team. As for the third category of interdisciplinary learning in the project-based approach, a dominant pattern emerged in the students' narratives regarding the significance of applying a cross-curricular approach which enhances students' motivation, arouses their interest in the subject matter by encountering new knowledge or skills and then integrating and applying that knowledge into a new context. The third examined category also confirmed our hypothesis that, according to the students' perception, the project-based method was more likely to foster learning and teaching than traditional teaching methods. The same is true for the fourth examined category of competency-based learning stimulated in a project-based approach where the dominant pattern which emerged, according to the students' perception, was that these projects were connected to real life and that they built up their competences and skills. Finally, the fifth examined category which summed up the key differences between traditional teaching approaches and the project-based method confirmed our hypothesis that students favoured learning and teaching according to the project-based method, as opposed to traditional teaching methods, which was illustrated by their positive attitudes, values and preferences.

\section{Conclusion}

The aim of this paper was to set out the basic frameworks for horizontal learning and to exemplify how some of the variations of this shared learning concept could enhance teachers' CPD. What we primarily focused on was that teachers could be both teachers and learners in their learning environments and that they could learn together and from one another, rather than from an external expert, through the horizontal learning concept. Teacher forums have been presented as a specific technique that gives teachers the opportunity to share various examples of good practice. As a whole, there are many benefits to teacher forums, some of which are examples of an exchange of good practice, directly relevant for classroom teaching practice 
and shown through the pedagogical qualitative research into students' perception of a novel teaching practice. We believe that further pedagogical research, of teachers' perspectives and attitudes or a self-assessment of teacher forums and possible benefits or obstacles to the same, would inevitably lead to broadening the teaching and learning horizon through the application of the horizontal learning concept in educational processes.

\section{Literature}

Giddens, Anthony. Beyond left and right: The future of radical politics, Oxford: Polity Press, 1994.

Gunduz, Feryal. „Instructional Techniques“. In Instructional Process and Concept in Theory and Practice. Improving the Teaching Process, edited by Akdeniz Celal, 147-233. N.p.: Singapore: Sprinser, 2016.

Hargreaves, Andy. Changing teachers, changing times: teachers work and culture in the postmodern age, London: Continuum, 1994.

Hashamdar, Mohammad, and Etela, Parisa. „A review of language teacher educations for a global society: A modular models for knowing, analyzing, recognizing, doing and seeing. „Modern Journal of Language Teaching Methods 7, no. 7(2017): 281-284.

Knudsen, Hans Jorgen et al. „Horizontal learning: A promising strategy for teachers' continuing professional development.“ In Learning from „Learn“ Horizontal learning in a community of practice in south eastern Europe, edited by Nielsen Soren, 31-39. N.p.: Luxembourg: Publication Office of EU, 2011.

Kolb, David. Experiential learning: experience as the source of learning and development. Englewood Cliffs (N.Y.): Prentice Hall, 1984.

Meier, Dave. The Accelerated Learning Handbook. New York: McGraw-Hill, 2000.

Sachs, Judyth. The activist teaching profession. New York: Open University Press, 2003.

Smylie, Mark A. „Teacher learning in the workplace." In Professional Development in Education. New Paradigms and Practices, edited by Guskey Thomas R. and Huberman Michael, 92-113.N.p.: New York: Teachers College Press, 1995.

Strauss, Anselm and Juliet Corbin. Basics of Qualitative Research: Techniques and Procedures for developing Grounded Theory. 2d.ed.Thousand Oaks, CA: Sage,1998. 


\section{Sources}

Buck Institute for Education. „Project-based learning for the 21st century.“ Accessed December 12, 2018. http://www.bie.org/about/what is pbl. 

socialni odnosi $v$ vzgoji in

izobraževanju 



\title{
Zaznava samoučinkovitosti učiteljev učencev $\mathrm{z}$ učnimi ter čustvenimi in vedenjskimi težavami
}

Maja Kuronja, Majda Schmidt Krajnc

\begin{abstract}
Uvod
Vključevanje učencev $\mathrm{z}$ učnimi ter čustvenimi in vedenjskimi težavami (UČVT) v redne osnovne šole zahteva od učiteljev spremembe v pristopih in načinih vzgojno-izobraževalnega dela (Sharma et al., 2012). Številne raziskave potrjujejo, da so učne ter čustvene in vedenjske težave soodvisno povezane. Vedenjska in čustvena odstopanja so lahko namreč sredstvo za prikrivanje učne neuspešnosti. Ali pa otrok ni zmožen obvladovanja lastnega vedenja in slabše pridobiva na učnem področju ter ima izrazite težave na področju socializacije (Bender, 2008; Payne et al., 2007; Kobolt 2008). Učenci z UČVT imajo pogosto slabe učne in delovne navade, kratkotrajno pozornost, omejen interes za šolo in učenje, njihova čustvena zrelost je šibka, prav tako se javljajo težave $\mathrm{v}$ socialnih odnosih $\mathrm{z}$ učitelji in vrstniki (Bender, 2008; Schmidt in Čreslovnik, 2010). V razredu pogosto motijo/ prekinjajo vzgojno-izobraževalni proces, ali sedijo tiho in niso vključeni $\mathrm{v}$ pouk (Nickerson in Brosof, 2003). Nedvomno je učiteljevo prepričanje o njegovi vlogi in odgovornosti vključevanja učencev s posebnimi potrebami $\mathrm{k}$ rednemu pouku in učinkovitosti poučevanja osrednjega pomena za uspešen vzgojno-izobraževalni proces (Jordan et al., 2009). Prav učenci z UČVT predstavljajo učiteljem največji izziv, pogosto čutijo razočaranje in nezadostnost, pa tudi krivdo za otrokove primanjkljaje in neuspehe (Gidlund in Boström, 2017). V razredih $\mathrm{z}$ učenci $\mathrm{z}$ UČVT se učitelji vsakodnevno srečujejo s situacijami, ki jim znižujejo občutek učinkovitosti.
\end{abstract}


$\mathrm{V}$ empirični raziskavi nas je zanimala stopnja zaznavanja samoučinkovitosti pri slovenskih osnovnošolskih učiteljih, ki poučujejo otroke z UČVT iz šolskega okoliša in učiteljih, ki poučujejo otroke, ki bivajo v vzgojnem zavodu. Osredotočili smo se na zaznavanje samoučinkovitosti na področju učenčevega sodelovanja, na področju poučevanja in na področju vodenja razreda, glede na šolo poučevanja.

Raziskave potrjujejo (Johnson-Harris in Mundschenk, 2014; Malinen et al., 2012; Tournaki in Podell, 2005), da je učinkovitost učiteljev ključna kompetenca za poučevanje v inkluzivnih razredih. Stopnja učiteljeve učinkovitosti pa je napovednik njegove večje pripravljenosti za delo $\mathrm{z}$ otroki, ki kažejo težave, primanjkljaje (Tschannen-Moran et al., 1998).

\section{Metodologija}

Raziskava temelji na deskriptivni in kavzalni neeksperimentalni metodi empiričnega pedagoškega raziskovanja.

$\mathrm{V}$ raziskavo so bili vključeni slovenski osnovnošolski učitelji, ki poučujejo otroke z UČVT iz šolskega okoliša, ter učitelji osnovnih šol, ki poučujejo otroke, ki bivajo v vzgojnem zavodu.

Zaradinizkegaodzivaučiteljevotrok,kibivajovvzgojnem zavodu(n=81), smo za potrebe raziskave, iz vzorca učiteljev, ki poučujejo na rednih osnovnih šolah ( $n=429)$, izbrali 81 učiteljev čim bolj izenačenih $z$ učitelji, ki poučujejo na osnovnih šolah, pri vzgojnih zavodih. Vzorec smo izenačili po spolu, starosti in regiji, za vsako skupino 81 učiteljev, skupno torej 162 učiteljev. Zajeti neslučajnostni namenski vzorec opredeljujemo na nivoju rabe inferenčne statistike kot enostavni slučajnostni vzorec iz hipotetične populacije.

Podatke za raziskavo smo zbirali s pomočjo spletnega anketnega vprašalnika.

Osredotočili smo se na zaznavanje samoučinkovitosti na področju učenčevega sodelovanja, na področju poučevanja in na področju vodenja razreda. Zanimale so nas razlike med učitelji glede na šolo poučevanja. Uporabili smo vprašalnik avtoric Tschannen-Moran in Woolfolk Hoy (2001), sestavlja ga 24 trditev, učitelji so zaznavanje samoučinkovitosti označili na devetstopenjski lestvici. Trditve smo po navodilih avtoric združili v skupine za zaznavanje samoučinkovitosti na področju učenčevega sodelovanja, na področju poučevanja in na področju vodenja razreda. 
Zanesljivost vprašalnika smo preverili s Cronbachovim koeficientom alfa, ki znaša $(\alpha=0,952)$ za ocenjevalno lestvico o učinkovitosti učiteljev.

Objektivnost smo zagotovili z jasnimi in enopomenskimi trditvami in postavkami, kar omogoča objektivno razbiranje odgovorov.

Podatki so statistično obdelani s pomočjo statističnega programskega paketa SPSS, na ravni deskriptivne (frekvenčne distribucije) in inferenčne (Mann-Whitneyev preizkus) statistike.

\section{Rezultati in ugotovitve}

\section{Učinkovitost učiteljev pri učenčevem sodelovanju glede na šolo}

Tabela i8: Izid Mann-Whitneyevega preizkusa razlik v samooceni učinkovitosti učiteljev pri učenčevem sodelovanju glede na šolo poučevanja

\begin{tabular}{|c|c|c|c|c|}
\hline Trditve & Poučevanje na & & $\mathrm{U}$ & $\mathrm{P}$ \\
\hline \multirow{2}{*}{$\begin{array}{l}\text { 1. Koliko lahko Vi osebno storite, da vzpostavite stik } \\
\text { z najbolj težavnimi učenci, ki kažejo učne in vedenj- } \\
\text { ske težave? }\end{array}$} & OŠ & 6,47 & \multirow[b]{2}{*}{3063,000} & \multirow[t]{2}{*}{, 457} \\
\hline & $\begin{array}{l}\text { OŠ, ki je del } \\
\text { VZ }\end{array}$ & 6,67 & & \\
\hline \multirow{2}{*}{$\begin{array}{l}\text { 2. Koliko lahko pomagate učencem z učnimi in ve- } \\
\text { denjskimi težavami pri razvijanju kritičnega miš- } \\
\text { ljenja? }\end{array}$} & OŠ & 5,75 & \multirow[b]{2}{*}{3261,000} & \multirow[t]{2}{*}{, 946} \\
\hline & $\begin{array}{l}\text { OŠ, ki je del } \\
\text { VZ }\end{array}$ & 5,75 & & \\
\hline \multirow{2}{*}{$\begin{array}{l}\text { 4. Koliko lahko storite, da motivirate učence z učni- } \\
\text { mi in vedenjskimi težavami, ki za šolsko delo ne ka- } \\
\text { žejo veliko zanimanja? }\end{array}$} & OŠ & 5,73 & \multirow[b]{2}{*}{2695,000} & \multirow[t]{2}{*}{, 044} \\
\hline & $\begin{array}{l}\text { OŠ, ki je del } \\
\text { VZ }\end{array}$ & 6,06 & & \\
\hline \multirow{2}{*}{$\begin{array}{l}\text { 6. Koliko lahko storite, da učenci z učnimi in ve- } \\
\text { denjskimi težavami verjamejo, da so pri šolskem } \\
\text { delu lahko uspešni? }\end{array}$} & OŠ & 6,28 & \multirow[b]{2}{*}{2402,000} & \multirow[t]{2}{*}{, 002} \\
\hline & $\begin{array}{l}\text { OŠ, ki je del } \\
\text { VZ }\end{array}$ & 6,89 & & \\
\hline \multirow{2}{*}{$\begin{array}{l}\text { 9. Koliko lahko Vi osebno storite, da učenci z učni- } \\
\text { mi in vedenjskimi težavami razumejo pomen, vred- } \\
\text { nost učenja? }\end{array}$} & OŠ & 5,77 & \multirow[b]{2}{*}{3277,000} & \multirow[t]{2}{*}{, 990} \\
\hline & $\begin{array}{l}\text { OŠ, ki je del } \\
\text { VZ }\end{array}$ & 5,85 & & \\
\hline \multirow{2}{*}{$\begin{array}{l}\text { 12. Koliko lahko Vi sami storite za spodbujanje } \\
\text { ustvarjalnosti pri učencih z učnimi in vedenjskimi } \\
\text { težavami? }\end{array}$} & OŠ & 6,36 & \multirow[b]{2}{*}{2766,500} & \multirow[t]{2}{*}{, 074} \\
\hline & $\begin{array}{l}\text { OŠ, ki je del } \\
\text { VZ }\end{array}$ & 6,77 & & \\
\hline \multirow{2}{*}{$\begin{array}{l}\text { 14. Koliko lahko storite za izboljšanje razumevanja } \\
\text { učnih vsebin pri učencu } \mathrm{z} \text { učnimi in vedenjskimi te- } \\
\text { žavami, ki ne dosega minimalnih ciljev? }\end{array}$} & OŠ & 5,8 & \multirow[b]{2}{*}{2711,000} & \multirow[t]{2}{*}{, 050} \\
\hline & $\begin{array}{l}\text { OŠ, ki je del } \\
\text { VZ }\end{array}$ & 6,30 & & \\
\hline \multirow{2}{*}{$\begin{array}{l}\text { 22. Koliko lahko storite glede pomoči družinam } \\
\text { učencev z učnimi in vedenjskimi težavami, da le-te } \\
\text { pripomorejo k boljšim dosežkom v šoli? }\end{array}$} & OŠ & 5,14 & \multirow[b]{2}{*}{2271,500} & \multirow[t]{2}{*}{,001 } \\
\hline & $\begin{array}{l}\text { OŠ, ki je del } \\
\text { VZ }\end{array}$ & 4,27 & & \\
\hline
\end{tabular}

V samooceni učinkovitosti učiteljev pri učenčevem sodelovanju se statistično značilno višje ocenjujejo učitelji, ki poučujejo na OŠ pri vzgojnem zavodu, prav tako pri motiviranju učencev z UČVT $(\mathrm{P}=0,044)$, pri spod- 
bujanju samozaznave šolske uspešnosti pri učencih $(\mathrm{P}=0,002)$ ter pri izboljšanju razumevanja učnih vsebin pri učencih, ki ne dosegajo minimalnih standardov $(\mathrm{P}=0,050)$. Tendenca $\mathrm{v}$ korist učiteljev OŠ pri vzgojnem zavodu se kaže tudi pri učinkovitosti spodbujanja ustvarjalnosti teh učen$\operatorname{cev}(\mathrm{P}=0,074)$. Učitelji, ki poučujejo na OŠ, se zaznavajo učinkovitejši le pri postavki o pomoči družinam učencev $\mathrm{z}$ učnimi in vedenjskimi težavami ( $\mathrm{P}$ = o,oo1). Dejstvo je, da so po Pravilniku o normativih in standardih (2018, 31. člen) v oddelkih OŠ pri vzgojnem zavodu skupine manjše. Menimo, da je tako v ospredju bolj osebni odnos do učencev, učitelji se bolj prilagodijo učenčevim potrebam in dajejo večji poudarek razvoju socialne vključenosti in pozitivne samopodobe. Tako lahko učenci čutijo, da je učitelju mar zanje, za njihove dosežke (Pšunder, 2011). Dober odnos med učiteljem in učencem ima pomemben vpliv na boljše učne dosežke učenca, na šolsko angažiranost, na bolj produktivno vedenje in na razvoj socialnih spretnosti (Goodmann in Burton 2010; Nash et al., 2016; Rapuš Pavel 2010). Odnos učitelja do učenca in učenčevih značilnosti pomembno vplivajo tudi na učiteljevo občutenje učinkovitosti (Tournaki in Podell, 2005). V teh oddelkih so učenci s podobnimi težavami, skupine so nekoliko bolj homogene in učenci na nekaterih področjih ne izstopajo tako zelo, kot bi na primer v oddelkih rednih osnovnih šol. Učitelji, ki poučujejo na OŠ, izražajo višjo učinkovitost glede pomoči družinam učencev $\mathrm{z}$ učnimi in vedenjskimi težavami. Upoštevati je potrebno, da otroci ostajajo v svojem primarnem okolju. Učiteljem je tako omogočen določen, sicer omejen pogled na kulturno in socialno ekonomsko ozadje otrokove družine, četudi starši (največkrat) slabše ali sploh ne sodelujejo s šolo (Muijs in Reynolds, 2010). So pa svetovalni delavci na šolah tisti, ki iščejo načine sodelovanja s starši, se povezujejo z zunanjimi ustanovami ter posredujejo učiteljem vse potrebne informacije o družini ter jim svetujejo. Na drugi strani pa učitelji otrok, ki bivajo $\mathrm{v}$ vzgojnem zavodu nimajo stikov $\mathrm{z}$ otrokovimi starši, saj to vlogo prevzamejo

vzgojitelji otrok v vzgojnih zavodih in mladinskih domovih. Tako je rezultat, da se učitelji na OŠ pri vzgojnem zavodu, čutijo najmanj učinkoviti na področju pomoči družinam, pričakovan.

\subsection{Učinkovitost učiteljev pri poučevanju glede na šolo}

Statistično značilna razlika zaznavanja samoučinkovitosti pri poučevanju glede na šolo poučevanja je le v eni postavki. Učitelji, ki poučujejo na OŠ pri vzgojnem zavodu, se čutijo učinkovitejši z vidika ocene razumevanja 
Tabela 19: Izid Mann-Whitneyevega preizkusa razlik v samooceni učinkovitosti učiteljev pri poučevanju glede na šolo poučevanja

\begin{tabular}{|c|c|c|c|c|}
\hline Trditve & Poučevanje na & & $\mathrm{U}$ & $\mathrm{P}$ \\
\hline \multirow{2}{*}{$\begin{array}{l}\text { 7. Koliko lahko storite glede Vašega osebnega odziva } \\
\text { na težka oziroma zahtevna vprašanja učencev z uč- } \\
\text { nimi in vedenjskimi težavami? }\end{array}$} & OŠ & 6,36 & \multirow[b]{2}{*}{2823,500} & \multirow[t]{2}{*}{, 117} \\
\hline & $\begin{array}{l}\text { OŠ, ki je del } \\
\text { VZ }\end{array}$ & 6,68 & & \\
\hline \multirow{2}{*}{$\begin{array}{l}\text { 10. Koliko lahko storite glede ocene razumevanja } \\
\text { poučevane učne snovi pri učencu z učnimi in vedenj- } \\
\text { skimi težavami? }\end{array}$} & OŠ & 5,93 & \multirow[b]{2}{*}{2660,000} & \multirow[t]{2}{*}{, 027} \\
\hline & $\begin{array}{l}\text { OŠ, ki je del } \\
\text { VZ }\end{array}$ & 6,25 & & \\
\hline \multirow{2}{*}{$\begin{array}{l}\text { 11. Koliko lahko Vi osebno storite, da oblikujete } \\
\text { ustrezna vprašanja za učence } \mathrm{z} \text { učnimi in vedenjski- } \\
\text { mi težavami? }\end{array}$} & OŠ & 6,78 & \multirow[b]{2}{*}{2892,000} & \multirow[t]{2}{*}{, 179} \\
\hline & $\begin{array}{l}\text { OŠ, ki je del } \\
\text { VZ }\end{array}$ & 7,10 & & \\
\hline \multirow{2}{*}{$\begin{array}{l}\text { 17. Koliko lahko Vi osebno naredite glede prilagodi- } \\
\text { tve pouka za vsakega posameznega učenca z učnimi } \\
\text { in vedenjskimi težavami? }\end{array}$} & OŠ & 6,14 & \multirow[b]{2}{*}{3137,000} & \multirow[t]{2}{*}{, 614} \\
\hline & $\begin{array}{l}\text { OŠ, ki je del } \\
\text { VZ }\end{array}$ & 6,23 & & \\
\hline \multirow{2}{*}{$\begin{array}{l}\text { 18. Koliko različnih ocenjevalnih strategij lahko } \\
\text { uporabite pri učencih z učnimi in vedenjskimi teža- } \\
\text { vami? }\end{array}$} & OŠ & 5,83 & \multirow[b]{2}{*}{2935,500} & \multirow[t]{2}{*}{, 235} \\
\hline & $\begin{array}{l}\text { OŠ, ki je del } \\
\text { VZ }\end{array}$ & 5,63 & & \\
\hline \multirow{2}{*}{$\begin{array}{l}\text { 2o. Koliko lahko storite glede tega, da učencem } \mathrm{z} \text { uč- } \\
\text { nimi in vedenjskimi težavami zagotovite alternativ- } \\
\text { no (drugačno) razlago ali primere, ko česa ne razu- } \\
\text { mejo? }\end{array}$} & OŠ & 6,07 & \multirow[b]{2}{*}{2854,000} & \multirow[t]{2}{*}{, 140} \\
\hline & $\begin{array}{l}\text { OŠ, ki je del } \\
\text { VZ }\end{array}$ & 6,43 & & \\
\hline \multirow{2}{*}{$\begin{array}{l}\text { 23. Koliko lahko storite glede vključevanja alterna- } \\
\text { tivne (drugačne) strategije poučevanja za učence z } \\
\text { učnimi in vedenjskimi težavami? }\end{array}$} & OŠ & 5,67 & \multirow[b]{2}{*}{3223,500} & \multirow[t]{2}{*}{, 844} \\
\hline & $\begin{array}{l}\text { OŠ, ki je del } \\
\text { VZ }\end{array}$ & 5,67 & & \\
\hline \multirow{2}{*}{$\begin{array}{l}\text { 24. Koliko lahko Vi osebno obvladujete moteče/ } \\
\text { neprimerno vedenje pri nadarjenih/zelo sposobnih } \\
\text { učencih? }\end{array}$} & OŠ & 6,259 & \multirow[b]{2}{*}{2965,000} & \multirow[t]{2}{*}{, 277} \\
\hline & $\begin{array}{l}\text { OŠ, ki je del } \\
\text { VZ }\end{array}$ & 6,457 & & \\
\hline
\end{tabular}

poučevane učne snovi pri učencih $\mathrm{z}$ učnimi in vedenjskimi težavami ( $\mathrm{P}$ $=0,027)$. Število otrok v oddelku jim omogoča lažje sprotno preverjanje razumevanja obravnavane učne snovi in izvajanje specifičnih prilagoditev vzgojno-izobraževalnega procesa. Ob tem pa je za učence z UČVT zelo pomembna dobra metodično-didaktična pripravljenost učitelja (Schmidt in Čagran, 2005). Pri poučevanju učencev z UČVT je izjemnega pomena fleksibilna individualizacija in diferenciacija ter sprotna pozitivna podkrepitev vedenja, ki lahko doprinese $\mathrm{k}$ boljšim učnim dosežkom teh učencev (Bouillet, 2013; Itković, 1998). Pri vseh drugih postavkah (osebni odziv na zahtevna vprašanja učencev, oblikovanje ustreznih vprašanj, prilagoditve pouka, uporaba različnih ocenjevalnih strategij, zagotovitev alternativne razlage, vključevanja alternativnih strategij poučevanja, obvladovanje motečega vedenja pri nadarjenih učencih) ni statistično značilnih razlik pri poučevanju učiteljev glede na šolo poučevanja $(\mathrm{P}>0,117<0,844)$. 


\subsection{Učinkovitost učiteljev pri vodenju razreda glede na šolo}

Tabela 20: Izid Mann-Whitneyevega preizkusa razlik v samooceni učinkovitosti učiteljev pri vodenju razreda glede na šolo poučevanja

\begin{tabular}{|c|c|c|c|c|}
\hline Trditve & Poučevanje na & & $\mathrm{U}$ & $\mathrm{P}$ \\
\hline \multirow{2}{*}{$\begin{array}{l}\text { 3. Koliko lahko storite glede nadzorovanja motečega } \\
\text { vedenja v razredu? }\end{array}$} & OŠ & 5,96 & \multirow{2}{*}{2500,500} & \multirow[t]{2}{*}{,007 } \\
\hline & OŠ, ki je d & 6,51 & & \\
\hline \multirow{2}{*}{$\begin{array}{l}\text { 5. Koliko lahko storite glede oblikovanja jasnih pri- } \\
\text { čakovanj o učencih z učnimi in vedenjskimi težava- } \\
\text { mi? }\end{array}$} & OŠ & 5,98 & \multirow[b]{2}{*}{2815,000} & \multirow[t]{2}{*}{, 104} \\
\hline & OŠ, ki je del VZ & 6,35 & & \\
\hline \multirow{2}{*}{$\begin{array}{l}\text { 8. Koliko lahko storite glede vzpostavljanja rutine, } \\
\text { da dejavnosti učencev z učnimi in vedenjskimi teža- } \\
\text { vami potekajo nemoteno? }\end{array}$} & OŠ & 5,93 & \multirow[b]{2}{*}{2253,500} & \multirow[t]{2}{*}{, } \\
\hline & OŠ, ki je del VZ & 6,77 & & \\
\hline \multirow{2}{*}{$\begin{array}{l}\text { 13. Koliko lahko storite, da učenci z učnimi in ve- } \\
\text { denjskimi težavami upoštevajo razredna pravila? }\end{array}$} & OŠ & 5,95 & \multirow{2}{*}{2443,500} & \multirow[t]{2}{*}{,o03 } \\
\hline & $\mathrm{OŠ}, \mathrm{k}$ & 6,53 & & \\
\hline \multirow{2}{*}{$\begin{array}{l}\text { 15. Koliko lahko Vi sami storite, da pomirite učen- } \\
\text { ca z učnimi in vedenjskimi težavami, ko je moteč ali } \\
\text { glasen? }\end{array}$} & OŠ & 5,84 & \multirow[b]{2}{*}{2773,000} & \multirow[t]{2}{*}{, 078} \\
\hline & OŠ, ki je del VZ & 6,10 & & \\
\hline \multirow{2}{*}{$\begin{array}{l}\text { 16. Koliko lahko storite glede vodenja različnih sku- } \\
\text { pin učencev v razredu? }\end{array}$} & OŠ & 6,05 & \multirow{2}{*}{3272,500} & \multirow[t]{2}{*}{, 978} \\
\hline & OŠ, ki je & 6,00 & & \\
\hline \multirow{2}{*}{$\begin{array}{l}\text { 19. Koliko lahko Vi sami storite za to, da razred, v } \\
\text { katerega so vključeni učenci } z \text { učnimi in vedenjskimi } \\
\text { težavami, ustrezno usmerjate in vodite? }\end{array}$} & OŠ & 6,22 & \multirow[b]{2}{*}{3218,500} & \multirow[t]{2}{*}{, 826} \\
\hline & OŠ, ki je del VZ & 6,25 & & \\
\hline \multirow{2}{*}{$\begin{array}{l}\text { 21. Koliko lahko storite glede Vašega odziva na klju- } \\
\text { bovanje učencev z učnimi in vedenjskimi težavami? }\end{array}$} & OŠ & 6,04 & \multirow{2}{*}{2588,500} & \multirow[t]{2}{*}{, 017} \\
\hline & OŠ, ki je & 6,56 & & \\
\hline
\end{tabular}

Obstoj statistično značilnih razlik v učinkovitosti učiteljev pri vodenju razreda glede na šolo poučevanja smo ugotovili pri nadzorovanju motečega vedenja $\mathrm{v}$ razredu $(\mathrm{P}=0,007)$, pri vzpostavljanju rutine, da dejavnosti učencev $\mathrm{z}$ učnimi in vedenjskimi težavami potekajo nemoteno $(\mathrm{P}=$ $\mathrm{o}, 000$ ), pri doseganju, da učenci $\mathrm{z}$ učnimi in vedenjskimi težavami upoštevajo razredna pravila $(\mathrm{P}=0,003)$ ter pri osebnem odzivu na kljubovanje učencev $\mathrm{z}$ učnimi in vedenjskimi težavami. Tendenca statistično značilne razlike se kaže tudi pri postavki o umiritvi učenca $\mathrm{z}$ učnimi in vedenjskimi težavami, ko je ta moteč ali glasen $(\mathrm{P}=0,078)$. V vseh omenjenih postavkah se čutijo učitelji, ki poučujejo na OŠ pri vzgojnem zavodu, učinkovitejši. Predpostavljamo, da omenjeni učitelji bolje poznajo značilnosti in potrebe učencev z UČVT. Pri delu z njimi izhajajo iz neposrednih izkušenj, poznajo strategije učinkovitega vodenja razreda s katerimi zmanjšujejo moteče vedenje in so bolje pripravljeni na delo z učenci z UČVT (Rapuš Pavel, 2010; Soodak, 2003; Tschannen-Moran et al., 1998). Pri obravnavi otroka, ki je vključen v vzgojni zavod, sodeluje širši strokovni tim (svetovalni delavec, učitelj, vzgojitelj, medicinski tehnik, psiholog, zunanji strokovnja- 
ki). Interdisciplinarni tim učiteljem v procesu skupnega odločanja pomaga in daje usmeritve za delo s temi učenci. Na podlagi tega lahko učitelji, ki poučujejo na OŠ pri vzgojnem zavodu, bolje načrtujejo in izvajajo prilagoditve potrebne za učinkovito vodenje učencev z UČVT in razredne skupnosti (Woolfson et al., 2007). Nasprotno pa v razredih rednih OŠ z različno učno sposobnimi učenci, vključno $z$ učenci s posebnimi potrebami in nadarjenimi, učitelji največ pozornosti namenjajo pridobivanju znanja in doseganju predpisanih standardov znanja ter čim višji šolski učinkovitosti, pri čemer jim najverjetneje zmanjkuje časa za sistematično ukvarjanje s problemi učencev. Najpogosteje prezrejo področja, ki promovirajo socialno vključenost, spodbujajo oblikovanje ustrezne razredne klime, uporabo pristopov za usmerjanje vedenja učencev in vodenje razreda kot celote, torej področja na katerih je nujna njihova proaktivna udeležba in zavzetost. Raziskave (Emmer in Gerwels, 2006; Kalin et al., 2017; Soodak in McCarthy, 2006) tudi potrjujejo, da so učitelji $\mathrm{v}$ inkluzivnih razredih slabo usposobljeni prav za vodenje razreda in zagotavljanje discipline pri pouku.

\section{Zaključek}

Ugotovitve raziskave kažejo na višjo stopnjo učinkovitosti učiteljev OŠ pri vzgojnem zavodu, v primerjavi z učitelji na OŠ, na področju učenčevega sodelovanju (motiviranje učencev $\mathrm{P}=0,044$; pri spodbujanju samozaznave šolske uspešnosti pri učencih $\mathrm{P}=0,002$ ter pri izboljšanju razumevanja učnih vsebin pri učencih, ki ne dosegajo minimalnih standardov $\mathrm{P}=0,050$ ) in pri vodenju razreda $\mathrm{z}$ učenci $\mathrm{z}$ UČVT (pri nadzorovanju motečega vedenja $v$ razredu $\mathrm{P}=$ o,oo7; pri vzpostavljanju rutine, da dejavnosti učencev $\mathrm{Z}$ učnimi in vedenjskimi težavami potekajo nemoteno $\mathrm{P}=0,000$; pri doseganju, da učenci $\mathrm{z}$ učnimi in vedenjskimi težavami upoštevajo razredna pravila $\mathrm{P}=0,003$; ter pri osebnem odzivu na kljubovanje učencev $\mathrm{z}$ učnimi in vedenjskimi težavami $\mathrm{P}=0,017)$. Višja samoučinkovitost učiteljev OŠ pri vzgojnem zavodu se kaže tudi pri poučevanju v postavki razumevanja poučevane učne snovi pri učencih z UČVT $(\mathrm{P}=0,027)$. V ospredju učinkovitejšega delovanja učiteljev OŠ pri vzgojnem zavodu je večje razumevanje in upoštevanje posebnih potreb, prisotnost bolj osebnega in podpornega pristopa, sistematično direktno poučevanje ter vodenju razreda, kar izpostavljajo tudi druge raziskave (Bouillet, 2013; Goodmann in Burton, 2010; Nash et al., 2016).

Učitelji, ki poučujejo na OŠ, izražajo višjo učinkovitost glede pomoči družinam učencev $\mathrm{z}$ učnimi in vedenjskimi težavami. Upoštevati je potreb- 
no, da otroci ostajajo v svojem primarnem okolju. V raziskavi dobljeni rezultati so najverjetneje odraz implementacije koncepta pomoči učencem $z$ učnimi in vedenjskimi težavami na OŠ (Magajna et al., 20o8), v okviru katerega učitelji nudijo pomoč učencem pri rednem pouku in dopolnilnem pouku. Ob stopnjevanju težav se obrnejo na pomoč k šolski svetovalni službi, specialnim pedagogom in drugim strokovnjakom, kar zmanjšuje pri učiteljih breme, ki ga lahko vzbujajo učenci $\mathrm{z}$ vedenjskimi težavami v inkluzivnem razredu. Le-ti pogosto ovirajo učenje drugih učencev in doseganje zastavljenih kurikularnih ciljev (Buttner et al., 2015; White, 2014). Opozorimo še na nekaj omejitev naše raziskave. Odziv učiteljev otrok, ki bivajo v vzgojnem zavodu, je bil nizek, kar je vplivalo na oblikovanje majhnega vzorca učiteljev, ki poučujejo na rednih osnovnih šolah. Pri vseh vprašanjih gre za samooceno učiteljev in ne za neposredno zasledovanje učinkovitosti učiteljev pri delu z učenci z UČVT. V nadaljnjih raziskavah samoučinkovitosti učiteljev učencev z UČVT bi veljalo vključiti še druge subjekte in uporabiti tudi druge tehnike empiričnega raziskovanja, npr. intervjuje ali opazovanje učiteljev pri delu z učenci z UČVT skozi daljše časovno obdobje. Kombinacija kvalitativnih in kvantitativnih podatkov pridobljenih v raziskavi bi ponudila bolj zanesljivo in vsebinsko globlje razumevanje učiteljeve samoučinkovitosti ter omogočila vpogled v dejavnike, ki sodelujejo pri oblikovanju njihove samoučinkovitosti.

\section{Literatura}

Bender, William N. Learning disabilities: characteristics, identification, and teaching strategies. United States of America: Pearson, 2008.

Bouillet, Dejana. »Djelotvorne strategije u poučavanju učenika s problemima u ponašanju.« Napredak: časopis za pedagogijsku teoriju i praksu 54, št. 1-2 (2013): 103-130.

Buttner, Svenja in sodelavci. »Triangulating Measures of Teacher Quality in Teaching Students With Behavioral Problems.« Journal Of Cognitive Education \& Psychology 14, št. 3 (2015): 294-313. doi:10.1891/1945-8959.14.3.294.

Emmer, Edmund T. in Mary C. Gerwels. "Classroom management in middle and high school classrooms." V Handbook of classroom management: Research, practice and contemporary issues, edited by C. M. Evertson and C. S. Weinstein, 407-437. Mahwah, NJ \& London, UK: Lawrence Erlbaum Associates Publishers, 2006. 
Gidlund, Ulrika in Lena Boström. »What Is Inclusive Didactics? Teachers` Understanding of Inclusive Didactics for Students with EBD in Swedish Mainstream Schools.« International Education Studies 10, št. 5 (2017): 87-99.

Goodmann, Robert L. in Diana M. Burton. »The inclusion of students with BESD in mainstream schools: teachers' experiences of and recommendations for creating a successful inclusive environment.« Emotional and Behavioural Difficulties 15 št. 3 (2010): 223-237.

Itković, Zora. »Neki pokazatelji uspješnosti nastave na više razina težine u radu s učenicima s teškoćama u učenju u redovitoj školi.« Hrvatska revija za rehabilitacijska istraživanja 34 št. 2 (1998): 103-116.

Johnson-Harris, Kimberly M. in Nancy. A. Mundschenk. »Working Effectively with Students with BD in a general Education Classroom: The Case for Universal Design for Learning." The Clearing House: A Journal of Educational Strategies, Issues and Ideas 87 št. 4 (2014): 168-174.

Jordan, Anne, Eileen Schwartz in Donna McGhie-Richmond. »Preparing teachers for inclusive classrooms. "Teaching and Teacher Education 25 št. 4 (2009): 535-542. doi: 10.1016/j.tate.2009.02.010.

Kalin, Jana in sodelavci. »Elementary and Secondary School Students’ Perceptions of Teachers' Classroom Management Competencies.« C.E.P.S Journal 7 št. 4 (2017): 37- 62.

Kobolt, Alenka. »Od individualnih razlik preko drugačnosti do psihosocialnih motenj.« V: Problemi inkluzivne obravnave vedenjsko izstopajočih, socialno in kulturno depriviligiranih učencev in dijakov, A. Kobolt (ur.). (2008): 60-67. Ljubljana: Pedagoška fakulteta.

Magajna in sodelavci. Učne težave v osnovni šoli: koncept dela. Ljubljana: Zavod Republike Slovenije za šolstvo, 2008.

Malinen, Olli-Pekka., Hannu Savolainen in Jiacheng Xu. »Beijing in-service teachers' self-efficacy and attitudes towards inclusive education." Teaching and Teacher Education 28 št. 4 (2012): 526-534. http://dx.doi.org. ezproxy.lib.ukm.si/10.1016/j.tate.2011.12.004.

Muijs, Daniel in David Reynolds. »Kako odpraviti neprimerno vedenje.« Vzgoja in izobraževanje 41 št. 5 (2010): 39-44.

Nash, Poppy, Annette Schösser in Tanya Scarr. „Teachers' perceptions of disruptive behaviour in schools: a psychological perspective.” Emotional and Behavioural Difficulties 21 št. 2 (2016): 167-180. doi: 10.1080/13632752.2015.1054670. 
Nickerson, Amanda B. in Amy M. Brosof. »Identifying skills and behaviors for successful inclusion of students with emotional or behavioral disorders." Behavioral disorders 28 št. 4 (2003): 401- 409.

Payne, Linda D., Lori J. Marks and Barry Bogan. »Using curriculum-based assessment to adress the academic and behavioral deficits of students with emotional and behavioral disorders. "Beyond Behavior 16 št. 3 (2007): 3-6.

Pravilnik o normativih in standardih za izvajanje vzgojno-izobraževalnih programov za otroke s posebnimi potrebami. (2018): 31. člen. Pridobljeno s: http://www.pisrs.si/Pis.web/pregledPredpisa?id=PRAV7972

Pšunder, Mateja. Vodenje razreda. Maribor: Mednarodna založba Oddelka za slovanske jezike in književnost, Filozofska fakulteta, 2011.

Rapuš Pavel, Jana. Značilnosti disciplinskih problemov in odzivi učiteljev pri delu $\mathrm{z}$ učenci s čustvenimi, vedenjskimi in socialnimi težavami. Ljubljana: Pedagoška fakulteta, 2010.

Schmidt, Majda in Helena Čreslovnik. »Learning habits of SSN in short-term vocational education programmes.« Educational Studies 36 št. 4 (2010): 415-430.

Schmidt, Majda in Branka Čagran. »Razredna klima v inkluzivnem razredu.« Sodobna pedagogika 56 št. 4 (2005): 24-40.

Sharma, Umesh, Tim Loreman in Chris Forlin. »Measuring teacher efficacy to implement inclusive practices." Journal of Research in Special Educational Needs 12 št. 1 (2012): 12-21. http://dx.doi.org.ezproxy.lib.ukm.si/10.1111/j. 1471-3802.2011.01200.X.

Soodak, Leslie C. »Classroom Management in Inclusive Settings. « Theory in to Practice 42 št. 4 (2003): 327-333.

Soodak, Leslie C. in Mary R. McCarthy. „Classroom management in inclusive settings.«V Handbook of classroom management: Research, practice and contemporary issues, edited by C. M. Evertson and C. S. Weinstein, 1005-1019. Mahwah, NJ \& London, UK: Lawrence Erlbaum Associates Publishers, 2006.

Tournaki, Nelly in David M. Podell. »The impact of student characteristics and teacher efficacy on teachers' predictions of student success." Taching and Teacher Education 21 št. 3 (2005): 299-314. doi: 10.1016/j.tate.2005.01.003.

Tschannen-Moran, Megan in Anita Woolfolk Hoy. »Teacher efficacy: capturing an elusive construct.« Teaching and Teacher Education 17 št. 7 (2001): 783-805. 
Tschannen-Moran, Megan, Anita Woolfolk Hoy in Wayne K. Hoy. »Teacher Efficacy: It's Meaning and Measure.« Review of Educational Research 68 št. 2 (1998): 202-248.

White, Arnold J. An Investigation of Teacher Efficacy: Understandings, Practices, and the Impact of Professional Development as Perceived by Elementary School Teachers. College of Saint Elizabeth, 2014.

Woolfson, Lisa, Elizabeth Grant in Lindsay Campbell. »A Comparison of Special, General and Support Teachers' Controllability and Stability Attributions for Children's Difficulties in Learning. « Educational Psychology 27 št. 2 (2007): 295-306. doi:10.108o/01443410601066826. 



\title{
Dejavniki doživljanja nasilja med mladostniki iz Slovenije, Hrvaške in Švedske
}

\author{
Tina Pivec, Ana Kozina
}

\begin{abstract}
Teoretični uvod
M

edvrstniška viktimizacija (doživljanje medvrstniškega nasilja) je ena izmed najbolj perečih težav v šolah po celotni Evropi (Barzilay et al., 2017). Težave žrtev nasilja so predvsem težave ponotranjenja, kot so npr. anksioznost, depresivnost, nižja samopodoba in osamljenost (Isaacs et al., 2008). Poznavanje dejavnikov viktimizacije je ključno pri vzpostavljanju učinkovitih intervencij, zato se prispevek osredinja na dejavnike doživljanja viktimizacije, in sicer na ravni odnosov $\mathrm{z}$ vrstniki, na ravni odnosov $\mathrm{z}$ učitelji in na ravni posameznika (čustvene in socialne kompetence). $Z$ namenom celovitejšega razumevanja bova dejavnike viktimizacije preverili pri mladostnikih v treh različnih državah (Slovenija, Hrvaška in Švedska),

Viktimizacijo je opredeljena kot doživljanje nasilja, ki se s strani enega vrstnika ali skupine vrstnikov ponavlja dalj časa (Olweus, 1997). Za izvajanje in tudi doživljanje nasilja značilno naslednje (Salmivalli in Peets, 2009): namen nasilja je škodovati, izvajanje nasilja se ponavlja dalj časa in med nasilnežem ter žrtvijo obstaja razlika v moči.

V obdobju mladostništva postanejo odnosi z vrstniki razvojnopsihološko pomembnejši kot $\mathrm{v}$ otroštvu. Sošolci svojim vrstnikom lahko nudijo čustveno in socialno oporo (Lafontana in Cillessen, 2010), zato predstavljajo pozitivni vrstniški odnosi, kot so prijateljstvo, socialna opora vrstnikov in socialna sprejetost, varovalni dejavnik v kontekstu viktimizacije (Card in Hodges, 2008). V odnosih $\mathrm{z}$ drugimi se učenci učijo prosocialnega vede-
\end{abstract}


nja, ki je razlog za večje število pozitivnih odnosov z vrstniki in tako tudi prosocialno vedenje predstavlja varovalni dejavnik viktimizacije (Griese et al., 2016). Nenazadnje pa obstaja tudi negativna plat vrstniških odnosov, kot je npr. težavno vedenje učencev, ki zajema široko paleto neželenih vedenj, kot sta agresivnost in delinkventnost (Racz in McMahon, 2011). Predhodne raziskave so pokazale, da lahko težavno vedenje viša možnost, da bo učenec postal žrtev nasilnega vedenja (Marengo et al., 2018).

$\mathrm{V}$ šolskem kontekstu so pomembni tudi odnosi med učenci in učitelji. Raziskovalni izsledki kažejo na pomembno vlogo negativnih odnosov med učenci in učitelji, ki so povezani z višjo stopnjo viktimizacije v šolskem okolju (Lucas-Molina et al., 2015). Zaznan negativen odnos je tudi eden od dejavnikov negativne razredne klime; slednja je lahko razlog za pojav viktimizacije (Thornberg, Wänström in Pozzoli, 2017). Po drugi strani so v kontekstu viktimizacije pomembni tudi pozitivni odnosi med učenci in učitelji. Učenci so bili namreč v manjši meri žrtve nasilja, če so odnos z učitelji videli kot pozitiven (Elledge et al., 2016). Kot že omenjeno, so lahko ti odnosi so varovalni dejavnik viktimizacije in tudi kompenzacijski dejavnik, saj podporni odnosi med učenci in učitelji blažijo vpliv nizke sprejetosti na pojav viktimizacije pri učencih (ibid.).

Nenazadnje so pri viktimizaciji zelo pomembne tudi lastnosti na ravni posameznika, kot so čustvene in socialne kompetence (Saarento et al., 2013). Med čustvene in socialne kompetence znotraj modela CASEL uvrščamo samozavedanje, samouravnavanje, socialno zavedanje, odgovorno sprejemanje odločitev in uspešno upravljanje z odnosi (Durlak et al., 2011). Učenci, ki so bolj čustveno in socialno kompetentni, so v manjši meri žrtve medvrstniškega nasilja, saj ne predstavljajo t. i. »lahkih tarč«, ki jih nasilneži navadno izbirajo med sramežljivimi in negotovimi učenci (Olweus, 1997). Žrtve namreč poročajo o nižji stopnji splošne in socialne samopodobe kot učenci, ki niso vključeni v medvrstniško nasilje (Košir et al., 2018). Nedavno je bilo ugotovljeno tudi, da je pomemben vidik samozavedanja, tj. čuječnost, negativno povezana $z$ izkušnjo viktimizacije (Riggs in Brown, 2017). Nadalje je zaradi tega, ker se viktimizacija pojavlja v medosebnih odnosih, še posebej pomemben vidik socialnega zavedanja, znotraj katerega je bila raziskana predvsem empatija. Rezultati raziskav niso enoznačni, saj je metaanaliza pokazala, da ni povezave med empatijo in viktimizacijo (Zych et al., 2019), medtem ko posamezne raziskave poročajo o negativni povezanosti (Jenkins et al., 2016). 
V tem prispevku sva želeli preveriti dejavnike viktimizacije v obdobju mladostništva v različnih državah (Slovenija, Hrvaška in Švedska) in jih primerjati med seboj ter predlagati smernice preprečevanja viktimizacije.

\section{Metoda}

\section{Udeleženci}

$\mathrm{V}$ pilotni raziskavi projekta Roka $\mathrm{v}$ roki: Socialne in čustvene spretnosti za nediskriminatorno in vključujočo skupnost (Kozina idr., 2017), katerega namen je krepitev čustvenih, socialnih in medkulturnih kompetenc med učenci in učitelji, je v Sloveniji sodelovalo 123 učencev, na Hrvaškem 82 učencev in na Švedskem 75 učencev, starih med 13 in 15 let.

\section{Pripomočki}

Viktimizacija. Za merjenje viktimizacije je bil uporabljen Olweusov vprašalnik nasilnež/žrtev (Olweus Bully/Victim Questionnaire, OBWQ; Olweus, 1997), kjer je bila uporabljena le lestvica viktimizacije, ki vsebuje 22 postavk. Udeleženci so na 4-stopenjski lestvici označili, v kolikšni meri so v zadnjih štirih mesecih doživljali posamezno obliko nasilja ( $1=$ nikoli ali skoraj nikoli, $2=$ enkrat na mesec, $3=$ enkrat na teden, $4=$ vsak dan ali skoraj vsak dan). Primer postavke: "Sošolci/-ke so se mi smejali/-e in s prstom kazali/-e name.« Na vseh vzorcih se je pokazala ustrezna zanesljivost mere viktimizacije (Slovenija: Cronbachov $\alpha=0,92$; Švedska: Cronbachov $\alpha=0,91$; Hrvaška: Cronbachov $\alpha=0,85)$.

Težavno vedenje, pozitivni odnosi $z$ vrstniki in prosocialno vedenje. Za merjenje omenjenih spremenljivk so bile uporabljene posamezne podlestvice Vprašalnika prednosti in slabosti (Strenghts and Difficulties Questionnaire, SDQ; Goodman, 1997). To so podlestvice Težavno vedenje, Prosocialno vedenje in Težave $\mathrm{v}$ odnosih z vrstniki, pri čemer sva pri slednji odgovore kodirali tako, da merijo pozitivne odnose z vrstnikiPodlestvica Težavno vedenje zajema 6 postavk, (»Pogosto se tepem z drugimi otroki.«), pri kateri so udeleženci na 4 -stopenjski lestvici ( $1=$ močno se ne strinjam, 4 = močno se strinjam) označili, kako posamezne postavke veljajo za njih. Na vseh vzorcih se je pokazala dokaj nizka zanesljivost mere težavnega vedenja (Slovenija: Cronbachov $\alpha=0,53$; Švedska: Cronbachov $\alpha=0,52$; Hrvaška: Cronbachov $\alpha=0,60$ ), kar lahko pripišemo temu, da se omenjeni vprašalnik uporablja kot presejalni test v kliničnem okolju in je bil prvotno namenjen za uporabo staršev in učiteljev. Podobno so o nižji zaneslji- 
vosti poročali v prejšnjih raziskavah (npr. Goodman, 2001). Podlestvica Težave v v odnosu z vrstniki zajema 5 postavk, primer postavke je »Na splošno sem med vrstniki priljubljen/-a.«; udeleženci so glede na njihovo strinjanje s posamezno postavko odgovarjali na 4 -stopenjski lestvici $(1=$ močno se ne strinjam, 4 = močno se strinjam). Na vseh vzorcih se je pokazala nizka zanesljivost (Slovenija: Cronbachov $\alpha=0,53$; Švedska: Cronbachov $\alpha=$ 0,59; Hrvaška: Cronbachov $\alpha=0,63$ ). Razlog za to je lahko, da je uporabljeni vprašalnik namenjen zaznavanju vedenjskih težav otrok in mladostnikov v kliničnem okolju. O nižji zanesljivosti poročajo tudi prejšnje raziskave (Goodman, 2001). Podlestvica Prosocialno vedenje zajema 6 postavk, na katere so se udeleženci na 4 -stopenjski lestvici ( $1=$ nikoli, $4=$ pogosto) odzvali, kako pogosto trditve veljajo zanje. Primer postavke: »Poskušam biti prijazen/-na do drugih.«. Na vseh vzorcih se je pokazala ustrezna zanesljivost podlestvice prosocialnega vedenja (Slovenija: Cronbachov $\alpha=0,82$; Švedska: Cronbachov $\alpha=0,83$; Hrvaška: Cronbachov $\alpha=0,78)$, ki je višja kot $v$ predhodnih raziskavah (npr. Goodman, 2001).

Pozitivni odnosi z učitelji. Za preverjanje zaznanega pozitivnega odnosa $z$ učitelji s strani učencev je bila uporabljena adaptirana verzija vprašalnika Učitelj kot socialni kontekst (Teacher as Social Context, TASC; Belmont, Skinner, Wellbron in Connell, 1992), saj so bile uporabljene le postavke, ki merijo pozitivno plat odnosa med učenci in učitelji. Udeleženci so na 4-stopenjski lestvici ( $1=$ za nobenega ali skoraj nobenega, $2=$ za nekatere, $3=\mathrm{za}$ večino, 4 = za vse ali skoraj vse) označili, za koliko njihovih učiteljev v obdobju zadnjih štirih mesecev veljajo trditve. Lestvica je zajemala 9 postavk, primer postavke: »Učitelji/-ce mi posvetijo svoj čas.«. Zanesljivost uporabljenega vprašalnika je bila na vseh vzorcih ustrezna (Slovenija: Cronbachov $\alpha=0,91$; Švedska: Cronbachov $\alpha=0,90 ;$ Hrvaška: Cronbachov $\alpha=0,91$ ).

Negativni odnosi z učitelji. Za merjenje zaznanega negativnega odnosa med učenci in učitelji s strani učencev je bil uporabljen vprašalnik o zaznavi odnosa učitelja, ki je bil uporabljen znotraj raziskave PISA (OECD, 2017) in mu je bila dodana postavka $» \mathrm{~V}$ zadnjih 4 mesecih so učitelji/-ice vpili/-e name.«. Udeleženci so na 4-stopenjski lestvici ( 1 = za nobenega ali skoraj nobenega, 4 = za vse ali skoraj vse) za koliko njihovih učiteljev v obdobju zadnjih štirih mesecev veljajo trditve. Primer postavke: $» V$ zadnjih 4 mesecih so me učitelji/-ice užalili/-e pred drugimi.« Lestvica zajema 6 postavk, zanesljivost lestvice je bila na vseh vzorcih ustrezna (Slovenija: Cronbachov $\alpha=0,81$; Švedska: Cronbachov $\alpha=0,78$; Hrvaška: Cronbachov $\alpha=0,85$ ). 
Samopodoba. Za merjenje samopodobe udeležencev je bil uporabljena podlestvica »splošna samopodoba« iz Vprašalnika samoopisovanja (Self-Description Questionnaire II, SDQ II; Marsh, 1992). Podlestvica vsebuje 10 postavk, pri čemer so udeleženci na 4 -stopenjski lestvici $(1=$ sploh se ne strinjam, 4 = popolnoma se strinjam) označili, v kolikšni meri posamezna postavka velja zanje. Primer postavke: »Dobro opravim večino stvari, ki se jih lotim." Zanesljivost je bila na vseh vzorcih ustrezna (Slovenija: Cronbachov $\alpha=0,74$; Švedska: Cronbachov $\alpha=0,93$; Hrvaška: Cronbachov $\alpha=0,88)$.

Empatija. Empatijo sva merili z Indeksom medosebne reaktivnosti (Interpersonal Reactivity Index, IRI; (Davis, 1980).V analizah sva združili lestvico Empatične skrbi (primer postavke: »Ko imajo ljudje probleme, mi včasih ni mar.«) in lestvico Zavzemanja perspektive (primer postavke: »Kadar se ljudje $\mathrm{v}$ čem ne strinjajo, poskušam videti problem $\mathrm{z}$ vidika vseh vpletenih.«), saj sva želeli tako preveriti kognitivno empatijo (lestvica Zavzemanja perspektive) kot tudi afektivno empatijo (lestvica Empatične skrbi) (glej Davis, 1983). Vsaka lestvica zajema 7 postavk, pri katerih so udeleženci na 5-stopenjski odgovorni lestvici označili, v kolikšni meri posamezne postavke veljajo zanje ( $1=$ to nikakor ne velja zame, $5=$ to zelo velja zame). Na uporabljenem vzorcih se je prav tako pokazala ustrezna zanesljivost uporabljenih lestvic (Slovenija: Cronbachov $\alpha=0,82$; Švedska: Cronbachov $\alpha=0,76$; Hrvaška $=$ Cronbachov $\alpha=0,75$ ).

Samozavedanje. Za merjenje samozavedanja je bila uporabljena Kentuckyjeva lestvica čuječnosti (Kentucky Mindfulness Scale, KIMS; Baer, Smith in Allen, 2004). Za analizo sva združili podlestvici Opazovanje in Opisovanje. Podlestvica Opazovanje obsega 12 postavk (primer postavke: »Namenoma posvečam pozornost svojim občutkom.«), podlestvica Opisovanje pa 8 postavk (primer postavke: »Z lahkoto ubesedim svoja prepričanja, mnenja in pričakovanja.«) na 5 -stopenjski odgovorni lestvici, s katero so udeleženci izrazili, kako pogosto določene postavke veljajo zanje ( $1=$ nikoli ali skoraj nikoli, $5=$ zelo pogosto ali vedno). Zanesljivost uporabljenih lestvic je bila na vseh vzorcih ustrezna (Slovenija: Cronbachov $\alpha=0,86$; Švedska: Cronbachov $\alpha=0,89$; Hrvaška: Cronbachov $\alpha=0,84$ ).

\section{Postopek in statistična obdelava podatkov}

Podatki so bili po predhodno pridobljenem soglasju staršev oz. skrbnikov zbrani v 8. razredih osnovnih šol. Reševanje vprašalnikov je trajalo od ene do dve šolski uri. Zaradi preverjanja merskih pripomočkov so bili prvot- 
ni vzorci razdeljeni na dva dela: $A$ in $B$, od katerih je vsak del vzorca reševal druge vprašalnike. $V$ tem prispevku je bil uporabljen vzorec $A$, ki je v Sloveniji obsegal 127 udeležencev, na Švedskem 95 učencev in na Hrvaškem 84 učencev. Naknadno so bili izključeni tisti udeleženci, ki so imeli na celotnem vprašalniku izpolnjenih manj kot 90 \% vprašanj. Manjkajoče vrednosti sva zaradi naključno manjkajočih podatkov nadomestili $\mathrm{z}$ EM algoritmom, ki vrednosti ne nadomesti direktno, ampak izračuna ocene za želene parametre po metodi največjega verjetja. Za preverjanje napovedne vrednosti posameznih spremenljivk je bila v programu IBM SPSS Statistics 25 uporabljena hierarhična multipla regresijska analiza, saj raziskave kažejo, da so največkrat prav odnosi z vrstniki pomembni napovedniki doživljanja nasilja, nadalje sledijo odnosi z učitelji in nazadnje še čustvene in socialne kompetence.

\section{Rezultati}

Tabela 2r: Deskriptivna statistika in korelacije na vzorcu učencev iz Slovenije

\begin{tabular}{|c|c|c|c|c|c|c|c|c|c|c|}
\hline & M & $\mathrm{SD}$ & 1. & 2. & 3. & 4. & 5. & 6. & 7. & 8. \\
\hline $\begin{array}{l}\text { 1. Viktimi- } \\
\text { zacija }\end{array}$ & 1,58 & 0,50 & & & & & & & & \\
\hline $\begin{array}{l}\text { 2. Pozitivni } \\
\text { odnosi z vr- } \\
\text { stniki }\end{array}$ & 3,12 & 0,48 & $-0,24^{\star *}$ & & & & & & & \\
\hline $\begin{array}{l}\text { 3. Težavno ve- } \\
\text { denje }\end{array}$ & 1,92 & 0,42 & $0,35^{* *}$ & $-0,03$ & & & & & & \\
\hline $\begin{array}{l}\text { 4. Prosocial- } \\
\text { no vedenje }\end{array}$ & 3,29 & 0,59 & $-0,25^{\star *}$ & 0,09 & $-0,50^{* *}$ & & & & & \\
\hline $\begin{array}{l}\text { 5. Pozitivni } \\
\text { odnosi z uči- } \\
\text { telji }\end{array}$ & 2,48 & 0,71 & $-0,06$ & 0,08 & $-0,33^{* *}$ & $0,47^{* *}$ & & & & \\
\hline $\begin{array}{l}\text { 6. Negativni } \\
\text { odnosi z uči- } \\
\text { telji }\end{array}$ & 1,34 & 0,41 & $0,43^{* *}$ & $-0,03$ & $0,54^{\star *}$ & $-0,39^{* *}$ & $-0,36^{* *}$ & & & \\
\hline $\begin{array}{l}\text { 7. Samopo- } \\
\text { doba }\end{array}$ & 3,51 & 0,39 & $-0,17$ & $0,32^{\star *}$ & $-0,37^{* *}$ & $0,17^{* *}$ & $0,34^{* *}$ & $-0,29^{* *}$ & & \\
\hline 8. Empatija & 3,38 & 0,58 & 0,03 & 0,01 & $-0,36^{* *}$ & $0,60^{\star *}$ & $0,41^{* *}$ & $-0,25^{*}$ & 0,09 & \\
\hline $\begin{array}{l}\text { 9. Samozave- } \\
\text { danje }\end{array}$ & 2,89 & 0,57 & 0,07 & 0,04 & $-0,15$ & 0,16 & $0,24^{* *}$ & 0,06 & 0,05 & $0,41^{\star *}$ \\
\hline
\end{tabular}

Opombe. $p<0,05, " p<<0,01$.

Iz Tabele 21 je razvidno, da so na vzorcu Slovenije vse spremenljivke povezane $\mathrm{v}$ pričakovani smeri. 
Tabela 22: Hierarhična regresijska analiza za spremenljivke, ki napovedujejo viktimizacijo na vzorcu učencev iz Slovenije

\begin{tabular}{|c|c|c|c|c|c|c|}
\hline & \multicolumn{6}{|c|}{ Viktimizacija } \\
\hline & \multicolumn{2}{|c|}{ Model 1} & \multicolumn{2}{|c|}{ Model 2} & \multicolumn{2}{|c|}{ Model 3} \\
\hline & B & $\beta$ & $\mathrm{B}$ & $\beta$ & $\mathrm{B}$ & $\beta$ \\
\hline \multicolumn{7}{|l|}{ Korak 1: } \\
\hline Pozitivni odnosi z vrstniki & $-0,17$ & $-0,20^{* *}$ & $-0,20$ & $-0,23^{* *}$ & $-0,19$ & $-0,22^{* *}$ \\
\hline Težavno vedenje & 0,29 & $0,29^{* *}$ & 0,14 & 0,14 & 0,16 & 0,17 \\
\hline Prosocialno vedenje & $-0,06$ & $-0,08$ & $-0,06$ & $-0,08$ & $-0,11$ & $-0,16$ \\
\hline$R^{2}$ & & $0,18^{* * *}$ & & & & \\
\hline \multicolumn{7}{|l|}{ Korak 2: } \\
\hline Pozitivni odnosi z učitelji & & & 0,13 & $0,22^{*}$ & 0,10 & 0,18 \\
\hline Negativni odnosi z učitelji & & & 0,34 & $0,41^{* * *}$ & 0,32 & $0,40^{* * *}$ \\
\hline$\Delta R^{2}$ & & & & $0,10^{* * *}$ & & \\
\hline \multicolumn{7}{|l|}{ Korak 3: } \\
\hline Samopodoba & & & & & 0,03 & 0,03 \\
\hline Empatija & & & & & 0,11 & 0,15 \\
\hline Samozavedanje & & & & & 0,01 & 0,02 \\
\hline$\Delta R^{2}$ & & & & & & 0,02 \\
\hline $\mathrm{R}^{2}$ & \multicolumn{2}{|c|}{$0,18^{* * *}$} & \multicolumn{2}{|c|}{$0,28^{* * *}$} & \multicolumn{2}{|c|}{0,30} \\
\hline F za spremembo $\mathrm{R}^{2}$ & \multicolumn{2}{|c|}{$7,64^{* * *}$} & \multicolumn{2}{|c|}{$10,80^{* * *}$} & \multicolumn{2}{|c|}{0,87} \\
\hline
\end{tabular}

Opombe: $p<0,05, " p<0,01$.

Iz Tabele 22 je razvidno, da so odnosi z vrstniki, ki so vključeni v prvem koraku, pojasnili $18 \%$ variance viktimizacije. Izmed njih sta spremenljivki pozitivni odnosi z vrstniki negativen značilen napovednik in težavno vedenje pozitiven značilen napovednik viktimizacije. Vključitev odnosov $\mathrm{z}$ učitelji dodatno pojasni $10 \%$ variance viktimizacije, pri čemer sta tako pozitivni kot tudi negativni odnosi $\mathrm{z}$ učitelji napovednika viktimizacije. $\mathrm{V}$ drugem koraku težavno vedenje več ni bilo statistično značilno. Vključitev čustvenih in socialnih kompetenc dodatno pojasni $2 \%$ viktimizacije, vendar nobena izmed vključenih spremenljivk ni statistično značilen napovednik viktimizacije. Po vključitvi čustvenih in socialnih kompetenc so pozitivni odnosi z učitelji izgubili svojo statistično značilnost. Skupaj dejavniki pojasnijo $30 \%$ variance viktimizacije, pri čemer največji delež variance pojasni prvi model, v katerega so vključeni le odnosi z vrstniki, čeprav so negativni odnosi $z$ učitelji najmočnejši napovednik viktimizacije znotraj celotnega modela. Pozitivni odnosi z vrstniki so se pokazali kot negativni napovednik viktimizacije, in sicer boljši so odnosi z vrstniki, manjša verjetnost obstaja, da je učenec žrtev nasilja. 
Tabela 23: Deskriptivna statistika in korelacije na vzorcu učencev iz Hrvaške

\begin{tabular}{|c|c|c|c|c|c|c|c|c|c|c|}
\hline & M & $\mathrm{SD}$ & 1. & 2. & 3 . & 4. & 5. & 6. & 7. & 8. \\
\hline 1. Viktimizacija & 1,30 & 0,34 & & & & & & & & \\
\hline $\begin{array}{l}\text { 2. Pozitivni odnosi z } \\
\text { vrstniki }\end{array}$ & 2,45 & 0,35 & $-0,33^{* *}$ & & & & & & & \\
\hline 3. Težavno vedenje & 1,91 & 0,49 & $0,36^{* *}$ & $-0,11$ & & & & & & \\
\hline $\begin{array}{l}\text { 4. Prosocialno ve- } \\
\text { denje }\end{array}$ & 3,37 & 0,58 & $-0,23^{*}$ & $0,28^{*}$ & $-0,44^{* *}$ & & & & & \\
\hline $\begin{array}{l}\text { 5. Pozitivni odnosi z } \\
\text { učitelji }\end{array}$ & 2,34 & 0,70 & $-0,16$ & 0,04 & $-0,20$ & 0,18 & & & & \\
\hline $\begin{array}{l}\text { 6. Negativni odnosi z } \\
\text { učitelji }\end{array}$ & 1,48 & 0,54 & $0,36^{* *}$ & 0,00 & $0,37^{* *}$ & $-0,18$ & $-0,38^{* *}$ & & & \\
\hline 7. Samopodoba & 2,46 & 0,20 & 0,20 & $0,50^{* *}$ & $0,26^{*}$ & $0,36^{* *}$ & $0,27^{*}$ & $-0,10$ & & \\
\hline 8. Empatija & 3,41 & 0,56 & $-0,14$ & 0,17 & $-0,24^{*}$ & $0,58^{\star *}$ & $0,21^{*}$ & $-0,38^{* *}$ & $0,30^{*}$ & \\
\hline 9. Samozavedanje & 3,17 & 0,67 & 0,13 & 0,17 & 0,27 & $0,44^{* *}$ & $0,35^{* *}$ & $-0,20^{\star}$ & $0,40^{* *}$ & $0,51^{* *}$ \\
\hline
\end{tabular}

Opombe. $p<0,05, " p<0,01$.

V Tabeli 23 so predstavljene opisne statistike na vzorcu učencev iz Hrvaške, ki prav tako korelirajo v pričakovani smeri.

Tabela 24: Hierarhična regresijska analiza za spremenljivke, ki napovedujejo viktimizacijo na vzorcu učencev iz Hrvaške

\begin{tabular}{|c|c|c|c|c|c|c|}
\hline & \multicolumn{6}{|c|}{ Viktimizacija } \\
\hline & \multicolumn{2}{|c|}{ Model 1} & \multicolumn{2}{|c|}{ Model 2} & \multicolumn{2}{|c|}{ Model $_{3}$} \\
\hline & B & $\beta$ & B & $\beta$ & B & $\beta$ \\
\hline \multicolumn{7}{|l|}{ Korak 1: } \\
\hline Pozitivni odnosi z vrstniki & $-0,20$ & $-0,30^{* *}$ & $-0,21$ & $-0,31^{* *}$ & $-0,23$ & $-0,34^{* *}$ \\
\hline Težavno vedenje & 0,22 & $0,30^{*}$ & 0,12 & 0,17 & 0,13 & 0,18 \\
\hline Prosocialno vedenje & $-0,01$ & $-0,01$ & $-0,01$ & $-0,01$ & $-0,06$ & $-0,10$ \\
\hline$R^{2}$ & & $0,20^{* *}$ & & & & \\
\hline \multicolumn{7}{|l|}{ Korak 2: } \\
\hline Pozitivni odnosi z učitelji & & & 0,00 & 0,01 & $-0,03$ & $-0,05$ \\
\hline Negativni odnosi z učitelji & & & 0,16 & $0,26^{*}$ & 0,17 & $0,26^{*}$ \\
\hline$\Delta R^{2}$ & & & & $0,05^{*}$ & & \\
\hline \multicolumn{7}{|l|}{ Korak 3: } \\
\hline Samopodoba & & & & & 0,03 & 0,05 \\
\hline Empatija & & & & & 0,01 & 0,02 \\
\hline Samozavedanje & & & & & 0,11 & 0,18 \\
\hline$\Delta R^{2}$ & & & & & & 0,03 \\
\hline $\mathrm{R}^{2}$ & \multicolumn{2}{|c|}{$0,20^{* * *}$} & \multicolumn{2}{|c|}{0,25} & \multicolumn{2}{|c|}{0,28} \\
\hline F za spremembo $\mathrm{R}^{2}$ & \multicolumn{2}{|c|}{$6,69^{* * *+}$} & \multicolumn{2}{|c|}{$2,57^{* * *}$} & \multicolumn{2}{|c|}{$1, \mathrm{OO}^{* * *}$} \\
\hline
\end{tabular}

Opombe: $p<0,05, " p<0,0 \mathrm{I}, \cdots p<0,00 \mathrm{I}$. 
Iz Tabele 24 je razvidno, da v prvem koraku dejavniki na ravni odnosov $z$ vrstniki skupaj pojasnijo 20 \% variance, pri čemer so pozitivni odnosi Z vrstniki negativen napovednik, težavno vedenje pa pozitiven napovednik viktimizacije. Z vključitvijo odnosov $\mathrm{z}$ učitelji v model je dodatno pojasnjenih $5 \%$ variance, pri čemer so negativni odnosi $z$ učitelji pozitiven napovednik, vendar postane težavno vedenje nepomemben napovednik viktimizacije. Socialne in čustvene kompetence, ki so bile vključene v tretjem modelu, sicer pojasnijo $3 \%$ viktimizacije, vendar nobena od spremenljivk ni pomemben napovednik viktimizacije. Spremenljivki pozitivni odnosi z vrstniki in negativni odnosi z učitelji sta statistično značilna napovednika viktimizacije, pri čemer pozitivni odnosi z vrstniki učence varujejo pred viktimizacijo, negativni odnosi z učitelji pa prispevajo k pojavu doživljanja nasilja pri učencih. Preučevane spremenljivke skupno pojasnijo $28 \%$ variance viktimizacije, pri čemer kar $20 \%$ variance pojasnijo dejavniki na ravni odnosov z vrstniki.

\section{Tabela 25: Deskriptivna statistika in korelacije na vzorcu učencev iz Švedske}

\begin{tabular}{|c|c|c|c|c|c|c|c|c|c|c|}
\hline & $\mathrm{M}$ & SD & 1. & 2. & 3. & 4. & 5. & 6. & 7. & 8. \\
\hline 1. Viktimizacija & 1,18 & 0,32 & & & & & & & & \\
\hline $\begin{array}{l}\text { 2. Pozitivni odnosi z } \\
\text { vrstniki }\end{array}$ & 3,04 & 0,48 & $-0,16$ & & & & & & & \\
\hline 3. Težavno vedenje & 1,88 & 0,41 & $0,43^{* *}$ & 0,09 & & & & & & \\
\hline $\begin{array}{l}\text { 4. Prosocialno ve- } \\
\text { denje }\end{array}$ & 3,58 & 0,39 & $-0,12$ & 0,13 & $-0,17$ & & & & & \\
\hline $\begin{array}{l}\text { 5. Pozitivni odnosi z } \\
\text { učitelji }\end{array}$ & 2,62 & 0,59 & $-0,26^{*}$ & 0,13 & $-0,05$ & 0,08 & & & & \\
\hline $\begin{array}{l}\text { 6. Negativni odnosi z } \\
\text { učitelji }\end{array}$ & 1,36 & 0,40 & $0,49^{* *}$ & $-0,15$ & $0,49^{* *}$ & $-0,13$ & $-0,40^{* *}$ & & & \\
\hline 7. Samopodoba & 3,10 & 0,60 & $-0,31^{* *}$ & $0,36^{* *}$ & $-0,13$ & 0,06 & $0,40^{* *}$ & $-0,07$ & & \\
\hline 8. Empatija & 3,32 & 0,56 & 0,02 & $-0,06$ & $-0,22$ & $0,48^{* *}$ & 0,18 & $-0,25^{*}$ & $-0,16$ & \\
\hline 9. Samozavedanje & 3,17 & 0,56 & $-0,02$ & 0,04 & $-0,08$ & 0,21 & $0,36^{* *}$ & $-0,18$ & $0,35^{* *}$ & $0,25^{*}$ \\
\hline
\end{tabular}

Opombe. " $p<0,05, " p<0,01, \cdots p<0,00 \mathrm{I}$.

$\mathrm{V}$ Tabeli 25 so predstavljene opisne statistike in povezanosti med spremenljivkami na vzorcu učencev iz Švedske, ki so med seboj povezane v pričakovani smeri.

Rezultati multiple hierarhične analize (Tabela 26) kažejo, da dejavniki na ravni odnosov z vrstniki v prvem koraku pojasnijo $16 \%$ variance viktimizacije, vendar je samo težavno vedenje pozitiven napovednik viktimizacije. V drugem koraku so vključeni odnosi z učitelji, ki dodatno pojasnijo $10 \%$ variance viktimizacije, vendar postane $\mathrm{v}$ tem modelu težavno vede- 
Tabela 26: Hierarhična regresijska analiza za spremenljivke, ki napovedujejo viktimizacijo na vzorcu učencev iz Švedske

\begin{tabular}{|c|c|c|c|c|c|c|}
\hline & \multicolumn{6}{|c|}{ Viktimizacija } \\
\hline & \multicolumn{2}{|c|}{ Model 1} & \multicolumn{2}{|c|}{ Model 2} & \multicolumn{2}{|c|}{ Model 3} \\
\hline & B & $\beta$ & B & $\beta$ & B & $\beta$ \\
\hline \multicolumn{7}{|l|}{ Korak 1: } \\
\hline Pozitivni odnosi z vrstniki & $-0,09$ & $-0,13$ & $-0,04$ & $-0,05$ & 0,02 & 0,03 \\
\hline Težavno vedenje & 0,32 & $0,36^{* * *}$ & 0,18 & 0,21 & 0,16 & 0,19 \\
\hline Prosocialno vedenje & $-0,02$ & $-0,02$ & $-0,03$ & $-0,04$ & $-0,08$ & $-0,08$ \\
\hline$R^{2}$ & & $0,16^{* *}$ & & & & \\
\hline \multicolumn{7}{|l|}{ Korak 2: } \\
\hline Pozitivni odnosi z učitelji & & & $-0,04$ & $-0,07$ & $-0,02$ & $-0,04$ \\
\hline Negativni odnosi z učitelji & & & 0,21 & $0,10^{*}$ & 0,24 & $0,32^{*}$ \\
\hline$\Delta R^{2}$ & & & & $0,08^{*}$ & & \\
\hline \multicolumn{7}{|l|}{ Korak 3: } \\
\hline Samopodoba & & & & & $-0,13$ & $-0,20$ \\
\hline Empatija & & & & & 0,01 & 0,01 \\
\hline Samozavedanje & & & & & 0,10 & 0,17 \\
\hline$\Delta R^{2}$ & & & & & & 0,04 \\
\hline $\mathrm{R}^{2}$ & \multicolumn{2}{|c|}{$0,16^{* *}$} & \multicolumn{2}{|c|}{$0,24^{*}$} & \multicolumn{2}{|c|}{0,27} \\
\hline F za spremembo $\mathrm{R}^{2}$ & \multicolumn{2}{|c|}{$4,72^{* * *}$} & \multicolumn{2}{|c|}{$3,61^{* * *}$} & \multicolumn{2}{|c|}{$1,24^{* * *}$} \\
\hline
\end{tabular}

Opombe: $p<0,05, " p<0,01, \cdots p<0,001$.

nje nepomembno. Vključitev čustvenih in socialnih kompetenc dodatno pojasni $3 \%$ variance viktimizacije, vendar nobena izmed spremenljivk ni statistično značilen napovednik viktimizacije. Skupno preučevane spremenljivke pojasnijo $27 \%$ variance viktimizacije, pri čemer največji odstotek pojasnijo odnosi z vrstniki, kljub temu da so se zgolj negativni odnosi z učitelji izkazali kot statistično značilen napovednik viktimizacije.

\section{Diskusija}

Namen prispevka je bil preveriti, kakšna je napovedna vrednost dejavnikov viktimizacije na ravni odnosov $\mathrm{z}$ vrstniki, $\mathrm{z}$ učitelji in na ravni posameznika. Rezultati so pokazali, da so skladno s pričakovanji dejavniki na ravni odnosov z vrstniki (pozitivni odnosi z vrstniki, težavno vedenje, prosocialno vedenje) v vseh državah pojasnili najvišji odstotek variance viktimizacije, vendar so kasneje delno izgubili svojo napovedno moč. V Sloveniji in na Hrvaškem se je pokazalo, da so na ravni odnosov z vrstniki pomembni pozitivni odnosi $\mathrm{z}$ vrstniki, ki so negativni napovednik viktimizacije. Bo- 
lje kot so učenci ocenjevali svoje odnose $z$ vrstniki, nižja je poročana stopnja viktimizacije učencev, kar je skladno $z$ rezultati predhodnih raziskav (Sentse et al., 2015). Težavno vedenje se je pokazalo kot pozitiven napovednik viktimizacije v vseh državah v prvem koraku, ko so bili preverjani zgolj odnosi z vrstniki. Po vključitvi odnosov z učitelji težavno vedenje ni bilo več statistično značilen napovednik viktimizacije. V predhodnih raziskavah se je težavno vedenje sicer pokazalo kot pozitivni napovednik viktimizacije (Marengo et al. 2018).

Rezultati kažejo, da v vseh vključenih državah pomembno vlogo pri doživljanju nasilja igrajo zaznave odnosa $z$ učitelji s strani učencev, pri čemer so se negativni odnosi z učitelji izkazali kot pozitiven napovednik viktimizacije. Torej, slabše zaznavajo učenci svoje odnose z učitelji, večja verjetnost je, da so žrtve nasilja in obratno, kar je skladno z rezultati predhodnih raziskav (Lucas-Molina idr., 2015). Ugotovljeno je bilo, da je dovolj, da so odnosi z učitelji ustrezni in da jih učenci ne označujejo kot negativne (Sulkowski in Simmons, 2017). To učiteljem omogoča, da vplivajo na razredno klimo, se učinkovito odzivajo na težave in pomagajo učencem, da se počutijo varne in sprejete, kar lahko pomaga pri zmanjševanju doživljanja nasilja med učenci (Jennings in Greenberg, 2009).

Čustvene in socialne kompetence sicer pojasnjujejo majhen delež variance viktimizacije, a nobena preučevana kompetenca (samopodoba, empatija in samozavedanje) na nobenem izmed preučevanih vzorcev viktimizacije ne napoveduje statistično značilno. To je skladno $z$ rezultati metaanalize, ki prav tako ni našla povezave med empatijo in viktimizacijo (Zych, Ttofi, and Farrington 2019), vendar je kontradiktorno rezultatom ostalih raziskav, $\mathrm{v}$ katerih sta bila samopodoba in samozavedanje negativna napovednika viktimizacije (Riggs and Brown 2017; Košir et al. 2018)defined by non-judgmental and accepting awareness of the constant stream of lived experience, during early adolescence. It was hypothesized that victimization would predict lower levels of mindfulness over a 4-month period. Study participants were 152 seventh and eighth grade students (female $=51 \%$, Caucasian $=35 \%$, Hispanic $/$ Latino $=34 \%$, African-American $=13 \%$, and multi-ethnic or other $=18 \%$.

$\mathrm{V}$ raziskavo so bile vključene tri različne države Evropske unije, vendar se je pokazalo, da so si, kar zadeva dejavnike viktimizacije, med seboj kar podobne. $\mathrm{V}$ vseh treh državah so se negativni odnosi z učitelji izkazali za statistično značilen pozitiven napovednik viktimizacije, v Sloveniji in na Hrvaškem pa so pozitivni odnosi z vrstniki statistično značilen napove- 
dnik viktimizacije. Pri vseh državah se je pri vključitvi zgolj odnosov z vrstniki kot statistično značilen napovednik pokazalo tudi težavno vedenje.

\section{Pomanjkljivosti in predlogi za prakso}

Ugotovitve imajo poleg znanstvene tudi praktično vrednost. Kar zadeva pozitivne odnose $z$ vrstniki je zelo pomembno, da se za obstoječe žrtve ustvari podporna mreža tistih učencev, ki niso več žrtve, in tistih učencev, ki so opazovalci medvrstniškega nasilja. Rezultati so prav tako pokazali, da je zraven spodbujanja pozitivnih odnosov med učenci prav tako pomembno, da učitelji skrbijo za razvoj podpornih odnosov, s čimer lahko preventivno poskrbijo, da se ne bi razvili negativni odnosi med njimi in učenci- Pri tem je pomembno sprejemanje odgovornosti za odnos, ki je zmeraj na strani odraslega (Jull in Jensen, 2010), razvijanje učinkovitih načinov delovanja, odnosne kompetentnosti ter čustvenih in socialnih kompetenc učiteljev (Jennings in Greenberg, 2009), kar bi bilo smiselno vključiti tudi v izobraževanje bodočih učiteljev.

Rezultate najinega prispevka je treba povzemati s previdnostjo, saj je bil v raziskavi uporabljen majhen vzorec učencev, raziskava je bila zastavljena prečno, pokazala se je nižja zanesljivost dveh podlestvic iz Vprašalnika prednosti in slabosti, prav tako so bile uporabljene zgolj mere samoporočanja s strani učencev in psihometrično nepreverjeni vprašalniki. Zaradi kompleksnosti preučevanega pojava in nezanesljivosti mer odnosov z učitelji, bi bilo v prihodnjih raziskavah smiselno vključiti učitelje in vrstniško poročanje. Dodana vrednost prispevka je primerjava dejavnikov v različnih državah. Dejavniki so si v vseh vključenih državah zelo podobni, kar kaže na to, da se vsaj v evropskem okolju kaže pomembna vloga negativnih odnosov z učitelji in pozitivnih odnosov med učenci.

\section{Literatura}

Baer, Ruth, Gregory T. Smith in Kristin B. Allen. 2004. „Assessment of Mindfulness by Self-Report.« Assessment 11: 191-206.

Barzilay, Shira, Anat Brunstein Klomek, Alan Apter, Vladimir Carli, Camilla Wasserman, Gergö Hadlaczky, Christina W. Hoven, et al. 2017. »Bullying Victimization and Suicide Ideation and Behavior Among Adolescents in Europe: A 10-Country Study." Journal of Adolescent Health 61 (2): 179-86.

Belmont, M., Skinner, E., Wellborn, J. in Connell, J. (1992). Teacher as social context (TASC). Student report measures of teacher provision of involve- 
ment, structure, and autonomy support (Technical Report). Rochester, NY: University of Rochester.

Card, Noel A. in Ernest V. E. Hodges. 2008. Peer Victimization Among Schoolchildren: Correlations, Causes, Consequences, and Considerations in Assessment and Intervention.« School Psychology Quarterly 23 (4): 451-61.

Davis, Mark H. 1980. "A Multidimensional Approach to Individual Differences in Empathy." JSAS Catalog of Selected Documents in Psychology 10: 85-104.

Durlak, Joseph A, Allison B. Dymnicki, Rebecca D. Taylor, Roger P. Weissberg in Kriston B. Schellinger. 2011. »The Impact of Enhancing Students' Social and Emotional Learning: A Meta-Analysis of School-Based Universal Interventions.« Child Development 82 (1): 405-432.

Elledge, L. Christian, Allison R. Elledge, Rebecca A. Newgent in Timothy A. Cavell. 2016. "Social Risk and Peer Victimization in Elementary School Children: The Protective Role of Teacher-Student Relationships.« Journal of Abnormal Child Psychology 44 (4): 691-703.

Fanti, Kostas A. in Christopher C. Henrich. 2015. „Effects of Self-Esteem and Narcissism on Bullying and Victimization During Early Adolescence.« Journal of Early Adolescence 35 (1): 5-29.

Goodman, Robert. 1997. »The Strengths and Difficulties Questionnaire: A Research Note." Journal of Child Psychology and Psychiatry 38 (5): 581-86.

Goodman, Robert. 2001. »Psychometric Properties of the Strengths and Difficulties Questionnaire." Journal of the American Academy of Child and Adolescent Psychiatry 40 (11): 1337-1345.

Griese, Emily R., Eric S. Buhs in Houston F. Lester. 2016. »Peer Victimization and Prosocial Behavior Trajectories: Exploring Sources of Resilience for Victims." Journal of Applied Developmental Psychology 44: 1-11.

Isaacs, Jenny, Ernest V.E. Hodges in Christina Salmivalli. 2008. »Long-Term Consequences of Victimization by Peers: A Follow-up from Adolescence to Young Adulthood.« International Journal of Developmental Sciences 2 (4): 387-397.

Jenkins, Lyndsay N., Michelle Kilpatrick Demaray, Stephanie Secord Fredrick in Kelly Hodgson Summers. 2016. „Associations Among Middle School Students' Bullying Roles and Social Skills." Journal of School Violence 15 (3): 259-278.

Jennings, Patricia A. in Mark T. Greenberg. 2009. »The Prosocial Classroom: Teacher Social and Emotional Competence in Relation to Student and Classroom Outcomes."Review of Educational Research 79 (1): 491-525. 
Juul, Jesper in Helle Jensen. 2009. Od poslušnosti do odgovornosti. Ljubljana: Didakta.

Košir, Katja, Tina Pivec, Lucia Klasinc, Tanja Špes in Marina Horvat. 2018. "Psihosocialne značilnosti učencev kot napovedniki različnih oblik medvrstniške viktimizacije in nasilnega vedenja.« Psihološka obzorja / Horizons of Psychology 186: 171-186.

Lafontana, Kathryn M. in Antonius H.N. Cillessen. 2010. »Developmental Changes in the Priority of Perceived Status in Childhood and Adolescence." Social Development 19 (1): 130-147.

Lucas-Molina, Beatriz, Ariel A. Williamson, Rosa Pulido in Alicia Perez-Albeniz. 2015. "Effects of Teacher-Student Relationships on Peer Harrassment: A Multilevel Study." Psychology in Schools 52 (3): 298-314.

Marengo, Davide, Tomas Jungert, Nathalie O. Iotti, Michele Settanni, Robert Thornberg in Claudio Longobardi. 2018. „Conflictual Student-Teacher Relationship, Emotional and Behavioral Problems, Prosocial Behavior, and Their Associations with Bullies, Victims, and Bullies/Victims.«Educational Psychology 38 (9): 1201-1217.

Marsh, Herbert W. (1992). »Self Description Questionnaire (SDQ) II: A theoretical and empirical basis for the measurement of multiple dimensions of adolescent self-concept: An interim test manual and a research monograph." Novi Južni Wales, Avstralija: University of Western Sydney, Faculty of Education.

OECD. 2017. »PISA 2015 Technical Report." http://www.oecd.org/pisa/data/ 2015-technical-report/.

Olweus, Dan. 1997. „Bully/Victim Problems in School: Facts and Intervention.« European Journal of Psychology of Education XlI (4): 495-510.

Racz, Sarah Jensen in Robert J. McMahon. 2011. "The Relationship Between Parental Knowledge and Monitoring and Child and Adolescent Conduct Problems: A 10-Year Update.« Clinical Child and Family Psychology Review 14 (4): 377-398.

Riggs, Nathaniel R. in Samantha M. Brown. 2017. "Prospective Associations Between Peer Victimization and Dispositional Mindfulness in Early Adolescence."Prevention Science 18 (4): 481-489.

Salmivalli, Christina in Kätlin Peets. 2009. "Handbook of Peer Interactions, Relationships, and Groups."V Handbook of Peer Interactions, Relationships, and Groups, ur. Kenneth H. Rubin, William M. Bukowski in Brett Laursen, 322-340. New York, NY: The Gulford Press.

Košir, Katja, Tina Pivec, Lucia Klasinc, Tanja Špes, and Marina Horvat. 2018. "Psihosocialne Značilnosti Učencev Kot Napovedniki Različnih Oblik 
Medvrstniške Viktimizacije in Nasilnega Vedenja." Psihološka Obzorja / Horizons of Psychology 186: 171-86. https://doi.org/10.20419/2018.27.494.

Riggs, Nathaniel R., and Samantha M. Brown. 2017. "Prospective Associations Between Peer Victimization and Dispositional Mindfulness in Early Adolescence." Prevention Science 18 (4): 481-89. https://doi.org/10.1007/ S11121-017-0750-Z.

Saarento, Silja, Antti Kärnä, Ernest V E Hodges, and Christina Salmivalli. 2013. "Student-, Classroom-, and School-Level Risk Factors for Victimization." Journal of School Psychology 51 (3): 421-34. https://doi.org/10.1016/j. jsp.2013.02.002.

Zych, Izabela, Maria M. Ttofi, and David P. Farrington. 2019. "Empathy and Callous-Unemotional Traits in Different Bullying Roles: A Systematic Review and Meta-Analysis." Trauma, Violence, and Abuse 20 (1): 3-21. https://doi.org/10.1177/1524838016683456.

Sentse, Miranda, Tina Kretschmer in Christina Salmivalli. 2015. »The Longitudinal Interplay between Bullying, Victimization, and Social Status: Age-Related and Gender Differences.« Social Development 24 (3): 659-677.

Solberg, Mona E. in Dan Olweus. 2003. »Prevalence Estimation of School Bullying with the Olweus Bully/Victim Questionnaire."Aggressive Behavior 29 (3): $239-268$.

Sulkowski, Michael L. in Jessica Simmons. 2017. »The Protective Role of Teacher-Student Relationships against Peer Victimization and Psychosocial Distress.« Psychology in the Schools 55 (2): 137-150.

Thornberg, Robert, Linda Wänström in Tiziana Pozzoli. 2017. »Peer Victimisation and Its Relation to Class Relational Climate and Class Moral Disengagement among School Children.« Educational Psychology 37 (5): 524536.

Zych, Izabela, Maria M. Ttofi in David P. Farrington. 2019. »Empathy and Callous-Unemotional Traits in Different Bullying Roles: A Systematic Review and Meta-Analysis.« Trauma, Violence, and Abuse 20 (1): 3-21.

\section{Viri}

Kozina, Ana, Maša Vidmar, Christine Saelzer, Maria Rasmunson, Iris Marušić, Helle Jensen, Birgitte Lund Nielsen, Sonja Vieluf, Aleš Ojsteršek in Svetlana Jurko. 2017. »Hand in Hand: Social and Emotional Skills for Tolerant and Non-discriminative Societies (A Whole School Approach), Erasmus $K_{3}$ project.« Pridobljeno s http://handinhand.si (2. 12. 2019). 



\section{Nekaj epistemoloških zapiskov o raziskovanju spola $v$ edukaciji}

Valerija Vendramin

Uvodne besede: feministične epistemologije

Pričujoči prispevek začenjam z dvema splošnima izhodiščema. Prvo zadeva šolo (oziroma izobraževalne institucije), ki jo v splošnem razumem kot ospoljen sistem, ki ima svoje učinke: npr. omejuje možnosti, stereotipizira, vrednostno razvršča različne tipe vednosti, določa, kaj je primerno za en in kaj za drug spol ipd. (še vedno v okviru binarne spolne klasifikacije, kar je danes teoretsko, aktivistično in še kako drugače preseženo).

Nadalje - kar je moje teoretsko izhodišče - črpam iz feminističnih

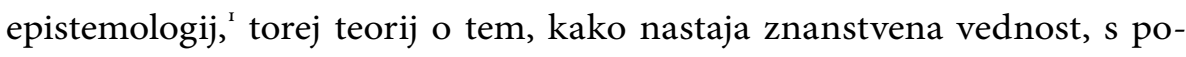
sebnim poudarkom na spolu. Spol je v tem okviru postavljen kot kategorija epistemske (tj. s pridobivanjem vednosti povezane) analize in rekonstrukcije (Janack, 2004). Na tem mestu je treba tudi opozoriti oziroma dodati, da spol seveda ni (več) postavljen kot izolirana spremenljivka ali spremenljivka, ki bi jo bilo mogoče ločiti od drugih osi zatiranja in podvreči ločeni analizi (Alcoff in Potter, 1993: 3-4).

To je moj konceptualni okvir, s pomočjo katerega sledim linijam vzdolž t. i. hegemonih »teorij« (ki zagovarjajo različne vrednote, kar pomeni, da ženske, denimo, lahko devalvirajo na različne načine (prim. Kegan Gardiner, 1984)), torej »teorij«, ki jih ne prepoznamo kot take, ker jih imamo za zdrav razum ali nujnost, kot temu pravi Sara Ahmed (2000: 99).

1 Uporabljam izraz v množini, ker gre za različne usmeritve in heterogenost »znotraj « feministične epistemologij. 
Osnovni zaznamek feminističnih epistemologij je »zaveza družbenim in političnim ciljem feminizma ter raziskovanje razmerja oziroma povezav med zatiranjem, ki temelji na spolu, in praksami iskanja [oziroma pridobivanja] vednosti (Grasswick in Owen Webb, 2002: 186). To pa med drugim pomeni tudi kritično vrednotenje znanstvenih oziroma raziskovalnih rezultatov, kjer se (po)kažejo vrednote, predsodki ter družbene, kulturne in zgodovinske posebnosti, za katere običajno velja, da niso prisotne zaradi objektivnosti znanosti in univerzalne veljavnosti znanstvenih izsledkov (gl. npr. Vendramin, 2013).

Mimogrede, vse te postavke niso nujno specifične za feministične epistemologije, tega se zavedam, a tu ni prostora za podrobno obdelavo (hkrati pa bi to pomenilo (pre)veliko zastranitev). Strinjala pa bi se z Aino Saarinen, da feministično raziskovanje ali iz feminizma izhajajoče raziskovanje predstavlja izziv obstoječi paradigmi (angl. a paradigmatic challenge) (Saarinen, 1988: 44). ${ }^{2}$

Ob tem - če se obrnemo k drugemu izhodišču - je pomembno vprašanje, kako kvantitativno raziskovati spol, ne da bi reproducirali spolni dualizem (že zgoraj sem omenila, da ta delitev ne zdrži več) in kako sploh definirati spol kot kategorijo. Kako bi torej lahko zavestno razgrajevale diskriminatorne poglede, če so naša metodološka orodja, posebej tista, ki delujejo skozi kvantitativne analize, nezadostna ali slepa za različnost diskriminacij (Vendramin in Šribar, 2010)?

\section{Glavna koordinata?}

Ta epistemološki okvir je velikega pomena tudi na področju globalnih raziskav na polju vzgoje in izobraževanja, ki jih na različne načine prežemajo trditve o "napredku« žensk oziroma deklet in vse večjih priložnostih in možnostih, ki jih imajo le-te domnevno v svojih življenjskih potekih. V prvi vrsti se je treba vprašati, kaj pomeni »ugotovitev«, da je v vzgoji in izobraževanju enakost med spoloma (spoli!) dosežena, kaj je temeljni označevalec te enakosti in kako na to razumevanje vpliva preplet medijskih vplivov, dominantnih diskurzov spola in raziskovalnih usmeritev. Obstoječi temeljni označevalec - uspeh ali neuspeh pri merjenju znanja - se zdi ne-

2 Če nas izraz "paradigma" spomni na delo Thomasa Kuhna The Structure of Scientific Revolutions (v slov.: Struktura znanstvenih revolucij, Ljubljana: Krtina, 1998), še toliko bolje. Od tod so možni nadaljnji razmisleki, npr. če se paradigma res spreminja in kakšne so te spremembe. 
zadosten (čeravno ga je najlažje podati kot udarno novico, ki jo še podkrepimo s številkami in grafi).

Kot pravi Anita Harris, je treba velikim izjavam (kot npr.: »Dekleta bodo zavladala svetu!«) ob bok postaviti nekoliko natančnejše preučene izkušnje posameznic, saj tovrstne »ugotovitve« puščajo le malo prostora za razmislek o vsakdanjem stresu in vsakdanjih borbah, seksizmu, ki ostaja del življenj (tudi uspešnih) deklet, pa tudi o kasnejših karierah (Harris v Pomerantz in Raby, 2017: xi-xii), ki se lahko zaustavijo bolj ali manj pod vrhom, kot pričajo denimo akademske poti marsikatere raziskovalke, znanstvenice, akademske profesorice ipd.

Seveda so »dekleta na vrhu« (kamor so prispela zaradi svojih izobraževalnih dosežkov/sposobnosti) že kar nekaj časa udarna fraza, "pametno dekle« je postalo blagovna znamka in tržna niša, pa tudi seksualni stereotip. Tako dekle je konstruirano kot samoustvarjena zmagovalka v svetu, kjer te odločnost in pamet lahko pripeljeta kamor koli. Poleg tega to v nadaljevanju pomeni ali omogoči tudi zapiranje zadnjega poglavja v knjigi feminizma (Harris v Pomerantz in Raby, 2017: x). ${ }^{3}$

Vse to se umešča v t. i. "postfeministično naracijo neoliberalizma« (Braidotti, 2005: 4), ${ }^{4}$ za katero so med drugim značilni:

- postavljanje feminizma kot blagovne znamke, »feminizem «" je postal nekaj, kar se prodaja (nekaj, kar je v luči t. i. zvezdniškega feminizma ${ }^{6}$ dobilo novo aktualnost),

- poudarjanje individualne vrednosti (in uspeha) posamezne ženske, ne da bi upoštevali konkretne okoliščine oziroma sistemske možnosti ali nemožnosti,

3 Kako je s feminizmom danes, je seveda obširna tema, ki se je tule dotaknem precej površno. Če nadaljujem z zgornjo prispodobo, lahko rečem, da nas v »knjigi feminizma« čaka še veliko poglavij.

4 Skupna značilnost tovrstnih naracij je, kot opozarja Rosi Braidotti, vrnitev različnih oblik determinizma, lahko je determinizem neoliberalne ali genske vrste. Prvi brani superiornost kapitalizma, drugi pa despotsko avtoriteto DNK-ja (Braidotti, 2005: 1). Tule gremo lahko še malo naprej, do nevroznanstvenega obrata, v katerem, kot piše Deboleena Roy, so možgani zamenjali gen kot biološki arbiter človekovega samospoznavanja (Roy, 2016: 531).

5 Feminizem je na tak način seveda razumljen zelo »razredčeno«, zato tudi narekovaji.

$6 \mathrm{Tj}$. »feminizma«, kot ga artikulirajo predvsem anglo-ameriške zvezdnice. Na tem mestu se ognimo premlevanju perečega vprašanja, za kakšen feminizem gre: za pravi feminizem, za feminizem »lite« ali sploh ne za feminizem. Za nekaj več o tem gl. Vendramin 2019b. 
- neoliberalni besednjak opolnomočenja in izbire (ki implicira, da je treba samo hoteti - da so torej izbire dejansko na voljo vsem in da je naš morebitni neuspeh samo naša krivda).

Torej je treba v luči povedanega razumeti trenutne specifike (npr. povezave postfeminizma in neoliberalizma) (za nekaj več gl. npr. Vendramin 2019a), hkrati pa je treba, kot meni tudi Becky Francis (2006: 189), v tej razpravi o spolu, uspehu, dosežkih in (ne)enakostih nujno ohraniti angažma v smeri kritike epistemološkega okvira te razprave (gl. tudi Vendramin, 2019a). To pa med drugim - v širšem okviru - pomeni, da so vprašanja »o obsegu, naravi in omejitvah vednosti osrednjega pomena za razumevanje razprav o legitimnosti in veljavnosti edukacijskega raziskovanja « (Kelly, 2006: 33). Hkrati (ibid.) se kot skupnosti, ki proizvajajo vednost (angl. »knowledge producing communities«), zavedajmo, da so (1) znanstvene metode odvisne od teorij, (2) da ima disciplinarna vednost družbeni temelj, (3) da obstaja pluralnost vednostnih sistemov in (4) da so v znanstveni vednosti (lahko) prisotne tudi ideološko pogojene distorcije (Kelly, 20o6: 36). ${ }^{7}$

Če se neposredno obrnemo k izobraževalnim, šolskim in podobnim realnostim, bi se tu rada osredotočila predvsem na vprašanja o oblastnih razmerjih in epistemološka vprašanja, na tista torej, ki zadevajo izjave o resnici ter posredovanju in konstituiranju vednosti. Sem sodita dva pomembna problemska sklopa: prvi je problem »uradne« vednosti in uradnega kurikula, drugi pa problem prikritega kurikula, čemur sem bom na kratko posvetila v nadaljevanju.

\section{Kurikulum kot epistemološka tema}

Prikriti kurikulum je izjemno pomemben koncept v raziskovanju vzgoje in izobraževanja, ki zahteva (in hkrati omogoča!) metodološko fleksibilnost in razumevanje specifičnosti konteksta, hkrati pa varuje pred zabrisovanjem individualnih specifičnosti z nekim od zunaj vsiljenim »objektivnim « sistemom pomenjenja (Henwood in Pidgeon, 1995: 10). Z izrazom označujemo različna, tudi neizrečena pravila, norme ipd., ki se jih otroci naučijo v šoli poleg t. i. uradnega kurikula, ki ga, mimogrede, prav tako ne more-

Vse štiri postavke skupaj, še posebej pa 2. in 4., so pogosto vir hudega nestrinjanja med pripadniki_cami različnih ved, disciplin ali šol. A znanost je podvržena družbenim in političnim »okužbam«, podatke je prav gotovo mogoče filtrirati skozi predsodke (Gould, 20oo: 46-47, 53). In še to: postavka 3 ne pomeni relativizma v smislu, da je mogoče kar koli: relativizem je zrcalni dvojček totalizacije v ideologijah objektivnosti (Haraway, 1999: 306). 
mo gledati videti kot rezultat »objektivnih« izbir, na katere ne vplivata ne ideologija ne politika in/ali osebne vrednote, spretnosti ter odprtost za tišine in izključitve. ${ }^{8}$ Zadeva tudi vrednostno razvrščanje po spolu in vednostih, kot npr.: jeziki in matematika, družboslovje in naravoslovje, mehke in trde znanosti, punce in fantje ... ${ }^{9}$ Da ga odkrijemo, potrebujemo določeno mero dvoma in premisleka/razmisleka/pomisleka ipd., kar gre $\mathrm{z}$ roko $\mathrm{v}$ roki z neke vrste ustanovnim geslom prikritega kurikula, kot ga je formuliral Philip Jackson (1968): "Za navadnim leži nenavadno. «"

Ko prekinemo $\mathrm{z}$ ustaljenim miselnim tokom, lahko rekonstruiramo realnost drugega in osvetlimo tisto, kar leži "pod površino ideološkega zdravega razuma (Henwood in Pidgeon, 1995: 19). Lahko generiramo vednosti, ki segajo onstran dominantnih modelov - tj. tistih, ki vsebujejo različne predsodke in - v našem primeru - vzpostavljajo zdravorazumsko razmišljanje o spolu (tako kar zadeva tako šolo kot tudi širši družbeni prostor).

Ker smo vedno vpleteni $\mathrm{v}$ družbena razmerja, ki so hierarhična ter zgodovinsko in kulturno specifična, to vpliva - poenostavljeno - na to, kako razbiramo svet okoli sebe. Ti načini pa so nadalje pomembni za epistemološke probleme in naše razumevanje izrazov, kot so »objektivnost«, »racionalnost «, »vednost (Janack, 2004).

Uvid, da vednost nosi odtise skupnosti, ki jo ustvarja (Hesse-Biber in Yaiser, 2004: 45), da so vednostne trditve perspektivične, tj. vedno jih »ustvari« nekdo v nekem času, je temeljnega pomena za razumevanje in interpretiranje znanstvenih izjav. Nujna je tudi samorefleksivnost, se pravi, razmislek o materialnih, zgodovinskih in družbenih pogojih, v katerih so vednosti nastale, in oblastnih razmerjih $\mathrm{v}$ raziskovalnem procesu (Prins, 1995: 354; Ramazanoğlu, 2002: 118 in nasl.). Raziskovanje v tem okviru, ni več razumljeno kot zunanje delovanje na družbeno realnost, ampak njen konstitutivni del. (Archer, 2003: 29 in nasl.). Zato je tu na mestu postaviti metodološko orientirano hipotezo, in sicer: da je pri oblikovanju analitičnih kategorij in zastavljanju vprašanj treba upoštevati tudi povezavo med

8 Katera/čigava vednost je predstavljena v kurikulu, je prav tako problem, ki nas tule zadeva.

9 O tem je denimo že pred časom pisala Valerie Walkerdine v delu Counting Girls Out, (London: Virago, 1989).

10 Phillip W. Jackson je definiral koncept prikritega kurikula v svojem delu Life in Classrooms (ki je prvič izšlo leta 1968). Jackson govori o nekaterih ključnih besedah, ki definirajo dejstva/okoliščine (»the facts of life«), ki se jim morajo prilagoditi učenci in učenke (pa seveda tudi učitelji in učiteljice). To so: množice, pohvala in moč. 
metodologijo in epistemološko orientacijo raziskovalca_ke (kar je blizu t. i. umeščeni vednosti ${ }^{\text {II }}$ feministične epistemologije).

\section{Zaključne besede}

Oblikovanje kurikula in refleksija prikritega kurikula je samo eno od polj, kjer feministična refleksija lahko odpre pomembno pot $\mathrm{k}$, pogojno rečeno, boljšim možnostim. Refleksijo sem tu usmerila k epistemološkim temeljem nekaterih praks in se poskušala navezati na obe plati kurikula. Kurikula kot dejavnosti in vsebine ne moremo predstavljati s problematično oznako »objektivnosti«, bržkone prav nasprotno, "priznati« je treba svoje korenine v kulturi, zgodovini in družbi ter vpliv, ki ga imajo te korenine na naše konstrukcije vednosti in naturaliziranje neenakosti (Apple, 1992: 70).

A bistven potencial kurikularnih kritik na ravni vsebine in forme vidim predvsem v senzibiliziranju na ideološke prakse, ki so prikrite, težko ugotovljive in zato izjemno vztrajne. Kljub temu, da interpretacija ne more biti enoznačna, je mogoče razviti možnosti za alternativna branja oziroma konstrukcijo pomena $\mathrm{v}$ kontekstu socialnih, zgodovinskih in oblastnih razmerij. V splošnem pa spopad s samoumevnostjo, kjer se lahko srečata feministična epistemologija in preučevanje kurikula kot del širšega polja vzgoje in izobraževanja, odpira pot k (sicer težavnemu) razvijanju občutljivosti na nesprejemljiva vedenja in odzive ali pa k pogledu »z druge strani«, zamišljanju drugačnih načinov življenja, razvijanje razumevanja in odgovornosti tudi za ljudi zunaj nam najbližjega kroga - torej k nekakšni rekonceptualizaciji možnih svetov. Bistven pa je prispevek feministične orientacije, ki razkriva progresivne politične možnosti tovrstne epistemologije (Alcoff in Potter, 1993: 2). Na ta način je predlagan korektiv, ki tematizira feministično epistemologijo kot spremembo perspektive - tj. korektiv v obstoječi kognitivni tradiciji. Tovrstne intervencije hkrati lahko pomagajo rekonstruirati področje konvencionalnih raziskav, pripeljejo na površje spregledane vidike družbene realnosti ipd.

Pomemben poudarek je na tem, da so spoznavajoči partikularni in konkretni, ne pa abstraktni oziroma univerzalni. Ustrezna epistemologija mora upoštevati kompleksne načine, na katere družbene vrednote vplivajo na vednost (Alcoff in Potter, 1993: 13). To pa pomeni, da namen epistemologije ni le »zadovoljevati intelektualne radovednosti, pač pa tudi prispeva-

11 Umeščene vednosti so eden temeljnih konceptov feminističnih epistemologij. Predpostavka je nujnost zaznavanja lastnih vpetosti v družbena razmerja, saj vednost, ki jo ustvarjamo, odseva našo umeščenost na različne družbene lokacije. 
ti k emancipatornemu cilju: ${ }^{12}$ širjenju demokracije v produkciji vednosti « (ibid.). Nujno je, kot se zdi, razumevanje povezave med raziskovanjem in oblikovanjem vednosti ter teorijami oziroma epistemologijami in vsakokratnimi metodologijami.

\section{Literatura}

Ahmed, Sara. Whose Counting? Feminist Theory 1, št. 1 (2000): 97-103.

Alcoff, Linda, Potter, Elizabeth. Introduction: When Feminisms Intersect

Epistemology. V Feminist Epistemologies, ur. Linda Alcoff, Elizabeth Potter. New York in London: Routledge, 1993: 1-14.

Apple, Michael W., Between Moral Regulation and Democracy: The Cultural Contradiction of the Text, The School Field 3, št. 1/2 (1992): 49-76.

Archer, Louise (2003). Evidence-Based Practice and Educational Research. V Boys and Girls in the Primary Classroom, ur. Christine Skelton, Becky Francis. Maidenhead: Open University Press, 2003: 26-40.

Braidotti, Rosi. A Critical Cartography of Feminist Post-Postmodernism. Australian Feminist Studies 20, št. 47 (2005): 1-15.

Francis, Becky. Heroes or Zeroes? The Discursive Positioning of »Underachieving Boys « in English Neo-Liberal Education Policy. Journal of Education Policy 21, št. 2 (2006): 187-200.

Gould, Stephen Jay. Za-mera človeka. Ljubljana: Krtina, 2000.

Grasswick, Heidi. E., Owen Webb, Mark. Feminist Epistemology as Social Epistemology. Social Epistemology 16, št. 3 (2002): 185-196.

Haraway, Donna. Opice, kiborgi in ženske. Reinvencija narave. Ljubljana: Študentska založba, 1999.

Henwood, Karen, Pidgeon, Nick. Remaking the Link: Qualitative Research and Feminist Standpoint Theory. Feminism and Psychology 5, št. 1 (1995): 7-30.

Hesse-Biber, Sharlene Nagy, Yaiser, Michelle L. (ur.). Feminist Perspectives on Social Research, New York in Oxford: Oxford University Press, 2004.

Jackson, Philip W. Life in Classrooms. New York: Holt, Rinehart and Winston, 1968.

12 To pa še ne pomeni, kot je bilo velikokrat očitano, da je bistvo feminističnih epistemologij politična korektnost, ali pa, da so vse dosedanje znanstvene izjave izmišljije, ki jih je (moška) oblast spremenila v dejstva ipd. (prim. tudi Haraway, 1999: 130). Seveda dopuščam tudi možnost, da se $\mathrm{z}$ vsem v vseh feminističnih epistemologijah ni mogoče vedno strinjati. 
Janack, Marianne (2004). Feminist Epistemologies, Internet Encyclopedia of Philosophy. Dostopno prek: www.iep.utm.edu/fem-epis/ (1. 12. 2019).

Kelly, Gregory J. Epistemology and Educational Research. V Handbook of Complementary Methods in Education Research, ur. Judith L. Green, Gregory Camilli, Patricia B. Elmore. Washington: Lawrence Erlbaum za American Educational Research Association, 2006: 33-55.

Kegan Gardiner, Judith. Gender, Values, and Lessing's Cats, Tulsa Studies in Women's Literature 3, št. 1/2 (1984): 111-124.

Pomerantz, Shauna, Raby, Rebecca. Smart Girls. Success, School, and the Myth of Post-Feminism, Oakland: University of California Press, 2017.

Ramazanoğlu, Caroline, Holland, Jane (2002). Feminist Methodology. Challenges and Choices. Los Angeles, London, New Delhi, Singapore in Washington: Sage.

Roy, Deboleena. Neuroscience and Feminist Theory: A New Directions Essay, Signs: Journal of Women in Culture and Society 41, št. 3 (2016): 531-552.

Saarinen. Aino. Feminist Research: In Search of a New Paradigm?, Acta Sociologica 31, št. 1, (1988): 35-51.

Vendramin, Valerija. Spol kot koordinata danes in postfeministična edukacija. V O pravičnosti izobraževalnih politik in praks, ur. Urška Štremfel, 103112. Ljubljana: Pedagoški inštitut, 2019a.

Vendramin, Valerija. »Tako je videti feminist_ka«: medijske reprezentacije feminizma in feminizem $\mathrm{v}$ učnih načrtih. V Raziskovanje v vzgoji in izobraževanju, ur. Igor Ž. Žagar, Ana Mlekuž, 149-156. Ljubljana: Pedagoški inštitut, 2019b. Dostopno prek: https://www.pei.si/ISBN/978-961-270-311-o. pdf (10. 12. 2019).

Vendramin, Valerija. Epistemološki (in metodološki) vidiki spolne perspektive v znanosti. V Ženske $v$ znanosti, ženske za znanost: znanstvene perspektive žensk $v$ Sloveniji in dejavniki sprememb, ur. Mirjana Ule, Renata Šribar, Andreja Umek-Venturini, 65-76. Ljubljana: Fakulteta za družbene vede: Komisija za ženske v znanosti pri Ministrstvu za izobraževanje, znanost in šport RS, 2013.

Vendramin, Valerija, Šribar, Renata. Spol v raziskovanju: od binarizma in homogenosti h kompleksnosti. Družboslovne razprave 26, št. 64 (2010): 2543 . 


\section{Raziskave digitalizacije branja in pisanja ter medijske večopravilnosti - kakšne so spremembe na kognitivnem, čustveno-socialnem in nevrološkem področju ter v učnih dosežkih?}

\section{Simona Tancig}

\section{Uvod}

Spretnosti branja in pisanja so bistvene za uspešnost v današnji družbi. Zato se še posebna velika pozornost posveča opismenjevanju. Današnji digitalni čas zaznamuje izjemno pomembna prelomnica $\mathrm{v}$ zgodovini pisave, pisanja in branja. Prvič v zgodovini človeštva se pojavljajo težnje, da bi se opustilo učenje pisanja $z$ roko in ga nadomestilo s tipkovnico - $z$ dolgoročno posledico, da sčasoma nihče ne bo več znal brati ročno napisane pisave, enega najpomembnejših civilizacijskih dosežkov. Podobno se pri branju kažejo težnje, da se na papirju tiskana besedila nadomestijo z besedili na digitalnih nosilcih.

Da bi odgovorili na vprašanje, kaj izgubimo in kaj pridobimo s temi spremembami, se je v zadnjem desetletju zvrstilo veliko število interdisciplinarnih raziskav in projektov, katerih cilj je izboljšati znanstveno razumevanje vpliva digitalizacije na bralno pismenost. Njihov namen je tudi nuditi pomoč različnim disciplinam in družbenim dejavnikom (edukacijski politiki, praktikom v izobraževanju, založnikom ipd.).

Pomembno mesto $\mathrm{v}$ teh prizadevanjih ima program COST Evropske zveze, ki povezuje znanost in tehnologijo s projektom E-READ (COST-IS1404, 2014), ki je združeval 70 evropskih raziskovalcev s področja nevroznanosti, družboslovja, humanistike in informacijske tehnologije pod vodstvom Anne Mangen iz Univerze Stavanger na Norveškem (Mangen in Weel, 2016). Razvita je bila nova raziskovalna paradigma, ki temelji na mul- 
tidimenzionalnem integrativnem modelu branja in različnih eksperimentalnih pristopih ter na edukometriki za preverjanje in ocenjevanje vpliva digitalizacije na branje. Projekt se je po štirih letih lansko leto končal z Deklaracijo iz Stavangerja o prihodnosti branja (COST-IS1404, 2019), ki podaja glavne ugotovitve raziskav, priporočila za edukacijsko politiko in vzgojno-izobraževalno prakso ter vprašanja za nadaljnje raziskave.

\section{Utelešena kognicija}

Sodobne teorije v kognitivni znanosti poudarjajo, da je kognicija utelešena (Glenberg, 2008; Thompson, 2007; Varela et al., 1991). To pomeni, da percepcija, telesna aktivnost in čustva pomembno prispevajo k višjim kognitivnim procesom (Gallese in Lakoff, 2005). Z utelešeno kognicijo se v okviru post-kognitivistične paradigme ukvarjajo številne konstitutivne vede kognitivne znanosti, kot so filozofija, psihologija, kognitivna nevroznanost, robotika, lingvistika - poleg še nekaterih drugih.

Utelešena kognicija je tudi predmet pomembnih razprav in raziskav $\mathrm{v}$ edukacijski nevroznanosti (nevroedukaciji) ozir. znanosti o človekovem umu, možganih in edukaciji.

Najnovejše razumevanje utelešene kognicije se uveljavlja na različnih področjih, kot so: spomin, konkretni in abstraktni pojmi, številčnost, aritmetika, branje in pisanje (Kiefer in Trumpp, 2012; Kiefer in Pulvermüller, 2012). Raziskave utelešene kognicije imajo pomembne implikacije $\mathrm{v}$ edukaciji kot tudi širše $\mathrm{v}$ današnji digitalni dobi, ki pomembno spreminja vlogo senzo-motorike, percepcije in telesne aktivnosti $v$ učenju in poučevanju ter reševanju problemov, ki jih prinaša sodobna družbena realnost.

Teorija utelešene kognicije dobiva vedno večjo podporo s psihološki$\mathrm{mi}$ in nevroznanstvenimi raziskavami, ki dokazujejo tesno povezanost med senzoričnimi in motoričnimi sistemi ter kognicijo (Kiefer in Barsalou, 2013).

Tehnike slikanja možganov, elektrofiziološke meritve, vedenjski eksperimenti (priming) in nevrofiziološke študije dajejo neposredne dokaze o vključevanju specifičnih senzoričnih in motoričnih sistemov med izvrševanjem kognitivnih nalog. Novejše raziskave utelešene kognicije na različnih kognitivnih področjih imajo pomembne posledice za učenje in poučevanje ter podpirajo širše vključevanje senzomotoričnih dejavnosti $\mathrm{v}$ poučevanje na različnih predmetnih področij - učenje skozi gibanje (Tancig, 2014a, 2014b). 
Teorija utelešene kognicije predpostavlja, da na branje vpliva pisanje kot tudi same tehnike pisanja, ker se motorični programi in senzorične izkušnje, pridobljeni med pisanjem, ponovno aktivirajo med branjem. Ti programi in izkušnje pa se zelo razlikujejo pri pisanju s pisalom na papir v primerjavi s tipkanjem na tipkovnico. Podobno se senzomotorične izkušnje močno razlikujejo pri branju s papirja $\mathrm{v}$ primerjavi $\mathrm{z}$ branjem besedila na digitalnih nosilcih.

\section{Zakaj je pisanje pomembno za branje}

S slikanjem možganov s funkcionalno magnetno resonanco (fMRI) sta Nakamura in Dehaene s sodelavci (Nakamura et al., 2012) tako pri francoskih kot pri kitajskih bralcih ugotovila, da sta bila vključena tako vizualni kot tudi motorični sistem za geste (kretnje), ko so udeleženci brali rokopisno besedilo v materinem jeziku. Branje tako vključuje dve živčni omrežji - eno, ki prepoznava obliko besed (VWFA - vizualno področje oblike besed), in drugo, ki dekodira fizične motorične geste, sodelujoče pri pisanju (Exnerjevo področje). Motorično procesiranje je pri pisanju univerzalno in vključuje področje, poimenovano Exnerjevo, ki se torej aktivira tudi pri branju ne glede na jezikovno kulturo.

Obe univerzalni omrežji - sistem za prepoznavanje oblik in sistem za prepoznavanje gest - se podobno aktivirata in kažeta identični vzorec aktivacije v obeh jezikovnih skupinah (Dehaene, 2014). Vizualni sistem oblike besed (VWFA) je občutljiv za statično zaporedje niza črk in Exnerjevo področje je občutljivo za smeri kretenj naprej in nazaj, s katerimi so dinamično predstavljene črke rokopisa.

\section{Pisati ali tipkati}

\section{Razlike v nevrokognitivnih procesih}

Nevroznanstvene raziskave so potrdile, da se pri pisanju $\mathrm{z}$ roko aktivirajo druga možganska področja kot pri tipkanju. Različne raziskave dokazujejo, da pisanje bolj spodbuja delovanje možganov kot tipkanje.

Tako so Longcamp et al. (2005) v raziskavi predšolskih otrok ugotovili, da so bolj uspešni pri prepoznavanju črk, če jih vadijo s pisanjem kot $s$ tipkanjem. Omenjeni raziskovalci so predpostavili, da pisanje podpira notranji model črk zaradi integracije vida, motoričnih ukazov in kinestetične povratne informacije, česar tipkanje ne omogoča. Podobno so bili tudi odrasli, ki so se učili pisati nove, t.i. psevdočrke, boljši po 3 in 6 tednih pri nji- 
hovem zapomnjenju in prepoznavanju njihove pravilne orientacije, če so jih pisali $\mathrm{z}$ roko.

Pri njih so s snemanjem možganske aktivnosti ugotovili, da je bilo zaznati aktivnost $\mathrm{v}$ možganskem predelu, odgovornem za artikulacijo in produkcijo govora (t.i. Brockovo področje v možganski skorji), medtem ko pri tipkajočih $\mathrm{v}$ tem področju ni bilo zaznati skoraj nobene aktivnosti.

Pomembne informacije za prakso je dala tudi raziskava avtoric Kersey in James (2013), $v$ kateri so otroci imeli aktiven trening s pisanjem in pasivnega $\mathrm{z}$ opazovanjem druge osebe pri pisanju; aktivacijo možganov so pri tem ugotavljali s fMRI. Rezultati so pokazali, da aktivni trening pisanja privede do večjega vključevanja senzomotoričnega omrežja, povezanega s percepcijo črk, medtem ko tega ni zaznati pri pasivnem opazovanju. To kaže, da je perceptivno omrežje za novo naučene pisane črke bolj upravljano z motorično izvedbo kot pa s povratno perceptivno informacijo.

Zanimiva je zelo kompleksna raziskava, s katero sta James in Engelhardt (2012) preverili, kako različne senzomotorične dejavnosti ozir. izkušnje vplivajo na obravnavanje črk $\mathrm{v}$ možganih. $\mathrm{V}$ raziskavi so sodelovali 5-letni otroci, ki se še niso učili brati in pisati. Otrokom so pokazali različne črke in oblike, ki so jih nato reproducirali na tri načine: tako, da so jih prostoročno prerisali na prazen papir; s sledenjem črke ali oblike, označene s pikami na predlogi; s pritiskom na ustrezno tipko. Nato so jim pokazali slike teh črk in oblik ter pri tem s fMRI snemali njihovo možgansko dejavnost. Rezultati so pokazali, da se je predhodno dokumentirano „bralno omrežje" aktiviralo samo med percepcijo črk in oblik, ki so jih otroci narisali prostoročno, ne pa med percepcijo tistih, ki so jih izvajali s sledenjem po predlogi ali s tipkanjem, kjer je bila aktivacija možganov bistveno manjša. Te ugotovitve kažejo, da je pisanje pomembno za zgodnje aktiviranje možganskih področij pri procesiranju črk, ki je osnova uspešnega branja. Torej pisanje pri otrocih spodbuja pridobivanje bralne spretnosti. James (2012) je $\mathrm{z}$ raziskavo ugotovila, da pisanje prispeva tudi $\mathrm{k}$ bralni fluentnosti $\mathrm{z}$ aktivacijo vizualne percepcije črk s povečanjem natančnosti ter hitrosti prepoznavanja črk.

\section{Razlike v kognitivnih procesih in učenju}

Berninger et al. (2009) so izvedli raziskavo pri učencih četrtega razreda $\mathrm{z}$ učnimi težavami na področju pisanja in črkovanja ter tistimi brez učnih težav. Raziskava je bila del širšega 5-letnega longitudinalnega projekta, v katerem je sodelovalo 240 učencev drugega, četrtega in šestega razreda. 
Učence $\mathrm{z}$ in brez omenjenih učnih težav so primerjali na treh nalogah pisanja (črke, stavki, pisanje eseja) s pisalom in z uporabo tipkovnice.

Rezultati so pokazali, da so učenci s pisalom napisali daljši esej s hitrejšo produkcijo besed kot s tipkovnico. Poleg tega so učenci četrtega in šestega razreda pisali bolj popolne stavke, ko so pisali s pisalom, kot s tipkovnico. Dodatna analiza je pokazala, da je število idej, izraženih v esejih, bilo večje pri pisanju v primerjavi s tipkanjem.

Glede na to, da se pri študentih vedno bolj širi praksa zapisovanja predavanj s prenosnim računalnikom, ki nadomešča zapiske, pisane s pisalom, sta Müeller in Oppenheimer (2014) raziskala učinkovitost obeh načinov zapisovanja pri študiju.

Izvedla sta tri eksperimentalne študije $\mathrm{v}$ naravnem okolju. $\mathrm{V}$ prvem eksperimentu so študenti poslušali isto predavanje, pri tem pa so nekateri delali zapiske v beležke in drugi v prenosnik. Pri tem so dobili navodilo, da naj uporabljajo svojo običajno strategijo zapisovanja. Po predavanju so vse študente preizkusili v priklicu dejstev in konceptualnem znanju iz vsebine predavanja. Ugotovili so enako uspešnost obeh skupin pri faktografskem znanju, vendar so bili študenti s prenosniki slabši pri konceptualnem znanju.

Zanimivo je, da se je tudi pri drugi različici eksperimenta, ko so uporabnikom prenosnika dali navodilo, naj predavanja ne zapisujejo dobesedno, ta intervencija pokazala za povsem neuspešno. Študenti so z uporabo prenosnika še vedno delali verbatim zapiske, kar je poslabšalo njihovo učenje. Ponovno se je pokazala povezava med slabšim konceptualnim znanjem in verbatim zapiski. Čeprav so ti zapiski obsežnejši in bolj berljivi, očitno način s tipkanjem bolj vodi v proces zapisovanja „brez misli“. In na drugi strani je zapisovanje s pisalom tisto, ki omogoča aktivnejše procesiranje informacij z njihovim selekcioniranjem glede na pomembnost, s preoblikovanjem, s parafraziranjem, $\mathrm{z}$ označevanjem ipd.

Ker študenti v predhodnih dveh študijah niso imeli možnosti pregledati in preštudirati gradiva $\mathrm{v}$ zapiskih, so jim $\mathrm{v}$ ponovljenem eksperimentu omogočili, da se pripravijo na izpit. Rezultati so bili tudi tokrat presenetljivi. Tisti, ki so delali zapiske $s$ pisanjem $\mathrm{v}$ beležke, so bili pomembno boljši kot kdor koli iz druge skupine. Boljši so bili tudi od tistih, ki so v celoti transkribirali predavanje. Študenti, ki so beležili predavanje s pisanjem, so v splošnem zapisali manj informacij kot tudi manj dobesedno. Vendar so bili boljši v faktografskem kot tudi v višjenivojskem znanju. Avtorja domnevata, da zapisovanje s pisalom ne samo, da vodi $\mathrm{v} k v a l i t e t n e j-$ 
še učenje, temveč je tudi boljša strategija za uskladiščenje novega učenja za poznejši študij.

Če povzamemo. Nevroznanstvene in nevroedukacijske raziskave kažejo, da je branje tesno povezano s pisanjem in da pisanje veliko bolj spodbuja bralno zmožnost kot tipkanje. Nesporno je, da je pisanje z roko pomembno za učenje branja in prispeva $\mathrm{k}$ tekočemu branju. In ne samo to, raziskave tudi kažejo prednosti pisanja z roko pri zapomnjenju in razumevanju učnega gradiva, pri osvajanju pojmov, pri razvoju spominskih in izvršilnih funkcij, refleksivnega učenja in višjenivojskega znanja kot tudi pri razvoju fine motorike, koordinacije oko-roka, spacializacije ipd. Pisanje $z$ roko je torej pomembno tudi za razvoj različnih kognitivnih funkcij in ne samo za učenje branja (Tancig, 2014).

\section{Kaj loči branje knjige od branja besedila na digitalnem nosilcu}

Podobno kot pri pisanju se tudi pri branju ugotavljajo razlike glede na medij, ki ga uporabljamo pri branju - tiskano gradivo ali bralnik Kindle ozir. tablica ali kakšen drugi digitalni pripomoček. Norveška raziskovalka Anne Mangen, vodja nove evropske raziskovalne mreže, ki je raziskovala, kako digitalizacija vpliva na branje besedil, ugotavlja, da je pri branju besedil v elektronski obliki težko vzdrževati daljšo pozornost, zato je branje bolj prekinjeno in razdrobljeno, kot tudi, da negativno vpliva na nekatere kognitivne (razumevanje) in emocionalne vidike branja (Mangen in Kuiken, 2014). Podobno kot pri pisanju je potrebno tudi pri branju iskati razlage omenjenih rezultatov v bistveno drugačnih senzoričnih (vidnih in tipnih) ter motoričnih oz. haptičnih značilnostih, ki ločijo branje knjige od uporabe digitalnega nosilca.

\section{Dve dimenziji utelešene kognicije}

Govorimo o haptičnosti, ki je opredeljena kot kombinacija tipne percepcije $z$ gibalno aktivnostjo, ki sproža propriorecepcijo ${ }^{1}$. Pri namernem premikanju rok - bodisi, da gre za raziskovanje ali rokovanje s predmeti - je vključena haptična percepcija, ki je velikega pomena pri pisanju in branju.

Drug pomemben vidik, ki stopa $v$ ospredje pri pojmovanju utelešene kognicije pri branju v digitalni dobi, izhaja iz ekološke psihologije Gibsona (1979), ki poudarja možnosti za akcijo in interakcijo z okoljem ali objek- 
tom (affordance), npr. možnosti za interakcijo z digitalnim sredstvom, kot jih zaznava oseba. Tako se rokovanje ozir. interakcija s pisalom ali tipkovnico pomembno razlikujeta, podobno kot se pomembno razlikuje interakcija s knjigo v primerjavi z interakcijo s tablico, kar vse pomembno vpliva na bralno uspešnost in višje kognitivne procese.

\section{Haptičnost in interakcija $z$ objektom pisanja in tipkanja}

Pisanje in tipkanje se razlikujeta glede dimenzij haptičnosti in interakcije $z$ objektom pisanja - pisalom ozir. tipkovnico. Pisanje z roko tipično označuje npr. omejen prostor pisanja (list papirja), ki je skupen za vizualno in motorično dejavnost $-\mathrm{z}$ očmi sledimo gibanju s pisalom. Za vsako črko je značilen specifičen gib (grafomotorika). Pri tem je odnos med vizualno obliko in motoričnim programom enoznačen. Pri tipkanju sta vizualni prostor (ekran) in motorični prostor (tipkovnica) ločena. Vsak gib (pritisk na tipko), ki je enostaven in enak za vse črke, je povezan s položajem tipke, pri čemer je pomembno učenje ozir. poznavanje sheme tipkovnice.

V okviru mednarodnega podiplomskega študija kognitivne znanosti v Ljubljani je bila pod mentorstvom avtorice opravljena raziskava o razlikah $v$ doživljanju pisanja $z$ roko in tipkanjem (Demšar, 2015). Uporabljena je bila metoda fenomenološkega intervjuja ter opazovanja in analize posnetkov dejavnosti. Večina udeležencev je poročala o podobnih ozir. enakih razlikah v subjektivnih izkušnjah tako pri pisanju na roko (bolj osredotočena pozornost, večja zavzetost, več razmišljanja in načrtovanja, tekoča aktivnost, večja povezava s tekstom, večja vključenost telesa) kot pri tipkanju (večja razdrobljenost izkušnje, pričakovanje napak, pomanjkanje stika $\mathrm{z}$ besedilom, tekst manj resničen in pomemben, okolica vplivala bolj moteče).

\section{Haptičnost in interakcija $z$ objektom branja glede na nosilec besedila}

Razlike so tudi $\mathrm{v}$ haptičnosti in interakciji z objektom branja glede na nosilec besedila - tisk na papirju ali črke na zaslonu. Tiska na papirju se je mogoče neposredno dotakniti in ga otipati, je fizično vezan na papir; besedilo na zaslonu je neoprijemljivo (neotipljivo in virtualno) in je ločeno od sredstva prikazovanja (Mangen \& Kuiken, 2014). Tiskana besedila se razlikujejo po volumnu, otipu papirja, zvoku obračanja listov, vonju, obarvanosti papirja, vezavi, obrabljenosti ipd. Digitalna besedila so bolj enaka, bolj ,ploska ' in ne glede na besedilo je naprava vedno ista. 
Knjiga zagotavlja bralcu večjo stalnost in trdnost. Psihološke raziskave kažejo, da pomanjkanje stalnosti in prostorsko-časovnih označevalcev, kot nam jih nudijo knjige, npr. ,pri vrhu leve strani na začetku knjigec, lahko v digitalnem okolju ovira bralno razumevanje (Kerr \& Symons, 2006).

Branje je utelešena in multisenzorna dejavnost, ki jo lahko raziskujemo preko fizioloških meritev (za čustva in zatopljenost v branje - pupilometrija, srčni utrip, prevodnost kože) ter z različnimi nalogami pozornosti in spomina, razumevanja besedil (globinsko-površinsko, semantično, sklepanje) in metakognicije ter s fenomenološkim subjektivnim izkustvenim poročanjem (COST-IS1404, 2014).

\section{Poglobljeno branje}

Raziskovalci so kot ključni del bralne pismenosti opredelili poglobljeno branje, ki vključuje več zahtevnih kognitivnih procesov, povezanih z razumevanjem, kot so sklepanje, kritična analiza, refleksija in vpogled (Wolf in Barzillai, 2009). Navezuje se na branje obsežnejšega kompleksnega besedila, ki zahteva tudi daljšo mentalno osredotočenost (romani, eseji in tudi neliterarna besedila).

Poglobljeno branje $z$ digitalizacijo upada. Povsod se srečujemo s skrajšanimi besedili literarnih, strokovnih in drugih del, s povzetki, z že vnaprej pripravljenimi odgovori, ki ne zahtevajo daljše pozornosti in vztrajnosti (COST-IS1404, 2014).

Čeprav ima lahko digitalno besedilo določene prednosti zaradi hitre dostopnosti do dodatnih informacij, slovarjev, diskusij ipd., je zaradi velikega števila možnosti in takojšnosti informacij ovira za poglobljeno branje in diskusijo.

Zato so potrebne dobro razvite eksekutivne (izvršilne) funkcije, samoregulativne sposobnosti, spretnosti načrtovanja in organiziranja dejavnosti, selekcioniranja in osmišljevanja informacij, nadzorovanja bralnega razumevanja, metakognitivnega zavedanja ipd.

Sposobnosti eksekutivnih (izvršilnih) funkcij, ki jih zahteva uspešno digitalno branje, kot so delovni spomin, pozornost, odločanje, evalvacija itd., se razvijajo kasneje $v$ življenju in so povezane $\mathrm{z}$ dozorevanjem prefrontalnega dela možganov, za katerega vemo, da se razvije pozneje in doseže polni razvoj šele okoli 20 . leta.

Hitra dostopnost do ogromne množice informacij učence zavede $\mathrm{v}$ prepričanje, da že posedujejo znanje, in si zato ne prizadevajo za razume- 
vanje in za poglabljanje znanja. Enostavnost pridobivanja instantnih informacij na svetovnem spletu daje študentom varljiv občutek, da so osvojili spretnosti pridobivanja znanja in da so te hitro pridobljene izgotovljene informacije že tudi njihovo znanje.

\section{Razlike med branjem besedil na papirju in na zaslonu}

$\mathrm{V}$ številnih raziskavah iščejo razloge in razlage za te razlike na širokem razponu od fizikalnih lastnosti nosilcev besedil, preko pozornosti, perceptivnih in kognitivnih procesov bralca do fenomenoloških/izkustvenih vidikov procesa branja. Besedilo na papirju je za bralca dosegljivo naenkrat in v celoti, medtem ko je besedilo na zaslonu omejeno na eno samo stran. Pri klasičnih virih bralec občuti prostorske in fizične dimenzije knjige, ki omogoča hitro rokovanje in konstruiranje mentalne predstave besedila (listanje, pregledovanje, preskakovanje, raziskovanje strukture itd.) ter sprejemanje različnih čutnih informacij o papirju, na katerem je natisnjeno besedilo (Mangen et al., 2013). Omejitev na eno samo stran na zaslonu pa otežuje hiter pregled organizacije, strukture in poteka besedila.

\section{Bralno razumevanje in metakognicija branja}

Anne Mangen je s sodelavci leta 2013 izvedla raziskavo na 72 učencih desetega razreda dveh osnovnih šol na Norveškem (Mangen et al., 2013). Želeli so ugotoviti, kako nosilec besedila (papir, zaslon) vpliva na bralno razumevanje. Rezultati so pokazali, da so učenci, ki so brali besedila na papirju, dosegli pomembno boljše rezultate na preizkusu bralnega razumevanja kot tisti, ki so brali besedila na zaslonu. Pri branju na zaslonu so prisotni novi dejavniki, ki vplivajo na dosežke bralca: premikanje besedila na zaslonu predstavlja dodatno kognitivno obremenitev, odsotnost prostorskih in časovnih označevalcev pri digitalnem besedilu negativno vpliva na pomnjenje in razumevanje besedila

Garner (1988) je dokazala, da sposobnost nadzorovanja lastnega kognitivnega delovanja pri branju (samoregulacija) korelira z dobrim razumevanjem prebranega. Ackerman in Goldsmith (2011) sta raziskovala, ali je mogoče razlike $\mathrm{v}$ rezultatih branja na papirju in zaslonu pripisati metakognitivnim procesom pri branju. V svoji raziskavi sta ugotovila, da osnovna razlika $\mathrm{v}$ dosežkih branja na papirju in zaslonu ni kognitivna ampak metakognitivna. Udeleženci so pri branju na zaslonu preveč samozavestno ozir. manj natančno napovedali svoje dosežke in tudi manj natančno nadzorovali čas za opravljanje naloge kot pri branju na papirju. Avtorja sta zaklju- 
čila, da imajo ljudje občutek, da je tiskani medij bolj primeren za učenje, pri katerem se je treba potruditi, medtem ko je elektronski medij (računalnik) bolj ustrezen za „hitro in plitvo branje kratkih besedil, kot so novice, e-pošta in novice na forumih".

V praksi je treba razmisliti, katera daljša zahtevnejša besedila je smiselno ohraniti $v$ tiskani obliki in katera manj zahtevna v e-obliki. Pomembno je tudi bralce spodbujati k razvoju strategij za prepoznavanje in razumevanje prebranega kot tudi za razvijanje sposobnosti načrtovanja in reguliranje procesa branja.

\section{Socialni in čustveni razvoj}

Vedno več raziskav potrjuje velik pomen branja leposlovnih del za emocionalni in socialni razvoj. $\mathrm{V}$ teh raziskavah so uporabljali različne psihometrične metode od opazovalnih tehnik in merjenja emocionalne dejavnosti bralca med in po branju literature do numerično podprtega fenomenološkega raziskovanja prvoosebne bralne izkušnje (Kuiken in Miall, 2001).

Branje literarnih del vpliva na razvoj in podporo socialnih in emocionalnih spretnosti, kot sta empatija in simpatija (Mar in Oatley, 20o8; Mason in Just, 2009).

Nekatere raziskave nakazujejo, da lahko uporaba tablic negativno vpli$v a$ na emocionalne vidike branja literarnih del, ki se razvijajo šele ob zatopljenosti v branje (Mangen in Kuiken, 2014).

Branje literarnih del vpliva tudi na verbalne spretnosti in intelektualne sposobnosti ter na razumevanje, kaj lahko drugi mislijo in občutijo - teorija uma (Kidd in Castano, 2013)2.

\section{Večopravilnost (multitasking) $\mathbf{v}$ digitalnem svetu}

Večopravilnost pomeni hkratno (simultano) izvajanje dveh ali več nalog lahko vključuje preskakovanje naprej ali nazaj od ene naloge do druge ali izvajanja večjega števila nalog $\mathrm{v}$ zelo hitrem zaporedju. Večopravilnost ni nekaj novega, vendar izpostavljenost nenehnemu toku informacij, ki nas preplavlja $\mathrm{v}$ digitalni dobi, predstavlja poseben pojav, ki ga imenujemo (digitalna) medijska večopravilnost. To je hkratna uporaba večjega števila različnih medijev, kot so medomrežje, video igre, televizor, telefon, pisanje sporočil in e-sporočil, Facebook, Instagram ipd. Poleg tega število različnih medijev stalno narašča in jih poleg odraslih vedno pogosteje uporablja-

2 Več v Tancig, 2008, 2016. 
jo tudi otroci in mladostniki. Ni redko, da pošiljajo sporočila, igrajo video igre, uporabljajo družabna omrežja, brskajo po medomrežju, medtem ko delajo domače naloge ali poslušajo predavanja.

Neredko se srečujemo $\mathrm{z}$ infomanijo, kompulzivno željo nenehnega preverjanja nakopičenih informacij in novic preko mobilnega telefona ali računalnika. Obsesivna želja biti na tekočem s sporočili in strah, da bomo kaj spregledali, zamudili, izpustili (FOMO - Fear Of Missing Out) ter hkratno pregledovanje različnih virov informacij, sta lahko močna ovira pri soočanju z življenjskimi nalogami in opravili v realnem svetu.

Možgani so postali preobremenjeni, k čemur veliko pripomorejo tudi pametni mobilni telefoni z najrazličnejšimi možnostmi uporabe (računalnik, slovar, koledar, Twitter, Facebook, fotografski aparat in album, čitalnik in knjižnica itd.). Pametni telefon je veliko močnejši in zmogljivejši kot najboljši računalniki pred 30 leti. Je stalni spremljevalec, ki ga nenehno uporabljamo v najrazličnejših položajih, priložnostih in dejavnostih.

Ko opravljamo vse te dejavnosti, hitro skačemo od ene naloge do druge in smo prepričani o svoji učinkovitosti, da smo opravili veliko število nalog, čeprav smo v resnici zelo neučinkoviti, kar potrjujejo številne raziskave.

\section{Večopravilnost, spremembe $v$ možganih, kognitivnih procesih in čustveno-socialni samonadzor}

S preklapljanjem med nalogami izgubljamo čas, čeprav mislimo ravno nasprotno, imamo vedno večje težave ostati na isti nalogi in se ji posvetiti $\mathrm{z}$ vso osredotočenostjo, kar močno vpliva na celotno delovno učinkovitost. Medtem ko izvajamo vse te različne naloge - telefoniranje, pisanje sporočil, pregledovanje pošte, brskanje po spletu - se zmanjšajo naše kognitivne in intelektualne sposobnosti.

Uporaba mobilnega telefona med vožnjo avtomobila predstavlja še posebno nevarnost in tveganje, ker se zmanjšata vidno in slušno zaznavanje ter pozornost, podaljša se čas odzivanja in poslabša prilaganje razmeram na cesti. Zato Agencija za varnost prometa (AVP) opozarja, da uporaba mobilnega telefona med vožnjo ni dovoljena in se zato kaznuje.

Večopravilnost poveča izločanje stresnega hormona kortizola kot tudi adrenalina, ki lahko pretirano stimulira naše možgane. Na dolgi rok lahko taka stresna stanja ogrožajo tudi zdravje. 
Psiholog in nevroznanstvenik Russell Poldrack posebej opozarja, da večopravilnost negativno vpliva na to, kako se učimo. Različne oblike učenja in spomina so odvisne od funkcionalnosti in strukture anatomsko ločenih živčnih omrežij. Skupaj s sodelavci je s slikanjem možganov (fMRI) ugotovil, da uporabljamo različna področja možganov za učenje in uskladiščenje informacij glede na to, ali smo osredotočeni samo na eno samo nalogo ali hkrati na večje število nalog, kot je to primer pri večopravilnosti (Foerde et al., 2006). V primeru učenja ene same naloge, na katero se osredotočimo z vso pozornostjo, je vključen hipokampus, ki je pomemben za ustvarjanje bogatih in prožnih spominov. Informacije so dobro organizirane in kategorizirane ter jih zlahka prikličemo in uporabimo v novem položaju. Pri takem učenju je naša sposobnost generalizacije (posploševanja) pridobljenega znanja zelo dobra.

V primeru večopravilnosti se kaže večja aktivnost v striatumu, področju, ki je specializirano za učenje nove spretnosti ali postopka. Znanje, ki ga pridobimo v tem primeru, ni tako prožno in je bolj specializirano. Težje ga prikličemo in manj smo ga sposobni posplošiti ter uporabiti v novem položaju. Morda to deloma vpliva tudi na manjšo ustvarjalnost.

S sistematičnimi študijami so tudi odkrili, da se zmanjša naše razumevanje gradiva, če smo v bližini nekoga, ki uporablja računalnik, saj nam naša pozornost nehote uhaja nanj, ker skušamo ugotoviti, kaj ta oseba gleda in dela (Sana et al., 2013).

Veliko raziskav $\mathrm{z}$ večopravilnostjo in različnimi spremenljivkami so opravili na Univerzi Stanford, da bi čim bolje pojasnili večopravilnost. V eni od študij je raziskovalec Nass s sodelavci (Ophir et al., 20og) ugotovil, da so osebe, ki pogosto uporabljajo večopravilnost, slabše v ločevanju pomembne informacije od nepomembnih. Poleg tega imajo več težav v preklapljanju z ene naloge na drugo in so miselno manj organizirani. Še bolj nepričakovana je bila ugotovitev, da so enaki rezultati prisotni tudi v primeru, ko niso bili vključeni v dejavnost večopravilnosti. Pokazalo se je, da so osebe, ki pogosto izvajajo večopravilnost, tudi pri osredotočanju na eno samo nalogo manj učinkovite in manj uspešne. Tudi sicer so slabše v različnih kognitivnih procesih, predvsem pri zahtevnejših.

Da bi dobili podrobnejši vpogled, kaj se dogaja v možganih pri osebah, ki so zelo pogosto aktivne $\mathrm{v}$ večopravilnosti, in $\mathrm{v}$ njihove psihosocialne značilnosti, so izvedli raziskavo povezav med večopravilnostjo in možgansko strukturo. $\mathrm{V}$ raziskavi so med drugim uporabili tudi osebnostne teste (Loh in Kanai, 2014). S slikanjem možganov so pri osebah, ki pogos- 
to uporabljajo večopravilnost, odkrili, da ima sprednji cingulatni korteks manjši volumen sive snovi, kar se verjetno povezuje $\mathrm{z}$ ugotovljeno zmanjšano kognitivno kontrolo in slabšo socialno-emocionalno regulacijo teh oseb (so bolj impulzivne in slabše kontrolirajo svoje vedenje) (ibid.). Čeprav ta kot tudi podobne korelacijske študije ne omogočajo sklepa, kaj je vzrok in kaj posledica, so rezultati raziskave osvetlili nove povezave med večopravilnostjo in strukturnimi spremembami v možganih. Predvsem pa je pomembno zavedanje, da pri uporabi digitalne medijske večopravilnosti ne gre samo za funkcionalne spremembe $v$ možganih temveč tudi za strukturne, ki se odražajo v spremembah kognitivnih procesov in vedenja.

Glede na to, da večopravilnost narašča tudi med otroki in mladostniki, katerih možgani se še razvijajo, je dobro poznavanje in razumevanje in kognitivnih posebnosti digitalne medijske večopravilnosti pomembna naloga. Raziskovalci so skušali empirično preveriti, kakšne so povezave med večopravilnostjo in učnim uspehom.

\section{Večopravilnost in učna uspešnost}

Ena novejših raziskav je preverjala odnos med medijsko večopravilnostjo (MV), opravljanjem domačih nalog, izvršilnimi (eksekutivnimi) funkcijami in učno uspešnostjo pri mladostnikih (Martín-Perpiñá et al., 2019). Rezultati raziskave so pokazali, da je pogosta MV med opravljanjem domačih nalog $\mathrm{v}$ negativnem odnosu $\mathrm{z}$ izvršilnimi funkcijami in učno uspešnostjo. Mladostniki so poročali o več težavah, povezanih z izvršilnimi funkcijami v vsakodnevnem življenju, s slabšim kognitivnim delovanjem glede komponent delovnega spomina, hitrosti procesov ter nižje uspešnosti v jeziku in matematiki. Raziskovalci so predlagali razvijanje strategij, ki bi mladostnikom omogočale osredotočanje pozornosti na naloge, in izogibanje motečim dejavnikom.

V pregledni raziskavi (sinteza večjega števila študij) se je pokazal negativen odnos med MV in učno uspešnostjo (May in Elder, 2018). Ugotovljeno je bilo, da MV interferira s pozornostjo in delovnim spominom, negativno vpliva na učno uspešnost, priklic, bralno razumevanje, delanje zapiskov, samoregulacijo in učinkovitost. Ta učinek se je pokazal tako pri pouku v razredu kot pri učenju. Pokazalo se je tudi, da imajo učenci velike težave pri točni oceni vpliva MV na svojo učno uspešnost. Avtorji raziskave navajajo možnost za izboljšanje učne uspešnosti s spodbujanjem samoregulacije.

V obsežni pregledni študiji so raziskovali povezave MV s spremenljivkami na kognitivnem področju (Uncapher et al., 2016, 2017). Pri učencih, ki 
zelo pogosto izvajajo MV, so se pokazale razlike v kogniciji (npr. slabše spominske funkcije - delovni in dolgoročni spomin), v psihosocialnem vedenju (npr. povečana impulzivnost) in na nevrološkem področju (zmanjšan volumen sprednjega cingulatnega korteksa - verjetno se to povezuje s povečano impulzivnostjo, slabšo čustveno kontrolo). Polega tega so raziskave odkrile, da lahko MV negativno vpliva na učno uspešnost ne glede na to, ali se izvaja v razredu ali doma.

Pomembna je pregledna raziskava problematike $\mathrm{MV}$ in učne uspešnosti pri mladostnikih, v kateri so avtorji integrirali ugotovitve večjega števila študij, v katerih so bili raziskani tudi odnosi MV z nekaterimi spremenljivkami na področju kognitivne kontrole in socialno-čustvenega področja (Schuur et al., 2015). Rezultati te pregledne raziskave so pokazali negativen odnos med MV in nekaterimi vidiki kognitivne kontrole (npr. fokusirana pozornost na relevantne informacije), med MV in socialno-čustvenim delovanjem (npr. depresija in socialna anksioznost, socialna uspešnost) ter negativen odnos med MV in učno uspešnostjo.

\section{Zaključek}

Digitalna tehnologija prinaša prednosti in hkrati tveganja. Obe dejavnosti klasično opismenjevanje (pisanje in uporaba tiskanih gradiv na papirju) ter uporabo digitalnih pripomočkov - je treba smiselno uskladiti. Spremembe, ki jih vnašamo v šolski prostor, morajo biti premišljene in znanstveno podprte. Predvsem pa je pomembno ohraniti poglobljeno branje in branje daljših in zahtevnejših besedil, ki pomembno prispevata k razvoju reflektivnega in kritičnega mišljenja ter k čustveno-socialnemu razvoju.

Dobro je vedeti, da branje ni del naše genetske opremljenosti. Branje je staro 5400 let, kar je daleč prekratko obdobje, da bi razvili posebno omrežje v možganih za branje. Bralno omrežje razvijamo v času svojega življenja $\mathrm{z}$ učenjem in $\mathrm{z}$ vplivi okolja, kar je mogoče zaradi plastičnosti možganov. Prav tako velja tudi pravilo »uporabi ali izgubi« (use it or lose it).

Zato bi bilo smiselno upoštevati glavne ugotovitve raziskav in priporočila že omenjene Deklaracije iz Stavangerja o prihodnosti branja (COST-IS1404, 2019) za edukacijsko politiko in vzgojno-izobraževalno prakso. 


\section{Literatura}

Ackerman, Rakefet in Morris Goldsmith. 2011. »Metacognitive Regulation of Text Learning: On Screen versus on Paper.« Journal of Experimental Psychology: Applied 17 (1): 18-32. doi: 10.1037/a0022086.

Berninger, Virginia W., Judith E. Rutberg, Robert D. Abbott, Noelia Garcia, Marci Anderson-Youngstrom, Allison Brooks in Cynthia Fulton. 2006. »Tier 1 and Tier 2 Early Intervention for Handwriting and Composing." Journal of School Psychology 44 (1): 3-30. doi: 10.1016/j.jsp.2005.12.003.

COST-IS1404. 2014. Memorandum of Understanding for the implementation of a European Concerted Research Action designated as COST Action IS1404: Evolution of reading in the age of digitisation (E-READ). http:// www.cost.eu/COST_Actions/isch/IS1404. (22. 2. 2016).

COST-IS1404. 2019. Deklaracija iz Stavangerja o prihodnosti branja. http://ereadcost.eu/stavanger-declaration/. (25. 4. 2019.)

Dehaene, Stanislas. 2014. "Reading in the Brain Revised and Extended: Response to Comments." Mind \& Language 29 (3): 320-35. doi: 10.1111/ mila.12053.

Demšar, Ema. »Experiential Differences between Typing and Handwriting «. Proceedings of the MEi:CogSci Conference 2015: 95, Ljubljana, 2015.

Foerde, Karin, Barbara J. Knowlton in Russell A. Poldrack. 2006. »Modulation of Competing Memory Systems by Distraction. « Proceedings of the National Academy of Sciences 103 (31): 11778-11783. doi: 10.1073/pnas.0602659103.

Gallese, Vitorio in George Lakoff. The brain's concept: The role of the sensory-motor system in conceptual knowledge. Cognitive Neuropsychology 22. (2005): 455-479.

Garner, Ruth. 1988. Metacognition and Reading Comprehension. Norwood, NJ: Ablex.

Gibson, James J. 1979. The Ecological Approach to Visual Perception. Boston: Houghton Mifflin.

Glenberg, Arthur M. 2008. Embodiment for education. V Paco Calvo \& Toni Gomila (ured.), Handbook of cognitive science: An embodied approach; 355-372. Amsterdam, The Netherlands: Elsevier.

James, Karin H. 2012. »How Printing Practice Affects Letter Perception: An Educational Cognitive Neuroscience Perspective."Presented at Handwriting in the 21st Century?: An Educational Summit. Washington, D.C., January 23, 2012. 
James, Karin H. in Laura Engelhardt. 2012. »The Effects of Handwriting Experience on Functional Brain Development in Pre-Literate Children." Trends in Neuroscience and Education 1 (1): 32-42. doi: 10.1016/j.tine.2012.08.001.

Kerr, Matthew A. in Sonya E. Symons. 2006. „Computerized Presentation of Text: Effects on Children's Reading of Informational Material.« Reading and Writing 19 (1) 1-19. doi: 10.1007/s11145-003-8128-y.

Kersey, Alyssa J. in Karin H. James. 2013. »Brain Activation Patterns Resulting from Learning Letter Forms through Active Self-Production and Passive Observation in Young Children.« Frontiers in Psychology 4 (567). doi: 10.3389/fpsyg.2013.00567.

Kidd, DavidC. in Emanuele Castano. 2013. »Reading Literary Fiction Improves Theory of Mind.« Science 342 (6156): 377-80. doi: 10.1126/science.1239918.

Kiefer, Markus in Natalie M. Trumpp. 2012. Embodiment theory and education: The foundations of cognition in perception and action. Trends in $\mathrm{Ne}$ uroscience and Education 1 (1): 15-20. doi: 10.1016/j.tine.2012.07.002.

Kiefer, Markus in Friedemann Pulvermüller. 2012. Conceptual representations in mind and brain: Theoretical developments, current evidence and future directions. Cortex 48 (7): 805-825. doi: 10.1016/j.cortex.2011.04.006.

Kiefer, Markus in Lawrence W. Barsalou. 2013. „Grounding the Human Conceptual System in Perception, Action in Internal States."Action Science (January) 381-407. doi: 10.7551/mitpress/9780262018555.003.0015.

Kuiken, Don in David S. Miall. 2001. Numerically aided phenomenology: Procedures for investigating categories of experience. FQS - Forum: Qualitative Social Research 2 (1). doi: 10.17169/fqs-2.1.976

Loh, Kep Kee in Ryota Kanai. 2014. »Higher Media Multi-Tasking Activity Is Associated with Smaller Gray-Matter Density in the Anterior Cingulate Cortex.«PLoS ONE 9 (9). doi: 10.1371/journal.pone.0106698.

Longcamp, Marieke, Céline Boucard, Jean-Claude Gilhodes in Jean-Luc Velay. 2006. "Remembering the Orientation of Newly Learned Characters Depends on the Associated Writing Knowledge: A Comparison between Handwriting and Typing." Human Movement Science 25 (4-5): 646-56. doi: 10.1016/j.humov.2006.07.007.

Longcamp, Marieke, Yevhen Hlushchuk in Riitta Hari. 2010. »What Differs in Visual Recognition of Handwritten vs. Printed Letters? An FMRI Study.« Human Brain Mapping 32 (8) 1250-59. Doi: 10.1002/hbm.21105.

Mangen, Anne, Bente R. Walgermo in Kolbjørn Brønnick. 2013. »Reading Linear Texts on Paper versus Computer Screen: Effects on Reading Com- 
prehension.« International Journal of Educational Research 58: 61-68. doi:10.1016/j.ijer.2012.12.002.

Mangen, Anne in Don Kuiken. 2014. "Lost in an iPad: Narrative engagement on paper and tablet.« Scientific Study of Literature 4 (2): 150-77. doi: 10.1075/ssol.4.2.02man.

Mangen, Anne in Adriaan Van Der Weel. 2016. »The Evolution of Reading in the Age of Digitisation: an Integrative Framework for Reading Research.« Literacy 50 (3): 116-24. doi: 10.1111/lit.12086.

Mar, Raymond A. in Keith Oatley. 2008. »The Function of Fiction Is the Abstraction and Simulation of Social Experience." Perspectives on Psychological Science 3 (3): 173-92. doi: 10.1111/j.1745-6924.2008.00073.x.

Martín-Perpiñá, Maria de las Mercedes, Ferran Viñas Poch in Sara Malo Cerrato. 2019. "Media multitasking impact in homework, executive function and academic performance in Spanish adolescents". Psicothema 31 (1): 8187, doi: 10.7334/psicothema2018.178.

Mason, Robert A. in Marcel Adam Just. 2009. »The Role of the Theory-of-Mind Cortical Network in the Comprehension of Narratives."Language and Linguistics Compass 3 (1): 157-74. doi: 10.1111/j.1749-818x.2008.00122.x.

May, Kaitlyn E. in Anastasia D. Elder. 2018. »Efficient, Helpful, or Distracting? A Literature Review of Media Multitasking in Relation to Academic Performance." International Journal of Educational Technology in Higher Education 15 (1). doi: 10.1186/s41239-018-0096-Z.

Mueller, Pam A. in Daniel M. Oppenheimer. 2014. »The Pen Is Mightier Than the Keyboard." Psychological Science 25 (6): 1159-68. doi: 10.1177/0956797614524581.

Nakamura, K., W.-J. Kuo, F. Pegado, L. Cohen, O. J. L. Tzeng in S. Dehaene. 2012. »Universal Brain Systems for Recognizing Word Shapes and Handwriting Gestures during Reading."Proceedings of the National Academy of Sciences 109 (50): 20762-67. doi: 10.1073/pnas.1217749109.

Ophir, Eyal, Clifford Nass in Anthony D. Wagner. 2009. "Cognitive Control in Media Multitaskers."Proceedings of the National Academy of Sciences 106 (37): 15583-87. doi: 10.1073/pnas.0903620106.

Sana, Faria, Tina Weston in Nicholas J. Cepeda. 2013. »Laptop Multitasking Hinders Classroom Learning for Both Users and Nearby Peers.« Computers \& Education 62: 24-31. doi: 10.1016/j.compedu.2012.10.003.

Schuur, Winneke A. Van Der, Susanne E. Baumgartner, Sindy R. Sumter in Patti M. Valkenburg. 2015. »The Consequences of Media Multitasking for 
Youth: A Review.« Computers in Human Behavior 53: 204-15. doi: 10.1016/j. chb.2015.06.035.

Tancig, Simona. 2008. »Razvoj empatije, teorije uma in metareprezentacije: interdisciplinarni pogledi.« V Marko Bohanec, Darja Mladenić, Marko Grobelnik, Milan Heričko, Urban Kordeš in Olga Markič (ured.), Zbornik 11. mednarodne multikonference Informacijska družba - IS 20o8, 13.17. oktober 20o8: zvezek A (Kognitivna znanost): 353-357, Ljubljana: Institut „Jožef Stefan“.

Tancig, Simona. 2014. "Kako branje spreminja možgane in kaj izgubimo, če pisanje nadomestimo s tipkanjem?« V Mojca Orel (ur.), Zbornik prispevkov na mednarodni konferenci EDUvision 2014, 27.-28. november 2014: 11-19, Ljubljana,.

Tancig, Simona. 2014a. "Novejša spoznanja nevroedukacijske znanosti o specifičnih učnih težavah." Vabljeno predavanje; Otroci in mladostniki s specifičnimi učnimi težavami - podpora pri uresničevanju njihovih potencialov. Zbornik prispevkov Četrte mednarodne konference o specifičnih učnih težavah: 72-82. Ljubljana: Društvo Bravo.

Tancig, Simona. 2014b. »Nevroedukacija in utelešena kognicija - pogledi na gibalno in plesno dejavnost «. Plenarno predavanje. V Vesna Geršak in Nina Meško (ured.) Zbornik 2. Mednarodne konference plesne pedagogike: 11. Velenje: Javni sklad RS za kulturne dejavnosti.

Tancig, Simona. 2016. »Od Prousta do Twitterja - nevroedukacijske raziskave bralne pismenosti v digitalni dobi.« V Tatjana Devjak, Igor Saksida, Dagarin Fojkar, (ured.). Bralna pismenost kot izziv in odgovornost: 9-26. 1. izd. Ljubljana: Pedagoška fakulteta.

Thompson, Evan T. 2007. Life in mind: Biology, phenomenology, and the sciences of the mind. Cambridge, MA: Harvard University Press.

Uncapher, Melina R., Monica K. Thieu in Anthony D. Wagner, A.D. (2016). "Media multitasking and memory: Differences in working memory and long-term memory”. Psych. on Bull. Rev. 23 (2): 483-49o. doi: 10.3758/ s13423-015-0907-3.

Uncapher, Melina R., Lin Lin, Larry D. Rosen, Heather L. Kirkorian,, Naomi S. Baron, Kira Bailey, Joanne Cantor, David L. Strayer, Thomas D. Parsons in Anthony D. Wagner. (2017). "Media Multitasking and Cognitive, Psychological, Neural in Learning Differences”. Pediatrics 140 (s2), doi: 10. 1542/ peds. 2016-1758D. 
Varela, Francisco J., Thompson, Evan T. in Eleanor Rosch. 1991. The embodied mind: Cognitive science and human experience. Cambridge, MA: MIT Press.

Wolf, Maryanne in Mirit Barzillai, M. 2009. The importance of deep reading. Educational Leadership 66 (6), 32-37. 



\title{
Besedna interakcija med poukom: kako nanjo vpliva znanje učencev \\ Monika Mithans, Milena Ivanuš Grmek
}

\begin{abstract}
Komunikacija v razredu
Med učitelji in učenci v razredu poteka nenehna interakcija, saj učni proces predstavlja predvsem proces komuniciranja (Han in Tosten, 2016) in zato Strmčnik (2003, str. 109) pouk opredeli kot »poseben komunikacijski pojav oziroma proces«.
\end{abstract}

Sodobna pedagoška spoznanja nas opozarjajo, da se ljudje učimo predvsem takrat, kadar imamo možnost aktivno sodelovati v dobri dialoški izmenjavi (Marentič Požarnik in Plut Pregelj, 2009), ki predstavlja temelj za uspešne medosebne odnose in učinkovito poučevanje ter učenje (Marentič Požarnik, 2016).

Učinkovita komunikacija je mogoča le, če je prisotno sodelovanje, samospoštovanje in spoštovanje drugih, strpno reševanje konfliktov in doživljanje osebne varnosti (Skalar, 1990). Torej lahko komunikacijo opredelimo kot ključen element pouka, ki odločilno vpliva na vzdušje. Z njo gradimo temelje za oseben in avtentičen stik (Jesper in Helle, 2009).

Učinkovita komunikacija $\mathrm{v}$ razredu je namenjena osmišljanju novega znanja, povezovanju z izkušnjami in ustvarjanju lastnega znanja, ki je trajnejše in prožnejše (Marentič Požarnik in Plut Pregelj, 2009). To pa lahko dosežemo $\mathrm{z}$ učnim pogovorom, ki pa zaradi vsega naštetega sodi med najpogosteje uporabljene učne metode.

V številnih raziskavah je bilo kljub temu ugotovljeno, da učitelj v razredu po navadi govori dve tretjini časa, preostalo tretjino so govorno ak- 
tivni vsi učenci. Najredkeje je zaznati izražanje lastnih idej s strani učencev ter posledično malo odzivanja učiteljev na iniciativo učencev (Marentič Požarnik in Plut Pregelj, 2009).

Tudi Pšundrova (1998) ugotavlja, da je v pedagoški praksi komunikacija najpogosteje enosmerna. Učitelj je tisti, ki v glavnem govori, učenci pa so pretežno tiho, čeprav bi morali spraševati, misliti in govoriti, kajti kakovostna vzgojno-izobraževalna komunikacija mora biti dvosmerna. Učitelj mora sprejeti in razumeti misli, vedenje in občutke učencev in temu primerno reagirati. V razredu je glede na vrste komunikacije mogoče govoriti o demokratični oz. participativni komunikaciji na eni strani in avtoritarni oz. direktivni na drugi (Pšunder, 1998; Prgić, 2010).

Pri avtoritarnem vodenju razreda o vsem odloča učitelj sam. Komunikacija je večinoma enosmerna, saj učitelji odklanjajo dialog in ne upoštevajo mnenj in pripomb učencev. Učenci imajo možnost sodelovanja v komunikacijskem procesu le v obliki odgovorov na zastavljena vprašanja. Le redko se pojavlja komunikacija o učni snovi med učenci samimi, saj prevladuje frontalna učna oblika (Marentič Požarnik, 2016). Takšen model komunikacije po mnenju Pšundrove (1998) ne sodi v sodoben vzgojno-izobraževalni proces.

Pri demokratičnem vodenju razreda učitelj učence vključuje v sprejemanje odločitev in jih spodbuja k podajanju idej in predlogov.

$\mathrm{V}$ razredu si prizadeva ustvariti dobre medosebne odnose, podpira sodelovanje in kakovostno komunikacijo med učenci ter v pouk vključuje tudi skupinsko delo. Preko takšnega pristopa učence postopno navaja na samostojnost in prevzemanje odgovornosti. Predpogoj za učinkovitost takšne komunikacije je obvladovanje osnovnih socialnih spretnosti dogovarjanja učencev in učiteljev (Marentič Požarnik, 2016).

Empirične raziskave so dokazale, da boljše odnose $\mathrm{z}$ učitelji doživljajo uspešnejši učenci (Skalar, 1990).

$\mathrm{V}$ raziskavi (Simonišek, 2013) pa je bilo ugotovljeno, da so učiteljevo komunikacijo bolje kot učenci z odličnim učnim uspehom ocenili učenci s prav dobrim, dobrim in zadostnim učnim uspehom, ki s strani učitelja zaznavajo tudi več spodbud in pohval.

\section{Participacija učencev}

Konvencija o otrokovih pravicah (1989) predstavlja prvi pravno zavezujoč mednarodni dokument, ki vključuje celotno paleto človekovih pravic. Je 
dokument, ki je otrokovim pravicam omogočil pot $\mathrm{v}$ nacionalne zakonodaje in šolske sisteme ter jih spodbudil k izražanju mnenj, odrasle pa k njihovemu upoštevanju. V njej je v okviru enega od štirih prednostnih področij opredeljena tudi pravica do participacije, ki se mora odražati tudi v šolskem vsakdanu.

V šoli naj bi bili učenci tako aktivni udeleženci vzgojno-izobraževalnega procesa, ki imajo možnost samostojnega in aktivnega učenja (Mithans in Ivanuš Grmek, 2012; Štefanc, 2005; Blažič et al., 2003), omogočanje za to ustreznih pogojev, pa je v rokah učiteljev (Šagud in Hajdin, 2018), saj je resnična participacija učencev veliki meri odvisna prav od pripravljenosti odraslih, da jim prisluhnejo in sprejmejo njihove poglede (Gril, Klemenčič in Autor, 2009). Participacija se razume kot pravica otrok, da aktivno sodelujejo in so vključeni v vse aktivnosti, ki se nanašajo nanje (Kovač, 2008).

$\mathrm{Na}$ ravni šole naj bi učenci tako imeli možnost aktivnega vključevanja $\mathrm{v}$ oblikovanje šole kot celote, šolskega življenja in pouka (Kurth Buchholz, 2011). Pri pouku koncept participacije predvideva aktivno sodelovanje učencev $\mathrm{v}$ fazi načrtovanja, izvajanja in vrednotenja šolskega dela (Kovač, Resman in Rajkovič, 2008).

Možnost sodelovanja mora učitelj učencem omogočiti že pri načrtovanju učnih ciljev in aktivnosti za njihovo uresničevanje. Pomembno je, da jim prisluhne in če je le mogoče upošteva njihove ideje (Tomić, 2002) ter tako ustvarja pogoje za njihovo aktivno sodelovanje pri pouku (Ivanuš Grmek et al., 2007).

V okviru obravnave učne snovi, lahko učitelj učence vključi v oblikovanje nalog oziroma ciljev, izbiro učnih metod, urjenje in uporabo znanja v praksi (Adamič, 1990). K aktivnemu sodelovanju pri pouku lahko učitelj učence spodbuja predvsem $\mathrm{z}$ upoštevanjem njihovih izkušenj in predznanj, $\mathrm{s}$ postavljanjem vprašanj ter tako, da jih vzpodbuja $\mathrm{k}$ samostojnemu iskanju in navajanju primerov. $Z$ vključevanjem učencev $\mathrm{v}$ razlago učne snovi pa lahko sodelovanje še poglobi (Ivanuš Grmek et al., 2007).

Odnosi med učenci in učiteljem postanejo še vidnejši pri preverjanju in ocenjevanju znanja, saj se po Kramarjevem (1990) prepričanju, ravno na tem področju pokaže realni položaj učencev. Kovačeva (2008) opozarja na to, da je prav ocenjevanje znanja področje, ki učencem povzroča največ preglavic in prav zato je njihovo sodelovanje v okviru tega področja še posebej pomembno.

Učenci naj bi tako imeli možnost dogovarjanja o vsebinah, oblikah in kriterijih preverjanja in ocenjevanja znanja. $Z$ učiteljem naj bi sodelovali pri 
dogovarjanju o rokih in pogojih preverjanja in ocenjevanje znanja. Aktivno pa naj bi bili vključeni tudi $\mathrm{v}$ dogovarjanja o možnostih samoocenjevanja, popravljanja slabih ocen in možnostih pritožbe na oceno (Rutar Ilc in Rutar, 1997).

Vzgojno-izobraževalni proces torej ponuja številne možnosti za participacijo učencev, njeno udejanjanje $\mathrm{v}$ pedagoški praksi pa je $\mathrm{v}$ veliki meri odvisno od tega, koliko možnosti za soodločanje učencem ponudijo učitelji, in od tega, ali so ponujene možnosti učenci pripravljeni izkoristiti (Bock, 2010).

Naloga pedagoških delavcev je, da kolikor je le mogoče, zagotovijo (so) odločanje ali vsaj soglasje učencev, saj se za tisto, kar so privolili, počutijo bolj odgovorne. Učenci, ki ne bodo imeli možnosti vplivati na vzgojno-izobraževalne cilje in procese, se ne bodo našli niti v rezultatih in posledično bodo postali objekti in si s tem onemogočili dejansko usvajanje znanj in vrednot (Blažič et al., 2003).

Pozitivni učinki participacije se odražajo v večji samostojnosti in odgovornosti učencev pri šolskem delu, $v$ večji učni motivaciji in posledično boljših učnih rezultatih (Reith, 2007; De Roiste, Kelly, Molcho, Gavin in Gabhainn, 2012; Ing, Webb, Franke et al., 2015). Participacija pri pouku pozitivno vpliva na počutje učencev, vzpodbuja veselje do šole in zmanjšuje frustracije (Baacke in Brücher, 1982; Kötters et al., 2001 in Kovač, 2008).

Poleg naštetega participacija zadovoljuje potrebe učencev po samorazpolaganju s seboj, svojim časom in močmi. Predvsem starejši učenci namreč težko prenašajo podrejeni učni položaj in učiteljevo nadrejenost dojemajo kot nespoštovanje njihove osebnosti (Blažič et al., 2003).

Kljub vsemu pa Kroflič (2013) ugotavlja, da se v vzgojno-izobraževalnih institucijah resnična participacija odvija zelo redko. Učenci vzgojno-izobraževalni proces ne dojemajo kot pravico, priložnost in možnost, temveč zgolj kot obveznost in dolžnost (Kramar, 2008).

Težave, ki otežujejo uveljavljanje participacije v vzgojno-izobraževalni praksi, so najpogosteje vezane na predstave in interpretacije odraslih, ki otroke dojemajo kot nemočna, nekompetentna bitja, ki ne zmorejo izraziti svojega mnenja (Kodela in Lesar, 2015). 


\section{Empirična raziskava}

\section{Namen raziskave}

Predstavljeni rezultati, so bili pridobljeni v obsežnejši raziskavi, v okviru katere smo raziskovali, kako učenci in kako učitelji zaznavajo možnosti participacije in kakšna je njena vloga $\mathrm{z}$ vidika razredne (delovne) klime, motivacije učencev in njihovega znanja, izraženega $\mathrm{z}$ modalno oceno (Mithans, 2017).

$\mathrm{V}$ prispevku predstavljamo le rezultate, vezane na analizo razlik $\mathrm{v}$ znanju učencev, izraženem $\mathrm{z}$ modalno oceno, in sicer glede na stopnjo govorne participacije učencev 5. razreda pri predmetu družba, 8. razreda pri predmetu zgodovina in dijakov 2. letnika pri predmetu sociologija, saj se preko teh predmetov uresničujejo cilji državljanske vzgoje, med katerimi je tudi dejavno vključevanje učencev (Državljanska vzgoja v Evropi, 2005).

\section{Raziskovalni vzorec}

V raziskavo je bilo vključenih 58 učencev oz. dijakov. Od tega je $16(27,6 \%)$ učencev obiskovalo 5. in prav toliko (27,6 \%) 8. razred osnovne šole. $26(44,8 \%)$ je bilo dijakov 2. letnika gimnazije.

Zajeti vzorec učencev je neslučajnostni namenski, ki ga na nivoju inferenčne statistike opredeljujemo kot enostavni vzorec iz hipotetične populacije.

\section{Postopki zbiranja in obdelave podatkov}

Podatke smo pridobili s pomočjo opazovanja pouka. Za opazovanje je bil uporabljen protokol Flandersove analize razredne interakcije, ki vsebuje 1o kategorij, razdeljenih $\mathrm{v}$ tri sklope, in sicer reagiranje (učitelj, učenec), iniciativo (učitelj, učenec) ter molk in zmedo. Flandersova analiza razredne interakcije temelji na ugotavljanju, kdo ima pri govorni izmenjavi v danem trenutku pobudo, kdo se nanjo odziva in kako. Učiteljevo iniciativo predstavlja razlaga učne snovi, zastavljanje vprašanj in kritično vrednotenje učenčevih odgovorov. Učenčeva iniciativa se kaže $\mathrm{v}$ zastavljanju lastnih vprašanj, z izražanjem zamisli in izkušenj ali z daljšimi odgovori na vprašanja, v katera vključi lastne misli. Če učenec na kratko odgovori na vprašanje, je to le odziv. Učitelj se na njegove pobude odziva, če sprejema njihova čustva, jih hvali, spodbuja, sprejme in uporabi njihove ideje. Kaj od navedenega se dogaja $v$ razredu, mora opazovalec ugotavljati in označevati $\mathrm{v}$ ustrezno rubriko $\mathrm{v}$ časovnem razmaku 3-5 sekund, nato pa s seštevanjem 
znakov ugotoviti, koliko učne ure je obsegala vsaka od navedenih kategorij (Marentič Požarnik in Plut Pregelj, 2009).

$\mathrm{V}$ vsakem razredu smo opazovali 8 ur pouka. Za izpeljavo spremenljivke govorna participacija smo uporabili kategorijo F 9: samostojne izjave učencev, pri kateri gre za izražanje novih idej, predstav, stališč (Marentič Požarnik in Plut Pregelj, 2009). Število zaznanih pojavljanj F 9 smo pretvorili na ordinalno raven in tako dobili spremenljivko govorna participacija učencev s tremi stopnjami (nižja, srednja, višja).

Po opazovanju smo $\mathrm{v}$ opazovanih razredih izvedli še anketiranje (Vprašalnik o učnih navadah mladostnikov (Thiel, Keller in Binder, 1999) in Vprašalnik: razredno okolje (Zabukovec, 1998)).

Spremenljivko znanje smo opredelili $\mathrm{z}$ modalno oceno učenca pri predmetu, kjer je potekalo opazovanje s Flandersovo analizo razredne interakcije.

Za vse uporabljene instrumente (Flandersova analiza razredne interakcije, Vprašalnik o učnih navadah mladostnikov (Thiel et al., 1999) in Vprašalnik: razredno okolje (Zabukovec, 1998)) velja, da smo jih prevzeli in se odlikujejo z vidika merskih karakteristik.

Podatke smo obdelali zračunalniškim programom SPSS (Statistical Package for the Social Sciences) na ravni deskriptivne in inferenčne statistike, pri čemer smo uporabili naslednje statistične metode:

- frekvenčna distribucija (f, $\mathrm{f} \%)$;

- osnovna deskriptivna statistika: aritmetična sredina $(\bar{x})$, standardni odklon (s), koeficient asimetrije (KA) in koeficient sploščenosti (KS);

- analiza variance;

- preizkus.

\section{Rezultati in diskusija}

$\mathrm{V}$ opazovanih razredih smo preverjali modalno oceno. Rezultate so predstavljeni v Tabeli 27.

Iz Tabele 27 je razvidno, da je največ v raziskavo zajetih učencev imelo pri opazovanem predmetu oceno $3(34,5 \%)$, sledijo učenci z oceno $4(27,6$ $\%)$ in 5 (20,7 \%). Najmanj učencev (13,8\%) je imelo oceno 2 . V času izvedbe anketiranja 2 učenca $(3,4 \%)$ še nista imela pridobljene nobene ocene pri opazovanem predmetu. 
Tabela 27: Števila (f) in strukturni odstotki (f\%) učencev po znanju, izraženi z modalno oceno, pri opazovanem predmetu.

\begin{tabular}{|c|c|c|}
\hline Znanje & $\mathrm{f}$ & $f \%$ \\
\hline 2 & 8 & 13,8 \\
\hline 3 & 20 & 34,5 \\
\hline 4 & 16 & 27,6 \\
\hline 5 & 12 & 20,7 \\
\hline Brez ocen & 2 & 3,4 \\
\hline Skupaj & 58 & 100,0 \\
\hline
\end{tabular}

Podatke o govorni participaciji učencev v opazovanih razredih smo pridobili s pomočjo opazovanja pouka s protokolom Flandersove analize razredne interakcije. Podatke prikazuje Tabela 28.

Tabela 28: Števila (f) in strukturni odstotki (f\%) učencev po govorni participaciji.

\begin{tabular}{lcc}
\multicolumn{1}{c}{ Govorna participacija } & $\mathrm{f}$ & $\mathrm{f} \%$ \\
\hline Nižja & 16 & 27,6 \\
\hline Srednja & 16 & 27,6 \\
\hline Visoka & 26 & 44,8 \\
\hline Skupaj & 58 & 100,0
\end{tabular}

Rezultati iz Tabele 28 kažejo, da je bila visoka stopnja govorne participacije zaznana pri 44,8 \% dijakov 2. letnika. Srednja stopnja govorne participacije je bila zaznana za 27,6 \% učencev 5. razreda. Za prav toliko $(27,6$ \%) učencev 8. razreda pa je bila zaznana nižja stopnja govorne participacije.

Predstavljeni rezultati kažejo, da je višja stopnja govorne participacije prevladuje pri najstarejših učencih oziroma dijakih, srednja stopnja se pojavlja pri učencih 5. razreda in nižja pri učencih 8. razreda.

Razloge za to, da so govorno najaktivnejši najstarejši učenci oz. dijaki, lahko po našem prepričanju iščemo $\mathrm{v}$ učiteljevih domnevah o povezanosti sposobnosti in resnosti učencev $\mathrm{z}$ njihovo starostjo, kar v svoji raziskavi domnevajo tudi Ivanuš Grmekova et al., (2007), ki hkrati opozarjajo na to, da se zaradi manj pogostega vključevanja $\mathrm{v}$ pouk pri učencih vzpodbuja in ohranja občutek, da jih učitelj ne dojema kot zrelih in sposobnih posameznikov in se temu primerno tudi vedejo. Izhajajoč iz te ugotovitve, lahko po našem mnenju razloge za nižjo stopnjo govorne participacije v 8. razredu osnovne šole, izpeljemo iz dejstva, da si učenci z leti šolanja na isti vzgojno-izobraževalni ustanovi pridobivajo izkušnje $\mathrm{z}$ vključevanjem $\mathrm{v}$ učni proces, če izkušnje niso pozitivne, se aktivnemu vključevanju raje izognejo. 
V nadaljevanju so nas zanimale razlike $\mathrm{v}$ znanju učencev, izraženem $\mathrm{z}$ modalno oceno. Rezultati so predstavljeni v Tabeli 29.

Tabela 29: Izid -preizkusa razlik v znanju glede na stopnjo govorne participacije.

\begin{tabular}{|c|c|c|c|c|c|c|c|c|}
\hline \multirow{3}{*}{ Znanje } & \multicolumn{8}{|c|}{ Govorna participacija pri pouku } \\
\hline & \multicolumn{2}{|c|}{ Nizka } & \multicolumn{2}{|c|}{ Srednja } & \multicolumn{2}{|c|}{ Visoka } & \multicolumn{2}{|c|}{ Skupaj } \\
\hline & f & $\mathrm{f} \%$ & $\mathrm{f}$ & $\mathrm{f} \%$ & f & $\mathrm{f} \%$ & $\mathrm{f}$ & $\mathrm{f} \%$ \\
\hline 2 & 1 & 7,1 & 5 & 31,3 & 2 & 7,7 & 8 & 14,3 \\
\hline 3 & 6 & 42,9 & 2 & 12,5 & 12 & 46,2 & 20 & 35,7 \\
\hline 4 & o & 0,0 & 6 & 37,5 & 10 & 38,5 & 16 & 28,6 \\
\hline 5 & 7 & 50,0 & 3 & 18,8 & 2 & 7,7 & 12 & 21,4 \\
\hline Skupaj & 14 & 100,0 & 16 & 100,0 & 26 & 100,0 & 56 & 100 \\
\hline $\begin{array}{l}\text { Izid } \\
\text {-preizkusa }\end{array}$ & $\begin{array}{l}=24,279, \\
P=0,000\end{array}$ & $=0,432$ & & & & & & \\
\hline
\end{tabular}

Iz frekvenc je mogoče razbrati, da je najvišja modalna ocena 5 najpogostejša $\mathrm{v}$ razredu (8. razredu) $\mathrm{z}$ nizko stopnjo govorne participacije učencev, medtem ko je modalna ocena 4 pogosta $v$ razredih $z$ višjo (2. letnik) in srednjo (5. razred) stopnjo govorne participacije učencev. Oceno 3 imajo na eni strani pogosteje učenci razreda $\mathrm{z}$ visoko (2. letnik) in na drugi nizko govorno participacijo (8. razred).

Iz rezultatov lahko razberemo, da je razlika $\mathrm{v}$ znanju učencev glede na stopnjo govorne participacije statistično značilna $(\mathrm{P}=0,000)$.

Povprečja kažejo, da je višja stopnja govorne participacije pogostejša pri oceni 3 ter nižja pri oceni 5. Takšnega izida nismo pričakovali, saj smo predvidevali, da se učenci, ki imajo kakovostnejše (pred)znanje, lažje aktivno vključujejo $\mathrm{v}$ pouk, ker jim prav njihovo vedenje omogoča, da aktivno sodelujejo $\mathrm{v}$ vsebinskem vidiku komunikacije $\mathrm{z}$ učiteljem.

Razloge za prevladujočo modalno oceno 5 pri nizki stopnji govorne participacije iščemo $\mathrm{v}$ rezultatih raziskav, ki opozarjajo, da vsi učno uspešni nadarjeni učenci niso enako motivirani za šolsko delo. Obstajajo učenci, ki so relativno nezainteresirani ali pa se zanimajo le za zanje pomembna področja (Kroflič, 2003; Rea, 2000). Juriševič in Kralj (2003, povz. po Juriševič, 2012) ugotavljata tudi, da ponudba in zahteve učnega načrta niso $\mathrm{v}$ skladu $\mathrm{z}$ nadarjenostjo nekaterih učencev, ki se zato $\mathrm{v}$ šoli pogosto dolgočasijo.

Učenci z modalno oceno 3 so po našem mnenju v večji meri pripravljeni sodelovati $\mathrm{v}$ komunikaciji $\mathrm{z}$ učiteljem, saj so učenci, ki nimajo odličnega učnega uspeha, v raziskavi (Simonišek, 2013) poročali o tem, da jim učitelj 
nudi več pomoči, jih pogosteje spodbuja in pohvali. Takšen odnos učitelja učence zagotovo opogumi, da se aktivneje vključujejo v razredno komunikacijo.

\section{Zaključek}

Kakovostno šolo in kakovosten pouk odlikuje lastnost, da zna učence motivirati tako, da $\mathrm{z}$ aktivnim sodelovanjem v vzgojno-izobraževalni praksi dosežejo dobre učne rezultate ter pridobijo različne, za življenje potrebne, vrednote in spretnosti (Kovač et al., 2008). Na osnovi tega dejstva lahko trdimo, da je za kvalitetno znanje učencev osrednjega pomena prav razredni pogovor. V rokah učitelja je, da ustvarja ozračje, v katerem se učenci počutijo varne in si posledično upajo sodelovati v razredni komunikaciji, čeprav niso povsem prepričani v pravilnost izraženih misli (Marentič-Požarnik in Plut Pregelj, 2009).

Namen naše raziskave je bil analizirati razlike v znanju učencev glede na stopnjo govorne participacije. Rezultati so pokazali, da se v komunikacijski proces v razredu pogosteje vključujejo učenci z oceno dobro (3), medtem ko so učno uspešnejši učenci, ki imajo pri opazovanem predmetu oceno 5, govorno manj aktivni. Morda se učno uspešnejši učenci pri pouku dolgočasijo, kar posledično vodi v nemotiviranost in nezainteresiranost za delo (Kastelič Hočevar, 2003) ter posledično nezainteresiranost za aktivno sodelovanje v komunikaciji.

Postavlja se nam vprašanje, kako vse učence vzpodbuditi k aktivnejšemu sodelovanju oz. kako prispevati k temu, da bodo učitelji pri pouku aktivneje vključevali učence.

$\mathrm{Na}$ osnovi raziskav lahko zaključimo, da je participacija učencev $\mathrm{v}$ veliki meri odvisna od pripravljenosti odraslih oz. učiteljev, da del svoje moči delijo z učenci (Wenzel, 2001; Bock, 2010). V njihovih rokah je, da vsebinsko in metodološko plat participacije prilagodijo razvojni stopnji učencev (Fatke in Schneider, 2008). Na učiteljeva stališča do participacije učencev pozitivno vplivajo predvsem njihove lastne možnosti soodločanja, zadovoljstvo $\mathrm{z}$ delovnim mestom in šolska klima (Kovač, 2008 in Mithans, 2017). Vsi ti dejavniki so v veliki meri odvisni od vodstva šole, ki svoj demokratičen način vodenja prenaša na učitelje in učence (Kovač, 2008).

K aktivnejšemu vključevanju učencev v sam učni proces bi pozitivno prispevalo tudi uvajanje večjega nabora izbirnih vsebin $\mathrm{v}$ učne načrte predmetov, s tem bi učenci dobili več možnosti, da aktivno sodelujejo pri izbiri obravnavanih vsebin, ki so v skladu z njihovimi interesi. Aktivno sode- 
lovanje pri izbiri učnih vsebin bi učence motiviralo tudi za sodelovanje v fazi obravnave učne snovi.

Vsekakor je za aktivnejše vključevanje učencev v pouk v prvi vrsti odgovoren učitelj. Marentič Požarnikova (2016) je v povezavi s tem prepričana, da se učitelj na podlagi lastnih pojmovanj oz. prepričanj o bistvu učenja, vlogah učitelja in učencev ter ciljih poučevanja, odloči za določeno reagiranje v razredu. Zato je za aktivnejše vključevanje učencev v pedagoško prakso pomembno predvsem kakovostno izobraževanje učiteljev, kajti, če želijo v pouk vključevati učence, morajo najprej sami razumeti koncept participacije ter učne metode in strategije pouka, ki pripomorejo $\mathrm{k}$ uspešnemu vključevanju učencev v pouk. Učitelji, ki bodo dobro poznali to področje, bodo pridobili zaupanje $\mathrm{v}$ svoje sposobnosti in bodo učencem ponujali več priložnosti za soodločanje ter jim zagotavljali pogoje za razvoj participacijskih kompetenc.

\section{Literatura}

Adamič, Milan. 1990. Analiza o položaju učenca pri pouku na razredni stopnji osnovne šole. Sodobna pedagogika, 41(3/4): 200-212.

Blažič, Marjan; Ivanuš Grmek, Milena; Kramar, Martin in Strmčnik, France. 2003. Didaktika: visokošolski učbenik. Novo mesto: Visokošolsko središče, Inštitut za raziskovalno in razvojno delo.

Bock, Torben. 2010. Bildungsprozesse pädagogischer Fachkräfte bei der Einführung von Partizipation: Evaluation eines Partizipationsprojektes im Rahmen der Fortbildung »Die Kinderstube der Demokratie« an der Flachsland Zukunftsschule Hamburg. Kiel: Fachhochschule Kiel. http:// www.partizipation-und-bildung.de/pdf/BA\%2oThesis\%2oTorben\%2O Bock\%20-\%2oEvaluation\%2oFlachsland.pdf.

Državljanska vzgoja v Evropi. (2005). Ljubljana: Ministrstvo za šolstvo in šport. Fatke, Reinhard in Schneider, Helmut. 2008. Partizipation von Kindern und Jugendlichen in Deutschland: Konzeptionelle Grundlagen und empirische Befunde zur Mitwirkung junger Menschen in Familie, Schule und Kommune. https://www.bertelsmann-stiftung.de/de/publikationen/publikation/did/partizipation-von-kindern-und-jugendlichen-in-deutschland/

Gril, Alenka; Klemenčič, Eva in Autor, Sabina. 2009. Udejstvovanje mladih v družbi. Ljubljana: Pedagoški inštitut.

Han, Bunyamin in Tosten, Rasim. 2016. In-class teacher-student communication according to high school students' perceptions. New Trends and Issues 
Proceedings on Humanities and Social Sciences. 11: 190-198. https://www. researchgate.net/publication/330854430_In-class_teacher-student_communication_according_to_high_school_students__perceptions.

Ing, Marsha; Webb, Noreen M.; Franke, Megan L.; Turrou, Angela C.; Wong, Jacqueline; Shin, Nami in Fernandez, Cecilia H. 2015. Student participation in elementary mathematics classrooms: the missing link between teacher practices and student achievement? Educational Studies in Mathematics, 90 (3): 341-356.

Ivanuš Grmek, Milena; Javornik Krečič, Marija; Vršnik Perše, Tina; Rutar Leban, Tina; Kobal Grum, Darja in Novak, Bogomir. 2007. Gimnazija na razpotju. Ljubljana: Pedagoški inštitut.

Javornik Krečič, Marija. 2003. Aktivnosti srednješolcev pri obravnavi nove učne snovi. Je aktivnost dijakov pri pouku v skladu s sodobnimi didaktičnimi koncepti? Vzgoja in izobraževanje, 34(6): 20-25.

Jesper Juul in Helle Jensen. 2009. Od poslušnosti do odgovornosti: za novo kulturo vzgajanja. Radovljica: Didakta.

Juriševič, Mojca. 2012. Motiviranje učencev v šoli: analiza ključnih dejavnikov zagotavljanja kakovosti znanja v vzgojno-izobraževalnem sistemu. Ljubljana: Pedagoška Fakulteta.

Kastelic Hočevar, Magda. 2003. Problemi, s katerimi se srečujejo nadarjeni in premagovanje le-teh. V Nadarjeni med teorijo in prakso: mednarodni znanstveni simpozij, ur. Marjan Blažič, 282-289. Novo mesto: Slovensko združenje za nadarjene: Visokošolsko središče.

Kodela, Tadeja in Lesar Irena. 2015. Ali formalni in strokovni dokumenti s področja šolstva spodbujajo participacijo učencev? Sodobna pedagogika, 66(3): 36-51.

Konvencija o otrokovih pravicah. 1989. https://www.gov.si/assets/ministrstva/ MZZ/Dokumenti/multilaterala/clovekove-pravice/porocila-SLO-po-instrumentih-o-clovekovih-pravicah/73241a9c65/Konvencija-o-otrokovih-pravicah.pdf .

Kötters, Catrin; Schmidt, Ralf in Ziegler, Christine. 20o1. Partizipation im Unterricht - Zur Differenz von Erfahrung und Ideal partizipativer Verhältnisse im Unterricht und deren Verarbeitung. V Partizipation in der Schule: Theoretische Perspektiven und empirische Analysen (Studien zur Schul- und Bildungsforschung), ur. Böhmer, Jeanette in Kramer, Rolf-Torsten, 93-122. Opladen: Leske in Budrich Verlag. 
Kovač, Tatjana. 2008. Vpliv participacije učencev na kakovost vzgojno-izobraževalnega dela šole. (Doctoral dissertation). Ljubljana: Univerza v Ljubljani, Filozofska fakulteta, Oddelek za pedagogiko in andragogiko.

Kovač, Tatjana; Resman, Metod in Rajkovič, Vladislav. 2008. Kriteriji ocenjevanja kakovosti šol na podlagi ekspertnega modela. Moč participacije učencev. Sodobna pedagogika, 59(2): 180-201.

Kramar, Martin, 1990. Učenci v vzgojno-izobraževalnem procesu sodobne šole. Radovljica: Didakta.

Kramar, Martin. 2008. Razmerja med šolo, učenci in starši v vzgojno-izobraževalnem procesu v luči avtonomije. V Šola in starši z vidika avtonomije; Zbornik prispevkov s posveta ob 2oo-letnici šolstva v Črenšovcih, ur. Meglič, Drago, 40-45. Črenšovci: Osnovna šola Franceta Prešerna.

Kroflič, Breda. 2003. Vedenjsko težavni otroci - neodkriti in zatrti nadarjenci? Nadarjeni med teorijo in prakso; Zbornik prispevkov; Mednarodni znanstveni simpozij, ur. Blažič, Marjan, 207-218. Novo mesto: Slovensko združenje za nadarjene.

Kroflič, Robi. 2013. Pripoznanje zmožnega otroka in ontološki angažma v dialogu - pogoj participacije in vzgoje za aktivno državljanstvo. Nacionalna konferenca Socialna in državljanska odgovornost: Zbornik prispevkov. Ljubljana: Ministrstvo RS za izobraževanje, znanost, kulturo in šport. https://www.zrss.si/sidro/files/SIDRO2013-zbornik.pdf.

Kurth Buchholz, Elke. 2011. Schülermitbestimmung aus Sicht von Schülern und Lehrern: Eine vergleichende Untersuchung an Gymnasien in Brandenburg und Nordrhein-Westfalen. Münster: Waxmann Verlag.

Marentič Požarnik, Barica. 2016. Psihologija učenja in pouka: Temeljna spoznanja in primeri iz prakse. Ljubljana: DZS.

Marentič Požarnik, Barica in Plut Pregelj, Leopoldina. 2009. Moč učnega pogovora: poti do znanja z razumevanjem. Ljubljana: DZS.

Mithans, Monika. 2017. Participacija učencev pri pouku in na šoli. (Doctoral dissertation). Maribor: Univerza v Mariboru, Pedagoška fakulteta.

Mithans, Monika in Ivanuš Grmek, Milena. 2012. Spreminjanje položaja učenca v Sloveniji v 20. stoletju. Revija za elementarno izobraževanje, 5(2/3): $55-72$

Prgić, Jani. 2010. Šolska in vrstniška mediacija: Vse kar morate vedeti o mediaciji v šoli. Griže: Svetovalno-izobraževalni center MI.

Pšunder, Majda. 1998. Kaj bi učitelji in starši še lahko vedeli? Ljubljana: Zavod Republike Slovenije za šolstvo. 
Rea, Dan W. 200o. Optimal motivation for talent development. Journal for the Education of the Gifted, 23(2): 187-216. https://journals.sagepub.com/ doi/10.4219/jeg-2000-574

Roiste de, Aingeal, Kelly, Colette, Molcho, Michal, Gavin, Aoife in Gabhain, Saoirse Nic. 2012. Is school participation good for children? Associations with health and wellbeing. Health Education, 112 (2): 88-104.

Rutar Ilc, Zora in Rutar Dušan. 1997. Kaj poučujemo in preverjamo v šolah. Radovljica: Didakta.

Simonišek, Katja. 2013. Zaznavanje učiteljeve komunikacije v razredu s strani učencevin učitelja. (diplomsko delo). Maribor: Pedagoška fakulteta.https:// dk.um.si/IzpisGradiva.php?id=41283\&lang=slv\&prip=rup:8760082: 1

Skalar, Marija. 1990. Od besede do odnosa v medosebni šolski komunikaciji. V Komunikacija in jezikovna kultura v šoli, ur. France Žagar, 9-16. Ljubljana: Pedagoška akademija.

Šagud, Mirjana in Hajdin, Ljubimka. 2018. Position of the Modern Teacher in Educational Theory and Practice. Croatian Journal of Education, 20(1): 149-16o.

Štefanc, Damijan. 2005. Pouk, učenje in aktivnost učencev: razgradnja pedagoških fantazem. Sodobna pedagogika, 56(1): 34-57.

Thiel, R. D., Keller, G., in Binder, A. (1999). Vprašalnik o učnih navadah za mladostnike; Priročnik za izvedbo, vrednotenje in interpretacijo. Ljubljana: Center za psihodiagnostična sredstva, Ministrstvo za izobraževanje, znanost in šport.

Tomić, Ana. 1997. Izbrana poglavja iz didaktike. Ljubljana: Center za pedagoško izobraževanje Filozofske fakultete.

Tomić, Ana. 2002. Spremljanje pouka. Ljubljana: Zavod RS za šolstvo.

Wenzel, Hartmut. 2001. Lehrereinstellungen und Partizipationsmöglichkeiten - Voraussetzungen für die pädagogische Schulentwicklung in den Schulen der neuen Bundesländer. Partizipation in der Schule: Theoretische Perspektiven und empirische Analysen (Studien zur Schul- und Bildungsforschung), ur. Böhme, Jeanette; Kramer, Rolf-Torsten, 15-26. Opladen: Leske in Budrich Verlag.

Zabukovec, V. (1998). Merjenje razredne klime; Priročnik za učitelje. Ljubljana: Produktivnost, Center za psihodiagnostična sredstva.

Žibert, Samanta. 2011. Vpliv samopodobe na osebnost in učno uspešnost učenca. Nova Gorica: Melior, Založba Educa. 



\section{Mathematical modelling in primary schools-advanced topics at elementary level}

Natalija Budinski

\section{Introduction}

Development of modern technology and industry makes mathematical modelling undeniably irreplaceable in many fields, such as environment or scientific computation (Quarteroni, 2009). According to Meerscshaert (2007), figurativelly speaking, mathematical modeling is joining mathematics and the rest of the world. Due to mathematical modelling various aspects of connection to the real world, it could be described in the language of science. Its importance is in being the third pillar of science and engineering, beside theoretical analysis and experimentation. Mathematical modelling starts with examination of basic information about the problem, continues with construction of mathematical models, and finishes with the solutions of the problem in the real-world sphere. Also, it is particularly important that every model need to be verified.

It is evident that mathematical model is central part of mathematical modelling. There are different definitions of models that could represent real-world situation. One of the most general division is to four broad categories: deterministic, stochastic, empirical and mechanistic (Marion, 2008). Deterministic models produce the same results for the fixed beginning values, while stochastic models produce various results which depend on the actual values. Empirical models describe how things work by relating independent and dependent variables, and empirical models are based on statistical regressions and data. There is also division of models depending on 
the mathematics and presentations, such as arithmetic, algebraic-analytic, graphical, geometrical, or combined. Models can be also equations or computer codes. For example, the strength of earthquakes is measured with the Richter's scale, which use logarithm. Magnitude of the earthquake can be calculated by formula (1)

$$
M(x)=\log \left(\frac{x}{x_{0}}\right)
$$

where $\mathrm{M}$ is the magnitude of earthquake, $x$ is the measure of the amplitude of earthquake wave and $x_{0}$.

\section{Mathematical modelling in education}

The mathematical modelling significantly came into the educational focus in recently years.

In this paper we elaborate how can mathematical modelling be applied in the younger students' mathematical education in order to introduce students with the notion of function. The described example is applied in the primary school "Petro Kuzmjak" in Ruski Krstur in Serbia, with students 10-11 years old. Mathematical curriculum for the primary school students propose mathematical topics such as: number and its graphical representation, fractions, calculations (addition, subtraction, multiplication and division), equations and inequalities, word problems, measures, area of square, rectangle, and cube. There is also a recommendation that students could be introduced to functions trough real life examples in order to get knowledge about variables. Formally, content related to function is introduced to students age 13-14 years old in upper primary level school, and starts with linear function.

Significance of mathematical modelling is related to the potential of learning and teaching mathematics based on mathematical modelling and developing students' competences, and in our case, it was chosen as a teaching method. Mathematical modelling helps to connect real-world situations and mathematical concepts. Students learn to understand and decide about real-world problems the importance of mathematics as a tool for solving problems and giving answers to the relevant questions is highlighted during mathematical modelling activities in the classroom. Such activities are helpful in developing transferable skills that students could apply in other subjects and situations.

Blomhoj \& Jensen (2003) identify six competences related to the mathematical modelling: formulation of the problem, recognition of the rele- 


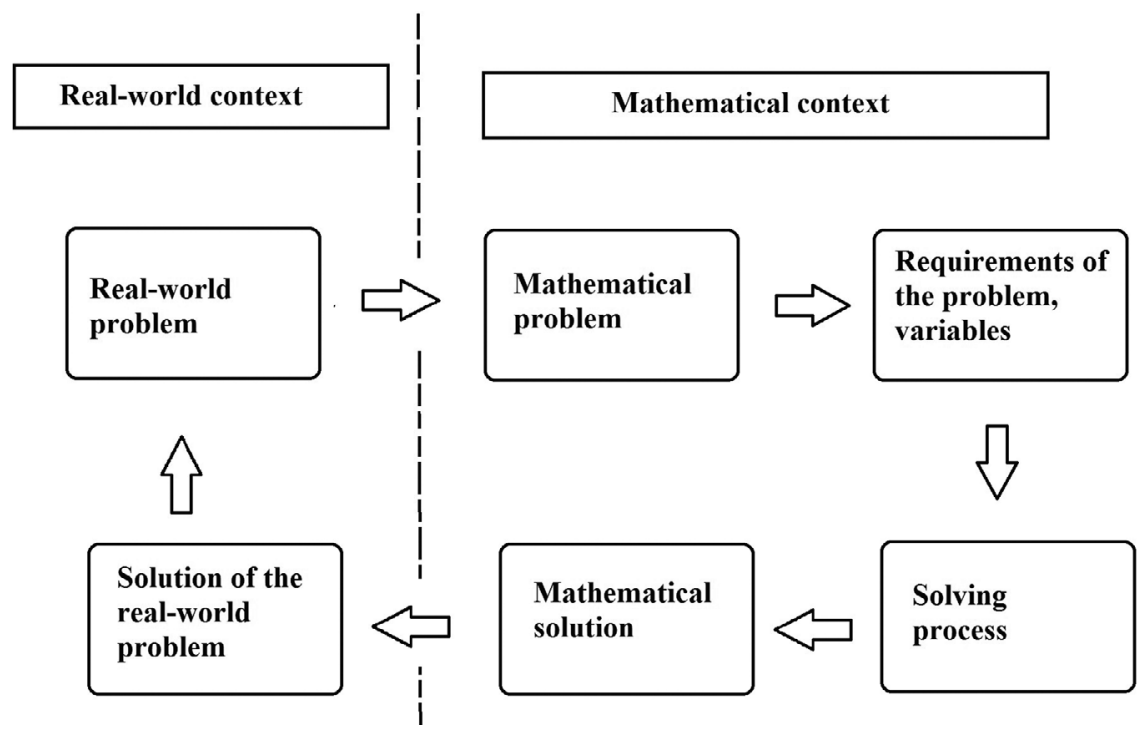

Figure ir: Mathematical modelling cycle in the educational settings

vant information, transition from real-world to mathematical context, use of mathematical methods, interpretation of mathematical results in the real-world context and evaluation or verification of the problem. Those competences are developing trough mathematical modelling phases.

The visual representation of the mathematical modelling application in the classroom can be seen in Figure 11 (Budinski \& Milinkovic, 2018). It can be seen how real-world and mathematical context could be connected through mathematical modelling phases. The transition from one phase to the other phase requires different kinds of cognitive activities, such as analysing, constructing, simplifying, structuring, mathematical working, interpreting, validating, and exploring (Blum \& Leis, 2007).

Mathematical modelling in the classroom begins with the starting point of situation or problem that needs the solution. Further step is to connect real-situations and mathematical content and producing a mathematical model. That phase is known as mathematization. According to Lukac \& Sekerak (2013), mathematization consider transition from the real-world to mathematical context. At the end, the mathematical model must be verified and interpreted in the real-world context. 


\section{Mathematical modelling in Primary School}

Mathematical modelling can be applied at all levels of education, but even though it is the case, (Diezmann et al., 2002; Doerr \& English, 2003) it is not much applied in primary schools and on the basic level of education. There is some research that shows that mathematical modelling can be effectively applied for developing mathematical competences in engaging and complex, but meaningful activities with primary school students (Doerr \& English, 2003).

In our study we used mathematical modelling as a base for teaching young students (age 1o years) different mathematical concepts: from basic mathematical calculating operation to the beginnings of one of the most important mathematical notion such as function. Learning mathematical operation and calculation is usual to connect with real-world context, but functions are not that common topic in primary schools, since that is an advanced concept. The idea for our study to introduce young learners with functions come from the fact that functions are one the most important mathematical concepts, but also a mathematical concept that is hard to grasp for students.

In order to introduce students in the elementary school (9-10 years old) to concepts of function we explored the possibilities of mathematical modelling application. We have applied mathematical modelling-based lessons in order to convey to students' different mathematical concepts and finally the mathematical concept of functions. The duration of the research was one year on the sample of 70 students in several primary schools in Bosnia and Herzegovina.

One of the modelling examples that was presented to students in order to highlight the concept of function was based on the real-world situation of population. For the purpose of the mathematical modelling we took the real-life situation of the population change. The real-life situation was a story about a village and its inhabitants. The task offered the information about population gender and age structure. It was written in the form of story. The first step was to understand the real-world situation and information given in the text. The text hide problems that students needed to solve. Problems were in the form of the unfinished sentences or visual representation of information from the text. In Figure 12 we can see the graphical representation of solution of the real-world problem where students needed to find and represent number of boys and girls in the one class in the village school. 


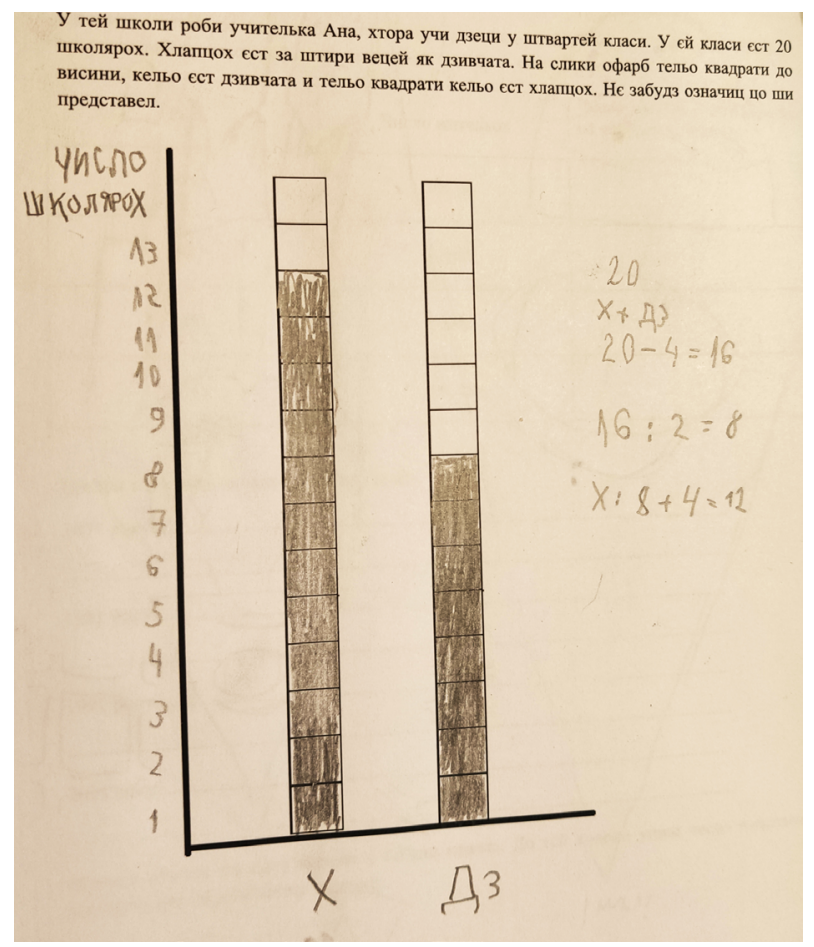

Figure 12: Solution of the real-world problem and its graphical representation

Following and solving tasks students were gradually guided to the solution of the main problem of the real-world situation which was to predict the population of the village in the future. Accordingly, to students age, the main problem required answer if the population of the village increase or decrease. Students needed to discuss dependence of the values, which in this case were time and number of inhabitants. This kind of activities helped students to verbally articulate relationship between variables in the problem of population in a village. Also, students graphically represented relationships between variables which they recognized in everyday situation. Modelling activities enabled students to have different kinds of experience, beside learning mathematics, such as dealing with problem of population or migration. According to their reactions, students liked activities and actively participated. During the solving tasks, they have many questions and issues since they never experienced this kind of activities. 


\section{Conclusions}

It is inevitable that teaching strategies need to be changed since we need students to be more creative, flexible and research oriented. They need to know how to solve problems that are not typical tasks from textbooks. The tasks based on mathematical modelling help students to learn how to work with data, how to represent them and draw conclusions. Beside that they could observe the dependence between the variables.

\section{Literature}

Blum, Werner and Leis, Dominik. "How do students' and teachers deal with modelling problems?" In: Haines, C. et al. (Eds), Mathematical Modelling: Education, Engineering and Economics. Chichester: Horwood, (2007): 222-231.

Budinski, Natalija and Milinković, Dragica. "Multidisciplinary approach in teaching mathematics in primary education". Нова школа, Часопис за теорију и праксу савремене школе и предшколства, XIII (1), (2018): 42-49.

Diezmann, Carmel, Watters, James and English, Lyn. "Teacher behaviors that influence young children's reasoning”, Proceedings 27th Annual Conference of the International Group for the Psychology of Mathematics Education 2, pp. 289-296, Norwich, UK.

Doerr, Helen and English, Lyn. 2003. "A Modeling Perspective on Students' Mathematical Reasoning about Data", Journal of Research in Mathematics Education, 34(2), (2002): 110-136.

Marion, Glenn. "An Introduction to Mathematical Modeling", Bioinformatics and Statistics, Scotland, 2008.

Meershart, Mark. "Mathematical Modeling", 3rd Academic Press, Inc. Orlando, FL, USA, 2007.

Lukac, Stanislav and Sekerák, Jozef. "Formation of the mathematical modeling competence using digital technologies". 265-269. 10.1109/ICETA.2013.6674441, 2013.

Quarteroni, Alfio. "Mathematical Models in Science and Engineering", Notices of AMS, 56(1), (2009): 10-19. 


\title{
Diverse teaching methods: How to approach to different levels of anxiety
}

\author{
Meleka Asotić, Ajša Bahović Latifović
}

\begin{abstract}
Introduction
Research onto the phenomena of language anxiety in foreign language communication has been present for almost four decades (Liu 2019). Despite decades of dealing with the topic of linguistic anxiety, professional literature is rich with a variety of understandings and theoretical settings (Tran 2012). However, the starting point of almost all researchers of language anxiety is a theory of Horwitz, Horwitz and Cope (1986) that formed the basis for the construction of a well-known instrument - the Foreign Language Classroom Anxiety Scale (FLCAS). In recent years, dealing with the phenomena of foreign language anxiety (FLA) has been evident. Not only have numerous articles testified to the factuality, but also publications, such as, New insights into language anxiety: Theory, Research and Educational Implications". The importance of this publication is not only illustrated by the fact that the authors of the texts are eminent experts who have been dealing with the FLA phenomenon for years, but also that the problem is addressed in a comprehensive way: through a theoretical discussion of Horwitz's classic research, through new empirical research on FLA and considering practical implications (Liu 2019). Moreover, the aforementioned publications, as well as numerous professional papers, confirm that FLA is not an abstract phenomenon but a real problem that today's students face (Tran 2012). In this regard, this research paper has focused on examining the level of linguistic anxiety of high school students by providing
\end{abstract}


an alternative way to measure FLA. Unlike the well-known FLCAS, the research work focused on designing a new measuring instrument - FLSAQ (Foreign language speaking anxiety questionnaire). The aim of the paper is not only to identify the extent of the anxiety problem but also to provide practical mechanisms to overcome this phenomenon. Having considered all the issues mentioned, our effort was set aside comprehension and provision of a general and universal view of the FLA phenomenon.

\section{Theory}

Most authors would probably agree that the pioneering work of Horwitz et al. (1986) is still a key theoretical basis for understanding the phenomenon of foreign language anxiety in a classroom environment. However, it is considered there are different understandings and definitions of FLA and that other authors have also made significant contributions to the development of this phenomenon. Perhaps utmost credentials for incentive and development the FLA concept go to McCroskey $(1970,1978)$ who defined the term „communication apprehension“. Communication apprehension is considered as the general anxiety associated with oral communication and associated with real or anticipated communication with others. Just a few years after McCroskey's work, the first definitions of the FLA emerged. Clement (1980) thought that FLA should be defined in terms of feelings, self-esteem and self-confidence. That's why he thought the FLA belonged to the field of learners' psychology (Clement 1980). Horowitz et al. (1986) seem to embrace Clement's idea by defining FLA as a construct associated with self-perceptions, beliefs, feelings, and behaviours. In their view, FLA is a unique type of anxiety associated with learning a foreign language in class and different from other types of anxiety (Horowitz et al. 1986). MacIntyre and Gardner (1994) and Zhang (2001) considered FLA as a (psychological) sense of persons' tension while learning a foreign language. Mihaljevic Djigunovic (2002) considers FLA to be a short-term excruciating condition that accompanies feelings of discomfort, nervousness and insecurity. Namely, this feeling is accompanied by certain physiological reactions such as rapid heart rate, chest pressure, rapid breathing, etc. (Popović-Babić, Apostolović, and Biskupljanin 2007). Almost all definitions describe FLA as a tense and uncomfortable condition similar to general anxiety. Therefore, understanding FLA also implies a clear distinction from general anxiety and other specific anxiety states, as it is a unique type of anxiety that is connected to specific situations, while general anxiety is related to all situations. (Horowitz 
et al. 1986).Also, some authors find it necessary to emphasize the difference between anxiety as a trait and as a state (Salehi and Marefat 2014). FLA is rather state anxiety (Brown 2000), and this is supported by research that has found that trait anxiety has no predictive value in second language achievement (MacIntyre and Gardner 1991). In that context, anxiety as a personality trait should be distinguished from one that binds to specific situations (Králová 2016). FLA should be distinguished from general academic anxiety as well. Thus, it will certainly happen that students who have general anxiety feel FLA, but it is evident that some students do not feel anxious about other school subjects except in learning a foreign language (Tran 2012). Considering language anxiety and looking for a way to make the terminological distinction, Horwitz et al. (1986) talked about the FLA components: communication apprehension, test anxiety and fear from the negative evaluation. While communication apprehension is related to the anxiety experienced in interaction (speaking and listening to others), anxiety on testing is a form of performance-related anxiety, and fear of negative evaluation is related to the students' perception of how others (teacher and classmates) can influence on his or her language ability (Horowitz et al. 1986). Based on the above-mentioned comments, Horwitz et al. (1986) constructed the instrument FLCAS, which measures anxiety levels taking into account data on negative performance expectations and social comparisons, psychophysiological symptoms and avoidance behaviours (Tran 2012). However, some authors have shown that the anxiety test is rather associated with general anxiety and therefore not specifically associated with foreign language learning (MacIntyre and Gardner 1989; Aida 1994). Understanding the specifics of the FLA, this concept also requires considering the causes. Young (1991) cites several causes of the occurrence of FLA in a classroom situation, which are: personal and interpersonal anxiety, learner beliefs about language learning, instructor beliefs about language teaching, instructor-learner interactions, classroom procedures and language testing. Von Wörde (2003) believes that causes should be sought in the inability to comprehend, negative classroom experiences, pedagogical practice, correction of mistakes and native speakers. The causes of FLA indicate the problems lie not only inside the student, but also in sources outside the individual, i.e. in the way of interaction between the student and the professor, in the procedures and the method of assessment of English, in pedagogical practice, and similar. 


\section{Methodology}

\section{Participants}

The research has involved 100 second and fourth-grade high school students located in the Sanjak region. One of the conditions for the selection of students in the research was the students had been attending English classes in five years' continuation. The study involved 54 female and 46 male students. Students who participated in the qualitative part of the research were not included in the quantitative part of the research. The first (qualitative) survey's part involved 15 students. The students were 17 years old, and comparing gender, 6 male and 9 female students were included. In the second (quantitative) part of the survey, 85 students participated, concerning the availability within classes. According to gender, 45 female students and 40 male students participated.

\section{Instruments}

A new FLSAQ questionnaire was constructed to survey the second phase. The FLSAQ is intended to assess anxiety during students' foreign language speech. The aforementioned questionnaire contains 20 items that are formulated based on data obtained through the qualitative part of the research. Items are assessing the thoughts, behaviours, and feelings of a student when speaking a foreign language during school class. The FLSAQ's format is five-level Likert item (from completely inaccurate to completely accurate). The reliability (internal consistency) of the instrument was also calculated and is $\alpha=.927$, indicating high reliability. The FLSAQ validity data is presented in the results section. In addition to the FLSAQ, the FLCAS instrument was also used (Foreign Language Classroom Anxiety Scale) (Horwitz et al. 1986). The FLCAS contains 33 items and is in the form of a 5-point Likert scale ranging from "completely disagree" to "completely agree". The primary purpose of FLCAS was to measure speech-language anxiety in the classroom situation (Horwitz et al. 1986), and later, in some studies, it was used to assess anxiety in other language skills than just speech (Saito, Horwitz and Garza 1999; Cheng 2002). Prior research has confirmed the high reliability of the instrument $(\alpha=.940)$ (Aida 1994) and this research confirmed the same as Kronbach's alpha coefficient is .923. FLCAS was used in this study to determine the construct convergent validity. Oral performance measures (OPM) were formulated to determine the criterion validity of the FLSAQ, and to assess whether 
and to what extent measured anxiety affects speech. OPM is a scale that contains grades 1 to 5 (grade 1 is the lowest and indicates the worst English language proficiency, while grade 5 is the best foreign language proficiency). The level of speaking language was assessed by grade, using the following criteria: vocabulary, sentence coherence - SVOMPT and grammar in constructing a sentence.

\section{Research design}

The research is of qualitative-quantitative type and was conducted in two phases. The research first phase was a qualitative type and involved conducting interviews. The interview was semi-structured. The aim of the interview was to get an answer to how pupils feel during second language speaking (their experience with anxiety) and what the best way to decrease anxiety is. The second phase of the research was of a quantitative type. In this phase, students were responding on FLSAQ and FLCAS items. Before selecting the examiner to participate in the second (quantitative) phase of the survey, foreign language teachers evaluated the respondent's proficiency in the language by the OPM scale.

\section{Data analysis}

Descriptive measures (arithmetic mean, standard deviation, frequency and percentages) were used to assess the level of anxiety in students in the second phase of the study. Correlation and factor analysis was applied to determine the constructive and criterion validity of FLSAQ. Parallel analysis was used as the criterion for determining the final number of factors underlying the FLA. Parallel analysis was conducted using SPSS syntax for parallel analysis (O'Connor, 200o). In the qualitative part of the research, information on respondents anxiety reactions during the English language class were recorded. In the end, the answers were summarized in several categories and only those that were repeated mostly by all respondents were presented and taken into account for FLSAQ design.

FLSAQ total score is calculated by the sum of all respondents' responses to items. All items had equal importance in calculating the total score. Before calculating the FLSAQ total score, negatively stated items are transformed in positively stated items. 


\section{Results}

As noted in the methodology, the research was conducted in two phases. In the first phase, an interview was conducted with 15 high school students. The aim of the interview was to obtain information on the questions of feeling anxiety during the speech in a foreign language and how the anxiety manifests. Respondents also described conditions opposite to anxiety in order to better understand the conditions to be pursued when learning a foreign language. The data are presented in Table 30.

\section{Table 30: Descriptions of anxiety reactions and opposite reactions to anxiety in foreign language learners.}

\begin{tabular}{lll}
\multicolumn{1}{c}{ Feelings } & \multicolumn{1}{c}{ Thoughts } & \multicolumn{1}{c}{ Behaviour } \\
$\begin{array}{l}\text { Fear } \\
\text { Panic } \\
\text { Confusion } \\
\text { Tension } \\
\text { Nervousness } \\
\text { Discomfort }\end{array}$ & $\begin{array}{l}\text { Worry about what others think } \\
\text { Worry not to be ridiculous } \\
\text { Thoughts blockade } \\
\text { The belief that everything must } \\
\text { turn out without mistakes }\end{array}$ & $\begin{array}{l}\text { Silence } \\
\text { Avoiding conversation } \\
\text { Having the desire to abandon } \\
\text { the class }\end{array}$ \\
$\begin{array}{l}\text { Contrary to anxiety } \\
\text { Fear in terms of tension, tre- } \\
\text { mors, discomfort exists but it } \\
\text { lasts briefly and quickly can be } \\
\text { overcome }\end{array}$ & $\begin{array}{l}\text { is grammatically correct } \\
\text { it does not matter if everything } \\
\text { the challenge is to learn } \\
\text { something new }\end{array}$ & $\begin{array}{l}\text { Concentrated on speech, ac- } \\
\text { cepting communication, re- } \\
\text { laxed in speech }\end{array}$ \\
\hline
\end{tabular}

By analyzing the data in Table 30 , it can be found that the descriptions of reactions during foreign language speech can be classified into three categories: thoughts, feelings and behaviours. In addition to the fact that the respondents felt fear, panic and nervousness during the foreign language speech, during the interview it could be heard that there were other reactions associated with and represent a manifestation of anxiety. For example, respondents stated that they: worry about what others will think, think they have to utter everything perfectly and without mistake, because otherwise they will be ridiculed, need to interrupt communication or remain silent, and those reactions go to such an extent they want to leave class. On contrary to anxiety reactions, students feel they would be more successful in speaking a foreign language: if they felt more relaxed, if they did not think what others thought of their speech, but were only oriented towards speech and when they stopped worrying that everything had to be spoken perfectly and correctly. During the interview, respondents were also asked 
questions about mechanisms to reduce anxiety in foreign language speaking in a classroom situation. Respondents' answers can be classified into several categories:

1. The professor must be less demanding, be patient, have more understanding for the mistakes made in the speech and must punish pupils who mock others while they speak in a foreign language.

2. Some of the pupils think anxiety is conditioned by poor knowledge of vocabulary and grammar of a foreign language, so anxiety will be decreased when pupils start to learn more.

3. Some pupils think that anxiety originates from personality and has little to do with what is happening in the classroom, so there are not ways to reduce anxiety.

So, in the pupils' opinion, anxiety will decrease if professors change their way of dealing with students and if students learn more. Some pupils think that anxiety is a matter of personality and therefore there is no way to solve the problem.

Interview data were used to formulate FLSAQ items. To verify construct validity of the FLSAQ, exploratory factor analysis was applied and the degree of association with another instrument - FLCAS in order to determine if different instruments, measuring the same construction, were correlated (Faljgelj 2009; Taherdoost 2016). At the beginning of the analysis, the items communalities were checked. According to some authors, all items whose communalities is lower than .32 (Tabachnick and Fidell 2014) and .30 (Field 2013) should be excluded from further analysis. In this regard, item no 2 are excluded from further analysis „When I speak English on class, I'm completely relaxed“ and item no 20 "I'm glad if the professor invites me to talk in English“. The justification for applying EFA is established by the values of Bartlett's test of sphericity $\left(\chi^{2}=1735.81, \mathrm{df}\right.$ $=153, \mathrm{p}<.001)$ and Kaiser-Meyer-Olkin Measure of Sampling Adequacy $(\mathrm{KMO}=.872)$. EFA was performed using the principal axis method with promax rotation. By applying Horn's parallel analysis (Çokluk and Koçak 2016) it was found that at the base of the FLSAQ lies one factor (see Table 31). 
Table 3r: Tabular view of applied Horn parallel analysis with data permutation $(K=300)$.

\begin{tabular}{ccc} 
Factor & $\begin{array}{c}\text { Eigen values } \\
\text { of the actual data }\end{array}$ & $\begin{array}{c}\text { Eigen values } \\
\text { of the simulative data }\end{array}$ \\
\hline 1. & 5,29 & 1,63 \\
\hline 2. & 1,46 & 1,51 \\
\hline 3. & 1,02 & 1,35 \\
\hline
\end{tabular}

Therefore, based on the parallel analysis, it can be concluded the presence of one factor in the structure of FLSAQ, which explains $57.40 \%$ of the total variance. An outline of the single-factor items structure is given in Table 32 .

Table 32: Correlation between items and factor.

\begin{tabular}{|c|c|c|}
\hline No & Items & $\mathrm{R}$ \\
\hline 1. & I worry what others think about my oral performance in English. & .909 \\
\hline 5. & I'm wondering if others will mock me. & .897 \\
\hline 11. & I keep quiet because if I say something, I can be mocked. & .887 \\
\hline 15 . & I feel constant tension. & .852 \\
\hline 7. & $\begin{array}{l}\text { I feel panic because I cannot remember the words or I do not know how to say } \\
\text { something. }\end{array}$ & .778 \\
\hline 9. & I'm completely confused. & .775 \\
\hline 3. & I'm blocking myself and I do not know what to say. & .721 \\
\hline 16. & I do not care what others think about my speaking. & .701 \\
\hline 8. & I do not think what others will think or being ridiculed. & .683 \\
\hline 12. & I am completely self-confident. & .605 \\
\hline 19. & I think that everything has to be correct and perfect, and that makes me confused. & .543 \\
\hline 13. & I'm afraid what the professor will say and if (s)he corrects me. & .539 \\
\hline 17. & I think that it's better to avoid my English class. & .500 \\
\hline 4. & $\begin{array}{l}\text { Although I feel anxiety (fear, nervousness, tension), it lasts shortly and it is quic- } \\
\text { kly overcome. }\end{array}$ & .456 \\
\hline 10. & I do not have a problem at all to say anything even if it's incorrectly said. & .433 \\
\hline 18. & I am completely concentrated on speech and I do not think about anything else. & .417 \\
\hline 14. & I think that I need to learn something new even if I make a mistake. & .403 \\
\hline 6. & I speak English as my native language. & .399 \\
\hline
\end{tabular}

It is of a notion in Table 32 that the items having the highest correlations with the factor related to the problem of speaking a foreign language of students in front of their peers. In further analysis, the association of summarizing scores on FLSAQ and FLCAS was checked. Pearson correlation coefficient is $\mathrm{r}=.656(\mathrm{p}<.01)$, which confirms the good construct validity of the FLSAQ. Critical validity was also checked, that is, whether FL$\mathrm{SAQ}$, which measures anxiety, indicates that anxiety in English speaking 
has an effect on speech performance. A mark on OPM was taken as a measure of assessment of spoken English (oral performance measure). The regression coefficient is $\mathrm{r}=-.489(\mathrm{p}<.01)$ and $\mathrm{R}=.239$. When the basic metric characteristics of FLSAQ (reliability and validity) were verified, further analysis determined the scores (degree of anxiety) distribution of the subjects on FLSAQ. Since the total score can range from 20 to 100 , the test scores were grouped into several categories: 20 to 39 (slight anxiety), 40 to 59 (moderate anxiety), 60 to 79 (heightened anxiety), and 80 to 100 (high anxiety). The distribution of anxiety on the sample can be viewed in Graph 1.

\section{Pupils anxiety level}

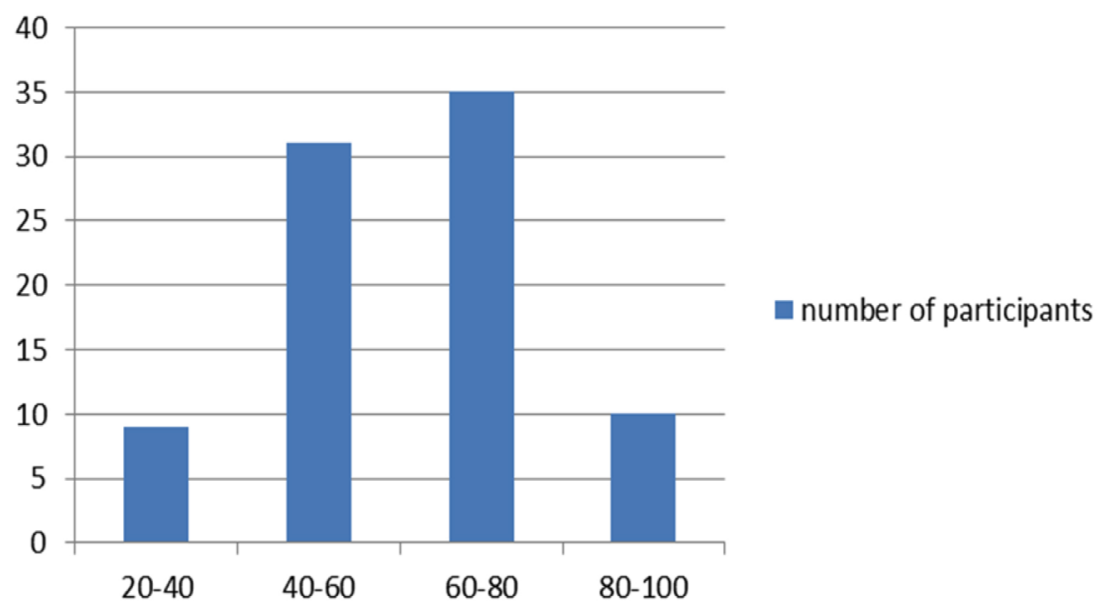

Figure I3: Distribution of anxiety during foreign language speaking.

Descriptive measures were also calculated $(M=58.32, S=14.23$, Skewness $=-.068$, Kurtosis $=-.554$ ), indicating that anxiety levels were generally moderate to heightened and it was observed that about $65 \%$ of respondents (greater summation score than 60 on FLSAQ) had increased and high anxiety in speaking English. Skewness and kurtosis values indicate that distribution is moderately negative skewed and platykurtic.

\section{Discussion}

From the research qualitative phase, students denote many obstacles they face with when learning a foreign language. As noted in previous researches, anxiety can be triggered by a real classroom situation or be anticipated 
by past negative experiences, for instance. Regardless of the multiplicity of causes of FLA, this research shows that anxiety reactions (manifestations) can be classified into thoughts, feelings, and behaviours. The above classification is different from the one presented by Horowitz et al. (1986), who perceives three dimensions in the FLA concept (communication apprehension, test anxiety and fear from negative evaluation). Unlike Horowitz et al. (1986), in this paper, anxiety in a classroom situation is viewed as a psychological construct that has its manifestation rather than an association with causes such as fear of negative evaluation or attachment to a particular situation such as anxiety test. Factor analysis results suggest that FLA is a one-dimensional rather than a multidimensional concept, as claimed by Horwitz et al. However, it should be kept in mind that the analysis in this paper was conducted on a compact sample of students. Therefore, the following analyzes must confirm the un-dimensionality of the FLA on a larger sample and by applying confirmatory factor analysis (CFA). The analysis showed that the most eminent problem with learning English in school conditions is that students speak the language in front of their peers. This is also set out by the results of Koch and Terrell's (1991) study, which shows that most students experienced the greatest anxiety when communicating in front of others. Von Wörde (2003) also discusses this phenomenon, explaining that negative classroom experiences have a great influence on learning a foreign language, due most students feel anxious when speaking in a classroom situation, fearing the opinions of peers as well as teachers. That's why students say that one way to reduce anxiety must come from a teacher who has to be sensitive and recognize anxiety and then work on the relationship teacher - pupils and between pupils themselves. Students state that the reason for anxiety is not only related to the problem of speaking in front of peers but also in poor knowledge of a foreign language. Therefore, the problem can be solved if students learn more and thus become more confident in themselves and their foreign language skills. There are also opinions that anxiety is not related to either the school situation or poor knowledge of a foreign language, but rather that it is a problem of students' personality. It should be bear in mind that most authors have defined FLA as state anxiety and not trait anxiety (Brown, 2000) and that even studies have shown that trait anxiety has no predictive value in second language achievement (MacIntyre and Gardner 1991). The study showed that FLA was presented at students' oral performance since $65 \%$ of students have got high-levelled anxiety during speaking a foreign language. Also, the nega- 
tive correlation between speaking foreign language anxiety and oral performance confirms that anxiety is an influential factor and interferes with foreign language speech.

\section{Conclusions}

The research provided a new valid and reliable instrument for measuring speaking foreign language anxiety - FLSAQ. In spirit to confirm FLSAQ validity and reliability, future researches have to conduct studies using the mentioned instrument on a larger sample and by applying confirmatory factor analysis. Unlike FLCAS, the FLSAQ provides a new perspective on the concept of FLA, which is not a cause-oriented but a manifestation of anxiety. The research also confirms that FLA is a serious problem and an obstacle to successfully mastering a foreign language. Therefore, the practice should focus on ways to reduce anxiety in foreign language speech. One way is certainly to raise awareness that teachers need to recognize FLA and work on improvement student-professor relationships. There is also a belief that FLA is an unsolvable problem because it is more a matter of personality rather than the situation. And that is why the question may be asked if it is time to use some psychological tool (meditation or stress-reducing techniques) in a classroom situation. So, that is the reason why new empirical research is needed and which would not only aim to determine the extent of FLA expression but to give evidence for supporting effects of decreasing anxiety techniques and methods.

\section{Literature}

Aida, Yukie. "Examination of Horwitz, Horwitz and Cope's construct of foreign language anxiety: The case of students of Japanese," The Modern Language Journal 78, no. 2 (1994): 155-168. doi: 10.2307/329005.

Brown, Douglas H. Principles of Language Learning and Teaching. New York: Pearson Education, 2000.

Cheng, Yuh-show. "Factors associated with foreign language writing anxiety." Foreign Language Annals 35, no. 5 (2002): 647-656.

Clément, Richard. "Ethnicity, contact, and communicative competence in a second language." In Language: Social psychological perspectives, edited by Howard Giles, William P. Robinson, and Philip M. Smith, 147--154, Oxford: Pergamon Press, 1980. 
Çokluk, 冈may, and Duygu Koçak. “Using Horn’s Parallel Analysis Method in Exploratory Factor Analysis for Determining the Number of Factors." Educational sciences: theory \& practice 16, no. 2 (2016): 537-551.

Fajgelj, Stanislav. Psihometrija: metod i teorija psihološkog merenja. Beograd: Centar za primenjenu psihologiju, 2009.

Field, Andy. Discovering Statistics using SPSS. 4th ed. London: SAGE, 2013.

Honggang, Liu. "New Insights into Language Anxiety: Theory, Research and Educational Implications.” ELT Journal 73, no. 1 (2019): 105-107.

Horwitz, Elaine, Michael B. Horwitz, and Joann Cope. "Foreign language classroom anxiety.” The Modern Language Journal 70, no. 2 (1986): 125-132.

Koch, A. S., and T. D. Terrel. "Affective reaction of foreign language students to Natural Approach activities and teaching techniques." In Language anxiety: From theory and research to classroom implication, edited by Elain Horwitz and Dolly J. Young, 109--126, Englewood Cliffs: Prentice Hall, 1991.

Králová, Zdena. Foreign Language Anxiety. Nitra, Slovakia: Univerzita Konštatina Filozofa v Nitre, 2016.

MacIntyre, Peter D., and Robert. C Gardner. "Anxiety and second language learning: Toward a theoretical clarification.” Language Learning 39, no. 2 (1989): 251-75.

MacIntyre, Peter D., and Robert. C Gardner. "The subtle effects of language anxiety on cognitive processing in the second language." Language Learning 44, no.2 (1994): 283-305.

McCroskey, James C. "Measures of Communication-Bound Anxiety." Speech Monographs 37, no.4 (1970): 269-277.

McCroskey, James C."Validity of the PRCA as an index of oral communication apprehension." Communication Monographs 45, no. 3 (1978): 192-203.

Mihaljević Djigunović, Jelena. Strah od stranog jezika. Zagreb: Naklada Ljevak, 2002.

O'Connor, Brian P. "SPSS and SAS programs for determining the number of components using parallel analysis and Velicer's MAP test." Behavior research methods, instrumentation, and computers, no. 32 (200o): 396-402.

Popović-Babić, Danica, Mirjana Apostolović, and Bogdan Biskupljanin. "Psychological Aspects of Fear Because of pain in stomatological offices." $\mathrm{Me}$ dicina danas, 7/8 (2007): 423-428.

Saito, Yoshiko, Elaine K. Horowitz, and Thomas J. Garza. “Foreign Language Reading Anxiety.” The Modern Language Journal 83, no. 2 (1999): 202-218. 
Salehi, Masoomeh, and Fahimeh Marefat. “The Effects of Foreign Language Anxiety and Test Anxiety on Foreign Language Test Performance." Theory and Practice in Language Studies 4, no. 5, (2014): 931-940.

Tabachnick, Barbara G., and Linda S. Fidell. Using Multivariate Statistics. 6th ed. Harlow: Pearson, 2014.

Taherdoost, Hamed. "Validity and Reliability of the Research Instrument; How to Test the Validation of a Questionnaire/Survey in a Research." International Journal of Academic Research in Management 5, no. 3 (2016): 28-36.

Tran, Trang T. T. "A review of Horwitz, Horwitz and Cope's theory of foreign language anxiety and the challenges to the theory. "English Language Teaching 5, no.1 (2012): 69-75.

von Wörde, Renée. "Students' perspectives on foreign language anxiety." Inquiry 8, no. 1 (2003): 21-40.

Young, Dolly J."Creating a low-anxiety classroom environment: What does foreign language anxiety research suggest?" The Modern Language Journal 75 , no. 4 (1991): 426-437.

Zhang, Jun L. "Exploring variability in language anxiety: Two groups of PRC students learning ESL in Singapore.” RELC Journal 32, no. 1 (2001): 73-94. 

evalvacija

in zagotavljanje

kakovosti 



\section{Trajnost projektnih rezultatov - ključ do učinka projektov EU}

\section{Andreja Lenc}

\section{Uvod}

Učinek oz. sprememba delovanja posameznika ali organizacije je ključen pokazatelj uspeha oz. kakovosti projekta. K temu pa lahko prispeva le kakovosten in trajen rezultat - rezultat, ki ga določena ciljna skupina potrebuje, je pripravljen skladno $\mathrm{z}$ razvojem stroke in ga organizacije in strokovni delavci pri svojem delu tudi dejansko uporabljajo. V kolikor ga je mogoče širiti oz. uporabiti tudi na drugih področjih izobraževanja, je ta rezultat še toliko bolj trajen. Zato morajo biti projekti med načrtovanjem dobro premišljeni, umeščeni v razpis in potrebe okolja, da bodo prinesli rešitve, ki jih izobraževalno okolje potrebuje. Glavna parametra načrtovanja sta kakovostna analiza potreb in natančno definiran pričakovani rezultat. Da se to zagotovi, je potrebna smiselna vključenost vseh deležnikov, ki jim je rezultat posredno ali neposredno namenjen (Evropska komisija, 2019; Pajnič, 2017; Pajnič et al., 2017).

Diseminacija oz. razširjanje informacij o projektu in rezultatih je parameter, ki prispeva tako k trajnosti rezultatov kot učinku projekta (Evropska komisija, 2019).

$\mathrm{Z}$ analizo smo želeli ugotoviti, kako trajni so rezultati projektov sodelovanja v programih EU, in sicer v obdobju od treh do šestih let po njihovem zaključku. Zanimalo nas je, kolikšen delež projektov je uresničil napovedane načrte in želene učinke s projektnimi rezultati po zaključku izvajanja projektov. 


\section{Opredelitev pojmov trajnost in učinek rezultatov}

Najprej bi želela opredeliti ključna pojma trajnost in učinek. Oba pojma se pogosto zamenjujeta oz. sta napačno razumljena. Namen projektov ne more biti zgolj priprava rezultatov, temveč trajna sprememba $\mathrm{v}$ organizaciji, med zaposlenimi ali učečimi se. Pri tem pa nam lahko pomagajo kakovostni, trajni rezultati in procesi.

Bistvo projektov torej niso rezultat, izdelek ali proces, ki jih načrtujemo, niti ne aktivnosti, ki jih izvajamo, temveč kakšne spremembe bo to prineslo posamezniku ali organizaciji.

V literaturi najdemo različne definicije trajnosti:

- $\quad$ »... je značilnost česa glede na to, koliko časa lahko obstaja, je uporabno« (SSKJ, 2019);

- $\quad \gg .$. je zmogljivost projekta, da se nadaljuje in da se njegovi rezultati uporabljajo po koncu obdobja financiranja (lahko tudi delno)« (Evropska komisija, 2019: 318);

- $\quad$ ».. je uporaba ali izkoriščanje proizvoda/rezultata - v poslovnem svetu predvsem v poslovne namene" (Stare, 2011: 22);

- $\quad$ »... sposobnost obstoja in delovanja/uporabe po zaključku financiranja projekta« (Pajnič, 2017: 4; Antunes, 2011: 6).

Za namen tega prispevka bom pojem trajnost projektnih rezultatov uporabljala kot "raba in/ali nadgradnja rezultatov« (Lenc in Žagar Pečjak, 2019).

Trajnost projektnih rezultatov ni le potreba za kakovostno izveden projekt, temveč zagotavlja tudi evropsko dodano vrednost programa EU. Raven in intenzivnost aktivnosti razširjanja in rabe rezultatov morata biti sorazmerna $\mathrm{z}$ obsegom projekta in strateško pomembnostjo projekta (Evropska komisija, 2019).

Učinek po SSKJ (2019) je opredeljen kot »Zaželena, pričakovana posledica kakšnega dela, prizadevanja«, Evropska komisija pa ga definira kot "vpliv, ki ga imajo aktivnost in njeni rezultati na ljudi, prakse, organizacije in sisteme« (2019: 318).

Trajnost in učinek projekta sta med najbolj pomembnimi kriteriji že v stopnji ocenjevanja projekta ter prav tako med ocenjevanjem končnega poročila projekta. Ker je trajnost učinkov težko predvideti in zagotoviti, se pri projektnem delu osredotočamo na trajnost rezultatov in izdelkov (Evropska komisija, 2019). 


\section{Definicija trajnosti projektnih rezultatov}

$\mathrm{Na}$ Centru večkrat razpravljamo o trajnosti in trajnih rezultatih ter kako jih definira program EU: raba in/ali nadgradnja rezultata. Ker so zahteve trajnosti do projektov različnih velikosti, kompleksnosti in akcij znotraj programa EU različne, je $\mathrm{z}$ besedami težko opisati in določiti, kako trajen mora biti posamezen rezultat. Zato smo na Centru želeli opise trajnosti rezultatov kvantificirati in s tem pomagati prijaviteljem, kaj so želeli z rezultati posameznih oblik mednarodnega sodelovanja doseči in kakšne učinke v skladu s tem pričakujemo.

Najprej smo določili dva glavna parametra trajnosti, in sicer rabo in nadgradnjo rezultatov. Dodali smo še parameter, kako razširjeno med organizacijami se rezultat uporablja pri rednem delu po zaključku projekta - v okviru partnerstva projekta, na nacionalni ravni oz. širše v državah partnericah projekta, $v$ organizacijah izven držav partneric in na evropski ravni.

Tabela 33: Definicija trajnosti rezultatov

\begin{tabular}{|c|cccc}
\hline \multicolumn{5}{c}{ TRAJNOST PROJEKTNIH REZULTATOV } \\
\hline \multirow{2}{*}{$\begin{array}{c}\text { Nivo o } \\
\text { Raba rezultatov }\end{array}$}
\end{tabular}

Vir: CMEPIUS, 2019

\section{Program Vseživljenjsko učenje, akcija Partnerstva}

$\mathrm{Z}$ analizo smo ugotavljali trajnost rezultatov akcije Partnerstva $\mathrm{v}$ okviru programa EU Vseživljenjsko učenje. Program Vseživljenjsko učenje (20072013) je bil program EU s področja izobraževanja in usposabljanja. Glavni namen programa je bil prispevati k razvoju družbe $\mathrm{z}$ vrhunskim znanjem, trajnostnim gospodarskim razvojem, več in bolj kakovostnimi delovnimi mesti in večjo socialno kohezijo ter zagotavljanje varstva okolja za prihod- 
nje generacije. Akcija Partnerstva so bili manj kompleksni projekti sodelovanja $z$ enostavnimi rezultati ali brez njih, saj je bil namen akcije povezovanje sorodnih institucij in izmenjava dobrih praks (Evropska komisija, 2013).

Kljub isti akciji za tri področja izobraževanja - šolsko, poklicno in strokovno (PSI) ter izobraževanje odraslih (IO) - so se aktivnosti v določeni meri medsebojno razlikovale. Partnerstva PSI in IO so bila usmerjena v konkretne rezultate (usposabljanje, gradiva za udeležence itd.), pri partnerstvih na šolskem področju pa je bil primarni fokus zgolj povezovanje med šolami in priprava enostavnih izdelkov (slovarček, učni listi, gozdna učna pot, video itd.) (Lenc in Žagar Pečjak, 2019).

\section{Metodološka opredelitev analize}

$\mathrm{Na}$ podlagi vprašanj končnih poročil projektov, vprašanj $\mathrm{v}$ okviru spletnih platform za poročanje o rezultatih projektov (v programu VŽU: EST, ADAM; v Erasmus+: EPRP; https://ec.europa.eu/programmes/erasmus-plus/projects_en) in definicije trajnosti (CMEPIUS, 2019) smo pripravili kratek vprašalnik in ga poslali vsem pogodbenikom programa Vseživljenjsko učenje, akcije Partnerstva na področjih šolskega izobraževanja, poklicnega izobraževanja in usposabljanja ter izobraževanja odraslih. Vprašalnik je bil razdeljen na dva dela. $V$ prvem delu so bila vprašanja vezana na identifikacijo tipa projekta, vsebin, tem in vključenosti v mednarodno sodelovanje. V drugem delu smo institucije spraševali po tipih rezultatov, nastalih v projektih, ki so jim anketiranci morali določiti nivo uporabe in nadgradnje na podlagi definicije, dostopnost in obliko rezultata.

Vprašalnik smo po elektronski pošti poslali koordinatorjem projektov iz razpisnih let 2011, 2012 in $2013(\mathrm{~N}=307)$. Ti projekti so se zaključili v letih od 2014 do 2016. Prejeli smo 115 popolnih odgovorov, kar predstavlja 37,5-odstotno odzivnost. S področja šolskega izobraževanja smo prejeli 67 odstotkov odgovorov, 18 odstotkov s področja IO in 9 odstotkov s področja PSI.

$\mathrm{Na}$ anketni vprašalnik so $\mathrm{v}$ največji meri odgovarjali koordinatorji projektov (učitelji in drugi strokovni delavci), ki so podali samooceno o trajnosti (raba, nadgradnja) posameznega rezultata, ki je nastal v njihovem projektu.

Podatke smo s pomočjo kvantitativnih analiz (program SPSS) statistično obdelali v skladu $\mathrm{z}$ nameni analize. 


\section{Rezultati}

Najpogostejši rezultati, ki so nastali v akciji Partnerstva, so brošure in tiskane publikacije, video in spletno gradivo, drugo učno gradivo, ankete in izobraževanja. Le ti so poleg oblike različni tudi glede na njihovo dosegljivost, obseg in kompleksnost. Kar 63 odstotkov rezultatov je javno dostopnih na spletni strani projekta ali sodelujoče organizacije, še dodatnih 25 odstotkov rezultatov je dostopnih na povpraševanje.

Po mnenju anketirancev največ rezultatov uporabljajo sodelujoči $v$ partnerstvu (1. nivo), sledijo druge relevantne organizacije $\mathrm{v}$ partnerskih $\mathrm{dr}$ žavah. Manj jih uporabljajo druge relevantne organizacije iz nepartnerskih držav ter relevantne organizacije v Evropi. Tudi glede nadgradnje projektnih rezultatov jih je največ na 1. nivoju, kar pomeni, da so rezultati podlaga za nove ideje na nacionalni ali mednarodni ravni. Rezultati kažejo, da je trajnost projektnih rezultatov večinoma na 1. nivoju (Tabela 33).

Najbolj rabljeni rezultati med koordinatorji in partnerji projektov (1. nivo) so navodila za izvedbo seminarja/usposabljanja, aplikacija za učenje in učno gradivo za udeležence seminarja. Med drugimi relevantnimi organizacijami iz partnerskih držav (2. nivo) sta bila najbolj uporabljena raziskovalna študija in zbornik primerov dobre prakse. Druge relevantne organizacije iz nepartnerskih držav in relevantne organizacije na ravni EU (3. nivo) so najbolj pogosto uporabljale video ali spletno gradivo, raziskovalne študije in elektronsko učno platformo.

Največkrat nadgrajeni rezultati na 1. nivoju (izdelek/rezultat je podlaga za ideje in nove aktivnosti) so bili navodila za izvedbo seminarja, učno gradivo za udeležence seminarja in raziskovalna študija. Rezultata, najpogosteje nadgrajena s strani partnerstva (2. nivo), sta izobraževalni seminar/ usposabljanje in navodila za izvedbo seminarja. Najpogostejši rezultati, ki so jih za nadgradnjo uporabile druge organizacije oz. so bili vpeljani v izobraževalni sistem ali bili upoštevani kot podlaga za politike ali smernice EU (3. nivo), so raziskovalna študija, učno gradivo za udeležence seminarja in izobraževalni seminar.

V okviru analize smo na podlagi odgovorov v anketnem vprašalni$\mathrm{ku}$ preverjali povezanost različnih spremenljivk $\mathrm{s}$ trajnostjo projektnih rezultatov.

Trajnost smo določili kot kombinacijo nivoja uporabe in nivoja nadgradnje, na katerem je temeljil posamezen rezultat. Spremenljivke so rekodirane tako, da se določi nivo za vsak posamezni rezultat. Poleg opredeljenih štirih nivojev (1-3) smo dodali še nivo o, ki je definiran kot »rezultati 
niso v uporabi in niso bili nadgrajeni«. Če so bili ali v uporabi ali nadgrajeni, potem so na nivoju 1. Uporaba je bila smatrana kot pomembnejša pri določanju nivojev. Če je izdelek na dveh različnih zaporednih nivojih, potem se tehtnica nagne proti uporabi. Če sta izdelka na še bolj oddaljenih nivojih, potem se izbere »mednivo «.

Glede na manj kompleksne projekte Partnerstev je večina rezultatov na prvem nivoju (Tabela 34 ), kar je nekako pričakovan rezultat, saj so $\mathrm{v}$ okviru akcije nastajali bolj enostavni rezultati. Kljub isti akciji pa so obstajale razlike v kompleksnosti tako projektov kot rezultatov, kar pokažejo tudi rezultati analize - rezultati na področju PSI in IO so nekoliko bolj trajni kot rezultati partnerstev na šolskem področju (2. nivo: IO - 25,9 \%; PSI 16,3 \%; 3. nivo: IO - 15,5 \%). Partnerstva na področju šolskega izobraževanja so imela največ rezultatov, ki niso v uporabi - nivo o (Tabela 34).

\section{Tabela 34: Trajnost rezultatov in tip projekta}

\begin{tabular}{|c|c|c|c|c|c|c|}
\hline & & & \multicolumn{3}{|c|}{ Tip projekta: Partnerstva } & \multirow[t]{2}{*}{ Skupaj } \\
\hline & & & Šolsko področje & $\begin{array}{c}\text { Poklicno } \\
\text { in strokovno } \\
\text { področje }\end{array}$ & $\begin{array}{c}\text { Izobraževanje } \\
\text { odraslih }\end{array}$ & \\
\hline \multirow{8}{*}{ Trajnost } & \multirow{2}{*}{ Nivo o } & Frekvenca & 45 & 2 & 2 & 49 \\
\hline & & $\%$ & $19 \%$ & $4,7 \%$ & $3,4 \%$ & $14,4 \%$ \\
\hline & \multirow{2}{*}{ Nivo 1} & Frekvenca & 170 & 32 & 32 & 240 \\
\hline & & $\%$ & $73 \%$ & $74,4 \%$ & $55,2 \%$ & $70,4 \%$ \\
\hline & \multirow{2}{*}{ Nivo 2} & Frekvenca & 13 & 7 & 15 & 35 \\
\hline & & $\%$ & $6 \%$ & $16,3 \%$ & $25,9 \%$ & $10,3 \%$ \\
\hline & \multirow{2}{*}{ Nivo 3} & Frekvenca & 6 & 2 & 9 & 17 \\
\hline & & $\%$ & $3 \%$ & $4,6 \%$ & $15,5 \%$ & $5,0 \%$ \\
\hline \multirow{2}{*}{ Skupaj } & & Frekvenca & 234 & 43 & 58 & 341 \\
\hline & & $\%$ & $100 \%$ & $100 \%$ & $100 \%$ & $100 \%$ \\
\hline
\end{tabular}

\section{Ugotovitve}

Trajen rezultat sam po sebi ni bistvo projektov EU, temveč učinek, ki ga udejstvovanje $\mathrm{v}$ mednarodnih projektih in njihovi rezultati prinesejo posamezniku in organizaciji (Evropska komisija, 2019). Trajnost projektnih rezultatov pomeni, da so rezultati uporabljeni in/ali nadgrajeni s strani organizacij, ki so jih pripravile, in širše.

Naše ugotovitve kažejo, da trajnost projektnih rezultatov ni odvisna od vsebine projekta, oblike rezultata ali dosegljivosti na spletu. Prav tako 
trajnosti projektnih rezultatov ne zagotavlja predhodno, dolgoletno sodelovanje v mednarodnih projektih. K trajnosti projektnih rezultatov prispeva le zahtevnost (tip) projekta in izkušnje mednarodnega sodelovanja, ki nam omogočajo, da temeljito razmislimo o tem, kaj in zakaj želimo nekaj spremeniti, kako bomo to naredili, koga bomo vključili (organizacije in končne uporabnike) in kako spremljali in preverjali kakovost. Ne glede na zahtevnost oz. tip projekta je ključno, da se projekta že med samo pripravo lotimo $z$ vso skrbnostjo in vnaprej razmislimo in opredelimo vse parametre za kakovosten in trajen rezultat (Lenc in Žagar Pečjak, 2019).

Izkušnje izvajanja projektov EU in ugotovitve analiz kažejo, da moramo v rezultat najprej sami verjeti in zaupati. Le če bomo sami stoodstotno verjeli v njegovo nujnost in uporabnost ter upoštevali vse dejavnike pri načrtovanju, bomo izdelali kakovosten in trajen rezultat (Antunes, 2011; Pajnič, 2017). Z učinkovitim razširjanjem informacij o projektu in rezultatih bomo prispevali $\mathrm{k}$ rabi in nadgradnji rezultatov ter širjenju učinka projektov, kar pa ni le pogodbeno določilo, temveč tudi dolžnost skrbnega koriščenja sredstev EU.

Analizo trajnosti projektnih rezultatov bomo ponovili v okviru trenutnega programa Erasmus+ in model razširili oz. opredelili tudi za projekte mobilnosti (usposabljanja za osebje in učeče se v tujini).

\section{Literatura}

Antunes, Maria Helena. Handbook for Dissemination, Exploitation and Sustainability of Educational Projects. DIVA konzorcij. Lisboa: AidLeard, 2011.

Evropska komisija. Vodnik za prijavitelje Erasmus+ 2019. Pridobljeno 15. 3. 2019, http://www.erasmusplus.si/razpis/razpis-2019/.

Evropska komisija. Vodnik za prijavitelje programa VŽU 2013. Pridobljeno 5. 12. 2019, http://www2.cmepius.si/vzu.

Pajnič, Neža. Razširjanje, raba in trajnost projektnih rezultatov. Erasmus+ priročnik. Ljubljana: CMEPIUS, 2017.

Pajnič, Neža, Andreja Lenc in Urška Šraj. »Razvoj evropskih programov sodelovanja na področju izobraževanja in usposabljanja ter učinki teh dejavnosti«. Vodenje v VIZ, št. 2, (2017): 135-158. Ljubljana: Šola za ravnatelje, 2017.

Stare, Aljaž. »Projektni management: teorija in praksa«. Ljubljana: Agencija POTI, Izobraževalna, svetovalna in založniška družba, 2011. 
Viri

CMEPIUS. Definicija trajnosti. Interno neobjavljeno gradivo. Ljubljana: CMEPIUS, 2019.

Lenc, Andreja in Mateja Žagar Pečjak. CMEPIUS. (2018). Analiza intervjujev. Interno gradivo. Ljubljana.

CMEPIUS. (2018). Analiza vprašalnikov orodje MobilityTool+ (EK 2014-2017). Izvoz podatkov 25. 4. 2018. Ljubljana.

Slovar slovenskega knjižnega jezika. Pridobljeno 5. 12. 2019, https://fran.si/. 
inovativni pristopi kučenju in poučevanju 



\title{
Mini-companies as an essential part of a lifelong learning program for high school students
}

\author{
Aleksandra Stevanović, Snježana Djurdjević, Bojana Sokolović
}

\section{Background and purpose of the research}

Education process today is an integral part of the era of turbulent exchanges, 4.0 industry, digitalization, and soft management. It requires an expanded definition of learning practicies where the significance of the relationship between schools and organizations becomes more prominent. In the literature, there is an attitude that business schools should respond with 'continuous attention' to theory/practice linkages (Porter, McKibbin, 1988). Systematic attention needs to be paid to the various types of company-based field experiences, their different learning objectives and expectations, the roles of all stakeholders in the learning process (Limerick, Moore, 1991). Authors pointed out on two clearly separated learning arenas: university and company. The university provides cognitive, intellectual framework; company or enterprise teaches skills in applying these to practice (ibid.). Everything aforementioned leads us to define 'student enterprises' which are presented by: extracurricular program of Junior Achievement Worldwide and Junior Achievement Europe.

In a junior achievements program, groups of high school students are organized into companies that 'sell' stock to raise capital, appoint employees, buy materials, manufacture and market a product, pay dividends to stockholders, and liquidate their company in the course of fifteen weeks. To manage their operations, students comprising each company make their own decisions regarding the appropriate amounts required for their own 
salaries, wages, and commissions. They must also keep production and financial records, pay rent for space and equipment, and pay taxes and dividends if profits are realized (Cousins R. et.al., 1995). Enterprise education is the application of creative ideas and innovations to practical situations with the aim to produce individuals with the mindset and skills of responding to opportunities, needs and shortfalls, the key skills including taking the initiative, decision making, problem solving, networking, identifying opportunities and personal effectiveness. Entrepreneurial frame can be applied to all areas of education, extending beyond knowledge acquisition to a wide range of emotional, social, and practical skills; and Entrepreneurship education is the application of enterprise skills specifically to the creation and growth of organizations, with entrepreneurship education focusing on developing skills and applying an enterprising mindset to the specific contexts of setting up a new venture, developing and growing an existing business, or designing an entrepreneurial organization (QAA, 2010).

Further,'student's enterprises', represents the world's largest enterpreneurship education program, which is attended by more than 10 million students a year. In Serbia, the program was implemented in 2006. Since then, over 60,000 students in 286 primary and secondary schools from all over the country have gone through educational programs in the field of enterpreneurship and financial literacy (Kisic, Petkovic, 2019). That way, students have the opportunity to learn through theoretical and practical lessons, a mentorship program, as well as through a number of fairs and competitions. During one academic year, students get an opportunity to create and manage their own enterprise with real issues and challenges. It seems to be their first practical enterpreneurship experience, so they get the opportunity to gain valuable knowledge and skills, and complement their theoretical knowlegde with basic skills of managing a business. In the paper we emphasise the significance of interactive learning projects involving students and their teachers, who are at the same time mentors and additional support of student organizations. In the research we aim to elaborate the influence of Junior Achievement programs (student-organizations) in Serbia, on the students' increasing knowledge and skills. We examined the possibility of students' skill development and knowldege expansion, and how these different aspects of practical learning lead students to increase competences for doing business. The development of those skills is guidance for their future business and management capabilities, and their competitiveness at the labor market. The key point of this program is to teach 
students how to be proactive and enterpreneurship-oriented, as well as to encourage them to think in an innovative and responsible way. European and worlwide researches refer to the impact of 'student-enterprises' on the significant improvement and development of skills: presentation skills, collaboration and team spirit, risk management, problem-solving abilities, adaptability, self-confidence, negotiation skills, ability to persuade, creative thinking, time management, etc. The ultimate goal of this study is to verify whether there is important influence of 'student-enterprises on the attitude of an individual ability for promoting skills, knowledge, and competences toward enterpreneurial spirit.

\section{Positive effects of different enterpreneurship programmes on student's knowlegde}

Results obtained in the study of ICEE (The Innovation Cluster for Entrepreneurship Education) indicate the following teacher's attitudes: Teachers believe that program offers clear and significant results in the development of:

1. Students' attitudes (creativity, achievement tendency, persistence, risk taking etc.)

2. Skills (setting goals, team work, communication skills, presentation skills)

3. Meaningful knowledge related to different phases in the business (ideas, business plan, production, presentation etc.)

4. Personal development of students (self-confidence, competence, responsibility, commitment, proactivity, independence) (Kisic, 2019).

Authors (Wiliamson N. et.al., 2013) presented outcomes and impacts of entrepreneurship education studying the literature and indicated that:

1. Participation does lead to students acquiring relevant business-related knowledge, skills and competences for enterprise and entrepreneurship;

2. Participants are more likely to change attitudes, such as those concerning risk taking, and intentions, such as attitudes concerning self-employed or being entrepreneurial, than non-participants; 
3. Studies show mixed results about whether such courses increase students' perception of feasibility; it is greater in Wales where enterprise and entrepreneurship education appears to be more embedded in school and FE (Further education) than in England;

4. There is no evidence that students are more likely to take steps as a result of courses towards the development stage of a new business or using the skills gained to develop new business opportunities in an existing small or large business;

5. There are, however, positive statistical relationships between various enterprise and entrepreneurship education learning activities in school and tertiary education and economic impacts including starting a new business (strong evidence for entrepreneurship course graduates); increasing employability and earnings; and contributing to the growth of businesses (especially for graduates entering small businesses). These suggest that enterprise and entrepreneurship education is a positive stimulus;

6. One study suggests a net positive impact on GVA (Gross value added) of enterprise and entrepreneurship education in $\mathrm{HE}$ (Higher education).

\section{Methodology}

An examination sample size was 269 respondents. It included 174 students employed in student companies, and 95 teachers hired as a menthors in student's companies founded by high schools of Serbia. The instrument used for the study was questionnaire ("student's organization questionnaire") conducted by the authors. The questionnaire is consisted of 12 items, based on the practical implications and theoretical framework of student organizations. Some questions were answered checking one or more answers, and some questions were based on Likert scale ( 1 - not at all true, 2 - mostly not true, 3 - not sure, 4 - mostly true, 5 - quite exactly), where respondends indicated their level of agreement with the given statement.

The questionnaire was anonymous, delivered via Google Forms, as a quick link, conducted in April and May 2017.

The structure of the whole sample with respect to sociodemographic variables (gender, age, occupation, professional experience/type of school, education) is presented as follows: 
Table 35: Gender of respondents

\begin{tabular}{lcccc} 
& \multicolumn{2}{c}{ Students } & \multicolumn{2}{c}{ Teachers } \\
Male & 66 & $38 \%$ & 19 & $20 \%$ \\
\hline Female & 108 & $62 \%$ & 76 & $80 \%$ \\
\hline & 174 & $100 \%$ & 95 & $100 \%$ \\
\hline
\end{tabular}

As shown in the Table 35 , in the survey participated $38 \%$ male students, and $62 \%$ female students. The age of student participants were in range 15 to 28 years old. Structure of students related to their current status is:

- $\quad 69,5 \%$ high school students,

- $\quad 20,1 \%$ university students,

- $\quad 10,4 \%$ already employed.

Analyzing data in the Table 36 . it is evident that $72,99 \%$ of respondents considered their participation in 'mini-company' will contribute increasing competencies for founding their own business.

Table 36: Contribution to student's competencies by participating in mini-companies in relation with current occupation of students

\begin{tabular}{|c|c|c|c|c|c|c|c|}
\hline \multirow{2}{*}{ S } & \multirow{2}{*}{$\begin{array}{l}\text { congly } \\
\text { sagree }\end{array}$} & \multicolumn{5}{|c|}{$\begin{array}{c}\text { Does Your participation in Mini-company contribute to your } \\
\text { competency for founding Your own business? }\end{array}$} & \\
\hline & & Disagree & $\begin{array}{l}\text { Neither } \\
\text { agree or } \\
\text { disagree }\end{array}$ & Agree & $\begin{array}{l}\text { Strongly } \\
\text { agree }\end{array}$ & Total & \\
\hline \multirow{4}{*}{$\begin{array}{l}\text { What is } \\
\text { Your cur- } \\
\text { rent oc- } \\
\text { cupation? }\end{array}$} & Unemployed & o & o & o & 1 & o & 1 \\
\hline & $\begin{array}{l}\text { Student-gra- } \\
\text { duated }\end{array}$ & 1 & 2 & 10 & 16 & 16 & 45 \\
\hline & $\begin{array}{l}\text { Student-cur- } \\
\text { rently }\end{array}$ & 2 & 5 & 25 & 45 & 44 & 121 \\
\hline & Employed & o & o & 2 & 4 & 1 & 7 \\
\hline \multicolumn{2}{|l|}{ Total } & 3 & 7 & 37 & 66 & 61 & 174 \\
\hline \multicolumn{2}{|l|}{$\%$} & 1,72 & 4,02 & 21,26 & 37,93 & 35,05 & 100 \\
\hline
\end{tabular}

Structure of teachers responsibility in the survey is shown as follows:

- $\quad 70 \%$ teaching vocational subjects

- $\quad 30 \%$ grammar school subjects (general education).

Question for the students: satisfaction with the program 'mini-companies'- it was suppose to estimate on the Likert scale. Results: 
- $\quad$ 93,11\% picked Agree and Strongly agree on the Likert scale which represents their high satisfaction with the program,

- $\quad 6,89 \%$ picked other items on the scale.

There is no significant difference between degree of satisfaction compared if respondents attend or not enterpreneurship course in the high school.

Table 37:Degree of satisfaction with the program and attenting subject entrepreneurship in school (cross tabulation)

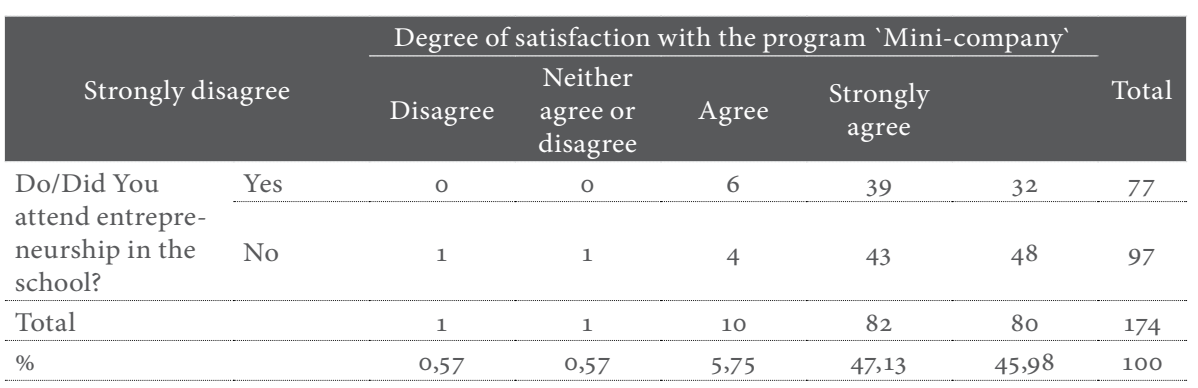

In terms of recommendation the program to other students, answers were:

$$
\begin{aligned}
& -\quad 98,85 \% \text { yes } \\
& \text { - } \quad 1,15 \% \text { no. }
\end{aligned}
$$

Table 38: Recommendation of the program and current occupation of students (cross tabulation)

\begin{tabular}{llccc} 
& & \multicolumn{2}{c}{$\begin{array}{c}\text { Would You recommend this pro- } \\
\text { gram to other students? }\end{array}$} & Total \\
\cline { 2 - 4 } & Unemployed & Yes & No & 1 \\
\hline \multirow{2}{*}{$\begin{array}{l}\text { What is Your } \\
\text { current occupation? }\end{array}$} & 1 & 0 & 45 \\
\cline { 2 - 4 } & Student -graduated & 45 & 2 & 121 \\
\hline Total & Student - currently & 119 & 0 & 7 \\
\hline Employed & 7 & 2 & 174 \\
\hline
\end{tabular}




\section{Results}

In our study we tried to assess different student and teacher statements related to work in 'mini-companies' in order to better understand their engagement in it, and study the positive effects of those engagements. There are certain observations there:

Students were asked to pick four of all proposed answers to declare why are they apply for program of 'mini-organizations'. Proposed answers were:

1. Curiosity

2. Techer's decision

3. Opportunity to earn something

4. Acquisition of new knowledge

5. Meeting new people and socializing

6. Absence from school

7. I estimate it as useful and profitable

8. Persuaded by friend

9. I can demonstrate my creativity and capacity for innovation

10. Personal development

11. I was idle

12. Other

Students are introduced to program -'mini-companies' mostly because of the following 5 reasons:

1. Acquisition of new knowledge $20,32 \%$

2. Meeting new people and socializing $17,31 \%$

3. Personal development $16,96 \%$

4. Curiosity $13,6 \%$

5. I estimate it as useful and profitable $12,72 \%$.

Results of teacher opinion have shown the similar grade of proposed categories.

1. Useful (for students) $32,44 \%$

2. Acquisition of new knowledge $27,86 \%$

3. Possibility of teacher's creative expression $14,88 \%$ 
Further, we investigate what knowledge and skills students have acquired during the program of 'mini-companies' according to their own opinion. This grade is shown in the Table 39.

Table 39: Students opinion about knowledge and skills improved during the program (the respondents were able to choose 4 answers in total)

\begin{tabular}{|c|c|c|c|}
\hline \multicolumn{4}{|c|}{ Students } \\
\hline \multicolumn{2}{|l|}{ Knowledge: } & \multicolumn{2}{|c|}{ Skills: } \\
\hline How the business world functions & $16,67 \%$ & Presentation skills & $13,82 \%$ \\
\hline $\begin{array}{l}\text { Creating a business plan \& a business } \\
\text { report }\end{array}$ & $14,88 \%$ & Teamwork & $12,54 \%$ \\
\hline Basics of how to run my own company & $13,84 \%$ & Confidence & $11,82 \%$ \\
\hline Time management + teamwork & $13,84 \%$ & Competitive spirit & $9,69 \%$ \\
\hline Marketing & $12,35 \%$ & Communication & $8,26 \%$ \\
\hline Decision making & $11,16 \%$ & Risk taking & $7,98 \%$ \\
\hline Basics of entrepreneurship & $10,42 \%$ & Creativity development & $7,55 \%$ \\
\hline Business correspondence & $2,68 \%$ & Setting goals & $7,55 \%$ \\
\hline Knowledge in English & $2,23 \%$ & Negotiation skills & $7,41 \%$ \\
\hline IT competencies & $1,64 \%$ & How to fight for my idea & $6,27 \%$ \\
\hline \multirow[t]{3}{*}{ No added value for me } & $0,30 \%$ & Organizing & $4,27 \%$ \\
\hline & & Dealing with conflict & $2,85 \%$ \\
\hline & & No added value for me & $0,0 \%$ \\
\hline
\end{tabular}

Equally important is opinion of teachers regarding accomplished skills and knowledge of their students during the attendance course of 'mini-companies'. It is shown in the Table 40:

Table 40: Teachers opinion of knowledge and skills students improved during the program (the respondents were able to choose 4 answers in total)

\begin{tabular}{lclc}
\multicolumn{1}{c}{ Teachers } & \\
\hline \multicolumn{1}{c}{ Knowledge: } & & & Skills: \\
\hline How the business world functions & $19,79 \%$ & Teamwork & $18,90 \%$ \\
\hline $\begin{array}{l}\text { Creating a business plan \& a business } \\
\text { report }\end{array}$ & $16,84 \%$ & Presentation skills & $17,59 \%$ \\
\hline $\begin{array}{l}\text { Basics of how to run my own company } \\
\text { Time management \& teamwork }\end{array}$ & $14,97 \%$ & Confidence & $14,44 \%$ \\
\hline
\end{tabular}




\begin{tabular}{lcll}
\hline Basics of entrepreneurship & $11,23 \%$ & Competitive spirit & $10,76 \%$ \\
\hline Decision making & $10,70 \%$ & How to fight for their idea & $6,82 \%$ \\
\hline Marketing & $9,36 \%$ & Communication & $6,04 \%$ \\
\hline IT competencies & $2,41 \%$ & Setting goals & $4,46 \%$ \\
\hline Knowledge in English & $1,60 \%$ & Negotiation skills & $2,62 \%$ \\
\hline Business correspondence & $0,80 \%$ & Risk taking & $2,62 \%$ \\
\hline No added value for students & $0,27 \%$ & Organizing & $1,57 \%$ \\
\hline & & Dealing with conflict & $0,79 \%$ \\
\hline
\end{tabular}

In addition to the previous, we analyze categories labeled 'other' in the questionnaire which was set up as a free form. Teachers got a chance to give descriptive answers on what the positive experiences working with students in 'mini-companies' were. Most of their answer can be summarized in the few following items:

1. Two - way communication with students.

2. Excellent feedback for the future teaching lessons.

3. Clear link between the business and economy.

4. Problem-solving techniques which are not related to education institutions.

5. The removal of barriers between students and teachers, encouraging students' motivation and innovation.

6. Personal development of students and their teachers.

7. Socializing and meeting interesting people.

8. Creative work with students.

Besides that, the most important visible result was upgraded knowledge of the students and positive attitude toward their future occupation. Teachers argue that students who attended the program of 'mini-companies' turn out to be individuals who successfully respond to all the opportunities and challenges of the business life. All this is due to the facts that they developed or promoted key skills important for business managing, gained self-confidence, took the initiative, learnt how to make decisions, mastered problem solving, coped with networking, and identified opportunities and personal effectiveness. 
It represents one step closer to sustainable careers of students as future employees in real corporations.

\section{Discussion and recommendation for the future research}

The analysis of the results leads to the conclusion that the main assumption "participation in the mini-companies will lead to increase in the knowldge of students and development of skills and competencies" is proven. Hence, results have shown a direct and clear connection between leading mini-companies and the major development of business-related student knowledge and soft skills. There is also an agreement between teacher and student opinion concerning the positive effects of participation in the mini-companies program. The students considered they've upgraded and improved their skills and knowledge, concurring with teachers' attitude that program has been successful and useful for students. Another positive side of participation in mini-companies could be motivating teachers with higher potential to utilize their professional and business knowledge. All the aforementioned is in accordance with the prior studies (Kisic Petkovic 2019; Lackeus 2005; Williamson et.al. 2013), which argue that mini-companies provide excellent foundation for continuous education, promoting business knowledge, encouragement to evolve skills and prepare students for future challenges in their academic, private and business life.

However, there are some limitations in our research. Research instruments need to be expanded for future researches in order to get a clear picture of all the aspects of participation in 'mini-organization' program: it is necessary to make a distinction between the opinions of current students and students who finished high school, broader opinion of teachers with regards to their experience in the real business situation, following further steps in the student's career after the finished program and high school, etc. Consequently, we propose additional research in the forthcoming year, with comprehensive instrument and more extended statistical analysis to encompass all types of schools, more students and their mentors, and broad spectrum of skills and competencies of students. Furthermore, it is suggested to consider how mini-companies can become sustainable, with regards to the sustainable venture creation approach (Lackeus, 2013). 


\section{Literature}

Kisic, S. Petkovic, 2019. Human Capital During the Fourth Industrial Revolution - from the lifelong learning up to lifelong Employability", Proceedings of the $14^{\text {th }}$ International Symposium on Corporate Governance "Sustainable Development of Small Economics in the Industrial Revolution 4.0 - Chances and Limitations", Teslic, 22. - 24. May 2019., p: 121 - 149, UDK 37.014:36776] 339.923)

Kisic S., 2015, Rezultati istrazivanja efekta programa 'Ucenicka kompanija" u srednjim skolama u Srbiji, Godisnja konferencija nastavnika Dostignuca mladih u Srbiji, 2019

Lackéus, Martin, Entrepreneurship in Education: What, Why, When, How, OECD, 2015.

Lackeus, Martin, Developing entrepreneurial competencies: An action-based approach and classification in entrepreneurial education, Chalmers University of Technology Gothenburg, Sweden, 2013.

Limerick, David C., Larry F. Moore, A winning Relationship: managing the student-company learning interface, Journal of management education, 1991.

Neck, Heidi M., Greene Patricia G., Brush Candida G., Teaching entrepreneurship: A Practice-Based Approach, Edward Elgar Publishing Cheltenham $\mathrm{UK}, 2014$.

Porter, Lyman W., McKibbin Lawrence E., Management education and development: Drift of thrust ino the $21^{\text {st }}$ century? New York: McGraw-Hill, 1988.

Cousins, Roland B., Thorn Ron G., Benitz Linds E., The junior achievement company as a living case, Journal of management education, 1995.

Williamson, Naomi, Beadle Shane, Charalambous Stephanie, Enterprise education impact in higher education and further education:Final report, Department for business, innovation and skills, ICF GHK International Company, 2013.

\section{Websites}

Entreprenurial Learning Toolkit for Teachers (https://ec.europa.eu/jrc/en/publication); (May 25, 2019).

Kisic, S. Petkovic, http://ses.org.rs/upload/Ekonomika\%2opreduzeca\%201-22019.pdf ( July 30, 2019).

The Quality Assurance Agency for Higher Education (QAA) guidance on enterprise and entrepreneurship provision7 draws the distinction set out in 
the box below. See http://www.qaa.ac.uk/Publications/InformationAndGuidance/Documents/EE_Draft_Guidance.pdf ; OECD, (July 8, 2020)

DG Enterprise and Industry website, http://ec.europa.eu/enterprise/policies/ sme/promoting-entrepreneurship/education-trainingentrepreneurship/ index_en.htm (July 7, 2020)

\section{Sources}

The Quality Assurance Agency for Higher Education (QAA) guidance on enterprise and entrepreneurship provision draws the distinction set out in the box below. See http://www.qaa.ac.uk/Publications/InformationAndGuidance/Documents/EE_Draft_Guidance.pdf ; OECD (2010) Ministerial report on the OECD innovation strategy; and OECD (2009) Evaluation of programmes concerning education for entrepreneurship: Report of the OECD Working Party on SMEs and Entrepreneurship; DG Enterprise and Industry website, http://ec.europa.eu/enterprise/policies/sme/ promoting-entrepreneurship/education-trainingentrepreneurship/index_en.htm

(2010) Ministerial report on the OECD innovation strategy; and OECD (2009) Evaluation of programmes concerning education for entrepreneurship: Report of the OECD Working Party on SMEs and Entrepreneurship 


\section{profesionalni razvoj pedagoških delavcev}





\title{
Timsko vodenje in sistematično razvijanje strokovnih timov v vrtcu v luči profesionalnega razvoja
}

\author{
Silvija Komočar
}

\begin{abstract}
Uvod
V prispevku je predstavljena študija primera sistematičnega uvajanja timskega dela na ravni vrtca $v$ Vrtcu Mavrica Brežice kot posledica timskega vodenja vrtca $\mathrm{z}$ namenom spodbujanja profesionalnega razvoja strokovnih delavcev.

Timsko naravnanost in sodelovalno kulturo smo sistematično širili med strokovne delavce in $\mathrm{v}$ zadnjih dveh letih iz delovnih skupin razvili visoko učinkovite strokovne time, ki delujejo na ravni celotnega vrtca. Strokovni delavci se $\mathrm{v}$ okviru svojih timov poglabljajo v različna kurikularna področja predšolske vzgoje in $\mathrm{v}$ skladu s sodobnimi pedagoškimi koncepti posodabljajo svojo prakso ter s tem spodbujajo lasten profesionalni razvoj.

$\mathrm{V}$ prvem razdelku je predstavljen teoretski okvir timskega dela. V njem pokažemo, da znanstvena literatura loči učinkovite time od neučinkovitih in poudarimo bistvene značilnosti uspešnih timov. Izpostavimo pomen komunikacije $\mathrm{v}$ timu ter spodbujanje profesionalnega razvoja v okviru timskega dela. Poudarjamo tudi, da temelji proces spodbujanja in razvijanja timskega dela na vzporednem spodbujanju refleksivnosti članov tima, tako temelji naša študija primera tudi na razvoju odgovornosti članov posameznega strokovnega tima za aktivno lastno vlogo tako pri spodbujanju razvoja tima kot tudi lastnega profesionalnega razvoja.

$\mathrm{V}$ drugem razdelku je predstavljena metodologija raziskave in vzorec za študijo primera. Sledi razdelek Rezultati in razprava, kjer najprej preds-
\end{abstract}


tavimo potek akcijske raziskave v obravnavani organizaciji skozi interpretacije raziskovalcev. Nato so predstavljeni izsledki študije primera, osredotočeni zlasti na primerjave, ki kažejo na dosežene spremembe v okviru pojmovanj in rezultatov sistematičnega razvoja strokovnih timov, ki so jih izpostavili udeleženci raziskave.

Sklepni razdelek predlaga premislek o timskem delu kot orodju za spodbujanje profesionalnega razvoja strokovnih delavcev vrtca v smislu zagotavljanja sodobnega učnega okolja v okviru učeče se skupnosti.

\section{Teoretična opredelitev timskega dela}

V praksi je s pojmom tim velikokrat poimenovana vsaka delovna skupina, sestavljena $\mathrm{z}$ namenom, da opravi neko skupno nalogo. Če pogledamo teoretična izhodišča, pa ugotovimo, da vsaka delovna skupina sama po sebi ni tim, če v njenem delu ne najdemo elementov, ki določajo tim:

- $\quad$ Problemi, ki jih člani tima skupaj rešujejo, so osnova za opredelitev nalog tima, le-te pa so oblikovane za uresničitev cilja.

- Tim dosega cilje $\mathrm{z}$ dobrim medsebojnim sodelovanjem članov tima, čigar velikost je odvisna od kompleksnosti naloge.

- Eden pomembnih elementov timskega dela je prav gotovo usmerjajoči vodja tima, v manjših in utečenih timih, ki so že utečeni pa delo usmerja koordinator. Od njegovih osebnostnih značilnosti in njegove strokovnosti je v marsičem odvisno delovanje tima.

- Zadnji, a zato nikakor najmanj pomembni element timskega dela so po Rozmanu medosebni odnosi med člani in morebitne izmenjave, saj je uspešno timsko delo ključno povezano s kakovostjo medosebnih odnosov (Kobolt, 2012: 6).

Vsako delovno področje zahteva od nas nagle odzive na spremembe, ki se nenehno dogajajo na vseh področjih, pa tudi v nas samih. V sodobnem izobraževalnem okolju pa si v celotni izobraževalni vertikali sprememb želimo, jih načrtno uvajamo. Rutar (2017) govori o dveh vrstah sprememb, ki jih sam sicer opisuje v šolskem okolju, pa vendar jih lahko umestimo tako $\mathrm{v}$ vrtec in v osnovno ali srednjo šolo, kot tudi na fakulteto: prve so notranje spremembe samih učencev in učiteljev, zlasti kakovostne osebnostne, simbolne, duhovne, duševne spremembe učencev, druge pa so zunanje, so spremembe ožjega in širšega družbenega okolja. Nekateri se na spremembe in nova znanja odzivamo hitreje, drugi počasneje, zagotovo pa zahtev- 
ne naloge lažje in bolj kakovostno rešujemo s sodelovanjem. Če izhajamo iz Rutarjeve trditve, da sta ključna dejavnika, ki poganjata dobre spremembe, resnica in vednost oziroma znanje (Rutar, 2017: 128), potem moramo iskati načine, da pedagoškim delavcem zagotovimo učno okolje, kjer bo dovolj prostora za pomembne dobre ideje in produktivne zamisli, ki bodo sprožale najprej nujne spremembe $\mathrm{v}$ njih samih, da bi jih nato lahko razvijali tudi pri svojem delu z otroki. Sodobna nevroznanost poudarja, da naši možgani niso ustvarjeni, da bi v njih zgolj shranjevali podatke, znanje mora biti izbrano, oblikovano in filtrirano skozi mrežo načrtov, ciljev in namer (Rutar, 2017: 128).

Primeren prostor za razvoj dobrih idej in produktivnih zamisli je gotovo tim, vendar ob predpogoju, da lahko $\mathrm{v}$ njem posameznik zadovolji potrebe po varnosti - po predvidljivosti socialnega prostora in zaupanju vanj, kot meni A. Polak (Polak, 2007: 22). Če izhajamo iz trditve Maslowa (Brajša, 1995), da so človeške potrebe hierarhično umeščene $\mathrm{v}$ pet nivojev potreb, pri čemer ugotavlja, da ko nekdo zadovolji en nivo, je motiviran in se trudi, da zadovolji naslednjega, potem lahko sklepamo, da je občutek varnosti ključnega pomena za ustvarjalno mišljenje in produktivno razmišljanje oziroma izpostavljanje posameznika do te mere, da bo svoje ideje tudi delil med ostale člane tima.

Različni avtorji postavljajo podobno pozitivne definicije timskega dela: timsko delo lahko pojmujemo kot večstopenjski proces, v katerem člani tima na individualni in skupinski ravni izpolnjujejo naloge in razvijajo timsko delo (Kozlowski in Klein, 20oo, v Hwang, 2018: 158), pri čemer zajema izpolnjevanje nalog individualno ali skupno opravljanje zadane naloge, običajno podprto $\mathrm{z}$ različnimi pripomočki, medtem ko se timsko delo nanaša na medosebne interakcije med člani tima (Bowers, Braun in Morgan, 1997 v Hwang, 2018). Avtorji se strinjajo, da učinkovito timsko delo opredeljujeta dobra komunikacija in sodelovanje med člani tima na poti do skupnega cilja. Rezultat timskega dela je timska učinkovitost (Salas, Cooke, and Rosen, 2008 v Hwang, 2018), ki je merljiva na različne načine, vključujoč objektivno evalvacijo in refleksijo timske učinkovitosti ter zadovoljstva posameznih članov z delom v timu (Gladstein, 1984; Guchait, Lei, and Tews, 2016; LePine et al., 2008, v Hwang, 2018). Tudi Mayer (2001) vidi v timu (v primerjavi s formalno delovno skupino) povsem novo kakovost in možnost, Brajša (1996) o timu piše kot o živem medosebnem siste$\mathrm{mu}$, njegovo medosebno problematiko pa lahko opazujemo $\mathrm{z}$ več zornih 
kotov: $\mathrm{z}$ vidika medosebne pripadnosti članov tima, njihovega sodelovanja, odnosov, komunikacije, prilagajanja in doživljanja.

Lahko torej povzamemo s sklepom A. Kobolt (2012), da

so timi posebne delovne skupine, ki jih opredeljujejo različne organizacijske oblike, raznolikost $\mathrm{v}$ pogostosti srečevanj, različna dolgost trajanja delovanja, raznovrstnost okoliščin njihovega nastanka in nalog, ki jih opravljajo (Kobolt, 2012: 6).

Učinkoviti timi pa vsebujejo tudi osnovne značilnosti ustvarjalnega tima, ki jih poudarja Mayer (2001: 6): nadseštevnost, vzajemni učinki, velika prožnost, napovedna moč in hitrost učenja ter večja verjetnost nastajanja ustvarjalnih dosežkov.

\section{Učinkovit tim}

Tabela 4r: Pet dimenzij učinkovitega timskega dela po Ohlandu

PRISPEVANJE K TIMSKEMU DELU

- Član prispeva več ali višjo kakovost od pričakovane.

- Članov prispevek pomembno vpliva na izboljšanje dela tima.

- Pomaga dokončati delo kolegov, ki imajo težave.

INTERAKTIVNOST S TIMSKIMI KOLEGI

- Timske kolege spodbuja k podajanju idej in izkazuje interes za njihove ideje in prispevke.

- Izboljšuje komunikacijo med timskimi kolegi. Opogumlja in spodbuja člane tima.

-Timske kolege prosi za povratno informacijo in njihove predloge tudi upošteva pri svojem izboljšanju.

SLEDENJE TIMU

- Opazuje, kako različni dejavniki vplivajo na tim ter opzuje napredek tima.

- Potrudi se, za ustrezen napredek svojih timskih kolegov.

- Svojim timskim kolegom podaja konkretne, redne in konstruktivne povratne informacije.

STREMENJE H KAKOVOSTI

-Tim motivira k odličnosti.

- Pomembno mu je, da tim dosega izjemne rezultate, tudi, kadar za to ni posebnih nagrad.

- Verjame, da lahko tim dosega odlične rezultate.

DOSEGANJE POTREBNEGA ZNANJA, SPRETNOSTI IN VEŠČIN ZA TIMSKO DELO

- Kaže potrebna znanja, spretnosti in veščine za odlično opravljanje dela.

-Pridobiva nova znanja ali spretnosti za izboljšanje učinkovitosti tima.

-Po potrebi prevzame katero koli vlogo v timu.

S. Komočar po: Ohland at al., 20I2, v Hwang, 2018 
Dejavniki, ki vplivajo na učinkovitost tima so predmet številnih raziskav. Različni avtorji poudarjajo, da sestava tima, struktura dela in razdelitev nalog v timu dokazano vplivajo na učinkovitost timskega dela (Gladstein, 1984; Salas, Cooke, and Rosen, 2008, v Hwang, 2018).

A. Polak (2007) po različnih avtorjih konkretneje opredeli lastnosti in delovanje, po katerih se učinkoviti timi razlikujejo od neučinkovitih. Povzamemo lahko, da se učinkovit tim zaveda pozitivne soodvisnosti, pomembnosti odprte in sproščene komunikacije, ki je temelj za boljše medsebojno razumevanje članov tima, poznavanja vlog drugih ter večjega zaupanja med člani, kar zagotovo spodbuja učenje članov tako o drugih kot o sebi. Skupna in jasna vizija povezuje člane tima, vse to pa jim pomaga tako $\mathrm{h}$ kakovostnejšem doseganju načrtovanih skupnih ciljev kot tudi k bolj intenzivnemu profesionalnemu razvoju posameznikov znotraj tima. Tudi sodelovalno vedenje članov tima je za učinkovitost tima izrednega pomena. Da bi lažje razumeli različna vedenja članov v timu, so Loughry, Ohland, and Moore (2007 v Hwang, 2018) razvili lestvico »the Comprehensive Assessment of Team Member Effectiveness « (op. prev.: celovita ocena učinkovitosti članov tima), ki učinkovitost posameznih članov tima razvrsti v 5 kategorij: prispevanje $\mathrm{k}$ timskemu delu, interaktivnost $\mathrm{s}$ timskimi kolegi, sledenje timu, pričakovanje kakovosti ter doseganje potrebnega znanja, spretnosti in veščin za timsko delo.

Tabela v nadaljevanju prikazuje pet dimenzij in opisov vedenj, ki predstavljajo primer učinkovitega timskega dela po Ohlandu (Ohland at al., 2012, v Hwang, 2018).

\section{Komunikacija}

Komunikacija je osnovno orodje timskega dela in je bistvenega pomena, da bi lahko v timu vzdrževali dobre medsebojne odnose in zagotavljali dobre rezultate tima. J. Lepičnik Vodopivec (2012: 15) opredeli komunikacijo kot sestavino človekove eksistence, saj človek nenehno komunicira. Številni raziskovalci timskega dela poudarjajo pomembnost dobre in odprte komunikacije za učinkovito timsko delo, saj vpliva tudi na ostale procese, ki so sestavni del timskega dela (Polak, 2012: 34). Avtorica (prav tam) opozarja, da prav komunikacijski zapleti običajno sprožijo konflikt v timu in vplivajo na timsko neučinkovitost, tako je komunikaciji v timu potrebno posvetiti dodatno pozornost. 
Pri timski komunikaciji se pogosto srečamo s težavami zaradi nepoznavanja štirih pomembnih elementov komunikacije, ki jih izpostavita Robbins in Finley (2000):

1. GOVORJENJE - zelo pomemben del komunikacije, vendar avtorja poudarjata (Ibid.), da še zdaleč ne tako pomemben kot je poslušanje. Pomembno je, da govorimo jasno, razločno, morda počasneje ali pa preprosto glasneje, da smo tako sogovorniku bolj razumljivi.

2. POSLUŠANJE - običajno težji del komunikacije, saj smo osredotočeni bolj na to, kaj želimo sporočiti sogovorniku, torej na lastno govorjenje.

3. POSLUŠANJE GOVORJENJA SAMEGA SEBE - opazovanje načina lastnega govorjenja. Govorec reflektira svoj način sporočanja ob opazovanju svoje verbalne in neverbalne komunikacije.

4. POSLUŠANJE POSLUŠANJA SAMEGA SEBE - razvoj še globljih veščin lastnega poslušanja. Gre za zavedanje zavedanja lastnega poslušanja, za spoštljiv odnos do sogovornika v smislu dejanskega poslušanja njegovega sporočila brez takojšnjega analiziranja, prenagljenega sklepanja, pa tudi sodb. $\mathrm{V}$ tem delu komunikacije gre pravzaprav za odlično avtorefleksijo o tem, kaj nas vznemirja. S poslušanjem lastnega poslušanja preizkušamo potrebe lastnega ega ter lastnih impulzivnih odzivov, raziskujemo torej elemente, ki onemogočajo kakovostno komunikacijo (Robbins in Finley, 2000).

\section{Timsko delo in profesionalni razvoj}

Kompetenten učitelj je zadovoljen s sabo in s svojim delom. Svoje zadovoljstvo prenaša na učence. Njegovo veselje do dela pomembno vpliva na vzdušje v učilnici in se odraža v celotnem izobraževalnem procesu (Grgurić et al., 2009).

Vloga vzgojiteljev in učiteljev se pomembno spreminja, zato jim je zelo pomembno zagotoviti dober sistem profesionalnega razvoja, jim omogočiti razvoj novih kompetenc, večjo avtonomijo in s tem posledično tudi povrniti zaupanje v ta pedagoška poklica. Pedagoški delavci morajo biti kos družbenim spremembam, novim tehnologijam, novim znanjem, novim generacijam. Nenehno se morajo izobraževati, da lahko uspešno opravljajo svojo novo vlogo, ki presega zgolj podajanje znanja. Zato posebej izpostavljamo 
pomen profesionalnega razvoja vzgojiteljev in učiteljev. Če vzamemo za izhodišče trditev, da je

vzgojiteljska profesija izjemno zapletena in zahteva visoko profesionalno zavest in širok razpon kompetenc in da so $\mathrm{z}$ vidika profesionalnega razvoja še posebej pomembne kompetence za raziskovanje prakse in gradnjo nove teorije na podlagi skupnega premišljanja (Šagud in Jurčević Lozančić, 2012, v Valenčič Zuljan in Blanuša Trošelj, 2014: 44),

potem je timska oblika, ki smo jo zastavili v ta namen, ustrezna. Tim je namreč varno okolje, v katerem lahko člani skupno premišljujejo, možgansko viharijo in prihajajo do novih idej, inovativnih pristopov in s tem do novih profesionalnih kompetenc.

Profesionalni razvoj lahko razumemo kot dejavnosti, namenjene podpori in razvoju prakse pedagoških delavcev (Noonan, 2019). In vendar se lahko te dejavnosti med seboj razlikujejo glede na družbeno okolje in oblike izvajanja, kot npr. tečaji na fakultetah, delavnice, formalni in neformalni mentorski odnosi, raziskovalne skupine ali medkolegijale hospitacije (Noonan, 2019).

Raziskovalci različno pristopajo raziskovanju profesionalnega razvoja pedagoških delavcev. Fuller, 1969; Kagan, 1992; Katz, 1972; Berliner,1992 se osredotočijo na faze profesionalnega razvoja in oblikovanje tako imenovanih linearnih faznih modelov. Nekateri raziskovalci se usmerijo na dejavnike, ki vplivajo na profesionalni razvoj, Scheckley in Allen, 1991; Kolb, 1991 pa izpostavljajo oblike in načine poklicnega učenja (v Valenčič Zuljan in Blanuša Trošelj, 2014: 46). P. Javrh (2011) kot eno učiteljevih/vzgojiteljevih temeljnih nalog navaja skrb za nenehno poglabljanje kakovosti vzgojno izobraževalnega dela. Ista avtorica (2011) razlaga, da se kariera razvija učinkovito in harmonično, kadar je uspešno združenih več najpomembnejših prvin: nenehno učenje in iskanje, vseživljenjsko izobraževanje, osebni načrt razvoja kariere, uravnoteženje osebnih ambicij s potrebami družine, razsodno upoštevanje stanja osebnega psihosocialnega razvoja, tekoče soočanje in usklajevanje s potrebami delodajalca ter pravočasno prilagajanje trgu dela.

\section{Metodologija in vzorec}

Kombinirana (kvantitativno-kvalitativna) raziskava, ki je potekala po metodi akcijskega raziskovanja $\mathrm{z}$ udeležbo kot študija primera, je zajemala 
neslučajno priložnosten raziskovalni vzorec, saj smo v raziskavo vključili vnaprej določen vrtec. Vzorec je zajemal 1 vrtec v mestnem okolju, ki ima 27 oddelkov, 88 zaposlenih in 429 otrok.

Izdelali smo akcijski načrt za sistematično razvijanje timskega dela, kjer smo časovno opredelili aktivnosti za dosego cilja z določenim postopkom zbiranja podatkov. Primer akcijskega načrta podajamo v nadaljevanju $\mathrm{v}$ Tabelah 42 in 43.

Tabela 42: Časovni in vsebinski potek akcijskega raziskovanja

\section{ČAS}

SEPTEMBER / 2017

AKCIJSKI KORAK 1

- OBLIKOVANJE STROKOVNIH TIMOV

- akcija: teoretična izhodišča za timsko delo

- akcija: načrtovanje in priprava dejavnosti za uvajanje elementov timskega dela

\section{AKTIVNOSTI ZA SISTEMATIČNO} RAZVIJANJE TIMSKEGA DELA

- oblikovanje akcijskega načrta za samoevalvacijo

- UVAJANJE SPREMEMBE: OBLIKOVANJE STROKOVNIH TIMOV

- Analiza osebne pripravljenosti delovanja v timu

- dogovor o stalnem terminu srečanj timov (mesečna srečanja)

- oblikovanje pravil, razdelitev vlog, dogovor o metodah dela

FEBRUAR / 2018

AKCIJSKI KORAK 2

- merjenje učinkovitosti tima

- akcija: timska evalvacija in refleksija

- akcija: ugotavljanje razvojne faze tima

- izobraževanje (4 ure): Timsko delo (dr. Alenka Polak)

- obravnava in sprejem akcijskega načrta tima za šolsko leto 2017/18

- pregled in evalvacija aktivnosti za preteklo obdobje

- UVAJANJE SPREMEMBE: SPROTNO MERJENJE ZAZNAVANJA UČINKOVITOSTI VODSTVENEGA TIMA (VPRAŠALNIK)

MAJ/ 2018

AKCIJSKI KORAK 3

- akcija: polletna evalvacija tima; individualna refleksija z diskusijo; izhodišča za AKCIJSKI KORAK (4)

\section{AKCIJSKI KORAK 4}

- načrtovanje in priprava dejavnosti za uvajanje elementov timskega dela

- akcija: oblikovanje vizije timskega dela za naslednje šolsko leto

- skupna predstavitev delovanja timov (razvojno in vsebinsko)
- vodstveni tim razpravlja o finančnih, organizacijskih in pravnih vprašanjih na ravni vrtca

- UVAJANJE SPREMEMBE: POLLETNA EVALVACIJA DELOVANJA TIMA (VPRAŠALNIK Z DISKUSIJO)

- ANALIZA POLLETNE EVALVACIJE 
ČAS

\begin{tabular}{ll}
\multicolumn{1}{c}{ ČAS } & \multicolumn{1}{c}{ AKTIVNOSTI ZA SISTEMATIČNO } \\
RAZVIJANJE TIMSKEGA DELA
\end{tabular}

Tabela 43: Čas zbiranja podatkov s posameznimi raziskovalnimi pripomočki

\begin{tabular}{ll}
\multicolumn{1}{c}{ ČAS } & \multicolumn{1}{c}{ POSTOPEK ZBIRANJA PODATKOV } \\
OKTOBER 2017 & $\begin{array}{l}\text { Vprašalnik za analizo osebne pripravljenosti za sodelovanje v timu Vprašalnik } \\
\text { za analizo osebne pripravljenosti za sodelovanje v timu (Polak, 1999 in 2001) }\end{array}$ \\
\hline \multirow{2}{*}{ FEBRUAR 2018 } & $\begin{array}{l}\text { merjenje zaznavanja učinkovitosti timov - Vprašalnik za sprotno merjenje za- } \\
\text { znavanja učinkovitosti tima (oblikovala S. Komočar po Arcaro, 1995: 14-15) } \\
\text { TIMSKA REFLEKSIJA }\end{array}$ \\
\hline \multirow{2}{*}{ MAJ 2018 } & $\begin{array}{l}\text { polletna evalvacija Vprašalnik za oceno delovanja tima (izvirnik Maas in } \\
\text { Ritschl, 1997,prevedla in delno priredila A. Kobolt v Kobolt, 2010: 184-186) }\end{array}$ \\
OKTOBER 2018 & $\begin{array}{l}\text { končna evalvacija delovanja timov - Vprašalnik za končno evalvacijo timskega } \\
\text { dela in nov začetek (prirejen po vprašalniku Intervizija in supervizija-evalva- } \\
\text { cija; (c) Simona Tancig, PeF, 2011) in diskusija }\end{array}$ \\
Analiza evalvacije timov (povratna informacija vodstva, dodatna refleksija ti- \\
mov, nadaljevanje razvoja tima z oblikovanjem novih ciljev, morebitnih no- \\
vih pravil, vizije) \\
Anketni vprašalnik \\
SAMOEVALVACIJA - evalvacija doseganja zastavljenega cilja za šolsko leto \\
2018/19
\end{tabular}

$\mathrm{Z}$ upoštevanjem elementov akcijskega raziskovanja smo člani vodstvenega tima uvajali spremembe (elemente timskega dela) $v$ strokovne time in jih skupaj z njimi sprotno in končno evalvirali. Glede na to, da temelji proces spodbujanja in razvijanja timskega dela na vzporednem spodbujanju refleksivnosti članov tima, smo želeli s sistematičnim uvajanjem sprememb $\mathrm{v}$ vodstveni tim vrtca razvijati tudi odgovornost članov posameznega strokovnega tima za aktivno lastno vlogo pri spodbujanju razvoja tima. Razvoj timskega dela smo prepletli skozi več ravni delovanja vrtca (strokovni ak- 
tivi, pedagoške konference, operativni sestanki, samoevalvacija, hospitacije) in tako razvijali aktivno, učečo se skupnost. Prednostna naloga vrtca je bila hkrati tudi izbrano področje ugotavljanja in zagotavljanja kakovosti vrtca, prednostno področje kakovosti pa je bil profesionalni razvoj, kar je razvidno iz primera samoevalvacijskega načrta v Tabeli $44 \mathrm{v}$ nadaljevanju.

Tabela 44: Dejavnosti in merila v šolskem letu 2017/18

\begin{tabular}{|c|c|c|c|c|}
\hline DEJAVNOSTI & $\begin{array}{c}\text { NOSILEC } \\
\text { DEJAVNOSTI }\end{array}$ & $\begin{array}{l}\text { VKLJUČENI V } \\
\text { DEJAVNOST }\end{array}$ & $\begin{array}{c}\text { ROK ZA } \\
\text { IZVEDBO } \\
\text { DEJAVNOSTI }\end{array}$ & $\begin{array}{l}\text { POTREBNI } \\
\text { VIRI }\end{array}$ \\
\hline Predavanje Timsko delo & $\begin{array}{l}\text { Silvija Komočar, } \\
\text { mag.prof.pred.vzg. } \\
\text { dr. Alenka Polak }\end{array}$ & & $\begin{array}{l}\text { oktober } 2017 \\
\text { februar } 2018\end{array}$ & \multirow[b]{10}{*}{$\begin{array}{l}\text { TIMA } \\
\text { kih in razvo- } \\
\text { m področju } \\
\text { delovanju, }\end{array}$} \\
\hline $\begin{array}{l}\text { Strokovne razprave na } \\
\text { aktivih }\end{array}$ & vodje aktivov & $\begin{array}{l}\text { strokovne de- } \\
\text { lavke }\end{array}$ & $\begin{array}{l}\text { oktober } 2017 \\
\text { januar } 2018 \\
\text { maj } 2018\end{array}$ & \\
\hline $\begin{array}{l}\text { Strokovni pogovori v } \\
\text { timu }\end{array}$ & strokovni delavci & $\begin{array}{l}\text { strokovni de- } \\
\text { lavci }\end{array}$ & $\begin{array}{l}\text { september } \\
\text { 2017-avgust } 2018\end{array}$ & \\
\hline $\begin{array}{l}\text { Načrtovanje timske- } \\
\text { ga dela }\end{array}$ & strokovni delavci & $\begin{array}{l}\text { strokovni de- } \\
\text { lavci }\end{array}$ & do maja 12018 & \\
\hline $\begin{array}{l}\text { Evalviranje timske- } \\
\text { ga dela }\end{array}$ & strokovni delavci & $\begin{array}{l}\text { strokovni de- } \\
\text { lavci }\end{array}$ & do maja 2018 & \\
\hline $\begin{array}{l}\text { Naloge znotraj tima v } \\
\text { povezavi s kurikularnim } \\
\text { področjem Gibanja }\end{array}$ & strokovni delavci & $\begin{array}{l}\text { strokovni de- } \\
\text { lavci }\end{array}$ & do maja 2018 & \\
\hline $\begin{array}{l}\text { Evalviranje nalog znot- } \\
\text { raj tima(kurikularno po- } \\
\text { dročje gibanja) }\end{array}$ & strokovni delavci & $\begin{array}{l}\text { strokovni de- } \\
\text { lavci }\end{array}$ & do maja 2018 & \\
\hline $\begin{array}{l}\text { Oblikovati pogoje za } \\
\text { timsko delo }\end{array}$ & $\begin{array}{l}\text { ravnateljica } \\
\text { pomočnica ravna- } \\
\text { teljice }\end{array}$ & $\begin{array}{l}\text { strokovni de- } \\
\text { lavci }\end{array}$ & do maja 2018 & \\
\hline $\begin{array}{l}\text { Študij strokovne litera- } \\
\text { ture o timskem delu in o } \\
\text { področju gibanja }\end{array}$ & strokovni delavci & $\begin{array}{l}\text { strokovni de- } \\
\text { lavci }\end{array}$ & ves čas & \\
\hline $\begin{array}{l}\text { MERILA } \\
\text { PODATKI }\end{array}$ & \multicolumn{3}{|c|}{$\begin{array}{l}\text { MERILO: UČINKOVITOST, RAZVOJ IN DELOVANJE TIMA } \\
\text { Načini pridobivanja podatkov: } \\
\text { Anketni vprašalniki: } \\
\text { Merjenje učinkovitosti tima } \\
\text { Merjenje razvoja tima } \\
\text { Merjenje delovanja tima } \\
\text { Opazovanje in beleženje lastne refleksije o timskih sestankih in razvo- } \\
\text { ju tima, timskem delu } \\
\text { Beleženje sprememb, ki so nastale v delovanju tima } \\
\text { Evalvacije in refleksije načrtovanja in dela na kulikularnem področju } \\
\text { Gibanje } \\
\text { Analiza strokovnih razprav na aktivih } \\
\text { Dnevniki zapisov (o izvedenih dejavnostih, o timskem sodelovanju, } \\
\text { nastalih težavah, uspešnih rešitvah, dilemah,...) }\end{array}$} & \\
\hline
\end{tabular}




\section{Rezultati in interpretacija}

Načrtovani cilj smo na nivoju vrtca v veliki meri dosegli. Na doseganje cilja je vplivalo:

- načrtovane dejavnosti,

- pripravljenost na timsko delo,

- menjavanje članov v timu.

V raziskovalni proces je bilo v šolskih letih 2017/18 in 2018/19 pri doseganju prioritetnega cilja vključenih od 53 do 60 strokovnih delavcev. Število strokovnih delavcev je naraščalo zaradi odprtja novih medletnih oddelkov. Do menjave strokovnih delavcev $\mathrm{v}$ timu je prihajalo tudi zaradi dolgotrajnih bolniških odsotnosti. Z vstopom novih članov je v timih prišlo do sprememb dinamike delovanja timov.

$\mathrm{Na}$ prvem strokovnem aktivu oktobra 2017 smo timom na kratko predstavili timsko delo, naloge, povezane s kurikularnim področjem gibanja ter metode in oblike dela, ki jih lahko uporabijo pri delu v timih. Timi so na prvem timskem sestanku:

- izbrali vodjo tima,

- predstavili drug drugemu svoja pričakovanja, želena pravila in načine dela,

- določili pravila v timu.

Tabela 45: Primerjava rezultatov zaznavanja elementov timskega dela

\section{Elementi timskega dela}

ŠOLSKO LETO 2017/18 ŠOLSKO LETO 2018/19

\begin{tabular}{lcc} 
SKUPNI CILJ & $98,1 \%$ & $100 \%$ \\
\hline SKUPNA NALOGA & $98,1 \%$ & $100 \%$ \\
\hline ČAS, NAMENJEN TIMSKIM SESTANKOM & $79,2 \%$ & $96,6 \%$ \\
\hline PROSTORSKI POGOJI & $83 \%$ & $89,5 \%$ \\
\hline
\end{tabular}

Vodstveni tim je za time pripravil anketni vprašalnik za sprotno merjenje učinkovitosti tima. Rezultati ankete so pokazali prisotnost elementov timskega dela $v$ posameznem timu in s tem so timi lahko pridobili informacijo o tem, katere spremembe je potrebno vnašati v posamezni tim, da bi se iz skupine razvil visoko funkcionalen tim. Člani timov v 92,6 \% ocenjujejo, da so kot tim dobro opravili zastavljeno nalogo s področja gibanja. 7, $4 \%$ članov je mnenja, da naloge kot tim niso dobro opravili. Iz poročil je razvidno, da člani vidijo tudi možnosti za izboljšavo zastavljene naloge. 
Rezultati in primerjave so pokazale, da so strokovni delavci dosegli zastavljen cilj. Iz primerjav je razvidno, da so se izboljšali rezultati glede organizacije časa in prostora kot dveh pogojev za timsko delo. Prostor je še vedno ocenjen kot neprimeren pri določenih članih tima, ki pa so podali argument in razlago, da so sami izbrali prostor, ki ni najbolj primeren. Imeli so možnost zamenjati prostor, a so se sami odločili, da bodo delali naprej v istem prostoru.

\section{Tabela 46: Primerjava rezultatov osebne pripravljenosti za timsko delo}

\section{Osebna pripravljenost za timsko delo}

\begin{tabular}{ll} 
September 2017 & Maj 2019 \\
\hline $\begin{array}{l}\text { Timsko delo vidim kot odličen način svojega } \\
\text { strokovnega dela in sodelovanja }\end{array}$ & $\begin{array}{l}\text { Timsko delo vidim kot odličen način svojega } \\
\text { strokovnega dela in sodelovanja }\end{array}$ \\
\hline $20,8 \%$ & $68,4 \%$ \\
\hline
\end{tabular}

Člani v večji meri zaznajo timsko delo kot odličen način njihovega strokovnega dela in sodelovanja. Strokovni delavci so na strokovnih aktivih izrazili željo, da se timsko delo nadaljuje ter da se ohranijo obstoječi timi. Strokovni pogovori v timu so prispevali k razvijanju sposobnosti za timsko delo. Strokovne delavke navajajo, da so skozi strokovne pogovore v timu razvile predanost in naklonjenost timu, da so čutile večjo soodgovornost za izvajanje zastavljene naloge. Posamezni strokovni delavci menijo, da skupni cilj, združevanje različnih pogledov, vidikov in izkušenj, nadgrajevanje idej, spoznavanje različnih močnih in šibkih področij (lastnih in od drugih članic tima), načrtovanje, kako učinkoviteje opraviti delo, razvijajo sposobnost za timsko delo. Strokovni delavci so skozi timsko delo in strokovne pogovore spremenili in izboljšali svoj način sodelovanja. Strokovni delavci navajajo, da so v timu slišani in sprejeti, da je njihovo mnenje pomembno ter uveljavljeno. Skozi strokovne pogovore so se strokovni delavci učili sprejemati mnenje drugih in sprejemati dejstvo, da nimajo vedno prav. Strokovni delavci so mnenja, da strokovni pogovori v timu dajo velik prispevek $\mathrm{k}$ razvijanju sposobnosti za timsko delo. Timske sestanke naj bi članice tima načrtovale že v začetku septembra v okviru timskega akcijskega načrta. Nekateri so sledili dogovorjenim datumom, nekateri timi pa so datume timskih sestankov načrtovali sproti, po dogovoru. Posamezni strokovni delavci navajajo, da so pri sprotnih dogovorih glede datuma sestanka imeli težave pri določitvi datuma. Strokovni delavci navajajo, da so si dela in naloge v timih razdelili glede na svoja močna področja, glede na znanja 
in spretnosti ter glede na sposobnosti vsakega posameznega člana tima. Posamezne naloge so si člani znotraj tima razdelili po tandemih.

\section{Zaključek}

Skozi razvoj timskega dela smo želeli vzpostaviti takšno raven medsebojnega sodelovanja in zaupanja med člani timov, da bi strokovni delavci znotraj teh ustvarjalnih delovnih celic najprej prepoznali že doseženo stopnjo lastnega poznavanja stroke in prakse in pridobili uvid v lastne sposobnosti in zmožnosti. Pričujoči rezultati kažejo, da so strokovni delavci raziskovanega vrtca $v$ svojih strokovnih timih pridobili pomembno medkolegijalno podporo in varno delovno in učno okolje, znotraj katerega z lastno aktivnostjo vplivajo na svoj profesionalni razvoj. Razvoj strokovnih timov je potekala po fazah razvoja, ki so izpostavljene v strokovni literaturi. Rezultati končne evalvacija delovanja timov, samoevalvacije in strokovne diskusije, ki je sledila refleksijam na srečanjih strokovnih aktivov, kažejo na to, da so timi razvili lastnosti, ki so značilne za učinkovite time. Člani se zavedajo pomembnosti lastne aktivnosti in odgovornosti posameznika za boljše delovanje tima in za lasten profesionalni razvoj. Člani strokovnih timov so bili skozi raziskovalni proces sodelovalno naravnani, spodbujali so drug drugega, odkrito so izražali svoja mnenja Zelo opazno je bilo kontinuirano naraščanje občutka pripadnosti posameznih članov svojemu timu. Člani timov so poudarili lastno motiviranost in željo po sodelovanju v enaki sestavi še naprej.

Glede na rezultate pričujoče raziskave lahko sklepamo, da je v vzgojno izobraževalnih organizacijah smiselno sistematično razvijati timsko delo, saj spodbudno vpliva tako na profesionalni razvoj zaposlenih kot na izboljšanje splošne organizacijske klime.

\section{Literatura}

Arcaro, Jerry. Teams in Education: Creating An Integrated Approach. Delray Beach, Florida: St. Lucie Press, 1995.

Berliner, David Charles. The Nature of Expertise in Teaching. V Oser, Fritz et. al. (ur.), Effective and Responsible Teaching: The New Synthesis (str. 227-249). San Francisco: Jossey Bass Publishers, 1992.

Bowers, C. A., Braun, C. C., \& Morgan, B. B. Team Workload: Its Meaning and Measurement. In M. T. Brannick, E. Salas, \& C. Prince (Eds.), Team 
Performance Assessment and Measurement (pp. 85-108). Mahwah, NJ: Lawrence Erlbaum, 1997.

Brajša, Pavao Sedem skrivnosti uspešne šole. Maribor: Doba, 1995.

Fuller, Frances F. Concerns of Teachers: A Developmental Conceptualization. American Educational Research Journal, 6(2), 207-226, 1969.

Kagan, Dona M. Professional Growth Among Preservice and Beginning Teacher. American Educational Research Journal, 2, 129-169, 1992.

Gladstein, Deborah L. Groups in Context: A Model of Task Group Effectiveness. Administrative Science Quarterly, 29(4), 499-517, 1984.

Guchait, Priyanko, Puiwa Lei and Michael J. Tews. Making Teamwork Work: Team Knowledge for Team Effectiveness. The Journal of Psychology, 150(3), 300-317, 2016.

Hwang, Mark I. Relationship between Teamwork and Team Performance: Experiences from an ERPsim Competition. Journal of Information Systems Education, 29(3), 157-168, 2018.

Javrh, Petra. Splošne in andragoške zakonitosti razvoja kariere. Ljubljana: Andragoški center Slovenije, 2011.

Kobolt, Alenka (ur.). Supervizija in koučing. Ljubljana: Pedagoška fakulteta. Zavod RS za šolstvo, 2010.

Kobolt, Alenka. Timsko delo - nuja in izziv. Vzgoja in izobraževanje, letnik XLIII, številka 3-4, 2012. Ljubljana: Zavod RS za šolstvo, 2012.

Kolb, David A. The challenges of advanced professional development. New York: Prentice-Hall, 1991.

Kozlowski, Steve W. J. and Katherine J. Klein. A Multilevel Approach to Theory and Research in Organizations: Contextual, Temporal, and Emergent Processes. In K. J. Klein \& S. W. J. Kozlowski (Eds.), Multilevel Theory, Research, and Methods in Organizations: Foundations, Extensions, and new directions, 2000.

Lepičnik-Vodopivec, Jurka. Priročnik Teorija in praksa sodelovanja s starši. Ljubljana: Pedagoška fakulteta, 2012.

LePine, Jeffery A., Ronald F. Piccolo, Christine L. Jackson, Mathieu, Jesica R. Saul. A Meta-Analysis of Teamwork Processes: Tests of a Multidimensional Model and Relationships with Team Effectiveness Criteria. Personnel Psychology, 61(2), 273-307, 2008.

Loughry, Misty L., Matthew W. Ohland and Moore, Dewayne Moore. Development of a Theory-Based Assessment of Team Member Effectiveness. Educational Psychological Measurement, 67, 505-524, 2007. 
Mayer, Janez. Nastajanje celostnega pogleda - ključ za ustvarjalnost tima. V Mayer, J. (in sod.). (2001). Skrivnost ustvarjalnega tima. Ljubljana: Dedalus - Center za razvoj vodilnih osebnosti in skupin, 2001.

Ohland, M. W., Loughry, M. L., Woehr, D. J., Finelli, C. J., Bullard, L. J., Felder, R. M., \& Schmucker, D. G. The Comprehensive Assessment of Team Member Effectiveness: Development of a Behaviorally Anchored Rating Scale for Self and Peer Evaluations. Academy of Management Learning and Education, 11, 609-630, 2012.

Polak, Alenka. (1999 in 2001). Aktivnosti za spodbujanje in razvijanje timskega dela. Priročnik za timsko delo v šoli. Tempus Respect. Pedagoška fakulteta Univerze v Ljubljani. (uporabljeno s privoljenjem avtorice)

Polak, Alenka. Timsko delo v vzgoji in izobraževanju. Ljubljana: Modrijan, 2007.

Polak, Alenka. Razvijanje in reflektiranje timskega dela v vrtcu: priročnik. Pedagoška fakulteta Univerze v Ljubljani, 2012.

Robbins, Harvey and Michael Finley. The new why teams don't work: What goes wrong and how to make it right. Berrett-Koehler Publishers, 2000.

Rutar, Dušan. (ur.). Kognitivna znanost v šoli za 21. stoletje. Kamnik: Cirius, 2017.

Salas, Eduardo, Nancy J. Cooke and Michael A. Rosen. On Teams, Teamwork, and Team Performance: Discoveries and Developments. Human Factors, 50(3), 540-547, 2008.

Sheckley, B. G. in Allen, G. J. Experiential Learning: A Key to Adult Development. V L. Lamdin (ur.), Roads to the Learning Society (str. 99-109). Chicago: The Council for Adult and Experiential Learning, 1991.

Šagud, Mirjana in Anka Jurčević Lozančić. Značenje kritičke refleksije i samorefleksije za istraživanje i unapređivanje pedagoške prakse. V M. Ljubetić in B. Mendeš, (ur.). Prema kulturi (samo)vrednovanja ustanove ranog i predškolskog odgoja - izazov za promjene. Split: Nomen Nostrum $\mathrm{Mu}-$ dnić, 2012.

Tancig, Simona. Vprašalnik: Intervizija in supervizija-evalvacija; (c) Simona Tancig, PeF, 2011.

\section{Viri}

Katz, Lilian. G. (1972). Developmental Stages of Preschool Teachers. The Elementary School Journal,73(1), 50-54. Pridobljeno s http://www.jstor.org/ stable/1000851 (8. 12. 2019) 
Gregurić, Mirjana, Ljubica Bakić-Tomić, and Ana Globočnik Žunac. „Primary School Teachers' Competence in Solving Interpersonal Conflicts.“ In The 3rd International Conference on Advances and Systems Research. 2009. https://www.bib.irb.hr/462618? $\mathrm{rad}=462618$ (8. 12. 2019)

Noonan, James. (2019). An Affinity for Learning: Teacher Identity and Powerful Professional Development. Journal of Teacher Education, 70(5), 526537. https://doi.org/10.1177/0022487118788838 (10. 12. 2019)

Valenčič Zuljan, Milena in Danijela Blanuša Trošelj. (2014). Profesionalni razvoj vzgojiteljev z vidika vzgojiteljevih pojmovanj. Andragoška Spoznanja, 2o(1), 43-6o. https://doi.org/10.4312/as.20.1.43-6o (8. 12. 2019) 


\title{
Internationalisation of the curriculum: A case study from Hungary
}

\section{Zsofia Hangyal}

\begin{abstract}
Background
In recent decades the importance of building knowledge economies has led to a demand for highly skilled workforce which resulted in several developments and trends of the education and training sector in the Hungarian context and outside of it (e.g., globally, global-regionally). Knowledge economies that rely on »intellectual capital « pushed higher education institutions to put more emphasis on developing international and intercultural competence for students and academics as well; therefore internationalisation has become one of the most significant trends concerning higher education institutions (Hayes, 2020). Internationalisation of higher education refers to certain processes that enable the institutions to become more international meanwhile maintaining national features of the local higher education system, therefore the term often concerns mobility programmes, bilateral collaborations, international research networks and English-taught degree programmes for foreign students. On the other hand, recent scholarly research emphasizes that internationalisation requires a shift from quantity towards enhancing quality in higher education 'at home' and therefore place the focus more on the domestic learning environments instead of mobility indicators (Leask, 2015; Beelen, 2015; De Wit, 2010). According to the definition of Knight, internationalisation by definition is «the process of integrating international, intercultural and global dimensions into post-secondary education» however, it should not be the privilege of mobile
\end{abstract}


students and academics only (Knight, 2004: 11). The incorporation of such dimensions according to Leask, should also focus on the curriculum content as well as on the learning outcomes, teaching methods, and support services of a program of study (Leask, 2009: 209). So who is really responsible for internationalisation at a given higher education institution? Meanwhile the traditional approach according to Leask leads to international officers as the key stakeholders and mobility indicators, a recent, often unrecognized shift can be seen towards academics who create the curriculum content and teaching-learning approaches (Leask, 2013). In the Hungarian academic context, this so called traditional approach regarding internationalisation is still more relevant, with more emphasis on mobile teaching staff and on building up international research networks of academics. As a recent research project conducted with Hungarian teaching staff highlighted (Teach with Erasmus+ Research Report - Horváth, Hangyál, Kasza, \& Czirfusz, 2020), international (short-term) teaching experiences rather lead to personal professional benefits in the field of research and new academic connections than to revised teaching methods and content.

\section{Internationalised curriculum in practice}

The broader idea of an internationalised curriculum is that it could and should be applied to any classroom in any learning environment, concerning students of any background and characteristics. Recent literature regarding implementing global and intercultural skills often emphasizes on the students' own learning process and on the individual interpretation of teaching content: the so-called transformational learning approach (Jones et al, 2016). Transformational learning is essential for curriculum internationalisation as it focuses on

exposing students to alternative perspectives and cultural contexts /.../ which can result in questioning of personal identity, values, beliefs and mindsets, and can offer significant results in terms of personal growth /.../ maturity and enhanced intercultural competence and transversal or employability skills (Jones et al, 2016:3).

In practice, transformational learning can be enhanced both at creating the teaching content and in respect of learning-teaching methodologies. As for creating enhanced teaching content, introducing local cultural, ethnic or religious groups, international organisations or volunteering agen- 
cies into class topics, or even organizing field trips is a way to expose students to different cultural contexts and to global dimensions of the given subject. Transformational learning activities also aim at exploiting the diversity within the classroom: the diverse background of students can create different perspectives and a rich variety of possible teaching content (ibid). In means of teaching methods, transformational education rather expects teachers to act as facilitators who guide students through an inquiry-based process in order for them to craft their own interpretations of the topics presented and of the literature: in this way learning becomes more of a personal learning process. Therefore, the task of the teacher is to design learning activities that enable students to become proficient in self-assessment, inquiry, evidence evaluation and collaboration with peers.

\section{Case study and methods}

The initiative of creating university course focusing on the internationalisation of the curriculum comes from two university lecturers who mainly work in the fields of sociology, pedagogy, cultural and higher education studies at Eötvös Loránd University in Budapest, Hungary. The elective course shaped around the idea of merging non-formal teaching and learning methods, teaching content with intercultural and global dimensions with transformational learning experiences within a course whereas the majority of students are Erasmus incoming mobility students and the language of instruction is English. The course has been running for 5 semesters so far with increasing number of international students, and a rather scarce number of Hungarian participants (6 out of 68 in total). Through document analysis the following section the study presents how the lecturers introduced a more internationalised curriculum within the course (by implementing global and intercultural dimensions into the teaching content) merging with other teaching-learning methods such as transformational- nonformal learning or flexible curriculum design. The study also involved student evaluation survey analysis about the teaching content and teaching methods, thus classroom observation. The written student evaluation survey's questions focused on the knowledge gained about the classroom topics and the local cultural context, opinions about the classroom activities, and suggestions for improving the course in general. Participation in the written evaluation survey was voluntary and anonymous, and $65 \%$ of the students filled in the questionnaire from which $76 \%$ were female students. The age cohort of the participants of the evaluation survey is be- 
tween 20-33 years. As the survey applied only open-ended questions, the study involved qualitative data analysis.

\section{Curriculum design for an internationalised syllabus}

In creating the course structure the lecturers emphasized on internationalisation of the curriculum by involving intercultural and global dimensions into the teaching content, methods and classroom activities. Therefore it was important to set the purpose of the course and the preferred learning outcomes in the syllabus:

The main purpose of the course is to better understand cultural diversity and the realities of culturally diverse societies. The course helps students understand the positions of people of different backgrounds through the toolkit of sociology and cultural anthropology. The involvement of non-formal teaching and learning methods helps to interpret and analyse concepts of stereotypes and to find possible solutions for multicultural challenges. Further aim is active student involvement in the class topics: each participant should reflect on his or her standpoint, experiences and cultural educational background throughout the semester, therefore active classroom participation is a must. (Extract from the syllabus)

In means of transformational learning, the aim of the course was to make students more interested in learning about the classroom topics and to motivate them to participate actively in the classroom activities. For this reason, the lecturers introduced a flexible curriculum design that allowed students to choose the topics of their interest at the beginning of each semester. The main course topics were cultural anthropology, cultures and subcultures, cultural diversity, ethnicity, the concept of nation, neo-nationalism, stereotypes, sexual and gender minorities, research methods. Furthermore, the lecturers' intention was also to involve the local (Hungarian) context into the teaching content, therefore concerning the topics of neo-nationalism case studies from Hungary were presented, for example a documentary reflecting Hungarian rock music subculture which also helped to reflect upon national symbols and concepts of collective memory. Throughout the semesters most voted topics were chosen to be the main classroom themes to discuss and plan around the classroom activities, thus shaped the directions towards the final individual/group assignments. The 
main topics which are discussed during the lectures also give the basis for individual homework and reflection papers. According to the syllabus, the students' final grade consists of the quality of classroom participation, individual assignments on course topics, and of the final individual or group assignment. Based on the experiences of past semesters, the lecturers created a clear syllabus and framework for students that consist of expectations, requirements and continuous evaluation.

\section{Teaching methods and transformational learning}

Apart from the teaching content which revolves around diversity and culture, the heterogeneity of participating students coming from different countries was also in favour for creating global and intercultural dimensions within the class. This fact also helped in shaping the teaching methods towards interactive classroom activities that encouraged students to engage with others from diverse cultural and educational background and to create working relationships through group projects. Lecturing was minimalized to introduce key concepts and definitions in order to make students understand the basic concepts and give background knowledge for discussion. Teaching methods involved playful activities (for example, reading Horace Miner's article on the 'Nacirema' culture to understand Cultural Anthropology narratives only to find out that the story is about American culture) whereas students' creative task was to create a similar riddle of a national custom from an outsider's perspective. Personalization of the teaching content also played an important role in planning out the activities: for example, in grasping the meanings of culture and identity, students' task was to bring an object to class that represents their identity. Another teaching method in favour of transformational learning aimed at aligning the classroom topics with non-formal activities, such as role-play and games that served to grasp the idea of diversity and among others, the differences between prejudice and discrimination. Practical application of the topics happened by organizing field trip to the local library and introducing the activity: Judge a book by its cover! - where the students have to apply their ideas about visual representation of discrimination and stereotypes.

\section{Student evaluation survey - Findings}

The first questions of the evaluation survey concerned the knowledge gained after the course about the classroom topics and the local, Hungarian 
cultural context. Students emphasized on learning about classroom topics and deepening their understanding in certain aspects: "I knew stereotypes exist but I wasn't able to look beyond them, nor giving a precise definition of it." The term 'intersectionality' also got mentioned most of the times as a new concept for many students. As far as it concerns gaining knowledge about the Hungarian cultural context, the evaluation survey shows that although most of the students really enjoyed the topics related to the Hungarian culture (such as neonationalism), they haven't felt the amount of classroom topics was satisfactory in this regard and that they would like to have a larger overview of such topics (20\%). As an additional outcome result of the questionnaire more students (about 30\%) mentioned that thanks to the final assignment project they gained knowledge in research methodology (DIVE method, approach of intersectionality).

The next questions of the survey concerned opinions about the classroom activities. Findings show that students enjoyed the most interactive classroom activities such as group work, nonformal creative exercises, energizers and icebreakers; thus practical activities such as the library fieldtrip. As students have expressed, "with these kinds of activities you learn more than studying from a book' and 'they make learning much more enjoyable'. Due to the nature of the Faculty, a great percentage of the students study for becoming pre-school teachers: therefore they mentioned that some of the activities (especially ice-breakers) were beneficial because they could implement them in their own teaching practice later on. Group activities were underlined by other students but rather for the sake of being confronted by different perspectives ("it is good to have a conversation with someone who doesn't have the same point of view") or because of "learning something by doing not just by sitting and listening").

The last question also asked survey participants about suggestions for improving the course in general; and some of the students would appreciate making the course more dynamic and fill the course content with more interactive games and activities. As it was mentioned before, most of the students would like to learn more about Hungarian culture and even the political context. Due to the flexible curriculum design not all the topics could get involved in the final course structure which has led to some negative opinion/room for improvement from the students. Other suggestions for improvement mainly concerned technical issues and the lecturers' abilities: time- management, having a clearer structure at times. 
As a conclusion of the survey and classroom observations, most of the students gained new knowledge in diversity stereotypes, discrimination, local Hungarian culture, nonformal teaching-learning and research methods. Although the semesters did not give the opportunity to fully emerge in these topics, some of the students expressed a shift in their understandings ('Before this class, stereotypes were always negative for me, and I learned they don't have to be' or 'Now I am more aware of the bubbles I live in') which means that these student participants have questioned their interpretations of the classroom topics and somehow became more aware of their own learning process- that can be assumed as transformational learning. On the other hand, to make a more direct link of student experiences to transformational learning, an extended research needs to be done in the future by involving focus groups or semi-structured interviews. As far as the data concerning the syllabus and the teaching content shows, implementing a more internationalised curriculum got mostly positive feedbacks and evaluation, with some room for improvement (time management, more topics on local cultural context, better structure of the syllabus).

\section{Discussion}

The study aimed to show how a university course could apply a more internationalised curriculum with experimental design, intercultural and global dimensions in the teaching content and with approaches aiming at transformational learning. Although further research is needed to analyse the links between internationalised curriculums and transformational learning, the case study showed how such course initiatives could bring curricular and instructional changes into domestic institutional environments in the means of internationalisation.

\section{Literature}

Beelen, Jos and Jones, Elspeth. »Looking back at 15 years of Internationalisation at Home.»In: EAIE Forum, Winter issue, 2015.

Beelen, Jos and Jones, Elspeth. »Defining Internationalisation at Home.» In: International Higher Education, vol. 85, 2016.

Crowther, Paul, Joris, Michael, Nilsson, Bengt, Teekens, Hanneke, and Wächter, Bernd. Internationalisation at Home. A Position Paper. Amsterdam: EAIE, 2001. 
de Wit, Hans. Internationalisation of Higher Education in Europe and Its Assessment, Trends and Issues. The Hague, Netherland, NVAO, 2010.

Freire, Paulo. Pedagogy of the Oppressed. New York: Continuum, 1970.

Hangyal, Zsofia, Déri, Andras. Talking 'bout my generation: new approaches to understanding identity-formation among young people. In: Europe in transition: Diversity, Identity and Youth Work. SALTO Cultural Diversity, 11-14, 2017.

hooks, bell. Teaching to transgress: Education as the practice of freedom. New York: Routledge. 1994.

Horváth, László, Hangyál, Zsófia, Kasza, Georgina, \& Czirfusz, Dóra. Teach with Erasmus+ Research Report. Budapest: ELTE Eötvös Loránd University Department of Erasmus+ and International Programmes, 2020.

Jones, Elspeth, Coelen, Robert, Beelen, Jos, and de Wit, Hans (eds.). »Global and local internationalization.« In: Global and Local Internationalization, 1-4, Sense Publishers, 2016.

Jones, Elspeth. »Internationalization and employability: the role of intercultural experiences in the development of transferable skills." In: Public Money and management, vol. 33, No. 2. 95-104, 2013.

Kasza, Georgina, Hangyal, Zsofia. Stipendium Hungaricum Scholarship holders' expectations and attitudes. Tempus Public Foundation, Budapest, Hungary, 2019.

Knight, Jane. »Internationalization remodeled: Definition, approaches, and rationales.« In: Journal of Studies in International Education, 8(1), 5-31, 2004.

Leask, Betty and Bridge, Christopher. „Comparing internationalisation of the curriculum across the disciplines: theoretical and practical perspectives." In: Compare: a journal of comparative and international education, Vol. 43, No. 01, 79-101, 2013.

Leask, Betty and Carroll, Jude. »Moving beyond 'wishing and hoping': internationalisation and student experiences of inclusion and engagement«. In: Higher Education Research and Development 30:5, 647-659, 2011.

Leask, Betty. »Using formal and informal curricula to improve interactions between home and international students." In: Journal of Studies in International Education, Vol. 13, no. 2, 205-221, 2009.

Leask, Betty. Internationalising the Curriculum. London: Routledge, 2015. 
učenje in poučevanje 



\title{
Bralni test v 3. razredu na OŠ Loka Črnomelj
} Ana Gorše

\begin{abstract}
Uvod
Namen mojega prispevka je predstaviti 5-letno izkušnjo izvajanja Bralnega testa na Osnovni šoli Loka Črnomelj. Z načrtnim procesom opismenjevanja se učenci srečajo že takoj ob vstopu v šolo in ena osrednjih učnih dejavnosti v tem obdobju je razvoj temeljnih bralnih spretnosti in zmožnosti - tj. usvajanje in avtomatizacija tehnike branja ter razvoj bralnega razumevanja.
\end{abstract}

Tudi naš učni načrt glede razvoja bralnih sposobnosti poudarja, da razvita bralna zmožnost, tj. hitro/avtomatizirano branje $\mathrm{z}$ razumevanjem, predstavlja osrednjo učno spretnost, od katere je v veliki meri odvisna tudi nadaljnja učna, s tem pa tudi izobrazbena in poklicna pot posameznika (Učni načrt za slovenščino, 2018). To pa vedno znova potrjujejo tuje in domače študije (Bryant in Nunes, 2004; Goswami in Bryant, 1990; Pečjak 2010; Verhoeven in Snow, 2001). Hkrati pa raziskave kažejo, da zaostanki v tehniki in avtomatizaciji branja, ki nastanejo v prvem triletju, pozneje ostajajo in ti učenci med izobraževanjem nikoli ne dohitijo vrstnikov (Magajna, Gradišar, Mesarič, Pečjak in Pust, 1999). Zato je spremljanje razvoja bralnih zmožnosti učencev v prvih treh letih šolanja ena glavnih dejavnosti učitelja in tudi svetovalnih delavcev.

Mednarodne raziskave bralne pismenosti kažejo, da imajo naši 1o-letni učenci (učenci $v$ 4. razredu) slabšo bralno pismenost kot njihovi vrstniki v razvitih, $\mathrm{z}$ nami primerljivih državah sveta (PIRLS, 2011). Ob tem 
spremljevalne študije bralnih dosežkov učencev kažejo, da k dobri bralni pismenosti vodita dve »orodji«, in sicer prvo je avtomatizirana tehnika branja (ki se kaže kot tekoče in sproščeno branje), druga pa je obvladanje različnih bralni strategij, ki jih učenec uporablja pri predelavi besedila.

Spremljanje razvoja bralnih zmožnosti je pomembno zaradi več razlogov: 1) učitelju nudi povratno informacijo, kako in koliko učenci dosegajo z učnim načrtom zastavljene cilje; 2) učitelju pomaga odkrivati močne in šibke točke učencev v razvoju te zmožnosti, kar je zlasti pomembno ob pojavljanju težav pri branju. To namreč 3 ) nudi izhodišče za učinkovito intervencijo - tako omogoča učitelju učinkovitejše poučevanje in prilagajanje dela učencu $v$ okviru rednega pouka, dopolnilnega pouka in/ali individualnega dela $\mathrm{z}$ učencem; hkrati pa mu pomaga tudi pri presoji, kdaj učenca napotiti $\mathrm{k}$ svetovalnemu delavcu ali pa $\mathrm{v}$ ustrezne specializirane ustanove (Pečjak, Magajna, Podlesek, 2012).

Pri svojem raziskovanju sem ugotovila, da rezultati bralnega testa hitro pokažejo, kateri učenci ob koncu tretjega razreda osnovne šole še niso $\mathrm{v}$ zadostni meri razvili tehnike branja in bralnega razumevanja. To jih uvršča v skupino učencev, ki potrebujejo dodatno diagnostiko oz. obravnavo. S predstavitvijo primera želim spodbuditi čim več učiteljev, svetovalnih delavcev $\mathrm{k}$ uporabi testa, zato se $\mathrm{v}$ nadaljevanju osredotočam na praktične napotke pri izvedbi testa. Dodala sem možne izboljšave pri izvedbi testiranja.

Za izvedbo testiranja sem uporabila bralni test avtoric dr. Sonje Pečjak in dr. Nataše Potočnik. Gre za presejalni test, ki je predviden za uporabo na celotni populaciji učencev. Njegov namen je zbiranje podatkov z namenom identifikacije učencev, ki potrebujejo dodatne, bolj intenzivne oblike ocenjevanja. Test mora biti učinkovit, hiter in zanesljiv. Predvsem pa je pomembno, da presejalni testi odkrijejo vse učence, ki so rizični za pojav težav pri učenju, ki jih ugotavljajo (Magajna, 2011). Testirala sem torej vse učence tretješolce ( $v$ skupini so bili učenci s posebnimi potrebami, učenci z učnimi težavami, Romi, tujci) na OŠ Loka Črnomelj ter na podružnični šoli Griblje in Adlešiči.

Test ugotavlja splošno bralno zmožnost učencev ob zaključku tretjega razreda. Je standardiziran merski instrument, s katerim izmerimo, do kakšne stopnje so razvite osnovne bralne zmožnosti pri učencih. Uporabljajo ga lahko učitelji in svetovalni delavci, pred uporabo pa je potrebno opraviti usposabljanje. Bralni test je sestavljen iz dveh podtestov, in sicer Hitrost razumevanje in Stopnja razumevanja. Pridobljene informacije nam služijo predvsem za načrtovanje nadaljnjega dela na področju bralne pi- 
smenosti. Ugotovljeno stanje nudi izhodišče za pomoč učencem v okviru petstopenjskega modela obravnave učencev z učnimi težavami (Pečjak, Magajna, Podlesek, 2011).

\section{Uporabljena metodologija}

Test sestavljajo: Knjižica z bralnimi nalogami, Odgovorni list, Šablona, Grafični prikaz rezultatov.

Knjižica $\mathrm{z}$ bralnimi nalogami vsebuje dva podtesta:

- Podtest Hitrost razumevanja nam pove, kakšna hitrost branja učencu še omogoča razumevanje. Test je sestavljen iz nalog izbirnega tipa. Vsebuje povedi, ki jih je potrebno dopolniti z eno besedo. Učenci izberejo ustrezno besedo izmed petih ponujenih. Reševanje traja 7 minut in pol.

- Podtest Stopnja razumevanja nam pove stopnjo razumevanja prebranega pri posameznem učencu. Test vsebuje več krajših besedil, ki vsebujejo približno 5 povedi. Besedilu sledijo vprašanja izbirnega tipa, učenci izberejo ustrezen odgovor izmed petih možnosti. Reševanje traja 10 minut (Pečjak, Magajna, Podlesek, 2011).

Učenci odgovore obkrožijo na odgovornem listu. Knjižice z nalogami lahko tako večkrat uporabljamo, odgovore na listu pregledamo zelo hitro in enostavno s pomočjo šablone za vrednotenje rezultatov.

V testiranje so od šolskega leta 2014/15 vključeni vsi tretješolci matične šole ter podružnične šole Adlešiči in Griblje. Testiranje se izvaja konec maja oz. v začetku junija, vedno 1. šolsko uro pouka.

\section{Rezultati in ugotovitve}

Ob izvajanju testa ugotavljam, da je v nekaterih oddelkih potrebno večkrat ponoviti navodila za reševanje in pri učencih tudi preveriti, ali so jih razumeli. A to se razlikuje od posamezne generacije, zato ne gre posploševati. Učenci so imeli veliko težav z odgovarjanjem na Odgovorne liste, saj je nanje potrebno pravilne odgovore zgolj obkrožiti. Učenci so se motili s tem, da so pravilne odgovore obkroževali v knjižice z nalogami.

Po prvem delu testa smo naredili nekaj sprostitvenih vaj, saj je drugi del predstavljal težji izziv. Ker je izhodiščno besedilo daljše, so nekateri učenci (učenci s posebnimi potrebami, učenci Romi - učenci, za katere so 
mi po testiranju povedale razredničarke, da njihovo branje še ni avtomatizirano) obupali in prenehali z reševanjem ali so celo naključno obkroževali odgovore.

Po končanem delu $\mathrm{z}$ učenci (traja $45 \mathrm{~min}$ ) sem rezultate pregledala. Uporabila sem šablono in za pregled testov enega razreda in grafično predstavitev rezultatov potrebovala približno pol ure. Za vsak razred sem pripravila grafični prikaz rezultatov učencev. Rezultat na podtestu Hitrost razumevanja je označen s simbolom \#, rezultat na podtestu Stopnja razumevanja pa s simbolom $o$.

Tabela za grafični prikaz je razdeljena na tri območja:

- $\quad$ nadpovprečen rezultat (75-100 percentil),

- povprečen rezultat (25-75 percentil),

- podpovprečen rezultat (o-25 precentil).

Učiteljem predstavim rezultate posameznega učenca in opažanja ob reševanju testa, posebno o vedenju med preizkusom in motivaciji učencev za reševanje. Nekaj učencev v 3. razredu bere potiho tako, da premika ustnice, ali bere šepetaje. Vse to vpliva na hitrost branja, zato je to potrebno čim prej odpraviti. Učiteljem razrednikom izpostavim učence, ki so na enem ali obeh podtestih dosegli podpovprečen rezultat. Večinoma rezultati niso presenečenje, saj učitelj odkrije učenca $z$ bralnimi težavami že pred testiranjem kakor tudi učence, ki dosežejo nadpovprečne rezultate. Nato pa predstavimo še staršem, da ima otrok težave in potrebuje dodatno pomoč na področju branja. Načrt pomoči naredimo ob pomoči šolske svetovalne službe. $\mathrm{V}$ individualizirani načrt vključimo konkretne napotke, da učenec premaga bralne težave. Nekaj nasvetov lahko najdemo v knjigi Sonje Pečjak z naslovom Kako do boljšega branja, Zavod RS za šolstvo in šport, Ljubljana (1993). Opažam, da se v vsaj kakšnem oddelku na leto najde učenec, ki vpraša (kar med testiranjem) za razlago posamezne besede. Ko se na koncu testiranja pogovorim z vsemi učenci, ali so to besedo razumeli, je po navadi odgovor negativen. To kaže na slabše razumevanje besedišča, kar lahko uspešno vadimo z vajami iz knjige Zrno do zrna pogača (Vaje za spoznavanje pomena besed in bogatenje besedišča), avtoric Jadranke Zupan in Daše Pelikan - Prek (Zavod RS za šolstvo, Ljubljana 1997). 
Tabela 47: Število testiranih tretješolcev OŠ Loka Črnomelj (N) po posameznih letih glede na podtest (Hitrost razumevanja in Stopnja razumevanja) ter rezultati (številčno in v odstotkih) po posameznih območjih (nadpovprečen, povprečen, podpovprečen rezultat).

\begin{tabular}{|c|c|c|c|c|c|c|c|}
\hline \multirow[b]{2}{*}{ Šolsko leto } & \multirow{2}{*}{$\begin{array}{c}\mathrm{N} \\
\text { (število testiranih } \\
\text { tretješolcev na OŠ } \\
\text { Loka Črnomelj, PŠ } \\
\text { Adlešiči, PŠ Gri- } \\
\text { blje) }\end{array}$} & \multicolumn{3}{|c|}{ Hitrost razumevanja (\#) } & \multicolumn{3}{|c|}{ Stopnja razumevanja $(o)$} \\
\hline & & $\begin{array}{l}75-100 \\
\text { percen- } \\
\text { til }\end{array}$ & $\begin{array}{c}25-75 \\
\text { percen- } \\
\text { til }\end{array}$ & $\begin{array}{c}0-25 \\
\text { precen- } \\
\text { til }\end{array}$ & $\begin{array}{l}75-100 \\
\text { percen- } \\
\text { til }\end{array}$ & $\begin{array}{c}25-75 \\
\text { percen- } \\
\text { til }\end{array}$ & $\begin{array}{c}0-25 \\
\text { precen- } \\
\text { til }\end{array}$ \\
\hline $2014 / 15$ & 59 & $25(42 \%)$ & $24(41 \%)$ & $10(17 \%)$ & $14(24 \%)$ & $27(46 \%)$ & $18(30 \%)$ \\
\hline $2015 / 16$ & 74 & $26(35 \%)$ & $28(38 \%)$ & $20(27 \%)$ & $17(23 \%)$ & $25(34 \%)$ & $32(43 \%)$ \\
\hline $2016 / 17$ & $\begin{array}{l}\text { Testiranje ni bilo } \\
\text { izvedeno zaradi } \\
\text { porodniške odsot- } \\
\text { nosti izvajalke. }\end{array}$ & I & I & I & I & I & I \\
\hline $2017 / 18$ & 55 & $17(31 \%)$ & $18(33 \%)$ & $20(36 \%)$ & $7(13 \%)$ & $23(42 \%)$ & $25(45 \%)$ \\
\hline $2018 / 19$ & 53 & $10(19 \%)$ & $26(49 \%)$ & $17(32 \%)$ & $6(11 \%)$ & $15(28 \%)$ & $32(61 \%)$ \\
\hline $2019 / 20$ & 58 & $23(40 \%)$ & $25(43 \%)$ & $10(17 \%)$ & $14(24 \%)$ & $19(33 \%)$ & $25(43 \%)$ \\
\hline
\end{tabular}

Tabela 47 prikazuje podatke od šolskega leta 2014/15 do šolskega leta 2019/20. Velikost vzorca variira od vpisa učencev, a v petih letih je povprečno na OŠ Loka Črnomelj s podružničnima šolama 60 tretješolcev. Testiramo vedno vse tretješolce, kar učenci vedo vnaprej. Testiranje opravimo konec šolskega leta - konec meseca maja ali v začetku junija. Razredničarka učencem pove, da pride 1. šolsko uro učiteljica, ki bo izvedla Bralni test. Starši pa to izvedo na 1. roditeljskem sestanku v začetku šolskega leta 3. razreda.

Tabela prikazuje, koliko učencev se je na posameznem podtestu uvrstilo v zgornjih $25 \% \mathrm{v}$ skupini vrstnikov (so dosegli nadpovprečni rezultat) oz. v spodnjih $25 \%$ v skupini vrstnikov (ti so dosegli podpovprečen rezultat) ali pa se njihovi rezultati ujemajo $\mathrm{z}$ doseženim povprečjem $\mathrm{v}$ skupini svojih učencev.

Naši učenci so na testu Hitrost razumevanja v šolskem letu 2014/15 in 2019/20 dosegli najboljše rezultate - v teh letih je največ učencev med $25 \%$ najboljših v skupini vrstnikov in najmanj jih je med $25 \%$ najslabših v skupini vrstnikov. Pri testu Stopnja razumevanja so letošnji rezultati sicer veliko boljši od rezultatov iz leta 2018/19, a so bili v šolskem letu 2014/15 še boljši. Enak odstotek ( $24 \%$ ) učencev je med boljšimi $25 \%$ v skupini vrstnikov, tako v šolskem letu 2014/15 kakor tudi 2019/20. Pri učencih, uvrščenih v spodnjo sivino (ki so dosegli rezultate primerljive s $25 \%$ slabših v skupini vrstnikov), pa je bilo v šolskem letu 2014/15 uvrščenih najmanj učencev, 
največ pa v šolskem letu 2018/19 (kar $61 \%$ ). Učencev, ki se na testu Stopnja razumevanja po rezultatih uvrščajo v samo povprečje (srednje, belo območje, gl. Tabelo 47), je bilo v šolskem letu 2014/15 največ (kar $46 \%$ ), najmanj pa v šolskem letu 2018/19 (28\%).

Za lažji pregled prilagam Tabelo 48, kjer je individualni rezultat za 9 učencev in se razločneje vidi, kaj pomeni zgornjih/spodnjih $25 \%$; v Tabeli 48 je zaznati spodnjo/zgornjo sivino.

\section{Tabela 48: Rezultati Bralnega testa posameznih učencev istega razreda}

\begin{tabular}{|c|c|c|c|c|c|c|c|c|c|c|c|c|}
\hline \multicolumn{3}{|c|}{$\begin{array}{c}\text { HITROST } \\
\text { RAZUMEVA- } \\
\text { NJA } \\
\end{array}$} & \multicolumn{8}{|c|}{$\begin{array}{l}\text { RAZRED: } 3 \cdot \text { (9 naključnih rezultatov učencev) } \\
\text { UČENEC }\end{array}$} & \multicolumn{2}{|c|}{$\begin{array}{c}\text { STOPNJA } \\
\text { RAZUMEVANJA } \\
0 \\
\end{array}$} \\
\hline $\begin{array}{c}\% \\
\text { Slabših } \\
\text { bralcev }\end{array}$ & $\begin{array}{l}\text { Števi- } \\
\text { lo PRA- } \\
\text { VILNO } \\
\text { rešenih }\end{array}$ & $\begin{array}{l}\text { Uče- } \\
\text { nec } 1\end{array}$ & $\begin{array}{l}\text { Uče- } \\
\text { nec } 2\end{array}$ & $\begin{array}{l}\text { Uče- } \\
\text { nec } 3\end{array}$ & $\begin{array}{l}\text { Uče- } \\
\text { nec } 4\end{array}$ & $\begin{array}{l}\text { Uče- } \\
\text { nec } 5\end{array}$ & $\begin{array}{l}\text { Uče- } \\
\text { nec } 6\end{array}$ & $\begin{array}{l}\text { Uče- } \\
\text { nec } 7\end{array}$ & $\begin{array}{l}\text { Uče- } \\
\text { nec } \\
8\end{array}$ & $\begin{array}{l}\text { Uče- } \\
\text { nec } \\
9\end{array}$ & $\begin{array}{l}\text { Števi- } \\
\text { lo PRA- } \\
\text { VILNO } \\
\text { rešenih }\end{array}$ & $\begin{array}{l}\% \\
\text { Slabših } \\
\text { bralcev }\end{array}$ \\
\hline 100 & $24-25$ & & $\#$ & & & & & & & & $19-20$ & 100 \\
\hline 95 & $21-23$ & & & $\# 0$ & \# & & & & & $\# 0$ & $16-18$ & 95 \\
\hline 90 & $19-20$ & & & & & & & & & & 15 & 90 \\
\hline 85 & $17-18$ & & 0 & & & & & & & & 14 & 85 \\
\hline 80 & 16 & & & & 0 & & & & & & 13 & 80 \\
\hline 75 & 15 & & & & & & & & & & 12 & 75 \\
\hline 70 & & & & & & 0 & & & & & 11 & 70 \\
\hline 65 & 14 & & & & & & & & & & & 65 \\
\hline 60 & 13 & & & & & & \# & \# & \# & & 10 & 60 \\
\hline 55 & 12 & & & & & & & & & & & 55 \\
\hline 50 & 11 & & & & & & & & & & 9 & 50 \\
\hline 45 & & & & & & & & & & & 8 & 45 \\
\hline 40 & 10 & & & & & & & & & & & 40 \\
\hline 35 & 9 & & & & & & & & 0 & & 7 & 35 \\
\hline 30 & 8 & & & & & & & & & & & 30 \\
\hline 25 & 7 & \# & & & & & & 0 & & & 6 & 25 \\
\hline 20 & 6 & & & & & & & & & & & 20 \\
\hline 15 & 5 & & & & & & & & & & 5 & 15 \\
\hline 10 & $2-4$ & & & & & \# & & & & & 4 & 10 \\
\hline 5 & 1 & 0 & & & & & 0 & & & & 3 & 5 \\
\hline 0 & 0 & & & & & & & & & & $0-2$ & 0 \\
\hline
\end{tabular}

Tabela 48 prikazuje rezultate Bralnega testa 9 učencev istega razreda, izbranih je nekaj naključnih učencev iz naključnega šolskega leta. Simbola \# in $o$ na grafičnem prikazu označujeta, koliko nalog je posamezen učenec pravilno rešil na posameznem podtestu. Iz Tabele 48 je razvidno, da imata Učenca 5 in 6 veliko razdaljo med simboloma na grafičnem prikazu - to pomeni, da je prevelika razlika pri rezultatu iz Hitrosti razumevanja in Stopnje razumevanja. To lahko kaže na težave pri branju - branje je prehitro, razumevanje besedišča pa slabše.

V splošnem opažam, da učenci niso vajeni, da se pri reševanju nalog meri čas. Zato bi bilo smiselno $\mathrm{v}$ drugi polovici 3. razreda načrtno več vaditi nalog z merjenjem časa. 
V šolskem letu 2019/20 se je v vsakem oddelku po 1 učenec skušal "prebiti« čez vse naloge. To se je v preteklih letih le redko dogajalo. Učence vedno znova pred začetkom testiranja motiviram, da test ni za oceno, a naj se vseeno potrudijo. Povem jim, da mogoče pa ravno njim uspe rešiti vsem 25 oz. 20 nalog.

Veliko nam pomeni tudi rezultat učencev posameznega oddelka (celotnega), saj vidimo, da so velike razlike med njimi. Ko sestavljamo oddelke za 4. razred, razporedimo učence tako, da so nadpovprečni in podpovprečni čim bolj enakomerno porazdeljeni med vse 3 oddelke, da se preseže neenakost in bodo njihovi učni dosežki ob koncu šolskega leta približno enaki v vseh oddelkih.

\section{Zaključek}

Učitelji 3.-5. r. si lahko pri razvijanju bralnih strategij pomagamo s priročnikom Sonje Pečjak in Mire Kramarič: Bralne strategije. Učenci so v kompletu z delovnimi zvezki za 3. razred prejeli brezplačno knjižico Bralne strategije, Primeri besedil za 3. razred. Učiteljem je priročnik v veliko oporo in pomoč; knjižica z besedili pa je namenjena diferenciaciji pouka; sposobnejši učenci jo rešujejo tudi pri urah dodatnega pouka.

Šolski projektni tim je znotraj projekta BUS letno pripravil veliko medsebojnih hospitacij - učitelji smo prehajali iz razredne na predmetno stopnjo in obratno. Pripravljali/analizirali smo učne ure, na katerih so hospitirali tudi novomeški svetovalci iz Zavoda za šolstvo. Mislim, da je vse to pripomoglo, da se je na OŠ Loka Črnomelj spremenila miselnost celotnega kolektiva, da smo za bralno razumevanje učencev odgovorni vsi.

$\mathrm{Na}$ OŠ Loka Črnomelj smo na dobri poti do še boljših rezultatov Bralnega testa, ki je vsakoletni del Samoevalvacijskega poročila našega zavoda. Pomembno se mi zdi predvsem to, da pravočasno prepoznamo individualne zmožnosti učencev, še posebej tistih, ki imajo nižje bralne zmožnosti.

\section{Literatura}

Bryant, Peter, Nunes, Terezinha. »Introduction."V Handbook of Children's Literacy, 3-10. Urednika T. Nunes in P. Bryant,. Dordrecht: Kluwer Academic Publishers, 2004.

Goswami, Usha, Bryant, Peter. Phonological skills and learning to read. London: Erlbaum, 1990. 
Magajna, Lidija, Gradišar, Ana, Mesarič, Vid, Pečjak, Sonja, Pust, Nataša. Strategije preprečevanja šolske neuspešnosti in spodbujanja kvalitete učenja: interpretativni pristop (kognicija, metakognicija in motivacija). Zaključno poročilo o realizaciji projekta (1997-1999). Ljubljana: Svetovalni center za otroke, mladostnike in starše. Republika Slovenija Ministrstvo za šolstvo in šport: Urad RS za šolstvo, 1999.

Magajna, Lidija. Učenci z učnimi težavami. Prepoznavanje in diagnostično ocenjevanje. Ljubljana: Pedagoška fakulteta, 2011.

MIZŠ. Učni načrt za slovenščino. Ljubljana: MIZŠ, 2018. https://www.gov.si/assets/ministrstva/MIZS/Dokumenti/Osnovna-sola/Ucni-nacrti/obvezni/ UN_slovenscina.pdf. (25. 7. 2020)

Pečjak, Sonja, Magajna, Lidija, Podlesek, Anja. Bralni test. Ljubljana: Filozofska fakulteta, 2012.

Pečjak, Sonja, Magajna, Lidija, Podlesek, Anja. Ocenjevalna shema bralnih zmožnosti učencev 1.-3. razreda OSBZ. Univerza v Ljubljani, Filozofska fakulteta, 2012.

Pečjak, Sonja. Psihološki vidiki bralne pismenosti. Od teorije k praksi. Ljubljana: Znanstveni institut Filozofske fakultete v Ljubljani, 2010.

Pečjak, Sonja., Kramarič, Mira. Bralne strategije. Priročnik za učitelje 3., 4. in 5. razreda. Ljubljana: Rokus Klett, 2015.

PIRLS. Mednarodna raziskava bralne pismenosti PIRLS 2011. Ljubljana: Pedagoški inštitut, 2011.

Verhoeven, Ludo,, Snow, Catherine E. »Literacy and motivation: bridging cognitive and sociocultural viewpoints. "V Literacy and motivation: reading engagement in individuals and groups, 1- 20. Urednika Verhoeven, L. in Snow, C. E. Mahwah: LEA, 2001. 


\title{
The opinion of the teachers and the pupils on teaching and learning at elementary school "Jovan Dučić”
}

\author{
Vesna Kostić, Jelena Mucić, Jovana Vasić
}

\section{Summary}

Changes in the contemporary society have brought a new way of working at schools. The traditional method of teaching was focused on the teacher and required the expertise of the teachers primarily as a lecturer. Active learning refers to the student who is directly involved in the learning process, whereas the teacher should give the students an intellectual incentive, encourage their curiosity and support them in their work.

The objective of this paper was to examine the students' and the teachers' opinions on the teaching process, on the methods and the ways of students' learning and the teachers' way of working in order to improve the quality of the teaching and the learning process itself. The research was carried out both among the students from the $5^{\text {th }}$ to the $8^{\text {th }}$ grade and the selected subject teaching teachers at school "Jovan Dučić". It was noted by descriptive analysis that there is a certain degree of disagreement in the way the students and the teachers see the teaching process. The research showed that the teachers should relate more material of their subjects to other school subjects, include more integrative and project teaching in their work as well as link school materials with everyday life. According to the students' answers, we can conclude that they would find the learning process more interesting if the experts in certain areas attended their lessons or if the elder students taught the younger ones. In addition, it is necessary to encourage students to strengthen their interdisciplinary competence 
and to link the acquired knowledge with the real requirements of the working context of the $21^{\text {st }}$ century. One of the important conclusions of our research shows that it is necessary to pay more attention to the individual characteristics of each student. By adopting these changes in the working process, the teachers would approach the principles of active learning, whereas the students would be more prepared for the future.

Key words: teaching, learning, student differentiation in teaching, multiple linking of teaching materials, career guidance for students.

\section{Background and the research purpose}

The characteristics of teaching which support creativity are consistent with the characteristics of good teaching and models of successful learning (De Corte, 2013; Desforges, 2001; Dryden, Vos, 2001; Meyer, 2005; 2009). ${ }^{\mathrm{I}}$ Starting with this thesis, we wanted to determine the degree up to which this model could be applied to our school.

The research on the way students learn, as well as the way the teachers at elementary school "Jovan Dučić" organise the teaching process, was carried out as a part of the planned activities of the team for the School Development Plan (SDP). Considering the previous researches, the students' results at the final exam, as well as the students' results at the competitions in the past period, the SDP team came to the conclusion that it is necessary to focus the teaching team on achieving even better results at the final exam and improving the teaching process, in general, as well as building a relationship of mutual understanding between students and teachers. Learning involves a change in achievement over time (Anderson, 2013: 22). The first and the most significant condition of continuous learning is to know how to learn. The specific goal of the research, which is based on the self-assessment of the students' and teachers' achievements, was to identify the specific learning and teaching problems the students and the teachers face with. It was primarily the students' learning habits, how much they understand the material, how much time they spend learning in classes and at home on their own, what makes learning easier for them, how much material from different subjects they connect with everyday life, that really interested us in this research. During the research, we paid special attention to the teachers' way of working and to the way both students and teachers see

$1 \quad$ Slavica Maksić and Jelena Pavlović, "Teaching That Supports Creativity," in Teaching and Learning - the Quality of the Educational Process - Ed. Radmila Nikolić (Kragujevac, Serbia: University of Kragujevac, 2013), 61. 
it. We were questioning how the students and the teachers see the teaching process, how much their opinions coincide, how much they differ, how the criteria for assessment are seen by students and by teachers. The results of the research will be used for identifying and continuous solving all the weaknesses in the subject teaching.

\section{Methodology}

The total number of the students from the $5^{\text {th }}$ to the $8^{\text {th }}$ grade who attended the lectures during the research at the time was 263 . The research was carried out on a sample of 176 students, out of which 82 were male (46.6\%) and 94 female students (53.4\%). 36 of them are the $5^{\text {th }}$ graders, 62 students are the $6^{\text {th }}$ graders, 32 students are the $7^{\text {th }}$ graders and the rest 46 students are the $8^{\text {th }}$ graders.

\section{Tabela 49: Structure of the sample in relation to the class that respondents attend}

\begin{tabular}{|c|c|c|}
\hline Grade & Frequency & Percentages \\
\hline $5^{\text {th }}$ & 36 & 20.5 \\
\hline $6^{\text {th }}$ & 62 & 35.2 \\
\hline $7^{\text {th }}$ & 32 & 18.2 \\
\hline $8^{\text {th }}$ & 46 & 26.1 \\
\hline Total & 176 & 100.0 \\
\hline
\end{tabular}

The other part of the respondents includes 20 out of 23 subject teachers in our school. The measuring instruments used in this research include two questionnaires specially designed for this purpose: 1 . The student questionnaire- contains 49 questions of the five-step Likert scale where 1 represents a complete disagreement, and 5 is a complete agreement with the claim. The first 20 items relate to the students' habits while learning and the remaining 29 items relate to the way students see the quality of teaching at school. 2. The teacher questionnaire - contains $30 \mathrm{qu}-$ estions in the form of the five-step Likert scale. The items refer to the way of teaching process. Unlike students' questions, the questions for the teachers were put in the first person in order to give teachers an opportunity to express their opinions on their way of working. Descriptive values were analysed in the SPSS statistical programme. Quantitative methods were used in data processing. 


\section{Research procedure}

The survey in the classes from the $5^{\text {th }}$ to the $8^{\text {th }}$ grade was conducted in November and December in 2018. Although it was carried out in the peer classes, the participation was voluntary. The teachers filled the questionnaire voluntarily as well. Before they completed the questionnaire, they had been familiarised with both the structure of the questionnaire and the objectives of the research. They had been also familiarised with the method of inputting the answers and the anonymity was guaranteed at the same time. The questionnaire lasted on average about 15 minutes.

\section{Results}

The first part of the analysis included the analysis of the students' opinion on learning and teaching at school. We will point out the most indicative students' responses ${ }^{2}$, which can be good guidelines for the teachers in their future work. We can notice that the students, on average, showed a high degree of agreement with the statements related with the first part of the questionnaire (questions from 1 to 20), where they answered the questions related to their way of learning. Most students agree with the statement "the more they like a particular school subject, the more easily they acquire it". Furthermore, they try hard to memorise the most significant things in the text, to understand what they read and to follow and listen to their teachers' lectures so as to learn as much as possible in class. A great majority of the students from the $5^{\text {th }}$ to the $8^{\text {th }}$ grade agreed with the statement: "I start learning by trying to realise what exactly I have to learn" $(\mathrm{M}=4.05, \mathrm{SD}=1.264)^{3}$ and "While learning I try to remember everything that has been written" ( $M=4.05, S D=1.197$ ), whereas a small number of students agreed with the statement: "I am not interested in learning at school because the content is boring" ( $M=2.58, \mathrm{SD}=1.488$ ). Most students think that they put a lot of effort into learning because they care about the success. During the learning process they often use tables, charts and pictures. According to the students' answers we can see what their learning habits are like. While learning, most students repeat old material although they do not have bad marks and they also try to understand how information from the classroom can be used in everyday life.

2 „SDP - results of research on teaching and learning“, Primary School Jovan Ducic, last modified April 20, 2019, https://www.jovanducic.edu.rs/wp-content/uploads/2019/04/20/SRP_rezultati_istrazivanja_o_nastavi_i_ucenju.pdf 
Concerning the questions from 21. to 49. in the questionnaire in which the students write about the school teaching, we notice that the students showed a high degree of agreement with the statements that the teachers praise them for both their successful work and activity in class $(M=3.89$, $\mathrm{SD}=1.269$ ), and that the teachers answer the students' questions related to the school material $(M=3.88, S D=2.234)$. The students also said that the teachers emphasised the most important parts of the lesson in order to make it easier for students to learn $(\mathrm{M}=3.84, \mathrm{SD}=1.321)$. Also, they say that it is important for them to be given the marks publicly and with an explanation. The students appreciate the use of ICT in class, too.

On the other hand, we also notice that the students' opinions on teaching differ from the teachers' opinions and they largely disagree with the statements referring to the teachers' way of working. The students note that the teachers, while giving a lecture, present facts without asking any questions, and when they work in groups, they do not receive a specific assignment from the teacher. The teachers answer the students' questions to a greater extent than the students really think they do. Both claim that the experts do not attend their lessons. There is a big difference in the assessment of claims regarding the support of students' unusual ideas when solving a task, because students consider it to be less $(\mathrm{M}=3.17, \mathrm{SD}=1.383)$ than teachers think $(M=4.60, S D=0.681)$. The same goes for the claims that the teachers insist on linking materials from different fields and that the teachers provide students with useful pieces of advice regarding the way they learn, because the students rate it lower than the teachers themselves.

\section{Conclusions}

All students' and teachers' assessments of the claims are quite different, which leads us to more conclusions. We can assume that the students have a different experience of teaching and learning compared to the teachers, but there is enough room for learning progress and improving the teaching process. Memorising facts and learning what has been written should show both students and teachers that changes in teaching and learning process are necessary. The students haven't fully mastered the learning techniques, they do not often apply critical thinking and see the connection among different school subjects, which makes their learning more difficult. On the other hand, the teachers do not sufficiently apply new techniques of working with students which would make them more active in class. The older the students are the less they are interested in learning, so it is necessary 
to determine more detailed measures to support the students and to work on updating the teaching process which will be in accordance with everyday needs, but primarily with the students' age who the teaching is designed for. This leads us to the conclusion that coordination of activities of several teachers or subjects could lead to the progress of the teaching process. Students could be put in a situation where the use of subject and cross-curricular competences are required, and a situation where the student will not copy their already acquired knowledge but will acquire new knowledge. Considering the research results, we can conclude that the learning process should take place as much as possible in class. We suggest more group and individual work, setting research tasks, solving problem situations. Learning would be easier if there were more room for greater use of different tasks which are in accordance with students' abilities. It is necessary for the teachers to pay more attention to individual characteristics of each student, although it is hardly feasible nowadays.

In general differentiation accepts all the aspects of teaching (or curriculum). That means that the content, the process and the expected products of learning can be easily adapted (Altaras Dimitrijevic in Tatic Janevski, 2016: 87).

A greater teacher's creativity, which involves the integrative and project teaching and connects the school material with everyday life, leads to the greater quality of teaching process and easier adopting the material. In order to motivate students to learn, it is necessary to emphasize the importance of the knowledge acquired by learning various subjects for their future employment (Cizmic et al, 2016: 163). Teachers should train students as much as possible during classes to make important decisions in order to later choose an appropriate high school. The goal for students is to master their own career management skills as much as possible and become aware of their interests in terms of future occupation.

By adopting and applying all these recommendations, we believe that the teaching process as well as the learning process would significantly improve in our school. This is a continuous process which takes place in accordance with contemporary trends in society, but which also starts with the personal readiness of each individual to accept and apply them. 


\section{Literature}

Altaras Dimitrijević, Ana, Tatić Janevski S., "Education of Students of Exceptional Abilities: Scientific Basics and Guidelines for School Practice.”, Belgrade, Serbia: Institute for the Advancement of Education, 2016.

Maksić Slavica and Pavlović Jelena in Nikolić, R. (Ed.) “Teaching That Supports Creativity" in Teaching and Learning - the Quality of the Educational Process, 53-64. Kragujevac, Serbia: University of Kragujevac, 2013.

Anderson, Lorin W., "Teaching that causes change: perspectives and an overview”, in: Anderson Lorin W. (Ed.) “(pdf) Teaching for Learning - A reference guide for results-oriented teachers”, 15-35. Thessaloniki: Center for Democracy and Reconciliation in Southeast Europe, 2013.

Čizmić, Svetlana, Ivana B. Petrović, and Milica Vukelić. "Challenges of the 21st Century for the Career Education of Primary School Students' Career Education." Essay. In Proceedings of the International Scientific Conference Improving the Quality of Education in Primary Schools: Proceedings:14. October 2016., Beograd, 161-165. Belgrade, Serbia: Institute for Pedagogical Research, 2016.

\section{Sources}

School Development Plan - Research Results on Teaching and Learning. Belgrade, Serbia: Primary School Jovan Dučić, Last modified April 20, 2019. https://www.jovanducic.edu.rs/wp-content/uploads/2019/o4/20/SRP_rezultati_istrazivanja_o_nastavi_i_ucenju.pdf 



\section{Povzetki - Summaries}

Pavel Zgaga

Raziskovanje edukacije in edukacijske politike, ali o razmerju 'kraljev' in 'filozofov'

Prispevek se posveča razmerju med raziskovanjem edukacije in edukacijskimi politikami v sodobnosti. To razmerje je ključno pri načrtovanju, izvajanju in evalviranju reform edukacijskih sistemov. Pri oblikovanju politik v sodobnih demokracijah velja načelo, da morajo temeljiti na dokazih, te pa prinaša akademsko, »objektivno « raziskovanje. Akademski diskurz zagotavlja znanje, ki ga administrativni diskurz uporablja kot instrument pri upravljanju družbenega življenja. Toda predpostavka o tem, da bi bil zaradi tega akademski diskurz obenem odrešen obveznosti upravljanja ter nadrejen administrativnemu diskurzu, je problematična. Koncept upravljanja nima le instrumentalne, pač pa tudi substancialno dimenzijo, na drugi strani pa je scientifikacija oblikovanja politik v moderni dobi pripeljala do politizacije znanosti. $\mathrm{V}$ tem je vir mnogih protislovij, ki niso značilna le za sedanjo dobo. Platon je potencialni konflikt med vednostjo in močjo poskušal rešiti s fuzijo »kralja-filozofa «, kar pa Kant mnogo kasneje zavrne z utemeljitvijo, da tega ne gre pričakovati, pa tudi ne želeti, »ker posedovanje oblasti nujno kvari svobodno sodbo uma«. Tega sicer ne gre razumeti kot klica k zapiranju v »slonokoščeni stolp«, kar pa se je v minulem stoletju na specifičen način dejansko zgodilo s pojavom t.i. »the disengaged academic«. V dobi populizma in post-resničnostnega sveta so se zato ta pro- 
tislovja še zaostrila, iskanje ravnotežja dveh diskurzov pa postaja še bolj nujno. Prispevek poskuša rehabilitirati pomen ne-instrumentalne dimenzije akademskega raziskovanja: pomen formuliranja in naslavljanja kritičnih vprašanj in hipotez, nasprotnih predpostavkam vseh akterjev, ki so vpeti v oblikovanje politik.

Ključne besede: edukacijske politike, oblikovanje politik, reforme, neoliberalizem, raziskovanje edukacije

\section{Education and education policy research or on relation between ,kings' and ,philosophers'}

The article deals with the relationship between education research and educational policies in the present. This relationship is crucial in the design, implementation and evaluation of education system reforms. Policymaking in modern democracies is based on the principle that they must be evidence-based, which brings about academic, "objective" research. Academic discourse provides the knowledge that administrative discourse uses as an instrument in managing social life. However, the assumption that academic discourse would at the same time be stripped of its management responsibilities and superior to administrative discourse is problematic. The concept of governance has not only an instrumental but also a substantive dimension; on the other hand, the scientification of policy-making in the modern age has led to the politicization of science. This is the source of many contradictions that are not specific to the present age. Plato tried to resolve the potential conflict between knowledge and power through the fusion of the "king-philosopher", which Kant later dismissed on the grounds that it was not to be expected, nor desired, "because the possession of power necessarily corrupts the free judgment of the mind". This is not to be construed as a call to imprisonment in the "ivory tower", which in the last century actually happened in a specific way with the appearance of so-called "the disengaged academic". In the age of populism and the posttruth world, however, these contradictions have only intensified, and the search for a balance between the two discourses becomes even more urgent. The paper attempts to rehabilitate the importance of the non-instrumental dimension of academic inquiry: the importance of formulating and addressing critical questions and hypotheses, contrary to the assumptions of all actors involved in policy making.

Keywords: educational policies, policy making, reforms, neoliberalism, educational research 


\section{Paul Stubbs}

\section{Neenakost, revščina in izobraževanje v post-}

jugoslovanskem prostoru: Od nemobilnosti k inkluziji?

$\mathrm{V}$ postjugoslovanskem prostoru se o pomenu izobraževanja pri spodbujanju socialne pravičnosti redkeje razpravlja kot o vlogi izobraževanja pri pripravi učencev za tako imenovane "veščine", ki so potrebne na trgu dela, ali kot o vlogi izobraževanja v službi prenašalca tako imenovanih "nacionalnih-kulturnih vrednot". V svojem predavanju bo Paul Stubbs, PhD, predstavil zgodovinsko perspektivo in pregled kompleksnega odnosa med izobraževanjem in socialno stratifikacijo $\mathrm{v}$ socialistični Jugoslaviji in $\mathrm{v}$ postsocialistični tranziciji. Z uporabo empiričnih dokazov iz nedavnih raziskav, ki so jih izvedli avtor in sodelavci znotraj raziskave "Otroška revščina in strategije obvladovanja revščine gospodinjstev na Hrvaškem” ter v okviru dela znotraj zagovorniške pobude "Prihodnost socialne države na Zahodnem Balkanu”, bo predavatelj predstavil pomembnost pravičnosti pri dostopu do izobraževanja v regiji, s posebnim poudarkom na strukturnih neenakostih in stičišču izključitev, ki temeljijo na razredu, spolu, etnični identifikaciji, državljanstvu, invalidnosti, spolnosti in geografski legi. Obravnavane bodo posledice uspešnega zaključka izobraževanja kot sredstva za socialno mobilnost v nekaterih delih regije. Na koncu bo avtor predstavil še problematiko in možnosti boja zontraj regije za pedagogiko, ki jo navdihuje Friere.

Ključne besede: neenakost, revščina, inkluzija, nemobilnost

\section{Inequality, Poverty and Education in the Post-Yugoslav Space: from immobility to inclusion?}

Compared to debates on the role of education in preparing students for so-called 'skills' needed in the labour market or, indeed, on education as a transmitter of so-called 'national-cultural values', the importance of education in promoting social justice is rarely discussed in the post-Yugoslav space. Adopting a historical perspective, this presentation provides an overview of the complex relationship between education and social stratification both in socialist Yugoslavia and in the post-socialist transition. Using empirical evidence from recent research carried out by the author and others into 'Child poverty and household coping strategies in Croatia', as well as work within an advocacy initiative 'The Future of the welfare state in the Western Balkans', I will explore the importance of equity in educational access and outcomes across the region, with a particular emphasis on structural inequalities and the intersection of exclusions based on class, 
gender, 'ethnicized' identification, citizenship, disability, sexuality and geographical location. The implications of the effective ending of education as a vehicle for social mobility in parts of the region will be addressed. Finally, the presentation will outline the problems and possibilities in struggling for a Freirian-inspired anti-oppressive pedagogy across the region.

Keywords: inequality, poverty, inclusion, immobility

\section{Ljiljana Gomerčić \\ Predšolska vzgoja v državah članicah (Slovenija, Hrvaška) in nečlanicah (Bosna in Hercegovina, Srbija) EU}

Predšolska vzgoja in izobraževanje sta prvi korak v organiziranem institucionalnem izobraževanju, ki skrbita za zgodnjo vzgojo in izobraževanje predšolskih otrok. Večinoma sta organizirani v javnih in zasebnih vrtcih, $\mathrm{v}$ katerih so zaposleni strokovni delavci (vzgojitelji, pedagogi, psihologi, socialni pedagogi, specialni pedagogi). V prispevku smo uporabili deskriptivno metodo in postopek razčlenjevanja vsebin veljavnih in dostopnih dokumentov ter virov. Namen preglednega članka je bil analizirati in ugotoviti podobnosti in razlike, prednosti in primanjkljaje v vzgojno-izobraževalnih sistemih na predšolski ravni v Sloveniji in Hrvaški (EU) in v tretjih državah, Bosni in Hercegovini ter Srbiji. V članku smo prikazali pregled in analizo zakonodajnih in programskih izhodišč, kurikule za vrtce ter zaposlene v vrtcih v zgoraj naštetih državah. Namreč, ko gre za pravice otroka do vzgoje in izobraževanja ter ustvarjanja kvalitetnih pogojev na institucionalni ravni, bi pričakovali, da se otrokom nudijo vsaj podobne možnosti. Ugotovitve pregledane dostopne literature kažejo nekoliko drugačno sliko. Še veliko otrok nima nobene možnosti za vključevanje v institucionalno vzgojo in izobraževanje na predšolski stopnji zaradi različnih ovir. Čeprav je veliko otrok zgodnjega in predšolskega obdobja vključenih v katero od oblik organiziranega vzgojno-izobraževalnega sistema, je to še vedno daleč od prizadevanja, da bi bilo v vrtcih $95 \%$ otrok, vsaj v tretjih državah ne. Želeli smo videti, kako in na kakšen način se odvijata predšolska vzgoja in izobraževanje v zgoraj naštetih državah, zato smo izvedli mednarodno primerjalno analizo in jo prikazali v članku.

Ključne besede: izobraževanje, mednarodna primerjava, predšolski otrok, predšolska vzgoja, zakonodaja 


\section{Preschool education in member (Slovenia, Croatia) and non-member (Bosnia and Herzegovina, Serbia) countries of the EU}

Preschool education is the first step in organised institutional education, which is involved in both early childhood education and preschool education. It is primarily organised in public and private kindergartens that employ professional staff (teachers, educators, psychologists, social educators, special educators). In the paper we used a descriptive method and a procedure for parsing the contents of valid and accessible documents and resources. The purpose of the review article was to analyse and determine the similarities and differences, advantages and disadvantages in educational preschool systems in Slovenia and Croatia (EU) and in third countries Bosnia and Herzegovina and Serbia. The article presents an overview and analysis of legislative, programme resources, kindergarten curricula and kindergarten staff in the above-mentioned countries. In fact, concerning children's rights and education, as well as the creation of satisfactory conditions at the institutional level, we expected the children to be provided at least similar opportunities. The findings resulting from the reviewed accessible resources paint a slightly different picture. There is still a large number of children without any opportunities for becoming involved in institutional education at the preschool level due to various obstacles. Irrespective of the fact that a large number of children attending early childhood and preschool education is involved in some form of organised educational system, that is still far from the expected $95 \%$ of children involved in kindergartens, primarily in third countries. We were striving to determine how and in what way preschool education functions in the above-mentioned countries. Hence, we performed an international comparative analysis and presented the findings in the article.

Keywords: education, international comparison, legislation and regulation, preschool child, preschool education

Elena Nacevska, Tanja Oblak-Črnić, Danica Fink-Hafner, Barbara Brečko

\section{Evropska študijska mobilnost in karierni načrti mladih}

Prispevek se osredotoča na študijsko mobilnost kot na dejavnik, ki vpliva na oblikovanje kariernih načrtov mladih in njihovih načrtov glede zaposlovanja. Na podlagi pregleda literature o potencialnih dejavnikih, ki vplivajo na mednarodno študijsko mobilnost, raziskava vključuje naslednje sklope dejavnikov: obstoj programa Erasmus, predhodne izkušnje z mednarodno 
izmenjavo, ekonomske, kulturne in socialne razmere študentov ter njihove osebne usmeritve. Predstavljeni so podatki raziskave, ki je bila izvedena jeseni 2018 med tujimi in domačimi študenti prve in druge stopnje na Fakulteti za družbene vede. Obdelava podatkov je pokazala, da v grobem lahko govorimo o dveh skupinah študentov - o skupini, ki ostaja doma in nima niti načrtov glede prihodnje kariere izven lastne države, in o skupini, ki je že bila na izmenjavi in/ali to še načrtuje.

Načrti za karierno prihodnost med anketiranimi se ne razlikujejo le zaradi individualnih želja in izbir, temveč tudi zaradi mnogih strukturnih dejavnikov. Med ključnimi navedenimi razlogi za vključitev v mednarodno izmenjavo so spoznavanje drugih kultur, vzpostavljanje medosebnih stikov in mednarodnih povezav, izboljšanje znanja tujega jezika in izboljšanje zaposlitvenih možnosti doma, med ključnimi ovirami zanjo pa so predvsem socialno-ekonomske okoliščine. Pri slednjem izstopa razlika med spoloma.

Ključne besede: karierna mobilnost, študijski program Erasmus, študentje, kvantitativna raziskava, Evropa

\section{European study on mobility and youth career plans}

The article focuses on student mobility as a factor which influences how young people create their careers and their plans for employment. Based on a literature review of potential variables impacting international student mobility, a study was conducted of the following groups of factors: existence of the Erasmus programme, previous experience with international exchange, students' economic, cultural and social backgrounds and their personal orientations. Data from a survey carried out in autumn 2018 among foreign and domestic students of the first and second levels of study at the Faculty of Social Sciences, University of Ljubljana, are presented. Analysis of the data shows we can roughly talk of two types of students: one group that is at home and does not plan a future career outside their own country, and another group that has already been on an exchange and/ or plans to do so. The respondents' creation of future career plans varies depending on individual preferences and choices, but also the impact of several structural factors. The key factors for participating in international exchanges are learning about other cultures, establishing interpersonal contacts and international connections, improving both foreign language skills and employment opportunities at home, regarding which socioeco- 
nomic circumstances are the main obstacles. Here, gender differences are also evident.

Keywords: Career mobility, Erasmus study programme, students, quantitative research, Europe

\section{Maruša Hauptman Komotar}

\section{Mobilnost študentov v primerjalni perspektivi:}

\section{Slovenija in Nizozemska}

Prispevek se ukvarja $\mathrm{z}$ razvojem in izvajanjem politik, strategij in praks na področju mobilnosti študentov v Sloveniji in na Nizozemskem. Obe državi sta od leta 1999 članici Evropskega visokošolskega prostora in s tem bolonjskega procesa, vendar $\mathrm{v}$ raziskovanju visokega šolstva nista pogosto $\mathrm{v}$ središču primerjalnih analiz. V tem okviru išče prispevek odgovore na raziskovalno vprašanje, kakšen poudarek namenjajo študentski mobilnosti politike in strategije (internacionalizacije) na nacionalni in institucionalni ravni slovenskega in nizozemskega visokega šolstva, in na tej podlagi ugotavlja, ali se v njih opredeljeni cilji glede študentske mobilnosti tudi uresničujejo v praksi. Uvodoma se osredotoča ločeno na slovenski in nizozemski primer, kjer najprej preučuje izvajanje nacionalnih in institucionalnih politik in strategij (internacionalizacije) visokega šolstva v kontekstu študentske mobilnosti. Za tem podrobneje analizira tudi gibanja v dolgoročni (diplomski) in kratkoročni (kreditni) mobilnosti, s čimer zagotavlja ustrezno iztočnico razprave o uresničevanju zastavljenih ciljev politik in strategij na tem področju v praksi. Predhodna spoznanja umešča v nadaljevanju v kontekst primerjalne analize in ugotavlja podobnosti in razlike v razvoju in izvajanju politik, strategij in praks v študentski mobilnosti med obema primeroma držav. V zaključnem delu postavlja (primerjalna) dognanja v širši kontekst Evropskega visokošolskega prostora, kjer po eni strani s teoretskimi argumenti koncepta institucionalnega izomorfizma pojasnjuje razloge v prid zbliževanju držav bolonjskega procesa na področju mobilnosti študentov, po drugi strani pa s priznavanjem omejitev tega teoretskega okvira izpostavlja vpliv kontekstualno pogojenih okoliščin, ki na nacionalni, institucionalni in disciplinarni ravni posameznih visokošolskih sistemov ustvarjajo tako priložnosti kot izzive za študentsko mobilnost.

Ključne besede: mobilnost študentov, internacionalizacija, Slovenija, Nizozemska, evropski visokošolski prostor 


\section{Student mobility from the comparative perspective:}

Slovenia and the Netherlands

This contribution deals with the development and implementation of student mobility policies, strategies and practices in Slovenia and the Netherlands. Since 1999, both countries are members of the European Higher Education Area and hence, the Bologna Process but they are rarely in the focus of analyses in comparative higher education research. In this context, the contribution seeks answers to the research question of what emphasis is given to student mobility in (internationalisation) policies and strategies at the national and institutional level of Slovenian and Dutch higher education and on this basis, it determines whether the defined strategic objectives related to student mobility are also being implemented in practice. Initially, it focuses separately on the Slovenian and Dutch county case, where it firstly examines the implementation of national and institutional (internationalisation) policies and strategies related to student mobility. After that, it also analyses in more detail trends in long-term (degree) and shortterm (credit) mobility, thereby providing an adequate starting point for discussing the implementation of the defined policy objectives in this field in practice. In the continuation, it places preliminary findings in the context of comparative analysis and identifies similarities and differences in the development and implementation of policies, strategies and practices in student mobility in the two country cases. In the final part, it places (comparative) findings in the broader context of the European Higher Education Area and theoretically explains the main arguments in favour of convergence among Bologna Process countries with the concept of institutional isomorphism. But by acknowledging the limits of this theoretical framework, it exposes the impact of contextually-determined circumstances on both opportunities and challenges for student mobility at the national, institutional and disciplinary level of individual higher education systems.

Keywords: student mobility, internationalization, Slovenia, the Netherlands, European Higher Education Area

\section{Barbara Baloh, Silva Bratož}

\section{Spodbujanje medkulturne zmožnosti s čezmejnimi razredi} Osnovni namen pričujočega prispevka je predstaviti rezultate akcijske raziskave, ki vključuje čezmejno sodelovanjue med šolami z istim in različnim učnim jezikom na meji med Italijo in Slovenijo. Raziskava je bila izvedena v okviru projekta EDUKA 2 - Čezmejno upravljanje izobraževanja (projekt 
Interreg med Slovenijo in Italijo). Akcijska raziskava je najprej vključevala oblikovanje skupnih učnih vsebin in orodij, in sicer z upoštevanjem izbranih učnih pristopov in strategij sodobnega učnega okolja. Sledila je izvedba dejavnosti v obliki čezmejnih razredov, v okviru katerih so se učenci sorodnih šol iz obeh strani meje srečevali ter vključevali v različne učne dejavnosti. Tovrstna oblika sodelovanja je omogočila medsebojno spoznavanje, vzpostavljanje prijateljskih vezi ter izmenjavo šolskih izkušenj tako med učenci kot med učitelji, kar je osnova za pozitivna stališča do jezikovne in kulturne raznolikosti.

Ključne besede: sodobna didaktična izhodišča, medkulturna zmožnost, sorazumevalna zmožnost, učna okolja

\section{Fostering intercultural competences through cross-border} classrooms

The main aim of the present paper is to present the results of an action research based on cross-border cooperation between schools with the same or different language of instruction in the cross-border region between Italy amd Slovenia. The research is related to the project EDUKA 2 - Cross-border Governance of Education, an Interreg project between Slovenia and Italy. The first part of the action research involved the development of learning content and tools taking into account selected teaching approaches and strategies of the contemporary learning environments. The second part consisted in carrying out activities in the form of »cross-border classrooms « which gave learners from both sides of the border the opportunity to meet and take part in common activities. This kind of cooperation gave the participants, both learners and teachers, the opportunity to develop friendly relationships and exchange learning/teaching experiences, which is the pre-condition for the development of positive attitudes towards cultural and linguistic diversity.

Keywords: contemporary teaching approaches, intercultural competences, communicative competence, learning environments

\section{Nebojša Pavlović}

\section{Socialni dejavniki in ocena uspešnosti učiteljev na fakultetah}

Povzetek: Obveznost, da je treba delo učiteljev na fakulteti oceniti, je bila od uvedbe bolonjskih reform v visokem šolstvu deležna različnih reakcij. Možnost, da bi bilo vrednotenje priložnost za reševanje problemov ali da bi prispevalo h kakovosti pri delu fakultete, ni bila upravičena. Cilj razi- 
skave se je osredotočal se na vrednotenje načina dela učiteljev. Raziskava je bila izvedena na vseh nacionalnih fakultetnih institucijah v Srbiji, kjer so bili anketirani učitelji, o tem, kako vrednotijo njihovo delo $\mathrm{v}$ teh institucijah. Analiza povedanega je pokazala pomanjkljivosti pri ocenjevanju dela učiteljev, vključno z njihovimi predlogi za izboljšanje samega procesa ocenjevanja. Te trditve bi morale voditi $\mathrm{k}$ boljšemu delu $\mathrm{v}$ visokošolskih zavodih. Ustvarjanje novih modelov vrednotenja dela učiteljev naj bi tako prispevalo $\mathrm{k}$ boljšim rezultatom. Med številnimi težavami, ki jih povzročajo bolonjske reforme, se ocenjevanje dela učiteljev pojavlja na vrhu seznama. Potreba po standardizaciji dela zaposlenih v visokem šolstvu je vključevala tudi obveznost ocenjevanja oziroma vrednotenja dela učiteljev. Pomanjkanje evalvacije pomembno vpliva na kakovost dela učiteljev. Zato je bila razvita definicija vrednotenja. $\mathrm{V}$ skladu s tem je evalvacija definirana kot postopek, $\mathrm{v}$ katerem učitelji analizirajo same sebe, in sicer po predhodno določenih merilih in standardih. Bolonjski proces zahteva natančno merjenje dela učiteljev, da bi razvili jasne norme, standarde in postopke v učnih procesih. Pri evalviranju dela učitelja pa so se pojavile težave. Kako opraviti evalvacijo? Kdo je kompetenten za evalviranje učiteljev? Kako oblikovati ocene? Kako so ocene za ocenjevanje lahko koristne učiteljem?

Ključne besede: ocena učiteljevega dela, fakulteta, socialni udeleženci, učitelji, študenti

\section{Social factors and teacher performance evaluation in faculties}

The obligation to evaluate the work of faculty teachers since the introduction of Bologna reforms in higher education developed different reactions of faculty members. Consideration of evaluation as a possible option for solving problems of quality in faculty work was not justified. The aim of this research is focusing on the evaluation of faculty teachers' work model. The research was conducted at all national faculty institutions in Serbia where teachers were interviewed in order to present the way how their work is valued in such institutions. Analyzes of their statements discovered deficiencies in the evaluation of teachers' work including their prepositions for the improvement of the evaluation process itself. These propositions should lead to better work in higher education institutions. Also, creating new models of evaluation of teachers' work would also contribute to better results. Among many problems inducted by Bologna reforms, evaluation of teachers' work is on the top of the list. Need for standardization of employees' work in higher education included the obligation of evaluating or 
measurement of teachers' work as a consequence. Lack of evaluation significantly impacts on good work of teachers. Therefore, the definition of evaluation has been developed. According to that, evaluation is explained as a process in which teachers are analyzed, evaluated and measured according to previously determined criteria and standards. Bologna process demands precise measurement of teachers' work in order to develop clear norms, standards, and procedures in teaching processes. Problems have appeared in the evaluation of teacher's work. How to perform the evaluation? Who is competent to evaluate teachers? How to form grades? How evaluation grades can be useful to teachers?

Keywords: evaluation of teachers' work, faculty, social participants, teachers, student

\section{Maja Šebjanič Oražem}

\section{Oblikovanje poklicne identitete učiteljev slovenščine}

Dodiplomsko/začetno izobraževanje bodočim učiteljem ne le ne more zagotoviti vsega znanja, spretnosti in (zlasti predmetnospecifičnih) kompetenc, ki jih potrebujejo za poučevanje, ampak jih tudi ne more pripraviti za vse situacije, s katerimi se ob vstopu v poklic soočajo. Zato je izjemnega pomena uvajalno obdobje $\mathrm{v}$ učiteljski poklic, ki zajema pomoč mentorja in pomeni intenzivno obdobje učenja ter začetek profesionalnega razvoja učitelja (Peklaj idr., 2009; Supporting teacher competence development for better learning outcomes, 2013; Valenčič Zuljan idr., 2006).

Obdobje uvajanja $\mathrm{v}$ učiteljski poklic je pomemben dejavnik profesionalnega razvoja učitelja začetnika, saj kontekst, v katerem uvajanje poteka, in kakovost mentorja vplivata tudi na napredovanje in profesionalni razvoj začetnika (Bela knjiga, 2011; Valenčič Zuljan idr., 2007b). Kot prvo obdobje (skupaj z izobraževanjem na fakulteti) v profesionalnem razvoju učitelja je najbolj občutljivo in odločilno v učiteljevi poklicni socializaciji (Javornik Krečič, 2008) in procesu oblikovanja poklicne identitete (Muršak idr., 2011), saj se učitelj začetnik v tem času identificira z drugimi učitelji, zlasti s svojim mentorjem, ki mu predstavlja referenčno točko identifikacije.

Namen prispevka je prikazati odnos učitelja začetnika in mentorja, pričakovanja začetnikov do svojih mentorjev ter oceno začetnikov glede usposobljenosti njihovih mentorjev za opravljanje vloge mentorja in oceno mentorjeve profesionalne kompetence za poučevanje slovenščine. Ti vidiki so namreč ključni $\mathrm{v}$ procesu oblikovanja identitete začetnikov kot učiteljev 
slovenščine, saj mentor kot model poučevanja predstavlja učitelju začetniku merilo kakovosti učitelja $\mathrm{z}$ vidika poučevanja in ima najbolj neposreden vpliv na učitelja začetnika (Javornik Krečič, 2008) z vidika oblikovanja poklicne identitete in mora torej služiti kot (zgleden) model učiteljeve vloge $\mathrm{v}$ izobraževanju (Koki, 1997).

Ključne besede: učitelj začetnik, uvajanje v pedagoški poklic, poklicna identiteta, vloga mentorja, profesionalni razvoj učitelja

\section{Forming the professional identity of Slovene language teachers}

University education can not provide prospective teachers all the knowledge, skills and (especially subject-specific) competences they need for teaching and also can not prepare them for all the situations they face while entering the profession. For this reason, it is very important, that the induction period in the teaching profession involves the assistance of a mentor and is an intensive period for learning and beginning's teacher's professional development (Peklaj et al., 2009; Supporting teacher competence development for better learning outcomes, 2013; Valenčič Zuljan et al. 2006).

The induction period into teaching profession is an important factor of beginning's teacher professional development, because the context, in which the induction takes place, and the quality of a mentor also affects progression and professional development of a beginning teacher (Bela knjiga, 2011; Valenčič Zuljan et al., 2007b). The first period (together with university education) in the professional development of teacher, is the most sensitive and decisive in his professional socialization (Javornik Krečič, 2008). It is also the process of forming his professional identity (Muršak et al., 2011), because beginning teacher identifies with other teachers, especially with his mentor, who poses him a point of identification.

The purpose of the paper is to show the attitude of beginning teacher and mentor, the expectations of beginners towards their mentors, as well as the judgement of beginners regarding their mentors' ability to perform the role of mentor and the judgement of their professional competence for teaching Slovene. These aspects are crucial in the process of forming the identity of beginners as teachers of Slovene, because mentor, as a model of teaching, represents the beginner teacher a measure of teacher quality in terms of teaching and has the most direct influence on the beginning teacher (Javornik Krečič, 2008) in terms of professional identity formation and 
must therefore serve as an (exemplary) model of the teacher's role in education (Koki, 1997).

Keywords: novice teacher, introduction to the pedagogical profession, professional identity, the role of the mentor, the professional development of the teacher

\section{Irina Lešnik}

\section{Konsenz o znanstveni terminologiji s področja gledališke pedagogike}

Gledališka pedagogika predstavlja mejno področje na preseku gledališke umetnosti in pedagoške znanosti. Zaobjema tri vidike vključevanja gledaliških elementov v izobraževalni proces: gledališko opismenjevanje, gledališko ustvarjanje ter gledališče kot sredstvo za doseganje vzgojno-izobraževalnih ciljev. Tretji vidik še naprej delimo na učne pristope (drama v izobraževanju, gledališče v izobraževanju), metode in tehnike gledališke pedagogike. $\mathrm{V}$ zadnjih letih se tretji vidik gledališke pedagogike razvija predvsem skozi neformalna izobraževanja, namenjena pedagoškim delavcem, študentje razrednega pouka na pedagoških fakultetah pa se lahko $\mathrm{z}$ raznovrstnimi metodami in tehnikami gledališke pedagogike seznanijo povečini samo v okviru izbirnih predmetov. Terminološka utemeljitev področja predstavlja obvezen predpogoj za nadaljnje raziskave in znanstveno priznanje gledališke pedagogike v okviru našega izobraževalnega sistema.

Za dosego konsenza o znanstveni terminologiji s področja gledališke pedagogike je Javni sklad za kulturne dejavnosti republike Slovenije (JSKD) imenoval delovno skupino za uskladitev terminologije na področju gledališke dejavnosti v sestavi predstavnikov Pedagoške fakultete Univerze v Ljubljani, Pedagoške fakultete Univerze na Primorskem, Zavoda za šolstvo RS, Društva za razvoj gledališča v izobraževanju, Slovenskega gledališkega inštituta ter Društva ustvarjalcev Taka tuka. Opredelitve pojmov, ki jih predstavljam v nadaljevanju prispevka, so rezultat zasedanja omenjene delovne skupine.

Ključne besede: gledališka pedagogika, terminologija, gledališko opismenjevanje, ustvarjanje gledališča, celostni učni pristopi

\section{Consensus on scientific terminology in the field of drama education}

Drama Education represents the confluence between the art of theatre and the educational science. Drama Education can be divided into three cat- 
egories: theatre literacy, theatre creation and theatre as a tool for achieving curriculum goals. The third category is divided further into teaching approaches (drama in education, theatre in education), methods and techniques. In recent years Drama Education has been developing mostly through informal educational courses since it is only a facultative part of Primary School Teaching university programmes. A unified terminology is necessary for the future research and scientific acknowledgment of Drama Education in Slovenia.

The Public Fund for Cultural Activities of the Republic of Slovenia (JSKD) formed a working body to achieve consensus on proper scientific terminology in Drama Education. The institutions represented in this group are as follows: Faculty of Education, University of Ljubljana; Faculty of Education, University of Primorska; National Education Institute of the Republic of Slovenia; Association for Theatre in Education; Slovenian National Theatre Museum; Association of Creatives Taka tuka. Terminology presented in the following paper is the consensus of all the mentioned representatives. Keywords: drama education, terminology, theater literacy, theater creation, integrated learning approaches

Nika Bedek, Maruša Loboda, Urška Žerak, Janez Vogrinc, Mojca Juriševič

\section{Mentalne reprezentacije študentov pedagoških smeri} do nadarjenih in njihovega izobraževanja

$\mathrm{V}$ prispevku se osredinjamo na ugotavljanje mentalnih reprezentacij študentov - prihodnjih učiteljev - o nadarjenih učencih in njihovem izobraževanju $\mathrm{z}$ uporabo analize skupinskih asociacij (AGA), ki na področju obravnave nadarjenih še ni bila uporabljena. $S$ prečnim raziskovalnim pristopom ugotavljamo, kakšne pomene mlajši $(n=50)$ in starejši študenti $(n=50)$ pripisujejo dvema izbranima pojmoma ob predpostavki, da osebni pomeni $\mathrm{v}$ smislu pojmovnih zemljevidov pomembno sooblikujejo njihov vrednotni sistem in stališča, omogočajo komunikacijo in narekujejo strokovni pristop oziroma vedenje. Prepoznane semantične kategorije analiziranih asociacij kažejo, da mentalne reprezentacije pojma nadarjeni učenec za sodelujoče študente predstavljajo predvsem psihosocialne značilnosti nadarjenih učencev (npr. pameten, nadpovprečen, vedoželjen), v šoli na splošno ali na enem ali več predmetnih področjih, med katerimi so eksplicitno navedeni umetnost, matematika in šport. Gre za predstave, da so nadarjeni učenci superiorni na splošno ali na posameznih področjih šolskega učenja, pri če- 
mer narava zapisanih asociacij kaže površinsko poznavanje preučevanega pojma. Kaže se v pojmovanju nadarjenega učenca kot absolutno uspešnega na določenih področjih učenja, kar predstavlja skrajni pol na kontinuumu heterogenosti značilnosti nadarjenih. Le v sledeh se pojavljajo še druge psihosocialne značilnosti, vse do pola značilnosti dvojno izjemnih ali učno neuspešnih nadarjenih učencev; nekatera področja delovanja, na katerih se prav tako (lahko) razvija nadarjenost (npr. družboslovje, humanistika, naravoslovje), niso omenjena. Analiza asociacij na pojem izobraževanje nadarjenih po drugi strani kaže prevladovanje semantične kategorije konkretnih didaktično-metodičnih prilagoditev. Med mlajšimi študenti so pogosteje zastopane dodatne oblike dela kot med starejšimi, na splošno pa se asociacije vežejo na pomene v smislu nizanja aktivnih metod dela in diferenciacije, ter na kritičen odnos do obstoječe prakse dela $\mathrm{z}$ nadarjenimi $\mathrm{v}$ šoli (pogosteje pri starejših kot mlajših študentih). Rezultati kažejo na smiselnost uporabe AGA tehnike za raziskovanje mentalnih reprezentacij študentov pedagoških smeri v odnosu do študijskih vsebin, ki omogočajo doseganje kompetenc za kakovostno strokovno delo $\mathrm{z}$ nadarjenimi učenci.

Ključne besede: stališča do nadarjenih, prihodnji učitelji,izobraževanje nadarjenih, izobraževanje učiteljev, stereotipi o nadarjenih

\section{Mental Representations of Pre-service Teachers towards Gifted Pupils and Their Education}

The paper focuses on identifying the mental representations of students prospective teachers - about gifted students and their education, using the Associative Group Analysis technique (AGA), that has not yet been used in the field of research in gifted education. Using a cross-sectional research approach, we identify the meanings that younger $(n=50)$ and older students $(n=50)$ attribute to the two chosen concepts, assuming that mental maps significantly shape their value systems and attitudes, facilitate communication, and direct a professional approach or behaviour. The recognized semantic categories of the analysed associations show that mental representations of the concept of gifted student for participants are primarily psychosocial characteristics of gifted students (e.g. smart, above average, inquisitive), in school in general or in one or more subject areas, among which are explicitly listed art, math, and sport. These mental representations suggest that gifted students are superior in general or in particular areas of school subjects, whereby the nature of the associations is showing a superficial knowledge of the concept. This is reflected in the conception of the gifted student as an absolute achiever in certain areas of learning, 
which is the extreme pole on the continuum of heterogeneity of the characteristics of the gifted. Other psychosocial characteristics of gifted students are underrepresented, including characteristics of twice-exceptional gifted students or underachievers. Besides, some domains of talent (e.g., social sciences, humanities, natural sciences) where gifted students can (also) develop their talent, are not mentioned. On the other hand, the analysis of associations of the concept of gifted education shows the dominance of the semantic category concrete didactic-methodical adjustments. Younger students in comparison to older ones are expressing more frequently associations regarding additional forms of work with gifted students. In general, associations are reflecting the awareness of the importance of gifted education in terms of enumerating active methods of work, differentiation and a critical viewpoint towards existing practices of working with gifted students in schools (more often expressed in older students). The results indicate that the AGA technique is a relevant method to investigate the mental representations of prospective teachers in relation to the study contents, which enable the achievement of the competencies for quality professional work with gifted students.

Keywords: attitudes towards gifted students, future teachers, education of gifted students, teacher education, stereotypes about gifted students

\section{Ana Stanovnik Perčič}

\section{Vpliv mednarodnega sodelovanja na profesionalni razvoj izobraževalcev odraslih}

V Sloveniji za nadaljnji profesionalni razvoj izobraževalcev odraslih skrbi Andragoški center Slovenije, v okviru EU pa je nadgrajevanju znanja izobraževalcev in sistema izobraževanja odraslih že od leta 2000 dalje namenjena veja EU programa. V okviru mednarodnega sodelovanja je moč pridobiti številna znanja in izkušnje. $V$ prispevku bomo prikazali, v kolikšni meri lahko sodelovanje $\mathrm{v}$ mednarodnem projektu vpliva na različne vidike profesionalnega razvoja izobraževalcev preko rezultatov izvedenih analiz učinkov sodelovanja $\mathrm{v}$ programu EU.

Rezultati so bili pridobljeni s pomočjo analize treh virov. Prvi vir je Vmesno nacionalno poročilo o implementaciji in učinkih programa Erasmus+, ki jo je v vmesni fazi izvajanja programa Erasmus+ pripravilo Ministrstvo za izobraževanje, znanost in šport $\mathrm{v}$ sodelovanju $\mathrm{z}$ zunanjo ekspertko in CMEPIUS-om. Drugi vir predstavljajo individualna poročila o izvedeni mobilnosti, ki jih izpolni vsak udeleženec projekta Individualna mobilnost 
posameznikov. Tretji vir pa so ugotovitve polstrukturiranih intervjujev s koordinatoricama projektov na dveh izbranih ljudskih univerzah o učinkih programa EU (individualna mobilnost, strateška partnerstva) na profesionalni razvoj zaposlenih v organizaciji.

$\mathrm{O}$ pozitivnih učinkih sodelovanja $\mathrm{v}$ mednarodnih aktivnostih so poročali že posamezni udeleženci EU projektov, vse izvedene analize pa so le to potrdile. Pozitiven vpliv se kaže na področju uporabe novih učnih pripomočkov in gradiv, seznanjenosti z novimi oblikami in metodami poučevanja in uporabo le-teh, v povečanem znanju tujega jezika izobraževalcev, pridobivanja novega znanja o dobrih praksah v tujini, na socialne, jezikovne in kulturne kompetence izobraževalcev, na profesionalno področje delovanja (oz. poučevanje) ter na praktične spretnosti, pomembne za njihov profesionalni razvoj (Klemenčič, 2017). Ugotovili smo tudi, da mednarodno sodelovanje ne prinaša pozitivnih učinkov le na področju profesionalnega razvoja izobraževalcev, temveč posledično tudi kakovosti dela same organizacije, a le, če mednarodno udejstvovanje ne predstavlja dodatne aktivnosti, ki poteka poleg rednega dela, ampak je mednarodno udejstvovanje in sodelovanje ena rednih aktivnosti organizacije in je temu namenjen tudi čas zaposlenih.

Ključne besede: profesionalni razvoj, institucionalni razvoj, usposabljanje in izpopolnjevanje za andragoško delo, mednarodno sodelovanje, Erasmus+

\section{The impact of international cooperation}

on the professional development of adult educators

In Slovenia continuous professional development of adult educators is covered by the Slovenian Institute for Adult Education (SIAE). In the context of international cooperation, professional development can be gained through cooperating in Erasmus+ programme of the European Union that promotes networking, cooperation and mobility in the fields of education and training, youth and sport.

The purpose of this article is to examine the impact of the EU programme on the professional development of adult educators in Slovenia.

We examined three sources of data. First were the results of Interim National Report on the Implementation and Impact of Erasmus+ Programme on the professional development of adult educators in Slovenia, second an analysis of the impact of the individual mobility of adult educators on their professional development and third the findings of interviews with two EU Programme Coordinators at two selected adult education centres about the 
impact of the EU programme (individual mobility, strategic partnerships) on the professional development of employees in the organisation.

Participation in projects or participation in mobility strengthens the professional development of educational staff, as in this way, they acquire new expertise and practical skills, as well as social, linguistic, (inter)cultural, IC, organisational and managerial competencies, which are relevant for their professional work. Consequently, the quality of the organisation (in our case, the adult education centre) also strengthens, which has a favourable impact both on the professional development of the staff in the organisation, as well as wider in the local and regional environment, although, unfortunately, it does not reach all staff in the organisation to the same extent. Due to the large number of outsourcers at people's universities, the effects of the EU programme primarily reach regular employees of the organisation.

Keywords: professional development, institutional development, training and advanced training for andragogical work, international cooperation, Erasmus+

\section{Lela Vuković}

\section{Horizontalno učenje: Učitelj kot učeči znotraj svojega profesionalnega razvoja}

Videti je, da je horizontalno učenje obetavna strategija za nadaljnji profesionalni razvoj učiteljev v sodobni spremembi izobraževalne paradigme. Skozi koncept horizontalnega učenja učitelji delijo svoje znanje, ideje in primere dobre prakse. V našem prispevku bo poseben poudarek znotraj koncepta horizontalnega učenja namenjen učiteljskim forumom, kot tehniki, ki učiteljem omogoča izmenjavo različnih primerov dobre prakse, razjasni neskladne točke predmeta, vzbuja zanimanje učiteljev/kolegov učiteljev in jim omogoča aktivno udejstvovanje. V metodološkem okviru tega prispevka smo predstavili nekatere vidike učencev, ki se nanašajo na spremembo učnega procesa, ki so ga izvajali njihovi učitelji po izmenjavi znanja na učiteljskih forumih. Odzivi učencev so bili analizirani s tematsko deduktivno analizo, ki je pokazala, da obstaja pozitiven odnos med odnosom učencev in novim učnim pristopom, ki ga delijo učiteljski forumi, v primerjavi s tradicionalnimi metodami poučevanja.

Ključne besede: horizontalno učenje, stalni profesionalni razvoj, forumi učiteljev, nova sprememba paradigme, naracije učencev 


\section{Horizontal Learning: Teachers As Learners In Continuing Professional Development}

Horizontal learning seems to be a promising strategy for teachers' continuing professional development in a modern educational paradigm shift. Through this concept of horizontal learning, teachers share their knowledge, ideas and examples of good practice. In our paper, a special focus of the concept of horizontal learning will be given to teacher forums, as a technique that allows teachers to share various examples of good practice, clarifies the incoherent points of a subject, arouses the interest of audience/colleague teachers and provides them with active engagement. In the methodological framework of this paper, we have exemplified some of the students' perspectives referring to a change in the teaching process their teachers performed after the specific exchange of knowledge at teacher forums. Students' responses have been analyzed through thematic deductive analysis, showing that there is a positive relationship between students' attitudes and a new teaching approach shared within teacher forums, compared to traditional teaching methods.

Keywords: horizontal learning, continuing professional development, teacher forums, new paradigm shift, students' narratives

\section{Maja Kuronja, Majda Schmidt Krajnc}

\section{Zaznava samoučinkovitosti učiteljev učencev z učnimi ter čustvenimi in vedenjskimi težavami}

Proučevali smo zaznavo samoučinkovitost učiteljev učencev $\mathrm{z}$ učnimi ter čustvenimi in vedenjskimi težavami (UČVT) v redni OŠ in v OŠ pri vzgojnih zavodih. Za ta namen smo uporabili vprašalnik o samoučinkovitosti učiteljev avtoric Tschannen-Moran in Woolfolk Hoy (2001). Rezultati kažejo, da so učitelji, ki poučujejo na rednih OŠ, učinkovitejši v postavki na področju sodelovanja $z$ družino učenca $z$ UČVT. Učitelji, ki poučujejo otroke na OŠ pri vzgojnih zavodih, pa izražajo višjo učinkovitost na področju učenčevega sodelovanja, pri oceni učenčevega razumevanja poučevane snovi in na področju vodenja razreda, vezanega na obvladovanje motečega vedenja, na vzpostavljanje rutine in upoštevanja razrednih pravil.

Ključne besede: samoučinkovitost učiteljev, učenci z učnimi ter čustvenimi in vedenjskimi težavami, osnovna šola, osnovna šola pri vzgojnem zavodu 
Teachers' perception of self-efficacy with students with learning, emotional and behavioral issues

This study investigates primary school teachers' sense of efficacy in their work with the pupils with learning, emotional and behavioural difficulties (LEBD) in mainstream inclusive classrooms and in special classrooms of the pupils with LEBD from residential treatment institutions. Data for this study were collected by using Tschannen-Moran's and Woolfolk Hoy's (2001). Findings indicate higher level of efficacy of mainstream classroom teachers compared to special classroom teachers in the area of collaboration with parents of the pupils with LEBD. On the other hand, the special classroom teachers rate their efficacy higher than the mainstream classroom teachers in the items related to their pupils' engagement, and in those related to their pupils' comprehension of the learning material. They also consider themselves to be more efficient in their classroom management ability, particularly in managing pupils' disruptive behaviour.

Keywords: teachers' self-efficiency, pupils with learning, emotional and behavioural difficulties, primary school, mainstream classroom, special classroom for the pupils with LEBD from residential treatment institutions

\section{Tina Pivec, Ana Kozina \\ Dejavniki doživljanja nasilja med mladostniki iz Slovenije, Hrvaške in Švedske}

Doživljanje medvrstniškega nasilja ima za učence tako kratkoročne kot tudi dolgoročne posledice, zato je ključno prepoznavanje dejavnikov, ki pojasnujejo na pojavnost viktimizacije in so $\mathrm{v}$ pomoč pri vzpostavljanju učinkovitih intervencij. Namen prispevka je bil ugotoviti napovedno vrednost dejavnikov na ravni odnosov $\mathrm{z}$ vrstniki, odnosov $\mathrm{z}$ učitelji in na ravni posameznika (čustvene in socialne kompetence) $\mathrm{v}$ treh različnih državah: Sloveniji, Hrvaški in Švedski ter te države primerjati med seboj. V pilotni raziskavi projekta Roka v roki: Socialne in čustvene spretnosti za nediskriminatorno in vključujočo skupnost (Kozina idr., 2017), je v Sloveniji sodelovalo 123 učencev, na Hrvaškem 82 učencev in na Švedskem 75 učencev, starih med 13 in 15 let. Za dejavnike na ravni odnosov z vrstniki smo uporabili Olweusov vprašalnik nasilnež/žrtev (OBVQ, Olweus, 1997; lestvica viktimizacije) za merjenje viktimizacije; Vprašalnik prednosti in slabosti (SDQ, Goodman, 1997) za merjenje pozitivnih odnosov z vrstniki, težavnega in prosocialnega vedenja. Za merjenje dejavnikov na ravni odnosov $\mathrm{z}$ učitelji smo uporabili Lestvico »učitelj kot socialni kontekst« (TASC, Belmont, 
Skinner, Wellbron in Connell, 1992) in vprašalnik, povzet iz raziskave PISA 2015 (OECD, 2017). Za dejavnike na ravni čustvenih in socialnih kompetenc smo uporabili Vprašalnik samoopisovanja (SDQ II, Marsh, 1992) za merjenje samopodobe, Indeks medosebne reaktivnosti (IRI; Davis, 1980) za merjenje empatije in Kentuckyjevo lestvica čuječnosti (Baer, Smith in Allen, 2004) za merjenje samozavedanja. Kot statistično značilen pozitiven napovednik viktimizacije so se $\mathrm{v}$ vseh državah pokazali negativni odnosi $\mathrm{z}$ učitelji, na Hrvaškem in v Sloveniji pa so bili statistično značilen negativni napovednik viktimizacije tudi pozitivni odnosi z vrstniki. Ugotovitve kažejo na pomembno vlogo neugodnih odnosov med učenci in učitelji pri doživljanju nasilja med učenci v treh različnih državah Evropske unije, pri čemer je treba poudariti tudi vlogo odnosov med učenci. Kjer so bili odnosi med učenci boljši, je bilo namreč manj viktimizacije.

Ključne besede: viktimizacija, čustvene in socialne kompetence, odnosi $\mathrm{z}$ vrstniki, odnosi z učitelji, primerjava med državami

\section{Factors of experiencing bullying among adolescents from Slovenia, Croatia and Sweden}

Experiencing bullying has short- and long-term consequences for students, thus identifying the factors that influence the incidence of victimization and helping to establish effective interventions is crucial. The purpose of the paper was to determine the predictive value of factors at the level of peer relations, relations with teachers and at the individual level (social and emotional competences) in three different countries: Slovenia, Croatia and Sweden, and to compare these countries with each other. A pilot study of the Hand in Hand project: Social and emotional skills for tolerant and non-discriminative societies (Kozina et al., 2017) included 123 students from Slovenia, 82 students from Croatia and 75 students from Sweden, aged between 13 and 15 years. On the peer relations level, Olweus bully/victim questionnaire (OBVQ; Olweus, 1997; victimization scale) was used to measure victimization; Strengths and Difficulties Questionnaire (SDQ, Goodman, 1997) was applied for measuring positive peer relations, conduct problems, and prosocial behaviour. On the teacher-student relationship level, the Teacher as a Social Context scale (TASC, Belmont, Skinner, Wellbron, \& Connell, 1992) and a questionnaire was taken from the PISA 2015 (OECD, 2017) survey were used. To measure emotional and social competencies, Self-Description Questionnaire (SDQ II; Marsh, 1992) was used to measure self-concept, Interpersonal Reactivity Index (IRI; Davis, 1980) was used to measure empathy and Kentucky Mindfulness Scale (Baer, Smith, \& Allen, 
2004) was used for measuring self-awareness. As a statistically significant positive predictor of victimization, negative relations with teachers were shown in all countries, while in Croatia and Slovenia positive relations with peers were also statistically significant negative predictor of victimization. The findings highlight the important role of unfavourable student-teacher relationships in experiencing bullying in three different countries of the European Union. The role of peer relations should also be emphasized, as there are fewer victims where peer relations have been better.

Keywords: victimization, social and emotional competencies, peer relations, relationships with teachers, international comparison

\section{Valerija Vendramin}

\section{Nekaj epistemoloških zapiskov o raziskovanju spola v edukaciji}

Osnovni cilj prispevka je osvetliti (in izboljšati osnove) aktualnega oz. z današnjo dobo zaznamovanega raziskovanja spola v edukaciji. Šolo gre v splošnem razumeti kot ospoljen sistem. Za izhodišče si prispevek jemlje feministične epistemologije kot konceptualni okvir, ki je velikega pomena na področju edukacijskih raziskav, ki jih na različne načine prežemajo trditve o »napredku « žensk oziroma deklet in vse večjih priložnosti, ki jih imajo le-te v življenjskih potekih. Ob tem je izpostavljena nujnost, da se zavežemo »odgovornemu diskurzu v znanosti«, ki zaznava različne družbeno pogojene neenakosti. Pomembno vprašanje je, kako kvantitativno raziskovati spol, ne da bi reproducirali spolni dualizem in kako sploh definirati spol kot kategorijo. Postavljena je tudi metodološko orientirana hipoteza, ki je: pri oblikovanju analitičnih kategorij in zastavljanju vprašanj je treba upoštevati tudi povezavo med metodologijo in epistemološko orientacijo raziskovalca_ke (kar je blizu t. i. umeščeni vednosti feministične epistemologije).

Ključne besede: spol, edukacijske raziskave, feministične epistemologije, postfeminizem, odgovorni diskurz $\mathrm{v}$ znanosti

\section{Some Epistemological Notes on Gender Research in Education}

The aim of this contribution is to shed light (and to improve the fundamentals) on the contemporary research in education, marked by the coordinates of today. School is to be understood as a gendered system. The starting point of this contribution is feminist epistemologies as a conceptual framework of great importance in the field of educational research, which 
is permeated by the statements about the "progress" of women and girls and their ever so great opportunities in their life courses. The necessity to bind oneself to the "responsible discourse in science", which identifies different socially dependant inequalities, is put at the forefront. An important question is also how to quantitatively research gender without reproducing sexual dualism and how to define gender as a category. Methodologically oriented hypothesis is presented: when defining analytical categories and asking questions one need to take into account the connection between methodology and epistemological orientation of the researcher (which is very much in line with the so called situated knowledges of feminist epistemology).

Keywords: gender, educational research, feminist epistemologies, postfeminism, responsible discourse in science

\section{Simona Tancig}

\section{Raziskave digitalizacije branja in pisanja ter medijske večopravilnosti: Kakšne so spremembe na kognitivnem, čustveno-socialnem in nevrološkem področju ter $v$ učnih dosežkih?}

Pomembna funkcija vzgoje in izobraževanja v globalnem svetu je učencem omogočiti razvoj spretnosti in znanj, ki jih potrebujejo za aktivno udeležbo v družbi, ki postaja vedno bolj kompleksna in jo označujeta eksplozija informacij ter izjemno hiter razvoj računalniške in komunikacijske tehnologije (IKT). Digitalne tehnologije prinašajo mnoge nove priložnosti in tudi tveganja. Nudijo izjemne možnosti dostopanja do informacij, do njihovega prenosa in shranjevanja, večje povezanosti v globalni skupnosti, kolaborativnega ustvarjanja znanja ipd. Vendar se srečujemo tudi z nekaterimi tveganji in negativnimi učinki, ki zahtevajo veliko previdnost in premišljeno ter znanstveno podprto uporabo digitalne tehnologije v vzgojno-izobraževalnem prostoru. Namen prispevka je podati znanstveno razumevanje sprememb (psiholoških in nevroloških), ki jih digitalizacija prinaša $v$ šolski prostor na področjih branja in pisanja ter vedno bolj razširjene medijske večopravilnosti, ki imajo daljnosežne posledice za šolsko uspešnost in razvoj kompetenc, ter kako se soočati z njimi. Prispevek vključuje kritičen pregled in sintezo ugotovitev interdisciplinarnih raziskav, ki pojasnjujejo spremembe v kogniciji, čustveno-socialnih procesih in nevroloških korelatih na omenjenih področjih digitalizacije ter kakšne implikacije imajo ugotovitve raziskave za edukacijsko politiko in prakso. Za čim boljšo poja- 
snitev problematike raziskave smo pri izboru raziskovalnih člankov upoštevali predvsem dva glavna kriterija: različnost epistemoloških osnov in metodoloških pristopov od eksperimentalnih do fenomenoloških ter interdisciplinarnost raziskav od nevroedukacijskih, psiho-fizioloških, pedagoško-psiholoških in drugih. Izhajali smo iz dveh paradigem. Prva je usmerjena $\mathrm{v}$ psihološke, nevrološke in edukacijske vidike branja, pisanja, bralne pismenosti in medijske večopravilnosti. Druga je paradigma utelešene kognicije, ki še posebno $\mathrm{z}$ digitalizacijo stopa $\mathrm{v}$ ospredje raziskav in omogoča razumevanje sprememb, ki jih prinaša digitalizacija, in imajo tudi pomembne implikacije za vzgojno-izobraževalno področje.

Za kritični pogled in analizo, primerjavo in združevanje ugotovitev raziskav smo uporabili metodo analize, komparativno metodo in sintetično raziskovalno metodo.

Ključne besede: pisanje, branje, večopravilnost, učna uspešnost, digitalizacija

Research on the digitization of reading and writing and media multitasking: What are the changes in the cognitive, emotional-social and neurological areas, as well as in learning achievements?

An important function of education in the global world is to enable students to develop the skills and knowledge they need to participate actively in an increasingly complex society, characterized by the explosion of information and the rapid development of computer and communication technology (ICT). Digital technologies bring many new opportunities and risks. They offer tremendous opportunities for accessing, transferring and storing information, greater connectivity in the global community, collaborative knowledge creation, etc. However, we also face some risks and negative effects that require careful and scientifically supported use of digital technology in the educational environment.

The purpose of the paper is to give a scientific understanding of the changes (psychological and neurological) that digitalization brings to the school space in the fields of reading and writing, as well as the widespread media multitasking that have far-reaching implications for school performance and the development of competences and how to deal with them.

The paper includes a critical review and synthesis of the findings of interdisciplinary research explaining changes in cognition, emotional-social processes and neurological correlates in the aforementioned fields of digitization, and the implications of research findings for educational policy 
and practice. In order to clearly explain the research problem, the selection of research articles was based on two main criteria: the diversity of epistemological bases and methodological approaches from experimental to phenomenological, and the interdisciplinary research from neuro-educational, psycho-physiological, pedagogical-psychological and others. We based our approach on two paradigms. The first focuses on the psychological, neurological and educational aspects of reading, writing, reading literacy and media multitasking. The second is the paradigm of embodied cognition, which, in particular with digitalization, enables understanding of the changes brought by digitization, and has important implications for the educational field. We used the analysis method, the comparative method and the synthetic research method to critically look and analyze, compare and combine the research findings.

Keywords: writing, reading, multitasking, learning performance, digitization

\section{Monika Mithans, Milena Ivanuš Grmek}

\section{Besedna interakcija med poukom: kako nanjo vpliva znanje} učencev

$\mathrm{V}$ prispevku predstavljamo ugotovitve raziskave, katere namen je bil ugotoviti razlike v znanju učencev glede na stopnjo govorne participacije.

Pričakovali bi, da so učenci, ki imajo visoke ocene, aktivni soustvarjalci učnega procesa. Kako je v šolskem vsakdanu, smo ugotavljali z raziskavo, ki je bila opravljena na vzorcu 58 učencev iz 5. in 8. razreda OŠ oziroma dijakov 2. letnika gimnazije. Za merjenje govorne participacije učencev smo uporabili Flandersovo analizo razredne interakcije, ki vsebuje 10 kategorij. V vsakem razredu smo opazovali 8 ur pouka. Za izpeljavo spremenljivke govorna participacija smo uporabili kategorijo F 9: samostojne izjave učencev. Število zaznanih pojavljanj F 9 smo pretvorili na ordinalno raven in tako dobili spremenljivko govorna participacija učencev s tremi stopnjami (nižja, srednja, višja).

Rezultati kažejo, da je višja stopnja govorne participacije pogostejša pri oceni 3 ter nižja pri oceni 5 .

Takšen rezultat je nepričakovan, saj smo predvidevali, da se učenci, ki imajo kakovostnejše (pred)znanje, lažje aktivno vključujejo v pouk in sodelujejo v vsebinskem vidiku komunikacije $\mathrm{z}$ učiteljem.

Ključne besede: demokracija, participacija učencev, znanje, Flandersova analiza razredne interakcije, otrokove pravice 


\section{Speech Interaction During Class: Impact of Students Knowledge}

The article presents study findings, which wanted to determine the differences in students' knowledge in regard to the level of speech participation. It would be expected that the students with higher grades are more active co-creators of the learning process. A study sampled 58 students from 5 th and 8 th grade of primary school and 2nd grade of high school in order to determine how this reflects in school. The speech participation was measured with the 10 category Flanders analysis of the class interaction. Eight hours of classes were observed for each grade. The F-9 category: Independent statements was used to derive the speech participation variable. The number of occurrences of F-9 was converted on the ordinal level, which gave us a 3-level variable (low, medium, high).

The results show that the speech participation level is higher for grades 3 and lower for 5 .

This is unexpected, since it was anticipated that students with better (fore) knowledge more easily participate in class and communicate with the teacher.

Keywords: democracy, student participation, knowledge, Flanders analysis of class interaction, children's rights

\section{Natalija Budinski}

\section{Matematično modeliranje $\mathbf{v}$ osnovni šoli}

- napredne teme na osnovnošolski ravni

$\mathrm{V}$ tem prispevku opisujemo, kako lahko v osnovni šoli uporabimo matematično modeliranje, da bi učence mlajših let naučili naprednih konceptov, kot so funkcije. Uporabili smo primere iz resničnega sveta, da smo prikazali koncept delovanja funkcij in njihove odvisnosti od spremenljivk. Ključne besede: matematično modeliranje, funkcija, osnovna šola

\section{Mathematical modeling in primary schools}

- advanced topics at elementary level

In this paper we describe how can mathematical modeling be applied in the primary school in order to teach students of young age advanced concepts such as functions. We have used the real-world situation of population in order to highlight concept of function and dependence of variables.

Keywords: mathematical modeling, function, primary school 


\section{Meleka Asotić, Ajša Bahović Latifović}

\section{Različne metode poučevanja: Kako pristopiti k različnim nivojem tesnobe}

Izraz »zaznavanje komunikacije«, ki ga je skoval McCroskey, se nanaša na anksiozni sindrom, povezan $z$ resnično ali pričakovano komunikacijo z drugimi. Raziskovalci kot Horwitz so med učenjem raziskovali različne vrste anksioznosti, toda na komunikacijo učencev ni bilo mogoče gledati tako preprosto, saj se povezuje tudi s socialnim ozadjem in $\mathrm{z}$ osebnostnimi značilnostmi učenca. Glede na to, da so različne metode zasnovane kot odgovor na izzive učenja tujega jezika, članek spodvuja učitelja, da premaga negativne vplive komunikacijskega razumevanja. Članek temelji na delu učiteljev v regiji Sanjak. Učitelji so eno leto sodelovali z dijaki drugega in četrtega letnika poklicne srednje šole in opredelili izzive vzpostavljanja komunikacije $\mathrm{v}$ angleščini med poučevanjem. Udeležence smo vprašali, ali so izkusili tesnobo pri govorjenju drugega jezika. Študija je vključevala kavalitativne podatke iz intervjujev. V raziskovalnem prispevku so predstavljene uspešnejše metode, ki so jih učenci izbrali za premagovanje učnih težav pri sporazumevanju. Na podlagi korpusa 100 študentov, vključenih v raziskavo, so bile ključne metode za izboljšanje komunikacijskih veščin primerjane s predhodno preučenimi teoretičnimi osnovami. Rezultati so pokazali podporo konceptualizaciji tujejezične anksioznosti, vprašalnik pa je bil zanesljiv in veljaven. Ugotovljeno je bilo pomembno negativno razmerje med tesnobo, med sporazumevanjem v tudjih jezikih. Glavni stresor, ki so ga identificirali udeleženci, je nastopanje pred vrstniki. Študija je tudi ugotovila, da je tesnoba težava pri učenju jezikov in pri nekaterih študentih izčrpavajoče vpliva na govorjenje angleščine. Zato je pomembno, da so učitelji občutljivi za interakcije $\mathrm{v}$ učilnici in si pomagajo zmanjšati tesnobo $\mathrm{v}$ drugem jeziku. Potrebni pa so tudi še empirični dokazi o tem, kako učinkovite so tehnike in metode za zmanjševanje tesnobe pri učenju tujih jezikov. Ključne besede: tesnoba, Sanjak, metodika, metode poučevanja, učenje tujih jezikov

\section{Diverse teaching methods: How to approach to different levels of anxiety}

The term "communication apprehension" coined by McCroskey refers to an anxiety syndrome associated with either real or anticipated communication with others. Researchers as Horwitz proposed various types of anxiety while learning but learners' communication apprehension could not be seen as simple as that. It is also combined with social background and in- 
nately given characteristics of a learner. Following the fact, various methods are designed to respond to the challenges of learning a foreign language, this paper proposes a teacher's goal to overcome the negative impact of communication apprehension. This research paper is based on teachers' work in Sanjak region. Teachers worked with second and fourth year students from vocational high school for a year and identified the challenges of establishing communication in English while teaching. The participants were asked whether they experienced second language speaking anxiety. The study involved qualitative data from the interview data. The research paper presents more successful methods chosen by students in order to overcome learning difficulties while communicating. Based on corpus of 100 students included in the research, the crucial methods for improvement of communication skills were compared to theoretical background previously studied. The results indicated support for a conceptualization of foreign language anxiety and the questionnaire was found to be reliable and valid. A significant negative relationship was found between foreign language speaking anxiety and oral performance. The major stressor identified by the participants was interacting in front of the peers. The study also provided anxiety is clearly an issue in language learning and has a debilitating effect on speaking English for some students. So it is important that teachers are sensitive to classroom interactions and provide help to minimize second language anxiety. Eventually, there is a need for empirical evidence considering how effective anxiety reducing techniques and methods are in foreign language learning.

Keywords: anxiety, Sanjak, methodics, teaching methods, foreign language learning

Andreja Lenc

Trajnost projektnih rezultatov je ključ do učinka EU projektov

Učinek oz. sprememba delovanja posameznika ali organizacije je ključen indikator uspeha EU projektov. Diseminacija in trajnost projektnih rezultatov sta elementa, ki pomembno vplivata na to. Projekti morajo biti v fazi načrtovanja dobro premišljeni, umeščeni v razpis in potrebe okolja, da bodo prinesli rešitve, ki jih izobraževalno okolje potrebuje in jih bo tudi koristilo. Glavna parametra načrtovanja sta kakovostna analiza potreb in 
vključenost vseh deležnikov, ki so potrebni za uspeh rezultata; od ministrstva in strokovnih institucij, do končnega uporabnika, kateremu je rezultat posredno ali neposredno namenjen (Pajnič, 2017; Evropska komisija, 2019). $\mathrm{Na}$ Centru smo najprej določili dva glavna parametra trajnosti in sicer uporabo in nadgradnjo rezultatov. Dodali smo še parameter, kako široko med organizacijami se rezultat uporablja pri rednem delu po zaključku projekta - v okviru partnerstva projekta; na nacionalni ravni oz. širše v državah partnericah projekta, $v$ organizacijah izven držav partneric in na evropski ravni. Pripravili smo kratek vprašalnik in ga poslali pogodbenikom programa EU, akcija Partnerstva na področjih šolskega izobraževanja, poklicnega izobraževanja in usposabljanja ter izobraževanja odraslih. Vprašalnik smo poslali koordinatorjem projektov po e pošti (307 e naslovov), ki so bili odobreni v okviru razpisov EU v letih 2011, 2012 in 2013 in se zaključili v letih 2014 do 2016. Prejeli smo 115 popolnih odgovorov, kar predstavlja $37,5 \%$ odzivnost. Podatke smo obdelali s programom SPSS. Z raziskavo smo ugotavljali, kako trajni so projektni rezultati programa EU po 3-6 letih od zaključka projektov in kateri preverjani parametri prispevajo $\mathrm{k}$ trajnosti. Ob zaključku projektov so koordinatorji projektov poročali kakšne načrte imajo s projektnimi rezultati po zaključku izvajanja projektov ter kakšne učinke beležijo oz. še pričakujejo, zato nas je zanimalo, ali bo dejansko prišlo do njihove uresničitve.

Ključne besede: trajnost projektnih rezultatov, uporaba in nadgradnja, program EU, partnerstva

\section{The sustainability of project results is a key factor in the efficiency of EU projects}

The effect or a change in the performance of an individual or organisation is a key indicator of success in the EU projects. This effect is significantly contributed to by the dissemination and sustainability of project results. Projects need to be well-thought-out in the planning stage and embedded in the tender and the needs of the environment in order to bring the solutions which the educational environment needs and can benefit from. The main planning parameters are a high-quality analysis of requirements and the involvement of all stakeholders who are needed for a successful outcome, from the ministry and expert institutions to the end user who the result is intended for either directly or indirectly (Pajnič, 2017; European Commission, 2019). The Centre first identified two main sustainability parameters, which were the use and upgrade of results. We also added a parameter for how widely is a result used across an organisation in its regular 
work processes after a project completion - within the project partnership at the national level or more widely in project partner countries, organisations outside the partner countries and at the European level. We prepared a short questionnaire and sent it to the EU program contractors, the Partnership action in the fields of school education, vocational education and training and adult education. The questionnaire was sent to project coordinators by e-mail (307 e-mail addresses), who were approved under the EU tenders in 2011, 2012 and 2013 and closed in 2014-2016. We received 115 complete responses, representing a 37.5\% response rate. The data was processed by using SPSS. The study tested the sustainability of the EU project results, 3-6 years after the completion of projects and which parameters contribute to the sustainability. At the end of the projects, project coordinators reported what plans they had with the project results after the completion, and what effects they recorded or expected, so we were interested to know if such effects would actually come to fruition.

Keywords: sustainability of project results, use and upgrade, EU Program, Partnerships

\section{Aleksandra Stevanović, Snježana Đurđević, Bojana Sokolovic \\ Mini podjetka kot ključni element programov vseživljenjskega učenja za srednješolce}

'Mini podjetja“ je obšolski program organizacije Junior Achievement (JA) Worldwide ter Junior Achievement Europe in je največji program podjetništva na svetovni ravni. V Srbiji se program izvaja od leta 2006. Tako lahko učenci pridobivajo znanja skozi teoretični in praktični pouk, mentorski program, pa tudi prek številnih sejmov in tekmovanj. V raziskavi smo želeli raziskati vpliv programa „mini podjetja učencev“ v Srbiji. Razvoj tovrstnih znanj prestavlja usmeritev prihodnjih poslovnih in upravljavskih zmožnosti teh učencev in njihovo konkurenčnost na trgu dela.

Ciljna skupina so bili dijaki in diplomirani študenti, udelenci programa. Dodatni vir informacij so bili podatki, zbrani z vprašalnikom, v katerem so sodelovali srednješolski učitelji v Srbiji, ki so bili mentorji v študentskih podjetij.

Rezultati po obsežni analizi potrjujejo, da obstaja neposredna povezava med vodenjem mini podjetij in razvojem mehkih veščin ter poslovnega znanja mladih. Študenti in dijaki so ocenili, da so nadgradili in izboljšali svoje veščine pisanja poslovnega načrta oziroma poročila, se srečali z osno- 
vami upravljanja s časom in koordiniranja skupine, osnovami, kako začeti začetek poslovanje, pa tudi z odločanjem in razumevanjem načina poslovanja. Razvili so veščine nasotpanja, veščine sodelovanja, samozavest, komunikacijo in tekmovalni duh. Opažamo, da se je spremenil tudi odnos študentov do ustanavljanja podjetja. Učitelji so se s temi izjavami strinjali. Glede na vse navedeno predlagamo nekatera priporočila v zvezi z organiziranjem in vodenjem mini podjetij, ki so prepoznane kot dober model podjetniškega učenja v srednjih šolah.

Ključne besede: Dijaška - podjetja, razvoj, podjetništvo, veščine, motivacija

Mini - companies as an essential part of a lifelong learning program for high school students

Mini - companies are an extracurricular program of Junior Achievement (JA) Worldwide and Junior Achievement Europe and the world's largest entrepreneurship education program. In Serbia, the program has been implemented in 2006. This way, students have the opportunity to learn through theoretical and practical lessons, mentorship program, as well as through a number of fairs and competitions. In our research we wanted to examine the influence of the JA program "students' mini - company" in Serbia. Thus, the development of those skills is guidance for the future business and management capabilities of these students, and their competitivness at the labor market.

The target group were students and graduated students who have attended the program. Additional information source, were informations received from the questionnaire in which participated high school teachers in Serbia, who were the mentors of students' companies.

The results after extensive analysis confirm that there is a direct connection between running students' companies and the major development of soft skills and business knowledge of young people. The students estimated that they've upgraded and improved their skills of writing a business plan/report, met with the basics of time and team management, the basics how to initiate start-up business, as well as making decisions and the understanding of the way how bussiness operate. They develop the presenting skills, cooperative skills, self-confidence, communication and competitive spirit. It is noticed the students' attitude towards initiate a business has changed as well. The teachers agreed with those statements. Considering all mentioned, we propose some recomendations due to organizing and lead- 
ing “Students' companies", recognized as a good model of entrepreneurial learning in high schools.

Keywords: Student - companies, development, entrepreneurship, skills, motivation

\section{Silvija Komočar \\ Timsko vodenje in sistematično razvijanje strokovnih timov v vrtcu v luči profesionalnega razvoja}

Prispevek obravnava sistematično uvajanje timskega dela na ravni vrtca $\mathrm{v}$ Vrtcu Mavrica Brežice $\mathrm{z}$ namenom spodbujanja profesionalnega razvoja strokovnih delavcev. $Z$ natančnim večletnim spremljanjem in spodbujanjem razvoja strokovnih timov smo v okviru študije primera po metodi akcijskega raziskovanja $\mathrm{z}$ udeležbo člani vodstvenega tima po korakih načrtno uvajali spremembe (elemente timskega dela) v strokovne time in jih skupaj z njimi sprotno in končno evalvirali. Skozi razvoj timskega dela smo želeli vzpostaviti takšno raven medsebojnega sodelovanja in zaupanja med člani timov, da bi strokovni delavci znotraj teh ustvarjalnih delovnih celic najprej prepoznali že doseženo stopnjo lastnega poznavanja stroke in prakse in pridobili uvid v lastne sposobnosti in zmožnosti. Pričujoči rezultati kažejo, da so strokovni delavci raziskovanega vrtca $\mathrm{v}$ svojih strokovnih timih pridobili pomembno medkolegijalno podporo in varno delovno in učno okolje, znotraj katerega $\mathrm{z}$ lastno aktivnostjo vplivajo na svoj profesionalni razvoj. Razvoj strokovnih timov je potekala po fazah razvoja, ki so izpostavljene v strokovni literaturi. Rezultati končne evalvacija delovanja timov, samoevalvacije in strokovne diskusije, ki je sledila refleksijam na srečanjih strokovnih aktivov, kažejo na to, da so timi razvili lastnosti, ki so značilne za učinkovite time. Člani strokovnih timov se zavedajo pomembnosti lastne aktivnosti in odgovornosti posameznika za boljše delovanje tima in za lasten profesionalni razvoj. Skozi raziskovalni proces so bili sodelovalno naravnani, spodbujali so drug drugega, odkrito so izražali svoja mnenja Zelo opazno je bilo kontinuirano naraščanje občutka pripadnosti posameznih članov svojemu timu. Člani timov so poudarili lastno motiviranost in željo po sodelovanju v enaki sestavi še naprej. Glede na rezultate pričujoče raziskave lahko sklepamo, da je v vzgojno izobraževalnih organizacijah smiselno sistematično razvijati timsko delo, saj spodbudno vpliva tako na profesionalni razvoj zaposlenih kot na izboljšanje splošne organizacijske klime.

Ključne besede: vodstveni tim, sistematični razvoj timskega dela, profesionalni razvoj, funkcionalni tim, akcijsko raziskovanje 


\section{Team management and systematic development of professional teams in kindergarten in the light of professional development}

The article deals with the systematic introduction of teamwork at the kindergarten in the Kindergarten Vrtec Mavrica Brežice, with the aim of promoting the professional development of professionals. By closely monitoring and encouraging the development of expert teams for several years, we have systematically introduced changes (elements of teamwork) into professional teams and evaluated them, together with them, on an ongoing and final basis. Through the development of teamwork, we wanted to establish such a level of mutual cooperation and trust between team members, so that professionals within these creative work cells would first recognize the already achieved level of their own knowledge of the profession and practice and gain insight into their own abilities. The present results show that the professionals of the research kindergarten in their professional teams have gained significant intercollegiate support and a safe work and learning environment, within which they influence their professional development through their own activity. The development of professional teams was carried out according to the stages of development that are highlighted in the professional literature. The results of the final evaluation of team performance, self-evaluation, and expert discussion that followed reflections at professional asset meetings indicate that teams have developed characteristics of effective teams. The members of the professional teams are aware of the importance of their own activity and responsibility of the individual for the better functioning of the team and for their own professional development. Throughout the research process, they were collaborative, encouraged each other, openly expressed their opinions. There was a marked increase in the individual members' sense of belonging to their team. Team members emphasized their own motivation and desire to participate in the same composition.

Based on the results of this research, we can conclude that it is reasonable to systematically develop team work in educational organizations, since it has a stimulating effect on both the professional development of employees and the improvement of the overall organizational atmosphere.

Keywords: management team, systematic development of team work, professional development, functional team, action research 


\section{Zsofia Hangyal}

\section{Internacionalizacija kurikuluma:}

Študija primera na Madžarskem

Čeprav se definicije internacionalizacije lahko razlikujejo, nedavne znanstvene raziskave poudarjajo, da bi se morala internacionalizacija visokošolskih zavodov osredotočiti predvsem na učni načrt, internacionalizirani učni načrt pa bi morali obravnavati kot osrednji element tega procesa (Leask, 2015; Beelen, 2015; De Wit, 2010 ). Zato je uvedba bolj internacionaliziranega kurikula $\mathrm{v}$ domača učna okolja $-\mathrm{z}$ vključitvijo mednarodnih in medkulturnih razsežnosti v cilje, vsebino in izvajanje poučevanja in učenja - postala eden glavnih ciljev internacionalizacije visokošolskih zavodov (Knight, 2015). Prispevek predstavi študijo primera internacionaliziranega učnega načrta na madžarskem visokošolskem zavodu: in sicer prek preučevanja vsebine kurikula (zlasti mednarodnih, globalnih in medkulturnih razsežnosti, vključenih $\mathrm{v}$ učne vsebine), učnih metod in učnih rezultatov. Študija je vključevala študije primera, vključno s polstrukturiranimi intervjuji s predavatelji, ocenjevalnimi poročili študentov in analizami dokumentov. Leaskov konceptualni okvir internacionalizacije učnega načrta je bil uporabljen za oceno prednosti, slabosti in izzivov univerzitetnega tečaja (Leask, 2015).

Ključne besede: internacionalizacija doma, internacionalizacija učnega načrta, medkulturna dimenzija, Madžarska, inovativni pristopi

\section{Internationalisation of the curriculum:}

\section{A single case study from Hungary}

Although definitions of internationalisation may vary, recent scholarly research emphasizes that internationalisation of higher education institutions should mainly focus on the curriculum and consider the internationalised curriculum as the core element of such process (Leask, 2015; Beelen, 2015; De Wit, 2010). Therefore implementing a more internationalised curriculum into domestic learning environments by incorporating international and intercultural dimensions into the goals, objectives, content and delivery of teaching and learning became some of the main objectives of internationalisation of higher education institutions (Knight, 2015). The purpose of this article is to look at a single case study of an internationalised curriculum at a Hungarian higher education institution: by examining the curriculum content (in particular international, global and intercultural dimensions incorporated into the teaching content), the teaching methods and the learning outcomes. The study involved case study rese- 
arch including semi-structured interviews with lecturers, evaluation reports of university students, and document analyses. Leask's conceptual framework of internationalisation of the curriculum has been applied to assess the strengths, weaknesses and challenges of the given university course (Leask, 2015).

Keywords: internationalisation at home, internationalisation of the curriculum, intercultural dimension, Hungary, innovative approaches

\section{Ana Gorše}

\section{Bralni test v 3. razredu na Oš Loka Črnomelj}

Branje ima $\mathrm{v}$ procesu šolanja pomembno vlogo in dobro razvita bralna zmožnost učenca je eden ključnih dejavnikov njegove učne uspešnosti. V 1. triletju osnovne šole poteka intenzivni razvoj temeljnih bralnih zmožnosti, pri čemer je cilj bralnega pouka razviti avtomatizirano tehniko branja in pisanja ob ustreznem bralnem razumevanju.

Namen mojega prispevka je predstaviti 5-letno izkušnjo izvajanja Bralnega testa na Osnovni šoli Loka Črnomelj. Ugotovila sem, da rezultati bralnega testa hitro pokažejo, kateri učenci ob koncu tretjega razreda osnovne šole še niso v zadostni meri razvili tehnike branja in bralnega razumevanja. To jih uvršča v skupino učencev, ki potrebujejo dodatno diagnostiko oz. obravnavo. S predstavitvijo primera želim spodbuditi čim več učiteljev, svetovalnih delavcev $\mathrm{k}$ uporabi testa, zato se $\mathrm{v}$ nadaljevanju osredotočam na praktične napotke pri izvedbi testa. Dodala sem možne izboljšave pri izvedbi testiranja.

Ključne besede: bralni tekst, bralna zmožnost, učna uspešnost, tehnika branja

\section{A reading test in the 3 rd grade at Loka Črnomelj Elementary School}

Reading has an important role in the process of education and a well-developed reading ability is one of the key factors of their learning success. In the first three years of primary school an intensive development of basic reading abilities takes place. In this period the goal of reading classes is to develop an automated reading and writing technique with and appropriate reading comprehension.

The purpose of my article is to present a five-year experience of carrying out a reading test at the primary school Loka Črnomelj. I figured out that the results of the reading test provide fast results of which students have not properly developed the reading and reading comprehension techniques by 
the end of the third grade. This puts them in the category of students who need additional diagnostic or treatment. By presenting a case study I would like to encourage as many teachers and advisers as possible to use the test. This is why, in the next part of the article I focus on practical guidelines for carrying out the test. I also added possible improvements for the testing. Keywords: reading test, reading ability, learning success, reading technique

\section{Vesna Kostić, Jelena Mucić, Jovana Vasić \\ Mnenja učiteljev in učencev o učenju in poučevanju na Oš Jovan Dučić}

Spremembe v sodobni družbi so prinesle nov način dela v šolah. Tradicionalno poučevanje je bilo usmerjeno na učitelja in je iskalo strokovno znanje učiteljev, v vlogi predavateljev. Aktivno učenje se nanaša na učenca, ki je neposredno vključen $v$ učni proces, učitelj pa učencem daje intelektualni zagon, spodbuja njihovo radovednost in jih podpira pri delu. Namen tega prispevka je preučiti mnenja učencev in učiteljev o učnem procesu, metodah in načinih učenja učencev in dela učiteljev, da bi izboljšali kakovost poučevanja in sam učni proces. Raziskava je bila izvedena na vzorcu učencev od 5. do 8. razreda in na vzorcu učiteljev predmetnega pouka iz šole „Jovan Dučić“. Opisna analiza je razkrila obstajajo razlike v načinum kako učenci in učitelji gledajo na učni proces,. Raziskava je pokazala, da bi morali učitelji več gradiva svojih predmetov povezati $z$ drugimi šolskimi predmeti, vključiti več integrativnega in projektnega poučevanja $\mathrm{v}$ svoje delo ter povezati šolsko gradivo $\mathrm{z}$ vsakodnevnim življenjem. Iz odgovorov učencev lahko sklepamo, da bi se jim zdelo zanimivo, če bi se strokovnjaki iz različnih področij lahko udeležili pouka ali če bi starejši učenci poučevali mlajše. Prav tako je treba študente spodbuditi, da okrepijo svoje interdisciplinarne kompetence in pridobljeno znanje povežejo $\mathrm{z}$ dejanskimi zahtevami delovnega okolja 21. stoletja. Eden od pomembnih zaključkov naše raziskave kaže, da je treba posvetiti več pozornosti posameznim značilnostim vsakega učenca. Učitelji bi s sprejetjem teh sprememb v svojem delu pristopili $\mathrm{k}$ načelom aktivnega učenja, učenci pa bi bili bolj pripravljeni na prihodnost. Ključne besede: poučevanje, učenje, zunanja diferenciacija, poklicno usmerjanje učencev, multiplo povezovanje učnih gradiv

The opinion of teachers and pupils on teaching and learning in elementary school Jovan Dučić

Changes in contemporary society have brought a new way of working in schools. Traditional teaching was directed at a teacher and sought the ex- 
pertise of teachers primarily as a lecturer. Active learning refers to a student who is directly involved in the learning process, while the teacher should give intellectual impetus to students, encourage their curiosity and support them in work. The aim of this paper was to examine the student's and teacher's opinions on the teaching process, the methods and ways of pupils' learning and the work of teachers, in order to improve the quality of teaching and the learning process itself. The research was conducted on a selected group of students from the 5 th to the 8 th grade and on a selected group of teachers of subject teaching in school "Jovan Dučić. Descriptive analysis has revealed that there is a certain degree of disagreement in the way students and teachers view the teaching process. The research has shown that teachers should relate more material of their subjects to other school subjects, include more integrative and project teaching in their work, and link school materials with everyday life. According to the students' answers, we can assume that they would find it interesting if the experts in certain areas could attend their lessons or if the older students taught the younger ones. It is also necessary to encourage students to strengthen their interdisciplinary competence and to link the acquired knowledge to the real requirements of the working context of the 21st century. One of the important conclusions of our research shows that it is necessary to pay more attention to the individual characteristics of each student. By adopting these changes in the work, teachers would approach the principles of active learning, while students would be more prepared for the future.

Keywords: teaching, learning, student differentiation in teaching, career guidance for students, multiple linking of teaching materials 



\section{O avtorjih}

Pavel Zgaga je redni profesor za filozofijo edukacijo na Pedagoški fakulteti Univerze v Ljubljani. Njegov primarni raziskovalni interes je usmerjen $\mathrm{k}$ študijam visokega šolstva. Vodil je več nacionalnih in mednarodnih raziskovalnih projektov, ki so se osredotočali predvsem na vprašanja, povezana z visokim šolstvom, izobraževalnimi politikami in reformami v sodobnem evropskem in globalnem okviru. Na tem področju je objavil številna dela. Na svojem strokovnem področju je sodeloval tudi z mednarodnimi organizacijami (npr. Svet Evrope, Evropska komisija, Unesco, OECD); bil je svetovalec in vabljeni predavatelj v številnih državah.

Pavel Zgaga is Professor of Philosophy of Education at the Faculty of Education, University of Ljubljana. His primary research interest is in higher education studies. He has held several research grants and directed a number of national and international research projects, mainly focused on higher education issues, education policy and reforms in the contemporary European and global context. In these areas he has published extensively. In his field of expertise, he has been also co-operating with international organisations, (e.g. the Council of Europe, the European Commission, UNESCO, OECD) and has been a consultant and invited speaker to a number of countries.

Paul Stubbs je angleški sociolog in višji raziskovalec na Ekonomskem inštitutu v Zagrebu, na Hrvaškem. Njegovi glavni raziskovalni interesi se osre- 
dotočajo na socialno zaščito in socialno vključenost v postjugoslovanskem prostoru; civilne družbe in družbena gibanja ter prenos politik. Trenutno se ukvarja $z$ raziskovanjem zgodovinskih vidikov socialistične Jugoslavije, socialnih pravic in gibanja neuvrščenih. Med njegovimi nedavnimi objavami so: 'Social Policy, Poverty and Inequality in Central and Eastern Europe and the Former Soviet Union' (so-urednik z Sofijo An, Tatiano Chubarovo in Bobom Deaconom); 'Making Policy Move' (z Johnom Clarkejem, Daveom Baintonom in Noemi Lendvai, Policy Press); 'Transformations in Global and Regional Social Policies' (so-urednik z Alexandro Kaasch, Palgraveom Macmillanom); in 'Social Inequalities and Discontent in Yugoslav Socialism’ (so-urednik z Roryjem Archerom in Igorjem Dudo, Routledge). Je član uredniškega odbora Critical Policy Studies in Croatian Journal of Social Policy.

Paul Stubbs is an English sociologist and senior researcher at the Institute of Economics in Zagreb, Croatia. His main research interests focus on social protection and social inclusion in the post-Yugoslav space; civil society and social movements and policy transfer. He is currently researching the historical aspects of socialist Yugoslavia, social rights and the non-aligned movement. His recent publications include: 'Social Policy, Poverty and Inequality in Central and Eastern Europe and the Former Soviet Union' (co-editors with Sofia An, Tatiana Chubarova and Bob Deacon); 'Making Policy Move' (with John Clarke, Dave Bainton and Noemi Lendvai, Policy Press); 'Transformations in Global and Regional Social Policies' (co-editor with Alexandro Kaasch, Palgrave Macmillan); and 'Social Inequalities and Discontent in Yugoslav Socialism' (co-editor with Rory Archer and Igor Duda, Routledge). He is a member of the editorial board of Critical Policy Studies and the Croatian Journal of Social Policy.

Ljiljana Gomerčić je zaposlena v Miklavževem vrtcu v Logatcu na delovnem mestu pomočnice direktorja - strokovne vodje vrtca. Na področju vzgoje in izobraževanja predšolskih otrok ima več kot 25 let delovnih izkušenj. $\mathrm{V}$ letu 2020 se je kot absolventka vpisala na doktorski študij edukacijskih ved na Univerzi na Primorskem - Pedagoški fakulteti Koper. Strokovno se večinoma osredotoča na razvoj, učenje in poučevanje otrok zgodnjega in predšolskega obdobja. S prispevki in predavanji je sodelovala na več mednarodnih in domačih konferencah, več o tem je dostopno na: https://orcid. org/oooo-0002-7834-6525. 
Ljiljana Gomerčić is employed at the Miklavž Kindergarten in Logatec as Assistant Director - Professional Kindergarten Manager. She has over 25 years of work experience in the field of preschool education. In 2020 she has enrolled in the third year of Graduate Doctoral Study Programme of Educational Sciences at the University of Primorska - Faculty of Education, Koper. She is particularly interested in the development, learning and teaching of children in early childhood and preschool. She has actively participated in several international and national conferences with both articles and lectures. More available on: https://orcid.org/oooo-0002-7834-6525

Elena Nacevska je raziskovalka na CPR, FDV, Univerza v Ljubljani. Leta 2013 je doktorirala na Fakulteti za družbene vede v Ljubljani. Kot Fulbrightova štipendistka je leta 2011 delovala kot raziskovalka na Univerzi v Massachusettsu, ZDA, na področjih ameriške politike, javne politike, vprašanja enakosti, etničnih in človekovih pravic. Delovala je tudi na Univerzi Harvard,v Virginiji,v Connecticutu in na Univerzi v Shippensburgu. Kot doktorska štipendistka je bila leta $2010 \mathrm{v}$ okviru Evropskega doktorata za migracije, različnosti in identitete raziskovalka na SydDansk Universitet, kjer je delovala v okvirju Transnacionalizem v globalni družbi. Leta 2009je bila imenovana za ambasadorko miru OZN.

Elena Nacevska is a researcher at the Centre for Political Science Research, Faculty of Social Sciences (FSS), University of Ljubljana (UL). In 2013, she was awarded a PhD at the FSS, UL. As a Fulbright Fellow, in 2011 she was a researcher at the University of Massachusetts, USA, in the fields of American politics, public policy, equality, ethnic and human rights. She attended Harvard University; Virginia; Connecticut and Shippensburg University. As a PhD fellow at SydDansk University, in 2010 she was a researcher in the frame of the European Doctorate on Migration, Diversity and Identities Denmark, Transnationalism in the Global City. In 2009, under the auspices of the UN, she was appointed an Ambassador for Peace.

Barbara N. Brečko je raziskovalka na Centru za družboslovno informatiko, FDV, Univerza v Ljubljani. Doktorirala je na FDV s področja družboslovne metodologije. Glavno področje njenega dela je metodologija družboslovnega raziskovanja, pri čemer se osredotoča predvsem na življenje mladih, IKT in področje izobražavanja. Med letoma 2012 in 2014 je bila kot raziskovalka zaposlena na Skupnem raziskovalnem centru Evropske komisije (JRC EC) v Sevilli v Španiji. 
Barbara N. Brečko is a researcher at the Centre for Social Science Informatics, Faculty of Social Sciences, University of Ljubljana. She holds a PhD in social sciences methodology. The main area of her work is social science research methodology, focusing on young people, ICT and education. Between 2012 and 2014, she worked as a researcher at the Joint Research Centre of the European Commission (JRC EC) in Seville, Spain.

Tanja Oblak Črnič je profesorica na Katedri za medijske in komunikacijske študije in skrbnica doktorskega programa Komunikologija na Fakulteti za družbene vede Univerze v Ljubljani. V letu 2001 je kot podoktorska raziskovalka delovala na Univerzi v Helsinkih (Finska), leta 2012 pa kot gostujoča raziskovalka na Univerzi Berkeley (ZDA). Njena področja raziskovanja so študije interneta in digitalne kulture, občinstva in novih medijev ter politično komuniciranje in digitalno državljanstvo. V zadnjih letih se posvečaproučevanjue komuniciranja, participacije in medijske potrošnje mladih.

Tanja Oblak Črnič is a professor and head of the doctoral programme in Communication Studies at the Faculty of Social Sciences, University of Ljubljana. In 2001, she was a postdoctoral researcher at the University of Helsinki (Finland) and in 2012 a visiting researcher at the University of Berkeley (USA). Her research interests are studies of Internet and digital culture, audiences and new media, political communication and digital citizenship. In recent times, her research focus has largely been on communication, participation and media consumption among young people.

Danica Fink Hafner je redna profesorica na Fakulteti za družbene vede Univerze v Ljubljani, ustanoviteljica dodiplomskega programa Analiza politik in javna uprava, magistrskega in doktorskega študija na področju analize politik ter magistrskega študija javne uprave na isti univerzi. Leta 1991 je bila gostujoča raziskovalka na University of Strathclyde v Glasgowu, leta 1993 pa na University of Warwick v Združenem kraljestvu. Kot Fulbrightova štipendistka je v študijskem letu 1996/1997 poučevala v ZDA, v okviru mednarodnega magistrskega študija MESPA v obdobju 1993-1998 pa na univerzah v Združenem kraljestvu in na Irskem. Sodelovala je pri več evropskih projektih in mrežah, trenutno vodi programsko skupino Politološke raziskave.

Danica Fink Hafner is a full-time professor at the Faculty of Social Sciences, University of Ljubljana, founder of the undergraduate study Policy Analy- 
sis and Public Administration, master and doctoral studies in the field of policy analysis, and a co-founder of master studies in public administration at the same faculty. In 1991, she was a visiting researcher at the University of Strathclyde in Glasgow and at the University of Warwick, UK. As part of international master studies MESPA (1993-1998), she taught in the UK and Ireland, while as a Fulbright scholar (1996/1997) she taught in the USA. She collaborated with several European projects and networks and is currently the head of the Political Science Research programme.

Dr. Maruša Hauptman Komotar je docentka za področje Vzgoja in izobraževanje, zaposlena na Alma Mater Europaea - Fakulteti za humanistični študij, Institutum Studiorum Humanitatis, Ljubljana, kjer deluje kot visokošolska sodelavka in raziskovalka v raziskovalnem programu, od novembra 2019 dalje pa tudi kot prodekanja fakultete. V letu 2018 je na Pedagoški fakulteti Univerze v Ljubljane uspešno zagovarjala doktorsko disertacijo z naslovom Internacionalizacija in zagotavljanje kakovosti v visokem šolstvu v Sloveniji in na Nizozemskem in pridobila naziv doktorica edukacijskih ved. Raziskovalno se ukvarja s primerjavo različnih visokošolskih sistemov $\mathrm{v}$ kontekstu zagotavljanja kakovosti internacionalizacije in internacionalizacije zagotavljanja kakovosti visokega šolstva, kot tudi z vplivi internacionalizacije oziroma zagotavljanja kakovosti na formacijo akademskih kultur $\mathrm{v}$ slovenskem visokem šolstvu. Univerzitetni študij pedagogike in sociologije je zaključila na Filozofski fakulteti Univerze v Ljubljani.

Dr. Maruša Hauptman Komotar is an Assistant Professor in the field of Education, employed at Alma Mater Europaea - Faculty of Humanities, Institutum Studiorum Humanitatis, Ljubljana. In 2018, she successfully defended her doctoral thesis entitled Internationalization and Quality Assurance in Higher Education in Slovenia and the Netherlands at the Faculty of Education, University of Ljubljana, and obtained the title Doctor of Educational Sciences. Her research focuses on the comparison of different higher education systems in the context of quality assurance of internationalisation and internationalisation of quality assurance in higher education, as well as on the impact of internationalisation and quality assurance on the formation of academic cultures in (Slovenian) higher education. She completed her university studies of Educational Sciences (i. e., Pedagogy) and Sociology at the Faculty of Arts, University of Ljubljana. 
Barbara Baloh je kot docentka za didaktiko slovenščine zaposlena na Pedagoški fakulteti, Univerzi na Primorskem. Trenutno se ukvarja z jezikovnimi in sociolingvističnimi vidiki razvoja otrokovega govora, predvsem $\mathrm{s}$ pripovedovanjem otrok $\mathrm{v}$ predšolskem in zgodnjem šolskem obdobju $\mathrm{v}$ enojezičnem in večjezičnem okolju, $z$ učenjem in poučevanjem slovenščine kot maternega, drugega in tujega jezika, ter predopismenjevanjem in opismenjevanjem v enojezičnem in večjezičnem okolju. Svoja strokovna in znanstvena spoznanja objavlja $v$ tujih in domačih strokovnih in znanstvenih revijah.

Barbara Baloh works at the University of Primorska, at the Faculty of pedagogy as an assistant professor of the Slovenian language teaching courses. Her focus is mainly on the research of the Slovenian language didactics and socio-linguistic isssues. Especially relevant are her publications in which a socio-linguistic approach and didactic and methodic questions are combined with the language of the environment and literacy teaching in a second language, as well as publications where new didactic approaches to language teaching in pre-school and school age children are considered. She publishes her scientific findings both in national and foreign scientific magazines.

Izr. prof. dr. Silva Bratož je na Pedagoški Fakulteti Univerze na Primorskem nosilka različnih predmetov na področju učenja angleščine in didaktike poučevanja tujega jezika. Doktorirala je iz jezikoslovja na Filozofski fakulteti Univerze v Ljubljani. V okviru svojega znanstveno-raziskovalnega dela raziskuje zlasti na področjih zgodnjega učenja tujega jezika in uporabnega jezikoslovja. V zadnjem času se raziskovalno posveča zlasti preučevanju stališč bodočih učiteljev do večjezičnosti, načinom, kako otroci zaznavajo različne jezike, analizi vloge učiteljev skozi metafore in preučevanju možnosti razredne interakcije za razvijanje jezikovnih zmožnosti.

Silva Bratož is Associate Professor of English at the Faculty of Education of the University of Primorska, Slovenia where she teaches several courses in the area of foreign language teaching. She earned her $\mathrm{PhD}$ in linguistics from the Faculty of Arts, University of Ljubljana. She has researched and published in the area of foreign language teaching methodology for young learners and applied linguistics. Her current research focuses on pre-service teachers' attitudes towards multilingualism, children's perceptions of different languages, analysing the roles of a teacher through metaphors, 
and exploring the potential of classroom interaction for language development.

Prof. dr. Nebojša Pavlović je diplomiral na Fakulteti za politične vede. Magistriral in doktoriral na Filozofski fakulteti v Novem Sadu. Nebojša je zaposlen na Fakulteti za hotel in turizem v Vrnjački Banji, ki spada pod Univerzo v Kragujevcu. Nebojša deluje tudi kot profesor pri predmetih kadrovanja, podjetništva, managementa ter poslovnega komuniciranja. Njegova področja zanimanja so menedžment, podjetništvo in izobraževanje. Je avtor in nadobudnik več knjig in več kot 70 znanstvenih člankov.

Prof.dr. Nebojša Pavlović graduated at Faculty for Political Sciences. He earned MSc and Ph.D degree at Faculty for Philosophy in Novi Sad. Nebojsa is employed at Faculty of Hotel and Tourism in Vrnjacka Banja which belongs to University in Kragujevac. Also, Nebojsa works as a teacher for subjects HR Management, Entrepreneurship and Management and Business Communications. His fields of interest are Management, Entrepreneurship and Education. He is the author or couathor several books and more than 70 scientific papers.

Dr. Maja Šebjanič Oražem je diplomirala iz slovenščine in pedagogike na FF UL in tam julija 2016 doktorirala iz didaktike slovenščine. Njeno raziskovalno delo je usmerjeno $\mathrm{v}$ proučevanje didaktične izvedbe sodobnega pouka slovenščine in kompetence učitelja za poučevanje slovenščine kot maternega jezika. Piše in objavlja članke v strokovnih revijah, kot sta Jezik in slovstvo in Slovenščina $v$ šoli. Njena vidnejša prispevka sta Pripravništvo profesorjev slovenščine $v$ Sloveniji in Avstriji in Učiteljeva usposobljenost za kompetentno rabo pedagoškega govora. Aktivno sodeluje na mednarodnih konferencah, na katerih predstavlja svoje raziskovalno in praktično delo. Je soavtorica učbeniškega kompleta za slovenščino v 7. in 9. razredu.

Maja Šebjanič Oražem, Ph.D., graduated in Slovene and Pedagogy at the Faculty of Arts University of Ljubljana. In July 2016 she received her Ph.D. Her main research domain is the study of didactic implementation of lessons and the teacher's competences for teaching Slovene as a mother tongue. She writes and publishes articles in journals, such as Language and Literature and Slovene at School. Her most noticeable contributions are Internship for Upper Secondary School Teachers of Slovene in Slovenia and Austria and Teacher's Qualification for Competent Use of Pedagogic Speech. She participates in international conferences, where she presents her research 
and practical work. She is a co-author of the textbook for Slovene language in $7^{\text {th }}$ and $9^{\text {th }}$ grade.

Irina Lešnik je po izobrazbi profesorica slovenščine in zgodovine ter diplomantka dramaturgije in scenskih umetnosti. Na Pedagoški fakulteti Univerze na Primorskem je trenutno zaposlena kot asistentka na dveh področjih - Didaktika slovenščine ter Filmsko, gledališko in lutkovno izobraževanje. Deluje tudi kot urednica, recenzentka in lektorica slovenščine kot drugega/tujega jezika.

Irina Lešnik has an MA in Slovene and History and a BA in Dramaturgy and Performing Arts. She currently works as a teaching assistant at the Faculty of Education, University of Primorska and is active in the field of Didactics of Slovene, as well as in the field of Film, Theatre and Puppetry in Education. She also works as an editor, reviewer and lecturer of Slovene as a second/foreign language.

Nika Bedek je profesorica razrednega pouka, trenutno študentka magistrskega študija poučevanja na razredni stopnji z angleščino na Pedagoški fakulteti Univerze v Ljubljani. V soavtorstvu je za raziskavo na področju stališč do nadarjenih učencev prejela Prešernovo nagrado Pedagoške fakultete Univerze v Ljubljani, za svoje delo na fakulteti pa je prejela univerzitetno Svečano listino za najboljše študijske dosežke. Je soavtorica strokovne monografije Moč pedagoškega dela. Aktivno sodeluje pri študentskem svetu, tutorstvu in pri projektu prirejanja Ustave Republike Slovenije v lahko berljivo obliko.

Nika Bedek has a bachelor's degree in Primary Education and is currently enrolled in the Master's programme Primary Teacher Education with English at the Faculty of Education, University of Ljubljana. In co-authorship, she received the faculty Prešeren Award for research in the field of attitudes towards gifted pupils, and for her work at the faculty, she received the University Certificate of Merit for High Academic Achievements. She actively participates in the student council, tutoring and the project of transforming the Constitution of the Republic of Slovenia to an easy-to-read form.

Maruša Loboda je profesorica specialne in rehabilitacijske pedagogike, trenutno študentka podiplomskega študija specialne in rehabilitacijske pedagogike, smer posebne razvojne in učne težave, na Pedagoški fakulteti Univerze v Ljubljani. Od septembra 2019 je zaposlena na Osnovni šoli Roje kot 
mobilna učiteljica za dodatno strokovno pomoč. V soavtorstvu je za raziskovalno nalogo o stališčih študentov do nadarjenih in njihovega izobraževanja prejela Prešernovo nagrado Pedagoške fakultete Univerze v Ljubljani. Trenutno v okviru magistrske naloge raziskuje razvitost izvršilnih funkcij pri predšolskih otrocih.

Maruša Loboda has a bachelor's degree in Special and Rehabilitation Pedagogy and is currently enrolled in the Master's programme Special and Rehabilitation Pedagogy, orientation Special Developmental and Learning Difficulties at the Faculty of Education, University of Ljubljana. Since September 2019, she is working at Primary School Roje as a specialized mobile teacher providing additional professional assistance. In co-authorship, she received the faculty Prešeren Award for research regarding pre-service teachers' attitudes toward gifted pupils and their education. Currently, she is working on her master's thesis researching executive functions in preschool children.

Urška Žerak je asistentka za pedagoško psihologijo na Pedagoški fakulteti Univerze v Ljubljani. Je študentka doktorskega študija Aplikativne psihološke študije na Filozofski fakulteti Univerze v Ljubljani. Njeni raziskovalni interesi so na področju samoregulacijskega učenja, učnih strategij, nadarjenih učencev, ustvarjalnosti in izobraževanja učiteljev. Je aktivna članica Centra za raziskovanje in spodbujanje nadarjenosti na Pedagoški fakulteti Univerze v Ljubljani ter Društva psihologov Slovenije.

Urška Žerak is a teaching assistant of educational psychology at the Faculty of Education of the University of Ljubljana. She is a Ph.D. student in Applied Psychological Studies at the Faculty of Arts of the University of Ljubljana. Her research interests are in the field of self-regulated learning, learning strategies, gifted education, and teachers' professional development. She is a member of Centre for Research and Promotion of Giftedness at the Faculty of Education University of Ljubljana and Slovenian Psychologists' Association.

Dr. Janez Vogrinc je izredni profesor za pedagoško metodologijo in statistiko na Pedagoški fakulteti Univerze v Ljubljani. Na znanstveno-raziskovalnem področju se ukvarja predvsem $\mathrm{z}$ različnimi raziskovalnimi pristopi, ki se uporabljajo na pedagoškem področju (npr. Kvalitativno raziskovanje, akcijsko raziskovanje), pa tudi s sistemom izobraževanja učiteljev. Je predsednik Državne komisije za vodenje nacionalnega preverjanja znanja, član 
Strokovnega sveta RS za splošno izobraževanje in dekan Pedagoške fakultete Univerze v Ljubljani.

Janez Vogrinc is Associate professor of statistics and methodology at the Faculty of Education, University of Ljubljana. His research interest are primarly connected with the various research approaches used in the field of pedagogy and education (e.g. qualitative research, action research), as well as the . He is the President of the National Comission for the Management of National Assessment, a member of the Expert Council of the Republic Slovenia for General Education and the Dean of the Faculty of Education at University of Ljubljana.

Dr. Mojca Juriševič je redna profesorica za pedagoško psihologijo na Pedagoški fakulteti Univerze v Ljubljani. Raziskuje na področju učenja in poučevanja, s poudarkom na motivaciji za učenje, samopodobi, izobraževanju nadarjenih učencih, ustvarjalnosti, mentorstvu in strokovnemu razvoju učiteljev. Je ustanoviteljica Centra za raziskovanje in spodbujanje nadarjenosti na Pedagoški fakulteti Univerze v Ljubljani. V Društvu psihologov Slovenije vodi sekcijo psihologov v vzgoji in izobraževanju.

Mojca Juriševič, Ph.D., is Professor of Educational Psychology at the Faculty of Education of the University of Ljubljana. Her research interests span the fields of learning and teaching with studies focusin on topics such as motivation to learn, self-concept, creativity, gifted education, mentoring and teacher professional development. She is founder of Centre for Research and Promotion of Giftedness at the Faculty of Education University of Ljubljana. She serves as the Chair of the Psychologists in Education division of the Slovenian Psychologists' Association, and as the member of Standing Committee of Psychology in Education at European Federation of Psychologists' Associations.

Ana Stanovnik Perčič je nosilka razvoja področja izobraževanja odraslih na slovenski nacionalni agenciji programa Erasmus+ CMEPIUS. Na tem področju dela že od začetka programa, v njegovem predhodniku (Vseživljenjsko učenje) pa je delala na področju poklicnega izobraževanja in usposabljanja. Pred zaposlitvijo na CMEPIUS-u je delala v nevladni organizaciji na lokalnem nivoju, kjer se je ukvarjala s kulturnimi in mladinskimi projekti.

Ana Stanovnik Perčič is in charge of Adult Education field at Slovenian Erasmus+ National Agency (CMEPIUS). She has been working on the field 
since the beginning of Erasmus+ Programme and on the field of vocational education and training in Lifelong Learning Programme. Prior to the employment at the NA, she worked in an NGO on a local level, covering cultural and youth projects, which gives her an insight on operating principle of organisations in the field.

Lela Vuković ima diplomo učitelja angleščine na Filozofski fakulteti v Novem Sadu, magisterij na fakulteti Združenja centrov za interdisciplinarne in multidisciplinarne študije in raziskave na Univerzi v Novem Sadu ter doktorat iz metodologije poučevanja iz Novega Sada, Filozofske fakultete v Novem Sadu. Njeno doktorsko disertacijo nosi naslov »Inovativni pristopi k poučevanju in učenju ter zagotavljanje standardov srednješolskih šol«. Njena bibliografija vsebuje 10 enot s področja inovativnih pristopov k poučevanju in učenju, PBL in horizontalnega učenja, objavljenih v različnih znanstvenih revijah ali predstavljenih na znanstvenih konferencah tako $\mathrm{v}$ Srbiji kot v tujini.

Lela Vukovićs educational background includes an English language teacher diploma from Faculty of Philosophy in Novi Sad, a MA in Educational Management from Association of Centers for Interdisciplinary and Multidisciplinary Studies and Research at the University of Novi Sad, and a PhD in Methodology of Teaching from the Faculty of Philosophy in Novi Sad. Her doctoral thesis is titled "Innovative teaching and learning approaches and securing secondary schooling standards«. Her bibliography contains 10 items in the field of innovative teaching and learning approaches, PBL and horizontal learning published in different scientific journals or presented at scientific conferences both in Serbia and abroad.

Dr. Maja Kuronja je učiteljica na osnovni šoli, ki poučuje v inkluzivnih oddelkih, v katere se vključujejo tudi učenci s čustvenimi in vedenjskimi motnjami, ki bivajo v vzgojnem zavodu.

Maja Kuronja, $\mathrm{PhD}$, is Primary School Teacher. She works as a primary school teacher and teaches inclusion classes attended also by the pupils with emotional and behavioural difficulties who live in a residential treatment institution.

Red. prof. dr. Majda Schmidt Krajnc je zaposlena na Pedagoški fakulteti Univerze v Mariboru na Oddeleku za temeljne pedagoške predmete. Pri delu se posveča raziskovanju inkluzivne vzgoje in izobraževanju otrok $s$ 
posebnimi potrebami, socialni integraciji in kvaliteti življenj družin z otroki z motnjami v duševnem razvoju in drugimi razvojnimi motnjami.

Majda Schmidt Krajnc, PhD, Full Professor, Employed at the Faculty of Education of the University of Maribor, Department of Basic Pedagogical Studies. Her work is focused on research of inclusive education of children with special needs, social integration and quality of life of families with children with mental disabilities and other developmental disorders.

Tina Pivec je trenutno zaposlena kot mlada raziskovalka na Pedagoškem inštitutu. Magistrirala je iz psihologije na Filozofski fakulteti Univerze v Mariboru. V magistrskem delu je preučevala psihosocialne značilnosti različnih skupin udeležencev medvrstniškega nasilja in viktimizacije. Njen znanstvenoraziskovalni interes sega na področje pedagoške in razvojne psihologije, v sklopu doktorskega študija pripravlja doktorsko disertacijo s področja pozitivnega razvoja mladih in nasilnega vedenja pri mladih v obdobju prehoda iz osnovne v srednjo šolo.

Tina Pivec is currently employed as an emerging researcher at the Educational Research Institute. She finished her postgraduate studies of Psychology at the Faculty of Arts, University of Maribor. In her thesis, she examined psychosocial characteristics between different groups of bullying and victimization participants. Her research interest is in the field of educational and developmental psychology. In her PhD studies, she is preparing a doctoral dissertation with the focus on positive youth development and bullying behaviour among adolescents in the transition between primary school and high school.

Ana Kozina je diplomirana univerzitetna psihologinja, doktorica psiholoških ved in docentka za psihologijo. Zaposlena je na Pedagoškem inštitutu, kjer je vodja Centra za evalvacijske študije. Njeno raziskovalno delo sega na področji pedagoške in razvojne psihologije. Ukvarja se z razvojem agresivnosti in anksioznosti (obdobje otroštva in mladostništva) ter njune interakcije na ravni posameznika in na ravni širšega družbenega okolja (vključno z razvojem preventivnih in intervencijskih dejavnosti). Na področju pedagoške psihologije se ukvarja s preučevanjem dejavnikov (šolska klima, socialno in čustveno učenje, motivacija ...), ki vplivajo na učne dosežke otrok in mladostnikov. Je članica programske skupine Edukacijske raziskave (2015-2020), članica uredniškega odbora Založbe Pedagoškega 
inštituta ter predsednica Slovenskega društva raziskovalcev na področju edukacije (SLODRE).

Ana Kozina is a researcher, assistant professor and the head of the Centre for evaluation studies in Educational Research Institute. Her work is in the field of developmental and educational psychology. She is focused on the developmental and time related trends of aggression and anxiety (in childhood and adolescence), their interplay and the role that anxiety and aggression play on the individual level, on the school level and on the community level (with possible prevention and intervention designs). In the field of education she is interested in the factors related to students' achievement (school climate, social and emotional learning, motivation...). She is a member of the program group Educational Research (2015-2020), a member of the editorial board of Educational Research Institute Publishing House and a president of The Slovenian Educational Research Association (SLODRE).

Valerija Vendramin je doktorica ženskih študij, zaposlena pa je kot znanstvena sodelavka na Pedagoškem inštitutu v Ljubljani. Med njenimi raziskovalnimi področji so edukacijske študije, ženske študije in feministična teorija ter kulturne študije (v tem okviru se ukvarja s problematiko, ki zadeva konceptualizacijo spolne razlike, kurikulum in feministične kritike znanosti oz. epistemološka vprašanja).

Valerija Vendramin, $\mathrm{PhD}$ in Women's Studies, is a research associate at the Educational Research Institute in Ljubljana. Among her current research fields are educational studies, women's studies and feminist theory, cultural studies (predominantly, but not exclusively, in connection to the issues concerning the conceptualization of sexual difference, curriculum and feminist critiques of science together with epistemological issues.).

Izr. prof. dr. Simona Tancig, univerzitetna diplomirana psihologinja in specializantka supervizije, se je izpopolnjevala v ZDA in na Nizozemskem. Trenutno je zunanja sodelavka Pedagoške fakultete Univerze v Ljubljani in Univerze Sigmunda Freuda v Ljubljani. Področja njenega pedagoškega in raziskovalnega dela: razvojna in kognitivna psihologija, specialna pedagogika, inkluzivno izobraževanje, supervizija, umetnostna terapija in kognitivna znanost. $\mathrm{V}$ zadnjih letih se je osredotočila na področje edukacijske nevroznanosti in implementacije tega interdisciplinarnega področja $\mathrm{v}$ izobraževalni in raziskovalni prostor. $\mathrm{V}$ tem okviru raziskuje in razvija problematiko metakognicije, samoregulacije, samodeterminacije, izvršil- 
nih funkcij ter čustveno-socialnega razvoja. Je članica International Mind, Brain and Education Society (IMBES), članica SIG Neuroscience \& Education pri European Association for Research on Learning and Instruction (EARLI).

Simona Tancig, $\mathrm{PhD}$, a Bachelor of Science in Psychology and a Supervisory Specialist, has continued her studies in the United States and the Netherlands. She is currently an associate professor at the Faculty of Education at the University of Ljubljana and the Sigmund Freud University in Ljubljana. Her fields of pedagogical and research work are developmental and cognitive psychology, special pedagogy, inclusive education, supervision, art therapy and cognitive science. In recent years, she has focused on the field of educational neuroscience and the implementation of this interdisciplinary field into education and research. In this context, she explores and develops the issues of metacognition, self-regulation, self-determination, executive functions and emotional and social development. She is a member of the International Mind, Brain and Education Society (IMBES), and a member of SIG Neuroscience \& Education at the European Association for Research on Learning and Instruction (EARLI).

Asist. dr. Monika Mithans je zaključila študij pedagogike in prevajanja in tolmačenja nemščine na Filozofski fakulteti Univerze v Mariboru. Leta 2017 je doktorirala na Pedagoški fakulteti Univerze v Mariboru. Kot asistentka za pedagogiko je zaposlena na Pedagoški fakulteti Univerze v Mariboru. Njeno znanstveno raziskovalno delo obsega dve glavni področji raziskovanja, in sicer participacijo v šoli in posodabljanju pouka. Rezultate svojega raziskovalnega dela objavlja $\mathrm{v}$ znanstvenih in strokovnih člankih $\mathrm{v}$ Sloveniji in tujini.

Asist. dr. Monika Mithans graduated in the fields of pedagogy and German translation studies at the University of Maribor, Faculty of Arts, in 2009. She completed her $\mathrm{PhD}$ in educational sciences at the University of Maribor, Faculty of Education in 2017. She currently holds an academic appointment at the University of Maribor, Faculty of Education, where she works as an assistant. Her scientific research work comprises two main fields of research, namely school participation and modernization of educational process. She has been publishing scientific and educational articles in Slovenian and foreign magazines. 
Prof. dr. Milena Ivanuš Grmek je zaključila študij pedagogike in sociologije na Univerzi v Ljubljani, na Filozofski fakulteti. Doktorirala je prav tako na Univerzi v Ljubljani, na Filozofski fakulteti. Kot redna profesorica za didaktiko je zaposlena na Univerzi v Mariboru na Pedagoški fakulteti. V svojem raziskovalnem delu se posveča posodabljanju pouka, kurikularnim spremembam na področju sekundarnega izobraževanja in profesionalnemu razvoju učiteljev. Rezultate svojega raziskovalnega dela objavlja v Sloveniji in tujini. Trenutno je dekanja Pedagoške fakultete Univerze v Mariboru.

Prof Dr Milena Ivanuš Grmek, graduated in the fields of pedagogy and sociology at the University of Ljubljana, Faculty of Arts. She defended her PhD thesis at the University of Ljubljana, Faculty of Arts. She works as the Full Professor of Didactics at the University of Maribor, Faculty of Education. Her scientific research work comprises three main fields of research: modernization of educational process, curriculum changes in secondary school education and professional development of teachers. She has been publishing scientific and specializing texts in Slovenian, as well as in foreign magazines. Considering her current position at the University of Maribor, Faculty of Education, she is dean.

Natalija Budinski je učiteljica matematike na osnovni in srednji šoli. Področje njenega zanimanja so inovacije pri pouku matematike. Osredotočena je na povezovanje matematičnih vsebin $\mathrm{z}$ drugimi predmeti in vsakodnevnimi situacijami. Napisala je številne prispevke na področju izobraževanja in za svoje inovativno poučevanje prejela več evropskih in srbskih nagrad. Poleg tega je doktorska študentka na Univerzi v vzhodnem Sarajevu v Bosni in Hercegovini.

Natalija Budinski is a teacher of mathematics in the primary and secondary school. The field of her interest is innovation in teaching mathematics. She is focused on connecting mathematical content to other subjects and real-world situations. She has written numerous papers in the field of education and received several European and Serbian awards for her innovative teaching. Also, she is a Phd student at the University of East Sarajevo in Bosnia and Herzegovina.

Mag. Meleka Asotic je srednješolska učiteljica in doktorska študentka Pedagoške fakultete v Sarajevu. Na doktorskem študiju je na smeri Sodobnega predšolskegag in osnovnošolskega izobraževanja. Njeno znanstveno 
delo je posvečeno pedagogiki, jezikovnemu učenju in vključujočim izobraževalnim procesom.

Msc. Meleka Asotic is a secondary school teacher and a PhD student of Pedagogy Faculty in Sarajevo. She is attending Contemporary Courses of Preschool and Elementary School Education on her PhD studies. Her scientific work has been dedicated to pedagogy sciences, language acquisition, and inclusive educational processes.

Mag. Ajša Bahović Latifović je osnovnošolska učiteljica in asistentka na Mednarodni univerzi v Novem Pazarju. Področja njenega študija so usvajanje jezikov, zgodnje učenje jezikov, vključujoči izobraževalni procesi in sociološki vidiki učenja jezikov.

Msc. Ajša Bahović Latifović is a primary school teacher and a teaching assistant at International University of Novi Pazar. She has dedicated her teaching and studies on language acquisition, early language learning, inclusive educational processes and sociological aspects of language learning.

Mag. Andreja Lenc je vodja sektorja za razvoj in kakovost na Center RS za mobilnost in evropske programe izobraževanja in usposabljanja, in sicer na naslovu Ob železnici 30a, 1000 Ljubljana, Slovenija. Njen e-naslov je andreja.lenc@cmepius.si.

Mag. Andreja Lenc is a Head of sector for development and quality in Centre RS for Mobility and European Educational and Training Programmes, Ob železnici 30a, 1000 Ljubljana, Slovenia. Her e-mail address is andreja. lenc@cmepius.si.

Aleksandra Stevanovič je 17. leto zaposlena kot psihologinja in pedagoška svetovalka v izobraževanju - ima več leta izkušenj iz vodenja, mentorstva, svetovanja in ukvarjanja s srednješolci ter učitelji. Je avtorica več izobraževanj in izobraževalnih programov. $\mathrm{V}$ programu JA sodeluje od samega začetka - od leta 2006. Ima izkušnje $\mathrm{z}$ moderiranjem, načrtovanjem in izvedbo delavnic, socialnimi empiričnimi raziskavami, anketami in statistiko. Aleksandra Stevanovic is a psychologist and educational advisor in education for 17 years - years of guiding, mentoring, consulting and dealing with high school students and teachers, author of several trainings and educational programs. She has been in the JA program from the very start - from 
2006. Experienced with moderation, workshop planning and performance, social empirical investigations, surveys and statistics.

Snježana Đurđević je učiteljica ekonomije, pedagoška svetovalka, uslužbenka Pete ekonomske srednje šole, Beograd. Je mentorica "študentskim podjetjem" od leta 2006 (do danes). Strokovni se osredotoča na vprašanja „Vpliva študentskih podjetij na razvoj študentskega podjetništva“.

Snjezana Djurdjevic is a teacher of economics, educational advisor, an employee of Fifth Economy High School, Belgrade. Mentor of the students' company from 2006 (to the present). Professional interests are focused on the topic „The influence of students' companies on the development of student entrepreneurship".

Bojana (Drakula) Sokolović je doktorska študentka na Fakulteti za tehnične vede Univerze v Novem Sadu, Srbija. Zaključila je dodiplomski in magistrski študij za inženirski menedžment na področju upravljanja s človeškimi viri. Kot zunanja sodelavka je sodelovala na različnih univerzitetnih delavnicah za študente. Ima poklicne izkušnje na področju upravljanja s človeškimi viri: več kot 5 let je bila zaposlena kot direktorica za človeške vire $\mathrm{v}$ tujih podjetjih (Magna International Kanada-Srbija, IGB Automotive, Srbija-GMBH Nemčija), pridobila si je izkušnje kot lastnica podjetja za kadrovsko svetovanje (Rakulo21) in kot zunanja kadrovska svetovalka (Global Star Beograd). Njeni objavljeni znanstveni prispevki so dostopni na njenem LinkedIn profilu.

Bojana (Drakula) Sokolović, Phd student on the Faculty of Technical Sciences on the University of Novi Sad, Serbia. Finished academic specialist and master studies for engineering management in the field of Human Resources Management. The author has been engaged at different University`s workshops for students as an external associate. She has reach occupational experience in Human Resource Management: more than 5 years employed as a Human Resource Director in foreign companies (Magna International Canada-Serbia, IGB Automotive, Serbia- GMBH Germany), some experience as owner of HR Consulting (Rakulo21) and external HR consultant (Global Star Belgrade). Published academic papers are available on the LinkedIn profile.

Silvija Komočar je magistrica profesorica predšolske vzgoje z 20-letnimi delovnimi izkušnjami v vzgoji in izobraževanju (od tega 9 let v vodenju vrt- 
ca), trenutno zaposlena v Vrtcu Mavrica Brežice kot ravnateljica. Trenutno je doktorandka Univerze na Primorskem, Pedagoške fakultete v programu Edukacijske vede.Poglobljeno se ukvarja $\mathrm{z}$ raziskovanjem na področju predšolske vzgoje in vodenja vrtca, profesionalnega razvoja, medgeneracijskega sodelovanja ter timskega dela, še posebej timskega vodenja. Redno sodeluje na strokovnih in zanstvenih konferencah s predstavitvami primerov dobre prakse in rezultatev raziskovanja ki ga izvaja na področju timskega dela kot spodbude za profesionalni razvoj.

Silvija Komočar graduated from Masters study program Preschool education and has 20 years of work experience in education (9 years in leadership), currently employed at the Vrtec Mavrica Brežice as Headmaster. She is currently a PhD student at the University of Primorska, Faculty of Education in the Education Sciences program. She is extensively involved in research in the field of preschool education, kindergarten management, professional development, intergenerational cooperation and team work, especially team management. She regularly participates in professional and educational conferences, presenting examples of good practice and research findings that she conducts in the field of teamwork as an incentive for professional development.

Dr. Zsofia Hangyal je predavateljica, raziskovalka in koordinatorica za internacionalizacijo na univerzi Eötvös Loránd, Budimpešta, Madžarska. Po končanem doktorskem študiju mednarodnega in primerjalnega izobraževanje na Pekinški pedagoški univerzi so njeni glavni raziskovalni interesi usmerjeni v internacionalizacijo visokega šolstva, v vpliv programov učne mobilnosti in sociologijo.

$\mathrm{PhD}$ Zsofia Hangyal is a lecturer, researcher and internationalisation coordinator at Eötvös Loránd University, Budapest, Hungary. After completing her $\mathrm{PhD}$ in International and Comparative Education at Beijing Normal University, her main research interests are internationalisation of higher education, impact studies of teaching mobility programmes, generation theories and sociology.

Ana Gorše je bila rojena 3. 2. 1985 v Novem mestu. Diplomirala je leta 2007 na ljubljanski Pedagoški fakulteti, smer razredni pouk. Od septembra tega leta je zaposlena na OŠ Loka Črnomelj kot razredna učiteljica. Za izvajanje bralnih testov se je dodatno usposabljala leta 2015 na Filozofski fakulteti. Udeležuje se različnih izobraževanj in konferenc, kjer tudi aktivno sodelu- 
je. Bila je članica šolskega projektnega tima pri projektu BUS - Bralne učne strategije, ki ga je izvajal Zavod za šolstvo.

Ana Gorše was born on $3^{\text {rd }}$ February 1985 in Novo mesto. She graduated in primary education in 2007 at The Faculty of Education, University of Ljubljana. She has worked at the primary school Loka Črnomelj since September 2007 as a primary school teacher. She has additional training in carrying out reading test in 2015 at the Faculty of Arts, University of Ljubljana. She has also taken part in various courses and conferences where she has also been an active participant. She was also a member of a school team in the BUS project - reading-learning strategies that was carried out by the National Education Institute Slovenia.

Vesna Kostić je učiteljica zgodovine na Osnovni šoli Jovana Dučića v Beogradu, v Srbiji. Kot članica tima za razvojni načrt šole deluje na področju izboljšanja učnega procesa šole. Je dobitnica več nagrad in avtorica obljavljenih strokovnih prispevkov, povezanih s poukom zgodovine in izvenšolskimi dejavnostmi, vključno s poklicnim usmerjanjem učencev. Je zunanja sodelavka Zavoda za izboljšanje šolstva Republike Srbije. Aktivno sodeluje na domačih in mednarodnih seminarjih. S sodelavci doma in v tujini sodeluje na projektih, $v$ katerih učenci povezujejo znanje iz naravoslovnih in družboslovnih predmetov.

Vesna Kostić is a history teacher at the Jovan Ducic Primary School in Belgrade, Serbia. As a member of the School Development Plan team, she works on improving teaching process in her school. She has several awards and published professional papers related to history teaching and extracurricular activities, including students' professional orientation. She is an external associate of the Institute for the Improvement of Education Republic of Serbia. She actively participates in domestic and international seminars. She collaborates with colleagues at home and abroad through projects in which students connect knowledge of natural and social subjects.

Jelena Mucić je učiteljica kemije na osnovnih šolah „Jovan Dučić“ in „Mladost“ $v$ Beogradu. Kot članica šolskih timov za razvojni načrt, poklicno orientacijo in strokovni razvoj sodeluje pri izboljšanju pouka. Je dobitnica več nagrad in avtorica objavljenih strokovnih člankov, povezanih s poučevanjem in promocijo kemije. Je zunanja sodelavka Inštituta za napredek izobraževanja in za vrednotenje kakovosti izobraževanja v Republiki Srbiji. 
Redno se udeležuje strokovnih usposabljanj. Kot avtorica več projektov sodeluje s kolegi iz drugih šol in vzgojno-izobraževalnih ustanov.

Jelena Mucić is a chemistry teacher at elementary schools "Jovan Ducic" and "Mladost" in Belgrade. As a member of the School Teams for Development Plan, Vocational Orientation and Professional Development, she works on improving teaching. She has several awards and published professional papers related to the teaching and promotion of chemistry. She is an external associate of the Institute for the Advancement of Education and for the Evaluation of the Quality of Education in the Republic of Serbia. She regularly undergoes professional training. As the author of several projects, she collaborates with colleagues from other schools and educational institutions.

Jovana Vasić je psihologinja na Osnovni šoli Mladost v Beogradu. Kot strokovna sodelavka sodeluje pri pripravi šolskih dokumentov v zvezi z letnim delovnim načrtom šole ter izboljšanjem izobraževalnih in učnih procesov. Skupaj z učenci in njihovimi starši nudi svetovanje o učnih težavah in svetovanje o medosebnih, vrstniških in družinskih odnosih. Objavila je več znanstvenih raziskav o poučevanju, učenju in vedenju mladih. Nenehno se strokovno izpopolnjuje in obiskuje program za pridobitev certifikata REBT.

Jovana Vasić is a psychologist at elementary school Mladost in Belgrade. As an expert associate she participates in making school documents regarding the school work plan and improving education and learning processes. Together with the students and their parents, she provides counseling on the learning difficulties as well as counseling on the interpersonal relations between classmates and on the family relations. She has published multiple scientific researches about teaching, learning and young people behavior. She is constantly developing further professionally, and she is attending classes to obtain a REBT certificate. 


\section{Stvarno kazalo}

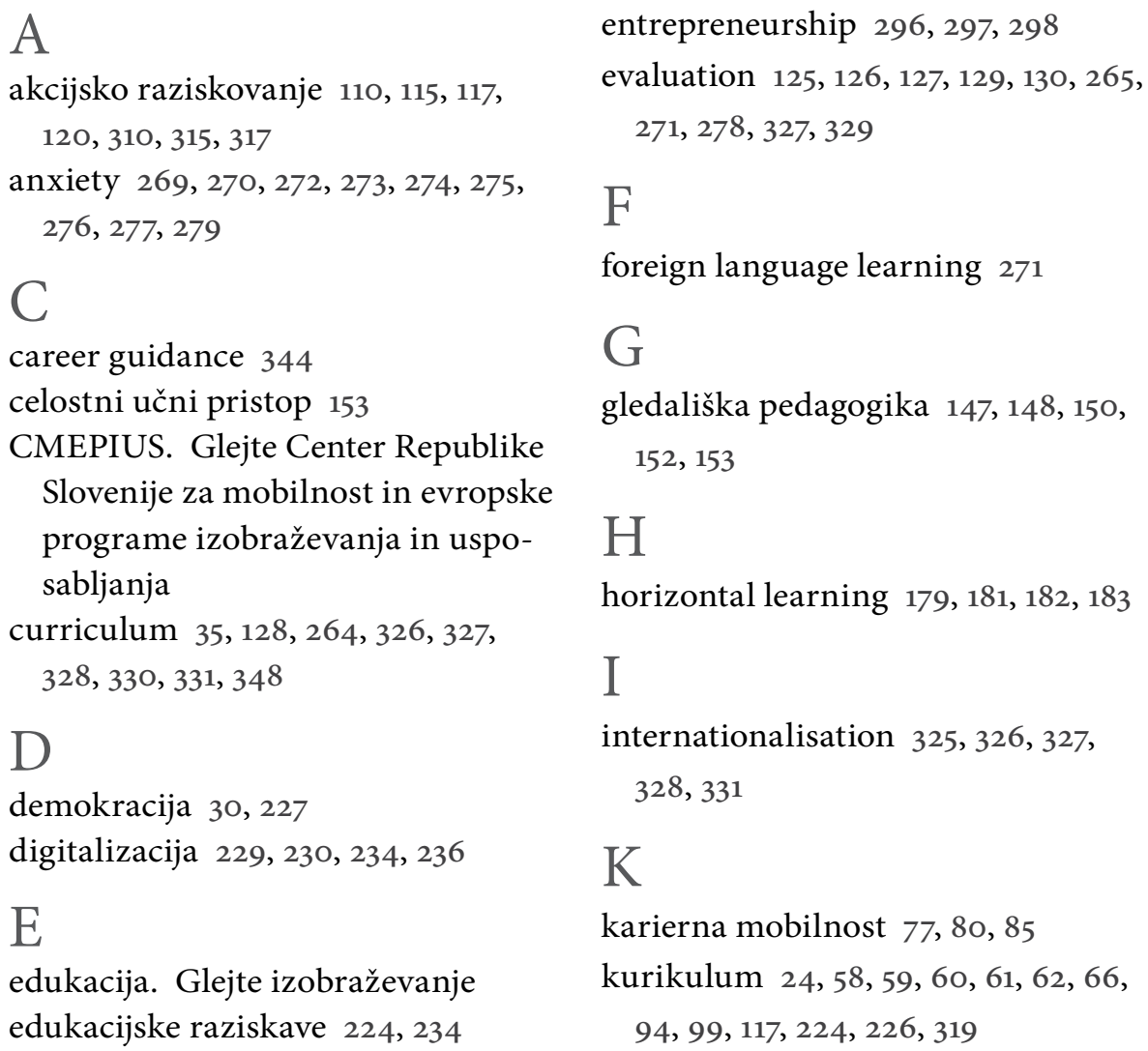

A

akcijsko raziskovanje 110, 115, 117, $120,310,315,317$

anxiety 269, 270, 272, 273, 274, 275, $276,277,279$

C

career guidance 344

celostni učni pristop 153

CMEPIUS. Glejte Center Republike Slovenije za mobilnost in evropske programe izobraževanja in usposabljanja

curriculum $35,128,264,326,327$, $328,330,331,348$

D

demokracija 30, 227

digitalizacija 229, 230, 234, 236

E

edukacija. Glejte izobraževanje edukacijske raziskave 224, 234

entrepreneurship 296, 297, 298

evaluation 125, 126, 127, 129, 130, 265 , $271,278,327,329$

F

foreign language learning 271

G

gledališka pedagogika 147, 148, 150, 152,153

\section{$\mathrm{H}$}

horizontal learning 179, 181, 182, 183

I

internationalisation $325,326,327$, 328,331

K

karierna mobilnost $77,80,85$

kurikulum 24, 58, 59, 60, 61, 62, 66, $94,99,117,224,226,319$ 
M

mathematical modeling 263, 264, 265, 266, 268

medkulturnost 109, 110, 121, 154

mednarodno sodelovanje 100, 174, 287, 288, 291

medvrstniško nasilje 205, 206, 216 mentorstvo $35,116,117,136,137,138$, $139,140,141,142,143,144,182,296$, 315

mobilnost 73, 74, 75, 76, 77, 78, 79, $80,82,84,91,92,93,94,95,96,97$, 98, 99, 100, 101, 102, 103, 175, 176, 291

N

nadarjeni $158,159,160,161,164,165$, 166, 197, 199, 256

Nizozemska 91, 92, 96, 97, 98, 99, 100, 101, 102, 103, 393

$\mathrm{O}$

otrokove pravice 64,250

$\mathrm{P}$

participacija 77, 121, 251, 252, 254,

255, 256, 257, 258

poklicna identiteta 133, 134, 135, 136, 139, 140

postfeminizem 224

predšolska vzgoja $57,58,60,61,62$, 63, 64, 66, 160, 309

profesionalni razvoj 136, 174, 175, 176, $178,309,315,318,321$

S

samoučinkovitost 194, 196, 199, 200 Slovenija 58, 59, 60, 61, 66, 91, 92, 93, 94, 95, 99, 205, 207, 208, 209, 214, 215 spol 73, 74, 82, 85, 221, 222, 224, 225

$\mathrm{T}$

teacher forums $182,183,184,187,188$

V

večopravilnost $238,239,240,241$

viktimizacija 205, 206, 207, 211, 213, 214, 215

vodstveni tim 317,319 

Raziskovanje v vzgoji in izobraževanju: mednarodni vidiki vzgoje in izobraževanja

Večavtorska znanstvena monografija

Urednika izdaje: Igor Ž. Žagar in Ana Mlekuž

Digitalna knjižnica

Uredniški odbor: Igor Ž. Žagar (Educational Research Institute \& University of Primorska), Jonatan Vinkler (University of Primorska), Janja Žmavc (Educational Research Institute),

Alenka Gril (Educational Research Institute)

Zbirka: Dissertationes (znanstvene monografije), 38

Glavni in odgovorni urednik: Igor Ž. Žagar

Recenzenti: Alenka Flander, Barbara Japelj Pavešić, Špela Javornik, Eva Klemenčič, Ana Kozina, mag. Ana Mlekuž, Mateja Mlinar, Jure Novak, Tina Pivec, Sonja Rutar, Tina Rutar Leban,

Klaudija Šterman Ivančič, Darko Štrajn, Urška Štremfel, Manja Veldin, Maša Vidmar, Tina Vršnik Perše, Petra Zgonec, Igor Ž. Žagar, Janja Žmavc

Oblikovanje, prelom in digitalna objava: Jonatan Vinkler

Založnik: Pedagoški inštitut

Za založnika: Igor Ž. Žagar

Ljubljana 2020

ISBN 978-961-270-324-o (pdf)

http://www.pei.si/ISBN/978-961-270-324-o.pdf

ISBN 978-961-270-325-7 (html)

http://www.pei.si/ISBN/978-961-270-325-7/index.html

DOl: https://www.doi.org/10.32320/978-961-270-324-0

(C) 2020 Pedagoški inštitut

\section{(cc) BY-SA}

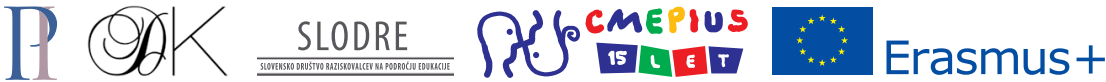





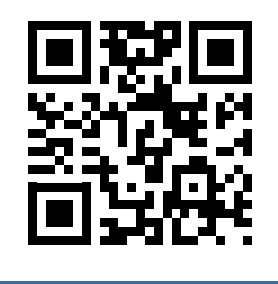

